TIETOLIPAS 252

M. A. Castrén

\title{
Luentoja suomalaisesta mytologiasta
}


TIETOLIPAS 252 


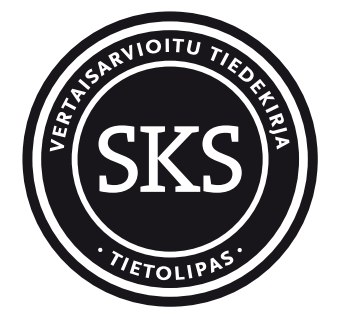

Tietolipas 252

Teos on Suomalaisen Kirjallisuuden Seuran nimeämien asiantuntijoiden tarkastama.

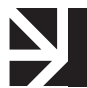

VERTAISARVIOITU

KOLLEGIALT GRANSKAD

PEER-REVIEWED

www.tsv.fi/tunnus

Kirjastokonsortio Aleksandria on tukenut teoksen avointa saatavuutta.

(C) 2016 Joonas Ahola ja SKS

Licenssi CC BY-NC-ND 4.0 International

Digitaalinen versio perustuu Suomalaisen Kirjallisuuden Seuran kustantamaan painettuun teokseen, joka on julkaistu vuonna 2016.

Kansi: Eija Hukka

EPUB: Tero Salmén

ISBN 978-952-222-741-6 (nid.)

ISBN 978-952-222-937-3 (PDF)

ISBN 978-952-222-936-6 (EPUB)

ISSN 0562-6129 (Tietolipas)

DOI: http://dx.doi.org/10.21435/tl.252

Teos on lisensoitu Creative Commons CC BY-NC-ND 4.0 International -lisenssillä.

Tutustu lisenssiin englanniksi osoitteessa http://creativecommons.org/licenses/by-nc-nd/4.0/ tai suomeksi osoitteessa https://creativecommons.org/licenses/by-nc-nd/4.0/deed.fi.

Teos on avoimesti saatavissa osoitteessa http://dx.doi.org/10.21435/tl.252 tai lukemalla tämä QR-koodi mobiililaitteella.

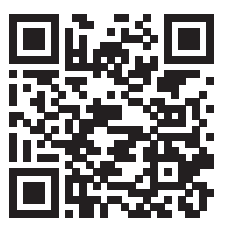




\section{A. Castrén}

\section{Luentoja suomalaisesta mytologiasta}

Suomentanut ja toimittanut Joonas Ahola 


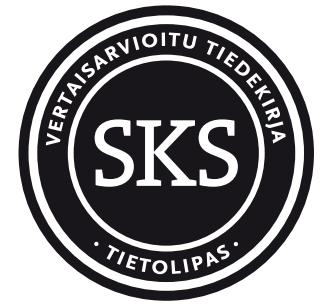

TIETOLIPAS 252

Teos on Suomalaisen Kirjallisuuden Seuran nimeämien asiantuntijoiden tarkastama.
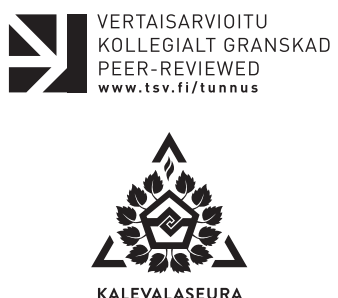

(C) 2016 Joonas Ahola ja SKS

$$
\begin{gathered}
\text { ISBN 978-952-222-741-6 } \\
\text { ISSN 0562-6129 } \\
\text { www.finlit.fi }
\end{gathered}
$$

Ulkoasu: Markus Itkonen

Taitto: Maija Räisänen

Painotyö: Hansaprint Oy, Turenki 2016 


\section{Sisällys}

Esipuhe 7

Joonas Ahola ja Karina Lukin

Matthias Alexander Castrénin suomalaisen mytologian taustoja

Johdanto 11

Castrénin lyhyt elämäkerta 12

Suomalaisen mytologian luentojen rakenne 15

Mytologialuentojen keskusteluympäristö ja lähdeaineistot 19

Historiallinen Kalevala - keskusteluja ennen

mytologialuentoja 20

Castrénin mytologian kirjallisia lähteitä 27

Kalevala ja kansanrunous Castrénin mytologian lähteinä 32

Castrénin mytologian etnografisia lähteitä 35

Mytologialuentojen ajatusmaailman taustoja 40

Historiallinen ja vertaileva menetelmä 43

Etnografisen tiedonintressin kehittyminen 55

Castrénin mytologialuentojen perintö 60

Huomautuksia tästä toimituksesta 66

Kielten ja kansojen nimitykset 68

Viittausjärjestelmä 71

Viitteet 71

Lähteet 73 
Matthias Alexander Castrén

Luentoja suomalaisesta mytologiasta

Johdanto 81

I Jumalat 84

1. Ilman jumaluudet 84

a) Jumala 84

b) Ukko 98

c) Päivä, Kuu, Otava, Tähti ja muita ilman jumaluuksia 115

2. Veden jumaluudet 128

3. Maan jumaluudet 139

4. Maanalaiset jumaluudet 161

II Erityisiä henkiolentojen lajeja 190

III Jumalkuvat ja pyhät luonnonkohteet 213

IV Sankarit 248

Castrénin mytologialuentojen lähteet 302

Toimitukselliset huomautukset eli loppuviitteet 305

Toimituksellisten huomautusten lähteet 317

Asiasanahakemisto 320

Henkilöhakemisto 327

Paikannimihakemisto 329 


\section{Esipuhe}

\section{A. Castrénin mytologialuennot vuonna 2016}

Kalevalaseurassa keskusteltiin alkuvuonna 2013, miten ottaisimme huomioon sen, että Matthias Alexander Castrénin syntymästä oli kulunut 200 vuotta. Seminaareihin ja keskusteluihin osallistumisen lisäksi päätimme julkaista suomeksi Castrénin teoksen Föreläsningar i Finsk mytologi (1853). Selvää oli, että käännös- ja toimitustyössä jouduttaisiin ratkaisemaan monia kielen ja kulttuurin muutoksista aiheutuvia ongelmia. Lisäksi käännöksenä julkaistava teksti olisi kyettävä laajan taustoituksen avulla sijoittamaan sekä 1800-luvun puolivälin että nykypäivän tieteelliseen kontekstiin.

Näiden kaavailujen inspiroimana sovimme, että hanke julkistetaan Tervolassa, Castrénin syntymäpitäjässä, 6. heinäkuuta 2013 järjestettävässä pitäjä- ja 200-vuotisjuhlassa. Esityksemme sai juhlaväeltä varauksettoman kannatuksen. Siitä alkoi tämän julkaisun käytännöllinen suunnittelu ja toteutus. Kääntäjäksi saimme mytologioiden kieleen perehtyneen FT Joonas Aholan sekä hänen lisäkseen johdantotekstin kirjoittajaksi suomalais-ugrilaisten perinteiden tutkijan FT Karina Lukinin.

M. A. Castrénin luennot suomalaisesta mytologiasta on alkujaan yli 300 sivua käsittävä esitys, joka perustuu paitsi kenttäaineistoihin myös monipuolisiin kirjallisiin lähteisiin. Castrén oli merkinnyt muistiin suomalaisen mytologian aineksia, "jumalaistaruja, vanhempia historiallisia kansantaruja ja satuja", 1830-luvun lopulla muun muassa Vienan Karjalasta. Tämä lajien nimeäminen viitannee saksalaisten Grimmin veljesten esittämään kansanperinteen lajien jakoon myytteihin, satuihin ja tarinoihin, jolla on perinnelajien jäsennys- ja järjestelyhistoriassa ollut huomattavaa kantavuutta. Luennoissa käydään läpi luonnonjumaluudet, muut merkittävät uskomusolennot sekä sankarit. Käytetty aineisto on runsas, ja kun katsoo julkaisun 
asiasanahakemistoa, huomaa, että tarkastelu on myös varsin yksityiskohtaista.

Castrénin luentojen vastaanotto on ollut mytologian tutkimushistoriassamme ristiriitainen. Niistä oli epäilemättä suuri hyöty Lönnrotille, kun hän Castrénin kuoleman jälkeen 1850-luvulla luennoi suomalaisesta mytologiasta Helsingin yliopistossa 17 lukukauden ajan. Teosta esiteltiin laajasti Tähti-lehdessä kesällä 1864 otsikolla "Suomalaisten pakanallinen usko". Tämän 4-osaisen kirjoitussarjan laatija lienee lehden julkaisija Johan Granlund, Frenckellin kirjapainon omistaja, suomentaja ja Gananderin Mythologia Fennican harras ihailija. Kirjoituksissa selostetaan luentojen sisältöä ja välillä käydään ikään kuin keskustelua kansanuskon erilaisista tulkinnoista, muun muassa monoteismihypoteesista.

Kaikilla kansoilla, syvimpään pakanuuteen ja raakuuteen wajonneillakin, on jonkunlainen aavistus Jumalasta. Heillä on jäljellä muutamia himeitä, waikkakin moni muodoin rumennettuja jäännöksiä puhtaammasta Jumalan tuntemisesta, joka ihmisillä iki vanhaan aikaan oli. [...] [Pakanallisen uskon] sekavuuteen suittaa syynä olla seki, ettei ole vielä kaikkia lähteitä tunnettu ja kukaties ei wastakaan tulla tuntemaan. Sitä sekavuutta on kuitenki muinaishistoriamme tarkka ja väsymätön tutkija, professori M. A. Castrén vainaja koettanut hälventää, ja kansamme muinaisia pimeitä asioita ja myös ajatuksia Jumalasta selittää. (Tähti nro. 24, 17.6. 1864.)

Castrénin luentoihin viitattaessa on usein kiinnitetty valittaen huomiota siihen, että hän tarkasteli mytologian sekä kansanuskon ja -runouden kysymyksiä ikään kuin Kalevalan ja eritoten vuoden 1835 laitoksen kautta, jonka hän itse oli kääntänyt ruotsiksi ja varustanut laajalla esipuheella (1841). Mutta asian voisi nähdä niinkin päin, että Kalevala eri versioineen oli Castrénin luennoissa ikään kuin pienin yhteinen nimittäjä, johon muita mytologian aineksia peilattiin. Suunnittelihan Lönnrotkin alun perin Runokokous Väinämöisestä -teoksensa (ns. Alku-Kalevala) nimeksi "Suomen kansan mytologia vanhoilla runoilla toimitettuna”. Mahdollisesti kävi niin, että runoainesten karttuessa ja niiden juonellisen järjestyksen kehittelyssä eepos voitti mytologian?

M. A. Castrén oli aikansa etevimpien kielen- ja kulttuurintutkijoiden tapaan monialaisesti ja kansainvälisesti orientoitunut empiristi. 
Lukuisten muiden töidensä ohella hän pyrki luennoissaan konstruoimaan sellaisen mytologian esityksen, jossa olisi sekä historiallista kerrostuneisuutta että suomalais-ugrilaisten kansojen perimätietoja vertailevaa perspektiiviä. Siinä missä Lönnrot ymmärsi Kalevalan olevan vain yksi tulkinta suullisen runouden koostamismahdollisuuksista, Castrénin näkemys mytologiasta eteni kattavasti kuvattavan uskomusjärjestelmän suuntaan. Kokonaisuuden ongelmaksi näyttää kuitenkinmuodostuvanyhäuudelleense, ettäainestenvariaationlisääntyessä kuva fragmentoituu: tihenee keskeltä ja laajenee reunoilta niin, että lopulta kokonaisuudesta on puhuttava metaforisesti keskeneräisenä mosaiikkina, fraktaaleina, merkitysprosesseina ja muuttuvina maailmankuvina. Tällaisen tieto-opin äärellä mytologit ja kosmologit nykyään kohtaavat. Avaruustähtitieteen emeritusprofessori Esko Valtaoja on Kaiken käsikirjassa (Ursa 2012, 203) arvioinut tieteellisten yksityiskohtien merkitystä seuraavaan tapaan: "Emme voi koskaan etukäteen tietää, mitä tulee tapahtumaan, mihin suurempaan kokonaisuuteen tämä tai tuo yksityiskohta yllättäen liittyykin tai mitä ne tulevatkaan paljastamaan: siksi kaikki on tutkittava, mahdollisimman tarkoin".

Suomalaisen mytologian tutkimuksella on ainutlaatuisen antoisa ja moniaineksinen oppihistoria Agricolan ajoista meidän päiviimme. On ollut inspiroivaa seurata M. A. Castrénin luentojen käännös- ja tulkintaprosesseja, joiden vaiheissa olemme useaan kertaan yhdessä ja erikseen hämmästelleet sitä, miten ajankohtaisilta monet hänen esittämänsä kysymykset ja tulkinnat nyt vaikuttavat, ja miksi samat asiat välillä ovat olleet pitkiäkin aikoja varjossa. Vanhoja mytologian esityksiä luetaankin uusien esitysten valossa ja opastamina. Tämän käännöksen myötä Castrénin kirjaamat ainekset, ajatukset ja tulkinnat suomalaisesta mytologiasta ovat nyt entistä paremmin nykyisen suomenkielisen yleisön tavoitettavissa ja uusien ideoiden lähteenä.

Kalevalaseuran Castrén-piiri

Seppo Knuuttila

Joonas Ahola

Karina Lukin

Elina Lampela

Ulla Piela 



\section{Matthias Alexander Castrénin suomalaisen mytologian taustoja}

Johdanto

Matthias Alexander Castrénin (1813-1852) Luentoja suomalaisesta mytologiasta (Föreläsningar i Finsk mytologi) on suomalaisen ja suomalais-ugrilaisen esikristillisen uskomusjärjestelmän juurten uraauurtava historiallinen ja vertaileva yleisesittely, jonka Castrén kirjoitti syksyllä 1851 pitämänsä luentosarjan aineistojen pohjalta ja tulevien luentojen käsikirjoitukseksi. Teos on julkaistu alkukielellään ruotsiksi vuonna 1853 Carl Gustav Borgin toimittamana ja saksaksi Anton von Schiefnerin kääntämänä ja toimittamana vuonna 1853 nimellä M. Alexander Castrén's Vorlesungen über die finnische Mythologie. Suomeksi sitä ei ole aiemmin julkaistu.

Castrén on tunnettu ennen muuta kielitieteilijänä, joka teki tärkeää perustutkimusta Aasian kielten dokumentoijana ja tutkijana (esim. Karttunen 1994, 161; Korhonen 1986, 34-35). Ajan tiedemiesten tapaan hänenkin kiinnostuksenkohteensa ulottuivat kuitenkin laajalle alueelle, myös hänen tutkimiensa kieliryhmien kansankulttuurin eri osa-alueille. Mytologiantutkimus ylipäätään ja eritoten suomalaisten menneisyyden tutkimus oli lähellä Castrénin sydäntä jo hänen opintojensa alkuvaiheista alkaen. Kimmokkeena Castrénin kiinnostukseen oli ennen muuta yliopistossa vaikuttanut suomalaiskansallinen aatemaailma, jota vuonna 1835 julkaistu Kalevalan ensimmäinen painos oli entisestään innoittanut.

Ilmestymisensä aikaan Castrénin teos oli erittäin tärkeä ja arvostettu, sillä se vei keskustelua suomalaisesta mytologiasta ja sitä kautta suomalaisuuden juurista tieteellisesti perustellulle pohjalle aiempien ideologisesti värittyneiden, paljolti intuitioon perustuneiden kannan- 
ottojen sijaan. Teos jäi 1800-luvun lopun jälkeen sivuun suomalaisen mytologian tutkimuksen keskiöstä, koska Castrénin korostettiin käyttäneen kansanrunousaineistona suurelta osin Elias Lönnrotin kokoamaa Kalevalaa ja muita julkaistuja lähteitä, eikä hänen sen vuoksi katsottu tukeutuneen sellaisiin kansanperinteen tallenteisiin, jotka olisivat täyttäneet myöhemmät etnografisen tutkimuksen kriteerit. Castrénin mytologialuentojen suurimmat ansiot nykypäivän näkökulmasta ovat nimenomaan etnografisen ja filologisen tutkimuksen poikkikulttuurisessa lähestymistavassa, joka aloitti suomalaisen mytologian varsinaisen vertailevan tutkimuksen suhteessa muiden suomensukuisten kansojen uskomusjärjestelmiin. Eritoten siksi luennoilla on merkittävä asema mytologiantutkimuksen historiassa. Mytologialuennot ovat innoittaneet ja ohjanneet monia tutkijoita vertailevan mytologian, kansanuskon, šamanismin ja pyhien paikkojen tutkimuksen äärelle.

Tässä johdantoartikkelissa tarkoituksemme on tulkita ja kuvata teoksen taustoja, joita vasten on mahdollista ymmärtää paremmin Castrénin pohdintoja. Käsittelemme Castrénin henkilöhistoriaa ja akateemista ympäristöä sekä sitä yhteiskunnallista keskustelua, jota hänen aikanaan Suomessa käytiin. Castrén ei esittele teoreettisia ja metodisia lähtökohtiaan, joten ne on tulkittava luentoteksteistä. Peilaamme tätä taustaa Castrénin aikana Suomessa, Venäjällä ja Euroopassa käytyä akateemista keskustelua vasten, jotta luennoista ilmeneviä ajatuksenjuoksuja ja tutkimustuloksia olisi helpompi hahmottaa tämän päivän näkökulmasta.

\section{Castrénin lyhyt elämäkerta}

Vuonna 1813 syntynyt Matthias Alexander Castrén on kotoisin Tervolasta ja paikallisen kappalaisen Kristian Castrénin poika. Ruotsinkielisessä perheessä kasvanut Castrén kävi koulunsa suomenkielisessä Oulun triviaalikoulussa. Castrén kirjoittautui Suomen Keisarilliseen Aleksanterin yliopistoon Helsinkiin vuonna 1830. Yliopistossa hän oli Lauantaiseuran jäsen ja toimi aktiivisesti Pohjalaisen osakunnan piirissä, missä hän tutustui kansallismielisiin aktiiveihin, joista esimerkiksi Runeberg, Topelius ja Nervander kohosivat sittemmin 
huomattaviksi nimiksi. Opintojensa aikana Castrén solahti ajan "pienoismaailmaan", "jonka jäsenet jokseenkin kaikki tunsivat toisensa ja olivat jossakin, usein sukulaisuussuhteessakin toisiinsa" (Karkama 2001, 48).

Kalevalan julkaiseminen vuonna 1835 herätti monien aikalaisten tavoin Castrénissakin innon omistautua "Suomen heimon ja sen sukulaisten kielten, uskonnon, tapojen ja muiden kansatieteellisten seikkojen tutkimiseen", kuten Castrén kirjoitti vuonna 1849 kokoamissaan matkakirjoituksissa (Castrén 1870a [1852], 4; suom. Joki 1953, 6). "Suomen heimon", käytännössä suomen sukukieliä puhuvien yhteisöjen tutkimuksen lisäksi Castrén halusi myös selittää ja täydentää Kalevalaa. Tehtävä edellytti "runsaamman ja luotettavamman aineiston kuin kirjallisuuden tarjoaman materiaalin hankkimista, ja tätä varten olisi pakko tehdä tutkimusmatkoja Euroopan ja Aasian eri osiin." (Castrén 1870a [1852], 4.) Castrén tekikin ensimmäiset kenttämatkansa saamelaisten parissa jo vuonna 1838. Vuonna 1839 Castrén työsti Kalevalasta ruotsinnosta ja matkasi Suomalaisen Kirjallisuuden Seuran tuella Venäjän Karjalaan kokoamaan "selvityksiä Kalevalaan" ja "lisiä Suomalaista Mytologiaa varten". Castrén oli kiinnostunut erityisesti jumalaistaruista, vanhemmista historiallisista kansantaruista ja saduista, joita Lönnrot ei ollut kerännyt, sillä hän oletti näiden, erityisesti satujen, valaisevan myös mytologiaa. (Castrén 1904, 3-4.) Matkansa aikana Castrén keräsi kuitenkin myös kalevalamittaista epiikkaa ja loitsurunoutta. Hän arveli niiden tarjoavan materiaalia, jota Lönnrot ei ollut vielä kerännyt (Castrén 1904, 11, 15).

Castrénin ruotsinnos Kalevalasta julkaistiin vuonna 1841. Samana vuonna hän matkusti yhdessä Elias Lönnrotin kanssa Lappiin, ja siinä missä Lönnrot palasi kotiinsa keväällä 1842, Castrén jatkoi matkaansa ensin Vienanmerellä ja sittemmin edemmäs itään Suomalaisen Kirjallisuuden Seuran 10000 ruplan avustuksen turvin. Castrénin matka kulki Venäjän Euroopan-puoleisen tundravyöhykkeen kyliä ja kauppapaikkoja niin maa- kuin jokireittejäkin pitkin Uralin vuoriston yli Obdorskiin (nyk. Salehard). Tuberkuloosin heikentämä Castrén matkasi Obdorskista Obia pitkin etelään Berezovin kylään, josta hän jatkoi Tobolskin ja Tjumenin kautta Suomeen.

Palattuaan Suomeen Castrén väitteli tohtoriksi syrjäänin (komin) kieliopilla. Vielä samana vuonna Pietarin akatemia nimitti hänet 
tutkimaan Länsi-Siperian kieliä ja kulttuureja. Vuosien 1845-1849 aikana Castrén teki varsin laajan tutkimusmatkan Länsi-Siperiassa, Sajanin vuoriston ja Baikal-järven ympäristössä hyvin raskaissa ja vaativissa oloissa, jotka vaativat hänen terveydeltään veronsa. Palattuaan pitkältä matkaltaan ja heikentyneen terveydentilansa lopulta niin salliessa Castrén ryhtyi saattamaan tekemiään tutkimuksia julkaisukelpoiseen kuntoon. Hänet nimitettiin suomen kielen ensimmäiseen professuuriin vuonna 1851. Syksyllä 1851 Castrén piti kahta luentosarjaa. Ensimmäinen, joka otsikon mukaan käsitteli altailaisten kansojen etnologiaa, on niin ikään julkaistu postuumisti. Toisen, nyt suomeksi julkaistavan luentosarjan hän piti suomalaisesta mytologiasta. Aulis J. Joki kuvailee luentosarjaa Föreläsningar i Finsk mytologi "Castrénin suomalais-ugrilaisten tutkimusten pääteokseksi" (Joki 1953, 12).

Castrén ei ehtinyt pitää luentosarjaansa suomalaisesta mytologiasta loppuun. Luennot julkaistavaksi toimittaneen Carl Gustav Borgin mukaan Castrén luennoi aiheesta kerran viikossa kahden ja puolen kuukauden ajan ja ehti päästä osaan "Maanalaiset jumaluudet" asti. Castrén kirjasi luentonsa tekstiksi luentojen kuluessa. Luentosarjan oli tarkoitus jatkua seuraavana lukukautena, ja Castrén työsti luentojaan talviloman aikana, mutta ei kyennyt enää poistumaan kotoaan kevätlukukauden alettua. Luentosarjan käsikirjoituksen Castrén saattoi loppuun kuolinvuoteellaan - viimeisen Kalevalan sankariepiikkaa koskevan luvun lyijykynällä, koska oli liian heikko kirjoittaakseen musteella - ennen menehtymistään tuberkuloosiin 7. toukokuuta 1852. Teksti on toisin sanoen osittain opiskelijoille esitettyä, mutta suurimmaksi osin puhtaasti kirjallista työtä. Opiskelijoille esitetyn tekstin suhteen on huomionarvoista, että Borgin muistelmien mukaan Castrén luki mytologialuennot suoraan paperilta (Borg 1853, 41) ja että Sjögrenille 5. marraskuuta 1851 lähettämässään kirjeessä Castrén pitää siihen asti kirjoittamaansa luentokäsikirjoitusta jo painokelpoisena (Sjögren 1854, 277). ${ }^{1}$

Luku "Ilman jumaluudet" (Luftens Gudomligheter) oli jo aiemmin julkaistu Suomi-sarjassa otsikolla Hvad beteckna i den finska mythologien orden jumala och ukko (Castrén 1851). Castrén oli käsitellyt suomalaiseen ei-kristilliseen uskontoon liittyviä asioita aiemmin myös Pohjalaisen Osakunnan juhlatilaisuuksissa pitämissään esitelmissä 
"Om Finnarnes Trollkonst" ('Suomalaisten noitataidoista', 1837; Castrén 1837a; 1837b) ja "Allmän öfversigt af Finnarnes gudalära och magi under hedendomen" ('Yleiskatsaus suomalaisten pakanuudenaikaiseen jumaloppiin ja magiaan', 1838; Castrén 1870b, 14-32). Näissä esitelmissä Castrén korosti, että Vanhan Kalevalan esittämissä runoissa heijastui luonnonuskonto. Keväällä 1841 Castrén luennoi Kalevalasta yleisölle, jonka joukosta nousi myöhemmin fennomaaniliikkeen keskeisiä hahmoja. Castrén ei siis luennoinut vuoden 1851 syksyllä ensimmäistä kertaa Kalevalaan kiinnittyvistä teemoista, mikä korostaa edelleen sitä, että mytologialuennoissa ei ollut kyse ainoastaan Kalevalan kommentoinnista.

\section{Suomalaisen mytologian luentojen rakenne}

Castrénin Föreläsningar i finsk mytologi palvelee tarkoitustaan suomalaiseen mytologiaan johdattavana luentosarjana etenkin käsitellessään ja arvioidessaan perusteellisesti aiempaa aihepiirin tutkimusta. Castrén ei kuitenkaan jää aiemman tutkimuksen esittelyn asteelle, vaan pyrkii rekonstruoimaan näistä ja muista lähteistä saadun tiedon varassa järjestelmän, jonka muinaissuomalaisten uskomukset, rituaalit ja myyttiset kertomukset ja hahmot muodostivat. Tämä järjestelmä rakentuu kuin muinaissuomalaista ajattelua ja ajatusmaailmaa kuvaava kielioppi. Samalla Castrén pyrkii järjestämään aiemmissa tutkimuksissa esitellyt, lähinnä 1700- ja 1800-luvuilla kootut kansanuskon ilmentymät uskontohistorialliseen järjestykseensä. Castrénin lähestymistapa oli aikanaan eurooppalaisen tutkimuksen aallonharjalla. Hän rakensi tutkimuksensa aiemman tutkimuskirjallisuuden ja omien kenttätyökokemustensa varaan soveltaen keskieurooppalaisen ja venäläisen etnografisen tutkimuksen ja kielentutkimuksen uusimpia menetelmiä. Kyseessä ei ole ainoastaan suomalaisten vaan myös laajemmin suomensukuisten kansojen mytologia, vaikka tekstin lähtökohtana ovatkin suomalaisuuden juuret.

Teos rakentaa kuvaa suomalaisesta mytologiasta kolmen aihepiirin kautta: yliluonnollisten olentojen kuvauksen, vertailevan etnografian ja sankariepiikan. Kirjan ensimmäinen ja toinen osa luettelevat suomalaisia esikristillisiä jumaluuksia. Castrén käsittelee jumaluuksien 
alkuperää, tehtäviä ja tehtävänjakoa lähtökohtanaan pitkälti aiempien mytografien tekstit, joiden perusteella muotoutuvaa kuvaa hän täydentää kalevalamittaisen rituaalirunouden, vertailevan kielitieteen ja uskonnon varhaismuotoja koskevien teorioiden avulla. Castrén luettelee suomalaisen mytologian jumaluuksia alkaen taivaassa majailevasta Jumala- tai Ukko-nimisestä ylijumalasta, jolle alisteisiksi hän katsoo kaikki muut jumaluudet. Hän jaottelee jumaluudet luonnonilmiöiden tai elementtien mukaisesti ilman, veden ja maan jumaluuksiin ja näiden lisäksi kuolemanjälkeisessä elämässä hallitseviin maanalaisiin manalan jumaluuksiin. Castrén erottelee näihin kategorioihin lukemansa jumaluudet edelleen keskenään hierarkkisesti jaettuihin ryhmiin: 1) pääjumaliin ja näiden perheenjäseniin, jotka hallitsivat eri luonnonelementtejä (ilma, vesi, (metsä), maa), 2) pääjumalten palvelijoihin eli jumaliin, jotka hallitsivat joitakin eri elementtien osatekijöitä (eläinlajia, puulajia jne.) mutta joka tapauksessa laajempia luonnon osia kuin 3) haltiat ja maahiset, jotka olivat eteerisempiä, jossain määrin personoitumattomia yksittäisten kohteiden suojelusjumalia (ks. s. 152, 190-193). Näiden lisäksi näkymättömiin, ihmisen elämään vaikuttaviin voimiin kuuluivat 4) kuolleiden henget, joista eritoten väkevien šamaanien henkiä pidettiin vaarallisina, 5) elävien ihmisten henget ja 6) sairaudenhenget (ks. s. 161-165, 194).

Castrénin mukaan suomalainen mytologia kehittyi luonnonilmiöiden palvonnasta. Ensin personifioitiin väkevät, pelottavat luonnonilmiöt itsessään, ja vasta myöhemmin jumaluuksien tulkittiin olevan luonnonilmiöistä erillisiä, niihin vaikuttavia voimia. Palvonnan kohde siis vaihtui itse luonnonilmiöstä sen takana vaikuttavaan voimaan, jumaluuteen. Hiljalleen jotakuinkin kaikkiin luonnonilmiöihin ja -kohteisiin liitettiin persoonalliset jumaluutensa, joihin saatettiin vedota vahinkojen välttämiseksi ja menestyksen saavuttamiseksi. (ks. s. 97-98, 190-191.) Jumaluuksien ja henkiolentojen määrä kasvoi aikojen kuluessa, ja niitä alettiin pitää keskenään eriarvoisina samaan tapaan kuin yhteiskunnassa oli eriarvoisia ihmisiä: isäntiä, emäntiä ja näiden erilaisia palvelijoita. Tämä lähes feodaalinen hierarkia ulottui vähäisimpiin, yksittäisiin kohteisiin liitettyihin henkiolentoihin asti. Castrén tulkitsee hierarkian viittaavan mytologian luoneen kansan yhteisölliseen rakenteeseen, mikä oli 1800-luvun puolivälissä varsin tuore ajatus: vastaavat ajatukset nousivat valtavirtaan vasta struktura- 
listisen tutkimussuunnan nousun myötä 1900-luvulla. (ks. s. 115-116, 134-135.) Yhteisöllisten olojen lisäksi mytologian muotoutumiseen vaikutti Castrénin mukaan myös elinympäristö; paikallisten luonnonolojen ja elinkeinojen vuoksi suomalaisessa mytologiassa oli keskeisessä asemassa luontevammin metsästykseen ja kalastukseen kuin maanviljelykseen liittyviä jumaluuksia (ks. s. 143-144).

Teoksen kolmas osa käsittelee uskomusjärjestelmän ritualistista ja etnografista puolta. Tämä osa perustuu hyvin pitkälti vertaileviin etnografisiin huomioihin, joita Castrén tekee sekä omien kenttätyöhavaintojensa että venäläisen ja saksalaisen etnografisen tutkimuskirjallisuuden pohjalta. Castrén kuvaa, kuinka suomalaiset ja heidän sukukansansa ovat palvoneet yksittäisiä luonnonmuodostumia, puita ja eläimiä, eritoten karhua. Palvontapaikkojen pyhyydestä on merkkejä esimerkiksi paikannimissä (ks. s. 129-130, 223). Tässä osassa Castrén myös pohtii hahmottamaansa jumalolentojen hierarkkista järjestystä ritualistiselta kannalta. Koska jumalat olivat etäisiä, ylivoimaisen mahtavia olentoja, niiden puoleen oli usein vaikea kääntyä suoraan. Tämän vuoksi esimerkiksi suomensukuisten kansojen parissa on tavallisempaa pyrkiä vaikuttamaan alempiin jumaluuksiin ja henkiin, jotka ovat lähempänä ihmisiä. (ks. s. 213-216.) Castrén siis liittää mytologian kehittymisen myös uskonnon rituaaliseen puoleen, mutta hän ei päättele havaintonsa perusteella alempien henkiolentojen edeltäneen ylempiä "elementtijumaluuksia", vaikka siihen olisi ollut perusteita Castrénin soveltamassa uskonnollisuuden kehittymistä koskevassa teoreettisessa viitekehyksessä (ks. s. 50-54). Tämäkin esimerkki asettaa Castrénin metodologiassa rituaalit todistusvoimaltaan kielellistä aineistoa vähäisemmälle sijalle.

Koska suomalaisten vanhoista palvontamenoista, palvonnan kohteista ja pyhistä paikoista on olemassa vain vähän tietoja, Castrén käsittelee hyvin pitkällisesti saamelaisten ja muiden suomensukuisten kansojen palvontamenoja ja nojaa vahvasti saagakirjallisuudessa mainittuun bjarmien jumalkuvaan nimeltään Jomali ja siihen liitettyihin palvontamenoihin. Kolmatta osaa teoksesta voi hyvällä syyllä kutsua tutkimukseksi nimenomaan suomalais-ugrilaisesta - tai altailaisesta - uskonnollisesta elämästä pikemmin kuin suomalaisesta. Castrén kuvaa eri kansojen jumalkuvia ja pyhiä paikkoja erittäin yksityiskohtaisesti ja vertailee niitä oivaltavasti, mutta ei tee vertailunsa 
pohjalta juurikaan varsinaisia johtopäätöksiä suomalaisen mytologian suhteen.

Teoksen neljäs osa keskittyy kalevalamittaiseen sankarirunouteen lähinnä Kalevalan pohjalta. Osassa on pitkiä Kalevalan juonta ja henkilöhahmoja kuvailevia jaksoja. Neljännessä osassa Castrén pohtii ennen muuta kysymystä sankarirunojen mahdollisesta myyttisestä alkuperästä. Castrén aloittaa aiheen käsittelyn vertailemalla kalevalamittaista sankariepiikkaa (josta Kalevala pääasiassa koostuu) sukulaiskansojen sankaritraditioihin ja päätyy näiden vertailujen perusteella Lönnrotin tapaan pitämään Väinämöistä, Ilmarista ja Lemminkäistä pohjimmiltaan ihmishahmoina eikä myyttisinä jumalhahmoina, kuten toinen vallitseva aikalaisnäkemys esitti. Hän ei kuitenkaan pidä kertomuksia historiallisina eli todellisista tapahtumista tai henkilöistä kertovina. Castrén pikemminkin näkee eeppisten runojen kuvaavan syntyaikojensa yhteisöllisiä oloja: eritoten runot luoneen yhteisön suhteita naapuriryhmään ("Pohjolan kansaan") ja tuolloin vallinneita kosintatapoja. Toisaalta Castrén näkee Kalevalan sankareiden ja skandinaavisten jumalten sekä näistä kertovien myyttien välillä yhtäläisyyksiä, joiden perusteella hän on taipuvainen pitämään samaisia hahmoja myös jumalallisina. Lopulta hän ei pysty tai edes pyri päättämään, onko jompikumpi näkökannoista toista oikeampi, vaan ikään kuin haastaa lukijan tekemään johtopäätöksensä itse tarjoamansa aineiston pohjalta.

Sama tendenssi leimaa koko teosta: Castrén käsittelee eri aihepiirejä erittäin seikkaperäisesti ja syvällisesti, mutta ei tee huomioistaan ja pohdinnoistaan juurikaan johtopäätöksiä. Hän hahmottelee mytologisen järjestelmän osia ja näiden kehityshistorioita ja suhteita naapurikulttuureihin, mutta pidättäytyy piirtämästä järjestelmästä ja sen kehityshistoriasta kokonaiskuvaa. Ei voi epäillä, ettei hänellä olisi ollut kykyä ja halua hahmotella ainakin jonkinlainen synteesi esittämistään analyyseistä. Syyt yhteenvedon puuttumiselle jäävät arvuuttelun varaan. Mahdollista on, että Castrén ei nähnyt yhteenvetoa alun alkaenkaan tarpeelliseksi, sillä hänen kuvaamansa mytologian järjestelmä on kuin kielioppi: kokonaisuus on kuvattavissa vain osiensa kautta. Castrénin käyttämässä aineistossa on mytologian historian hahmottamisen suhteen taas niin paljon aukkoja, että kokonaiskuvan 
saavuttaminen on ollut vaikeaa. On myös mahdollista, että Castrénilta loppui aika kesken. Loppua kohden kirjan teksti muutenkin tiivistyy ja suoraviivaistuu, mikä kertonee kirjoittamisen vaikeutumisesta.

\section{Mytologialuentojen keskusteluympäristö ja lähdeaineistot}

Castrén piti mytologialuentonsa Suomen suuriruhtinaskunnassa, joka luotiin vuoden 1809 Porvoon valtiopäivillä. Venäjä oli koko 1800luvun ajan vaihtelevan suopea suomalaisille kulttuurisille pyrkimyksille ja suomen kielen kehittämiselle, kunhan ne eivät olleet luonteeltaan nationalistisia eli itsenäisyyteen pyrkiviä. Suomalainen älymystö keskustelikin avoimesti suomen kielen asemasta, Suomen historian luonteesta ja sen kirjoittamisen tarpeesta sekä kansanrunoudesta ja -kulttuurista. Keski-Euroopan vuosien 1848-1849 vallankumousliikehdintä sai vallanpitäjät Venäjälläkin varpailleen, mikä näkyi esimerkiksi vuonna 1850 voimaanpannussa sensuurimääräyksessä, joka rajoitti suomen kielen käyttöä. Venäläisyyden ja venäjän kielen korostaminen huolestutti älymystöä, erityisesti J. V. Snellmania, joka toivoi Castréninkin ryhtyvän käytännön toimiin suomen kielen puolesta sanakirjojen ja kielioppien kirjoittamisen sijaan. (Klinge 1986, 19, 133-136; Karkama 2001; Virtanen 2002, 78-82.) Castrén vastasi vetoomukseen kirjeellä, joka huojensi Snellmania ja auttaa myös taustoittamaan mytologialuentojen välittämää ajatusmaailmaa:

[...] Olen päättänyt osoittaa Suomen kansalle, ettemme me ole maailmasta ja maailmanhistoriasta erillään elävä yksinäinen suomaan kansa, vaan olemme sukulaisuussuhteessa ainakin kuudesosaan ihmiskunnasta. Ei kielioppien aikaansaaminen ole tärkein tavoitteeni, mutta ilman kielioppeja tavoitteeseen ei päs̈stä. (Castrén 1844.) ${ }^{2}$

Kirje tuo esiin, että Castrénin tieteellinen toiminta nivoutui ajan politiikkaan, vaikka hän vältteli poliittisia kannanottoja tutkimusteksteissään. Se, että Castrén kirjoitti luennot ruotsiksi, vaikka olisi kyennyt epäilemättä kirjoittamaan ne myös suomeksi, ei liittynyt hänen poliittisiin näkemyksiinsä. Vanhastaan ruotsinkielisessä Keisarillisessa 
Aleksanterin yliopistossa alettiin luennoida suomeksi vasta 1850luvun lopulla, ja vuoden 1850 kieliasetus olisi estänyt joka tapauksessa luentojen julkaisemisen suomeksi.

Tarkastelemme seuraavassa Suomalaisen mytologian luentojen sisältöä ja Castrénin luentojen aineistoja, niin aiempia mytologian hahmotuksia kuin hänen kenttätöitäänkin, suhteessa niihin tutkimusperinteisiin, joihin Castrénin työ selkeästi kiinnittyy ja joiden kanssa se keskusteli - mahdollisesti myös ilmestymisensä jälkeen. Olemme lähteneet siitä, että vaikka Kalevalan runot ovat teoksessa keskeisessä osassa, työn päämääränä on ollut kurottaa historiallisesti ja maantieteellisesti Kalevalan ja kalevalamittaisen runon tuonne puolen niin aineistojen kuin akateemisten keskustelujenkin suhteen. Kalevalan roolia mytologialuentojen taustalla ei ole kuitenkaan syytä ohittaa, minkä vuoksi luomme katsauksen myös niihin Castrénille ajankohtaisiin Kalevalaa käsitelleisiin keskusteluihin, joihin teos ottaa kantaa.

\section{Historiallinen Kalevala - keskusteluja ennen mytologialuentoja}

Friedrich Rühs kirjoitti lähinnä Gananderin Mythologia Fennican pohjalta kuvauksen suomalaisesta mytologiasta teokseensa Finland und Seine Bewohner (1809; ruots. Finland och Dess Invånare, 1811), johon kansanrunoutta kerännyt ja tutkinut Carl Axel Gottlund kirjoitti pitkän vastineen kirja-arvostelussaan Swensk Literatur-Tidningissä 1817. Kirjoituksessaan Gottlund pyrkii kumoamaan Rühsin esittämät, lähinnä tämän Gananderilta lainaamat ajatukset erilaisten epäjumalten palvonnasta muinaissuomalaisten keskuudessa. Gottlund toteaa, että suomalaisessa mytologiassa erisnimi Jumala on merkinnyt, saksalaisen uskonnonfilosofian käsittein, "absoluuttisen subjektiivista subjekti-objektiviteettia" ${ }^{3}$ eli maailmankaikkeuden takana olevaa ykseyttä (vrt. Schröter 1819, xiix). Yksi toisensa jälkeen Gottlund kumoaa Rühsin (ja Gananderin) luettelemien jumalolentojen jumalallisuuden ja esittää näiden olleen luonnollisia olentoja ja historiallisia henkilöitä, jotka vasta myöhemmän tradition sekaantumisen vuoksi on käsitetty muinaisiksi jumaluuksiksi. ${ }^{4}$ Vaikka Castrén viittaa panteistisiin käsityksiin jossain määrin vastaavin ajatusmallein kuin Gottlund puhuu Jumalasta (ks. s. 98), hän ei näytä ottaneen Gottlundin näkemystä varsinaisesti huomioon mytologialuennoissaan. 
Yhdessä Poppiuksen, A. I. Arwidssonin ja A. J. Sjögrenin kanssa Gottlund avusti sittemmin Hans Rudolf Schröteriä julkaisemaan suomalaisia kansanrunoja saksankielisine käännöksineen teoksessa Finnische Runen (1819). Teoksen avausruno on luomisruno, jossa Väinämöinen esiintyy maailman luojana. Sitä seuraavat loitsurunot ja synnyt ovat keskeisimmällä sijalla, koska ne kuvaavat eri ilmiöiden myyttistä alkuperää. Teoksen jälkimmäinen osa sisältää lähinnä kansanlyriikkaa ja balladirunoja. Teos kuvastaa yhtäältä kalevalamittaisen kansanrunouden moninaisuuden arvostusta, toisaalta myyttisille aiheille osoitettua erityiskiinnostusta.

1800-luvun alkupuolella suomalaisissa sanomalehdissä oli ilmestynyt jonkin verran kirjoituksia liittyen suomalaiseen mytologiaan. Nykypäivänä erikoiselta vaikuttava julkaisukanava johtui siitä, että varsinaisia tieteellisiä lehtiä ei kulttuurintutkimuksen alalla juuri ollut, mutta myös siitä, että suomalaisten omaan menneisyyteen liittyvä kiinnostus oli usein poliittisesti motivoitua, minkä vuoksi siihen liittyvät näkemykset pyrittiin saamaan mahdollisimman laajan yleisön saavutettavissa olleisiin julkaisuihin. Näin ollen Reinhold von Becker kirjoitti Turun Wiikko-Sanomiin artikkeleita, joissa pohti kalevalamittaisen runouden aiheita pitäen runoja lähinnä suomalaisten menneisyyttä kuvaavina teksteinä. Hän esimerkiksi piti kansanperinteessä tavattuja, peikonomaisia "turilaiksi" kutsuttuja olentoja historiallisena ihmisryhmänä (Becker 1820a) sekä Ukkoa ja Väinämöistä historiallisina henkilöinä, joista etenkin Väinämöistä "yksinkertainen kansa" alkoi von Beckerin mukaan pitää puolijumalana tämän tietoviisauden ja kyvykkyyden vuoksi (1820b). Vielä saman vuoden kuluessa von Becker (1820c) esitteli suomalaisten sukulaiskansoja ja esitti ostjakkeja (hanteja) ja suomalaisia vertaillessaan, että ostjakkien häätavat vastasivat muinaissuomalaisten häätapoja. Tämä väite näyttäisi kiinnostavasti toistuvan Castrénin näkemyksessä siitä, että Kalevalan runouden toinen pääaihealue, kosintarunot, kuvaavat menneisyyden sosiaalisia oloja ja käytänteitä (ks. s. 262-265).

Castrén viittaa Zachris Topelius vanhemman teossarjassa Suomen Kansan Vanhoja Runoja, ynnä myös Nykyisempiä Lauluja (18221831) julkaisemiin runoihin joitakin kertoja, mutta ei ota sen enempää kantaa Topeliuksen teostensa esipuheissa (eritoten 1. ja 2. osa) 
esittämiin ajatuksiin esimerkiksi runojen alkuperästä, siirtymisestä tai olemuksesta historiallisina lähteinä.

Anonyymiksi jättäytynyt kirjoittaja julkaisi Helsingfors Morgonbladissa 95-96/1836 artikkelin "Några ord om Kalevala". Artikkelin kirjoittaja viittaa tuoreeseen saksalaiseen tutkimukseen, jossa kootaan kansankertomuksia ja selitetään niiden pohjalta kansallisia muistomerkkejä. Kirjoittaja esittää, että Kalevalassa "alkuperäinen ja kotoperäinen suomalaisten kansanluonne on tallentunut samoin kuin vanhimmat heidän uskonnollisista käsityksistään” (nro 95, s. 3). Kirjoittaja esittää Väinämöiselle osoitettujen loitsujen perusteella, että runot ovat mytologiaa eivätkä historiaa kuten "doctor Lönnrot" esittää, ja tulkitsee niitä valon ja pimeyden välisenä taisteluna (nro 96, s. 3). Anton von Schiefner, joka toimitti Castrénin jälkeensä jättämät tutkimukset julkaisuiksi, olettaa Castrénin artikkelin kirjoittajaksi, mutta Jouko Hautalan (1954, 140-142) mukaan E. N. Setälä on osoittanut vakuuttavasti, että kirjoittaja oli joku muu. Sekaannus tai ei, tapaus osoittaa Castrénin keskeisen roolin Kalevalan tulkinnoista käydyissä keskusteluissa. Myös Castrénin mytologialuennot ottivat osaltaan kantaa kysymykseen Kalevalan historiallisuudesta.

Kuten Pertti Karkama on osoittanut, Elias Lönnrotin käsitys kokoamansa Kalevalan historiallisesta arvosta muuttui vanhan ja uuden Kalevalan välissä. Lönnrotille Kalevala oli "historiallisesti tosi", toisin sanottuna se esitti suomalaisten menneisyyden kansatieteellisesti ja historiallisesti todenmukaisesti. Ensimmäisen laitoksen kokoonpanossa korostui kuitenkin myös Kalevalan "luonnollinen totuus", joka heijastaa kansan kertomien myyttien ja uskomusten jatkumoa. Kalevalan toisessa laitoksessa Lönnrot päätyi esittämään näkemyksensä tästä luonnollisesta historiasta, mutta samalla hän väittää, että kansan myyttinen historia oli päättynyt kristinuskon saapumiseen. (Karkama 2002.) Näin Lönnrot jätti eepoksen tulkintoihin historiallisten ja myyttisten tulkintojen siemenet.

Fabian Collan julkaisi Helsingfors Morgonbladissa vuonna 1838 useassa eri numerossa artikkelin nimeltään "Wäinämöinen och Ilmarinen", jonka hän esitteli otteina laajemmasta suomalaista mytologiaa käsittelevästä tutkielmastaan. Artikkelissa Collan käsittelee Kalevalan runoja vertauskuvina hyvän ja pahan välisestä taistelusta: "Sota lappalaisten kanssa, siinä määrin kuin sitä käsitellään eeppisissä lauluissa, 
on ymmärrettävä eettisenä myyttisenä sotana, ei historiallisena" (nro 59, 7). Collan on huolissaan siitä, että ilman oikeaa ymmärrystä Ukosta, Väinämöisestä ja Ilmarisesta käsitys suomalaisten muinaisuskosta jää olemattomaksi tai sen kuvitellaan olleen "typerää fetisismiä" (usel fetischism) (nro 56, 1). Collan todistelee Ilmarisen ja Väinämöisen jumaluutta pitkään kautta tutkielman ja esittää, että vasta myöhempinä aikoina nämä olisivat muuttuneet runoissa ihmisiksi. Castrén ei hyväksynyt myyttisten runojen eettisiä tulkintoja (ks. s. 269-270), mutta mytologialuentojensa viimeisillä sivuilla hän esittää Collania mukailevasti, että Väinämöinen, Ilmarinen, Lemminkäinen ja Louhi olisivat tosiaan saattaneet degeneroitua jumaluuksista sankareiksi (ks. s. 298-300).

Jacob Grimm käsitteli Kalevalan mytologiaa esitelmässä "Über das finnische Epos”, jonka hän piti Berliinin keisarillisessa akatemiassa vuonna 1845. Esitelmän ruotsinnos julkaistiin Suomessa vielä samana vuonna otsikolla "Om det Finska Epos" (Grimm 1845). Castrén ei viittaa tekstiin, mutta J. V. Snellman oli kertonut siitä hänelle kirjeessään 23. lokakuuta 1845 ja maininnut Lönnrotin saaneen alkuperäistekstin käsiinsä (Snellman 1845). Lisäksi Castrénin hyvä ystävä Robert Tengström oli toimittajana julkaisusarjassa, jossa teksti Suomessa julkaistiin. Castrénin voi siis olettaa tunteneen Grimmin esitelmän, ja mytologialuennoissa onkin tunnistettavissa kaikuja Grimmin ajatuksista. Esitelmässään Grimm kiinnittää huomiota esimerkiksi siihen, että sammon valmistusainekset ovat peruselintarvikkeita, ja esittää, että sampo olisi ollut onnea tuottava talismaani (Grimm 1845, 75-76; vrt. myös Grimm 1844, 1229). Myös Castrén kiinnittää huomionsa samoihin seikkoihin (ks. s. 265-266). Grimm esittää myös väitteen, johon Castrén ottaa varsin perusteellisesti kantaa mytologialuentojensa luvussa "Sankarit": Grimmin mukaan Väinämöinen, Ilmarinen ja Lemminkäinen ovat "epäilyksettä todellisia jumalia ja muodostavat kolmikon, joka, joskaan ei täysin yhtäpitävästi, muistuttaa vastaavia toisissa mytologioissa” (Grimm 1845, 89). Castrén pyrkii sovittamaan ajatusta näkemykseensä sankareiden kehittymisestä jumaluuksista, mutta lopputulos ei ole kaikkein selkeimpiä osia Castrénin teoksessa (ks. s. 298302). Grimm esittää Kalevalan sankareille useita yhteyksiä skandinaaviseen ja germaaniseen traditioon nimistöä myöten. Esimerkiksi Väinämöisen hän esittää vastaavan skandinaavien Odinia (Grimm 1845, 92), mikä vastaa myös Castrénin teoksensa lopulla esittämää käsitystä. 
Johan Robert Tengström (1823-1847) julkaisi Pohjalaisen osakunnan Joukahainen-julkaisusarjan toisessa osassa artikkelin "Finska folket, såsom det skildras i Kalevala" (Tengström 1845). Artikkelissa Tengström pohtii suomalaisen esikristillisen uskonnon kehitystä lähinnä mukaillen saksalaisen filosofin Georg W. F. Hegelin teoriaa uskonnollisen ajattelun kehittymisestä. Tengströmin mukaan "luonnonihminen" havahtui luonnossa näkymättömien voimien olemassaoloon vaikeuksien ja luonnonmullistusten äärellä. Pyrkimys hallita luonnonoloja johti magian syntyyn, ja kehittyvä mytologia muodostui paljolti loitsuista. Talismaanit olivat magiassa keskeisiä, sillä tämä "fetissi-uskonto" ei erottanut jumalallista voimaa asiasta, johon voima oli kiinnittynyt. Sampo oli Tengströmin mukaan tällainen talismaani. Uskonnollisen ajattelun seuraava taso oli elementtijumaluuksien (elementäriska gudamakter) palvonta, jossa elementtien eri muotoja saatettiin palvoa jumaluuksina (esimerkiksi joella, koskella ja merellä oli omia veden jumaluuksiaan). Uskonnollisen ajattelun seuraava taso oli eläinten, suomalaisessa muinaisuskossa eritoten karhun palvominen:

Eläin on vapain itsenäinen olento, johon luonto voi kohota; se on mikrokosminen totaliteetti, jossa luonnon kaikki muodot yhdistyvät eläväksi kokonaisuudeksi, organismiksi, joka käsittää itsessään kaiken, mitä sen ulkopuolella on erillään siitä. Siksi niiden [eläinten] palvonta muodostaa korkeimman tason, johon luonnonuskonto yltää. (Tengström 1845, 143-144.)

Uskonnon kehittymisen ylin taso olisi ollut monoteismi, mihin suomalainen muinaisusko Tengströmin mukaan ei kuitenkaan ehtinyt yltää ennen kristinuskon omaksumista.

Robert Tengströmin pohdinnat muistuttavat paljolti muodoltaan ja osin sisällöltäänkin Castrénin pohdintoja uskonnollisen ajattelun kehittymisestä. Castrén näki kehityskulun kuitenkin hiukan toisin, mahdollisesti osin sen kritiikin vuoksi, jota J. V. Snellman osoitti Tengströmin ajatuksia kohtaan lehdessään Saimassa (1846a, nro 8-9). Snellmanin mukaan esimerkiksi persoonallisten jumalten synty vasta uskonnon magiavaiheen jälkeen ei ole luultavaa, sillä loitsuissa vedotaan juuri näihin jumalhahmoihin. Tengströmin päätelmät perustuvat Snellmanin mukaan katteettomille arvioille eri runojen 
suhteellisesta iästä. Kalevalassa ei myöskään ole merkkejä fetissien palvonnasta, mutta Auringon, Kuun ja tähtien palvonnasta siinä on paljon viitteitä. Ukko on valtajumalana selkeä ylijumala, mikä on Snellmanin mukaan merkki monoteistisistä käsityksistä. Verraten muinaissuomalaista kulttuuria muinaiseen kreikkalaiseen kulttuuriin Snellman korostaa lopuksi, että suomalaiset olivat aivan riittävän korkealla kulttuurisella tasolla kyetäkseen kehittyneeseen uskonnolliseen ajatteluun. Snellmanin hyökkäys vaikuttaa suomalaisuusaatteen puolesta tehdyltä, mutta se on silti yllättävän raju ottaen huomioon hänen ja Tengströmin välisen lämpimän kirjeenvaihdon ja sen, että myös Tengström oli aktiivinen suomalaisuusmies.

Robert Tengström julkaisi samana vuonna 1845 suomalaisten menneisyyttä käsittelevän artikkelin, jossa hän pohtii edellisessä artikkelissaan esittämänsä mytologian ajoittumista. Artikkelissa hän käsittelee eeppistä runoutta lähteenä historiallisten olojen tutkimukselle ja esittää, että eepokset kuvastavat syntyaikansa miljöötä ja henkeä, sillä ne on sepitetty todellisuuden ja todellisten tapahtumien pohjalta. Tengström erottelee Kalevalassa esiintyviä hahmoja sankareiksi ja luontojumaluuksiksi ja korostaa eeposten kuvaavan kansoille merkittäviä sotia: "Mikäli Kalevalasta halutaan välttämättä löytää jokin yleinen kansallinen pyrintö, jolla olisi historiallista pohjaa, siinä on epäilemättä helpointa nähdä se, kuinka suomalaiset alistavat pohjoiset naapurinsa lappalaiset” (Tengström 1845b, 132). Tengström ajoittaa kalevalamittaisen runouden synnyn ja sitä myötä myös runouden heijasteleman mytologian ajalle 400-1300 jaa. Ajoituksessaan Tengström vetoaa käsityksiin, joiden mukaan karjalaiset saapuivat asuinpaikoilleen vuoden 400 tienoilla ja kristinusko saapui kyseisille alueille vuoden 1300 tietämissä. Hän huomauttaa kuitenkin, että monet kertomusten elementit viittaavat runouden taustalla olevien käsitysten tätä paljon korkeampaan ikään. Varsin modernilta kuulostaa Tengströmin ajatus, että vaikka runoja ei voi käyttää ulkoisesta historiasta kertovana lähteistönä, ne kertovat sisäisestä (eli kulttuurisesta kehitys-) historiasta paljonkin. Näin ollen niitä on Tengströmin mukaan siis käsiteltävä ja tulkittava runoutena. (Tengström 1845b, 135.)

Robert Tengström oli Castrénin oppilas ja ystävä sekä Castrénin seuralainen tämän tutkimusmatkalla Venäjän Karjalaan vuonna 1839. Castrén oli myös tiiviissä tekemisissä Tengströmien perheen kanssa ja 
oli Robertin isän, professori Johan Jakob Tengströmin ystävä. Robert Tengströmin varhaisen kuoleman jälkeen Castrén meni melko pian naimisiin tämän siskon Lovisa Natalia Tengströmin kanssa. Heidän poikansa nimettiin Robertiksi. Ei ole selvää, missä määrin Tengström vaikutti Castrénin ajatteluun, mutta vaikuttaa luultavalta, että tiiviin suhteen vuoksi Castrén ei suhtautunut ainakaan suoraviivaisen torjuvasti Tengströmin ajatuksiin. Castrén kirjoittaa esimerkiksi matkakertomuksessaan vuoden 1839 matkastaan Suomalaisen Kirjallisuuden Seuralle (1904):

[...] sisin vakaumukseni on, että taikuus muodostaa suomalaisten jumalaistarullisessa kehityskulussa ensimmäisen ja tärkeimmän aineksen, ja se on myös sen kehittynein osa. Jumalaisoppi on vielä aivan alussaan. Kristinoppi esti sen pääsemästä täyteen kypsyyteen.

Näkemys vastaa Tengströmin myöhemmin esittämää (1845a) käsitystä uskonnollisen ajattelun kehittymisestä. Tengströmin tuolloin nuoren iän vuoksi (hän oli 16-vuotias) on kuitenkin oletettavaa, että hän omaksui käsityksen Castrénilta eikä toisin päin. Castrén muutti sittemmin näkemystään ennen mytologialuentojensa kirjoittamista, mikä näkyy hänen kuvauksessaan mytologian varhaisimmasta muodosta (ks. esim. s. 81-83).

Historian professori Gabriel Rein (1800-1867) kirjoitti vuonna 1845 aikakauslehti Suomeen artikkelin "Försök till utredande af Fornfinnarnes mythologie", jossa hän valittelee, ettei suomalaisesta mytologiasta ole tehty uutta kokonaisesitystä Topeliuksen ja Lönnrotin julkaisemien tuoreiden kansanrunokokoelmien valossa. Näin hän antoi osaltaan ponninta Castrénin mytologiaa koskevalle työlle. Rein itse esittää artikkelissaan maailmanmunamyytin olevan luomistarustossa alkuperäisin ja pohtii luonnotarten ja näitä vähäisempien hahmojen roolia maailman luomisessa. Hän myös epäilee, että mytologisissa runoissa esiintyvät käsitteet luoja ja kaikkivaltias olisivat kristillistä perua. Rein esittää kuitenkin, että vielä kristinuskon vallitessakin Suomessa on muistettu esi-isien alkuperäisiä jumalia, "jotka hyvillä teoillaan ja korkeammalla viisaudellaan antoivat kansan ottaa ensimmäiset itsenäiset, vaikkakin epävarmat ja kompuroivat askeleet raakalaisuudesta kulttuuriin ja ihmisyyteen" (Rein 1845, 238). Tällä tavoin 
hän pohjustaa, joskin varsin lakonisesti, Castrénin pohdintoja suomalaisen mytologian kehittymisestä.

Castrén ottaa siis teoksessaan kantaa suomalaista mytologiaa käsitelleeseen keskusteluun hyvinkin monipuolisesti, vaikkei juuri nimeä vastineidensa kohteita. Sen sijaan teoksesta käy selkeästi ilmi arvostus ja kunnioitus, jota Castrén tunsi itseään edeltäneitä suomalaisen mytologian laajojen yleisesitysten tekijöitä kohtaan.

\section{Castrénin mytologian kirjallisia lähteitä}

Castrénin teos viittaa taajaan aiempiin suomalaista muinaisuskontoa kuvaaviin teoksiin, joita ei ollut lukuisasti ja jotka myös poikkesivat Castrénin teoksesta suuresti etenkin lähtökohdiltaan. Mikael Agricolan Psalttarin (1551) esipuheeseen kirjoittama runomuotoinen luettelo hämäläisistä ja karjalaisista pakanajumalista oli kaikessa suppeudessaan, vajavuudessaan ja ristiriitaisuuksissaankin varhaisin laatuaan. Tämän vuoksi siihen on viitattu käytännöllisesti katsoen kaikissa tutkielmissa, joissa on käsitelty suomalaisten muinaisjumalia (esipuheen historiasta ja tulkinnoista ks. esim. Harva 1948, 1-21; Hautala 1954, 26-30; Anttonen 2010, 52-54). Henrik Gabriel Porthan (1739-1804) ei julkaissut mytologiantutkimuksen alalta itse mitään, mutta hänen kiinnostuksenkohteensa kansanuskon ja kansanrunouden aloilta liittyivät mytologiaan läheisesti. Hän julkaisi teoksen Suomalaisesta runoudesta (De Poësi Fennica) viidessä osassa vuosina 1766-1778. Teoksessaan Porthan käsittelee etupäässä suomen kielen ja kalevalamittaisen runouden mitan ominaisuuksia, ja sen suurin arvo suomalaisen mytologiantutkimuksen kehitykselle onkin kansanrunouden luennassa ja tulkinnassa. Porthan nostaa esiin myös kansanrunouden tarjoamat mahdollisuudet menneisyyden tutkimuksessa (Porthan 1983, 77-78, 88), mutta hänen työnsä jäi mitä ilmeisimmin tämän suhteen kesken, sillä teoksessa viljellyt lupaukset aiheen perusteellisemmasta käsittelystä jäävät lunastamatta. Toisaalla Porthan kirjoittaa liittäneensä Erik Lencqvistin väitöskirjaan paljon sellaista, mikä muuten oli tarkoitettu teokseen Suomalaisesta runoudesta (Kajanto 1983, 13).

Kristian Erik Lencqvist (1761-1808) kirjoitti väitöskirjansa Vanhojen suomalaisten tietoperäisestä ja käytännöllisestä taikauskosta 
(De superstitione veterum fennorum theoretica et practica, 1782) isänsä Erik Lencqvistin ja Porthanin tekemien tutkimusten pohjalta ja jälkimmäisen ohjauksessa. Porthanilla oli ajan tavan mukaan siis todennäköisesti suuri vaikutus teokseen. Lencqvistin teos jakaantuu kolmeen osaan. Ensimmäisessä, teoksen johdanto-osassa Lencqvist kuvaa yleisesti suomalaisten esikristillistä uskontoa, toisessa osassa siihen liittyneitä käsityksiä ja kolmannessa käytännön rituaaleja ja käytänteitä. Lencqvist pohtii ensimmäisessä osassa ennen muuta "taikauskon" jakautumista teoreettiseen ja käytännölliseen taikauskoon, millä hän perustelee tutkimuksensa rakenteen.

Teoksensa toisessa osassa Lencqvist luettelee palvonnan eri kohteita, jotka ulottuivat luonnonilmiöistä henkilöityneisiin jumaluuksiin. Hän aloittaa pohtimalla jumala-sanan alkuperää ja merkitystä, kuten Castrén mytologialuennoissaan, ja jatkaa esittelemällä eri luonnonkohteiden kuten auringon, kuun, tähtien, kivien ja kasvien palvontaa. Näiden lisäksi hän luettelee muita jumaluuksia, joita pitää eufemistisen tulkintaperinteen mukaisesti muinaisina sankareina, jotka kansa on kohottanut jumalalliseen asemaan. Nämä Lencqvist jakaa edelleen ensimmäisen ja toisen luokan jumaliin (vrt. Castrénin jumalluokat). Ensimmäisen luokan jumalia olivat hänen mukaansa Ukko, Kaleva, Hiisi, Tapio, Ilmarinen, Kekri, Väinämöinen sekä Turri eli Turisas, joihin liittyviä mainintoja, kansanrunoja ja käsityksiä hän esittelee tiiviiseen mutta informatiiviseen tapaan. Tämän jälkeen hän luettelee Agricolan mainitsemien jumalten lisäksi vähäisemmistä, siis vain paikoittain tunnetuista jumaluuksista kapeet, Vuolaisen, Lemminkäisen, Uroon ja Meri-Turisaksen, jotka hän esittelee yksityiskohtaisesti. Jumalten puolisoista Lencqvist esittelee Raunin, Veden emän, Pohjolan emännän (jonka Lencqvist tulkitsee pohjoistuulen puolisoksi), Tapiolan emännän, Sukkamielen sekä Vuolattaren. Tämän jälkeen Lencqvist esittelee vahingolliset ja pahat olennot, joista erityisesti hän mainitsee Perkeleen, Lemmon, Syöjättären ja Liekkiön. Teoksen toisen osan lopuksi Lencqvist käsittelee muita uskomusolentoja, joita suomalaiseen ei-kristilliseen traditioon on kuulunut. Näitä ovat haltiat, tontut, maahiset, kapeet, menninkäiset, parat ja painajat.

Castrén luokittelee jumaluudet ja uskomusolennot täsmällisemmin kuin Lencqvist, mutta noudattelee varsin pitkälti samaa pääjakoa elementtijumaluuksiin, ylempi- ja alempiarvoisiin jumaliin sekä 
muihin uskomusolentoihin. Castrén käyttää Lencqvistin varsin suppeaa teosta keskeisenä lähteenään. Hän lainaa siitä suoraan monia jaksoja ja kommentoi lähes kaikkia Lencqvistin teoksessaan esittämiä väitteitä tai jatkaa niissä esitettyjä ajatuksia edelleen. Lencqvistin teoksella on siis varsin merkittävä osa Castrénin työssä.

Castrén viittaa teoksessaan taajaan myös Christfried Gananderin (1741-1790) laatimaan suomalaisen mytologian ruotsinkieliseen sanakirjaan Mythologia Fennica (1789), jonka kokoonpanossa Porthanilla oli niin ikään merkittävä rooli (Pentikäinen 1995, 136). Esipuheensa mukaisesti Ganander ei ainoastaan kuvaa suomalaista mytologiaa, vaan osoittaa yhtäläisyyksiä suomalaisen, lappalaisen (saamelaisen) ja ruotsalaisen mytologian välillä. Lähteinä Gananderilla on ruotsalaisen, lähinnä saamelaista kulttuuria kuvaavan tutkimuskirjallisuuden lisäksi Agricolan laatima jumalluettelo sekä runsaasti itse tallennettua ja muilta tutkijoilta saatua ja kopioitua kansanrunoutta. Keskeisen osan tästä muodostavat Porthanin hänelle vuonna 1783 toimittamat suomalaista mytologiaa käsittelevät tekstikokoelmat (Kuusi 1997, xli-xlii). Ganander ilmoittaa saaneensa mytologisen sanastonsa ja niihin liitetyt merkitykset kansanrunoudesta. Mythologia Fennicassa onkin paljon runoesimerkkejä. ${ }^{5}$ Teoksessa käsiteltävät aiheet on jaettu pääsanojen mukaiseen aakkosjärjestykseen. Pääsanoista valtaosa on mytologisten olentojen, paikkojen ja rituaalien nimityksiä. Monia termejä käsitellään niin perusteellisesti, että kuvaukset muistuttavat pienoistutkielmia.

Castrén käyttää tutkimuksessaan näitä teoksia ennen muuta lähteinään suomalaisen kansanuskon uskomusolennoista ja jumaluuksista sekä kansanuskoon liittyneistä rituaaleista. Hän myös käyttää paljon niissä olevia runoesimerkkejä etenkin rituaalisesta runoudesta.

Castrén viittaa Gustav Renvallin Suomalaiseen Sana-Kirjaan (1826) yksittäisten kansanuskoon liittyvien sanojen merkityksiä hahmottaessaan, mutta sitä vanhempaan Daniel Jusleniuksen sanakirjaan (1745) hän ei viittaa laisinkaan, vaikka esimerkiksi Jacob Grimm mainitsee sen suomalaisten mytologiaa käsittelevässä artikkelissaan (1845). Toisaalta Renvallin ja Jusleniuksen tulkinnat ovat niin samankaltaisia, että Renvall on todennäköisesti käyttänyt Jusleniusta lähteenään. Se tekee yksinomaan Renvalliin viittaamisen ymmärrettäväksi varsinkin, kun Renvallin tulkinnat ovat Jusleniusta yksityiskohtaisempia. 
Kolmantena keskeisenä kirjallisena lähteenä Lencqvistin ja Gananderin teosten lisäksi Castrénille olivat Elias Lönnrotin kokoonpanemat Kalevalan kaksi laitosta (1835 ja 1849). Castrén tunsi Kalevalan varsin hyvin: juuri Vanha Kalevala innoitti hänet tutkimaan suomalaisten menneisyyttä, ja hän laati siitä kehutun ruotsinnoksen (1841). Käännöstyötä varten hän vietti Karjalassa kesän 1839 hakemassa kieli- ja kansatieteellisiä aineksia Kalevalan runojen selityksiin (MAC Fennica I: Vocabularia \& Commentaria Kalevalae). Castrén tunsi Elias Lönnrotin henkilökohtaisesti. Vuonna 1841 hän teki Lönnrotin kanssa tutkimusmatkan Suomen Lappiin, Kuolaan ja Vienan Karjalaan. Vaikka miehet riitelivätkin matkan aikana ja heidän tiensä erosivat Arkangelissa, säilyi Castrénin ja Lönnrotin välinen ystävyys ja keskinäinen kunnioitus läpi vuosien. Raija Majamaa on todennut heidän kirjeenvaihtonsa todistavan "syvää yhteenkuuluvuutta ja veljeyttä” (Majamaa 2002).

Vanhan Kalevalan (1835) esipuheessa Lönnrot katsoo runojen kuvaavan pitkälti historiallisia tapahtumia. Hän esittää, että runoissa esiintyvä Kaleva olisi ollut jonkin varhaisen Suomeen muuttaneen suomalaisjoukon päällikkö (1835, xi-xiii) ja että Ilmarinen, Väinämöinen ja Lemminkäinen olivat varhaisten suomalaisten sankareita. Hän perustelee näkemystään hahmojen inhimillisyydestä lähinnä (itse rekonstruoimiensa) kertomusten sisäisellä logiikalla: esimerkiksi Väinämöisen olisi ollut hänen mukaansa vaikea lennättää Ilmarista ilman halki Pohjolaan kuusen kyydissä, mikäli Ilmarinen olisi ollut ilman jumaluus. Väinämöiseen hän katsoo liitetyn jonkin muinaisen jumaluuden piirteitä, mutta koska Väinämöinen esimerkiksi rukoilee runoissa Ukolta apua, Lönnrot ei pidä Väinämöistä itseään jumalana. Lönnrot pitää esipuheessaan muinaissuomalaisia monoteisteinä, koska nämä palvoivat runojen todistuksen mukaan Jumalaa eli Ukkoa ylimpänä jumaluutenaan. (Lönnrot 1835, xiii-xvi.)

Lönnrot jatkoi muinaissuomalaiseen mytologiaan liittyviä pohdintojaan etupäässä toimittamassaan lehdessä Mehiläinen. Artikkelissa "Muinelmia" (Lönnrot 1836a) hän esittää sanalle jumala etymologian, johon Castrénkin viittaa. Sen mukaan sana viittasi alun perin ukkosen jyrinään (jumu, jumaus) ja sitä myötä merkitsi 'taivaan ja ukkosen jumaluutta'. Kun muihinkin ilmiöihin liitettiin omia jumaluuksiaan, pääjumalaa (taivaan jumalaa) alettiin kutsua Ukoksi ja jumala muuttui 
Ukon ja tälle alisteisten muiden jumaluuksien yleisnimitykseksi. Castrénin tulkinta ei poikkea tästä merkittävästi. Lönnrot käsittelee artikkeleissaan myös laulamisen eli lukujen olemusta ja merkitystä kalevalamittaisessa runoudessa pitkälti samassa hengessä kuin Castrén sittemmin (Lönnrot 1836b, 71) (ks. s. 286-291) ja pohtii Castréninkin (ks. s. 284-286) käsittelemää maailmanluomismyyttiä, niin sanottua alkumuna-myyttiä, jota hän vertaa intialaiseen sekä Pohjois-Amerikan intiaanien mytologiaan (Lönnrot 1839c). Samassa yhteydessä Lönnrot tulkitsee Väinämöisen nimen oikean muodon maailmanluonti-runon yhteydessä "veen emoseksi", joka samankaltaisen äänneasun vuoksi olisi sekoittunut ajan saatossa Väinämöiseen. ${ }^{6}$

Lönnrot antoi muinaissuomalaisten uskonnosta tai mytologiasta yleiskuvauksen Johan Fredrik Cajanin kokoamassa Mehiläisen historiaosassa vuonna 1839(Cajan 1839). ${ }^{7}$ Lönnrotin mukaan muinaissuomalainen uskonto kehittyi Permiassa, missä Lönnrotin käsityksen mukaan kalevalamittainen runouskin kehittyi. Hänen mukaansa Vienanjoen pohjoispuolella oli palvontapaikka, jota Lönnrot kuvailee skandinaavisten saagojen kuvauksen mukaisesti bjarmien palvontapaikaksi, jolla sijaitsi Jomali-nimisen jumalan kuva. Lönnrot kirjoittaa, että suomalaisilla oli jo vanhastaan "tieto yhdestä, korkeimmasta, olennosta" (Cajan 1839, 7), taivaassa asuvasta Jumalasta, jota alettiin kutsua ylijumalaksi tai vanhempana jumalana ukoksi tai taatoksi siinä vaiheessa, kun alempia haltioita alettiin myös kutsua jumaliksi. Näitä jumaluuksia oli lukuisa määrä: "Ylehensä ei näytä löytyneen mitään niin suurta eikä pientä kohdelmata maailmassa, jolla MuinaisSuomalaisten uskossa ei olisi erityinen lähin haltiansa ollut" (Cajan 1839, 8). Väinämöistä, Ilmarista ja muita epiikan hahmoja kutsutaan paikoin jumaliksi, vaikka he näyttävät alun perin olleen ihmisiä, joita on vasta myöhemmin verrattu jumaliin erinomaisuutensa vuoksi. Lönnrot käsittelee lyhyesti myös maailmanluomismyyttiä, jossa muna merkitsi kenties "sitä muodotointa alkuolentoa, josta Jumala mailman loi, ja jota raamattu nimittää tyhjäksi” (Cajan 1839, 10) alustaen tavallaan Castréninkin pohdintoja (ks. s. 284-286).

Lönnrot kuvaa niin ikään muinaissuomalaisten käsitystä tuonpuoleisesta suppeasti ja esittää, että kuoleman jälkeen uskottiin jouduttavan Tuonelaan, missä oli varsin samankaltaiset olot kuin maan päällä. Hän korostaa, että muinaissuomalaiset eivät näytä uskoneen, että 
tuonpuoleisessa joutuisi erityisemmin vastaamaan eläessään tekemistään teoista. Lönnrot kuvaa lyhyesti myös muinaissuomalaisten pyhiä paikkoja, joita on tunnistettavissa esimerkiksi paikannimistä, joissa sana pyhä esiintyy (vrt. s. 129). Hän määrittelee tuonaikaisen uskonnollisen asiantuntijan tietäjäksi, joka kykenee sekä šamaanina lähettämään henkensä toisiin paikkoihin että sanojensa voimalla vaikuttamaan asioihin, esimerkiksi parantamaan ihmisiä (Cajan 1839, 66-67). Vaikka Lönnrot ei pyrkinytkään yleistajuisiksi tarkoitetuissa teksteissään kuvaamaan muinaissuomalaisten uskonnollista elämää ja käsityksiä järin tarkasti, hänen yleisten ajatustensa kaikuja on tunnistettavissa Castrénin tekstissä, ja usein Castrén vaikuttaa ikään kuin testaavan näiden ajatusten kestävyyttä omia pohdintojaan ja tutkimustuloksiaan vasten.

\section{Kalevala ja kansanrunous Castrénin mytologian lähteinä}

Castrénin mytologialuentoja on arvosteltu nojautumisesta Kalevalaan alkuperäisten runotallenteiden sijaan. Yksi ensimmäisistä on Julius Krohnin huomautus:

Yhden tärkeän muistutuksen vaan häntä [Castrénia] vastaan, mitä lähteitten käyttämiseen tulee, voisi tehdä, ja se on tosin painava, nimittäin, ett’ei hän perustanut esitystänsä Suomen Suomalaisten jumalista loitsuin käsikirjoituksiin. Niinkuin näyttää, hän pääasiallisesti käytti lähteenään painettua Kalevalaa, joka kyllä aina on esteettisessä katsannossa oleva kirjallisuutemme kulmakivi, vaan tieteellisiin tutkimuksiin on aivan kelpaamaton, vieläpä usein eksyttäväinen. (Krohn J. 1894, 2.)

Castrénin työtä on jopa pidetty ainoastaan Kalevalan kommentaarina (Haavio 1952; 1967, 7; Hautala 1954, 152-156; Kemppinen 1957, vii; Siikala 2012, 43). Mytologialuennot ovatkin kiistämättä yksi puheenvuoro keskustelussa, jota suomalainen älymystö kävi 1800-luvun alun lehdistössä ja esitelmissä Kalevalan ilmestymisestä lähtien, kuten yllä on käynyt ilmi. Keskustelu koski Kalevalan ja sen runojen historiallisten ja mytologisten tulkintojen linjoja sekä suomalaisten uskonnon varhaisia muotoja.

Mytologialuentoja ei voi kuitenkaan pitää ainoastaan Kalevalan kommentaarina, vaikka Castrén viittaakin mytologialuennoissaan 
Kalevalan runoihin ja käyttää niitä esimerkkiaineistonaan. Kalevala oli tuohon aikaan Topelius vanhemman julkaisujen ohella ainoa tekstikokonaisuus, jonka kautta kalevalamittainen runous oli suurena kokonaisuutena laajan yleisön saavutettavissa. Castrén kirjoitti teoksensa yleisölle, joka tuskin tunsi runoutta entuudestaan, joten on luonnollista, että hän viittaa tämän yleisön saavutettavissa olleisiin aineistoihin. Kalevalamittaista runoutta ei ollut 1800-luvun puolivälissä edes arkistoissa saatavilla vastaavalla tavalla kuin myöhemmin. Suurin osa kenttätyöaineistosta oli Lönnrotin hallussa, sillä Lönnrot luovutti aineistonsa Suomalaisen Kirjallisuuden Seuralle vasta vuonna 1874 (Apo 2008, 372). Castrén viittasi Kalevalaan todennäköisesti myös tämän vuoksi.

Castrén ei ole kuitenkaan kritiikitön Kalevalan käytössä vaan huomauttaa paikoin Kalevalan epäjohdonmukaisuuksista ja ristiriidoista omien havaintojensa kanssa (esim. s. 282-283). On muistettava, että Castrén oli D. E. D. Europaeuksen kanssa ensimmäisiä, jotka vaativat kaiken kerätyn runoaineiston julkaisemista Kalevalan rinnalle (Castrén 1850a; 1850b; Kaukonen 1956, x; 1988, 79-80). Runoston variaatio oli siis yksi Castrénin lähtökohdista, eikä hän - kuten ei Lönnrotkaan - pitänyt Kalevalaa yhtenä ja ainoana mahdollisena eepoksena (Siikala 2008, 314-318; Apo 2008, 366). Nykylukijan on myös hyvä huomata, että Castrénin mytologialuennoissa viitataan selkeästi Kalevalan eri painosten runojaksoihin, minkä ansiosta alkuperäistekstit ovat jäljitettävissä ja Castrénin tekemät tulkinnat niiden pohjalta arvioitavissa. Väinö Kaukosen suurtöiden Vanhan Kalevalan kokoonpano I-II (1939-1945) ja Elias Lönnrotin Kalevalan toinen painos (1956) ansiosta runojen jäljittäminen on suhteellisen vaivatonta. Castrénin teosta ei voi myöskään kokonaisuutena arvioida ainoastaan siinä tehtyjen kansanrunouden tulkintojen pohjalta, sillä suuri osa teoksesta nojaa suomalaisen mytologian suhteen muihin lähteisiin: Lencqvistin ja Gananderin tutkimuksiin sekä kielitieteellisiin, etnografisiin ja mytologisiin vertailuaineistoihin.

Kansanrunous on Castrénille herderiläisen käsityksen mukaisesti kansan ääntä, runojen esittäjien yläpuolella olevan kollektiivisen tradition ilmentymää (ks. Saariluoma 2006, 195-197). Castrénin viljelemä, ajalle tyypillinen käsite laulunjumalatar (sånggudinnan), johon hän viittaa ikään kuin runojen sepittäjänä, voidaan epäilemättä tulkita 
runouden yliyksilöllisyyden, kollektiivisen äänen personifioitumaksi. Termi variantti (variant), jota Castrén käyttää samaa aihetta käsittelevistä mutta keskenään erilaisista runoista tai runon osista, implikoi käsitystä runon vakio- tai alkumuodosta, joka eri laulajien esityksissä on aikojen saatossa alkanut muuntua ja varioida. Termi oli vakiokäytössä jo esimerkiksi Lönnrotilla. Vaikka Castrén viittaa alkuperäisiin runotoisintoihin vain muutamassa kohdassa, hän nostaa esiin perusteet, joiden mukaan arvioi runon elementin alkuperäisyyttä eli vanhakantaisuutta. Näitä perusteita ovat hänen mukaansa ennen muuta runoelementin levinneisyys ja tietynlainen eheys, "poeettinen arvo" (ks. s. 282, 287). Nämä ovat myös Julius ja Kaarle Krohnin vuosikymmeniä myöhemmin kehittelemän maantieteellis-historiallisen menetelmän peruskriteerit runon alkuperäisen muodon jäljittämiseksi.

Castrén katsoo kalevalamittaisen runon kerronnallisen rakenteen tai juonen määräävän runon sisältöjä: esimerkiksi henkilöhahmon ominaisuudet määräytyvät tämän roolista kertomuksessa. Näin ollen hänen mukaansa esimerkiksi sankariepiikan hahmot, kuten Väinämöinen, muotoutuivat heihin liitettyjen kertomusten eli tapahtumasarjojen antamien edellytysten mukaisesti, eikä Väinämöisen ympärille sepitetty hänen hahmoonsa sopivia kertomuksia. Mikäli vakiintunut henkilöhahmo liitettiin uuteen kertomukseen, Castrénin mukaan tätä henkilöhahmoa, ei kertomusta, muokattiin tarpeen mukaan. (ks. s. 278-280.) Castrén vaikuttaakin pitävän Lönnrotin hahmottelemaa eeposkokonaisuutta varsin luotettavana esityksenä siinä olevan kalevalamittaisen epiikan kertomusrakenteista nojatessaan näkemyksissään Kalevalassa esitettyihin, erilaisista runoista koottuihin kertomussykleihin eritoten luentojen kolmannessa osassa "Sankarit". Toisaalta käsitellessään mytologian ritualistista puolta Castrén käyttää monin paikoin Kalevalan eeppisen kerronnan lomassa olevia loitsujaksoja. Ne liittyvät tässä tekstiympäristössä Kalevalan juoneen, mutta Castrén käyttää niitä esimerkkeinä erilaisista rituaalisista teksteistä, joita on käytetty kansan parissa. Hän vaikuttaa suhtautuvan Kalevalaan Elias Lönnrotin tulkintana suomalaisesta mytologiasta (vrt. Hyvönen 2008) käsitellessään yksittäisiä runojaksoja irrallaan varsinaisesta tekstikokonaisuudesta, jossa ne esiintyvät. Lönnrotin perusteet eri perinnelajeja edustavien runojen upottamiseksi epiikan lomaan tukivat tapaa, jolla Castrén jälleen 
irrotti ne Kalevalan tekstiympäristöstä (Lönnrot 1849, ii-iii; ks. Tarkka 2005, 69-70).

Castrén käyttää siis mytologialuennoissaan Kalevalaa yhtäältä esimerkkiaineistona, jolla hän pystyy valaisemaan omakohtaiseen tutkimustyöhönsä perustuvia näkemyksiään, toisaalta kalevalamittaisten kertomusten ehjät muodot ja keskinäisen suhteen osoittavana kokonaiseepoksena, johon hän vetoaa päätelmiensä perusteluissa. Kalevalan käyttö ei riistä Castrénin mytologialuennoilta käyttökelpoisuutta tyystin tänäkään päivänä, mutta kalevalamittaisen runouden suhteen Castrénin työhön on suhtauduttava kriittisesti.

\section{Castrénin mytologian etnografisia lähteitä}

Castrén hyödynsi teosta kirjoittaessaan laajaa kenttätyökokemustaan ja kokoamiaan tietoja Koillis-Euroopan ja Keski- ja Pohjois-Aasian eri kielistä ja kulttuureista. Näiltä osin mytologialuennot eivät suinkaan enää kommentoi Kalevalaa tai tuo lisiä Suomen kansalliseepokseen vaan rakentavat etnografisiin aineistoihin perustuvaa vertailevaa kuvaa pohjoisessa ja Siperiassa asuvien kansojen mytologiasta. Castrén ei viittaa ainoastaan omiin kenttätöihinsä, vaan mytologialuentojen alaviitteissä vilisee jatkuvasti Siperian-tutkimuksen pioneereja, joiden teoksiin ja matkakertomuksiin luennot perustuvat mutta joiden tuloksia Castrén myös kritisoi ja tarkentaa.

Castrénin elämää ja kenttämatkoja on tavattu tarkastella romanttisen herätyksen saaneen nuoren tutkijan toimintana. Tarkemmin katsottuna Castrénin kenttätöiden taustalla on kansainväliseen tutkimukseen perustuvia virikkeitä ja tehtäviä, joita niin suomalainen kuin venäläinenkin älymystö valjasti Castrénin toteuttamaan. Castrénille asetettu kenttätyöohjelma vaikutti merkittävästi myös mytologialuentojen sisältöön, minkä vuoksi kenttätöiden taustoja on syytä tarkastella lyhyesti tässäkin.

Kenttätöiden taustalla vaikutti kehittymässä ollut historiallinen ja vertaileva tutkimusmenetelmä (ks. seuraava luku), joka edellytti yhä enemmän ja yhä tarkempia aineistoja ja sitä myötä uusia ja entistä laajempia kenttätyöhankkeita. Kenttätyötä oli tehtävä erityisesti siellä, missä ei ollut kirjallisia perinteitä eli yhteisöissä, joiden kulttuuria ja kieltä ei ollut tallennettu. Venäjän tiedeakatemiassa oli pitkään 
suunniteltu etnografisia matkoja, joiden tarkoituksena oli tuottaa aiempaa tarkempaa tietoa pohjoisen ja Siperian kansoista. Castrénin kenttätyöt vastasivat suunnitelmiin. Historiallisen ja vertailevan menetelmän lisäksi Castrénin matkat nivoutuvat siis myös etnografian yleiseen kehitykseen (ks. luku "Etnografisen tiedonintressin kehittyminen").

Venäjällä oli toteutettu 1700-luvulla laajoja tutkimusmatkoja Siperiassa. Koska matkojen pääpainotus oli ollut luonnontieteissä, niiden tulokset väestön ja kielten lukumäärien ja rakenteen suhteen olivat epätarkkoja. Pietarin akatemian 1700-luvun niin sanotut suuret tutkimusmatkat kohdistuivat kolmeen suuntaan. Ensiksikin Venäjän ja Siperian pohjoiselle rannikkoseudulle tehtiin pohjoisen merireitin avaamista palvelevia tutkimusmatkoja; toiseksi matkoja tehtiin Kamtšatkalle, jossa haluttiin selvittää Aasian ja Amerikan mahdollista maayhteyttä; kolmanneksi tutkimusmatkat suuntautuivat Venäjän sisämaan tuntemattomille alueille, joissa luonnonvarojen lisäksi tutkijoita kiinnosti Siperian kautta avattava kauppareitti Kiinaan ja Intiaan. Suurten tutkimusmatkojen aikana kerättiin kuitenkin tietoa myös Siperiassa puhuttavista kielistä ja kansoista.

Suurten tutkimusmatkojen ohella tämän kirjan kannalta merkittävä tutkija oli Daniel Gottlieb Messerschmidt, saksalainen lääkäri ja luonnontieteilijä, jonka Pietari Suuri kutsui Venäjälle tutkimaan Siperian maantiedettä, luonnonhistoriaa, lääketiedettä, kansoja ja niiden kieliä, muistomerkkejä ja antikviteettejä sekä keräämään kaikkea näiden suhteen merkittävää tietoa (Vermeulen 2015, 117). Messerschmidtin matkareitti kulki Tobolskin kautta Krasnojarskiin, Jeniseijokea pitkin Jäämeren rannikolle Mangazejan kauppapaikkaan ja itään Lena-joelle Ala-Tunguska-joen vesistöjä myöten. Matka jatkui Irkutskista Taka-Baikalian alueen kautta Kiinan ja Mongolian rajoille Argunskiin, joka on Baikal-järven itäpuolella. Sieltä Messerschmidt matkasi takaisin Irkutskiin ja Jeniseiskiin ja lopulta Samarovskin kautta Tobolskiin ja Pietariin. Matka kesti vuoden 1719 maaliskuusta vuoden 1727 maaliskuuhun; kahdeksan vuotta, joiden aikana Pietari Suuri oli kuollut, eikä hänen seuraajansa Katariina I ollut juurikaan kiinnostunut Messerschmidtin tutkimusmatkan tuloksista tai niiden julkaisemisesta. Materiaalit tutkija joutui kuitenkin luovuttamaan Pietarin akatemialle. (Vermeulen 2015, 119-124; Tokarev 1966, 78.) 
Messerschmidtin aineistoja kuitenkin hyödynnettiin myöhemmin. Esimerkiksi Vasili Nikititš Tatištšev (1686-1750) ja Gerhard Friedrich Müller (1705-1783) käyttivät Messerschmidtin aineistoja toisen Kamtšatkan tutkimusmatkan suunnitteluun (Vermeulen 2015, 144146; Tokarev 1966, 79-85). Myös samojedikielten puhujilta aineistoja kerännyt Peter Simon Pallas käytti samoja aineistoja ja tietoja hyväkseen suunnitellessaan osuuttaan Orenburgin tutkimusmatkasta. Myös Castrén tutustui Messerschmidtin aineistoihin.

Suurten tutkimusmatkojen tekijöistä Castrén viittaa teoksessaan toistuvasti Peter Simon Pallasin teksteihin. Pallasin matka vuosina 1768-1774 suuntautui Venäjän länsiosista Uralille, Tobolskiin, Omskiin, Länsi-Siperian pohjoisosiin ja sieltä Altaille, Baikalille lähelle Kiinan rajaa ja Sajanin vuorille - siis käytännössä samoille alueille, joilla Castrén ja Messerschmidt matkasivat. Teksteissään Pallas kuvaa paikkojen geologiaa ja maaperää, kasvillisuutta, eläimiä, paikallisia asukkaita sekä heidän arkeaan, työvälineitään ja "muinaisuutensa jäänteitä”. (Pypin 1892, 254-259.)

1700-luvun niin Pietari Suuren kuin Katariina II:n toteuttamien suurten tutkimusmatkojen yhtenä keskeisimmistä tuloksista kielitieteen ja etnografian suhteen voidaan pitää Johann Gottlieb Georgin Saksassa painettua teosta Beschreibung aller Nationen des Russischen Reichs (1776-1780). Se herätti Keski-Euroopassa kasvavaa kiinnostusta Venäjällä asuvia kieli- ja kulttuuriyhteisöjä kohtaan, ja myös Castrén viittaa toistuvasti Georgin työhön. Neliosainen kokoomateos on ollut aikanaan huima, kokonaisen imperiumin monikulttuurisuutta kuvaava aikaansaannos. Siinä kuvataan 65 kansan "elämäntapaa, uskontoja, tapoja, asujaimistoa, pukeutumista ja muita kuriositeetteja" (lainaus Vermeulen 2015, 308), minkä lisäksi Georgi luokittelee kansoja kielen, uskonnon ja talouden suhteen. Luokitteluista teetettiin 95 kuparipiirrosta, jotka julkaistiin erikseen. Georgin tiedot perustuvat 1700-luvun suurten tutkimusmatkojen julkaistuihin ja julkaisemattomiin tuloksiin. (Tokarev 1966, 95-108.)

Castrénin matkahankkeen valmistelussa Anders Johan Sjögrenillä oli merkittävä rooli. Sjögren toimi 1830- ja 40-luvuilla Pietarin akatemian piirissä, missä hän pystyi järjestämään Castrénin tutkimusmatkoille rahat. Sjögrenin kautta Castrénin työ voidaan liittää paitsi venäläisen tutkimusmatkailun historiaan, myös ennen kaikkea 
suomalaisen humanistisen tutkimuksen jatkumoihin. (Branch 1968.) Michael Branchin mukaan Sjögrenin toiminta sijoittuu hedelmällisellä tavalla Porthanin Suomessa johtaman tutkimusperinteen ja nousemassa olleen systemaattisen historiallis-vertailevan kielitieteen välimaastoon. Sjögren kykeni toteuttamaan jo Porthanin kaavailemia kenttätöitä, joiden aikana kerättyjen aineistojen pohjalta kyettiin tekemään tarkkoja johtopäätöksiä suomalais-ugrilaisten kielten suhteista. Sjögren keräsi aineistonsa systemaattisesti niin, että niiden pohjalta voitaisiin osoittaa kielten väliset suhteet ei ainoastaan sanastoon, vaan myös rakenteisiin perustuen. Tässä Sjögrenin otteessa tulee esiin tanskalaisen kielitieteilijä Rasmus Raskin vaikutus. Käytännössä Sjögren todisti suomalais-ugrilaisen kieliperheen olomassaolon. Hän epäröi samojedi- ja suomalais-ugrilaisten kielten mahdollisen sukulaisuuden suhteen, mutta ei enää itse halunnut eikä kyennyt lähtemään pohjoiseen keräämään aineistoa, joka olisi vastannut kysymykseen. Sjögren oli kuitenkin vakuuttunut oman kenttätyömetodinsa tehokkuudesta, ja hänen tuloksensa olivatkin siinä määrin vaikuttavia, että metodi herätti epäilemättä kiinnostusta 1800-luvun alun akateemisessa Pietarissa. (Branch 1968; 2006.)

Sjögrenin kenttämatkat sijoittuivat vuosille 1824-1829, joiden aikana hän matkusti Karjalan alueen itämerensuomalaisten kielten, saamen kielten, nenetsin, komin, udmurtin ja marin puhujien parissa. Varsinaisia kenttätöitä voidaan luonnehtia kielitieteellisesti orientoituneiksi, mutta Sjögren keräsi silti varsin monimuotoista aineistoa: puheaineisto koostui muun muassa paikannimistä, kansanrunoista ja sananlaskuista, minkä lisäksi tutkija käytti ylijääneen ajan arkistoissa ja kirjastoissa. (Branch 1973, 207-219.)

Sjögren antoi Castrénille selkeät kenttätyöohjeet ja -tavoitteet. Ohjeet julkaistiin Pietarissa Bulletin de la Classe des Sciences historiques, philologiques et politiques -lehdessä ja niistä käytiin aikanaan jonkin verran keskustelua: esimerkiksi Venäjän etnografista karttaa laativa Köppen esitti Castrénille joitakin lisäkysymyksiä, joihin Castrén matkansa aikana julkaistuissa raporteissa vastasi. (Sjögren 1844; Köppen 1844.) Huomionarvoista on, että ennen toista matkaansa Siperiaan Castrén vieraili Pietarissa akateemikko Sjögrenin luona, jolloin tutkijat työstivät yhdessä matkaohjeen. Vaikka teksti noudattelee 
Sjögreniltä aiemmin tuttuja teemoja, siitä löytyy myös muotoiluja, jotka voidaan tulkita Castrénin vaikutukseksi.

Voimakkaimmin kenttätyöohjeista nousee esiin kaksi seikkaa. Ensinnäkin matkojen ajateltiin lähtökohtaisesti olevan kielitieteellisiä ja etnografisia ja niiden nähtiin tieteen näkökulmasta palvelevan historiallisia tulkintoja. Toisekseen näkemys kenttätöissä kerättävästä aineistosta oli laaja ja kokonaisvaltainen: kielitieteellistä materiaalia tuli kerätä kaikilta mahdollisilta aloilta ja sitä tuli täydentää etnologisilla, arkeologisilla sekä arkistojen aineistoilla. Castrénin matkojen pääasiallisena kohteena olivat niin sanotut samojedilaiset heimot (samojedische Völkerstamm) ja niiden levinneisyys Siperiassa, mihin liittyen hänen tuli kiinnittää huomiota myös hantin kieleen sekä hantien ja samojedien välisiin kontakteihin. Länsi-Siperian etnisen kartan epäselvyyksien korjaaminen oli yksi matkojen merkittävimpiä tavoitteita.

Kenttätyöohjeissa korostetaan monesti, että aineisto on kerättävä itse paikan päällä kielten puhujilta. Tässä kohtaa kenttätyöohjeissa on ajalle tyypillinen empiriaa korostava henki (Bunzl 1996). Kielitieteellisen aineiston tuli koostua mahdollisimman laajan alueen kielimuodoista eli itse kielistä ja niiden murteista, jotta voitaisiin analysoida kielten sukulaisuutta ja näiden välisiä suhteita. Kenttätyöohjeissaan Sjögren tekee selvää eroa entiseen sanaston keräilyyn ja neuvoo Castrénia keräämään mahdollisimman aukotonta kieli-, muoto-, äänne- ja lauseoppia valaisevaa aineistoa. Kentältä tulisi kuitenkin kerätä myös folklorea ja tässä tarkoituksessa "kiinnittää kaikki huomio kansojen parissa kiertäviin tarinoihin ja perinteisiin, jotka koskevat heidän alkuperäänsä ja muinaisuuttaan olivatpa ne sisällöltään yleisiä tai tiettyyn paikkaan kiinnittyneitä."8 Kirjallisuuden lajeista ohjeistettiin keräämään ainoastaan lauluja, koska ne olivat historian kannalta merkittävää aineistoa ja koska ne saattoivat kertoa tärkeitä seikkoja tutkittavien asuttamien paikkojen historiasta. Vastaavaa historiallista intressiä palvelivat myös etnonyymit ja paikannimet sekä näihin liittyvä tietous. Lisäksi tuli kerätä yleistä ilmastoa ja kasvillisuutta sekä maantietoa koskevaa tietoutta.

Ohjelman etnografisten päämäärien toteuttamiseksi tutkijan tuli olla selvillä tutkittujen heimojen ruumiinrakenteesta, elintavoista, 
vaateparresta, tavoista, kulttuurin tilasta, uskonnollisista käsityksistä, šamanismista, pakanuudesta, kristinuskosta ja "ylipäätänsä kaikesta, jonka avulla voidaan luonnehtia heitä ja heidän erityisyyttään.” Ohjelmassa mainitaan myös mytologisten tutkimusten jatkaminen, minkä voidaan tulkita olleen Castrénin lisäys. Castrénin kielellisen ja etnografisen aineiston monipuolinen tuntemus näkyy mytologialuennoissa monissa kohdissa, joissa Castrén esimerkiksi liittää paikoin yllättäviinkin arkisiin käytäntöihin ja kielellisiin ilmauksiin mytologisia merkityksiä.

Kuten kaikesta tästä on nähtävissä, Castrén oli varsin tietoinen suomalaista mytologiaa käsitelleestä keskustelusta kootessaan luentojaan. Hän käytti keskustelua pohdintojensa pohjana monin tavoin ja toi mytologialuennoillaan keskusteluun perustellun ja punnitun puheenvuoron. Vaikka tämä puheenvuoro liittyi suomalaisuuden juurista ja olemuksesta käytyyn poliittisesti virittyneeseen keskusteluun, sen pohjana oli ennen muuta tieteellinen, teoreettisiin malleihin ja empiriaan perustuva tutkimustyö, jonka taustalla vaikuttivat osaltaan Castrénin kenttätyökokemukset siperialaisten kansojen parissa sekä aiempi näitä kansoja koskeva tietous. Castrén lavensi keskustelua suomalaisesta mytologiasta uusiin suuntiin, mutta hänen työnsä lepäsi vankalla tutkimushistoriallisella pohjalla.

\section{Mytologialuentojen ajatusmaailman taustoja}

Castrén ei erittele teoreettisia tai metodologisia lähtökohtiaan työnsä yhteydessä. Hän viittaa tutkimuskirjallisuuteen pääasiassa halutessaan yksilöidä käyttämäänsä tutkimusaineistoa mutta ei avaa tulkintansa yleisiä lähtökohtia. Näin ollen Castrénin teoreettisia esikuvia ja malleja ei tunneta tarkkaan. Castrénin aikaan käydystä tieteellisestä keskustelusta löytyy kuitenkin joitakin viitteitä hänen teoreettisista lähtökohdistaan.

Castrénin lähestymistapa on aineistolähtöinen. Hän pyrkii hyödyntämään mahdollisimman laajasti erityyppisiä tutkimusaineistoja sekä suomalaisesta että lähikulttuureista. Hän käsittelee teoksessaan mytologiaa järjestelmänä ja pyrkii kuvailemaan ei vain yksittäisiä 
uskomusmaailmaan liittyviä ilmiöitä, kuten myyttejä, vaan myös itse järjestelmää, jonka perusteella ne olisivat ymmärrettävissä. Tämän lisäksi hän pyrkii määrittelemään käsittelemiensä ilmiöiden keskinäisen suhteellisen syntyajankohdan 1800-luvulla vallalla olleiden kulttuurien ja uskonnon kehityskaarta kuvaavien teorioiden pohjalta. Castrén tukeutuu ensisijaisesti kotoperäiseen aineistoon, mutta missä kohden siinä on puutteita, hän tukeutuu analogisiin vertailuaineistoihin kulttuureista, joita voi pitää "kehittymättömämpinä" ja joilla voi kuvitella olevan historiallisia yhteyksiä suomalaiseen kulttuuriin. Aineiston valintaperusteiksi kohoavat etupäässä kielisukulaisuus ja historiallisen kanssakäynnin mahdollisuus kulttuurisen lainautumisen taustana. Castrénin tekstistä on myös aistittavissa varsin moderneja kulttuurientutkimukseen liittyviä ajatuksia mm. siitä, että tutkijan näkemys aiheestaan on aina väistämättä jossain määrin subjektiivinen ja että aineistotulkinnoissa on otettava huomioon myös kulttuurinen konteksti, johon aineisto liittyy (ks. esim. s. 215, 248).

Castrénin mytologiavertailut liittyvät kiinteästi hänen uralilaisaltailaiseksi hypoteesiksi kutsuttuun teoriaansa suomen kielen ja sitä myötä suomalaisen kulttuurin juurista. Hän esitteli teorian pääpiirteissään Helsingissä Porthanin muistojuhlassa 9. marraskuuta 1849 luennossaan "Hvar låg det Finska folkets vagga?" ('Missä oli suomalaisen kansan kehto?'; Castrén 1849). Itse teoria nojasi niin kielitieteelliseen kuin perinnemateriaaliinkin, ja sen mukaan suomen- ja turkinsukuisten sekä samojedikansojen alkukoti oli Altai- ja Sajan-vuoristoissa, jonne näiden esi-isät olivat aikoinaan paenneet suullisessa perinteessä kuvattua tulvaa. Castrén ei ollut ensimmäinen, joka ehdotti kyseisten kansojen keskinäistä sukulaisuutta, vaan esimerkiksi kielitieteilijä Willhelm Schott, johon Castrén mytologialuennoissaankin viittaa, oli ehdottanut samaa jo aiemmin. Uralilais-altailainen hypoteesi on sittemmin todistettu virheelliseksi, ja Mikko Korhonen onkin luonnehtinut sitä romanttiseksi sepitteeksi, jossa yhdistyvät muinaiset tarut, raamatulliset kertomukset ja perusteettomat kielelliset vertailut. Uralilais-altailaisen hypoteesin vaikutukset näkyivät kuitenkin pitkään käsityksissä altailaisista kielistä ja suomalaisten kuulumisesta mongolirotuun. (Korhonen 1986, 59-60.) Mytologialuentojen vertailujen lähtökohta perustuu paljolti uralilais-altailaiseen hypoteesiin: Castrén 
korostaa altailaisiksi määrittelemiensä kansojen uskonnollisia yhdenmukaisuuksia (ks. esim. s. 163, 208, 213) ja puhuu suomalaisten siirtymisestä Aasiasta nykyisille asuinsijoilleen (ks. esim. s. 265, 285).

Yleisesti ottaen Castrénin työskentelyn lähtökohdat olivat romantiikassa, mutta valistusajattelun pitkät linjat näkyvät niin ikään hänen tutkimusotteessaan (Karkama 2001; Vermeulen 2015). Mytologian nousu tutkimuksen kohteeksi kumpusi 1800-luvun alkupuolella pitkälti juuri eurooppalaisesta ja vielä täsmällisemmin saksalaisesta romantiikasta, jonka piirissä kansaa (saks. Volk) ja etenkin kansankulttuurin saavutuksia ihannoitiin kulttuurin aitoina ja alkuperäisinä muotoina. Mytologia totuuden korkeana muotona oli jo vakiintunut ajatus, ei enää pelkkä kiehtova idea, mitä se oli ollut vielä 1700 -luvun puolella (Feldman \& Richardson 1972, 303). Johann Gottfried von Herder, yksi keskeisimmistä hahmoista kansallisromantiikan syntyvaiheissa, korosti teksteissään, kuinka kulttuurit ovat omanlaisiaan ja että niitä myös tulee lähestyä sellaisina (Wilson 2005, 9-12). Hän näki myytin olevan kulttuurin kasvupohja, johon kieli, uskonto ja muut kulttuurin osa-alueet pohjimmiltaan perustuvat (Williamson 2004, 8). Georg Creutzer nosti kansanperinteen eri muodot mytologiantutkimuksen aineistoiksi, ja eritoten Jacob Grimm (1844) käsitteli juuri erityyppisiä aikalaisperinteitä heijastumina muinaisesta mytologiasta.

Vertailevalle tutkimukselle luontaista on löytää vastaavuuksia tutkimuskohteiden välillä. Myös Castrén tunnisti tutkimissaan kulttuureissa keskenään vastaavia ilmiöitä, mutta hän pohti myös paljon näiden ilmiöiden eroavaisuuksia eri konteksteissaan. Osa Castrénin havaitsemista yhtäläisyyksistä vaikuttaa nykylukijan silmissä enemmän tai vähemmän satunnaisilta, mutta tavassa, jolla Castrén niitä käsittelee ja tulkitsee, on havaittavissa teoreettisen kokonaiskuvan aineksia. Ylipäätään Castrén kuvaa uskontoa pikemmin muotojen sikermänä kuin yhden teoreettisen postulaatin pohjalta, mikä oli ajanmukaista ja myös linjassa empirismin perusperiaatteiden kanssa. Castrén ei siis ollut niinkään teoreetikko, joka pyrkisi sovittamaan aineistoaan yhteen aihetta kuvaavaan malliin, kuin pragmaatikko, joka hyödyntää tuntemiaan teorioita käytössään olevaan materiaaliin soveltuvilta osin. Käsittelemme seuraavassa joitakin aikalaispohdintojen linjoja, jotka vastaavat Castrénin mytologialuennoissaan esittämiä ajatuksia. 


\section{Historiallinen ja vertaileva menetelmä}

Castrénin elämäntyön saksalaiset laitokset toimittaneen Anton von Schiefnerin mukaan Castrén oli hyvin perehtynyt häntä edeltäneeseen vertailevaan kielen- ja mytologiantutkimukseen. Schiefner toteaa kirjeessään J. V. Snellmanille:

[...] vertailevan tutkimuksen toteuttamiseksi hänen oli välttämättä perehdyttävä mitä tarkimmin vertailevan kielitieteen aiempiin tuloksiin, ja niinpä hän tutkiskeli W. v. Humboldtin, Boppin, Vossin, Grimmin, Diezin, Schleicherin, Raumerin, Diefenbachin ja muiden teoksia pyrkien alituisesti laajentamaan kielitieteellistä näköpiiriään. Erityisesti häntä innosti yhteys Böhtlingkiin, [...] Kuten kielitieteen alueella Castrén pyrki myös myyttien tutkimuksen alueella tutustumaan uusimpiin aikaansaannoksiin ja siten avartamaan näköpiiriään. Vaikka hänen luentonsa suomalaisten mytologiasta ovat jo merkittäviä, ne olisivat kehittyneet vielä suunnattomasti ansiokkaammiksi, jos hänen olisi suotu käyttää hyväkseen vuosien varrella karttuvia uusia aineistoja samalla myyttien tutkimuksen uusien näkökantojen tasalla edeten. Hänen kirjeensä todistavat sangen selkeästi, miten uutterasti hän pyrki täydentämään tämän alan tietojaan [...] (von Schiefner 1857.)

Castrénin mytologialuentojen tausta-ajatuksia onkin löydettävissä 1800-luvun alussa Keski-Euroopassa intensiivisesti kehittyneestä historiallisen ja vertailevan kielen- ja mytologiantutkimuksen piiristä. Alat nivoutuivat tiiviisti yhteen. Kyse ei ollut ainoastaan tutkimusalan kehittymisestä, vaan kokonaisesta tutkimusparadigman käänteestä, jonka taustalla olivat indoeurooppalaisten kielten tutkimuksen mullistavat löydöt (Stipa 1990, 241). Vertailevan metodin kehittymisen taustalla voidaan nähdä myös valistusajan suuret aineistojenkeruuhankkeet, jotka mahdollistivat ensin pintapuoliset sanastoon perustuvat kielten vertailut ja myöhemmin myös havainnon kielten vaihtelevista rakenteista ja äänteellisen variaation säännönmukaisuuksista (Korhonen 1986, 40-41; Campbell 2002, 86-90). 1700-luvun lopulla ja 1800-luvun alussa etenkin saksalaisessa tutkimuksessa myytteihin liitettiin mystillissävytteisiä luonnonfilosofisia ajatuksia.

Filologia oli 1800-luvulla hyvin monialaista, ja mytologiantutkimuksenkin vertaileva luonne on George Williamsonin (2004, 13) mukaan peruja tältä ajalta. Käytännössä ala pohjaa kolmen samoihin 
aikoihin julkaisseen tutkijan, Franz Boppin (1791-1867), Jacob Grimmin (1785-1863) ja Rasmus Raskin (1787-1832) kirjoituksiin, jotka käänsivät pysyvästi lingvistien katseet eri kielten kuvailusta systemaattisiin historiallisiin vertailuihin (Campbell 2002, 94; Lehmann 1992, 28-30).

Erityisesti Boppin ja Grimmin ajattelun taustalla voidaan nähdä Friedrich von Schlegelin (1772-1829) luonnontieteellisiin analogioihin perustuvat teoriat vertailevasta kieliopista. Schlegelin teoriat olivat suosittuja myös Turun yliopistossa 1700-luvun lopulla ja 1800luvun alussa niin kutsutun Turun romantiikan kaudella (Hautala 1954, 88; Siikala 2002). Kieliä tuli Schlegelin mukaan tutkia järjestelminä, joiden sisäisen rakenteen elementit ovat toisiinsa vuorovaikutussuhteessa siten, että muutokset yhdessä elementissä vaikuttavat myös toisiin. Analogia tuotti myös käsityksen siitä, että yhtä (säilynyttä) osiota tutkimalla voitaisiin rekonstruoida jo kadonneita osioita. Schlegeliltä on peräisin myös ajatus siitä, että kielten sukulaisuuden voi todistaa vain sisäisen rakenteen eli kieliopin vastaavuuksien, ei ainoastaan pinnallisten sanalistojen vertailun avulla. (Lehmann 1992, 27-30; Campbell 2002, 90.) Varsinainen läpimurto tapahtui kuitenkin vasta, kun Franz Bopp kehitti menetelmää kielen muotojen eli morfologian alueelle ja laajensi tutkittujen kielten kenttää (Pedersen 1962, 255-258). Jacob Grimm keskittyi Boppia kapeammalle alueelle ja vertaili keskenään vain germaanisia kieliä, mutta Boppin tavoin paneutui ainoastaan morfologiaan (Pedersen 1962, 260-262).

Von Schlegelin, Boppin ja Grimmin vertailevien kielioppien rinnalla tanskalainen Rasmus Rask esitti muinaisskandinaavin ja saksan sekä slaavilaisten, kreikkalaisten ja latinalaisten kielten historiallisen yhteyden vertailevan menetelmän avulla. Raskin vertailuissa korostui äänteiden variaatioiden tarkastelu, vaikka hänkin korosti kieliopillisten piirteiden merkitystä kielisukulaisuuden määrittämisessä. Raskin löytämät äänteiden vastaavuudet, käytännössä äännelait, tunnetaan Grimmin lakina, sillä Jacob Grimm kehitti Raskin mallista historiallisen fonologian mallinnuksen Deutsche Grammatik -teoksensa toiseen painokseen (1822) (Lehmann 1992, 30; Campbell 2002, 90; Pedersen 1962, 261). Silti Rask oli jo vuonna 1818 julkaistun tutkimuksensa esipuheessa tuonut esiin äänteiden vertailun metodin perusteet: kielet ovat toistensa sukukieliä silloin, kun tutkija voi eksplikoida niiden 
keskeisestä sanastosta äänteiden muutosten sääntöjä. Äännelaki tarkoittaa siis systemaattista äänteiden vastaavuutta kielten välillä. Tutkimuksensa Rask toteutti kartoittamalla, mitkä muinaisskandinaavin maantieteellisistä lähikielistä olivat sen sukukieliä, ja etenemällä niistä maantieteellisesti etäämmällä puhuttuihin kieliin. (Pedersen 1962, 249-251.) Raskin merkitystä on pidetty huomattavana suomalaisessa tutkimusperinteessä, sillä hänen vierailunsa Suomessa ennen Intianmatkaansa inspiroi lukuisia tutkijoita, muun muassa nuorta Anders Johan Sjögreniä (Branch 1968; Stipa 1990, 242-243, 295-298). Kuten aiemmin on jo todettu, Sjögrenillä puolestaan oli huomattava vaikutus Castrénin työhön.

Castrén soveltaa historiallisen ja vertailevan kielitieteen metodeja mytologiantutkimukseen analogisesti: kielellisen piirteen tavoin myös mytologiaan liittyvän käsityksen tapaaminen laajalla alueella ja monen kansan parissa kertoo sen vanhuudesta, kun taas jonkin käsityksen esiintyminen ainoastaan yhdellä tai muutamalla kansalla merkitsee käsityksen nuorta ikää. Erityisen selvästi tämä tulee esille mytologialuentojen ensimmäisessä luvussa, jossa Castrén esittää jumalan olevan alkuperäisin ja vanhin jumalnimitys. Perustelut liittyvät nimityksen laajaan esiintymiseen: se tunnetaan jopa samojedikielissä, kun taas muita suomalaisen mytologian jumaluuksia ei tunneta yhtä laajasti muiden kansojen parissa. Esimerkiksi nimitystä $u k k o$ ei tunneta "jumalallisuuden merkityksessä" muualla kuin suomalais-karjalaisessa, virolaisessa ja saamelaisessa perinteessä, minkä vuoksi Castrén ei oleta käsityksen olevan vanhaa perua (ks. s. 86-87, 98-100). Vastaavasti Castrén pitää kalevalamittaisen runouden sota- ja kosintateemojakoko altailaista kielikuntaa yhdistävänä tekijänä, mutta joutuu toteamaan, että samporunot ovat myöhäisiä lisiä kalevalamittaiseen runouteen, sillä "traditiota tästä merkittävästä välineestä ei tavata ainoankaan sukukansan keskuudessa”. Lisäksi perinteelle löytyy vastineita skandinaavisesta mytologiasta, mikä kertoo myöhempien kulttuurikontaktien vaikuttaneen runouteen. (ks. s. 265-268.)

Ajatus "alkuperäisistä" kansallisista erityispiirteistä oli tärkeä osa saksalaista romantiikkaa ja näiden piirteiden etsintä sen keskeisimpiä tavoitteita. Jacob Grimm (1785-1863) oli saksalainen kielitieteilijä, mytologi ja kansanperinteentutkija, jonka teoksen Deutsche Mythologie toiseen painokseen (1844) Castrén viittaa usein. Viitteet liittyvät 
lähinnä germaanisen mytologian yksityiskohtiin, mutta Grimmin vaikutus Castrénin mytologiatutkimukselle lienee ollut merkittävä yleiselläkin tasolla. Johann Gottfried von Herderin (1744-1803) kansankulttuuria ihannoivat ajatukset elävät Grimmin työssä vahvasti. Myös kolonialismin ja Napoleonin valloitussotien kritiikki Euroopassa lienee pohjustanut Grimmin kotoperäisen kulttuurin arvoa painottavia ajatuksia, joita kuvaa hyvin seuraava katkelma hänen teoksestaan Deutsche Mythologie:

Jokainen kansa vaikuttaa syntyjään täydelliseltä ja torjuvan vieraita vaikutteita. Kieli, epiikka viihtyy ainoastaan kotipiirissä yhtä lailla kuin joki jylisee kovimmin kuohuessaan uomassaan. Kaikki sen häiriintymättä kehittynyt oma voima ja syvimmät vaikuttimet kumpuavat tästä keskuksesta, eikä vanhimmalla puheellamme, runoudellamme ja kertomustollamme ole nähtävissä muuta kasvupohjaa. (Grimm 1844, xxi-xxii.) $)^{9}$

Grimmin kansanperinteeseen liittyneen työn keskeisenä lähtökohtana oli Georg Creutzerin (1810-1812) ajatuksiin pohjaava usko siihen, että alkuperäisin ja aidoin germaanimenneisyys ja sen henki oli tavoitettavissa kansanperinteestä (Creutzer 1810-1812; Bascom 1977, 3). Myytti oli hänen mukaansa kansan mielessä alati pohjavireenä vaikuttava elävä ilmiö ja tämän ansiosta tavoitettavissa uudemmassakin kansanperinteessä eikä ainoastaan muinaisuudessa kirjoitetuissa teksteissä (Williamson 2004, 81, 90, 111-112). Myytti oli Grimmin mukaan kiinnittynyt nimenomaan kieleen. Grimm ilmaisee tämän runollisesti teoksensa Deutsche Mythologie toisen painoksen esipuheessa:

Mikäli kielen suhteen kelpuutetaan johtopäätökset siitä, mitä siinä ei ole, sen perusteella että kielen tämänhetkiset ominaisuudet palautuvat kuitenkin kauas vanhempiin ja vanhimpiin [kielimuotoihin], on vastaava käytäntö oikeutettu mytologiankin suhteen. Sen haihtuvasta vedestä voikin aavistaa lähteen, seisovasta suosta vanhan virran. Kansat kiinnittyvät ja takertuvat perinteisiin, mutta emme käsitä traditioita emmekä taikauskoa lainkaan, mikäli emme osoita niille pohjaa pakanallisella maaperällä. $(\text { Grimm 1844, vi. })^{10}$

Vastaavasti myös Castrén pyrkii tutkimuksessaan juuri suomalaisen mytologian lähteille tavoitellessaan sen alkuperäisiä muotoja. Käsite alkuperäinen on kuitenkin jo itsessään ongelmallinen, sillä kansan- 
kulttuurin ilmiöille on vaikeaa ellei mahdotonta osoittaa tiettyä alkumuotoa, jolla ei olisi edeltäjiä. Castrén vaikuttaakin viittaavan alkuperäisellä pragmaattisemmin sellaisiin mytologian muotoihin, joille ei tunnista edeltäjiä. Nämä muodot ovat esimerkiksi sellaisia, joiden vastineita tavataan etäisimpienkin sukulaiskansojen parissa, jotka kielellisesti vaikuttavat alkukantaisimmin kotoperäisiltä tai jotka ovat maailmankatsomukseltaan Castrénin teoreettisen viitekehyksen nojalla aineiston vanhimpia. Vanhimpien tai alkukantaisimpien uskonnollisten käsitysten ja niihin viittaavien myyttien tunnistaminen edellytti Castrénilta teoreettista mallia, jonka perusteella hän saattoi määrittää erilaisten käsitysten keskinäisen suhteellisen iän.

Suullisessa kansanperinteessä elävien kielellisten muistomerkkien, kuten myyttisten kertomusten, syntyajankohdan ajoittaminen on kuitenkin varsin hankalaa, sillä niissä on vain harvoin piirteitä, joiden perusteella ne olisivat liitettävissä mihinkään tiettyyn ajankohtaan tai aikakauteen. Castrénkin oli varsin tietoinen siitä, että kansanperinne on luonteeltaan kerrostuvaa: ikivanhojen elementtien päälle kasaantuu jatkuvasti uutta, ja eri aikakausilta periytyviä käsityksiä ja käytänteitä saattaa elää rinnan jopa saman perinneyhteisön sisällä. Castrén esimerkiksi valittelee useassa kohdassa sitä, kuinka kirjauskonnot ovat turmelleet vanhakantaisia käsityksiä, ja vastaavasti Jacob Grimm valittelee kristinuskon syrjäyttäneen germaanien kotoperäisen uskonnon (Grimm 1844; vrt. myös Tengström 1845a). ${ }^{11}$

Castrénin mytologialuentojen taustalla oleva Grimmin inspiroima ajatus ilmiöiden alkuperästä ja vertailtavuudesta herätti kiinnostusta ympäri Eurooppaa, eikä Castrén suinkaan ollut ainoa, joka pohdiskeli vertailevan mytologian mahdollisuuksia Venäjän keisarikunnan alueella. Samoihin aikoihin Castrénin kanssa venäläinen folkloristiikka otti ensimmäisiä askeliaan samankaltaisissa merkeissä. Venäläisen historiallisen ja vertailevan mytologiantutkimuksen perustajana voidaan pitää Fjodor Ivanovitš Buslajevia (1818-1897), jonka ajattelu palautuu edellä esitetyn yleisen eurooppalaisen vertailevan filologisen tradition lisäksi Venäjällä 1800-luvun puolivälissä vaikuttaneeseen voimakkaaseen dekabristiseen, kansallismieliseen ajatteluun (Toporkov 1997, 69-71; Balandin 1988, 13-15; Azbelev 1991, 4). Buslajevin tieteellisen uran ensimmäiset tekstit on julkaistu 1840-luvulla eli samoihin aikoihin kuin Castrén julkaisi keskeisimmät tekstinsä. Vas- 
taavasti Buslajevin ja Castrénin ajattelun taustalla ovat samat tutkijat, ja aatehistoriallisesti heidän romanttinen ajattelunsa nousi samoista taustoista, vaikkakin suuntautui eri kieliryhmiin ja kulttuurispoliittisiin konteksteihin. Buslajevin ura oli Castrénin elämää pidempi, minkä vuoksi hänen viimeiset ja menetelmällisesti täsmällisimmät tekstinsä on julkaistu 1870- ja 1880-luvuilla, jolloin Julius Krohn kehitteli Suomessa maantieteellis-historiallisen menetelmän perusteita.

Castrénista poiketen Buslajev ei tehnyt itse kenttätöitä, vaan perusti tutkimuksensa ennen kaikkea arkistomateriaaleihin. Buslajev sovelsi ensimmäisenä historiallista ja vertailevaa menetelmää venäjän kieleen. Häntä on pidetty merkittävänä muista aikalaistutkijoista erottuvana kirjoittajana juuri menetelmän korostamisen ja sen eksplikoimisen ansiosta (esim. Toporkov 1997, 52), minkä vuoksi hänen työtään on mielenkiintoista verrata Castrénin mytologialuentoihin. Buslajevin mukaan historiallisen ja vertailevan tutkimuksen tarkoituksena oli selvittää ennen kaikkea, millaista kansan ajattelu on alun perin ollut ja miten kansat ja niiden ajattelu ovat eriytyneet. Tässä tehtävässä tutkijan tulisi erottaa saatavilla olevan kansanrunousmateriaalin (laulujen, sananlaskujen, tarinoiden) perusteella historiallisten sivilisaatioiden aikaansaamista keinotekoisista kulttuurin kerroksista kansan perustavaa laatua olevat elementit. Historia on siis kantakulttuurien ja -kielten eriytymisen ja muuntumisen prosessi, jonka eri hetkiin voidaan päästä käsiksi historiallisen ja vertailevan menetelmän avulla. (Balandin 1988, 40.) Kielen ja kansanrunousmateriaalin lisäksi Buslajev korosti kaiken saatavilla olevan kulttuurista kertovan materiaalin yhtäaikaista, synteettistä käsittelyä (Balandin 1988, 32).

Buslajevin näkemysten mukaan kieli on kansan esihistoriallisesta elämästä kertovista muistomerkeistä vanhin, ja sen muodossa ja sisällössä tulee esiin paitsi ihmisen yksilöllinen ajattelu, myös koko kansan luovuus. Kielen historiallinen ja vertaileva tutkimus, vaikka se keskittyikin kielen rakenteiden vertailuun, avasi näkymän kokonaiseen kansan henkisen elämään. Toisaalta kielitieteen historiallisvertaileva menetelmä soveltui myös suullisen perinteen, mytologian ja kansan tapojen tutkimuksen välineeksi; myös niiden alkuperäinen olemus oli tavoitettavissa analyysin keinoin. Menetelmän keskiössä oli yleisen ja yksilöllisen aineksen erottaminen toisistaan. 
(Toporkov 1997, 76-77.) Buslajevin mukaan kieli on syntynyt ja kehittynyt samanaikaisesti myyttien, tapojen ja rituaalien kanssa. Kulttuurin kehityksen vaihetta, jolloin kielen sanasto ei ole vielä eriytynyt vaan jolloin samoilla sanoilla voidaan ilmaista erilaisia tarkoitteita, Buslajev kutsuu "esihistoriallisen ajan henkisen elämän eheydeksi". Eheys perustuu siihen, että luonnonilmiöitä on nimetty niihin liittyvien elämysten ja vaikutelmien perusteella, minkä vuoksi esimerkiksi muinaisslaavin nopeutta edustavat stri 'tuuli' ja strela 'nuoli' sekä muinaisslaavilaisen mytologian nopea lintuhahmo (Stribog) nousevat samasta slaavilaisesta juuresta, stri.

Buslajev rakensi uransa aikana selkeän kehyksen, johon venäläisen mytologian ja kielen historia asettui. Siinä on runsaasti samankaltaisuuksia Castrénin mytologialuennoista heijastuvan kehyksen kanssa, vaikka Castrén ei luultavasti tuntenut Buslajevin tekstejä. Sen sijaan Grimmin Deutsche Mythologie näyttää olleen Castrénille keskeinen malli, sillä metodisten lähtökohtien ohella Castrénin mytologialuennot vastaavat sitä jossain määrin myös rakenteeltaan. Molempien otsikointi on monin osin identtistä, mikä heijastelee aiheen jäsentämisen ja käsittelytapojen yhdenmukaisuutta. Molempien pohdinnan kohteena ovat paljolti mytologinen termistö juurineen, ennen muuta erilaisten olentojen nimitykset, sekä termistöön liittyvien myyttien ja muiden kansanuskon ilmiöiden keskinäiset, kulttuurienväliset rajat ylittävät yhteydet. Castrénin teoksen kaksi ensimmäistä päälukua ("Jumalat" ja "Erityisiä henkiolentojen lajeja") vastaavat sisällöltään Grimmin teoksen lukuja I-XXIX, joskin Castrén on jaotellut Grimmin lukuja XVII-XXIX vastaavat, lähinnä luontoon ja erilaisiin elämänilmiöihin liittyvät jumaluudet ja mytologiset ilmiöt luonnon keskeisimpien elementtien mukaan laatimansa typologian mukaisesti. Toisaalta Castrén on sijoittanut luvun "Sankarit" teoksensa loppuun, kun taas Grimm käsittelee sankareita jumalten jälkeen, heti jumalista seuraavina palvottuina olentoina (luku XV). Sijoittaminen korostaakin Castrénin tulkintaa suomalais-ugrilaisista sankarikertomusten taustoista varsin maallisina ja myöhemmän lainaaineksen värittäminä kertomuksina. Näin ollen voidaan sanoa, että Castrénin lähtökohtana oli Lencqvistin ja Porthanin mallin ohella Grimmin Deutsche Mythologien osaltaan edustama keskieurooppalainen tutkimusparadigma, mutta että hän ei yrittänyt sovittaa 
tuntemaansa materiaalia väkisin näiden puitteisiin vaan teki aineistosta omannäköisensä tulkinnan.

Castrén on kuitenkin tarvinnut jonkinlaisen ulkoisen viitekehyksen määrittäessään tiettynä aikana kootun tradition eri aineksista "vanhinta" tai "alkuperäistä". Kielen muuntumisen teorioiden lisäksi Castrénille tällainen viitekehys oli malli uskonnollisen ajattelun kehittymisestä, joka puolestaan liittyi teoriaan kulttuurisista kehitystasoista. Castrén ei paneudu teorioihin kulttuurin tai uskonnollisen ajattelun kehittymisestä sen tarkemmin, vaan hänen näkemyksensä on luettava eri puolilla tekstiä erottuvista irrallisista termeistä, huomioista ja päätelmistä. Eri lukujen johdannoissa hän käsittelee aihepiiriä perusteellisimmin. Seuraavassa esittelemme lyhyesti teorioiden taustoja eurooppalaisessa tutkimuksessa sekä sitä, kuinka eurooppalaisessa tutkimuksessa vallinneita ajatuksia näkyy Castrénin tekstissä.

1700-luvulla oli asianmukaista tieteellisessäkin diskurssissa tukeutua uskonnon varhaisimpien muotojen suhteen Raamattuun ja sen kuvaukseen alkumonoteistisestä, yhtä Jumalaa palvoneesta tilasta, josta ihmiskunta erkaantui ja harhautui palvomaan monituisia eri kohteita. Lencqvistin väitöskirjassa on tästä monta esimerkkiä. 1800-luvun lähestyessä Raamattua ei kuitenkaan enää pidetty tutkimuksen piirissä sinä todellisuutta ja historiaa suoraan tai kuvaannollisesti kuvaavana ehdottomana auktoriteettina, joka se oli ollut keskiajalta ja yliopistolaitoksen synnystä asti (Williamson 2004, 10-11). Erilaisten kulttuurien ja uskonnollisten järjestelmien tuntemuksen lisääntyessä 1700-luvun loppua kohden eurooppalaisessa kirjallisuudessa alkoi nousta esiin ajatus siitä, että uskonnollinen ajattelu kehittyy ajan saatossa alkukantaisemmasta hienostuneemmaksi (korkeimpana asteenaan kristinuskon edustama monoteismi). (Ks. Meek 2010; Vaughan 1972, 10-12; Simon 1956.) Ajatus kulttuurien yleismaailmallisesti yhdenmukaisesta vaiheittaisesta kehittymisestä kohti länsimaiden edustamaa korkeinta tasoa sai alkunsa 1700-luvulla ja kehittyi myöhemmin, 1800-luvun loppupuolella, evoluutioteorian hyväksymisen myötä ajatuksiksi kulttuurievoluutiosta (ks. Stocking 1967, 87-94).

Näissä ajatuksissa kulttuurin kehitys samastettiin pitkälti ihmislajin psyyken kehittymiseen, jolloin korkea kulttuurinen taso merkitsi kehittynyttä ajattelukykyä ja päinvastoin. Uskonnon muotojen katsottiin 
vastaavasti määrittyvän kulttuurin kehitystason mukaan: alkeellisissa kulttuureissa uskonnollisuus oli yksinkertaista ja liittyi vaistonvaraiseen, älyllisesti rajalliseen ajattelukykyyn. Uskonnon juurten tulkittiin näin ollen liittyvän pelottavien, selittämättömien ilmiöiden rationalisointiyrityksiin vajavaisin tiedoin ja kognitiivisin kyvyin. David Hume korosti 1757, että uskonnon alku oli filosofisen pohdiskelun sijaan tunteessa, erityisesti pelossa (Beauchamp 2007, 37-38). ${ }^{12}$ Myöhemmin myös filosofit kuten Paul Holbach (1868 [1770], 174-175), Charles Dupuis (1798) ja Georg W. F. Hegel (Hodgson 1988, 225) esittivät, että juuri luonnonilmiöiden, kuten ukonilman, pelko antoi uskonnolliselle ajattelulle alkusysäyksen.

Kulttuurien universaalin kehityksen teoriaan liittyi implisiittisesti ajatus siitä, että nykypäivän kehittymättömissä kulttuureissa oli tavattavissa ilmiöitä, kuten uskonnollista ajattelua, jotka olivat analogisia myös länsimaisten kulttuurien varhaisemman, kehittymättömän vaiheen kanssa. Eräs varhaisimmista tähän ajatteluun liittyvistä teoreetikoista oli ranskalainen paroni Charles de Brosses (1709-1777), joka teoksessaan Du culte des dieux fétiches (1760) vertailee Länsi-Afrikan uskonnollisia käytänteitä muinaisen Egyptin uskonnollisia käsityksiä kuvaaviin muistomerkkeihin. De Brosses esittää, että kivikuvien ja muiden esineiden palvonta, fetisismi, edustaa ihmiskunnan varhaisinta uskonnon muotoa (Brosses 1760; Feldman \& Richardsson 1972, 172). ${ }^{13}$ De Brossesin mukaan "villin" mieli tarvitsee palvonnalle konkreettisen kohteen ja vasta kulttuurin kehittyneemmässä vaiheessa tämä kykenee palvomaan abstraktia, näkymätöntä jumalaa (Ellen 1988, 214). De Brossesin aikalainen, David Hume, selitti fetisismin eli "idolatrian" juurten olevan alkukantaisten ihmisten tavassa liittää näkymättömät voimat näkyviin kohteisiin (Beauchamp 2007, 49).

Auguste Comte, joka laati yhden varhaisimmista hahmotelmista kulttuurien kehitysasteista, määritti uskonnon kehitysvaiheet 18301842 luennoissaan fetisismiksi, polyteismiksi eli monijumalaisuudeksi ja monoteismiksi. Comte katsoi fetisismin olevan yksi magian muoto, tapa pyrkiä vaikuttamaan erilaisiin ilmiöihin yliluonnollisin keinoin. (Martineau 1853, 1-5.) Vastaavasti myös Hegel luki vuoden 1827 luennoissaan Christian Gottlob Heyneä mukaillen fetissit magian harjoittamisen rinnakkaisilmiöksi. Hänen mukaansa silloin, kun uskonnollinen ajattelu ei vielä kykene abstraktioihin, "[jumalallinen] 
voima käsitetään ulkoisena ja aistittavana" (Hodgson 1988, 235; myös Williamson 2004, 32). Comten mukaan uskonnollinen ajattelu kehittyi siis käsityksestä esineillä olevasta voimasta abstraktimpaan suuntaan: ensin käsitykseksi moninaisista aistein tavoittamattomista jumaluuksista ja lopulta käsitykseksi yhdestä, kaikkivaltiaasta jumaluudesta.

Castrén tunsi Georg W. F. Hegelin (1770-1831) teorian uskonnollisen ajattelun muodoista, vaikkei siihen luennoissaan viittaakaan. Hegelin mukaan uskonnon muotoja on kolme: luonnonuskonto, jossa henki ja luonto ovat yhtä ja ihminen itse on korkein kuviteltavissa oleva olento; uskonto, jossa henki on irtaantunut luonnosta mutta on siihen kiinnittyneenä ja jossa jumalten käsitetään olevan luonnonilmiöiden takana; sekä tarkoituksellisuuden tai kohtalon uskonto, jossa jumaluus antaa kaikelle merkityksen (Hodgson 1988, $207-$ 209, 229-235, 271-292). Hegelin teorian kaikuja on tunnistettavissa Castrénin mytologialuennoissa yleisellä tasolla hänen ajatuksissaan mytologian kehittymisestä (eritoten s. 97-99), mutta Castrénin pohdinta etenee joka tapauksessa aineiston ehdoilla, ei aineistoa teoreettiseen malliin sovittamalla, mihin taas esimerkiksi Tengström pyrkii uskonnon kehittymistä käsittelevässä artikkelissaan (1845a). Castrén mainitsee muistiinpanoissaan, ettei omien kenttäkokemustensa nojalla voi hyväksyä Hegelin näkemystä sellaisenaan, koska siinä ilmenevä käsitys jumaluuksista ei sovi yhteen šamanismin (magian) periaatteen kanssa (MAC Fennica II:2: 22-23; Hegelin näkemyksestä ks. Hodgson 1988, 235).

Eurooppalaisessa tutkimuksessa myös kielten rakenteen perusteella tehtiin johtopäätöksiä puhujien kehityksen tasosta, kuten Willhelm von Humboldtin (1767-1835) kirjoituksissa vertailevasta antropologiasta ja kielitieteestä. Humboldtin mukaan jokaisella kansalla on luonteenomaiset perinteensä, tapansa, uskontonsa, kielensä ja taiteensa, jotka ilmaisevat kansanluonnetta mutta kertovat myös kansan kehityksen tai sivistyksen (Bildung) tasosta. Humboldt korosti kansallisten saavutusten relatiivisuutta: niitä ei voinut eikä tullut vertailla toisiinsa. Sen sijaan antropologien tuli keskittyä inhimillisen olemassaolon monimuotoisuuden ja säännönmukaisuuksien kuvaamiseen ilman ennakko-oletuksia ja havaintoja ohjaavia teorioita. (Bunzl 1996, 22-28.) 
Teoria kulttuurin kehityksestä kantaa läpi Castrénin teoksen, mikä käy ilmi esimerkiksi termeistä, joilla hän viittaa kehittymättömämpinä pitämiinsä kansoihin (ohyfsade 'sivistymättömät, säädyttömät'; vildar 'villit'; råa menniskor 'kypsymättömät ihmiset, raakalaiset'; lägre kulturgrad 'alempi kulttuuritaso'; nationens barndom 'kansakunnan lapsuus' jne.). Nämä termit sattuvat nykylukijan silmään ylimielisinä tai jopa rasistisina, mutta ne olivat tyypillisiä kolonialismin perinteeseen nojautuneessa tieteellisessä ajattelussa ja puhetavassa 1800-luvulla. Castrénin tutkimuksen kohde oli alkukantainen mytologia, jonka tuli siis vastata kehittymättömiä kognitiivisia kykyjä. Castrén pyrkiikin eläytymään alkukantaiseen ajatteluun tulkitessaan tekstejä ennen muuta konkretian kautta, välttäen abstraktioiden ja metaforien käyttöä tulkinnan avaimina (poikkeuksena tulkinta sammosta, ks. s. s. 266-268).

Yleistä aikalaiskäsitystä mukaillen Castrén näkee ihmetyksen luonnonilmiöiden edessä johtaneen käsitykseen niiden jumalallisuudesta. Koska ukkonen oli luonnonilmiöistä vaikuttavin, se kohosi keskeisimmäksi jumaluudeksi, ylijumalaksi. Castrénin käsityksen mukaan luonnonkohteita palvottiin alkujaan ulkoisen olemuksensa mukaisina, mikä näkyy jo siinä, että kohteilla ja niihin liitetyillä jumaluuksilla on usein sama nimitys. Saman sanan eri merkitysten tai tarkoitteiden suhteellisen iän määrittely niiden abstraktiotason perusteella on erityisen valaisevasti näkyvissä Castrénin pohdinnassa hiiden suhteen: hiisi merkitsee suomalaisessa mytologiassa pahaa olentoa ylipäätään mutta erisnimenä myös pahaa metsänjumalaa. Koska jälkimmäinen merkitys on konkreettisempi, se on Castrénin mukaan myös "alkuperäinen" eli vanhempi. (ks. s. 156.)

Castrénin mukaan jumaluus erotettiin sitä edustavasta kohteesta vasta uskonnollisen ajattelun kehittyneemmässä vaiheessa (vrt. David Hume [Beauchamp 2007, 49] ja Georg Hegel [Hodgson 1988, 229235]). Suomalaisetkin siis palvoivat hänen mukaansa aluksi luonnonkohteita niiden aistittavassa hahmossa ja vasta myöhemmin erottivat jumaluudet itse luonnonkohteista (ks. s. 152). Kuten Castrénin perintöä arvioineet venäläistutkijat ovat huomauttaneet, Castrénin käsitys jumaluuksien manifestoitumisesta tai olennoitumisesta palvottavissa kohteissa (ks. esim. s. 190-193) muistuttaa Edward B. Tylorin kaksikymmentä vuotta Castrénin jälkeen määrittelemää animismia (jonka perusta tosin oli luotu jo varhaisissa teorioissa fetisismistä). Tylorin 
mukaan "primitiivisten" kansojen parissa tavattavat käsitykset yhtäältä kaikessa materiassa olevasta hengestä tai hengistä ja toisaalta käsitykset näiden henkien itsenäisyydestä edustavat uskonnollisen ajattelun alkukantaisinta muotoa. (Tylor 1871, esim. 385, 430-432; Bogoraz 1927, 31-33; Štenberg 1927, 50-53; Nordberg 2013, 67-73.) ${ }^{14}$ Castrénin kuvaukset luonnonilmiöissä ja -kohteissa elävistä hengistä näyttävätkin sijoittuvan Hegelin edustaman uskonnonfilosofisen ajattelun ja Castrénin jälkeen syntyneen antropologisen tutkimuksen piirissä käydyn keskustelun välille. Yhtä kaikki, jumaluuden erottamisen sitä edustavasta kohteesta voi tulkita Castrénin pohdinnoissa merkinneen polyteismin alkua (ks. s. 97-98, 152, 190-191).

Rinnan muiden jumaluuksien palvonnan kanssa Castrén käsittelee vainajainpalvontaa. Castrénia aiemmin myös Hegel oli pohtinut vainajien vaikutusmahdollisuuksia luontoon ja esittänyt vainajiin vetoamisen olleen yksi magian muoto ja sellaisena varhaisimpia uskonnon muotoja (Hodgson 1988, 231-234). Castrén määrittelee vainajainpalvonnan perustan paljolti samaan tapaan kuin se käsitettiin myöhemminkin vainajainpalvontaan liittyvän keskustelun piirissä: "Vainajan [...] kunnioitus ei perustunut monien kansojen kohdalla pelkästään [...] pelkoon hänen haitallisesta paluustaan, vaan johtui osin uskosta hänen kuoleman kautta saavuttamaansa korkeampaan, jumalalliseen luontoon" (s. 163). Myöhemmän englantilaisen antropologian piirissä Herbert Spencer määritteli manismin, vainajien henkien palvonnan, kenties tiiviimmillään näin: "Kaiken uskonnollisuuden alkumuoto on kuolleiden esivanhempien lepyttely, kun näiden oletetaan yhä olevan olemassa ja kykeneviä aiheuttamaan hyvää tai pahaa jälkeläisilleen" (Spencer 1870, 536; ks. Nordberg 2013, 6061). Castrénille, kuten englantilaiselle antropologialle myöhemmin, rituaaliset toiminnot olivat keskeisiä uskonnollisen ajattelun määrittäjiä, eikä "henkiin" ja "jumaluuksiin" suhtauduttu hänen mukaansa rituaaleissa juurikaan eri tavoin, vaan niihin vedottiin yhtäläisesti (ks. s. 200). Castrénin mytologialuennoissa piili siis jo sen keskustelun siemen, mitä hänen jälkeensä käytiin antropologian piirissä etenkin sielu-uskoon liittyen. (Myös Štenberg 1927, 50-56.) 


\section{Etnografisen tiedonintressin kehittyminen}

Historiallis-vertailevan otteen rinnalla Castrénin mytologialuennoissa kulkee pyrkimys hyödyntää etnografisia aineistoja ja luokitella Venäjän vähemmistöjä ryhmiksi kielitieteellisin perustein. Kuten Jukka Siikala on huomauttanut, Castrénin etnografiaa leimaa erottelun sijasta pyrkimys luoda yhteyksiä kulttuuristen yksiköiden eli eri kielimuotoja puhuvien heimojen ja kansojen välille. Yhteydet todistettiin kielen historiallisten vertailujen avulla, ja etnografisten vertailujen rooli oli lähinnä täydentävä ja vahvistava. (Siikala 2006, 157-160.) Mytologialuentojen toisessa osassa Castrén kiinnittää kielitieteellisten vertailujen tulokset mytologiaa ja uskonnollista elämää koskevaan etnografiseen aineistoon systemaattisesti ja kokonaisvaltaisesti käyden läpi ryhmän toisensa jälkeen. Etnografiset aineistot esitellään kuitenkin vasta varsinaisen kieleen keskittyneen analyysin jälkeen, eikä Castrén vedä tästä aineistosta yhtä voimakkaita johtopäätöksiä kuin kielellisestä aineistosta. Etnografisia aineistoja ei ollut ennen Castrénia juurikaan kerätty tai käytetty historiallisten analyysien lähteinä, jollei Sjögrenin työtä oteta lukuun. Vastaavanlaisten aineistojen keruu, laajemmin ottaen etnografinen tiedonintressi, oli vasta kehittymässä 1700- ja 1800-lukujen vaihteen jälkeen.

Venäjän etnografisen tutkimuksen perinteet ovat muun Euroopan ja maailman perinteitä iäkkäämmät. Sen voidaan nähdä johtuvan siitä, että Venäjän "toinen" eli vieraiksi koetut kulttuurit ovat olleet kiinteä osa imperiumia ja sijainneet niin kaukaisilla alueilla kuin "omien" keskuudessakin, venäjän- ja ukrainankielisen väestön seassa. Hallinto on tarvinnut systemaattista tietoa koko laajan Venäjän alueen kansoista jo varhain, sillä Venäjän alue on aina ollut monikulttuurinen. (Knight 2000; Clay 1995.) Olennaisempaa kuin korostaa, että etnografia syntyi Venäjällä aiemmin kuin Keski-Euroopassa tai Yhdysvalloissa (ks. Tokarev 1966, 14-15), on huomata, että kehitys tapahtui kaikkialla samankaltaisen hengen ja ajattelun pohjalta. Yhtäältä etnografian kehitys määräytyi valistukseen ja Herderin ajatuksiin perustuvan kansojen monimuotoisuuden arvostuksen pohjalta, jonka perustalle muun muassa Humboldt rakensi tutkimusohjelmansa. Toisaalta kehitys tapahtui samaan aikaan nousevan kielten ja mytologioiden historiallisen ja vertailevan tutkimuksen lähtökohdista. Romantiikan 
ja nationalismin nousun myötä yleisinhimilliset ohjelmat muuntuivat Euroopassa 1800-luvun aikana suurelta osin oman historian ja perinteen tutkimuksen projekteiksi. (Karkama 2001; Bunzl 1996; Stepanov 1956; Lincoln 1999, 54-74.)

Castrénin työ erottuu Siperian tutkimuksen perinteistä hyvin poikkeuksellisena. Ennen Castrénia tutkimusmatkojen luonnontieteellinen tiedonintressi ja yksittäisten sotilaiden tai vankien tiedot tuottivat epämääräisin nimityksin määritellyistä Siperian alkuperäiskansoista vain fragmentaarista tietoa. Näin oli osittain myös muiden Venäjän vähemmistöjen kohdalla. Venäläisen älymystön etnografinen kiinnostus kohdistui lähinnä venäläiseen väestöön, mutta Sjögren ja Castrén kohdistivat vastaavan katseen suomensukuisia kieliä puhuviin yhteisöihin. Castrén oli erityisen tarkka koettaessaan hahmottaa tutkimiensa kielten ja murteiden suhteita ja niiden sanastoja, mikä selvensi jo sinänsä Siperian etnisen kartan koostumusta aiemmasta. Castrénin jälkeenkään Siperia ei houkutellut pitkään aikaan kielitieteellisesti orientoituneita tutkimusmatkailijoita, minkä vuoksi etnografisen kokonaiskuvan kehittämiseen kului vielä vuosikymmeniä Castrénin jälkeenkin. (Myös Pypin 1892, 385-389.)

Inhimillisen kulttuurin monimuotoisuuden tutkimus kehittyi samaan aikaan historiallisen ja vertailevan kielentutkimuksen kanssa. Kuten Lyle Campbell (2002) on huomauttanut, 1800-luvun alun tutkijat ajattelivat kieltä tutkiessaan tutkivansa esimerkiksi rotujen tai kansojen historiaa. On tärkeää kuitenkin huomata, että etnografisen ja lingvistisen tiedonintressin yhteinen kehityspolku alkoi jo 1700-luvun alussa saksalaisen valistusajattelun piirissä. Han F. Vermeulen $(2015,39-58)$ on viimeaikaisissa tutkimuksissaan osoittanut, että Gottfried Wilhelm von Leibnizin kielitieteelliset teoriat ja intohimo kerätä uutta aineistoa niitä tukemaan saivat myönteistä vastakaikua juuri Venäjän hallitsijoissa. Pietari Suuren 1700-luvun alussa alulle panemat suuret Siperian tutkimusmatkat olivatkin ajassaan poikkeuksellisia juuri siksi, että niiden pääosin luonnontieteellisiin päämääriin oli lisätty kielitieteellisiä osioita. Väestöä luokiteltiin (etnisiin) ryhmiin kielten perusteella. Venäläisessä historiankirjoituksessa on korostettu, että vaikka tutkimusmatkojen johtajat olivat suurimmaksi osaksi saksalaisia, matkojen ohjelmat laadittiin Venäjällä ja ne noudattelivat Vasili Tatištševin maantieteellisiä ohjelmia, joiden 
elimellisenä osana oli alueiden asujaimiston, kielellisen erityisyyden ja näiden historian kuvaaminen (Pypin 1890, 135-140; Tokarev 1966, 80). Vermeulen taas korostaa Leibnizin ajattelun vaikutusta Tatištševin ajatteluun. Leibnizin kielitieteelliset tutkimushankkeet ja niiden taustalla olevat keskustelut eivät vaikuttaneet kuitenkaan välittömästi, sillä Leibniz kävi keskusteluja pääosin kirjeenvaihdossaan. Hänen ajatuksensa vaikuttivat Venäjällä toteutettuihin kenttätöihin esimerkiksi edellä mainitun Messerschmidtin välityksellä.

Muutkin Venäjän suuria tutkimusmatkoja valmistelleet tai niihin osallistuneet tutkijat olivat saaneet koulutuksensa poikkeuksetta joko Göttingenissä tai Hallessa. Kenttätyöohjeistuksessa tämä näkyy selkeimmin toista Kamtšatkan tutkimusmatkaa valmistelleen ja siihen osallistuneen Gerhard F. Müllerin laatimissa keruuohjeissa, jotka koskevat etnistä historiaa (Völkergeschichte). Ohjeiden tarkoituksena oli tuottaa Siperian kansoista perustiedot, jotka koskivat niiden 1) asuma-alueita ja asumisolosuhteita, 2) omaehtoista historiaa, 3) uskontoa, 4) tapoja, riittejä, 5) taloutta ja elinkeinoja, 6) kieltä, 7) paikannimiä sekä 8) aineellista kulttuuria, minkä lisäksi pyydettiin tuottamaan piirroksia ihmisten arkiasuista. Ohjeissa korostettiin henkilökohtaisen havainnoinnin, vuorovaikutuksen ja kodeissa vierailemisen tärkeyttä (Vermeulen 2015, 164-168, 175.) Müllerin päämääränä oli tuottaa kaikista kansoista systemaattinen ja kokonaisvaltainen aineisto, jonka perusteella kansoja voitaisiin vertailla keskenään. Vermeulen kuvaa myös Pallasin matkakertomuksia "ällistyttävän Völker-henkiseksi”, jolla hän viittaa etnografisen kuvauksen, Völker-Beschreibung, runsauteen (Vermeulen 2015, 307).

Messerschmidtin aineistot vaikuttivat ratkaisevalla tavalla August Ludwig Schlözerin ajatteluun. Schlözerin tähtäimessä oli niin ikään Siperian kansojen vertaileva kuvaus ja kansojen historia. Schlözerin Allgemeine Nordische Geschichte (1771) on yritys korvata aiemmat epätarkat "myytit" pohjoisten kansojen historiasta uudella tiedolla. Hän jaotteli pohjoisen asukkaat viiteen pääryhmään (Haupt- und Stammvölker). Jaottelu perustui aiempien tutkimusmatkailijoiden tietoon ja heidän esiintuomiinsa kielellisiin jaotteluihin. Schlözer toi kirjassaan esiin myös käsitteet Ethnographie ja Völkerkunde, joiden Vermeulen tulkitsee tarkoittaneen Schlözerille samaa asiaa: kansojen empiiristä kuvausta, jonka tulisi olla luonteeltaan kokonaisvaltaista ja 
universaalia. Schlözerin pohjoisten kansojen historia oli osa maailmanhistorian etnografisen kuvauksen kokonaisuutta, joka täydentäisi maailmanhistorian "kronologista", "teknografista" ja maantieteellistä kuvausta. (Vermeulen 2015, 278-280.) Schlözerin teoksen jälkeen Euroopassa ilmestyi Georgin Venäjän kansoja kuvaava teos, joka perustui vastaaviin aineistoihin ja omiin kenttätöihin. Georgi jaotteli Venäjän kansoja niin ikään kielen perusteella.

Saksankielinen Völkerkunde ei hankkinut aineistojaan monietnisessä Keski-Euroopassa eikä alusmaissa, kuten myöhemmin tapahtui muissa Euroopan maissa. Sen sijaan saksalainen menetelmä sai jalansijaa Venäjällä, jonka hallitsijat allekirjoittivat muista hallitsijoista poiketen matkaohjeita, joissa eksplisiittisesti edellytettiin kielitieteellisen ja etnografisen aineiston keräämistä.

Castrénin kenttämatkat asettuvat historiallisesti tähän venäläissaksalaiseen etnografiseen perinteeseen sekä aatteellisesti että käytännön matkareittien valinnan suhteen. Vallanpitäjien nopeasti vaihtelevat näkemykset etnografisen aineiston arvosta ovat vaikuttaneet niin kerättyjen aineistojen kuin menetelmällisten keskustelujenkin julkaisemiseen. Castrén olikin Pallasin ja Georgin jälkeen ensimmäinen, joka julkaisi Siperian matkan tuloksia, ja niistä oltiin kiinnostuneita niin Venäjällä kuin Keski-Euroopassakin. Castrénin reitit rakentuivat jo 1700-luvulla toteutettujen tutkimusmatkojen reiteille ja tiedoille niiden varrella asuvista kansoista tai heimoista. Uutta oli kuitenkin se, että Castrén oli ensimmäinen alueella matkannut tutkija, jonka matkaohjeistus keskittyi ainoastaan kielitieteeseen ja etnografiaan ja joka oli saanut koulutuksensa humanistisissa eikä luonnontieteissä. Sikäli Castrén toteutti Leibnizin alkuun panemaa unelmaa. Leibnizin unelmalla oli kuitenkin 1800-luvulla uudet vaatteet, joita väritti kansallisuusaate ja romantiikka. Onkin huomattavaa, että kielentutkimus ja etnografia omina tieteenaloinaan löi pitkistä keskustelulinjoista huolimatta institutionaalisesti läpi vasta silloin, kun kieltä ja kulttuurin piirteitä tarvittiin syntyvien tai muuntuvien kansakuntien rakennusaineiksi.

Ihmiskunnan yhteyteen perustuvat teoriat yhdistyivät 1800-luvun kuluessa Euroopan eri osissa paikallisen erityisyyttä korostaviin näkemyksiin tavoilla, jotka aiheuttivat jännitteitä. Castrénin ja Sjögrenin suhteen jännitteet näkyvät esimerkiksi suomalaisuusliikkeen kärki- 
hahmoksi nousseen J. V. Snellmanin nuivassa suhtautumisessa heidän kenttätyöhankkeitaan kohtaan. Snellman torui Sjögreniä julkisesti omassa Saima-lehdessään, mutta Castrénia hän ainoastaan kehotti yksityiskirjeissään palaamaan niin pian kuin mahdollista Suomeen toteuttamaan kansakunnan rakentamiseen liittyviä käytännöllisiä toimia kielentutkimuksen sijaan (Snellman 1844; 1846b). Venäjällä jännitteet näkyivät vaatimuksissa siirtää etnografinen huomio keisarikunnan alkuperäiskansoista venäläiseen ja niin ikään ukrainalaiseen ja valkovenäläiseen väestöön, mikä näkyi vuonna 1845 perustetun Venäjän keisarillisen maantieteellisen seuran (Imperatorskoje russkoje geografitšeskoje obštšestvo) alkuvuosien keskusteluissa. Maantieteellisen seuran etnografisen osaston johtajana toimi aluksi K. M. Baer, saksalaistaustainen tutkija ja etnografi, joka korosti kaikkien Venäjän kansojen etnografisen tutkimisen tärkeyttä. Hän kiinnitti etnografian tiedonintressin ennen kaikkea historiaan: hänen mukaansa kansojen nykykulttuurin kokonaisvaltainen tutkimus avaisi ihmiskunnan historiaan portteja, jotka ovat suljettuja kirjoitettujen lähteiden tutkijoille (Ber 1849, 72). Baerin linja ei vakuuttanut maantieteellisen seuran venäläismielistä siipeä, joka kannatti "venäläisen ihmisen" tutkimusta. Seuran tulisi selvittää, "mikä erityisesti tekee Venäjästä Venäjän”. (Nadeždin 1849, 149-165.) Tällaisia näkökantoja esittänyt Nikolai Ivanovitš Nadeždin valittiinkin seuran etnografisen osaston johtajaksi.

Edellä kuvaamaamme venäläistä etnografisen tutkimuksen perinnettä on pidetty sikäli keskieurooppalaisesta poikkeavana, että se keskittyi Venäjän valtion alueella ja venäläisten keskuudessa asuvien etnisten ryhmien tutkimukseen. Venäjällä "toiseutta" tai "orienttia" ei voitu tutkimuksessa ulkoistaa tai sijoittaa maantieteellisesti toisaalle, sillä toinen ja orientti olivat osa imperiumia, jossa venäläiset olivat jo pitkään asuneet ja eläneet. Venäläisessä keskustelutavassa imperiumin keskuksesta etäällä olevat maan pohjois- ja itäosat ja Siperia edustavat kuitenkin toiseutta, ja sikäli tästä argumentista voidaan kiistellä. Silti voidaan nähdä, että Venäjän monikulttuurisuus ja ennen kaikkea niin kielellisen, taloudellisen kuin hallinnollisenkin erilaisuuden valtava kirjo tarjosivat venäläiselle etnografialle erittäin vahvan kasvualustan. Vaikka etnografista keskustelua on käyty vuoropuhelussa keskieurooppalaisten ajattelijoiden kanssa, venäläisen 
etnografisen perinteen pitkät juuret ja monikulttuurisen keisarikunnan todellisuudesta nousevat kysymyksenasettelut laajentavat näkemystä etnografian yleisemmästä olemuksesta. Venäjä ei asetu helposti esimerkiksi Diarmuid Ó Giolláinin (2014) hahmotelmaan, jonka mukaan kansanperinteentutkimus ei kehittynyt tieteenalaksi varhain modernisoituneissa, dynastisissa (ja kolonialistisissa) valtioissa, joissa folklore nähtiin sosiaalisesti toisen kielteisesti arvotettuna toimintana. Sen sijaan kansanperinteentutkimus on Ó Giolláinin mukaan vahvistunut ja institutionalisoitunut pienemmissä valtioissa, joissa suullinen perinne määriteltiin esteettisesti ja myönteisesti. Venäjällä on pitkä etnografisen tutkimuksen ja voimakkaan folkloristisenkin keskustelun perinne. Castrénin työ asettuu näiden molempien puitteisiin, ja sitä on luettava myös niitä vasten.

\section{Castrénin mytologialuentojen perintö}

Castrénin mytologialuennoissa yhdistyvät kielitieteellinen, etnografinen ja rituaalien tutkimus niin perusteellisella, pohdiskelevalla ja tieteellisesti perustellulla tavalla, että se poikkeaa kaikista sitä edeltäneistä suomalaista ja suomensukuista mytologiaa käsitelleistä hankkeista täysin. Teos noudattelee ajanmukaista tieteellistä keskustelua ja pohjaa siihen monelta osin, mutta samaan aikaan se raivaa uusia uria paitsi keskustelussa suomalaisesta mytologiasta, myös mytologiantutkimuksessa ylipäätään. Castrén ei ainoastaan rakenna sirpaleisista mytologian ilmentymistä synkreettistä kokonaisuutta vaan huolimatta vastakkaisesta väitteestään (ks. s. 83) hahmottaa samalla mytologisen järjestelmän kehityshistoriaa mytologian viimeaikaisimmista ilmentymistä ajassa taaksepäin kohti sen vanhinta, "alkuperäistä" muotoa. Tämä kehityshistoria liittyy vertailevan tutkimuksen kautta suomalaisen mytologian ja suomensukuisten kansojen mytologioiden välisiin yhteyksiin, joita Castrén hakee monipuolisesta ja laajasta tutkimusaineistostaan muun muassa kertomuksista, sanastosta, rituaaleista ja etnografisesta aineistosta. Castrénin lähestymistapa ei sinänsä ollut aikanaan täysin uusi, mutta hänen käyttämiensä aineistojen laajuus on todella vaikuttava vielä nykymittapuullakin mitattuna. Vertailevaa etnografista tutkimusta suomensukuisten kansojen aineistojen 
kesken oli harjoitettu ennen Castrénia melko vähän, mikä saattaa olla yksi syy siihen, että hänen etnografiset johtopäätöksensä eivät vaikuta yhtä valmiilta tai kypsiltä kuin hänen johtopäätöksensä monen muun luennoissa käsitellyn aihepiirin suhteen.

Castrénin mytologialuennot osallistuivat suomalaisiin keskusteluihin Kalevalasta. Näissä keskusteluissa ei pohdittu ainoastaan eeposta sinänsä, vaan niiden ydin oli suomalaisten historiassa ja suomalaisten ja suomensukuisten kansojen uskonnossa sekä sen historiassa. Osana näitä keskusteluja luennoilla oli ja on ollut niiden julkaisemisen jälkeenkin merkittävä rooli suomalaisuuden idean rakennusaineena. Konkreettisimpana elämään jäi ajatus suomalaisten alkukodista ja mongolilaisuudesta. Keskusteluun suomalaisesta mytologiasta Castrén toi uuden metodologisen kentän ja uusia aineistoja Venäjältä ja saamelaisten parista. Castrénin pohdinnat laajenivat historiallisesti pidemmälle menneisyyteen ja alueellisesti laajemmalle kuin aiemmin. Castrénin avaamia latuja hiihdellään, koetellaan ja levennetään osin edelleen suomalaisen mytologian tutkimuksessa. Niistä avautuu pitkä suomalaisen mytologian tutkimuksen perinne Julius Krohnista tähän päivään asti.

Vanhakantaisia myyttejä ja mytologista perinnettä oli säilynyt suomalais-karjalaisen kulttuurin piirissä 1800-luvulle asti kielellisessä muodossa ennen muuta kalevalamittaisena suullisena runoutena. Tämän vuoksi kalevalamittainen runous oli keskeisessä roolissa Castrénin kielellisesti orientoituneessa tutkimuksessa. Kalevalamittaisen runouden suhteen Castrén kuitenkin nojautuu mytologialuennoissaan etupäässä Elias Lönnrotin kokoamiin Kalevalan kahteen painokseen. Etnografisen ja antropologisen tutkimuksen kehitys Euroopassa 1800 -luvun toisella puoliskolla alkoi edellyttää enenevässä määrin tutkijan jalkautumista tutkijankammiostaan tutkimuskohteidensa pariin. Kehitys näkyi myös siinä, että primääriaineistojen merkitys tutkimusaineistona kasvoi eikä aiempia tulkintoja enää pidetty sellaisenaan käypinä tutkimuksen lähtökohtina. Kalevalaa onkin pidettävä Elias Lönnrotin tulkintana kalevalamittaisesta epiikasta. Kun kansanrunoudentutkimus näin irrottautui Kalevalasta ja kansanuskontutkimus kiinnostui enenevässä määrin uskomusten ja käsitysten lainautumisesta kulttuurien välillä sen sijaan, että se olisi ollut kiinnostunut uskomusten suhteesta kunkin kulttuurin "alkuperäiseen" 
uskomusjärjestelmään, viittaukset Castrénin mytologialuentoihin jäivät alaviitteisiin. Castrénin työ oli kuitenkin ollut suuri askel samaan suuntaan siitä paljolti spekulatiivisesta ja tieteellisesti kestämättömästä kirjoittelusta, jota suomalaisen mytologian suhteen oli harrastettu häntä ennen.

Castrénin etnografisiin aineistoihin liittyvät vertailut ja tulkinnat synnyttivät Suomeen tutkimusperinteen, jossa mytologisten aineistojen kerääminen ja tulkinta limittyi osaksi kielentutkijoiden työtä. Tämä näkyy selkeästi myös Castrénin työtä jatkamaan perustetun Suomalais-Ugrilaisen Seuran stipendiaattien, esimerkiksi K. F. Karjalaisen (1918) ja Toivo Lehtisalon (1924) kenttätöissä ja tutkimuksissa. Etnografisten vertailujen toissijaisuus kielitieteellisten ja folkloretekstien vertailujen rinnalla sekä tarve hahmottaa mieluummin yhden etnisen ryhmän mytologia ja uskonto kuin vertailla monien järjestelmiä toisiinsa ovat kuitenkin leimanneet tutkimusta.

Julius Krohn julkaisi vuonna 1894 teoksensa Suomen suvun pakanallinen jumalanpalvelus, jossa hän kuvaa nimenomaisesti suomalaisugrilaisten kansojen uskonnollisuuteen liittyvää etnografiaa. Krohn keskittyy pyhien paikkojen ja jumalkuvien, šamanismin muotojen ja erilaisten rituaalien kuvaukseen. Teoksessaan Krohn ottaa kielteisen kannan Kalevalan käyttöön kalevalamittaisen kansanrunouden lähteenä. Tämä pesäero Kalevalaan johti kentältä kerättyjen kansanrunojen analyysimenetelmien kehittämiseen etenkin niiden "alkuperäisen" muodon tavoittamiseksi ja lopulta kansanrunoudentutkimuksen syntyyn itsenäisenä oppiaineena.

Julius Krohnin poika Kaarle Krohn, kansanrunoudentutkimuksen ensimmäinen professori, käsittelee suomalaista mytologiaa erityisesti teoksessaan Suomalaisten runojen uskonto (1915), jossa hän esittää vainajainpalvonnan vanhimmaksi uskonnon muodoksi myös suomensukuisten kansojen parissa. Päätelmään hän tulee vertailevan tutkimuksen kautta: vainajainpalvonta on ainoa yhteinen tekijä kaikkien suomalais-ugrilaisten kansojen kesken ja näin ollen myös vanhin. Eurooppalaisessa tutkimuksessa yleistyneiden animististen ja manististen käsitysten mukaisesti hän käsittelee paljon luonnon elollistamiseen liittyvää aineistoa, samastaen esimerkiksi metsänjumala Tapion itse metsään. Pääpaino tutkimuksessa on erilaisilla rituaaleilla. Hänen mukaansa ukkosen palvonta oli uskonnollisissa käsityksissä kristin- 
uskon saapumista edeltävä vaihe. (Krohn 1915, iv-v, 116-119.) Itse kansanrunoja Krohn pitää paljolti keskiaikaisina.

Emil Nestor Setälä erkani Krohnien edustamalta, kalevalamittaista epiikkaa pohjimmiltaan historiallisina teksteinä tulkitsevalta tutkimuslinjalta käsitellessään teoksessaan Sammon arvoitus (1932) runoja mytologisina teksteinä ennen kaikkea luonnonmyytilliseltä pohjalta. Teoksessaan Setälä esimerkiksi lukee sammon patsaaksi, jonka ympäri muinaissuomalaisten mielikuvissa maailma pyöri, ja joka konkretisoitui luonnossa Pohjantähdessä. Setälä jäi yhdeksi viimeisistä kalevalamittaisen runouden luonnonmytologisista tulkitsijoista.

Uno Harva (Holmberg) toteuttaa teoksessaan Altain suvun uskonto (1933) laajan ja perusteellisen vertailevan uskontotieteellisen tutkimuksen keskiaasialaisista turkkilais-, mongoli- ja tunguusikansoista, seuraten tällä tavoin Sjögrenistä ja Castrénista alkanutta tutkimusperinnettä. Suomalaiseen mytologiaan hän paneutuu teoksessaan Suomalaisten muinaisusko (1948), jossa hän käyttää runsaasti erilaisia lähdeaineistoja ja kiittelee näiden suhteen eritoten E. N. Setälän organisoimia kansanuskonkeräyksiä. Teoksen pääpaino onkin kansanuskossa. Teos lähtee siitä huolimatta suomalaisen mytologian jumaluuksista ja etenee haltioihin ja henkiin samalla tavoin kuin Castrénin mytologialuennot. Poiketen Castrénista, ja huolimatta laajasta potentiaalisen vertailuaineiston tuntemuksestaan, Harva käyttää lähinnä vain suomalaista ja naapurikansojen folkloreaineistoa. Hän pohtii mytologiaa etupäässä maanviljelysyhteisön näkökulmasta, tehden näin pesäeroa esimerkiksi Castrénin työssä painottuvaan pyyntikulttuurin uskontoon. (Anttonen 1987.)

Iivar Kemppinen julkaisi suomalaisen mytologian alalta useita kirjoja, keskeisimmät lienevät Johdatus suomalaiseen mytologiaan (1957) ja Suomalainen mytologia (1960). Kemppisen tapa vetää johtopäätöksensä melko suoraviivaisesti ja selittelemättä ja mahdollisesti myös kilpailullinen suhde akateemisesti korkeammassa asemassa olleeseen Martti Haavioon saattoivat vaikuttaa siihen, että hänen tutkijauransa jäi melko lyhyeksi. Kemppinen korostaa tutkimuksissaan ennen muuta suomalaisen mytologian kansainvälisyyttä yhteneväisten aihelmien ja teemojen kautta. Tässä suhteessa Kemppinen eroaa Castrénin "alkuperäistä" hakevasta ja siten lainattua ylenkatsovasta näkökulmasta, vaikka molemmat käyttivät samankaltaista, vertailevaa tutkimus- 
otetta. Kemppisen lähestymistapa ja aineisto ytimöityvät varsin hyvin hänen kirjoittaessaan: "[...] vanhoista, korkealle kehittyneistä kulttuureista tapahtuu kulttuuriomaisuuden, kulttuurisisällön, virtaamista aina periferiaan päin. Itämaiset kansat loivat jo aikaisin korkean kulttuurin alueita ja kehittivät korkeita uskontoja, joiden vaikutusta [...] ei käy kieltäminen.” (Kemppinen 1957, 178.) Kemppisen havainnot painottuvat siis suomalaisen uskomus- ja riittitradition sekä itämaisten korkeakulttuurien välillä havaittaviin samankaltaisuuksiin.

Martti Haavion Suomalainen mytologia (1967) muistuttaa peruslähtökohdiltaan Kemppisen samannimistä aiemmin julkaistua teosta hyvin paljon, mutta on laajuudeltaan, aineistoviitteidensä määrältä ja johtopäätösten yksityiskohtaisuudessa aivan eri luokkaa. Haavio tekee jo teoksensa alkuun painetuissa johtolauseissa pesäeron Castrénin edustamaan kotoperäisyyttä korostavaan tutkimustapaan sekä itse asiassa suoraan Castrénin mytologialuentoihinkin. Kaksiosainen teos jakaantuu ensin palvonnan kohteiden esittelyyn ja toiseksi rituaaleihin ja rituaalirunouteen. Haavio hahmottelee erilaisten mytologisten käsitysten ja näitä heijastelevien traditioiden kulkeutumisreittejä Suomeen päätyen usein itämaisiin korkeakulttuureihin näiden lähtöpaikkoina.

Juha Pentikäinen pohtii teoksessaan Kalevalan mytologia (1987) Elias Lönnrotin Kalevalassa välittämiä mytologiakäsityksiä ja periaatteita, joiden pohjalta tämä kokosi Kalevalan: "Kalevala oli Lönnrotille 'mythologia' kahdessa suhteessa, toisaalta folkloren pohjalta välittyvä esikristillisen mytologia-aineiston kokoelma ja toisaalta laatijansa synteesi, tutkimustulos" (Pentikäinen 1987, 18-19; vrt. Hyvönen 2008). Sen lisäksi että Pentikäinen käsittelee Lönnrotin omaa osuutta Kalevalasta välittyvään mytologiakuvaan, mikä on kiinnostavaa Castrénin mytologialuentojen tulkinnan kannalta, hän pohtii myös Kalevalan sisällön, kansanrunouden, olemusta muinaisten myyttisten käsitysten heijastelijana. Hän nostaa esiin eritoten luomisrunon, "maailmanmunamyytin", universaalin olemuksen ja liittää lisäksi kalevalamittaisen epiikan šamanismiin.

Kalevala- ja mytologiakeskustelujen lisäksi Castrénin luennot kiinnittyivät etnografisiin hankkeisiin, joista oltiin Suomessa keskusteltu jo Porthanista alkaen tai aiemminkin (Sarajas 1956), ja joilla oli jo vuosisadan pituiset perinteet Venäjällä. Nämä keskustelut linkittävät 
Castrénin toiminnan ja mytologialuennot keskieurooppalaisiin ajatuslinjoihin, joissa kieli ja yhteisö edellyttävät toisiaan ja antavat toisilleen ytimen. Viime vuosina tätä mallia on kuvattu kieli-ideologiaksi, joka on yksi keskeisimpiä eurooppalaisen kansallisvaltio- ja kulttuuripoliittisen keskustelun pohjavireistä (Bauman \& Briggs 2000; Irvine \& Gal 2000). Mytologiantutkimuksessa malli on tarkoittanut pysyvää pyrkimystä hahmottaa mytologioiden ydintä, josta on karsittu ajalliset kerrostumat ja muutokset. Malli on ollut kestävä, ja vasta myyttien esittämiseen, käyttöön ja kontekstuaalisiin merkityksiin keskittyneet tutkimukset ovat siirtäneet huomion ideaalimalleista käytänteisiin (Timonen 2004; Tarkka 2005).

Unto Salo on käsitellyt paljon suomalaista mytologiaa kirjoituksissaan, joissa hän yhdistää arkeologista tutkimusta folkloristiikan ja kielihistorian tuloksiin. Salon hiljattain julkaisema kolmiosainen Kalevalaiset myytit ja uskomukset I-III (2012) on suomalaisia esikristillisiä uskomuksia ja niiden juuria käsittelevä tutkimus, jossa tarkastellaan monitieteisesti muinaisten uskomusten jälkiä ja hahmotellaan niiden alkuperää ja kehityskulkuja. Castrén pyrki aikoinaan samaan, mutta siinä missä hän joutui tukeutumaan kronologioissaan löyhään teoreettiseen malliin kulttuurien kehityksestä, viime aikoina on pyritty täsmällisempiin kronologioihin yhdistelemällä eri tieteenalojen tuloksia. Esimerkiksi Salo hakee kronologista tukea näkemykselleen aineettoman kulttuuriperinnön historiasta ennen muuta arkeologian tarjoamasta tiedosta. Teoksesta käyvät kuitenkin hyvin ilmi haasteet, joita hajanaisen ja sirpaleisen aineiston tulkinta asettaa.

Anna-Leena Siikalan mytologiaan keskittyneet tutkimukset ovat olleet niin ikään merkittäviä uusia avauksia. Siikalan Suomalainen šamanismi (1992) käsittelee kalevalamittaisessa runoudessa esiintyviä myyttisiä mielikuvia, jotka voidaan tulkita maailmankuvaltaan šamanistisiksi ja siis suomalaisten vastaavaan kulttuuriseen kauteen palautuviksi. Siikalan Itämerensuomalaisten mytologia (2012) on merkittävä suomalaisen mytologian yleisesitys ja kattava tulkinta. Teoksessa Siikala käsittelee kansanrunojen myyttisiä mielikuvia kerrostuneena perinteenä, jonka eri osissa väikkyy eri aikakausiin liittyneitä käsityksiä, jotka ulottuvat kaukaisimmillaan tuhansien vuosien taakse. Siikala sitoo tradition mielikuvien kehittymisen ja vaikutteiden omaksumisen kielihistoriallisiin ja arkeologisiin aikakausiin. Uuden 
tutkimuksen ansiosta mielikuvien historia on siis tarkentunut. Siikala pohtii myös syitä myyttisten mielikuvien alueellisiin eroihin itämerensuomalaisten kansojen piirissä ja kykenee erottamaan jopa historiaan pohjaavia mytologian "paikallismurteita".

Karkeistetusti voidaan sanoa, että Castrénin harjoittama "alkuperäisen" suomalaisen mytologian etsintä on täsmentynyt mytologian lähteiden heijastamien historiallisten kerrostumien tutkimiseksi ja että myyttisessä traditiossa tavattavat lainat muista kulttuureista on opittu tulkitsemaan näiden kerrostumien sisällöksi, osoituksiksi traditiopiirteiden omaksumisesta osaksi alati muuttuvaa ja elävää mytologista käsityskompleksia. Tämän käsityskompleksin muuntuminen on siis itsessään kohonnut kiinnostuksenkohteeksi. Tutkimushistorian kehityskulkua vasten voidaan sanoa, että Castrénin suomalaisen mytologian luennot viitoittivat tutkimukselle aikoinaan suuntaa. Mytologialuennot muodostavat klassikkotekstin, joka välittää sujuvassa muodossa aikaansa edellä olleen, monipuolisesti lahjakkaan tutkijan pohdintoja vasta muotoutumassa olleen kansan ajatusmaailman ja maailmankuvan syvimmistä kerroksista. Teos on samalla matka 1800-luvun tieteelliseen ajatteluun ja käsityksiin, jotka liittyivät muinaisuudesta kumpuaviin myyttisiin kuviin.

\section{Huomautuksia tästä toimituksesta}

Tämän käännöksen pohjatekstinä on toiminut Carl Gustav Borgin painokuntoon toimittama ja Suomalaisen Kirjallisuuden Seuran julkaisema teos (Castrén 1853). Ruotsinkielisen editionsa esipuheessa Borg toteaa, ettei ole tehnyt käsikirjoitukseen suuria muutoksia, vaan että hän on ainoastaan korjannut joitain ilmaisuja selkeämmäksi ja suorittanut kielenhuoltoa. Näin suurimmaksi osaksi onkin. Nyt julkaistavan edition lähtökohtana ei ole ollut selvittää kaikkia Borgin tekemiä korjauksia, mutta Kansalliskirjaston käsikirjoituskokoelmassa säilytetystä käsikirjoituksesta on kuitenkin tuotu joitain Borgin poistamia Castrénin marginaaliin kirjoittamia lisiä suomenkielisten lukijoiden luettavaksi. Lisäykset löytyvät loppuviitteistä.

Käännöksen kieliasussa on pyritty kunnioittamaan Castrénin varsin sujuvaa ja värikästä ilmaisua. Sanajärjestystä on silti paikoin muutettu 
vastaamaan nykysuomen vaatimuksia, ja pisimpiä virkkeitä on katkottu useammaksi lyhyemmäksi virkkeeksi ymmärrettävyyden vuoksi. Virkkeiden sisältö ja usein myös rakenne on kuitenkin pidetty alkuperäisinä. Käännöksessä on pyritty noudattelemaan alkuperäistä termistöä, mutta epäselvyyksiä aiheuttavissa kohdissa on haettu tukea nykyisestä tieteellisestä terminologiasta eritoten kielitieteen kohdalla - kielitieteen pioneerivaiheen henki kuitenkin säilyttäen. Esimerkiksi sana begrepp (nykyruotsi: 'käsite, käsitys') osoittaa Castrénin tekstissä lähinnä viittaussuhdetta tai merkitsee 'tarkoitetta, merkitystä. Castrénin aikaan Wolmar Kilpinen ehdotti sille aikakauslehti Suomessa $(1844,224)$ suomenkielistä vastinetta ymmärre. Sana on varsin osuva, mutta koska se ei ole vakiintunut suomen kieleen, tässä käytetään tilanteesta riippuen joko termiä käsitys tai tarkoite. Teoksen avaintermi on mytologia (mytologi), jolle Castrén käyttää rinnakkaisilmaisuna termiä gudalära (alkup. saks. Götterlehre). Tämä on suomennettu muotoon jumaloppi. Vastaavasti edda-läran ('edda-oppi') viittaa skandinaavien jumalrunouden välittämään mytologiakuvaan. Adjektiivi rå on käännetty kulttuuriseen kehitysvaiheeseen viitatessaan muotoon kypsymätön, jotta sanaan raaka liitetyt arvolatautuneet assosiaatiot eivät johtaisi lukijan ajatuksia harhaan. Vastaavasti sana vild, viitatessaan substantiivina primitiivisen kansan edustajaan (vrt. saksan Wilde), on käännetty suoraan muotoon villi, mutta sen viitatessa adjektiivina tällaiseen kansaan tai sen edustajaan on paikoin käytetty myös termiä kesytön. Vastaavia valintoja on jouduttu tekemään käännöstyön kuluessa loputon määrä, joten täsmällistä ilmaisua tarvittaessa on suositeltavaa kääntyä alkuperäistekstin puoleen. Epäselviä tai monitulkintaisia kohtia on mainittu loppuviitteissä.

Tapa, jolla Castrén käsittelee suomenkielisiä sanoja, aiheuttaa paikoin epäselvyyksiä suomennettaessa. Esimerkiksi ruotsin sanalle gud ei ole juuri muuta järkevää suomenkielistä vastinetta kuin jumala, mikä voi aiheuttaa sekaannusta, kun Castrén käsittelee esimerkiksi 'jumalaan' viittaavaa suomenkielistä sanaa jumala ja sen erilaisia merkityksiä. Kun Castrén käyttää sanaa jumala erisnimenä viittaamassa yhteen tiettyyn jumalolentoon, on käytetty muotoa Jumala. Tämä muoto ei siis viittaa kristilliseen jumalaan, josta Castrén käyttää nimitystä Jehova. Ruotsin sanalle underjorden on vastaavasti vaikea löytää sopivampaa suomenkielistä vastinetta kuin manala, mikä voi 
aiheuttaa sekaannusta, kun Castrén yhtäällä käsittelee sanaa manala, toisaalla nimityksellä Manala kutsuttua suomalaisten tuonpuoleista, paikoin myös muiden kulttuurien maanalaisia tuonpuoleisia, manaloita. Ajan tavan mukaan Castrén käyttää suurta alkukirjainta melko vapaasti, jolloin aina ei ole selvää, viittaako hän erisnimeen. Näin on esimerkiksi sammon kohdalla. Vaikka Castrén kirjoittaa sen suurella alkukirjaimella, hän tulkitsee sen yleisnimeksi (ks. s. 268). Näin ollen sampo kirjoitetaan tässä käännöksessä pienellä alkukirjaimella, mikä onkin yleinen nykykäytänne. Ylijumalan suomenkielistä nimitystä Ukko ja virolaista Vanna taat 'vanha isä' Castrén käyttää paikoin leikitellen ilmausten ominaisuuksilla eris- ja yleisniminä, ja hän saattaa viitata näihin esimerkiksi sanoilla gubbe tai gamla mannen. Tekstissä on pyritty saattamaan viittaussuhteet selkeiksi käyttämällä kursiivia viittaamaan alkukieliseen sanaan (kun teksti käsittelee itse sanaa eikä sen tarkoitetta), 'puolilainausmerkkejä' viittaamaan sanan merkitykseen sekä suurta alkukirjainta viittaamaan sanan käyttöön erisnimenä. Paikoin on jouduttu muotoilemaan alkuperäistä lauserakennetta jossain määrin uusiksi, jotta sanojen tarkoitteet välittyisivät selvinä. Kursiivia käytetään lisäksi vakiintuneen tavan mukaisesti merkitsemään teoksen nimeä (esim. Kalevala). Toimitukselliset lisäykset tai poistot ovat [hakasulkeissa].

\section{Kielten ja kansojen nimitykset}

Castrén viittaa luennoissaan useisiin Euraasiassa asuviin etnisiin ryhmiin, joista hän käyttää pääosin vanhentuneita tai käytöstä poistuneita nimityksiä. Hän viittaa tiettyihin kieliin "altailaisina" ja niiden puhujiin "altailaisina kansoina", kuten toisinaan tehdään vielä 2000-luvullakin kirjoitetuissa teksteissä. Teoria altailaisista kansoista on kuitenkin jo osoitettu epäpäteväksi, minkä lisäksi tietämys Euraasiassa puhutuista kielistä on luonnollisesti lisääntynyt huomattavasti Castrénin ajoista. Kielet luokitellaan nykyään toisin. Alla olevassa taulukossa on esitelty mytologialuennoissa esiintyvien etnisten ryhmien ja kielien nykyiset nimitykset ja niiden jakautuminen kieliryhmiin. Kansoja on aiemmin kutsuttu kirjallisuudessa usein naapurikansojen niille antamilla nimityksillä, joihin on liittynyt myös pejoratiivisia, halventavia merkityksiä. Nykyään käytettävät nimitykset pohjautuvat kansojen 
itse itsestään käyttämiin nimityksiin, endonyymeihin. Samojeditermi esimerkiksi liitetään helposti kannibalismiin ja jurakki venäjän tyhmää merkitsevään sanaan durak. Termistä ostjakki luopuminen palvelee historiallisten kieliryhmien erottamista toisistaan. Ostjakki näyttäisi 1800-luvulla viitanneen ennen kaikkea elämäntapaan, johon kuului jokikalastus, metsästys ja pienporonhoito. Nämä ostjakit puhuivat niin samojedilaisia (ostjakkisamojedit eli selkupit), obinugrilaisia (ostjakit eli hantit) kuin jeniseiläisiäkin (jeniseinostjakki eli ketti) kieliä. Sen sijaan samojedi näyttäisi viitanneen tundralla eläneisiin suurporonhoitajiin tai peuranmetsästäjiin, kuten jurakkisamojedeihin (nenetsit), jeniseinsamojedeihin (enetsit) ja tavgisamojedeihin (nganasanit). Nykyään samojedi-nimitystä käytetään lähinnä viittaamaan laajempaan samojedikielten ryhmään.

\begin{tabular}{|l|l|l|}
\hline Endonyymi & Castrénilla & kuollut \\
\hline Uralilaiset kielet & & \\
\hline Samojedikielet & & \\
\hline tundra- ja metsäenetsi & jeniseinsamojedi & \\
\hline tundra- ja metsänenetsi & jurakkisamojedi & \\
\hline nganasani & tavgi & \\
\hline & juratsi & $\dagger$ \\
\hline selkuppi & ostjakkisamojedi & \\
\hline & kamassi & $\dagger$ \\
\hline & matori & $\dagger$ \\
\hline & koibaali & $\dagger$ \\
\hline Ugrilaiset kielet & & \\
\hline & unkari & \\
\hline hanti & ostjakki & \\
\hline mansi & voguli & \\
\hline Permiläiset kielet & & \\
\hline komi & syrjääni (komisyrjääni) & \\
\hline komipermjakki & & \\
\hline udmurtti & votjakki & \\
\hline mari (niitty- ja vuorimari) & tšeremissi & \\
\hline Mordvalaiset kielet & & \\
\hline ersä & & \\
\hline mokša & & \\
\hline
\end{tabular}




\begin{tabular}{|l|l|l|}
\hline Saamelaiskielet & lappi & \\
\hline eteläsaame & & \\
\hline uumajansaame & & \\
\hline piitimensaame & & \\
\hline luulajansaame & & \\
\hline pohjoissaame & & \\
\hline koltansaame & & \\
\hline inarinsaame & & \\
\hline kiltinänsaame & & $\dagger$ \\
\hline turjansaame & & $\dagger$ \\
\hline kiltinänsaame & & \\
\hline turjansaame & & \\
\hline Itämerensuomalaiset kielet & & \\
\hline inkeroinen & & \\
\hline varsinaiskarjala & & \\
\hline livvi (aunuksenkarjala) & & \\
\hline lyydi & & \\
\hline suomi & & \\
\hline vatja & & \\
\hline vepsä & lamuutti & \\
\hline viro & & \\
\hline liivi & & \\
\hline Jeniseiläiset kielet & & \\
\hline ketti & & \\
\hline kotti & & \\
\hline Tunguusikielet & & \\
\hline evenki & & \\
\hline eveeni & & \\
\hline Turkkilaiskielet & & \\
\hline tataari & & \\
\hline tšuvassi & & \\
\hline hakassi & & \\
\hline tofa & & \\
\hline Mongolilaiset kielet & & \\
\hline burjaatti & & \\
\hline
\end{tabular}




\section{Viittausjärjestelmä}

Castrénin alkuperäiset viittaukset on merkitty tekstiin aakkosmuotoisin viittein ( $a, b, c$ jne.), ja viitteet ovat sivun alalaidassa alaviitteinä. Toimituksellisiin huomioihin viitataan tekstissä juoksevin viitenumeroin, ja ne ovat loppuviitteinä tekstin lopussa. Karina Lukin on avustanut etenkin siperialaisiin kulttuureihin liittyvissä toimituksellisissa huomautuksissa. Castrénin muodoltaan vaihtelevat lähdeviittaukset on yhteismitallistettu nykystandardin mukaisiksi. Tekstin lopussa ovat erikseen Castrénin viittausten lähdeluettelo ja toimituksellisten huomioiden lähdeluettelo. Teoksen lopusta löytyy asiasanahakemiston lisäksi henkilö- ja paikannimihakemistot.

\section{Viitteet}

1 Jagläserneml. en timme iveckan mythologie, ochanställerdervidjemförande betraktelser både öfver Finnarnes och andra beslägtade folkslags religiösa föreställningar. Hvad jag hittills nedskrifvit, är i det närmaste tryckfärdigt, och jag har ärnat låta öfversätta deraf ett och annat för bulletinen. Under loppet af denna termin ärnar jag hinna gudaläran till ända, och i nästa vår vore meningen att få hela mythologien ur händerna.

2 [Jag har beslutit, att wisa för Finlands folk, att wi icke äro ett ifrån werlden och werldhistorien lösryckt, enstaka kärr-folk, utan stå i förwandtskap med åtminstone en sjette del af menskligheten. Grammatikorna utgöra ej mitt hufwusakliga ändamål, men utan Grammatikor winnes ändamålet icke.]

3 [Den absolut-subjectiva subject-objectiviteten]

4 Hwar och en, som litet grundligare studerar Finska mythologien, skall snart inse att det är hwarken fetischism eller idolatrism. Det är en fabelaktig historia om fordna tiders händelser, finska äfwentyr och kämpar, som genom tradition och corruption förlorat sig uti ett mystiskt mörker, eller kaske någongång af fantasi och inbillningskraft fostradedikter och drömmar, utan att derföre wara trosartiklar, kyrkosånger, eller på något sätt åsysta en gudomlik dyrkan. (Gottlund 1817: 349-350.)

5 Matti Kuusi ja Senni Timonen ovat hahmotelleet ja käsitelleet Gananderin käyttämiä kansanrunotekstejä varsin perusteellisesti Suomen Kansan Vanhojen Runojen osassa XV (Kuusi \& Timonen 1997, erit. s. xxvii-xxxi, 13-191.) Tutkimuksesta käy selkeästi ilmi, kuinka laajaan ja monimuotoiseen korpukseen Ganander sanakirjassaan lopulta nojasi.

6 Kirjeessään F. J. Rabbelle 18.6.1848 Lönnrot ilmoittaa muuttaneensa Uuden Kalevalan maailmanluomisrunon päähahmoksi Vein emosen (Majamaa 1990a: 295-296) vaikka lopulta päätyykin alkuperäiseen ratkaisuunsa. 
7 Cajan kirjoitti teoksen Lönnrotin kehotuksesta. Cajan ilmoittaa julkaisun esipuheessa, että Lönnrotin kirjoittamat osiot ss. 1-12 ("Suomalaisen Kansan Muinaisaika"; "2a) Niiden alku, asuntopaikat ja muutto pohjalaisille maille"; "b) Suomalaisten muinaisusko ja Runolaatu") ja ss. 65-71 (kuvaus Suomen muinaisista yhteiskunnallisista tai yhteisöllisistä oloista otsakkeella "Muista sisämaisista menoista") olivat koko historiateoksen lähtökohtia.

8 [alle Aufmerksamkeit auf die unter den Völkern selbst etwa gangbaren Sagen und Traditonen über ihre Herkunft und Vorzeit wenden, mögen solche Sagen und Traditonen allgemeinen Inhalts, oder an gewisse Localitäten.]

9 [Jedwedem volke scheint es von natur eingeflölst sich abzuschliessen und von fremden bestandtheilen unangerührt zu erhalten, der sprache, dem epos behagt es nur im heimischen kreis, nicht länger als er zwischen seinem ufer wallt, hält der ström seine färbe lauter. aller eignen kraft und innersten triebe ungestörte ausbildung ergeht aus dieser mitte, und unsre älteste spräche, poesie und sage sehen wir keinen andern zug einschlagen.]

10 [... gelten also in der spräche schlüsse auf das was abhanden ist, zuckt ihre gegenwärtige beschaffenheit noch weit zurück in die ältere und älteste; so mufs auch in der mythologie ein ähnliches verfahren sich rechtfertigen und aus ihrem versiegenden wasser die quelle, aus den stehngebliebnen sümpfen der alte strom geahnt warden. die völker hängen und halten fest am hergebrachten, wir werden ihre überlieferung, ihren aberglauben niemals fassen, wenn wir ihm nicht ein bett noch auf heidnischem grund und boden unterbreiten.]

11 Grimm nosti kristinuskon tuhoavan vaikutuksen esiin vastineena saksalaisessa tutkimuksessa vallinneille näkemyksille siitä, että saksalainen kulttuuri olisi ollut paljolti kristinuskon vaikutuksesta korkeimmillaan keskiajalla (Williamson 2004, 81).

12 On syytä huomata, että Castrén kirjoittaa muistiinpanoissaan saman ajatuksen hyvin samankaltaisin sanavalinnoin kuin Hume: Religionen är ej en produkt af philosofering, utan har sin grund $i$ känslan (MAC Fennica II:2: 10).

13 Ces deux points de la Théologie Payenne roulent, ou sur le culte des astres, connu sous le nom de Sabéïsme, ou sur le culte peut - être non moins ancien de certains objets terrestres \& matériels appellés fetiches chez les négres Africains, parmi lesquels ce culte subsiste, \& que par cette raison j'appellerai fétichisme. (Brosses 1760, 10.)

14 Edward B. Tylor nojasi suureen määrään etnografista kirjallisuutta kootessaan teosta The Primitive Culture, jossa hän määrittelee animismin, ja teoksessa on useita viittauksia myös Castrénin mytologialuentoihin. Tylor viittaa luentoihin lähinnä etnografisena lähteenä, mutta on kiehtovaa, että Castrénin esittämät ajatukset uskonnollisuuden varhaisvaiheista toistuvat pitkälti samansuuntaisina Edward Tylorin sittemmin klassikoksi kohonneessa teoksessa. 


\section{Lähteet}

\section{Käsikirjoitusaineistot}

MAC: Manuscripta Castreniana. Kansallisarkisto.

\section{Kirjeet}

Castrén, Matthias Alexander 1844: Kirje J. V. Snellmanille 18.10.1844. Teoksessa J. V. Snellman: Kootut teokset [online]. Toimittaneet Raimo Savolainen et al. Snellman-instituutti, Helsinki. <http://snellman.kootutteokset.fi/fi/dokumentit/mathias-alexander-castr\%C3\%A9nilta> Viitattu 15.3.2016.

von Schiefner, Anton 1857: Kirje J. V. Snellmanille 26.2.1857. Teoksessa J. V. Snellman: Kootut teokset [online]. Toimittaneet Raimo Savolainen et al. Snellman-instituutti, Helsinki. <http://snellman.kootutteokset.fi/fi/dokumentit/anton-von-schiefnerilt\%C3\%A4> Viitattu 1.9.2015.

Snellman, J. V. 1844: Kirje M. A. Castrénille 1.10.1844. Teoksessa J. V. Snellman: Kootut teokset [online]. Toimittaneet Raimo Savolainen et al. Snellman-instituutti, Helsinki. <http://snellman.kootutteokset.fi/fi/dokumentit/mathias-alexander-castr\%C3\%A9nille>. Viitattu 1.9.2015.

Snellman, J. V. 1845: Kirje M. A. Castrénille 23.10.1845. Teoksessa J. V. Snellman: Kootut teokset [online]. Toimittaneet Raimo Savolainen et al. Snellman-instituutti, Helsinki. <http://snellman.kootutteokset.fi/fi/dokumentit/mathias-alexander-castr\%C3\%A9nille-0> Viitattu 1.9.2015.

\section{Kirjallisuus}

Agricola, Mikael 2007 [1551]: Psalttari. Teoksessa Vanhan kirjasuomen korpus. Kotimaisten kielten keskus, Helsinki. <http://kaino.kotus.fi/korpus/ vks/meta/agricola/agri3ps_rdf.xml> Viitattu 1.9.2015.

Apo, Satu 2008: Kansanrunouden tutkijat Kalevalan kriitikkoina. Teoksessa Kalevalan kulttuurihistoria. Toimittaneet Ulla Piela, Seppo Knuuttila \& Pekka Laaksonen. Suomalaisen Kirjallisuuden Seura, Helsinki.

Anttonen, Veikko 2010: Uskontotieteen maastot ja kartat. Suomalaisen Kirjallisuuden Seura, Helsinki.

[anonyymi] 1836: Några ord om Kalevala. - Helsingfors Morgonblad 95-96.

Balandin 1988 = Баландин А. И. 1988: Мифологическая школа в русской фольклористике. Наука, Москва.

Bascom, William 1977: Frontiers of Folklore. Westview Press, Boulder.

Bauman, Richard \& Briggs, Charles 2000: Language Philosophy as Language Ideology: John Locke and Johann Gottfried Herder. Teoksessa Regimes 
of Language: Ideologies, Polities, and Identities. Toimittanut Paul V. Kroskrity. School of American Research Press, Santa Fe, New Mexico.

Beauchamp, Tom (ed.) 2007: David Hume: A Dissertation on the Passions \& The Natural History of Religion. A Critical Edition. Clarendon Press, Oxford.

Becker, Reinhold von 1820a: Wanhan-aikaisista ihmisistä, jotka owat asuneet wuorten luolissa ja maa-kuopissa. - Turun Wiikko-Sanomat 3.

Becker, Reinhold von 1820b: Wäinämöisestä. - Turun Wiikko-Sanomat 10; $11 ; 20$.

Becker, Reinhold von 1820c: Muutamia lyhykäisiä tietoja Suomalaisten Esiwanhemmista ja heiän entisistä asunto-paikoistansa. - Turun WiikkoSanomat 26.

Ber, К. М. 1849 = Бэр, К. М. 1849: Об этнографических изследованиях вообще и в России в особенности. - Записки русскаго географическаго общества I \& II (2), 64-81.

Bogoraz 1927= Богораз-тан, В. Г. 1927: Кастрен - человек и ученый. Teoksessa Памяти М.А. Кастрена. К 75-летию дня смерти. Toimittanut B. Г. Богораз-Тан. Академия наук союза советских социалистических республик, Ленинград.

Borg, Carl Gust. 1853: Matthias Alexander Castrén. Uppläst vid Österbottniska Afdelningens årsfest, den 9 Nov. 1852. Suomalaisen Kirjallisuuden Seura, Helsinki.

Branch, Michael 1968: M. A. Castrénin Siperian matkojen alkuvaiheista. - Virittäjä 72, 336-348.

Branch, Michael 1973: A. J. Sjögren. Studies of the North. SuomalaisUgrilainen Seura, Helsinki.

Branch, Michael 2006: Herderin vaikutus Anders Johan Sjögreniin ja sen seuraukset. Teoksessa Herder, Suomi, Eurooppa. Toimittaneet Sakari Ollitervo \& Kari Immonen. Suomalaisen Kirjallisuuden Seura, Helsinki.

Bunzl, Matti 1996: Franz Boas and the Humboldtian Tradition. From Volksgeist and Nationalcharakter to an Anthropological Concept of Culture. Teoksessa Volksgeist as Method and Ethic. Essays on Boasian Ethnography and the German Anthropological Tradition. Toimittanut George W. Stocking. University of Wisconsin Press, Madison.

Brosses, Charles de 1760: Du culte des dieux fétiches, ou Parallele de I'ancienne Religion de l'Egypte avec la Religion actuelle de Nigritie. Fayard, Paris.

Cajan, Johan Fredrik 1839: Suomen historia koetteeksi kerrottu lyhykäisessä järjestyksessä. Helsinki.

Campbell, Lyle 2002: The History of Linguistics. TeoksessaThe Handbook of Linguistics. Toimittaneet Mark Aronoff \& Janie Rees-Miller. Blackwell Publishers, Oxford, Malden.

Castrén, M. A. 1837a: Om Finnarnes trollkonst. - Helsingfors morgonblad 27, 14.4.

Castrén, M. A. 1837b: Om Finnarnes trollkonst. - Helsingfors morgonblad 28, 17.4 . 
Castrén, M. A. 1849: Hvar låg det Finska folkets vagga? Föredrag, hållet i Universitets Solennitetssal, den 9 November 1849. Teoksessa Litterära Soiréer i H:fors under hösten 1849. Andra soiréen.

Castrén, M. A. 1850a: Kalevala. Toinen painos. [arvio] - Litteraturblad för allmän medborgerlig bildning 2, Februari, 33-39.

Castrén, M. A. 1850b: Über die neueste Redaction der Kalewalarunen - Bulletin de la Classe des Sciences historiques, philologiques et politiques de l'Académie Impériale des Sciences de Saint-Pétersbourg VII (164-165), 303-314.

Castrén, M. A. 1851: Hvad beteckna i den Finska mythologien orden jumala och ukko. - Suomi: Tidskrift i fosterländska ämnen, 117-162.

Castrén, M. A. 1870a [1852]: Nordiska resor och forskningar l: Reseminnen från åren 1838-1844. [2. painos.] Suomalaisen Kirjallisuuden Seura, Helsinki.

Castrén, M. A. 1870b: Nordiska resor och forskningar VI: Tillfälliga uppsatser. Suomalaisen Kirjallisuuden Seura, Helsinki.

Castrén, M. A. 1904: M. A. Castrénin kertomus runonkeruumatkastansa Venäjän-Karjalassa v. 1839. (Suomennos.) Teoksessa Runonkerääjiemme matkakertomuksia 1830-luvulta 1880-luvulle. Toimittanut A. R. Niemi. Suomalaisen Kirjallisuuden Seura, Helsinki.

Clay, Catherine B. 1995: Ethnographers in the Service of Empire, 1856-1862 - Slavic Review 54(1), 45-61.

Collan, Fabian 1838: Wäinämöinen och Ilmarinen. - Helsingfors Morgonblad 56; 57; 59; 61; 62.

Creutzer, Georg Friedrich (1810-1812): Symbolik und Mythologie der alten Völker, besonders der Griechen. Heyer und Leske, Leipzig \& Darmstadt.

Dupuis, Charles 1798: The Origin of all Religious Worship. New Orleans.

Ellen, Roy 1988: Fetishism. - Man New Series 23(2), 213-235.

Feldman, Burton \& Richardson, Robert 1972: The Rise of Modern Mythology 1680-1860. Indiana University Press, Bloomington \& London.

Ganander, Christfrid 1984 [1789]: Mythologia Fennica. Suomalaisen Kirjallisuuden Seura, Helsinki.

Georgi, Johann Gottlieb 1776-1780: Beschreibung aller Nationen des russischen Reichs : ihrer Lebensart, Religion, Gebräuche, Wohnungen, Kleidungen und übrigen Merkwürdigkeiten. Erste Ausgabe, Nationen vom Finnischen Stamm. Kupfer zur Beschreibung aller Nationen des Russischen Reichs. C.W. Müller, St. Petersburg.

Gottlund, Carl Axel 1817: Recension: Finland och Dess Inwånare, af Friedr. Rühs. - Swensk Literatur-Tidning 19; 22; 24-26; 49-51.

Grimm, Jacob 1844 [1835]: Deutsche Mythologie. Göttingen.

Grimm, Jacob 1845: Om det Finska Epos. Teoksessa Fosterländskt album II. Toimittaneet Herman Kellgren, Robert Tengström \& Karl Tigerstedt.

Haavio, Martti 1952: M. A. Castrén ja suomalainen kansanrunous. - Kotiseutu, 35-40.

Haavio, Martti 1967: Suomalainen mytologia. Werner Söderström Osakeyhtiö, Porvoo \& Helsinki. 
Harva, Uno 1933: Altain suvun uskonto. WSOY, Porvoo.

Harva, Uno 1948: Suomalaisten muinaisusko. WSOY, Porvoo.

Hautala, Jouko 1954: Suomalainen kansanrunoudentutkimus. Suomalaisen Kirjallisuuden Seura, Helsinki.

Hodgson, Peter C. (ed.) 1988: Georg Wilhelm Friedrich Hegel: Lectures on the Philosophy of Religion. The Lectures of 1827. University of California Press, Berkeley, Los Angeles, London.

Holbach, Paul 1868 [1770]: The System of Nature, or The Laws of the Moral and Physical World I-II. Kääntänyt H. D. Robinson. J. P. Mendum, Boston. Hyvönen, Jouni 2008: Kalevala Elias Lönnrotin tieteellisenä projektina. Teoksessa Kalevalan kulttuurihistoria. Toimittaneet Ulla Piela, Seppo Knuuttila \& Pekka Laaksonen. Suomalaisen Kirjallisuuden Seura, Helsinki.

Irvine, Judith T. \& Gal, Susan 2000: Language Ideology and Linguistic Differentiation - Teoksessa Regimes of Language: Ideologies, Polities, and Identities. Toimittanut Paul V. Kroskrity. School of American Research Press, Santa Fe, New Mexico.

Joki, Aulis J. 1953: Johdanto. Teoksessa M. A. Castrén: Tutkimusmatkoilla pohjolassa. Suomentanut Aulis J. Joki. Tammi, Helsinki.

Juslenius, Daniel 1745: Suomalaisen Sana-Lugun Coetus. Stockholm.

Kajanto, liro 1983: Johdanto. Teoksessa Porthan, Henrik Gabriel 1983: Suomalaisesta runoudesta. Suomalaisen Kirjallisuuden Seura, Helsinki.

Karjalainen, K. F. 1918: Jugralaisten uskonto: Suomensuvun uskonnot 3. WSOY, Porvoo.

Karkama, Pertti 2001: Kansakunnan asialla: Elias Lönnrot ja ajan aatteet. Suomalaisen Kirjallisuuden Seura, Helsinki.

Karkama, Pertti 2002: Oppinut mies kansan asialla: Elias Lönnrot ja aatteet. Teoksessa Lönnrotin hengessä 2002. Toimittaneet Pekka Laaksonen \& Ulla Piela. Suomalaisen Kirjallisuuden Seura, Helsinki.

Karttunen, Klaus 1994: Itää etsimässä: Eurooppalaisen Aasian-tutkimuksen vaiheita. Yliopistopaino, Helsinki.

Kaukonen, Väinö 1939-1945: Vanhan Kalevalan kokoonpano I-II. Suomalaisen Kirjallisuuden Seura, Helsinki.

Kaukonen, Väinö 1956: Elias Lönnrotin Kalevalan toinen painos. Suomalaisen Kirjallisuuden Seura, Helsinki.

Kaukonen, Väinö 1988: Europaeuksen osa Kalevalan laadinnassa. Teoksessa D. E. D. Europaeus. Suurmies vai kummajainen. Toimittaneet Matti Kuusi, Pekka Laaksonen \& Senni Timonen. Suomalaisen Kirjallisuuden Seura, Helsinki.

Kemppinen, livar 1957: Johdatus muinaissuomalaiseen mytologiaan. Kirja-Mono, Helsinki.

Kemppinen, livar 1960: Suomalainen mytologia. Kirja-Mono, Helsinki. Kilpinen, Volmar 1844: Muutama sana Suomenkielen rikastamisesta. - Suomi: Tidskrift i fosterländska ämnen, 217-224.

Klinge, Matti 1996: Senaatintorin sanoma. Otava, Helsinki.

Knight, Nathaniel 2000: Grigor'ev in Orenburg, 1851-1862: Russian Orientalism in the Service of Empire? - Slavic Review 59(1), 74-100. 
Korhonen, Mikko 1984: Suomalais-ugrilaisen kielitieteen alkuvaiheet. Teoksessa Ystävät, sukulaiset: Suomen ja Unkarin kulttuurisuhteet 1840-1984. Toimittaneet János Nagy, Jaakko Numminen et al. Suomalaisen Kirjallisuuden Seura, Helsinki.

Korhonen, Mikko 1986: Finno-ugrian Language Studies in Finland 18281918. Societas Scientiarum Fennica, Helsinki.

Krohn, Julius 1894: Suomen suvun pakanallinen jumalanpalvelus: Neljä lukua Suomen suvun pakanallista jumaluus-oppia. Suomalaisen Kirjallisuuden Seura, Helsinki.

Krohn, Kaarle 1915: Suomalaisten runojen uskonto. Suomen suvun uskonnot I. Suomalaisen Kirjallisuuden Seura, Helsinki.

Kuusi, Matti 1997: Kristfrid Ganander. Teoksessa Suomen Kansan Vanhat Runot XV: Runoja Henrik Florinuksen, Kristfrid Gananderin, Elias Lönnrotin ja Volmari Porkan kokoelmista. Toimittaneet Matti Kuusi \& Senni Timonen. Suomalaisen Kirjallisuuden Seura, Helsinki.

Kuusi, Matti \& Timonen, Senni 1997 (toim.): Suomen Kansan Vanhat Runot XV: Runoja Henrik Florinuksen, Kristfrid Gananderin, Elias Lönnrotin ja Volmari Porkan kokoelmista. Suomalaisen Kirjallisuuden Seura, Helsinki.

Köppen, M. 1844: Instruction supplémentaire donnée à M. Castrén, par Koeppen (Lu le 15 mars 1844). - Bulletin de la Classe des Sciences historiques, philologiques et politiques de l'Académie Impériale des Sciences de Saint-Pétersbourg. I (24), 373-384.

Lehmann, Winfred P. 1992: Historical Linguistics: An Introduction. Routledge, Oxford, New York.

Lehtisalo, Toivo 1924: Entwurf einer Mythologie der Jurak-Samojeden. Sociéte finno-ougrienne, Helsinki.

Lencqvist, Christian 1782: De superstitione veterum Fennorum theoretica et practica I-Il. Aboae.

Lincoln, Bruce 1999: Theorizing Myth: Narrative, Ideology, and Scholarship. The University of Chicago Press, Chicago \& London.

Lönnrot, Elias 1835: Kalewala taikka Wanhoja Karjalan Runoja Suomen Kansan muinoisista ajoista. Suomalaisen Kirjallisuuden Seura, Helsinki.

Lönnrot, Elias 1836a: Muinelmia. (Mehiläinen 1/ 1836). Teoksessa Elias Lönnrot - Valitut teokset 2: Mehiläinen. Toimittanut Raija Majamaa. Suomalaisen Kirjallisuuden Seura, Helsinki.

Lönnrot, Elias 1836b: Muinelmia: Lieto Lemminkäinen. (Mehiläinen toukokuu 1836). Teoksessa Elias Lönnrot - Valitut teokset 2: Mehiläinen. Toimittanut Raija Majamaa. Suomalaisen Kirjallisuuden Seura, Helsinki.

Lönnrot, Elias 1839: Alkuluomisesta. (Mehiläinen joulukuu 1839). Teoksessa Elias Lönnrot - Valitut teokset 2: Mehiläinen. Toimittanut Raija Majamaa. Suomalaisen Kirjallisuuden Seura, Helsinki.

Lönnrot, Elias 1849: Kalevala. Suomalaisen Kirjallisuuden Seura, Helsinki.

Majamaa, Raija (toim.) 1990a: Elias Lönnrot - Valitut teokset 1: Kirjeet. Suomalaisen Kirjallisuuden Seura, Helsinki.

Majamaa, Raija (toim.) 1990b: Elias Lönnrot - Valitut teokset 2: Mehiläinen. Suomalaisen Kirjallisuuden Seura, Helsinki. 
Majamaa, Raija 2002: Hengen rientomiehet. Teoksessa Lönnrotin hengessä 2002. Toimittaneet Pekka Laaksonen \& Ulla Piela. Suomalaisen Kirjallisuuden Seura, Helsinki.

Martineau, Harriet (ed.) 1853: The Positive Philosophy of Auguste Comte. John Chapman, London.

Meek, Ronald (ed.) 2010: Turgot on Progress, Sociology and Economics: A Philosophical Review of the Successive: Three Major Texts Translated. Cambridge University Press, New York.

Nadeždin 1849 = Надеждин, Н. И. 1849: Об этнографичческом изучении народности русской (статья д. Ч. Н. И. Надеждина). - Записки русскаго географическаго общества I \& II (2), 64-81.

Nordberg, Andreas 2013: Fornnordisk religionsforskning mellan teori och empiri: Kulten av anfäder, solen och vegetationsandar i idéhistorisk belysning. Kungl. Gustav Adolfs Akademien för svensk folkkultur, Uppsala.

Ó Giolláin, Diarmuid 2014: Narratives of Nation or of Progress? Genealogies of European Folklore Studies. - Narrative Culture 1(1), 71-84.

Pedersen, Holger 1962 [1931]: The Discovery of Language: Linguistic Science in the Nineteenth Century. Indiana University Press, Bloomington.

Pentikäinen, Juha 1987: Kalevalan mytologia. Gaudeamus, Helsinki.

Pentikäinen, Juha 1995: Kristfrid Ganander mytologina. Teoksessa Kristfrid Ganander: Myhologia Fennica. Toimittanut Juha Pentikäinen. Recallmed, Helsinki.

Porthan, Henrik Gabriel 1983: Suomalaisesta runoudesta. Suomalaisen Kirjallisuuden Seura, Helsinki.

Pypin 1890 = Пыпин, А. Н. 1890: История русской этнографии I: Общий обзор изучении народности и этнографрия великорусская. Типография М. М. Стасюлевича, С.-Петербург.

Pypin 1892 = Пыпин, А. Н. 1892: История русской этнографиии IV: Белоруссия и Сибирь. Типография М. М. Стасюлевича, С.-Петербург.

Rein, Gabriel 1845: Försök till utredande af Fornfinnarnes mythologie. - Suomi: tidskrift i fosterländska ämnen, 225-238.

Renvall, Gustav 1826: Suomalainen Sana-Kirja: Lexicon linguæ Finnica cum interpretatione duplici, copiosiore Latina, breviore Germanica. Aboae.

Rühs, Friedrich 1809: Finland und seine Bewohner. Leipzig.

Rühs, Friedrich 1811: Finland och Dess Invånare. Stockholm.

Saariluoma, Liisa 2006: Herderin kulttuurin tutkimuksen menetelmä. Teoksessa Herder, Suomi, Eurooppa. Toimittaneet Sakari Ollitervo \& Kari Immonen. Suomalaisen Kirjallisuuden Seura, Helsinki.

Salo, Unto 2012: Kalevalaiset myytit ja uskomukset arkeologian, kielihistorian ja kulttuurihistorian näkökulmasta I-III. Amanita, Somero.

Sarajas, Annamari 1956: Suomen kansanrunouden tuntemus 1500-1700lukujen kirjallisuudessa. WSOY, Porvoo.

Schlözer, August Ludwig von 1771: Allgemeine Nordische Geschichte: Aus den neuesten und besten Nordischen Schriftstellern und nach eigenen Untersuchungen beschrieben, und als eine geographische und historische 
Einleitung zur richtigern Kenntnis aller skandinavischen, finnischen, slavischen, lettischen, und sibirischen Völker, besonders in alten und mittleren Zeiten. Bey Johanna Justinut Gebauer, Halle.

Schiefner, Anton 1853: M. Alexander Castrén's Vorlesungen über die finnische Mythologie. Kaiserlichen Akademie der Wissenschaften, St. Petersburg.

Setälä, Emil Nestor 1932: Sammon arvoitus. Otava, Helsinki.

Siikala, Anna-Leena 1992: Suomalainen šamanismi: Mielikuvien historiaa. Suomalaisen Kirjallisuuden Seura, Helsinki.

Siikala, Anna-Leena 2002: Elias Lönnrot etnografina. Teoksessa Lönnrotin hengessä 2002. Toimittaneet Pekka Laaksonen \& Ulla Piela. Suomalaisen Kirjallisuuden Seura, Helsinki.

Siikala, Anna-Leena 2008: Kalevala myyttisenä historiana. Teoksessa Kalevalan kulttuurihistoria. Toimittaneet Ulla Piela, Seppo Knuuttila \& Pekka Laaksonen. Suomalaisen Kirjallisuuden Seura, Helsinki.

Siikala, Anna-Leena 2012: Itämerensuomalaisten mytologia. Suomalaisen Kirjallisuuden Seura, Helsinki.

Siikala, Jukka 2006: The Ethnography of Finland. - Annual Review of Anthropology 35, 153-170.

Simon, Walter M. 1956: History for Utopia: Saint-Simon and the Idea of Progress. - Journal of the History of Ideas 17(3), 311-331.

Sjögren, A. J. 1844: Instruction générale donnée à $M$. Castrén, voyageur chargé par I-Académie de l'exporation de la Sibérie septentrionale et centrale sous le rapport de l'ethnographie et de la linguistique, par M. Sjoegren (Lu le 12 janvier 1844). - Bulletin de la Classe des Sciences historiques, philologiques et politiques de l'Académie Impériale des Sciences de Saint-Pétersbourg I(20-21), 326-332.

Sjögren, A. J. 1854: Teckning af M. A. Castréns lefnad och verksamhet. - Suomi 14, 237-283.

Snellman, J. V. 1846a: Björnen Finnarnes Gud. - Saima 8, 26.2.1846; 9, 5.3.1846.

Snellman, J. V. 1846b: Kuuluisuuksien paljous Suomessa. - Saima 30, 1.8.1846. Spencer, Herbert 1870: The origin of animal-worship, etc. - Fortnightly Review 13(May), 535-550.

Stepanov 1956 = Степанов, Н. Н. 1956: Этнографические исследования Василя Федоровича Зуева. Teoksessa Очерки истории русской этнографои, фрольклористики и антропологии 1. Академия наук СССР, Москва. Štenberg 1927= Штенберг, Л. 1927: Кастрен - алтаист и этнограф. Teoksessa Памяти М.А. Кастрена: К 75-летию дня смерти. Toimittanut В. Г. Богораз. Академия наук союза советских социалистических республик, Ленинград.

Stipa, Günter Johannes 1990: Finnisch-Ugrische Sprachforschung von der Renaissance bis zum Neupositivismus. Société Finno-Ougrienne, Helsinki. Stocking, George 1968: Race, Culture, and Evolution: Essays in the History of Anthropology. University of Chicago Press, Chicago. 
Tarkka, Lotte 2005: Rajarahvaan laulu: Tutkimus Vuokkiniemen kalevalamittaisesta runokulttuurista 1821-1921. Suomalaisen Kirjallisuuden Seura, Helsinki.

Tengström, Robert 1845a: Finska folket, såsom det skildras i Kalevala. - Joukahainen II, 122-144.

Tengström, Robert 1845b: Teckningar från den fosterländska vitterhetens område I: Kalewala. Teoksessa Fosterländskt album I. Toimittaneet Herman Kellgren, Robert Tengström \& Karl Tigerstedt. A.C. Öhmans förlag, Helsingfors.

Timonen, Senni 2004: Minä, tila, tunne: Näkökulmia kalevalamittaiseen lyriikkaan. Suomalaisen Kirjallisuuden Seura, Helsinki.

Tokarev 1966 = Токарев, С. А. 1966: История русской этнографии. Наука, Москва.

Toporkov 1997 = Топорков, А. Л. 1997: Теория мифа в русской фрилологической науке XIX века. "Индрик", Москва.

Topelius, Zachris 1822-1831: Suomen Kansan Vanhoja Runoja, ynnä myös Nykyisempiä Lauluja I-V. J.C. Frendell \& Son, Turku.

Tylor, Edward B. 1871: Primitive Culture: Researches into the Development of Mythology, Philosophy, Religion, Art, and Custom. John Murray, London.

Uusi Kalevala: ks. Lönnrot 1849.

Vanha Kalevala: ks. Lönnrot 1835.

Vaughan, Frederick 1972: The Political Philosophy of Giambattista Vico: An Introduction to La scienza nuova. Martinus Nijhoff, Hague.

Vermeulen, Han F. 2015: Before Boas: The Genesis of Ethnography and Ethnology in the German Enlightenment. University of Nebraska Press, Lincoln.

Virtanen, Matti 2002: Fennomanian perilliset: Poliittiset traditiot ja sukupolvien dynamiikka. Suomalaisen Kirjallisuuden Seura, Helsinki.

Williamson, George 2004: The Longing for Myth in Germany: Religion and Aesthetic Culture from Romanticism to Nietzsche. The University of Chicago Press, Chicago \& London. 


\section{Matthias Alexander Castrén}

\section{Luentoja suomalaisesta mytologiasta}

Föreläsningar i finsk mytologi

\section{Johdanto}

Altailaisten kansojen vanhimmat kotoperäiset uskonnot on tavattu yhdistää termiin šamanismi, mikä merkitsee noituuden uskontoa. Kuten nimityksen, myös itse asian ymmärtämiseksi on tarkasteltu enemmän tämän uskonnon ulkoista, näkyvää puolta kuin sen sisäistä laatua ja olemusta. Koska monet näiden kansojen parissa uskovat, että on šamaanin vallassa loitsia henkiä, suitsia luonnonvoimia, aiheuttaa terveyttä ja sairauksia, onnea ja onnettomuutta yms., on haluttu vetää johtopäätös, että he kunnioittavat šamaanin mahtia ylimmäisenä ja etteivät he tunnusta mitään jumaluutta, jota palvoisivat ja rukoilisivat. Mitä laajemmalle šamaanin toiminta ulottuu ihmiselle vihamielisen luonnon suitsimisessa ja hallinnassa, sitä kerkeämmin on šamanistisen uskonnon koko olemus ja merkitys käsitetty niin, että se pyrkii vapauttamaan ihmisen luonnon siteistä ja puolustamaan hengen vapautta kuinka järjettömillä tavoilla hyvänsä. Kukapa ei hyväksyisi kernaasti, että šamaanin koko olemus on protesti luonnonvoimien sokeaa ylivaltaa vastaan ihmishengestä, mutta tämä protesti ei ole lähestulkoonkaan ylimmäinen altailaisten kansojen pakanallisen uskonnon lävitse käyvä aate. Perusedellytys jokaiselle uskonnolle, joka ansaitsee uskonnon nimityksen, on yksilön riippuvuuden tunnustaminen ylemmistä voimista, joita hän joko rakkaudesta tai pelosta, joko temppelin suojissa tai sydämensä syvyyksissä kunnioittaa ja palvoo. Keski-Aasian autiomaissa tai Siperian autioilla tundrilla ei ole kansaa, joka ei tuntisi tiettyjen korkeampien, ihmistä mahtavampien voimien läsnäoloa. Voimme oppia kiinalaisista lähteistä, että Keski-Aasian vanhin kansa, niin sanottu hiongnu-kansa, palvoi 
Aurinkoa, Kuuta, taivasta, maata sekä esi-isiensä henkiä. Theophylactus Simocatta välittää kuvauksen, jonka mukaan turkkilaiset (Tu-kiu) osoittivat suurta arvostusta tulta, ilmaa, vettä ja maata kohtaan, ja että he sitä paitsi palvoivat jumalaa, jota pitivät maailman luojana, ja toivat tälle uhreina kameleita, härkiä ja lampaita. Abulghasi Bahadur -kaanin mukaan turkkilaiset alkoivat Alindje-kaanin hallinnon alaisina lisäksi palvoa kuvia. Plano Carpinilta, Marco Pololta ja muilta keskiaikaisilta oppineilta matkaajilta opimme, että mongolien vanhassa uskonnossa palvottiin suurta ja mahtavaa jumalaa nimeltä Natagaj (Natigay) tai Itoga (Plano Carpinin mukaan) ja että he lisäksi osoittivat suurta kunnioitusta Aurinkoa, tulta ja vettä kohtaan, ja että heillä oli sitä paitsi jumalkuvia, joille osoittivat uhrinsa ja rukouksensa. Tunguusit ovat yhä tänä päivänä šamanismille uskollinen kansa, mutta yhtä lailla jopa he palvovat korkeampaa olentoa nimeltä Buga, [ja he] palvovat vastaavasti kuviaan eli fetissejä ja suhtautuvat kunnioittavasti Aurinkoon, Kuuhun ja tähtiin, maahan, tuleen ja veteen sekä metsien, vuorten, yrttien ja monien muiden luontokappaleiden suojelusjumaliin. Myös samojedit uskovat korkeampaan olentoon, Num nimeltään, ja palvovat sen lisäksi niin ikään jumalkuviaan kuin myös tiettyjä luontokappaleita. Suomalaiseen heimoon ${ }^{1}$ kuuluvien kansojen parista useimmat, joilla on yhä muistoja jäljellä pakanallisuudestaan, tuntevat tunguusien Bugaa ja samojedien Numia vastaavan suuren, mahtavan, taivaallisen jumaluuden ja sen lisäksi loputtoman määrän pienempiä, alempiarvoisia jumalolentoja.

Suomalaisten ja suomensukuisten kansojen jumaluuksien tarkempi esittely johtaa epäilemättä siihen tulokseen, että ne ovat joko pelkkiä luonnonvoimia, niin kutsuttuja elementtijumaluuksia ${ }^{2}$, tai lisäksi persoonallisia jumalia, mutta jopa tässä [jälkimmäisessä] tapauksessa ne edustavat yhtä tai toista mahtavaa luonnonvoimaa. Jopa sellaisina, joku voi väittää vastaan, [nämä kansat] ovat riippuvaisia šamaaneista, joille kuuluu luonnon hallitseminen ja ihmishengen vapauttaminen sen kahleista. Tämä ei ole minun nähdäkseni asianlaita, vaan šamaanit ainoastaan käyvät mittelyyn ja taistoon sitä vastaan, mikä on heidän käsityksensä mukaan pahaa luonnossa: sairauksia, pahoja henkiä jne. vastaan. Saavuttaakseen tässä taistelussa voiton he anovat jumalilta apua ja pyrkivät saamaan ne suosiollisiksi uhrien ja rukousten 
kautta. Välillä voi käydä niin, että jotakin luonnonvoimaa (esim. tulta), jota kunnioitetaan jumalana, kutsutaan jossakin tilanteessa avuksi, toisessa tilanteessa taas šamaani on karkottamassa. Tämä ristiriita ei kuitenkaan osoita mitään muuta kuin että šamanismi ei ole sidottu ${ }^{3}$ mihinkään järjestelmään vaan kaikkien kansanuskontojen tavoin on täynnään epäjärjestystä ja sekavuutta. Altailaisten kansojen niin kutsutusta šamaanikultista käy tämän sekavuuden takaakin ilmi selvästi ja kirkkaasti se perusajatus, että luonnossa on absoluuttisia voimia, joilla on ihmisiin ehdoton vaikutusvalta.

Sen hiljalleen kehittyvän käsityksen myötä, että ihminen ei ole välittömästi luonnon herra, hänessä herää tarve kehittää ja käyttää varmoja keinoja tavoitteidensa saavuttamiseksi. ${ }^{4}$ Kuuluu šamanismin luonteeseen, ettei keinoja ole sovitettu kohteen ominaisuuksiin, ja ainakaan se ei perustu tietämykseen yhteydestä keinon ja sen asian välillä, mihin sitä käytetään. Tämä šamanismin muoto käsittää kuitenkin yhden kehittyneen piirteen siinä määrin kuin se tunnustaa subjektiivisen halun riippuvuuden kohteesta. ${ }^{5}$ On ajateltavissa, että juuri tämän kohteen tunnustamisessa on jumalanpalvonnan ensimmäinen siemen, sillä kuinka paljon arvokkaampia ovatkaan fetissit, joita villikansat palvovat, kuin ne noitakapistukset, joita šamaanit käyttävät kaikkiin kohtaamiinsa tarpeisiin? Yhtä lailla edelliset kuin jälkimmäiset koostuvat tavallisesti kuitenkin aineesta, joka voi olla orgaanista tai epäorgaanista.

Aikomukseni on käsitellä tässä uskontoa ja šamanismia sellaisina kuin ne löydettävien lähteiden mukaan todellisuudessa ilmenevät suomalaisten ja heidän sukulaiskansojensa parissa, mutta sitä vastoin aikomukseni on tyystin ohittaa niiden mahdollinen synty ja kehitys ennen historiallista aikaa. En tarkastele šamanismia omana uskonnon muotonaan vaan yhtenä jumalopin osana ${ }^{6}$.

Kun nyt alan esitellä edellä käsiteltyä, siis jumaloppia, tulee minun etukäteen mainita, että sekä suomalaisten että muiden sukulaiskansojen jumaluudet ovat jaettavissa: 1) ilman, 2) veden, 3) maan ja 4) maanalaisiin jumaluuksiin. 


\section{Jumalat}

\section{Ilman jumaluudet}

\section{a) Jumala}

Vanhempien mytologiemme joukosta sekä Lencqvist että Ganander ovat yhtä mieltä siitä, että sana jumala ei merkinnyt muinaissuomalaisten parissa mitään yksittäistä jumaluutta vaan että sillä oli merkitys 'jumaluutena, jumalolentona yleensä ja siten vastasi latinan sanaa deus, saksan sanaa Gott, ruotsin sanaa gud. a Tämä merkitys on yhä tänä päivänä yleisimmin hyväksytty, ja onkin myönnettävä, että siihen on painavat perusteet. Lencqvist vetoaa yleiseen kielenkäyttöön, joka sallii, että sanaa jumala käytetään monikossa tiettyjen jumalvoimien nimeämiseen, mikä luonnollisestikaan ei voisi käydä päinsä, mikäli "jumala", kuten Lencqvist asian ilmaisee, "olisi jonkin pakanallisen jumaluuden erisnimi yhtä lailla kuin Jupiter, Thor, Odin". Lencqvist näkee muinaisrunojemme perusteella olevan osoitettavissa, että tämä kielenkäyttötapa johtuu aina pakanallisuudesta, ja hän lainaa tätä tarkoitusta varten eräästä metsästysrunosta seuraavaa metsästäjän puheenpartta: Julki tulin jumalista, kanssa saalin (saaliin) iloisesti, so. 'tulin avoimesti jumalten luota ja noudin saaliini ilolla'.

Havaintojeni mukaan sanaa jumala ei käytetä kovinkaan usein runoissa monikossa, mutta tällaisesta käytöstä pystyn kuitenkin viittaamaan yhteen jos toiseenkin esimerkkiin Lencqvistin lainaaman lisäksi. Kalevalan uudessa painoksessa (runo 12, säkeet 229 ja 230) lausutaan miekasta, jok' oli Hiiessä hiottu, jumaloissa kuuraeltu, so. 'joka oli hiottu Hiiden luona, kiillotettu jumalten luona'. Vanhemmassa Kalevalan laitoksessa (runo 4, säe 352) kutsuu šamaani jumalia nimityksellä jumalat, lausuen jumaloista turva tulko, so. 'suokoot jumalat tukensa'. Tässä voidaan myös viitata runoon 10, säkeet 229 ja 230 samassa laitoksessa, missä sanat kuuluvat: saakohon joku jumala, tuhatkunta perkeleitä, so. 'tulkoon jokin jumala, tulkoon tuhat paholaista (karkottamaan kärsimykset)'. 
Tueksi Lencqvistin ja muiden ilmaisemalle näkemykselle sanan jumala alkuperäisestä merkityksestä voidaan edelleen esittää, että sitä käytetään runoissa toisinaan epiteettinä tietyille ihmismäisille jumaluuksille. Erityisesti kunnioitetaan Ukkoa tällä epiteetillä, mutta jonkin kerran se liitetään myös Hiiteen (Kalevala, runo 14, säe 83), Pahaan (Topelius [1822-1831, II], 3), Koihin eli aamuruskoon (Kalevala, runo 17, säe 478) jne. Kalevalan vanhassa laitoksessa (runo 18, säe 456) tulee jopa Lemminkäinen nimetyksi jumalaksi.

Näitä vastaan voi nostaa runoissa monta sellaista kohtaa, joissa jumala on käsitetty yhden, tietyn jumalan merkityksessä; mutta vähintäänkin suurimmassa osassa näkyy kristinopin vaikutus johtaneen tällaiseen käsitykseen. Se näkyy jo siitä, että jumalaan tässä merkityksessä on tavallisesti liitetty lisänimitys kuten kaikkivalta, autuas, armollinen, pyhä sekä muita epiteettejä, jotka ilmiselvästi on lainattu kristinopista. Tällaisten epiteettien lukuun kuuluu selvästi myös luoja, sillä jumalan käsittäminen maailman alkuunpanijana ja luojana ei ole alkuperäistä suomalaisessa mytologiassa. Jumalalla ei ole mitään osaa luomistapahtumassa siten kuin se esitetään runoissamme, vaan sekä taivas että maa, Aurinko, Kuu ja tähdet ovat eri varianttien mukaan joko ilman tyttären, niin kutsutun Ilmattaren, tai Väinämöisen tuottamia, joista kumpaakaan ei sanan varsinaisessa merkityksessä rukoilla ja kunnioiteta jumalana. Näin ollen voi panna merkille, että sana luoja ei runoissamme aina edellytä osallisuutta luomistyöhön, sillä ennen muuta se on liitetty epiteettinä Päivän poikaan ('auringon poika') ja muihin myyttisiin henkilöhahmoihin, joilla ei ole ollut mitään tekemistä maailman luomisen kanssa. Toisekseen 'uuden luominen' ei välttämättä kuulu sanan luoja etymologiaan, vaan sanan voi käsittää 'jakajaksi, antajaksi'. Varmastikin juuri tässä merkityksessä metsän jumaluuksille on annettu nimitys antoluojat, so. 'lahjojen antajat'. Tietoisena tästä luoja-sanan merkityksen epämääräisyydestä pidän epäilyksettä selvänä, että kun jumala esiintyy runoissa tiettynä jumaluutena ja häntä nimitetään luojaksi, viitataan kristilliseen, maailman luoneeseen jumalaan. Se, että sana jumala suomalaisissa runoissa usein merkitsee 'kristillistä jumalaa', on todettavissa myös monista hänelle suunnatuista rukouksista, joista suurimmassa osassa on kristillinen, hyvin alistuva luonne. Haluan esimerkkinä 
tuoda esiin seuraavan Kalevalassa (runo 9, säkeet 567-586) esiintyvän kiitosrukouksen palautuneen terveyden johdosta:

\author{
Tuoltapa aina armot käyvät, \\ Turvat tuttavat tulevat, \\ Ylähältä taivahasta, \\ Luota luojan kaikkivallan. \\ Ole nyt kiitetty jumala, \\ Ylistetty luoja yksin, \\ Kun annoit avun minulle, \\ Tuotit turvan tuttavasti \\ Noissa tuskissa kovissa, \\ Terän rauan raatamissa. \\ [...] \\ Jumalass' on juoksun määrä, \\ Luojassa lopun asetus, \\ Ei uron osoannassa, \\ Vallassa väkevänkänä.
}

Vaikka kuinka näyttäisi edellä mainitulta pohjalta olevan kiistämätöntä, että yksittäiseksi jumaluudeksi käsitetty Jumala paljastuu runoissa tavallisesti alkuperältään kristilliseksi, minun on mahdotonta yhtyä käsitykseen, jonka mukaan tämä sana alkuperäisen merkityksensä mukaisesti merkitsisi abstraktin jumaluuden käsitettä, 'jumalaa yleensä. Ylipäätään tällaista käsitettä ei esiinny kansojen lapsuudessa, vaan sen ilmaantuminen edellyttää pidemmälle edennyttä kulttuuria. Kypsymättömiltä ja sivistymättömiltä kansoilta puuttuu tavallisesti ilmaisut jopa arkisille abstrakteille käsitteille. On olemassa kansakuntia, joilla ei ole nimitystä 'tulvalle', mutta kylläkin jokaiselle yksittäiselle tulvalle; ei 'sormelle', mutta kylläkin 'peukalolle,' 'etusormelle' jne; ei 'marjalle', mutta kylläkin 'puolukalle', 'hillalle', 'mustikalle' jne; ei laisinkaan 'puulle', mutta kylläkin 'koivulle', 'kuuselle', 'tuomipuulle'. Sitäkin vähemmän ne voivat luonnollisestikaan käsittää ja ilmaista niinkin korkeaa käsitettä kuin 'jumala' yleisessä, abstraktissa merkityksessä, sillä heille on olemassa vain tämä tai tuo yksittäinen jumala. Mutta jumala on epäilyksettä vanhin ja alkuperäisin jumalnimitys, joka suomalaisessa mytologiassa tavataan, sillä sitä ei tavata ainoastaan lappalaisten, virolaisten, syrjäänien ja tšeremissien parissa vaan myös Siperian samojedien parissa, kun taas suomalaisten muut jumaluudet 
ovat näiden kansojen parissa suurimmaksi osaksi vieraita. Näin ollen on syytä olettaa jo näiden seikkojen pohjalta, että jumala ei alun perin merkinnyt yleistä vaan tiettyä ja määrättyä jumaluutta.

Tällä näkemyksellä on ollut edustajansa, mutta useimmat heistä ovat eksyneet tyhjien arvailujen labyrinttiin ja perustaneet tuloksensa pelkkiin filosofisiin merkityksettömyyksiin. Joku on johtanut jumalan heprealaisista sanoista jom 'päivä ja el 'jumala' ja tämän perusteella esittänyt, että suomalainen jumalnimi merkitsi 'valon jumalaa'. Toinen taas väittää, että jumala saattoi merkitä 'taivaan herraa', ja että sana olisi johtunut heprean sanoista ium 'taivas' ja bal 'herra.' On jopa esitetty analogioita toisaalta jumalan ja toisaalta ruotsin sanojen himmel, gammal, ymer 'jättien isä' jne. välille. Schefferus siteerasi Tornæuksen mukaan perinnettä, jonka mukaan mies nimeltä Jumi eli Jumo oli lappalaisten ja suomalaisten kantaisä, ${ }^{a}$ ja on esitetty sellainen hypoteesi, että häntä kuolemansa jälkeen alettiin palvoa jumaluutena ja nimittää Jumalaksi. ${ }^{\text {b }}$ Ohittaen monta samassa hengessä tehtyä sanojenjohtamisyritystä haluan kuitenkin lisätä, että Lönnrot johti sanan jumala samasta kannasta kuin sanan jumu, jumaus 'jyrinä, jylinä, ja otaksuu tämän perusteella, että suomalaiset nimittivät sanalla jumala alun perin 'ukkosenjumalaa.' Palaan vielä tähän kiinnostavaan hypoteesiin, mutta sitä ennen minun on esiteltävä johdanto yritykseeni alistaa sana jumala huolellisemmalle etymologiselle tarkastelulle kuin mitä Lönnrot ja muut kirjoittajat ovat tehneet.

Tässä esitetään ensin, että jumala, joka muodostuu kolmesta tavusta, ei voi olla kantasana, vaan sen täytyy olla kehittynyt toisesta, yksinkertaisemmasta kannasta. Siinä tunnistaa helposti johdinpäätteen -la, joka yhtä lailla kuin -lä esiintyy suomessa lukuisana merkitsemässä paikkaa tai lokaliteettia yleensä ja myös asuinpaikkaa. Tämän johdoksen mukaisesti sanan jumala kanta olisi juma, ja tšeremissien parissa tavataan sana juma vielä tänä päivänä 'jumalan' merkityksessä. Useimmista muista suomensukuisista kielistä tämä kanta puuttuu, ja käsite 'jumala' ilmaistaan siitä johdetuilla muodoilla, kuten viron

a Schefferus $1673,43$.

b Lencqvist 1782.

c Lönnrot 1836. 
kielessä läheisellä sanalla jummal, lappalaisten kielessä sanalla jubmel, ibmel tai immel ja syrjäänissä sanalla jen (itse asiassa jemel). Kuitenkaan en pysty lainkaan pitämään jumaa alkuperäisenä kantana, vaan otaksun, että siihen kuuluva vokaali $a$ on ainoastaan eufoninen lisäys. En voi nyt syventyä niiden perusteiden lähempään tarkasteluun, jotka ovat johtaneet minut tähän otaksuntaan, vaan minun on pidättäydyttävä tuomaan ne esiin jossakin toisessa yhteydessä. Tässä haluan vain mainita, että konsonantti $m$ ei suomen kielessä mielellään päätä sanaa vaan tavallisesti ottaa apuvokaalin jälkeensä. Todennäköinen kanta jumalalle on näin ollen jum-nimitys, jonka samojedit aiempien kirjoittajien todistusten mukaan liittävät jumalaan. ${ }^{b}$ Itse en ole tämän kansan parissa koskaan pannut merkille kyseistä nimitystä vaan sen sijaan sanan num. Huolimatta erosta alkuäänteessä on num todennäköisesti samaa alkuperää kuin suomen jum, sillä samojedikielissä ei j:n ja $n: n(n j: \mathrm{n})$ vaihtuminen keskenään ole epätavallista. ${ }^{8}$

Kuten seuraavassa nähdään, olen tullut siihen näkemykseen, että sana jumala ei ole äänneasultaan sukulainen yksinomaan viron sanan jummal, lapinkielen sanan jubmel ja syrjäänin sanan jen kanssa vaan myös tšeremissin sanan juma ja samojedin sanan num kanssa. Siksi haluan nyt lyhyesti valmistaa meidät siihen tarkoitteeseen, jota eri kansat ja etenkin samojedit nimeävät näillä sanoilla, toivoen tarjoavani yhden jos toisenkin vihjeen sen selvittämiseen, mitä muinaissuomalaiset alun perin käsittivät sanalla jumala. Högström tarjoaa meille tervetulleen tiedon liittyen lappalaisten sanaan jubmel "joka sana, lukuun ottamatta sitä käsitystä mikä heillä (lappalaisilla) on Kristuksesta siellä perukoilla, ei varsinaisesti vastaa Deusta vaan pikemmin latinalaisten Jupiteria.` Tämän vuoksi tällä sanalla on aivan sama merkitys kuin suomen sanalla jumala, jolla tarkoitetaan 'kristillistä jumalaa’ siinä kuin jokaista pakanallistakin jumaluutta. Vastaavasti

a Sana Jen on varsinaisesti kadottanut m:n äänneasussaan, sillä se on instruktiivimuodossa jenm-än, st. f. jen-än ja inessiivissä jenm-yn, st. f. jen-yn mutta nyt olisi kanta jenm, ja se päättyy kahteen konsonanttiin, kaikin puolin kieleen sopimattomasti, ja edellyttää vielä alkuperäisempää muotoa, joka epäilyksettä on ollut jemel, josta jeml, jemm, jem ja jen ovat myöhemmin kehittyneet.

b Lencqvist 1782, 14.

c Högström 1747, 175, huomautus r. 
virolaiset käyttävät sanaa jummal ja syrjäänit sanaa jen epiteettinä, jolla nimittävät kaikkia jumalia ylipäätään ja kristillistä eritoten. Tämä merkitys on myös sanalla juma kastettujen tšeremissien parissa, mutta kastamattomat käsittävät tämän itse asiassa ylimpänä jumaltensa joukossa ja ajattelevat hänen asuvan taivaassa. Luultavasti kristinuskon tulon myötä myös pakanalliset tšeremissit alkoivat palvoa häntä maailman luojana ja ylläpitäjänä sekä onnen ja hyvinvoinnin antajana ym.

Äsken mainittujen kansojen lisäksi myös samojedien käsitykseen Jumalaa vastaavasta Numista on sekoittunut kristillisiä käsityksiä. Monet yhä kastamattomat samojedit palvovat häntä maailman luojana ja kristinuskoa mukaillen uskovat, että hän on kaikkivoipa, kaikkitietävä jumaluus, joka hallitsee luomustaan oikeudenmukaisesti, suojelee viattomia, palkitsee hyveellisyyden, rankaisee rikoksista jne. Vaan jos Numista erotetaan kaikki myöhempinä aikoina kristinuskon vaikutuksesta tulleet käsitykset, palvovat samojedit hänessä itse asiassa taivasta. Joko näkyvän, materiaalisen taivaan tai tiettyjen siellä majailevien jumalvoimien palvominen on aiemmin ollut hyvin tavallista Aasiassa. Kiinalaisten keskuudessa on ollut tällaista palvontaa, ja Herodotoksen mukaan Strabo, kuten useat kiinalaisetkin kirjoittajat, kertoo myös muinaisten persialaisten uhranneen taivaalle. Mongolien vanhasta uskonnosta tiedetään melko vähän, mutta ilmeistä on, että myös he palvoivat taivasta nimityksellä tengri (ks. alempana). Tunguusit palvovat taivaallista jumaluutta nimeltä Buga yhä tänä päivänä, ja monet turkkilaiset heimot osoittavat palvontansa taivaallisille voimille, joita kutsuvat nimityksellä $k u d a i^{9}$ ja joita vaikuttaisi olevan lukumäärältään seitsemän. Kiinalaiset kertovat nykyisten turkkilaisten esi-isistä, joita kutsuvat nimityksellä $t u$-kiu, että he palvoivat koko taivasta, ja samalla tavoin on erään kiinalaisen tiedon mukaan ollut laita hiongnu-kansan keskuudessa. Aasian laajalle ulottuvien rajojen sisällä on sanalla sanoen tuskin ollut yhtäkään sellaista pakanallista kansaa, jonka uskonnosta meillä on mitään tuntemusta, joka ei olisi omistanut palvontaansa taivaalle ja sen jumalolennoille. Tätä palvontaa ei ole vallinnut vain Aasiassa, vaan kaikki villit kansat ovat aina olleet luonnonpalvojia ja osoittaneet kunnioituksensa ensi sijassa taivaanpiirille. Mitä sellaista olisikaan luonnossa, mikä olisi paremmin omiaan herättämään villin ihmetyksen ja houkuttelemaan hänet 
palvontaan kuin taivas aurinkoineen, kuineen ja tuhansine tähtineen? Taivaan alueellahan ukkonen jyrisee, salamat välkkyvät ja revontulten liekit leimuavat. Lumi, sade ja rakeet, myrsky ja rajuilma ja monet muut luonnon ihmeet ovat peräisin ylemmistä piireistä. Monet näiden ihmeiden joukossa ovat sen verran vaikuttavia olemukseltaan, että myös šamaanit kokevat alemmuutensa ja osoittavat niille nöyriä palvontamenoja, vaikka tietämättöminä luonnonjärjestyksestä [he] uskovat pystyvänsä noitavoimin hallitsemaan itse elementtejä ja olemaan yhteydessä niihin ja etenkin ukonilmaan.

Kieli paljastaa, että samojedit todella palvovat taivasta, sillä samojedin kieli kuvaa sekä jumalaa että taivasta yhdellä ja samalla sanalla, yllä esitetyllä sanalla num. Tällaisella kielenkäytöllä on luonnollisesti oltava perusta siinä, että taivasta on pidetty jumalallisena olentona. Tietyt samojedikansat käyttävät käsitteen 'jumala' nimeämiseen myös sanaa jilibeambaertje, mutta tämä on varsinaisesti vain epiteetti Numille ja merkitsee hänen ominaisuuttaan 'asuinpaikan vartijana' tai 'suojelijana'. Tämän ominaisuuden pitäminen osana Numia on epäilyksettä myöhempää perua, ja itse sanaa jilibeambaertje käyttävät enimmäkseen sivistyneet, kristinuskoon käännytetyt kansat, jotka toisinaan yhdistävät sanan Kristukseen. Sivistymättömät [samojedi-] kansat eivät tiedä paljoakaan jilibeambaertjesta, vaan käyttävät sanaa num ${ }^{10}$ ja sitäkin lähes aina 'taivaan' merkityksessä. He eivät käsitä taivasta kuitenkaan elottomaksi vaan eläväksi, persoonalliseksi olennoksi, jonka luontoon kuuluu aiheuttaa ukonilmaa ja salamoita, sadetta, lunta, rakeita, myrskyä ja tuulta ym. Sanalla num siis ilmaistaan, mikäli asiaa tarkastellaan meidän näkökulmastamme, sekä 'taivasta' että 'taivaan jumalaa'. Samojedien parissa nämä kaksi käsitettä ovat kuitenkin enimmäkseen erottamattomia, niin pitkälti he palvovat näkyvää taivasta elävänä ja persoonallisena jumaluutena.

Edellä esitettyjen merkitysten lisäksi sanalla num on tiettyjen kansojen parissa joitakin muitakin merkityksiä, joita käsittelen nyt lyhyesti. Merkillepantava on etenkin sen merkitys 'ukkonen'. Tässä merkityksessä tavataan num etenkin erään kansan parissa, jota kutsutaan nimellä kagmaši eli kamassit, kamassintsit. ${ }^{11}$ Ei löydy yhtä ainutta samojedikansaa, joka ei palvoisi ukkosen mahtia erityisellä kunnioituksella, vaan useimmat pitävät tätä ilmiötä yhtenä taivaan tai taivaallisen jumalan ominaisuuksista, kuten jo mainitsin. Kamassit sitä 
vastoin pitävät ukonilmaa omana jumaluutenaan ja käyttävät sanaa num ainoastaan tässä merkityksessä. On mahdollista, että sanan tämä merkitys on alkuperäinen myös samojedikielissä kuten myös suomessa. ${ }^{12}$ Mikäli näin ei kuitenkaan ole, täytyy olettaa, että samojedit ovat palvoneet pääasiassa Numin ukkostavaa ominaisuutta, sillä sanan eri merkitykset ovat voineet syntyä ainoastaan tällä tavoin.

Olen lisäksi kuullut samojedien liittävän sanan num tai jilibeambaertje poikkeuksellisesti Aurinkoon. Eräs samojedinainen kertoi minulle, että joka aamu ja ilta hän tapasi mennä ulos teltastaan ja kumartaa Auringolle, lausuen sen lisäksi aamuisin: "Kun sinä Jilibeambaertje kohoat, kohoan minäkin pedistäni" ja iltaisin: "Kun sinä Jilibeambaertje lasket, käyn minäkin lepäämään". Nainen esitti tämän kuin todisteena väitteelleen, että myös samojedien parissa suoritetaan aamuja iltarukous, mutta myönsi murheellisena, että heidän parissaan on myös sellaisia villejä, jotka eivät koskaan osoita jumalalle rukousta.

Toisinaan samojedit käyttävät nimitystä num myös muista kuin taivaallisista asioista. Tähän törmäsin kerran eräällä matkalla Jäämeren rannoilla. Seisoessani meren rannalla seuralaisen kanssa, joka oli samojedi, ja suunnatessani katseeni mittaamattomille ulapoille mieleeni tuli esittää samojedille kysymys: "Missä Num on?" - "Tuolla", hän vastasi lyhyesti osoittaen meren tummaa pintaa. Lisäksi olen kuullut samojedien jonkin kerran kunnioittavan maata nimityksellä num. On selvää, että sanaa käytetään äärimmäisen harvoin näin laajassa merkityksessä. Toisaalta myös samojedien parissa oleskelleet lähetyssaarnaajat ovat vakuuttaneet minulle, että tällainen käyttö ei ole täysin tavatonta. Minusta siinä ei olekaan mitään epäuskottavaa, sillä samojedien tavoin myös useimmat muut heille sukua olevat kansat, jotka ovat yhä pakanallisuudelle uskollisia, palvovat niin taivasta, maata, vettä, Aurinkoa, ukkosta kuin lukemattomia muitakin luonnonkohteita. Ainoa ero on, että siinä missä muut kansat tavallisesti palvovat yksittäisiä kohteita kutakin eri nimellä, käyttävät samojedit sanaa num kernaasti kuvaamaan niitä kaikkia. Heilläkin on luonnollisesti erityiset nimityksensä maalle, Auringolle, merelle, ukkoselle ja muille asioille, mutta näillä nimityksillä ei ole välttämättä jumalallisen olennon merkitystä. He käyttävät niitä kyseisistä kohteista pääasiassa silloin, kun niihin viitataan pelkästään kuolleina, materiaalisina asioina. Kun niihin viitataan jumalallisina olentoina, niistä käytetään samaa nimi- 
tystä kuin taivaasta. Näin ollen sana num yltää yksinkertaisesta 'taivaan' tai 'taivaallisen jumalan' merkityksestä merkitsemään 'jumalallista olentoa ylipäätään' Alemmilla merkitystasoilla tällaiset siirtymät sanojen merkityksessä ovat melko tavallisia. Niinpä useimmat kansat ovat tarkoittaneet 'ihmistä' merkitsevällä sanalla pelkästään oman kansansa yksilöä, mutta kun ovat yltäneet näkemykseen inhimillisen luonnon yhdenmukaisuudesta kaikkien kansojen piirissä, on sana jälkikäteen saanut nykyisen, kaikki ihmisyksilöt käsittävän merkityksensä. Samalla tavoin on monia yksittäisten kasvien ja puiden nimiä alettu käyttää merkitsemään kokonaisia [niiden] sukuja. Tämän kielille tavallisen kehitysprosessin vuoksi on esim. samojedin 'peukaloa' merkitsevä sana jälkikäteen saanut merkityksen 'sormi', 'variksenmarjaa' merkitsevä sana merkityksen 'marja' jne. Pyrin myöhemmin selventämään täsmällisemmin, millainen kehityskulku on ollut merkityksestä 'taivas' tai 'taivaallinen jumala' merkitykseen 'jumala ylipäätään', ja ryhdyn nyt jatkamaan aloittamaani suomen kielen sanan jumala merkityksen tutkiskelua.

Samalla tavoin kuin esittelemäni nimitykset, samojedien num, lappalaisten jubmel ja tšeremissien juma, merkitsevät 'taivaallista jumaluutta, joka pääasiallisesti on ukkosen valtias, myös muinaissuomalaiset ovat mielestäni ennen muinoin palvoneet jumalaa 'taivaallisen jumalan' ominaisuudessa. Eräiden muinaispohjoismaisten saagakertomusten kuvausten perusteella voidaan päätellä, että tämä sana ei ainakaan alkujaan merkinnyt pelkästään yleistä, abstraktia jumalepiteettiä vaan oli yksittäisen jumaluuden nimi. Esimerkiksi Pyhän Olavin saagassa kerrotaan: "Kartanolla seisoo bjarmien jumala, joka on nimeltään Jumala", ja Bósin ja Herrauðrin saaga kertoo: "Siellä palvottiin jumalaa, jonka nimi on Jomala."13 Mikäli Jumala oli bjarmien palvoman jumalkuvan nimi, on luultavaa, että tämä sana ei merkinnyt sitä abstraktia jumaluuden käsitettä, josta on vain heijastus havaittavissa. Ainakaan muinaissuomalaiset eivät ole voineet kuvaa siihen yhdistää. Omista muinaisrunoistamme saamme kuitenkin todisteita lausumallemme näkemykselle, että jumala ei ollut pelkästään jokin tietty jumala vaan pikemmin merkitsi 'taivaallista jumaluutta'. Paljon painoa on sillä jo yllä mainitulla seikalla, että kun nimitystä jumala käytetään epiteettinä, se liitetään yleensä yläilmoissa valtaistuintaan 
pitävään Ukkoon. Kaikissa tähän asti julkaistuissa runoissa on osoitettavissa vain äärimmäisen harvoja kohtia, joissa jumalaa käytetään epiteettinä muille jumaluuksille, ja yhtä harvoin sitä tapaa käytettynä monikossa merkitsemässä tiettyjä jumalia. Sitä vastoin Ukko mainitaan melko harvoin runoissa ilman, että jumala (taivahan jumala, ylijumala, ilmojen jumala ym.) liitettäisiin häneen lisänimityksenä. Etupäässä Ukko käy sanalla sanoen jumalasta.

Olen aiemmin maininnut, että jumalaa ei itse asiassa aina käytetä muinaisrunoissamme epiteettinä (nomen appellativum), vaan sitä käytetään myös erisnimenä [proprium], joskin näissä tapauksissa se viittaa tavallisesti kristilliseen jumalaan. Silti tavataan myös joitakin runokohtia, joissa Jumala ilmenee henkilönnimenä ja joissa sillä on sama merkitys kuin nimityksellä Ukko, siis 'taivaan jumala'. Kalevalassa (runo 45, säe 211-) synnyttämäisillään oleva Pohjolan emäntä kutsuu häntä tällä tavoin rukouksessa, joka alkaa näin: Tule nyt löylyhyn jumala, Iso ilman lämpimähän, so. 'tule nyt kylpyyn jumala, tule lämpöön, ilman isä. Kuten ilmaus ilman iso paljastaa, tässä ei jumalaa voi käsittää 'jumalaksi ylipäätään', vielä vähemmän 'kristilliseksi jumalaksi', vaan ainoastaan 'ilman tai taivaan jumalaksi'. Tätä nimitetään muutoin Ukoksi, millä nimellä häntä kutsutaan toisinaan avuksi myös lapsenpäästöön (vrt. Kalevala, runo 1, säe 169-).

Tarvitessaan tuulta tapasivat muinaissuomalaiset lähes aina kääntyä rukouksineen tämän saman taivaallisen Ukon puoleen. Olen kuitenkin tavannut Kalevalassa kohdan, jossa Väinämöinen kääntyy Jumalan puoleen rukoillessaan suotuisaa tuulta. On totta, että Jumalaan liittyy tässä tapauksessa epiteetti armollinen ja että rukous ulkoisestikin on luonteeltaan kristillinen, mutta tällaisiin tarkoituksiin ei runoissa tavata kutsua avuksi kristillistä jumalaa. Kyseinen rukous on Kalevalassa (runo 18, säkeet 29-34), ja kuuluu seuraavasti:

Tule nyt purtehen jumala,

Aluksehen armollinen,

Väeksi vähän urohon,

Miehen pienen miehueksi

Noilla väljillä vesillä,

Lakeilla lainehilla. 
Kun sanaa jumala käytetään erisnimenä (nomen proprium), siihen liittyy toisinaan epiteetti ilmoinen, mikä osoittaa [sen tarkoitteen] identiteetin Ukoksi. Tätä epiteettiä ei voi antaa kristittyjen jumalalle, ainakaan sen luontoisissa rukouksissa kuin tämä, joka esiintyy Kalevalassa (runo 15, säkeet 352-362):

Itse ilmoinen jumala

Valjastele varsojasi,

Rakentele ratsujasi,

Aja kirja-korjinesi

Läpi luun, läpi jäsenen,

Läpi liikkuma-lihojen,

Läpi suonten soljuvaisten,

Liitä luu lihoa myöten,

Suoni suonen päätä myöten,

Luo hopea luun lomahan,

Kulta suonen sortumahan.

Tässä voidaan palauttaa mieleen, että myös suomen kielen ilmaisu jumalan ilma viittaa siihen, että jumala ei muinaissuomalaisten parissa alun perin merkinnyt mitä hyvänsä jumalaa, vaan sillä oli tietty, 'taivaan jumalan' merkitys. Kaikki jumaluudet eivät hallinneet ilmojen alaa, vaan sen määrääminen kuului pääasiassa yhdelle, mahtavalle jumalalle, jota runoissa tavallisesti nimitetään Ukoksi mutta jota alun perin näyttää nimitetyn Jumalaksi. On tuskin tarvetta mainita, että kyseinen ilmaus ei voi olla käännös ruotsista: ilmaisu herrans väder eroaa tästä ilmauksesta ennen muuta merkitykseltään, ${ }^{a}$ ja suomensukuisten kansojen parissa tavataan vastaavia kielikuvia. Tässä hengessä ilmaisevat muiden muassa samojedit säätiloja, kuten ilmaisulla tanser numgana, joka merkitsee 'rajuilmaa Numin luona'.

Sanan jumala alkuperäisen merkityksen suhteen on merkillepantavaa, että niin moni oppinut on yrittänyt johtaa sen etymologisissa pohdinnoissaan johonkin sanaan, jolla on taivaan tai jonkin sinne kuuluvan asian kuten valon, ukkosen tai muun sellaisen merkitys.

a Runokielessä jumalan ilma ei merkitse huonoa ilmaa vaan Jumala-jumaluuden ilmanalaa. Niinpä esim. Kalevalassa (runo 13, säe 97-): "eip' on ilmalla jumalan, tämän taivon kannen alla" jne. 
Tämä ei ole varmastikaan sattumaa vaan perustuu epäilemättä epämääräiseen käsitykseen siitä, että sana jumala merkitsi pakanaaikana taivaallista jumaluutta. Tähän perustuu erityisesti Lönnrotin sanan johtaminen onomatopoieettisesta kannasta jumi (jumu) 'jyrinä, järinä. Paitsi että nämä sanat äänteellisesti muistuttavat toisiaan, on myös melko todennäköistä, että juuri ukkosen jyrinä on kaikkien luonnonilmiöiden joukosta vahvimmin herättänyt kypsymättömässä luonnonihmisessä ajatuksia ylemmästä voimasta.

Aiemmassa olen osoittanut, että jumala-sanan affiksi -la, joka takavokaalisen kannan jälkeen kuuluu -lä, on paikallisuuspääte. Mutta mistä syystä jumalalla on tämä pääte? Se on tärkeä kysymys, josta muinaistutkijamme eivät ole muodostaneet mielipidettä. Vaikuttaa siltä kuin siihen ei olisi uskottu löytyvän selventävää vastausta, eikä mikään ole kuitenkaan helpompaa kuin tähän kysymykseen vastaaminen. Mikäli jum (jumu) merkitsee ukkosta, merkitsee jumala 'paikkaa (aluetta), missä ukkosta tavataan', siis 'taivasta', eli täysin samaa tarkoitetta kuin mihin samojedin num viittaa. Sana jumala on etymologisesti synonyymi nykysuomen sanan taivas kanssa, ja löytyy varsin perusteltu syy otaksua, että muinaissuomalaiset todella kutsuivat materiaalista taivasta jumalaksi. Kuten Schott huomauttaa, suomen sana taivas on epäilemättä laina indogermaanisista kielistä. Tätä sanaa tavataan koko altailaisen kielikunnan piirissä tietääkseni pelkästään suomessa ja virossa. Jopa lapinkielessä se on tuntematon.

On helppo huomata, että kyseisellä affiksilla -la (-lä) ei sanassa jumala ole lainkaan sama merkitys kuin useissa muissa mytologisissa nimityksissä kuten Ahtola, Tapiola, Tuonela, Manala, Kalevala, Väinölä jne. Näissä sanoissa -la (-lä)-päätteellä on ahtaampi merkitys 'asuinpaikkana, kotina'. Kuten seuraavassa yritän tarkemmin tuoda esiin, käsitetään suomalaisessa mytologiassa jumalten asuvan kotonaan, kukin kartanollaan, missä jumala elää kuin rikas isäntä, tai linnassaan, jossa hän hallitsee kuin mahtava kuningas. Suunnilleen sama käsitys tavataan myös lappalaisten mytologiassa, vaikka tätä ei ilmaistakaan paikallisuuspäätteellä -la (-lä) vaan omalla sanallaan aimo tai aibmo, esim. Jabme-aimo, Sarakka-aimo ja Saivo-aimo, 'kuoleman, Sarakan ja Saivon koti'. Klemm esittää, että kyseinen käsitys on lainaa edda-opista ${ }^{14}$ niin lappalaisten kuin myös suomalaisten parissa. Hän kertoo: 
Koko Aimo-opissa tunnistan germaanisen edda-opin jäljitelmän moninaisine 'koteineen' (Muspelheim, Fiflheim, Jotunheim), erityisesti kun huomataan, kuinka vähän noitien opeissa on yleensä yhdenmukaisuutta ja kuinka karussa ympäristössä tavataan värittää ulkomaisia lainoja. ${ }^{\text {a }}{ }^{15}$

Olen ollut samaa mieltä jo pitkään, ja tätä tukee varsin vahvasti se, että käsitystä jumalten kodeista ei tavata muiden suomalaisten kansojen parissa vaan vain niiden, jotka ovat olleet läheisissä kosketuksissa germaanisten kansojen kanssa. Ajattelisin myös, että mikäli tämä käsitys todella olisi alkuperäistä suomalaisille kansoille, se ilmaistaisiin analogisella tavoin tai että ainakaan sen ilmaisutavoissa ei olisi niin suurta eroa kuin on laita suomalaisten ja lappalaisten välillä. Kuinka tähän suhtautuukin, on näkemykseni mukaan jumala kuitenkin ilmiselvästi kotoperäinen suomalainen sana. Päätän tähän merkityserojen käsittelyn, sillä jumalan merkitys ei vähäisimmässäkään määrin muistuta germaanisia jumalkoteja ja koska kyseinen sana tavataan tiettyjen suomalaisten kansojen parissa ja on säilyttänyt ainakin joitakin merkkejä päätteestä -la myös sellaisten kansojen kielessä, joilla ei ole ollut mitään tekemistä germaanisten kansojen kanssa, kuten on laita esim. syrjäänien suhteen.

Siinä määrin kuin kaikki yllä esitetty on oikeellista, huomataan, että sanalla jumala on ollut muinaissuomalaisten keskuudessa kolmitahoinen merkitys, sillä se on merkinnyt 1) taivasta; 2) taivaan jumaluutta; 3) jumaluutta ylipäätään. Molempia ensin mainituista merkityksistä tavataan myös monissa muissa kielissä kiinnittyneinä yhteen ja samaan sanaan. Siten kiinassa sana tien merkitsee samalla kertaa sekä taivasta että taivaan jumaluutta. Sama kaksoismerkitys on myös joissakin turkkilaisissa murteissa sanalla tengri, mokšassa (mordvalainen murre) sanalla skei, Jenisein ostjakkien kielessä sanalla es jne. Samojedissa sanalla num on edellä osoittamani mukaisesti samat kolme merkitystä kuin jumalalla suomen kielessä, joskin viimeinen näistä merkityksistä on vain vähän käytössä muiden kuin kristittyjen samojedien parissa. Suomalaisten jumala on merkitykseltään läheisessä yhteydessä mongolien tengriin tai tegriin, joka Kowalewskin

a Klemm 1843-1852: III, 76. 
mukaan merkitsee: 1) taivasta (ciel [ransk.]) ja taivaan jumalaa (génie du ciel); 2) jumalallisuutta ylipäätään (divinité); 3) kaikenlaisia hyviä ja pahoja, taivaallisia ja maallisia henkiä (esprits, génies terrestres et céléstes, bons et mauvais). ${ }^{\text {a }}$

Yllä mainittujen merkitysten joukossa täytyy luonnollisesti jokaisessa kielessä olla aistittava, materiaalinen ja samalla myös ensimmäinen ja alkuperäinen, sillä kuuluu ihmishengen tapoihin kohota aistittavasta hiljalleen kohti yliaistillista, yksittäisestä kohti yleistä, konkreettisesta kohti abstraktia. Tämä merkitys on myös yhä tänä päivänä yleisimmin hallitseva monissa kyseisistä kielistä, kuten esim. samojedissa, jakuutissa, jenisein-ostjakissa, monissa eteläsiperialaisissa tataarikielissä jne. Mahtavat ja suurenmoiset ilmiöt, jotka sijoittuvat avaruuteen, ovat myöhemmin herättäneet käsityksen, että taivas on jumalallinen olento. Olemme aiemmin nähneet, että samojedien parissa palvotaan itse asiassa pelkkää taivasta jumalan ominaisuudessa. Epäilemättä on tilanne alun perin ollut vastaava myös muiden sukulaiskansojemme keskuudessa. Lönnrot esittää, että Jumala on ollut suomalaisten vanhin jumaluus, ${ }^{16}$ ja minun mielestäni tämä väite on varsin todenmukainen, sillä suomalaisten muut jo mainitut jumalat ovat suurimmaksi osaksi tuntemattomia muille sukulaiskansoillemme ja sen vuoksi niiden on oltava myöhempää alkuperää. On kuitenkin luonteenomaista, että pelkän taivaan palvomisen on hiljalleen muututtava yleisemmäksi luontokultiksi. Kaikessa mahdissaan ja loistossaankin taivas on yksittäinen, rajallinen kohde, ja sen palvonta ei voi sen vuoksi täyttää ihmisen uskonnollisia tarpeita. Vaistonvaraisesti jopa villi tapailee äärettömyyttä todellisena palvontansa kohteena. Jokapäiväiset kokemukset opettavat hänelle, että taivaallisten ilmiöiden lisäksi luonnossa on monia muitakin asioita, jotka eivät taivu hänen tahtoonsa eivätkä tottele hänen toiveitaan. Meren vihaiset aallot, tulen ahneet liekit, maa korkeine vuorineen, kolkot metsät, villit eläimet, kaikki nämä ja lukemattomat muut luonnonilmiöt osoittautuvat kypsymättömälle luonnonihmiselle ylivoimaisiksi ja pakottavat mahtavuudellaan tämän kaatumaan ja taipumaan. Tällä tavoin käsitys jumalallisuudesta kehittyy yhä moninaisemmaksi; palvottavien

a Kowalewski 1844-1849, 1763. 
kohteiden määrä voi tällä luonnonuskontojen yleisellä tiellä helposti kasvaa lukemattomaksi. ${ }^{17}$ Mutta kyseessä ei ole niinkään lukemattomuus kuin sisäinen ykseys. Erillisten luonnonkohteiden palvominen, vaikka niiden lukumäärä olisikin loputon, ei sen vuoksi pysty täyttämään uskonnollista tarvetta. Ihminen alkaa hiljalleen aavistaa, että näissä hajanaisissa asioissa vaikuttaa yksi ja sama voima, että ne kaikki ovat samanlaatuisen jumalluonnon täyttämiä. ${ }^{18}$ Epäilemättä juuri tällainen käsitys saa samojedit toisinaan kutsumaan Aurinkoa, maata ja merta, kun tarkoitetaan niiden jumaluutta, yhdellä ja samalla nimityksellä, joka alun perin kuului 'taivaalle' tai 'taivaalliselle jumaluudelle'. Samalla perusteella mongolien sana tengri ja suomalaisten sana jumala, jotka alun perin merkitsivät 'taivasta' ja 'taivaan jumalaa', ovat jälkeenpäin saaneet abstraktin merkityksen 'jumala ylipäätään'. Mutta siitä lähtien kun sanaan jumala liitettiin viimeksi mainittu tarkoite, sen alkuperäinen, yksinkertainen tai konkreettinen merkitys on hiljalleen kadonnut ja uusi sana omaksuttu sen ilmaisemiseen. Taivaalle tämä sana on taivas ja taivaalliselle jumalalle Ukko.

\section{b) Ukko}

Edeltävässä kuvauksessani olen yrittänyt todentaa näkemykseni, että suomen kielen sana jumala ei alun perin ole ollut yleinen jumalepiteetti, vaan että sillä oli erityinen merkitys 'taivas' ja 'taivaan jumala'. Tämä sana sai, kuten olen yrittänyt yllä selittää, jo pakana-aikana abstraktin merkityksen 'jumalolento ylipäätään', jolloin suomalaiset omaksuivat sen sijalle sanan Ukko persoonalliseksi nimitykseksi taivaalliselle jumalalle. Lencqvist ${ }^{\mathrm{a}}$ esittää ajatuksen, että Ukko oli suomalaisten vanhin jumala, ja samaa näkemystä olen itsekin kehitellyt tarkastellessani sanan merkitystä. Sen perusteella, mitä sanan äänteellinen asu paljastaa, en voi kuitenkaan suoda sen merkitykselle 'taivaan jumala' kovinkaan korkeaa ikää. Kuten pian saamme nähdä, välittää sana $u k k o$ varsinaisen perusmerkityksensä kautta käsityksen persoonallisesta jumalasta. Tällainen käsitys jumaluudesta on kuitenkaan tuskin voinut olla minkään kansan parissa vanhin, ja erityisesti

Lencqvist 1782, 24. 
suomalaisten runoissa tavataan kaikkialla aiemmin vallinnutta luonnonvoimien palvontaa. Mikäli nimitys Ukko todella johtuisi kaukaisesta menneisyydestä, pitäisi sitä tavata myös useiden muiden suomalaisten sukukansojen parissa, kun taas siinä määrin kuin minä tiedän, kyseistä nimitystä tavataan jumalallisuuden merkityksessä Suomen rajojen ulkopuolella ainoastaan Virossa ja hiukan muuntuneessa muodossa myös Lapissa. Toisissa merkityksissä tämä sana on levinnyt varsin laajalle sukulaiskansojemme parissa. Sitä tavataan unkarissa muodossa agg, joka merkitsee 'vanhusta, vanhaa'. Ugrilaisten ostjakkien parissa sana kuuluu jig ja heidän kielessään sillä on merkitys 'isä, mutta sitä käytetään myös epiteettinä jumalana palvotulle karhulle. Jakuuttien kielessä on sukulaissana $a g a$, joka myös merkitsee 'isää. Toisissa itäturkkilaisissa kielissä ilmaistaan sanalla aga tai aka tiettyä, 'vanhemman veljen', 'sedän' tai 'enon', 'isoisän' tai 'vanhemman henkilön' käsitettä ylipäätään. Osmanit eivät tunne tätä sanan $a g a$ tai $a k a$ merkitystä, vaan käyttävät sitä korkea-arvoisten henkilöiden arvonimenä eritoten soturiluokan piirissä. ${ }^{a}$ Itäturkkilaisten ja mantšujen parissa annetaan sanalle agu, age merkitys 'herra.' Mongolin kielessä on myös sen sukuinen sana $a k a$, acha, joka Kowalewskin mukaan itse asiassa merkitsee 'vanhempaa veljeä', mutta jota käytetään myös 'vanhemmista mieshenkilöistä' ylipäätään, ja sitä paitsi sitä käytetään korkea-arvoisista henkilöistä: "Se on kunnioittava termi kuten ranskalaisten monsieur [herra].` ${ }^{19}$ Yhteys yllämainittujen kielten eri merkitysten välillä on helppo havaita. Perusmerkitykseltään sanalla on vanhempi käyttöyhteys miessukupuolen ilmaisemisessa: 'isoisä, 'isä, 'setä' ('eno') tai 'vanhempi veli. Tästä on kehittynyt sanan merkitys 'ikänsä tai ansioidensa vuoksi kunnioitettu mieshenkilö. Suomen sanalla $u k k o$ on nämä molemmat merkitykset, sillä se merkitsee: 1) 'isoisää, myös 'naitua miestä; 2) 'vanhaa miestä, vanhusta'.

Yllä esitetyt sanan varsinaisen merkityksen hahmotelmat johtavat väistämättä ajatukseen, että Ukko ei ole alun perin ollut persoonallinen jumalnimi vaan pelkästään kunnioittava epiteetti (une expression

a Schott 1849, 65.

b Schott 1849, 65.

c Kowalewski 1844-1849, 22. 
respecteuse [ransk.]) yhdelle tai useammalle mahtavalle jumaluudelle, aivan samalla tavalla kuin sen sukulaissanat turkin, mongolin ja mantšun kielissä ovat kunnioitettujen miesten arvostavia nimityksiä tai kuten ostjakkien sana jig ja jakuuttien äsä ('isänisä) liitetään kunnioittavana epiteettinä karhuun. ${ }^{a}$ Kunnioituksen osoittaminen jumalille tällä tavoin on pakanallisille kansoille hyvin tavallista. Niinpä ostjakkisamojedit liittävät Num-jumalaan usein epiteetin ildja tai ildša, jotka ovat molemmat merkitykseltään yhtäläisiä suomen $u$ kon kanssa. Ruotsalaiset, jotka tosin ovat tässä yhteydessä meille vähempimerkityksinen kansa, kutsuvat yhä tänä päivänä ukkosenjumalaa nimityksellä godgubben, gofar ['jumal-ukko', 'jumal-isä]. Latinan nimitys Jupiter merkitsee kirjaimellisesti 'isä jumalaa' ja saksan kielellä kutsutaan [kristinuskon] jumalaa toisinaan nimityksellä der alte Gott, der alte Vater. ${ }^{\mathrm{b}}$ Kristinopissakin käsitetään jumaluus 'isäksi', 'herraksi'.

Vanhoissa runoissamme kunnioitetaan useampaa kuin yhtä jumalvoimaa nimityksellä $u k k o$, mikä vahvistaa juuri esittämäni näkemyksen, että se oli alun perin vain jumalepiteetti. Tämä seikka ei ole välttynyt herkkävaistoisen Porthanin tarkkaavaisuudelta. Kun Lencqvist edellä mainitussa tutkielmassaan käsittää Ukon suomalaisten korkeimpana taivaallisena jumalana (totius auloe colestis senior et proeses [lat.]), hän esittää myös sivuhuomautuksen, että Porthan on asettanut tämän näkemyksen tiettyjen epäilysten alaiseksi. Näistä hän tuo esiin erikseen, että "nimitystä $u k k o$ voi käyttää appellatiivina, jonka voi kunnioituksesta liittää johonkin toiseenkin jumalaan (alii cuidam numini)". Kirjoittaja jatkaa:

Ja paitsi jumalia, kunnioitetaan myös muita kohteita (alice res) toisinaan nimityksellä $u k k o$, kun niille halutaan osoittaa kunnioitusta (venerationis quasi testandoe caussa). Mikäli halutaan esim. saada karhu itselle myötämieliseksi, sitä puhutellaan ystävällisin sanoin ja kutsutaan laulussa: ukkoiseni, linduiseni, kaunoiseni, kuldaiseni, so. '(rakas) ukkoni, pieni lintuni, minun kaunis, kultainen (ystäväni)'. Toisessa laulussa, jolla pyydetään suotuisaa jänisjahtia, ja on siis todennäköistä, että Tapiolta, vaikka tätä kutsutaankin ukoksi, kyseistä jumalaa puhutellaan seuraavasti:

a Samassa hengessä jakuutit nimittävät suurta virtaa tai merta äbäksi, joka varsinaisesti merkitsee 'äidinäitiä'. 
Anna ucko uuhiansi,

Anna oinahat omansi,

[...]

Ukko kullainen kuningas

Tuuvos ilman tuusimata,

Varomata vaaputtele. ${ }^{20}$

Vaikka nämä ja myös muut Porthanin samassa yhteydessä tekemät huomiot pitävätkin täysin paikkansa, ne ovat silti aivan liian puutteellisia johtamaan hänet selvään käsitykseen $u$ kon merkityksestä suomalaisessa mytologiassa. Nykyisin saatavilla olevien runsaampien runokokoelmien avulla meille on mahdollista päästä paremmin tämän merkityksen jäljille.

Muinaisista lauluistamme ilmenee varsin selvästi, että mahtavat jumalat eivät aiemmin mainitun mukaisesti majailleet kartanoissaan tai linnoissaan yksinään vaan että heillä oli ympärillään enemmän tai vähemmän lukuisa perhe. Tällaisen perheen jäsenten joukosta kutsutaan isäntää $u k o k s i$ ja emäntää akaksi. Ukkoa saatetaan jopa kutsua isännäksi, vanhimmaksi, taatoksi tai isäksi, toisinaan jopa kuninkaaksi, valtiaiseksi tai hallitsijaksi jne. Nimitys akka vaihtelee eukon kanssa merkityksessä 'kunnioitettava rouva' (matrona vetula [lat.], Renvall ${ }^{21}$ ) ja muita nimityksiä ovat emäntä, emo, emonen 'äiti'. Merenjumala Ahtia kutsutaan runoissa näin: veen ukko 'veden ukko', aaltojen kuningas, ja vedenjumalatar Vellamoa kutsutaan veen emännäksi 'veden emäntä. Metsänjumala Tapiota kutsutaan nimityksillä metsän ukko, Tapiolan ukko, kummun ukko, metsän kuningas, ja metsänjumalatar Tellervo tunnetaan nimellä metsän emäntä. Tuoni, kuoleman jumala, on nimeltään Tuonen tai Tuonelan ukko ja hänen vaimonsa Tuonen akka. Myös runoissa puhutaan peri-isännästä 'alkuisäntä' ('maan isäntä'), mannun eukosta 'maan emäntä, maan emosta, emosesta 'maan äiti' jne. Samalla tavalla kutsutaan taivaanjumalaa nimityksellä taivahan ukko, ilman ukko, taivon taatto tai taatto taivahinen 'taivaan isä, mies vanha taivahinen, ilman kultainen kuningas, hopeinen hallitsija, taatto taivon valtiainen jne. Kuten metsän ukko on epiteetti Tapiolle, veen ukko Ahdille, Tuonen ukko Tuonelle, vastaavasti käytettiin alun perin myös nimitystä taivahan ukko epiteettinä taivaanjumalalle eli Jumalalle. Kun sana jumala sai jälkikäteen laajemman merkityksen 
'jumala ylipäätään', alettiin sanaan $u k k o$ liittää taivaanjumalan persoonan merkitys. Ajateltiin varmaankin, että mahtavimpana kaikkien jumalten joukossa ennen muuta hän ansaitsi nimityksen Ukko, 'kaikkien ukkojen ukko'. Lencqvistin mukaan häntä tavataan joillakin paikoin kutsua isäiseksi, joka on sanan isä deminutiivi [hellittelymuoto]. Myös virossa Ukkoa kutsutaan tavallisesti nimityksellä Vanna issa tai Vanna taat 'vanha isä. Kukaan ei epäilisi, että nimityksiä isäinen, vanna issa ja vanna taat alun perin käytettiin epiteetteinä, ja tämä koskee luonnollisesti myös sanaa $u k k o$, sillä merkitykseltään se tuskin eroaa muista epiteeteistä.

Nimitystä $u k k o$ käytettiin alun perin pelkästään jumalten epiteettinä, ${ }^{22}$ minkä vahvistaa minun nähdäkseni sekin seikka, että taivaanjumalaa kutsutaan erittäin harvoin sillä tavoin runoissa ilman, että siihen liitettäisiin jokin toinen sana tai ilmaisu merkitsemään, että kyse on juuri taivaallisesta Ukosta. Häntä kutsutaan usein ylijumalaksi, taivahan jumalaksi ja ilmojen jumalaksi, toisinaan myös nimityksellä taivahan napanen, pilvien pitäjä tai hattarojen hallitsija, puhumattakaan monista muista nimityksistä, jotka on jo mainittu aiemmin. Näitä nimityksiä on epäilemättä alettu käyttää niin ahkerasti sen vuoksi, että sana $u k k o$ ei itse asiassa ollut erisnimi, ja siten sillä ei ollut 'taivaan jumalan' merkitystä. Runoissa tavataan tosin myös yksittäisiä kohtia, joissa $u k k o$ ilman kaikkia selventäviä epiteettejäkin viittaa 'taivaalliseen jumalaan', kuten esim. Kalevalassa (runo 18, säe 421): laske ukko uutta lunta; säe 425: laskip' ukko uutta lunta; runo 45, säe 237-: jos ei minusta miestä liene, urosta ukon pojassa, [...] Onp' on itsessä ukossa, joka pilviä pitävi; runo 47, säe 46: ukon ilman istuimilla; säe 50: ikävä itsen ukonki, jne. Saamme seuraavassa nähdä, että nimitystä Ukko käytetään myös erisnimenä merkitsemään 'ukkosen jumalaa. Tämä sama persoonakäsitys ilmenee myös tietyissä yleisissä ilmauksissa, esim. ukon kaari, so. 'sateenkaari'; ukon kivi, ukon pii, so. 'piikivi'; ukon tuhnio 'maamuna, Lycoperdon bovista'; ukon lehti, ukon lummet 'rentukka, Caltha palustris'.

Pyrittyäni selvittämään edellä niitä eri merkityksiä, joita sanalla $u k k o$ on suomalaisissa runoissa, aion nyt lähemmin selvittää niitä käsityksiä, joita muinaissuomalaisilla oli tämän sanan merkityksestä 
tietyn jumalolennon erisnimenä. Olen jo aiemmin maininnut, että Ukkoa pidettiin 'taivaan, avaruuden, ilmanalan valtiaana' ja että sellaisena häneen liitettiin epiteetit: taivahan jumala, taivon taatto, taivahan ukko, ylijumala, ilmojen jumala, ilman kuningas, mies taivahinen ym. Hänellä uskottiin olevan istuin pilven päällä, minkä vuoksi häntä kutsuttiin nimityksellä pilven päällinen jumala. Hän oleili pääasiassa keskellä taivasta, ja tästä johtuen häntä kutsutaan lempeästi taivaan navaksi (taivahan napanen). Ilmeisesti on myös ajateltu, että hän jollain tavalla kannatteli taivaanpalloa, sillä häntä kutsutaan runoissa usein nimityksellä ilman kaiken kannattaja. Oletettavasti hänen uskottiin lepäävän avaruudessa taivaankappaleena ja kannattelevan voimakkailla harteillaan koko taivaankantta. Tämä käsitys ei kuitenkaan sitonut häntä tiukasti, vaan hänen ajateltiin voivan liikkua avaruudessa kuten tahtoi. Niinpä lausutaan Kalevalassa (runo 47, säe 59-), että hän vaelsi horisontissa pilven reunaa myöten etsimässä Aurinkoa ja Kuuta, jotka Pohjolan emäntä oli piilottanut vuoren sisään. Hänen sanotaan myös pukeutuvan sinisiin sukkiin ja kirjaviin kenkiin (sukassa sinertävässä, kirjavassa kaplukassa). Hän esiintyy kaikin puolin hyvin varustautuneena ja aseistautuneena miehenä. Hänen sanotaan pukeutuvan tuliseen (tulenloistavaan) paitaan. Sateenkaari on hänen taistelujousensa ja sitä kutsutaan, kuten on jo mainittu, ukon kaareksi. Tällä hän ampuu nuoliaan, jotka ovat vaskea ja joita jousen tavoin kutsutaan tulisiksi. Hänen miekkanaan on salama. Sitä kutsutaan runoissa nimityksillä tulinen miekka, miekka tuliteräinen, säkehinen säilä. Hänen aseisiinsa kuuluu myös vasara (kurikka), joka muistuttaa skandinaavisesta mytologiasta tuttua Thorin vasaraa. ${ }^{23}$

Useimpien muiden suomalaisten jumalten tavoin Ukolla ei näytä olleen asuntoa, ja runot eivät mainitse mitään täsmällistä hänen perheestään. Aiemmat mytologit kertovat, että hänellä on ollut akkan$s a$, jota piispa Agricola nimittää Rauniksi ja jota karjalaisten heimon sanotaan palvoneen ukkosenjumalattarena: Qvin rauni ukon naini härsky, Jalosti ukoi pohjasti pärsky, so. 'kun Rauni, ukon vaimo, jyrisi, jyrisi voimalla myös ukko', kuuluu Agricolan tunnettu runo muinaissuomalaisten epäjumalista. Kuten Lencqvist huomauttaa, ei Raunia koskaan mainita muinaisrunoissamme, ja siksi nimen autenttisuutta 
on epäilty. Toisaalta tietyt muutkin Agricolan luettelemista jumalannimistä ovat tuntemattomia sekä lauluista että taruista ${ }^{24}$, ja osa niistä jopa sotii suomen kielen äännelakeja vastaan, kuten esim. Kratti, Rongoteus, Egres ym. Mutta vaikka nimi Rauni olisikin epäsuomalainen, näyttää olevan syytä yhtyä Gananderiin siinä, että Ukolla oli puoliso nimeltään Akka (myös Akko). Tämä nimitys vaihtelee paikoin Ämmän kanssa kuten Ukko Äijän kanssa. Todisteena tämän jumaluuden olemassaolosta Ganander esittää runofragmentin, jossa mehiläistä kehotetaan pistämään siipensä vanhan akan pieneen koriin (Akan vanhan vakkaseen) ja tuomaan sieltä hunajaa. Tulemme näkemään heti seuraavassa, että monet joet, järvet, kosket jne. oli pyhitetty Akalle eli Ämmälle ja kantavat hänen nimeään yhä tänä päivänä. Sen sijaan sen puolesta, että hän olisi ollut Ukon puoliso, pystyn pelkästään vetoamaan Lapissa ja Suomessa tavattuun traditioon, jonka mukaan Ukko ja Akka muodostavat tosiaan jumalparin. En voi tyystin vaieten ohittaa kysymystä siitä, onko heillä lapsia samalla tavoin kuin monilla muilla suomalaisten jumalilla ja jumalattarilla, sillä Ukon poika mainitaan usein runoissa. Muun muassa Grimm on käsittänyt tämän ilmaisun kirjaimellisessa merkityksessään. ${ }^{25}$ Minusta näyttäisi siltä, kuin nimitys Ukon poika olisi kuvaannollinen ilmaus, jota käytettiin mahtavista yksilöistä, lähinnä noidista, joita samassa merkityksessä nimitetään usein jumaliksi tai maa-jumaliksi. Tämän olen päätellyt siitä, että mainittuja ilmaisuja käytetään vain, kun sairauksia, pahoja henkiä tai vihamielisiä voimia manataan ja kun halutaan peitota vastustaja siten, että hänen annetaan ymmärtää taistelevansa mahtavia voimia vastaan ja toimivan järkevimmin myöntämällä ajoissa hävinneensä. "Mutta", noita esittää, "jollei minussa ole miestä, Ukon pojassa urhoa ajamaan sinua tiehesi, haen tukea muilta voimilta, kuten Ukko ja Lempo, jotka löylyttävät sinut kunnolla.” Noita näyttää kutsuvan itseään Ukon pojaksi pelkästään herättääkseen pelkoa vastustajassaan. Tämän ilmauksen kuvaannollisuus näkyy myös siinä, että Kalevalan

a Finn Magnusen väittää, eikä aivan perusteitta, että Rauni, ainakin nimen ulkoasun perusteella, on sama jumalolento kuin edda-opin Rán, joka islanniksi lausutaan [raun]. Magnusen 1824-1826: IV, 247. [Toim. huom. islannin pitkä a (á) alettiin lausua diftongimuodossa [au] vasta keskiajalla, n. 13501550 jaa., jolloin Rauni olisi omaksuttu Suomessa ainakin tässä muodossa lainanimityksenä aikaisintaan tuolloin.] 
vanhassa editiossa (runo 10, säe 238) Vipunen kutsuu itseään Ukon pojaksi, kun taas heti seuraavassa kutsuu Ukkoa nimityksellä veikko, joka merkitsee 'veljeä ja toveria, ystävää ja jota ei voi liittää epiteettinä isään. Myös Väinämöinen käyttää itsestään Uudessa Kalevalassa (runo 45, säe 238) nimitystä Ukon poika, vaikka tämän runoteoksen ensimmäisessä runossa sanotaankin, että hänen vanhempansa olivat tuuli ja Ilmatar-neito. Kalevalan vanhemmassa laitoksessa (runo 4, säe 257) kehuskelee myös aivan tavallinen noita olevansa Ukon poika. On selvää, että ilmaisu Ukon poika merkitsee kaikissa mainituissa paikoissa ainoastaan mahtavaa noitaa, mutta minusta on epäselvää, miksi vastenmielisellä meripeikko Tursolla, jonka Väinämöinen manaa olemaan koskaan nostamatta päätään pinnan yläpuolelle (Kalevala, runo 42, säe 450-), on epiteetti äiön (äijön) poika. Kenties muinaissuomalaiset palvoivat nimellä Äiö jumaluutta, joka erosi Ukosta, mutta tähän eivät runot anna minkäänlaista valaistusta. Ukon perheestä voidaan vielä ohimennen mainita, että hänen sanotaan luoneen naispuolisia jumaluuksia, joita nimitetään luonnottariksi ja jotka käsitetään runoissa Ukon auliiksi apuhengiksi. Heidän esittelynsä jätän toiseen yhteyteen.

Syy siihen, että muinaisrunomme ylipäätään käsittelevät vain vähän Ukko-jumalan perheoloja, on varmastikin se, että hänellä ajatellaan olevan tärkeämpääkin huolehdittavaa kuin kotipiirinsä pulmat. Taivaan mahtava jumala esitettiin tavanomaisten puuhien yläpuolella: kaiken, mihin hän ryhtyi, tuli olla suurta ja epätavallista. Yksi hänen tärkeimpiä tehtäviään oli määrätä pilvien kulusta, mistä johtuvat hänen runoissa loputtomiin toistuvat epiteettinsä pilvien pitäjä ja hattarojen hallitsia. Muinaissuomalaisten käsityksen mukaan oli suuri ja mahtava ominaisuus kyetä alistamaan valtaansa ilmassa kelluvat pilvet, joilla on niin suuri vaikutus niin merimiehen, metsästäjän kuin viljelijän pyrintöihin. Kiinalaisten annalistit kertovat, että hiongnu-kansan šamaaneilla oli kyky hallita pilviä ja saada ne lähettämään lunta, rakeita, sadetta ja hurjia myrskytuulia. Suunnilleen samoin kerrotaan skandinaavisissa saagoissa omista esi-isistämme. Mutta jos tarkastelemme runoja, ne eivät myönnä tätä kykyä kellekään muulle kuin jumalista mahtavimmalle. Itse Väinämöinen ei kykene omin voimin saamaan aikaan sadetta kylvökselleen, vaan kutsuu sitä varten Ukon apuun, lausuen: 
Oi ukko ylijumala, Tahi taatto taivahinen, Vallan pilvissä pitäjä, Hattarojen hallitsia! Piä pilvissä keräjät, Säkehissä neuvot selvät, Iätä iästä pilvi, Nosta lonka luotehesta, Toiset lännestä lähetä, Etelästä ennättele, Vihmo vettä taivosesta, Mettä pilvistä pirota Orahille nouseville, Touoille tohiseville!

(Kalevala, runo 2, säkeet 317-330.)

Samaten täytyy Ilmarisen turvautua Ukkoon ja pyytää häneltä lunta valmistautuessaan kosiomatkalle Pohjolaan, mitä varten tarvitsee talvikelit (Kalevala, runo 18, säkeet 421-424). Ilmarinen kääntyy toisenkin kerran Ukon puoleen pyytäen tätä tuomaan yhteen pilvet idästä ja lännestä, jotta saisi niistä satavan jään ja lumen rohdoksi palovammaan (Kalevala, runo 48, säe 356-). Kun Lemminkäinen näkee Pohjolan väen seuraavan häntä ja kokee vaaran olevan käsillä, hän muuntautuu kotkaksi ja nousee ilmaan. Auringonsäteet polttavat hänen poskiaan, jolloin hän kutsuu Ukkoa tuomaan pilvisen sään ja lähettämään pienen pilven, jonka varjossa hän voisi palata äitinsä luokse (Kalevala, runo 28, säkeet 37-46).

Yrittäessään pyydystää Hiiden nopean hevosen Lemminkäinen kääntyy Ukon puoleen uudelleen rukoillen, että vanha mahtaja avaisi taivaan ikkunat ja laskisi niistä rautaisia rakeita ja jäätä hidastamaan pakenevaa hevosta (Kalevala, runo 14, säe 304-). Tämäntyyppisiä rukouksia tavataan runoissa lukuisia, mutta ohittaen kaikki muut haluan liittää tähän yhden, jossa Pohjolan emäntä pyytää Ukolta myrskyä ja rajuilmaa. Se tavataan Kalevalan runossa 42, säkeet 358366, ja kuuluu seuraavasti:

Oi ukko ylijumala, Ilman kultainen kuningas, Hopeinen hallitsia! 
Rakenna rajuinen ilma,

Nosta suuri säien voima,

Luo tuuli, lähetä aalto

Aivan vastahan venettä,

Jott’ei päästä Wäinämöisen,

Kulkea Uvantolaisen.

Taivaan ja ilman hallitsijana ukon on luonnollisesti myös määrättävä salamoita ja ukkosta, ja juuri näissä ilmiöissähän hänen koettiin käyttävän mahtavimpia kykyjään. Olen edellisessä ilmaissut oletuksen, että kenties juuri ukkonen herätti luonnonihmisessä ensimmäiset ajatukset jumaluuksista. Minusta on sitäkin todennäköisempää, että tämä pätee myös esi-isiimme, kun suomalaisten vanhimman jumalan nimitys Jumala merkitsee 'ukkosen jylinää. Ukko eli ukkonen (ukon deminutiivi) merkitsee nykyäänkin vallitsevassa kielenkäytössä ukkosta ilmiönä, mistä näkee varsin selvästi, että myös Ukko, joksi Jumala myöhemmin nimettiin, merkitsi sanana pääasiassa 'ukkosenjumalaa'. ${ }^{26}$ Tällaisen merkityksen synty edellyttää välttämättä Ukon palvontaa ukkosenjumalana. Tässä ominaisuudessa häntä kutsutaan runoissa nimityksillä pauannet 'jyrisijä, remupilven reunahinen ja jymypilvien pitäjä. Salamoiden herrana hänelle ei ole annettu tietääkseni erityistä epiteettiä, ellei pitkäiselläa mahdollisesti ole tätä merkitystä. ${ }^{27}$ Tämä osoittaa selvästi, että Ukon persoonassa palvottiin pikemmin ukonilman kuin salamoiden jumalaa. Kotimaiset lähteemme eivät kerro tyhjentävästi, millä tavoin Ukko sai aikaan ukonilman, sillä ilmaukset kuten ukko tai ukkonen pauhaa, jyskyy; ukon tai ukkosen jylinä, jyrinä eivät tämän suhteen kerro mitään. Läheisten heimosukulaistemme virolaisten parissa viitataan ukkosen jyrinään ilmaisulla Vanna issa hüab, mürrisep 'vanha isä huutaa, murisee', joka selvästi osoittaa, että ukkosen jylyn käsitettiin aiheutuvan Ukon mahtavasta huudosta. Siihen suuntaan viittaavat Kalevalassa myös hänen epiteettinsä: puhki pilven puhuja, halki ilman haastelia. Salamoiden uskottiin leimahtelevan, kun Ukko heilautti hohtavaa miekkaansa

a Pitkäinen on deminutiivi sanasta pitkä ja sen käsitetään viittaavan ukon pitkään, suureen kokoon. Mahdollisesti tämä epiteetti merkitsi myös maahan iskevän salaman pitkänomaista välähdystä. 
ilmassa tai kun hän iski tulta taivaallisessa asunnossaan, kun siellä oli liian pimeää. Tästä johtuu suomen kielessä yhä tänä päivänä käypä ilmaus ukko iskee tulta, valkiata 'salamoi' (vrt. Kalevala, runo 47, säe 67-). On merkillepantavaa, että runoissa Ukon ei koskaan esitetä aiheuttavan ukonilmaa. Syy tähän löytyy varmastikin tavattomasta pelosta, jota tämä ilmiö aiheutti - tämä pelko elää joissakin paikoin Suomessa yhä niin vahvana, ettei ukonilmalla uskalleta mainita Ukon nimeä eikä päästää huulilta kirousta tai muuta varomatonta sanaa, ja vielä vähemmän rohjetaan millään sopimattomalla teolla suututtaa Ukkoa. ${ }^{a}$ Selvästikin sekä suomalaiset että heidän heimosukulaisensa ovat pitäneet mitä sopimattomimpana toimintana kirouksin yrittää taltuttaa ukkosta, ja vastaavasti näyttää varotun millään mahdollisella tavalla aiheuttamasta tätä kauhistuttavaa luonnonilmiötä, sillä omasta syyllisyydestään tietoisen ei uskottu olevan turvassa sen tuhoisalta vaikutukselta. Salamoita pidettiin paljon vähemmän pelottavina, ja siksi Ukkoa pyydetään toisinaan kiiruhtamaan hädänalaisen avuksi taistelemaan vihamielisiä voimia vastaan tuliteräisine miekkoineen. Avuntarvitsija rukoilee usein tätä miekkaa käyttöönsä peitotakseen sillä kaikki vitsaukset, kaikki vihamieliset olennot. Niinpä esim. Lemminkäinen lausuu Kalevalassa (runo 12, säe 279-):

Oi ukko ylijumala,

Taatto vanha taivahinen,

Puhki pilvien puhuja,

Halki ilman haastelia!

Tuo mulle tulinen miekka

Tulisen tupen sisässä,

Jolla haittoja hajotan,

Jolla riitsin rikkehiä,

Kaa'an maalliset katehet,

Ve'elliset velhot voitan

Etiseltä ilmaltani,

Takaiselta puoleltani,

Päältä pääni, viereltäni,

Kupehelta kummaltani jne.

a Tässä voisi ohimennen mainita, että hiongnu-kansan parissa vaatteiden ja muiden esineiden pyyhkimisen katsottiin kuuluvan toimiin, jotka eivät miellyttäneet ukkosenjumalaa vaan joihin hän vastasi jyrinällä ja salamoin. 
Myös Väinämöinen rukoilee Ukolta hänen tulenhohtoista miekkaansa karkottaakseen sillä kaikki inhottavat sairaudet, jotka Louhi, Pohjolan emäntä, on synnyttänyt ja lähettänyt tuhoamaan Kalevan kansan (Kalevala, runo 45, säe 253-). Yhtä lailla Kullervo pyytää Ukkojumalan parasta miekkaa, jonka hän saakin ja jota hän käyttelee sillä tuloksella, että koko Untamon joukko joutuu hänen iskujensa uhreiksi. ${ }^{28}$

Jyrinän ja salamoiden lisäksi kuului koko ukkosen ilmiöön kreikkalaisten ja roomalaisten käsityksen mukaan vielä kolmaskin teki-

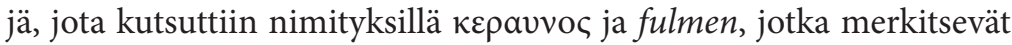
'salamaniskua maahan'. Eri kansat käsittävät tämän valojuovan joko teräväksi nuoleksi tai kiilanmuotoiseksi kiveksi, kirveeksi, vasaraksi jne. Kuten jo aiemmin mainitsin, puhutaan myös suomalaisten parissa ukon tulisista vaskinuolista, ukon kivistä, ukon vasarasta. Näiden aseiden ja työkalujen joukossa ovat ilmeisesti nuolet eli vaajat erityisen pelättyjä. Mikäli viholliselle toivottiin turmiota, pyydettiin Ukkoa toisinaan ottamaan jousensa, asettamaan siihen vaskinuoli ja ampumaan vihollinen hengiltä. Tätä rukoilee Ilmarin emäntä Kalevalassa (runo 33, säkeet 264-276) seuraavin sanoin:

Oi ukko ylijumala!

Jou'uttele jousi suuri,

Katso kaaresi parahin,

Pane vaskinen vasama

Tuon tulisen jousen pällle,

Työnnytä tulinen nuoli,

Ammu vaskinen vasama,

Ammu kautta kainaloien,

Halki hartio-lihojen,

Kaa’a tuo Kalervon poika,

Ammu kurja kuoliaksi

Nuolella teräsnenällä,

Vasamalla vaskisella.

Suunnilleen samalta kuulostavan rukouksen lähettää myöhemmin myös Kalervon poika Ilmarin emäntää vastaan. Ukon kiviä ei mainita runoissa, ja myös hänen vasaransa (kultainen kurikka) tavataan mainittuna vain yhdessä ainoassa rukouksessa, jossa Tuonelan paha 
tytär kutsuu Ukkoa raivaamaan tällä aseella tietä niille vaivoille, jotka hän on aikomuksissa synnyttää maailmaan (Kalevala, runo 45, säkeet 139-146). Ukon tulista paitaa tai turkkia käsitellään ainoastaan Kalevalan runossa 43 (säe 197-), jossa Ilmarinen anoo tätä varustetta suojautuakseen taistelussa Pohjolan emäntää vastaan. Mainittujen vaatekappaleiden esittely on epäilyksettä lainattu tulenväriseltä, punahehkuiselta pilveltä, jota kutsutaan Ukon paidaksi tai turkiksi, sillä ukkonen tapaa piiloutua ja ikään kuin kietoutua sellaiseen pilveen. Samaan perustuu Ukolle toisinaan annettu epiteetti poutapilvessä asuva.

Salamoiden hallitsijana Ukolla oli luonnollisesti valtaa tuleen. Kun kerran tapahtui niin, että Louhi varasti tulen, Ukko loi uuden tulen lyömällä tuliteräistä miekkaansa napaansa vasten. Tähän aiheeseen palaan myöhemmin, ja haluan tässä mainita pelkästään, että Ukko on yhdistetty tulimiekkaan, tulijouseen, tulinuoleen, tulipaitaan jne. nimenomaan tulen herrana.

Koska Ukko määräsi säitä ja tuulta, sadetta, lunta, rakeita ym., hänellä oli Kudortša Juman eli tšeremissien ukkosenjumalan sekä virolaisten Ukon lailla mahtava vaikutusvalta maaperään ja erityisesti sen kasvillisuuteen. Olemme jo edellä nähneet, kuinka Väinämöinen, kylvettyään pellon, kääntyy Ukon puoleen rukoillen taivaallista jumalaa herättämään sateen avulla kasvun hänen kylvetyillä saroillaan. Agricola kertoo paljon käsitellyssä runossaan, että vuotuisen sadon katsottiin olevan juuri Ukon käsissä: Se sis (siis) annoi ilman ja wden (vuoden) tulon, so. 'hän antoi siis (suotuisan) ilman ja (hyvän) sadon', kuuluu runo. Tämän johdosta järjestivät entisaikojen suomalaiset kevätkylvön aikaan Ukon kunniaksi juhlan, jossa juotiin Ukolle malja: Ja qvin (kuin) keväkyluö kyluettin, Silloin Ukon malja juottiin, so. 'ja kun kevätkylvö kylvettiin, juotiin Ukon malja', sanotaan samassa runossa. Yhä edelleen elää joissakin paikoin muisto tästä juhlasta, jota aion myöhemmin tarkemmin kuvailla. Tässä yhteydessä mainittakoon pelkästään, että tässä tilaisuudessa asetettiin tiettyjä ruokalajeja ja muita lahjoja korkeille kallioille ja harjuille, jotka oli pyhitetty Ukolle. Kenties juuri tämän johdosta eräät kalliot Suomessa kantavat nimeä Ukonvaara.

Ukon mahtia pidettiin niin kaikenkattavana, että toisinaan se ulottui jopa veteen. Tämä mahti ei näy pelkästään siinä, että Ukko lähettää 
sateen taivaalta ja että tuulten hallitsijana hän kykenee sekä nostamaan että tyynnyttämään tuulen, vaan myös muissa töissä, jotka ovat kauempana hänen luontevista toimistaan. Lemminkäinen kutsuu häntä Kalevalassa (runo 40, säe 77-) nimityksellä Ukko taivahan jumala ohjaamaan tuliteräisellä miekallaan veneen pois kuohuvasta vesiputouksesta. Samassa tilanteessa kutsutaan myös Akkaa nimityksellä aaltojen alainen kohoamaan vedestä ja työntämään käsillään kuohuvat aallot veneen alta. Ukon eli Äijän sekä Akan (Akko) eli Ämmän uskottiin olevan jossain suhteessa veteen, minkä todistavat lukuisat näistä sanoista lainatut nimitykset järville, koskille, lahdille ym., kuten Akonjärvi, Akka (järvi), Akon koski, Ämmä (koski), Äijän paikka (suuri vesiputous), Akonlahti, Ämmän lahti jne. ${ }^{29}$ Suomen kielessä on ilmaukset ukon virta, joka merkitsee veden kulkua myötävirtaan, ja ämmän virta [akanvirta], jolla nimitetään veden kulkua vastavirtaan. Näistä nimityksistä on olemassa kertomus, jonka mukaan jokainen joki oli alun perin luotu niin, että vesi kulki toisella puolella myötävirtaan ja toisella vastavirtaan, mutta paha, joka on pilannut niin paljon muutakin maailmassa, antoi ihmisten kiusaksi joille niiden nykyisen suunnan.

Koska muinaissuomalaiset palvoivat Ukkoa mahtavimpana jumalana, hänen apuunsa vedotaan runoissa alituiseen, usein sellaisissakin tilanteissa, joissa hän ei näyttäisi olevan oikea auttaja. Olen jo yllä maininnut, että hänen tukeensa vedotaan joitakin kertoja synnytyksessä. Tätä ei toki tapahdu koskaan tavallisissa tilanteissa, vaan kun lapsenpäästö on vaikeammasta päästä ja vaatii mahtavampaa avustajaa, kuten Ilmattaren synnyttäessä seitsemänsataavuotiasta Väinämöistä ja Tuonelan tyttären aikoessa tuoda maailmaan yhdeksän mitä pahinta vitsausta. Yhtä lailla häntä kutsutaan pysäyttämään verenvuoto, kun Väinämöinen satuttaa itseään niin pahasti jalkaan, että kuohuvaa verivirtaa ei saada tyrehtymään tavallisin keinoin. Lemminkäinen kääntyy Ukon puoleen rukoillen hyviä, kevyitä suksia, joiden avulla kykenisi pyytämään Hiiden nopean hirven (Kalevala, runo 14, säe 13-). Ilmarin emäntä kutsuu häntä muun muassa Kalevalassa (runo 32, säe 441-) suojelemaan asuntoaan suurelta ja mahtavalta karhulta, mikä kuuluisi itse asiassa metsänjumalan toimiin. Edellä kerrotun perusteella on nähtävissä, että Gananderin sanoista löytyy tietty totuus, kun hän lausuu Ukosta näin: "Häneen yhdistettiin 
monia ominaisuuksia ja tehtäviä. Häntä kutsuttiin kaikkiin yrityksiin ja pelättiin ikänsä ja mahtinsa vuoksi." Ganander tarkoittaa, että Ukkoa kutsuttiin epätavallisen suuren valtansa vuoksi avuksi kaikkiin mahdollisiin tilanteisiin, myös sellaisiin, joissa hän astui toisten jumalten toimialueelle.

Lähes kaikki, mitä olen yllä kertonut suomalaisten Ukosta, koskee myös virolaisilta tuttua hahmoa, jota kutsutaan erilaisilla nimityksillä kuten Vanna issa, Vanna taat, Tara, Ukko. Myös hän hallitsi pääasiallisesti taivaallisia seutuja ja piti vallassaan ukkosta ja salamoita, pilviä ja tuulia, sadetta, lunta sekä pilvistä ja kirkasta säätä. ${ }^{a}$ Vastaavasti hänen uskottiin jahtaavan pahoja vaivanhenkiä ja murskaavan ne salamoil-

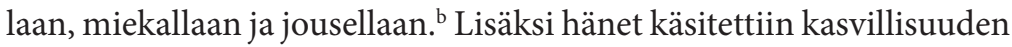
edistäjäksi, ja tässä ominaisuudessa häntä kunnioitettiin kevään alussa samanlaisilla juhlilla kuin suomalaista Ukkoa. Eräässä Gutslaffin 1644 muistiinpanemassa rukouksessa häntä kutsutaan nimellä Picker (Picken) seuraavalla tavalla:

Rakas Picker (woda Picker), uhraamme sinulle härän, jolla on molemmat sarvet ja neljä sorkkaa, ja pyydämme sinulta kyntömme ja kylvömme vuoksi, että halmeestamme tulee kuparinpunainen ja siemenistämme kultaisia. Lähetä muualle kaikki mustat, paksut pilvet, aja ne tiehensä yli suurten soiden, korkeiden metsien ja laajojen korpien. Anna kynnöllemme ja kylvöllemme kaunis ilma ja hunajanpehmeää sadetta. Pyhä Picken, suojele peltojamme niin, että niissä on kauniit korret alla, hyvät akanat pälllä ja hyvät jyvät sisällä.

On helppo huomata, että tässä runossa on läheistä vastaavuutta suomalaisten Ukolle suuntaamien rukousten kanssa, vaikka hän esiintyykin tässä epätavallisella nimellä Picker tai Picken. Tämän nimityksen on täytynyt johtua sanasta Pikkene, joka ilmenee viron kielessä myös muodossa Pitkne ja joka vastaa suomalaisten sanaa pitkäinen, joka puolestaan on yksi Ukon monista epiteeteistä. Olisi helppoa osoittaa monia muitakin vastaavuuksia suomalaisten ja virolaisten käsi-

a Kreutzwald 1850, 45.

b Ganander 1821 [toim. Kristjan Jaak Petersen], 17. 
tyksissä Ukosta, mutta koska niiden esittely johtaisi vain jo todetun toistamiseen, en halua enää pidempään pysytellä tässä aiheessa. Tässä yhteydessä riittäköön mainita ohimennen molempien kansojen käsitysten erilaisuudesta, että Ukko esiintyy virolaisessa mytologiassa nimellä Vanna issa tai Vanna taat maailman tekijänä ja luojana, mikä ei suomalaisessa mytologiassa ole asian laita.

Muinaisten lappalaisten parissa Ukko tunnettiin yleisimmin nimellä Aija tai Aije, Aijeke (deminutiivi sanasta aije), joka vastaa suomen Äijää ja merkitsee varsinaisesti 'isoisää, myös 'ukkosta', kuten Jupiterista muistuttavissa ilmaisuissa aija jutsa tai klibma 'ukkostaa.' Tämä nimitys muuntuu joissakin paikoin muotoon atzhie, attje, jonka perusmerkitys 'isä' vastaa Ukon suomenkielistä epiteettiä isä ja vironkielistä nimitystä Vanna issa tai Vanna taat. Norjan Finnmarkissa hänet tavataan nimellä Radien-attje, so. 'määräävä, hallitseva, mahtava isä; mutta tämä nimitys ei voi olla alkuperäinen, sillä radien on selvästi lainasana, joka vastaa ruotsin sanaa råd, tanskan sanaa raad jne. ${ }^{\mathrm{b}}$ Joidenkin aiempien kirjoittajien tulosten mukaan tätä jumaluutta on voitu aiemmin kutsua nimityksellä Tiermes tai Diermes, Djermes. Siitä, että tätä niin monilla eri nimillä kutsuttua jumalolentoa palvottiin samassa ominaisuudessa kuin suomalaisten ja virolaisten Ukkoa, löytyy lukuisasti todisteita Schefferukselta, Gananderilta, Högströmiltä ja monilta muilta kirjoittajilta. Ganander esittää, että Tiermes on "lappalainen ylijumala", joka hallitsee tuulia, merta ja vettä ja joka määrää ukkosta ja jyrinää samaten kuin "ihmisten terveyttä, elämää ja

b "Tästä Radien-Atzhiesta", sanoo Jessen-Schardebøll teoksessaan Afhandlungen om de Norske Finners og Lappers hedenske religion $(1767,11)$ : "uskoivat lappalaiset, että hän hallitsi vähenemättömällä mahdilla ja vaikutusvallalla sekä taivasta että maata, kaikkia muita jumalia sekä itse lappalaisia siinä kuin kaikkea muutakin maan päällä. Siksi he ovat antaneet hänelle nimen Radien, joka merkitsee mahtia ja valtaa." Kuten itse nimitys, on myös käsitys tämän jumaluuden ominaisuuksista yhtäläinen jesseniläisen käsityksen kanssa myöhäisestä, kristillisestä alkuperästä. Hän käsittää Radien-Atzhien kaikkivoipana jumalana, maailman luojana ja ylläpitäjänä, liittää häneen "ainoan pojan" Radien-Kiedde tai Rarara Kied, joka konkreettisesti esiintyy vapahtajana, ja käsittelee myös joitakin hänen alaisiaan, joita kutsutaan nimityksellä Ailekes-olmak tai helgon (sanoista ailek, joka vastaa sanaa 'pyhä', [kuten] muinaisnorjan heilagr, ja olmak 'olento') ym. 
kuolemaa". ${ }^{a}$ Vastaavasti Samuel Rheen kertoo, että tämän saman Tiermesin, jota myös kutsutaan nimityksellä Thor tai Thordoen, lappalaiset käsittivät "eläväksi olennoksi, joka jyrisee taivaassa" ja jolla "on valta ihmisten terveydestä ja hyvinvoinnista, elämästä ja kuolemasta". Hänen tehtävänsä, sanoo Rheen, on "tappaa ja surmata kaikki peikot", ja hän lisää: "Sateenkaarta he kutsuvat Thorin jouseksi, jolla hän ampuu ja surmaa kaikki peikot, jotka aikovat aiheuttaa heille jotain vahinkoa." Schefferus mainitsee, että tämän saman jumaluuden uskottiin pitävän hallussaan vasaraa, Aijeke vuetšera nimeltään, jolla hänen uskottiin lyövän peikkoja ja murskaavan heidän päänsä. Lindahl ja Öhrling antavat Aijasta seuraavan kuvauksen:

Lappalaiset olivat aikoinaan vakuuttuneita siitä, että ukkonen (aija) oli elävä olento, joka majaili ilmassa ja teki tiettyjä toimia ihmisten lukuun. Jos he sanoivat hänestä jotakin pahaa tai loukkasivat häntä tavalla tai toisella, hän ei koskaan jättänyt rankaisematta heidän rikkeitään. [...] Oli myös lappalaisia, jotka uskoivat, että ukkonen oli jumala, joka jahtasi taivaassa peikkoa karkottaakseen sen ja samalla aiheutti jyrinän käyttämillään kanuunoilla. ${ }^{c}$

Vastaavasi Högström kertoo, että Aijeke on ukkosenjumala, "jonka päällimmäinen ja varsinainen tavoite on tappaa ja tuhota kaikki Peikot ja kummitukset [...], minkä hän heidän (lappalaisten) mielestään tekee jousellaan, sateenkaarella, jota he kutsuvat nimityksellä Ajanjoksa." Kuten vasta siteeratut eri kirjoittajien lausumat osoittavat, lappalaiset palvoivat taivaan ja erityisesti ukkosenjumalaa nimityksellä Aija tai Tiermes. Schefferus mainitsee, ${ }^{\mathrm{d}}$ että Aijaa palvottiin nimityksellä Tiermes vain ukkosenjumalan ominaisuudessa (Qui cum tonat, est Tiermes [lat.]). Myös Leem näyttää olleen suunnilleen samaa mieltä, sillä hän kääntää sanan Diermes 'ukkoseksi' (tonitru [lat.]). Sitä vastoin Ganander käsittää tämän sanan laajemmassa merkityksessä 'taivaan jumalaksi', ja myös Högström esittää, että Schefferuksen Tiermes on sama, "jota lappalaiset muutoin kutsuvat nimityksellä

\footnotetext{
Ganander 1789, 90.

Schefferus 1673, 95, 96.

Lindahl \& Öhrling 1780, 4.

Schefferus 1673, 95, 96.
} 
aijeke (aja, atja)". ' Vaikka sana Tiermes ei ole koskaan osunut korvaani Lapissa, en epäile vähimmässäkään määrin yhtyä Högströmin näkemykseen, koska taivaan ja ukkosen jumala käsitetään lähes kaikkien sukulaiskansojemme parissa yhdeksi ja samaksi hahmoksi, yhdeksi ja samaksi olennoksi. Sitä paitsi mainittujen kansojen parissa on sellaisia, joilla on tälle olennolle tiettyjä korvinkuultavasti Tiermesin (kannasta Tierm tai Dierm, Djerm) sukuisia nimityksiä. Ugrilaisten ostjakkien parissa sana Tūrm (Tōrm, Tōrom) merkitsee 'taivaan, ukkosen jumalaa' ja laajemmassa merkityksessä 'koko maailman jumalaa' samalla tavoin kuin Num samojedien ja Jumala suomalaisten parissa. Sama merkitys on tšuvassin kielen sanalla Tora, ja on jo tullut mainittua, että viron kielen Tara on Ukon kanssa synonyyminen sana. Näyttäisi siltä, että Tiermes, Turm, Tora ja Tara edellänimettyjen kansojen parissa ovat henkilönnimiä taivaalliselle jumalalle, sillä mitään appellatiivista merkitystä tälle sanakannalle ei voi niiden kielissä osoittaa. Näin ollen on taivaallisella jumalalla täytynyt lappalaisten ja virolaisten parissa olla kaksi henkilönnimeä: Jubmel (Ibmel) ja Tiermes sekä Jummal ja Tara. En näe tätä miltään osin epätodennäköisenä, vaan pidän päinvastoin varsin uskottavana, että nimitykset Tara ja Tiermes korvasivat nimitykset Jummal ja Jubmel, minkä jälkeen nämä kadottivat alkuperäisen merkityksensä 'taivaan jumala'. Kysymykseen siitä, ovatko sanat Tara, Tiermes jne. todella kotoperäisiä vai indogermaanisista kielistä lainattuja nimityksiä, en tässä yhteydessä usko kykeneväni vastaamaan. ${ }^{30}$

\section{c) Päivä, Kuu, Otava, Tähti ja muita ilman jumaluuksia}

Vaikka muinaissuomalaiset palvoivat Ukkoa taivaanjumalana (taivahan jumala), hänen vaikutuksensa ulottui laajalle taivaallisten piirien ulkopuolelle, mutta toisaalta näiden piirien sisäpuolella oli yhtä ja toista, mikä ei kuulunut hänen välittömään valtaansa. Ukon käsitettiin taivaanjumalan ominaisuudessa hallitsevan pilviä ja tuulia, salamoita ja jyrinää, sadetta, lunta ja rakeita ym. Sitä vastoin Auringon, Kuun, tähtien ja monien muiden taivaallisten ilmiöiden ei nähty olleen

a Högström 1747, 177. 
riippuvaisia hänen tahdostaan vaan olleen omien erityisten jumaluuksiensa alaisuudessa. Monet näistä esiintyvät vähäisinä ja merkityksettöminä olentoina, mutta ne ovat silti kukin paikallaan itsenäisiä mahteja. Yksittäiset jumaluudet eivät ole suomalaisessa mytologiassa ylipäätäänkään riippuvaisia toisistaan, vaan vähäisinkin jumala toimii piirissään itsenäisenä, riippumattomana voimana tai, puhuaksemme runojen hengessä, itsellisenä isäntänä samalla tavoin kuin kreikkalaisessa ja roomalaisessa mytologiassa. Kuten kuolevaisten parissa, myös jumalten keskuudessa on yksi isäntä rikas ja mahtava, laajan omaisuuden, suuren karjan ja lukuisten palvelijoiden ja palvelijattarien haltija, kun taas toisen omaisuus käsittää vain pienen alueen ja joko merkityksettömän perheen tai ei perhettä lainkaan. Molemmat ovat silti omalla tontillaan, omalla kartanollaan yhtäläisen itsellisiä isäntiä. Tähden jumaluus liikuttaa pelkästään täysin merkityksetöntä täplää avaruudessa, mutta tällä täplällä hän on joka tapauksessa oma herransa ja isäntänsä.

Olen jo aiemmin maininnut, että tämä käsitys jumalista on harvinainen sukulaiskansojemme parissa ja että näillä ei ylipäätään ole persoonallisia jumalia, vaan että he alemman kulttuuritasonsa mukaisesti palvovat luonnonkohteita sellaisina, kuin ne näyttäytyvät ulkoisessa olemuksessaan. Mutta vaikka käsitykset jumalten luonteesta ovat erilaisia, itse palvonnan kohteet ovat pohjimmiltaan samoja. Ainakin Aurinkoa, Kuuta ja tähtiä palvotaan muodossa tai toisessa kaikkien kyseisten kansojen parissa. Niinpä mongolien parissa, jotka suurelta osin ovat buddhismin kannattajia, tavataan yksittäisiä heimoja, jotka yhä tänä päivänä harjoittavat tällaista palvontaa, mistä myös keskiaikaiset lähetyssaarnaajat osaavat kertoa. He [mongolit] osoittavat pääasiallisesti suurta kunnioitusta Aurinkoa kohtaan, ja olen joitakin kertoja nähnyt heidän šamaaniensa kutsuvan tätä jumaluutta ja samalla heittävän maitoa ilmaan uhriksi sille. Georgi ${ }^{a}$ kertoo, että tunguusit palvovat niin Aurinkoa (Delatša tai Tirgani), Kuuta (Bega) kuin tähtiäkin (Ositka), mutta että he kunnioittavat Aurinkoa eniten ja yhdistävät sen itse Bugaan. Heillä on jopa tapana tehdä tästä jumalolennosta kuva, joka esittää pitkänomaisia 
ihmiskasvoja ja jonka he lahjoittavat Auringolle, kun taas Kuuta he kuvaavat puoliympyrällä ja tähtiä täplillä. Myös monet Etelä-Siperian paimentolaistataarikansoista palvovat kyseisiä jumaluuksia ja kuvaavat mielellään Auringon ja Kuun noitarumpuihinsa ${ }^{31}$ pyöreinä hahmoina. Georgi ${ }^{a}$ kertoo, että yksi näistä kansoista, nimeltään karagassit, palvoo yhtäläisesti niin Aurinkoa kuin koko maanpiiriä ja uhraa ensiksi mainitulle karhun tai hirven pään ja sydämen (Rothwild [saks. 'saksanhirvi']). Auringonpalvontaan liittyy myös se, että työskentely auringonlaskun jälkeen ei näytä olevan sallittua pakanallisten tataarien parissa. Kiinalaisista lähteistä löytyy tieto, että ainakin Auringon ja Kuun palvonta on ollut vallitsevaa myös hiongnu-kansan parissa, sillä niissä mainitaan, että hiongnu-päällikkö, tšenju, tapasi lähteä kahdesti päivässä teltastaan (kenttäleiristään) palvoakseen aamulla Aurinkoa ja illalla Kuuta. Sama palvontamerkitys on aiemmin mainitulla samojedien tavalla uhrata yksinomaan Auringolle, joka heillä tunguusien tavoin sekoittuu Numiin tai Jilibeambaertjeen. Ostjakit, vogulit ja muut suomalaiset kansat, jotka ovat säilyttäneet muinaisuudestaan joitakin muistoja, osoittavat suurta kunnioitusta Auringolle, Kuulle ja tähdille. Näiden kansojen joukosta eivät myöskään vogulit näytä tekevän jyrkkää eroa Auringon ja taivaanjumala Toromin välille, sillä Georgin mukaan he selittävät, että Aurinko on Toromin asuinpaikka. ${ }^{\mathrm{b}}$ Lappalaisista tiedetään, että he muinoin pitivät Aurinkoa (bøivve) mahtavana jumaluutena ja sukulaiskansojensa tavoin tapasivat kuvata sen noitarumpuihinsa. Kuva esitti neliötä, jonka jokaisesta kulmasta lähti tie tai ohjas, jota kutsuttiin nimityksellä brivve labikie. JessenSchardebøll sanoo, että näillä teillä haluttiin "kuvata, että Auringon vaikutus ja voima ulottuu ylitse koko maailman"c

Useimpien juuri käsiteltyjen kansojen lailla myös suomalaiset ja virolaiset ovat varhemmalla ajalla epäilyksettä palvoneet Aurinkoa, Kuuta ja muita taivaankappaleita niiden ulkoisessa, materiaalisessa olemuksessa. Myös käytettävissämme olevissa runoissa ne sekoittuvat usein keskenään, ja juuri mainitusta syystä Auringon, Kuun ja tähtien jumaluuksilla on samat nimet kuin materiaalisilla kohteilla. Niinpä

\footnotetext{
Georgi 1776-1780, 291, 292

Georgi 1776-1780, 69.

Jessen-Schardebøll 1767, 12, § 4.
} 
merkitsee kuu (deminutiivi kuuhut) 'kuuta' ja 'kuun jumalaa', päivä (demin. päivyt, viro pävä) 'aurinkoa' ja 'auringon jumalaa', otava 'Otavaa' ja 'Otavan jumalaa', tähti (viro tähte) 'tähteä' ja 'tähden jumalaa'. Jumalten ominaisuudessa ne käsitetään ihmismäisiksi olennoiksi, ja eräässä laulussa kerrotaankin matkasta, jonka Aurinko, Kuu ja Pohjantähti tekevät maan päälle tavoitteenaan hankkia sieltä puoliso. Tämän kosiomatkan kohteena on Kantelettaren ${ }^{32}$ (III: 1) mukaan kaunis, hanhenmunasta syntynyt neito nimeltään Suometar. Kyseisestä laulusta on runsaasti variantteja, joita tavataan sekä suomalaisten että virolaisten parista. Kalevalassa (runo 11) kerrotaan, että kauniin neidon nimi on Kyllikki, ja että Aurinko, Kuu ja Tähti pyytävät hänen kättään, eivät itselleen, vaan pojilleen. Virolaisessa laulussa neitoa kutsutaan nimellä Salme, kun taas kosijat ovat Auringon, Kuun ja Tähden poikia, joista kukin saapuu viidelläkymmenellä hevosella ja kuudellakymmenellä vaunulla. Kaikki nämä variantit pitävät toistensa kanssa yhtä siinä, että Auringosta ja Kuusta tulleet kosijat saavat kieltävän vastauksen kosintaansa, kun taas Tähdestä tulleen kosijan tavataan esittää saavan tytön suosion. "Kuulle", hän lausuu Kantelettaressa, "en tahdo tulla, sillä hänellä on outo, moninaiseksi muuttuva ulkomuoto. Välillä hän on kapea, sitten taas leveä kasvoiltaan. Öisin se ruoja on liikkeellä, päivisin hän lepää, ja hänen kartanonsa ei tällä tavoin tule koskaan menestymään.” Auringolle hän taas antaa seuraavan vastauksen: "En halua mennä Auringolle, koska hänellä on huonoja tapoja. Kesällä hän kiusaa kuumuudella, talvella kylmyydellä. Parhaaseen heinäntekoaikaan hän antaa odottamatta sateen, ja kun kaura alkaa kypsyä, hän lähettää loputtoman kuivuuden.” Tähden kosintaan hän vastaan tällä tavoin: "Voin hyvin tulla tähdelle, sillä hänellä on hyvät tavat. Hän on aina kunnollisesti kartanollaan ja säntillinen kotonaan Otavan olkapäillä ja Seulasten selässä.” Kalevalasta löytyvän variantin mukaan myös Tähti saa rukkaset, koska tytöstä ei olisi hauskaa yöt läpeensä loistaa täplänä (pilkkiä) talvitaivaalla. ${ }^{33}$

Vaikka tämä kosintayritys päättyi onnettomasti ainakin Auringolle ja Kuulle, näyttävät muinaissuomalaiset silti ajatelleen, että kaikilla kyseisillä jumaluuksilla, myös Otavalla, oli kullakin puolisonsa. Ainakin niillä kaikilla sanotaan olevan tytär, ja kuten näimme, uskottiin Auringolla, Kuulla ja Tähdellä olevan kullakin poika. Heistä Kuun ja Tähden pojat tavataan tosin ainoastaan juuri lainatussa runossa, kun 
taas Auringon pojasta (päivän poika) puhutaan myös muissa lauluissa. Ilmaisu päivän poika ei tosin näytä aina merkitsevän 'auringonjumalan poikaa', vaan se käsitetään paikoin samanmerkityksiseksi kuin Pohjan poika tai Pohjolan isäntä (vrt. Kalevala, runo 17, säkeet 575, 650, ja Topelius [1822-1831, I], s. 14, 16). Päivän pojan alkuperäinen merkitys 'auringon poika' ilmenee runosta, joka käsittelee Väinämöisen pyytämää haukea, joka on niellyt taivaasta pudonneen tulikipunan. Väinämöinen ei uskalla avata haukea paljain käsin, mutta siinä samassa saapuu Päivän poika ja selittää olevansa valmis tähän tehtävään, kunhan vain saa haltuunsa isänsä (Auringon) veitsen. Hädin tuskin hän on tämän lausunut, kun kultakahvainen ja hopeateräinen veitsi kierii Kuusta ja antaa hänelle mahdollisuuden toteuttaa toiveensa (vrt. Kalevala, runo 48, säe 207-). Syy siihen, että Auringon poika uskalsi käydä tulen kimppuun niin pelottomasti, on luonnollisesti se, että alkuperänsä puolesta hän kuului taivaankappaleelle, jonka käsitettiin koostuvan tulesta ja liekeistä. Kuinka hän voisikaan hehkuvan Auringon asukkina pelätä pienen tulikipunan käsittelyä? Kalevalan vanhemmassa laitoksessa (runo 26, säe 356-) Päivän poika tarjoutuu olemaan Väinämöiselle avuksi myös, kun edellä mainittu hauki pitää ajaa nuottaan, mutta Uudessa Kalevalassa tämän tehtävän hoitaa "pieni mies merestä". ${ }^{4}$

Niin kutsutusta Päivän pojasta tulee erottaa Auringon toinen poika, joka on tulenjumala ja jota nimitetään Panuksi erotuksena materiaalisesta tulesta, jota nimitetään tuleksi. Tämä ero tavataan usein jättää huomiotta, ja sanaa panu käytetään myös merkitsemään itse materiaalista tulta. Yllä esitetty ero sanojen merkityksessä on kuitenkin toisinaan merkitsevä, mistä todistaa seuraava rukous Kalevalan vanhassa laitoksessa (runo 26, säkeet 431-441):

Panu poika aurinkoisen,

Armas auringon sikiä!

Tuli nosta taivosehen,

Kehän kultasen keselle,

Vahan vaskisen sisälle,

Kun kuki emonsa luoksi,

Luoksi valtavanhempansa.

Pane päivät paistamahan,

Yöt laita lepeämähän,

Aamulla ylenemähän,

Illalla alenemahan. 
Tämä kohta paljastaa myös sen, että muinaissuomalaiset käsittivät Auringon koostuvan jollain tapaa kahlitusta tulimassasta ja että maallisen tulen uskottiin olevan peräisin Auringosta eli runon sanoin Aurinkoemon lapsi. ${ }^{35}$ Kun näin ollen Aurinko ja tuli ovat pohjimmiltaan yksi ja sama asia, on selvää, että tulen palvonnan on täytynyt liittyä auringonpalvontaan esi-isiemme parissa, ja että Panua ei voitu palvoa itsenäisenä jumalvoimanaan vaan pelkästään Auringon poikana. En osaa varmuudella sanoa, onko tilanne ollut sama muiden sukulaiskansojemme keskuudessa, mutta varmaa on, että he ovat Auringon ohella palvoneet myös tulta. Yhä tänä päivänä uhraavat monet tunguusi-, mongoli- ja turkkilaiskansat tulelle, ja niiden keskuudessa on yksittäisiä heimoja, jotka eivät koskaan uskalla nielaista lihaa, elleivät ole sitä ennen heittäneet palaa nuotioon. Schmidtin ${ }^{a}$ mukaan tuli nauttii mongolien keskuudessa niin suurta arvostusta, että maanomistaja säännöllisesti omistaa sille syksyisin uhraus- ja pyhityspäivän, ja jokainen mongoli pitää tulen sammuttamista vedellä, siihen sylkemistä tai sen saastuttamista millään tavoin suurena syntinä. Georgi kertoo, että jokaiseen uhriin, jonka tunguusit osoittavat tulelle, suhtautuvat muutkin jumalat yhtä suopeasti kuin uhri olisi osoitettu niille itsel-

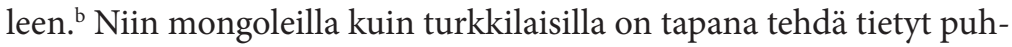
distustoimet tulella. Tämä tapa on vallinnut muinaisista ajoista asti, sillä Theophylactus Simocatta kertoo, että turkkilaiset kuljettivat lähettiläs Justinus Zemarchusta roihuavien liekkien ympärillä puhdistaakseen hänet sillä tavoin. Vastaava tapa oli Plano Carpinin mukaan myös mongoleilla, mutta sillä erotuksella, että lähettilästä kuljetettiin edestakaisin kahden tulen välillä. Mongoleilla on vanhoina aikoina ollut lisäksi tapana puhdistaa tulella edesmenneiden ihmisten omaiset ja kumppanit samaten kuin kaikki sellaiset henkilöt, joihin oli iskenyt salama, kuin myös kaikki, jotka asuivat samassa teltassa näiden kanssa. Nykyaikana joutuvat lähinnä naiset tietyissä oloissa käymään läpi kyseisen puhdistusprosessin. Se on käytössä muun muassa samojedien parissa ja toteutetaan sytyttämällä tukko poronkarvoja ja savustamalla sillä saastunut kohde. ${ }^{36}$ Kaikki tämäntyyppiset seremoniat

\footnotetext{
Schmidt 1824, 147.

b Georgi 1775, 276.
} 
perustuvat siihen, että tulta palvotaan pyhällä kunnioituksella, ja tästä periytyy sekä suomalaisilla että monilla muilla kansoilla käytössä oleva tapa sytyttää tietyissä juhlatilanteissa suuria tulia, jotka Suomessa tunnetaan nimityksillä hela-valkiat, kokko-valkiat ym.

Kyseisiin jumalperheisiin kuuluvat myös Auringon tytär Päivätär eli Päivän tytär, Kuun tytär Kuutar, Otavan tytär Otavatar ja tähden tytär Tähetär. Näistä Päivätärtä ja Kuutarta käsitellään runoissa usein, kun taas Otavatar ja Tähetär mainitaan harvemmin. Kaikki kuvataan nuoriksi ja kauniiksi, kudonnassa huomattavan taitaviksi neidoiksi. Korostaakseen vielä enemmän heidän sädehtivää hehkuaan tapaa suomalainen laulunjumalatar esittää heidät istumassa kutomustensa äärellä punareunaisen pilven tai värikkään sateenkaaren reunalla, toisinaan varjoisan lehtimetsän laidalla. Käsitys heidän kudontataidoistaan perustuu selvästi samankaltaisuuteen Auringon, Kuun ja tähtien säteiden ja kangaspuiden loimen välillä. Kutomisen jumalattarena Päivätär nimetään toisinaan runoissa kirjokynneksi. Tämä epiteetti muistuttaa Auringon monenkirjavia säteitä. Päivätär on tämän lisäksi myös kehräämisen mestari, sillä Kalevalassa (runo 24, säe 81-) sanotaan, että eräs kutomus on kaunis kuin olisi Kuun kutoma ja Auringon kehräämä. Gananderin mukaan Kuuttarella ja varsinkin Päivättärellä oli myös eräitä muita tehtäviä huolehdittavanaan, mutta niihin palaamme myöhemmin.

Tietyt kohdat runoissamme paljastavat, että Auringossa, Kuussa ja tähdissä majailevilla jumalolennoilla ajateltiin olevan useimpien muiden jumalten tavoin omat kartanonsa. Otavan kartanosta ei puhuta millään erityisellä nimellä, mutta Auringon kartanoa nimitetään Päiväläksi, Kuun Kuutolaksi ja tähden Tähteläksi (Kalevala, runo 11, säkeet 32, 36, 40). Nämä kartanot ja niillä olevat asunnot kuvataan tavallisesti erikoisen kauniiksi ja loisteliaiksi. Kun kaunis Suometar-neito torjuu yhden toisensa jälkeen kolme kosijaansa Auringon, Kuun ja Tähden, nämä taivuttelevat häntä jättämään kotinsa asuakseen heidän luonaan hopeatuvissa ja kulta-asunnoissa (Kanteletar III: 1). Neito hyväksyy, kuten näimme, Tähden kosinnan, sillä hän pitää parhaana yhtä lailla Tähteä itseään kuin myös hänen kartanoaan. Tulee kenties huomauttaa, että Tähdellä tarkoitetaan tässä variantissa itse asiassa Pohjantähteä, jota muinaissuomalaiset pitivät helmenä tähtien joukossa ja joka näyttää saaneen osakseen suurempaa palvontaa kuin 
useimmat muut. Muissa varianteissa ei osoiteta mitään tiettyä tähteä vaan puhutaan pelkästään tähdestä ylipäätään, mikä tuntuu osoittavan, että minkä tähden hyvänsä koettiin voivan edustaa jumalallista persoonallisuutta.

Topeliuksen runokokoelmassa olevat ilmaukset Päivilä tuo ilman ukko ja Päiviläinen ilman ukko johtavat minut toiseen huomioon koskien Auringon kartanoa. ${ }^{a}$ Yhteys osoittaa, että Päivilällä on sama merkitys kuin Pohjolalla, mutta minusta näyttää lisäksi siltä, kuin Päivilä ja Päivälä olisivat alkujaan vain varioivia muotoja samasta sanasta. Tämän näkemyksen puolesta puhuu se jo aiemmin mainittu seikka, että niin Pohjolan isäntää kuin myös Auringon poikaa nimitetään usein Päivän pojaksi. Kun tämän lisäksi Päivilää eli Päiviläistä kutsutaan nimityksellä ilman $u k k o$, vaikuttaa runo viittaavan siihen, että Pohjola ja Päivilä olisivat sama kartano kuin Päivälä ja että Auringon asukkaat olisivat samoja kuin Pohjan kartanon. Tämä sekoittuminen voi varmaankin perustua johonkin satunnaiseen väärinkäsitykseen, mutta kun otetaan tarkastelun kohteeksi se monitasoinen yhteys, joka on Pohjolan kansan ja varsinkin sen emännän ja Auringon välillä, jonkinlaisen yhteyden myöntäminen Pohjolan ja Päivälän välille vaikuttaa vääjäämättömältä. Olen tässä kuitenkin halunnut vain ohimennen tuoda esiin sellaisen yhteyden mahdollisuuden, ja pidättäydyn lähemmin kehittelemästä tätä aihetta.

Suomalaiset palvoivat kaikkia tässä käsiteltyjä jumaluuksia pääasiassa lempeinä, hyväntahtoisina olentoina, joita kutsuttiin usein antamaan kuolevaisille tukeaan. Erityisesti valollaan maailmaa valaisevan olemuksensa vuoksi he nauttivat rakastavaa palvontaa ja päätyivät usein ihmisten rukousten kohteiksi. Itse Väinämöinen kutsuu niin Aurinkoa, Kuuta kuin Otavaakin päästämään hänet lopultakin valoon kohdusta, jossa on maannut kolmekymmentä talvea ja yhtä monta kesää. Jacob Grimm mainitsee kuvaavasti, että yhtä lailla mongoli- kuin germaanikansatkin tapasivat muinoin esittää Auringolle, Kuulle ja tähdille kysymyksiä salatuista asioista. ${ }^{\mathrm{b}}$ Sama tapa vallitsi myös slaavilaisten kansojen keskuudessa, ja runomme osoittavat, ettei

\footnotetext{
a Aurinko vaihtuu tässä ukoksi, kuten tunguuseilla, samojedeilla, voguleilla ym.

b Grimm 1844, 670.
} 
se ollut tuntematon myöskään suomalaisille. Kun Lemminkäisen äiti etsii kadonnutta poikaansa, hän kysyy sekä Kuulta että Auringolta, ovatko ne huomanneet hänen "kultaista omenaansa", hänen "hopeista sauvaansa”. Kuu antaa tähän kysymykseen epätyydyttävän vastauksen, kun taas Aurinko antaa hänelle huolellisen kuvauksen rakastetun pojan olinpaikasta (Kalevala, runo 15, säe 161-). Samalla tavoin ja samoin tuloksin kysyy myös Neitsyt Maria Auringolta ja Kuulta kadonneesta Kristus-lapsestaan (Kalevala, runo 50, säe 373-). Syy näihin tiedusteluihin ei voi olla mikään muu kuin että niiden jumaluuksien, jotka hallitsivat Aurinkoa, Kuuta ja tähtiä, nähtiin pitävän valoa vallassaan ja kykenevän sen avulla tutkimaan sitä, mikä oli kätketty ihmisen heikolta katseelta.

On mitä todennäköisintä, että suomalaiset palvoivat auringonjumalaa hänen lämmittävän ominaisuutensa vuoksi ylipäätään ja erityisesti hänen tuottavan, maata hedelmöittävän luontonsa vuoksi. Runomme eivät tosin anna tästä näkökulmasta tyydyttävää todistusta. Tunnen yhden ainoan rukouksen, jossa auringonjumalalta anotaan lämpöä, ja syy tähän on aivan omanlaisensa. Lemminkäisen äiti haluaa haravoida Tuonen virtaan levinneitä surmatun poikansa kappaleita, mutta pelosta, että Tuonelan väki ei mielellään näkisi tätä toimintaa alueellaan, hän rukoilee Aurinkoa nukuttamaan koko Tuonen kansan kuumilla säteillään. Aurinko toteuttaa auliisti hänen rukouksensa, ja runo lausuu tästä:

Tuo päivyt jumalan luoma,

Luoma luojan aurinkoinen,

Lenti päätönnä kanana,

Siipipuonna siuotteli;

Lenti koivun konkelolle,

Lepän lengolle lehahti,

Paisti hetken heltehestä,

Toisen himmestä hiosti,

Kolmannen koko terältä;

Nukutteli nuivan kansan,

Väsytti väen Manalan.

[...]

Siitä lenti leuhautti

Entisellensä sialle, 
Paikallensa muinoselle,

Tasaselle taivahalle.

(Vanha Kalevala, runo 8, säe 191-)

Päivä eli auringonjumala sai osakseen rakkaudentäyteistä palvontaa lempeänä ja hyvää tekevänä olentona, mutta hänellä katsottiin olevan myös tiettyjä vähemmän erinomaisia ominaisuuksia. Kuten yllä näimme, Suometar-neito lukee niihin hänen tapansa tuoda sadetta ja pilvistä säätä sekä kuihduttavaa hellettä ja ankaraa kylmyyttä. Hänen hohtonsa tuskin himmenee näiden tahrojen vuoksi, sillä kaikki suloisin, paras ja kaunein, mitä maailmassa on, kuului esi-isiemme mielestä Auringolle, Kuulle ja tähdille. Itse asiassa juuri Suometar-neidon ihailtu kauneus saa joko heidät itsensä tai heidän poikansa kosimaan häntä. Voisiko pohjoisen synkän taivaan alla elävä ihminen nähdäkään Aurinkoa, valkeaa Kuuta ja tuikkivia tähtiä muunlaisina kuin kauniina, lempeinä ja rakastettavina olentoina? Toisten kansojen parissa ne esiintyvät toisinaan armottomina, ihmisille vahingollisina voimina, mutta tällainen käsitys on luultavasti peräisin maista, joiden taivas lepää kuumana maan päällä, ja sen sijaan että herättäisi eloon, [se] usein tukahduttaa kaiken sietämättömällä lämmöllään.

Muinaissuomalaiset palvoivat ja rukoilivat jokaisesta jumalperheestä etupäässä isäntää. Emäntä oli arvoltaan heti seuraavana, ja häneenkin vedottiin usein, mutta poikien ja tyttärien puoleen käännyttiin rukouksin harvoin. Päivättäreen, Kuuttareen ja Otavattareen ja erityisesti kahteen ensiksi mainittuun vedotaan tietyissä poikkeuksellisissa tilanteissa silti. Eräässä Gananderin esittelemässä runofragmentissa vedotaan Otavattareen, että hän palauttaisi jotakin varastettua tai kadotettua ("omoani ottamahan, kadonnutta kaihtemahan"). Joukahaisen äiti kertoo Kalevalassa (runo 4, säe 137-), kuinka hän vielä naimattomana oli rukoillut Päivätärtä ja Kuutarta, että ne lahjoittaisivat hänelle hopeansa ja kultansa; ja lempeinä luonteeltaan ne olivatkin antaneet tälle köyhälle tytölle kuusi kultaista vyötä, seitsemän sinistä paitaa ja muita kauniita koruja. Gananderin mukaan Päivätärtä ja Kuutarta rukoiltiin myös suojelemaan ampiaisenpistoilta. Sama kirjoittaja esittää, että suomalaiset palvoivat Päivätärtä olentona, joka "pelasti Auringon ja Kuun pimeydestä, jonka ilkeä Kuumet aiheutti". 
Suomalaisilla ja muilla heidän sukulaiskansoillaan ei näytä olevan yhteisiä traditioita koskien kuun- tai auringonpimennyksiä eikä useimmilla ole kertoa niistä mitään. Kansoista, joilla on edes jonkinlaisia käsityksiä mainituista ilmiöistä, ansaitsevat erityisesti mongolit tulla mainituiksi. Erään heidän keskuudessaan kulkevan kertomuksen mukaan jumalat haluavat rangaista Arachoa eräistä hänen pahoista teoistaan, mutta tämä on ymmärtänyt piiloutua kostonhaluisilta voimilta niin hyvin, ettei yksikään niistä saa selville hänen pakopaikkaansa. Sitä kysellään myös Auringolta, joka ei pysty antamaan tyydyttävää vastausta. Pahantekijän olinpaikka löytyy lopulta Kuun avulla, ja Aracho kärsii hyvin ansaitsemansa rangaistuksen. Mutta kostaakseen puolestaan Auringolle ja Kuulle hän jahtaa näitä taivaankappaleita alati vielä nykyisinkin, ja kun hän pääsee käsirysyyn jommankumman kanssa, tapahtuu auringon- tai kuunpimennys. Mongolit tapaavat tällöin nostaa kovan metakan musikaalisin instrumentein ja muin rämisevin välinein tarkoituksenaan pelastaa Aurinko ja Kuu hädästään. Aracho häiriintyykin lopulta ja jättää vihollisensa rauhaan.

Suomalaisten käsityksissä auringon- ja kuunpimennykset näyttävät merkinneen, että pahat voimat vievät nämä taivaankappaleet paikoiltaan ja sulkevat ne jonkinlaiseen vankilaan. Niinpä Kalevalassa (runo 47, säe 21-) kerrotaan, että Louhi, Pohjolan emäntä, ollessaan kerran väkevästi vihastunut Kalevan miehiin, yrittää vahingoittaa heitä piilottamalla Auringon ja Kuun vaskivuoreen, minkä vuoksi koko taivas pimenee. Toisessa, Gananderin ${ }^{a}$ siteeraamassa runossa, pelkästään tässä yhteydessä mainittu Kuumet ${ }^{\mathrm{b}}$ vangitsee Auringon ja Kuun rauta-aitaukseen. Kave vapauttaa ne lopulta sieltä, ja tästä lausutaan: "Päästi päivän paistamahan, päästi kuun kumottamahan." Tätä vastoin Agricola kertoo traditiosta, jonka mukaan kapeet (kave-sanan monikko) eivät olleet kovinkaan hyväntahtoisia Kuuta kohtaan. Kuun vähenemisen ja lopullisen katoamisen uskottiin nimittäin johtuvan siitä, että kerta toisensa jälkeen kapeet syövät sen. On mahdollista, että Agricolan väite kapeista, kuten Ganander järkeenkäyvästi esittää, johtuu jostakin väärinkäsityksestä. Käsityksellä Kuun syömisestä on

b Agricolan mukaan hämäläiset ajattelivat, että kuunpimennykset johtuivat jumaluudesta, jota kutsuttiin nimellä Rahkoi. 
kuitenkin epäilyksettä pohja traditiossa, mikä ilmenee yhä tänä päivänä käytössä olevasta ilmauksesta kuu syödään, so. 'kuu vähenee'. Jonkinlainen analogia tälle löytyy myös saksalaisesta ja skandinaavisesta mytologiasta, sillä niissä puhutaan jättiläisten sukuisesta sudesta nimeltä Mánagarmr, jonka uskotaan jahtaavan Kuuta ja lopulta nielevän sen. ${ }^{\text {a; } 37}$

Näiden Aurinkoa, Kuuta ja tähtiä koskevien pohdintojen jälkeen haluan esittää joitakin huomioita tietyistä muistakin ilman piiriin kuuluvista jumaluuksista. Niihin lukeutuu ennen muuta Koi, joka sanana merkitsee yhtä lailla 'aamuruskoa' kuin 'aamuruskon säteissä ilmentyvää jumaluutta'. Se, että Koi varsinaisesti merkitsee persoonallista jumalaa, näkyy selvimmin siihen liitetyssä epiteetissä jumala, joka tavataan Kalevalassa (runo 17, säe 478). Runomme eivät anna minkäänlaista selvyyttä siihen, millainen käsitys suomalaisilla ylipäätään oli tästä jumaluudesta. Erityisen valaiseva ei ole myöskään naapuriheimomme [virolaisten] parissa tavattava kertomus, jonka henkilöhahmot ovat Koit (aamurusko) ja Ämarik (iltarusko). Tässä kertomuksessa esitetään Aurinko lyhtynä, jonka Koit sytyttää aamuisin ja Ämarik sammuttaa iltaisin. He työskentelevät Vanna issalle, joka palkkiona heidän uskollisesta palveluksestaan haluaa tehdä heistä miehen ja vaimon. He haluavat itse mieluummin olla sulhanen ja morsian, mihin vanha isä suostuukin. Hän sallii heidän tavata toisensa kesäisin neljän viikon ajan keskiyöllä ja nauttia ihanasta morsiusonnesta. Tänä aikana Ämarik jättää sammuvan lyhdyn välittömästi Koitille, joka herättää liekin hengityksellään. Tätä seuraa "kädenpuristus ja suudelma, ja Ämarikin posket punoittavat ja heijastavat taivaan purppuraa". Vaikka tämä kertomus onkin sekä muodoltaan että sisällöltään äärettömän kaunis, siinä on nykyisessä muodossaan selviä jälkiä uudemmasta kulttuurista. Käsitystä Koitista ja Ämarikista taivaallisina jumaluuksina on kuitenkin pidettävä siinä epäilyksettä alkuperäisenä.

Näihin jumaluuksiin on sisällytettävä runoissamme esiintyvät ilman luonnottaret tai ilman impyet ihanat. Heitä näyttää olleen luku-

b Kellgren et al. 1847, 15-. 
määrältään kolme, ja Kalevalassa (runo 9, säe 39-) kerrotaan, että Ukko loi heidät hieromalla molempia käsiään vasenta polveaan vasten. Runossa kerrotaan, että hän loi heidät raudan äideiksi. He synnyttivät raudan kulkemalla pilven laidalla ja antamalla maidon valua turvonneista rinnoistaan maahan. Yhdellä neidoista sanotaan olleen mustaa, toisella valkoista ja kolmannella punaista maitoa. Näistä kolmesta maitolajista saatiin sittemmin kolmea erilaatuista rautaa. Yhdellä ilmassa majailevista luonnottarista on erisnimenä Ilmatar. Sanan etymologia viittaa siihen, että hän ei kuulunut niiden kolmen luonnottaren joukkoon, jotka Ukko loi polvestaan, vaan oli ilman tytär, ilman tyttö, kuten häntä runoissa vaihtelevin nimityksin kutsutaan. Ilmatar ei itse tunnusta syntyneensä ilmasta, vaan väittää (Kalevala, runo 47, säe 154-) olevansa naisista vanhin, äideistä ensimmäinen (ensin emä itselöitä). Myös ilman sanotaan olevan ensimmäinen ja vanhin kaikista äideistä (ilma on emoja ensin, Kalevala, runo 9, säe 29). Näin ollen näyttää siltä, että Ilma ja Ilmatar ovat pelkästään yhden ja saman henkilön, yhden ja saman luonnottaren eri nimiä. Sana ilma merkitsee varsinaisesti 'konkreettista ilmaa', mutta suomalaiset palvoivatkin alun perin juuri sitä jumaluutena kuten samojedit ja useat muut heidän sukulaiskansansa. Myöhemmin suomalaiset alkoivat käsittää ylemmän ilman pelkästään siellä asustavan naispuolisen jumalallisen olennon ilmentymänä, ja silloin sai ilma sukupuolta osoittavan päätteensä ${ }^{38}$-tar (-tär). Tämä pääte ei näin ollen merkitse tässä, kuten muuallakaan, tytärtä vaan naispuolista olentoa ylipäätään. Ilmatar ei näytä olevan itsenäinen, ilmaa hallitseva jumalatar, vaan Ukon palvelijatar, mikäli ei ole yksi hänen juuri esitellyistä tyttäristään. Hänen riippuvaisuutensa Ukosta paljastuu siinä, että Ukko (Kalevala, runo 47, säe 80) antaa hänelle tehtäväksi vaalia liekkiä, josta aikoo luoda uuden Auringon ja Kuun Pohjolan emännän paikoiltaan viemien tilalle. Ilmatar-neidosta lausutaan lisäksi Kalevalan uudessa laitoksessa (runo 1, säe 111-), että hän laskeutuu "ilman laajoilta kartanoilta" meren aalloille ja kierrellessään autioita vuonoja luo maailman ja synnyttää viisaan Väinämöisen.

Muutamassa paikoin Kalevalassa puhutaan naispuolisesta jumaluudesta nimeltään Uutar (Udutar, U’utar) tai Terhenetär, myös Utu-tyttö, Terhen-neito. Kuten itse nimitykset vihjaavat, hän hallitsi kaikkia ilman usvia ja sumuja, sillä sanoilla $u t u$ ja terhen on nämä 
merkitykset. Taivaan korkeissa avaruuksissa, missä hänellä on kotipaikkansa, hän tapaa seuloa kaikenlaisia hienoja höyryjä seulan läpi ja laskea ne alas maan päälle (katso Kalevala, runo 19, säkeet 137-142; runo 42, säkeet 338-344).

Myös tuulella ajateltiin olevan jumaluutensa, sillä Kalevalassa puhutaan paidasta, joka on tuulen tyttären tekemä. Otaksun nimittäin, että tässä tulisi tuulen tytär käsittää 'tuulenjumalattareksi' aivan samoin kuin ilman tyttärellä tarkoitetaan 'ilmanjumalatarta'. Suomalaisilla ei näytä olleen Tuulen tyttärestä paras käsitys. Hänen valmistamansa paidan sanotaan ainakin olevan mitä kehnointa laatua. Merenjumalatar Vellamo pukeutuu siihen, mutta Väinämöinen lupaa hänelle paremman, Kuuttaren ja Päivättären tekemän, kunhan hän olisi Väinämöiselle suosiollinen ja vastaisi hänen rukoukseensa (Kalevala, runo 48, säe 129-).

Tuulen tyttären lisäksi runoissa puhutaan myös toisesta, leutoa etelätuulta hallitsevasta naispuolisesta jumalvoimasta, joka kantaa nimeä Etelätär, sanasta etelä 'etelä, etelätuuli'. Ganander siteeraa runofragmenttia, jossa tätä pyydetään ajamaan pilvet yhteen eri ilmansuunnista ja antamaan niiden sataa hunajaa lääkkeeksi kipeisiin paikkoihin. Kalevalassa häneen vedotaan pelkästään asunnonsuojelijan ominaisuudessa, ja hän kulkee silloin myös nimellä Suvetar, sanasta suvi 'kesä, etelä' (Kalevala, runo 32, säkeet 83-84). Häntä pidetään säännönmukaisesti hyvää tekevänä jumaluutena, ja hänet esitetään nuoren neidon ominaisuudessa (neiti nuori), joskin myös iäkkäänä naisena ja yhtenä luonnon suopeista emännistä (luonnon eukko).

\section{Veden Jumaluudet}

Ilman ohella pidetään vettä elementtinä, jolle suomalaiset ja sukulaiskansamme osoittivat muinaisuudessa ja osoittavat osin yhä tänä päivänä kaikkein kunnioittavinta palvontaa. Toisin ei voisikaan olla, sillä villinkin sielussa on hämärä aavistus siitä, että jumalallisuus on hengellistä, yliaistillista laatua, ja vaikka hän jatkuvasti tapaakin osoittaa palvontansa materialle, hän arvottaa sen yleensä sitä korkeammalle mitä vähemmän se on rajattu ja mitä eteerisempi se on. Mutta verrattain epämateriaalisen luonteensa lisäksi vedellä on monta muutakin ominaisuutta, jotka ovat omiaan herättämään luonnonihmisen 
ihmetyksen ja taivuttamaan hänet palvontaan. Meren mittaamattoman ulapan ja vihaisten, myrskyn nostattamien aaltojen, jokien tasaisen juoksun, kuohuvien vesiputousten ja tuhoisien tulvien sekä rauhaisten lampien, kirkkaiden lähteiden ja pikku puron rauhallisuuden ja vaatimattomuuden pohtimisen on ruokittava uskonnollista tunnetta ja annettava vahva ärsyke palvontaan. Mutta vielä mahtavammalla tavalla luonnon helmassa kasvaneen ihmisen vakuuttaa veden jumalolentojen olemassaolosta se, kun hän toisaalta näkee, kuinka helppo on kohdata kuolema kuohuvissa aalloissa ja toisaalta tajuaa, että näistä samoista aalloista hän monta kertaa saa ne hyödykkeet, jotka muodostavat hänen hengissäpysymisensä ehdot.

Mitkä veden palvontaan johtaneet syyt sitten ovatkin, on ainakin selvää, että tämä palvonta on levinnyt maailmassa varsin laajalle. Meidän heimossamme sitä ilmenee vielä tänä päivänäkin ostjakeilla, samojedeilla ja tunguuseilla samaten kuin monilla suomalaisilla, turkkilaisilla ja mongolikansoilla. Useimmista mainittujen kansojen vesikulteista tiedetään hiukan enemmänkin, kuten myös tiettyjen järvien, jokien ja lähteiden muistamisesta ajoittain tietyntyyppisin uhrein. Kerrotaan, että votjakit tapaavat uhrata vedelle vuohen tai kukon. ${ }^{a}$ Ugrilaiset ostjakit ja monet samojedikansat lahjoittavat poroja Ob-joelle, jota he pitävät hyvin pyhänä. Eteläisen Siperian monilla tataarikansoilla on käytäntönä heittää ennen ruokailua veteen jokin osa ruoasta nimeltään takan aina, kun he itse syövät sitä. Myös tiedetään, että lappalaiset, suomalaiset ja virolaiset osoittivat muinaisina aikoina palvontansa vedelle, minkä vuoksi monilla joilla ja järvillä on Suomessa yhä tänä päivänä nimenä Pyhäjärvi, Pyhäjoki, Pyhävesi jne. Erityisesti virolaiset näyttävät osoittaneen tavatonta kunnioitusta pienelle purolle nimeltään Võhandu, jonka alku on Tarton piirissä Otepään kunnassa Ilmjärven kylässä ja joka laskee Peipsijärveen yhdyttyään Mädäjokeen. Tätä puroa kutsutaan myös nimityksellä pöha jögge [püha jõgi (viro)]. Se oli muinaisille virolaisille niin pyhä, että sen läheisyydessä ei uskallettu kaataa yhtäkään puuta tai edes katkaista oksaa. Jos joku teki moisen hillittömyyden, hän tuli kuolemaan samana vuonna. Puro ja lähde, josta se alkaa, puhdistettiin vuosittain, ja

a Georgi 1776-1780, 62. 
uskottiin, että nousi rajuilma, mikäli siihen heitettiin jotakin saastaista. Gutslaff kertoo, ${ }^{\text {a }}$ että eräs saksalainen maanomistaja rakensi puroon myllyn, mutta kun pian sen jälkeen nousi huono ilma, jota jatkui pitkän aikaa, virolaiset polttivat myllyn uskoessaan, että huono sää johtui puron häpäisystä. Tarina kertoo, että tälle purolle ei kannettu uhriksi pelkkiä eläimiä vaan myös pieniä lapsia. Nämä uhrit osoitettiin "sinikeltasukkaiselle miehelle", jonka sanotaan asuneen purossa ja toisinaan jopa nousseen siitä. Mainitun puron lisäksi virolaiset palvoivat myös Eim-järveä. Tähän järveen liittyy kertomus, jonka Jacob Grimm kertoo seuraavin sanoin:

Järven rannalla asui pahoja, villejä ihmisiä. He eivät niittäneet niittyjä, jotka järvi kasteli eivätkä he kylväneet peltoja, jotka se teki hedelmällisiksi, vaan he ryöväsivät ja murhasivat niin, että järven kirkas pinta samentui murhattujen verestä. Järvi suri syvästi. Eräänä iltana hän kokosi kaikki kalansa yhteen ja nousi niiden kanssa ilmaan. Kun ryövärit huomasivat veden pauhun, he huusivat: "Eim on noussut, kerätään sen kalat ja aarteet!" Mutta kalat olivat tiessään eikä järven pohjassa ollut muuta kuin matoja, liskoja ja rupikonnia, jotka nousivat järvenpohjasta ja siirtyivät ryövärien asumuksiin. Eim kohosi yhä korkeammalle ja lipui ilman läpi valkoisen pilven lailla. Metsästäjät sanoivat metsässä: "Mikä tumma myrsky tulee päällemme?" ja paimenet sanoivat: "Mikä valkoinen joutsen lentää korkeuksissa?" Koko yön hän kellui tähtien alla. Aamulla niittoväki havaitsi hänet ja näki, kuinka hän alkoi laskeutua matalammalle, muutti itsensä joutsenesta valkoiseksi laivaksi ja sitten tummaksi pilveksi. Niittoväki kuuli vedestä kuuluvan äänen: "Siirtykää pois sieltä heininenne, haluan asua luonanne." Väki toivotti hänet tervetulleeksi, mikäli hän halusi hedelmöittää heidän peltonsa ja niittynsä, ja hän laskeutui alas ja levittäytyi kaikkialle uuteen asuinpaikkaansa. Niittoväki järjesti hänen petinsä, teki patoja ja istutti taimia rantaan vilvoittaakseen hänen laineitaan. Koko seudusta tuli hedelmällinen, pellot viheriöivät ja väki tanssi hänen ympärillään niin, että vanha järvi tunsi itsensä nuorekkaan iloiseksi. ${ }^{b}$

Vettä on alun perin palvottu välittömässä, aistittavassa muodossaan kuten ilmaa, tulta ja muita elementtejä, ja tällaista palvonta on yhä tänä päivänä monien juuri mainittujen kansojen parissa. Heidän kuulee 
vakuuttavan, että vedessä on jumalallisia olentoja mutta että ne ovat alhaista, pahaa laatua, eikä ole helppo uskoa, että ne olisivat joskus olleet uhrien ja rukousten kohteita. Suomalaisessa mytologiassa tavataan kuitenkin korkeampi, vettä hallitseva jumaluus Ahti eli Ahto, joka runojen todistuksen mukaan nautti tavatonta kunnioitusta. Mutta samalla tavoin kuin Ukon palvonta on todistetusti myöhempää alkuperää kuin taivaan palvonta, olen myös sitä mieltä, että suomalaiset jonakin aiempana ajanjaksona eivät palvoneet Ahtoa vaan itse vettä. Itse asiassa veteen viitataan jumalallisena olentona oikealla nimellään Vesi vanhoissa runoissamme joitakin kertoja. Kalevalassa (runo 42, säe 529-) on rukous, joka alkaa näillä sanoin: "Vesi kiellä poikoasi, laine lastasi epeä." Sekä vesi että laine käsitetään tässä selvästi persoonina, mutta tämä persoonallisuus ymmärretään kuuluvaksi sen ulkoiseen perusolemukseen. Ahdin eli Ahdon kohdalla on kokonaan toinen tilanne. Hänellä ei ole vesielementin kanssa muuta tekemistä kuin että hän asuu siinä ja hallitsee sitä rajattomasti. Häntä on suomalaisten muiden jumalolentojen tavoin siunattu ihmismäisellä olemuksella sekä inhimillisillä tunteilla ja kärsimyksillä. Melko usein hänet sekoitetaan runoissa sankariin nimeltään Lemminkäinen tai Kaukomieli. Lönnrot on käyttänyt Kalevalan uudessa laitoksessa sanaa Ahti merkitsemään Lemminkäistä kun taas nimitystä Ahto hän käyttää viittaamaan ainoastaan vedenjumalaan välttääkseen tämän sekaannuksen. Mielestäni Lönnrot on voinut erehtyä tässä erottelussaan, sillä ensinnäkään runonlaulajat eivät tee tällaista erottelua, ja toisekseen deminutiivimuotoisella sanalla Ahto voi kielen hengen mukaisesti viitata yhtä vähän mihinkään muuhun kuin Ahtiin kuin deminutiiveilla päivö, päivyt, päivöinen viitata mihinkään muuhun kohteeseen kuin päivään ('Aurinko'). Näkemykseni on näin ollen se, että sankari Lemminkäinen ja merenjumala Ahti tai Ahto ovat itse asiassa alun perin olleet yksi ja sama henkilö, mutta tätä käsittelen tarkemmin myöhemmin. Suomalaiset kielet eivät anna sanan ahti etymologiaan mitään selvennystä. Sen sijaan indogermaanisen heimon piiristä löytyy sanskritinkielinen, veda-runoissa käytetty sana ahis ('järvi'), joka on yhdistetty muinaisskandinaavin sanaan $a h i$, joka puolestaan 
merkitsee 'maanpiiriä ympäröivää käärmettä' (hafvet [ruots.]). ${ }^{a}$ Vastaavasti sanskritin sanaa ahis on verrattu muinaisskandinaavin sanaan cegir 'meri' sekä latinan sanaan cequor, ja myös sana ahti on yhdistetty siihen. ${ }^{\mathrm{b}}$ Kenties suomalaiset lainasivat nimityksen Ahti, samalla tavoin kuin monet muut sanat, muinaispohjoismaisesta kielestä. ${ }^{39}$

Muinaissuomalaisten käsityksissä kyseinen jumala nimeltä Ahti oli useimpien muiden mahtavampien jumalten tavoin vanha, kunnioitettava mies (ukko, vanhin), jolla on parta ruohosta (ruoho-parta) ja viitta vaahdosta (vaahti-vaippa). Hän hallitsee vesialueita ylimmäisenä ja sen vuoksi häntä kutsutaan usein runoissa nimellä veen isäntä, aaltojen kuningas, satahauan hallitsia 'satojen syvänteiden hallitsija'. Hänen aarteitaan pidetään mittaamattomina, ja niiden sanotaan tulleen hänen haltuunsa, kun Pohjolan emäntä upotti ison osan onnea tuovasta sammosta meren syvyyksiin.

Niin meni muruja noita,

Sammon suuria paloja

Alle vienojen vesien,

Pälle mustien murien,

Ne jäivät ve’en varaksi,

Ahtolaisten aartehiksi;

Siitäp’ ei sinä ikänä,

Kuuna kullan valkeana

Vesi puuttune varoja,

Ve'en Ahto aartehia.

(Kalevala, runo 43, säkeet 267-276.)

Tässä tilanteessa Ahto sai haltuunsa myös Väinämöisen hauenluukanteleen, jonka myrsky suisti mereen vanhan laulajan veneestä. Runo kertoo, että Ahto-jumala oli hädin tuskin huomannut kanteleen aalloilla, kun hän kiirehti ottamaan sen haltuunsa kansansa ikuiseksi iloksi ("Ahtolan iki-iloksi"). Yleisesti ottaenkin merenjumala käsitettiin varsin mieltyneeksi vieraiden tavaroihin, ja laulu valittaa, kuinka harvoin hän palauttaa sen mitä kerran on onnistunut saamaan haltuunsa ("harvoin Ahti antanevi, kun on kerran keksinynnä"). Ajoittain

b Ibid: II, 732. 
käy niin, että hän päästää sydämeensä myötätuntoa ja palauttaa saamansa saaliin kaikkineen. Sadussa kerrotaan, että ollessaan paimenessa joen rannalla eräs paimenpoika pudottaa veitsensä veteen. Hänen onnettomuudesta johtuvan itkunsa liikuttamana Ahti ui rantaan, sukeltaa joenpohjaan ja noutaa sieltä kultaveitsen. Poika kertoo vilpittömästi, ettei tämä kuulu hänelle, ja Ahti sukeltaa toisen kerran pohjaan noutaen hopeaveitsen tilalle. Kun poika ei halua ottaa sitäkään, Ahti painuu vielä kolmannen kerran syvyyksiin ja noutaa oikean veitsen, jonka poika myös ilolla tunnustaa omaisuudekseen. Palkitakseen köyhän paimenen rehellisyyden Ahti antaa hänelle kaikki kolme veistä. ${ }^{a}$ Hukkuneet ihmiset ovat tervetulleita Ahdon asuntoon. Ainoa odottaa siellä (Vanha Kalevala, runo 31, säkeet 119-129) suurempi onni kuin minkä hän voisi saavuttaa vanhan Väinämöisen vaimona. Indogermaanista heimoa tarkastellessaan Jacob Grimm lausuu: "Yleisesti ottaen vedenhenget näyttävät mielellään kaappaavan sieluja",; 40

Ahdilla on monenlaista omaisuutta, mutta hänen varsinaisen rikkautensa ymmärrettiin muodostuvan kaloista. Häntä kutsutaan runoissa nimityksellä satahauan hallitsia kalojen omistajan ominaisuudessa, sillä kalat oleskelevat pääasiassa juuri syvänteissä. Ahdin itsensä uskottiin oleskelevan meren syvänteessä, jota runoissa kutsutaan nimellä Ahin hauta 'Ahdin syvänne' ja jota kutsutaan lohen ja muun kalan runsauden vuoksi myös nimityksillä lohinen louhikko ja kalanen kartano. Kartano, jossa hän siellä asui, kantaa nimeä Ahtola, ja sen oloista lausuu runo:

Tuolla Ahtola asuvi,

Neiot Wellamon venyvi,

Nenässä utuisen niemen,

Päässä saaren terhenisen,

Alla aaltojen syvien,

Pällä mustien mutien.

Siellä Ahtola asuvi,

Neiot Wellamon venyvi,

a Mehiläinen, helmikuu 1836. [Majamaa 1990, 28.]

b Grimm 1844, 800; vrt. s. 288. 
Pikkuisessa pirttisessä,

Kamarissa kaitaisessa,

Kiven kirjavan kylessä,

Paaen paksun kainalossa.

(Kalevala, runo 5, säkeet 23-34.)

Tässä voidaan ohimennen mainita, että myös Ahtiin sekoitetun Lemminkäisen käsitettiin asuvan nenässä utuisen niemen, päässä saaren terhenisen. Kuten Ahti, myös hän asuu paikassa, jossa on runsaasti kaikenlaisia kaloja, sillä Kalevalassa (runo 11, säkeet 9 ja 10) sanotaan, että Ahti kasvatettiin kala- ja ahvenaterioilla ("kaloin siinä Kauko kasvoi, Ahti ahvenin yleni”).

Veden ja sen lukuisan asujaimiston johtamiseen osallistui Ahdin ohella hänen puolisonsa Vellamo, myös Vellimoksi ja Vellimykseksi nimitetty, jota usein kunnioitetaan epiteeteillä veen eukko ja veen emäntä. Kuten Ahti, myös hän on melko iäkäs ja korkealle arvostettu sekä ikänsä että mahtinsa vuoksi. Hänellä on vakava luonne (vakainen vaimo) ja hän on yleensä hyvä, lempeä ja huomaavainen emäntä (veen ehtoisa emäntä, veen armas anti-vaimo). Runoissa kerrotaan, että hän pukeutuu siniseen tai vedenväriseen myssyyn (sinilakki), leninkiin jossa on hienot helmat (hieno-helma), ruoosta valmistettuun paitaan ja rintamukseen (rytinen paita, ruoko-rinta) sekä vaahtoavaan viittaan (vaahti-vaippa). Tämä asu ei ole erityisen loistelias, mutta silti niin hyvä kuin on mahdollista saada siitä elementistä, johon Vellamo kuuluu.

Veden muut jumaluudet sisällytetään runoissa yleisiin nimityksiin ahtolaiset 'Ahtolan tai Ahto-kartanon asukkaat', veen väki, Vellamon väki, Vellamon ikiväki 'Vellamon ikuinen väki', Ahon lapset 'Ahdon lapset', Vellamon neiot, meren hauan haltiat 'meren syvänteiden hallitsijat', veen vallat 'veden mahtavat' jne.

Kaikki nämä jumaluudet ovat, kuten osa itse nimityksistä paljastaa, Ahdin ja hänen puolisonsa käskyläisiä. Muinaissuomalaiset näyttävät käsittäneen heidät eri kulttuuritasoilla toisinaan iäkkään jumalparin lapsiksi (Ahon lapset, Vellamon neiot), toisinaan heidän alaisikseen ja palvelijoikseen (Vellamon väki, veen väki, veen vallat jne.). He eivät oleile pelkästään meressä, vaan myös järvissä, joissa, lähteissä, kaivoissa jne., kuten Kalevala (runo 12, säe 257-) ja monet muut runot 
selvästi osoittavat. Näiden jumaluuksien joukossa on joillekin annettu erityinen nimi, kuten Pikku mies, Aallotar, Kosken neiti, Melatar, Sotkottaret jne. Niin kutsuttu Pikku mies kuvataan Kalevalassa (runo 2, säkeet 111-124) seuraavalla tavalla:

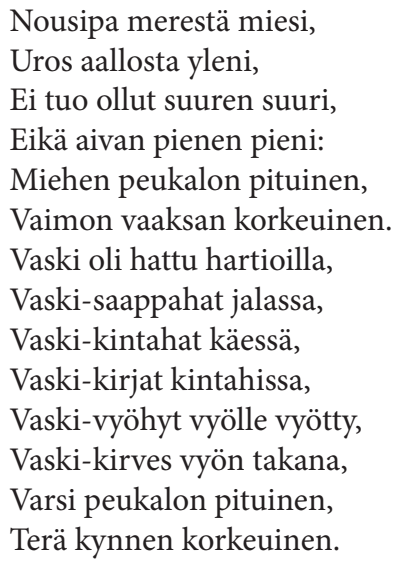

Merkityksettömästä ulkonäöstään huolimatta hänellä on tavattomat voimat, joiden johdosta laulu antaa hänelle melko raskaan vaatetuksen, kuten kivikengät ja kypärän, joka on kivenlohkareesta. ${ }^{a}$ Aallotar mainitaan tietääkseni pelkästään Kalevalan runossa 48 (säe 130), missä kerrotaan, että hän on kutonut valtiattarensa Vellamon paidan, jota ylistetään hiukan. Kosken neidistä ja Melattaresta runot eivät anna mitään kuvausta, mutta Sotkattarista lausutaan, että suojattiensa sotkien lailla he oleskelevat mieluiten pääasiassa ruovikkoisilla rannoilla. Laulu ylistää heidän pitkiä hiuksiaan, joita he huolellisesti harjaavat hopeavartisella harjalla (Kalevala, runo 41, säkeet 143-148).

Niin Ahto ja hänen puolisonsa Vellamo kuin myös monet muut vedessä majailevat jumaluudet olivat, kukin toimipiirinsä luonteen mukaan, muinaissuomalaisten rukousten kohteena. Kalevalassa (runo 42, säkeet 531 ja 532) anotaan Ahtoa ja Vellamoa yhdessä tyynnyttämään aallot ja rauhoittamaan veden väki. Molempiin vedottiin kalastuksen yhteydessä yhtä lailla, ja yksi runo, joka tässä tarkoituksessa osoitetaan Ahdille, kuulostaa tältä:

a Ganander 1789, 106. 
Ahto aaltojen isäntä, Sata-hauan hallitsia! Ota virpi viittä syltä, Salko seitsentä tapoa, Jolla selät seuruelet, Meren pohjat meuruelet, Nostat routaisen romuen, Kaiotat kalaisen karjan Tämän nuotan nostimille, Sata-lauan laskimille Kalaisista kaartehista, Lohisista loukeroista, Suurilta selän navoilta, Synkiltä syväntehiltä, Päivän paistamattomilta, Hiekan hieromattomilta.

(Kalevala, runo 48, säkeet 135-150.)

Kuten useimpiin muihinkin jumalolentoihin, Ahtiin ja Vellamoon vedotaan myös jotta he antaisivat suojan noitien rautakärkisiä nuolia ja muita kauhistuttavia aseita vastaan (Kalevala, runo 12, säe 263-). Ahdilta tavattiin myös rukoilla apua ja tukea vaikeiden koskien laskemiseen (Kalevala, runo 40, säkeet 56-60), ja yleisesti häneen näkyy luotetun syvästi kaikkien vesillä tehtävien matkojen alla. Ennen erästä sellaista matkaa Väinämöinen rukoilee häntä seuraavin sanoin:

Oisko airot pikkaraiset, Soutajat vähä-väkiset, Pienoiset perä pitäjät, Lapset laivan hallitsiat, Anna Ahto airojasi, Venettäsi veen isäntä, Airot uuet ja paremmat, Mela toinen ja lujempi! Itse airoillen asetu, Sovitaite soutamahan, Anna juosta puisen purren, Rautahangan hakkaella Halki kuohujen kovien, Lakkipäien lainehien! (Kalevala, runo 42, säkeet 203-216.) 
Kuten Ahtia ja Vellamoa, myös yllä käsiteltyä Pikku miestä rukoillaan olemaan suosiollinen kalastuksen yhteydessä. Väinämöisen rukouksen jälkeen tämä nousee aalloista ja tekee vanhalle laulajalle sen palveluksen, että ajaa lukuisan joukon kaloja nuottaan tarpomalla vettä suurella männyllä, jonka päähän on kiinnittänyt kivipaaden (Kalevala, runo 48, säkeet 151-178). Samaan Pikku mieheen vedottiin myös muissa tilanteissa. Erään kerran käy niin, että maa kasvattaa tammen, joka kohottaa latvansa aina pilviin asti ja oksillaan peittää auringonsäteet. Valon puutteessa elämä tuntuu tuskaiselta ja ihmiset toivovat, että tammi kaadettaisiin. Mutta koko maan piiristä ei löydy miestä, joka jaksaisi kaataa jättipuun. Silloin viisas Väinämöinen kääntyy rukouksella äitinsä puoleen ja pyytää tätä lähettämään väekkäästä vedestä jonkun, joka kykenisi tähän tehtävään. Silloin Pikku mies nousee uudelleen merestä kantaen vaskikirvestä vyöllään. Väinämöinen katselee häntä aluksi epäuskoisena, mutta pian näkee veden miehen olemuksen saavuttavan mitä kolossaalisimmat mittasuhteet. Runo lausuu tästä:

Jalka maassa teutaroivi, Päähyt pilviä pitävi,

Parta on eessä polven päällä,

Hivus kannoilla takana,

Syltä oli silmien välitse,

Syltä housut lahkehesta,

Puolta toista polven päästä,

Kahta kaation rajasta.

(Kalevala, runo 2, säkeet 153-160.)

Noustuaan merestä tämä pieni mies teroittaa kirveensä hiomakivellä. Sen jälkeen hän menee tammen luokse, ja se kaatuu maahan jo kolmannella iskulla.

Lemminkäinen vetoaa veden muiden jumalvoimien joukosta kerran Kosken neitiin ja Melattareen, kun hänen on laskettava vaarallinen koski. Edellistä kutsutaan opastamaan perämiestä vetämällä vedenpintaan kulkureitti, jälkimmäistä anotaan valitsemaan paras peräsin ja ohjaamaan vene sillä kuohuvan kosken läpi varmasti ja onnellisesti (Kalevala, runo 40, säe 61-). 
Kaikki yllä luetellut vettä hallitsevat jumalvoimat olivat muinaissuomalaisten yleisen käsityksen mukaan jaloja, hyviä ja ihmisystävällisiä luonnoltaan, mutta vedessä oli myös muita, melko mahtavia joskin pahoja ja kauhistuttavia olentoja. Sellaisia olivat Vesi-Hiisi, Turso tai Tursas ja Vetehinen. Vesi-Hiidestä puhutaan Kalevalassa (runo 12, säe 262) inhottavana olentona, mutta tämän lisäksi runo kertoo vain, että Lemminkäinen anoo häneltä apua ja tukea Pohjolan pahoja peikkoja vastaan. Ganander ei usko tämän jumaluuden olevan mikään muu kuin "suursukeltajan toukka (Larva dytisci [lat.]), joka vie täyt ja kalat kalastajalta" ja jota taikauskoiset manaavat vedestä "vahingoittamaan kanssaihmisiään, erityisesti varkaita". ${ }^{a}$ Kalevalassa (runo 42, säe 348-) kerrotaan, että Pohjolan emäntä anoo Tursoa, jota myös kutsutaan Iku-Tursoksi, upottamaan Väinämöisen, Ilmarisen ja Lemminkäisen heidän purjehtiessaan kotiin päin Pohjan kartanon kivivuoresta ryöväämänsä sammon kanssa. Siinä samassa mereen kohoaa kauhistuttava karikko, ja korkeat vaahtopäät hyökyvät päin sankareiden punaista venettä. Merta pelkäävä Ilmarinen pelästyy sitä kovasti: veri pakenee hänen poskiltaan ja hän vetää hädässään peiton silmilleen, korvilleen ja kasvoilleen. Väinämöinen sitä vastoin alkaa rauhassa selvittää voimakkaan merenkäynnin syytä ja löytää veneen viereltä hirviön, jonka tunnistaa päänsä aaltojen ylle kohottaneeksi "Iku-Turso Äiön pojaksi”. Väinämöinen tarttuu meripeikkoa sankarillisesti korvista, nostaa sen vedestä eikä jätä sitä rauhaan, ennen kuin Turso on antanut hänelle lupauksen, ettei koskaan enää kohoaisi aalloista kuolevaisten vahingoksi. Sama hirviö tavataan epäilemättä eräässä Gananderin siteeraamassa runossa nimellä Tursas tai Meri-Tursas, ja sen kerrotaan synnyttäneen Pohjolan neidon kanssa maailmaan yhdeksän poikaa, joista sittemmin tuli ihmisten pahim-

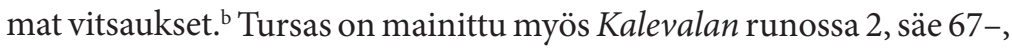
mutta siinä hän esiintyy Väinämöisen avustajana luomistyössä. Veden viisi neitoa ovat niittäneet heinää eräällä niityllä ja koonneet sen yhteen, kun Tursas astuu merestä ja sytyttää heinäkasat tuleen edistääkseen siten maaperän hedelmällisyyttä ja saadakseen sen kasvattamaan tammen, jonka Väinämöinen istuttaisi maahan. ${ }^{41}$ 
Vetehinen ('vedessä oleileva', sanasta vesi) vaikuttaa Kalevalan (runo 26, säkeet 693 ja 694) perusteella olevan sama henkilö kuin Syöjätär, käärmeen äiti. Kalevalassa (runo 19, säe 217-) Vetehinen kohottaa päätään vedestä ja tarttuu Ilmariseen, kun tämä yrittää Pohjolan emännän käskystä pyydystää haukea kuoleman hämyisestä virrasta. Onnekkaasti hän vapautuu peikosta, kun kotka kiskoo sen takaisin joen pohjaan. Kannattaa huomioida, että sanana vetehinen vastaa sekä merkitykseltään että etymologialtaan täydellisesti vedenhenkeä, jota venäläiset kutsuvat nimellä Vodennoj [водяной]. Luultavasti suomalaiset ovat lainanneet käsityksensä tästä olennosta slaavilaisesta mytologiasta, missä Vodennoj esittää paljon merkityksellisempää roolia kuin Vetehinen suomalaisessa. Vastaavasti pidän varsin todennäköisenä, että myös turso eli tursas ${ }^{a}$ on lainasana ja johtuu muinaisskandinaavin sanasta thurs, joka myöhemmin on muuntunut muotoon thuss. ${ }^{42}$ Tämän vuoksi näyttää siltä, kuin tässä käsiteltyjen vesipeikkojen joukossa Vesi-Hiisi olisi ainoa, joka alun perin on kuulunut suomalaiseen mytologiaan. Tätä vastaavat ostjakkien, syrjäänien ja permien Kulj, votjakkien Wu-murt, tšeremissien Jo jne. Kaikki nämä nimitykset merkitsevät ainakin nykyään pahoja ja vahingollisia vedenhenkiä, mutta on mahdollista, että ne ovat saaneet tämän merkityksen kristinopin vaikutuksesta ja että ne ovat alun perin merkinneet jalompia olentoja, jotka vastaisivat suomalaisten Ahtoa ja hänen puolisoaan Vellamoa.

\section{Maan jumaluudet}

Varsin monet kansakunnat ovat lapsuudessaan tavanneet pitää maata jumalallisena olentona ja palvoa sitä suopeana äitinä, joka lahjoittaa syntymän ja ravinnon sekä ihmisille että eläimille. Epäilemättä juuri ravitsevan, ylläpitävän tai niin sanotun äidillisen ominaisuutensa vuoksi maa on ollut jumalkultin kohde myös monien sukulaiskansojemme, kuten tunguusien, mongolien, turkkilaisten jne. parissa. Ainakin suomalaisten maanpalvonta perustuu tällaiseen käsitykseen, mikä näkyy jo itse nimityksestä maa-emä ('maaäiti', terra mater [lat.]), joka

a Turso on deminutiivimuoto sanasta Tursas kuten taivo sanasta taivas. 
runoissa merkitsee materiaalista maata. Tämä nimitys tavataan kuitenkin Kalevalassa pelkästään joissakin äärimmäisen harvoissa kohdissa (vanha laitos, runo 1, säe 224; uusi laitos, runo 6, säe 172). Syy tähän sanan maa-emä harvaan käyttöön on varmaankin se jo mainittu seikka, että suomalaiset, vaikka olivatkin luonnonpalvojia, eivät kuitenkaan mielellään palvoneet luonnonkohteita ulkoisessa, näkyvässä olemuksessaan, vaan kuvittelivat tavallisesti persoonallisen jumalolennon asuvan materiassa ja hallitsevan sitä. Tällainen, maan kokonaisuudessaan käsittävä olento on Maan emo (emonen) 'maan äiti', jota myös kutsutaan nimillä mannun eukko, maan emäntä, akka manteren alainen. Ganander esittää, että muinaissuomalaiset palvoivat tätä jumalatarta ukkosenjumalan, taivaallisen Ukon puolisona, tai aiemmin mainitsemanani Akkana. En uskalla taata tämän väitteen luotettavuutta, sillä runot eivät valaise asiaa lainkaan. Sama kirjoittaja on esittänyt, että Maan emoa on pidetty varsin mahtavana jumalattarena ja että häntä on anottu suomaan voimia heikoille ja avun tarpeessa olijoille. Todisteena tästä hän siteeraa seuraavaa runofragmenttia: "Nouse maasta maan emoinen, väikseni, voimakseni."a Myös Kalevalassa häntä anotaan eräässä tilanteessa muiden maan jumaluuksien kanssa kiiruhtamaan hädänalaiselle avuksi (vanha laitos, runo 10, säe 217-). Eräässä toisessa häntä anotaan toimialansa todellista luontoa vastaten suomaan kasvuvoimansa maalle, ja tässä yhteydessä Pellervoinen lähettää rukouksen myös itse maalle. Runon sanat ovat seuraavat:
Akka manteren alainen,
Mannun eukko, maan emäntä!
Pane nyt turvet tunkemahan,
Maa väkevä vääntämähän;
Eip' on maa väkeä puutu
Sinä ilmoisna ikänä,
Kun lie armo antajista,
Lupa luonnon tyttäristä.
Nouse maa makoamasta,
Luojan nurmi nukkumasta,

a Ganander 1789, 54. 
Pane korret korttumahan,

Sekä varret varttumahan,

Tuhansin neniä nosta,

Saoin haaroja hajota

Kynnöstäni, kylvöstäni,

Varsin vaivani näöstä!

(Kalevala, runo 2, säkeet 301-316.)

Lappalaisessa mytologiassa vastaa Maan emoa minun näkemykseni mukaan niin kutsuttu Madderakka (suom. manteren akka). JessenSchardebøll ja muut lappalaismytologit esittävät, että Madderakka ja hänen puolisonsa, niin kutsuttu Madderattje, keskeisellä tavalla osallistuivat elävien olentojen muotoutumiseen, mutta heidän tulkintansa näyttävät olevan myöhemmän ajan kuvitelmaa ja pääasiassa perustuvan sanojen muuntumiseen. Saamen kielen sana madder, kuten sen kanssa äänteellisesti likeinen suomen sana manner, merkitsee 'maata, mannerta. Tässä kielessä on kuitenkin myös toinen sana mad (maddo), madar (madder), jolla esitetään olevan merkitys 'synty, alkuperä. Nämä kaksi sanaa on sekoitettu keskenään, ${ }^{a}$ ja niin ovat [nimitykset] madderattje ja madderakka, jotka alun perin merkitsivät 'maan isää ja äitiä, tulleet merkitsemään 'luomistyön isää ja äitiä. Tämä vaihtuminen oli sitäkin helpompaa, kun näiden jumalvoimien uskottiin lappalaisessa, ja virolaisessa, mytologiassa huolehtivan naisten hedelmällisyydestä maata hallitsevien olentojen ominaisuudessa.

Virolaisten parissa tavataan maan jumalatar nimeltä Maa-emma, jonka suomalaisten Maan emon tavoin uskotaan olleen ukkosenjumalan vaimo ja tukeneen häntä kaikissa tämän toimissa. ${ }^{b}$ Merkillepanemisen arvoista on, että tälle jumaluudelle oli uskottu maan kasvuvoiman lisäksi myös naisten hedelmällisyys ja heidän sekä syntyneet että syntymättömät kasvattinsa. Suomalaisille tämä käsitys näyttää runojen todistuksesta päätellen olleen täysin vieras. Yleensä ottaen muinaislaulumme antavat varsin vähän kuvauksia Maan emosta, ja sama koskee myös kaikkia muita maan jumaluuksia joille oli uskottu sen

a Luultavasti tämä sekoittuminen ei ole oppineiden syytä vaan kansalta itseltään.

b Ganander 1821, 20. 
kasvuvoimasta ja hedelmällisyydestä huolehtiminen. Kerrotaan, että pelloilla on ikivanha isäntänsä (peri-isäntä) ja että maan povessa on miekalla varustautuneita miehiä ja ratsastajia (Kalevalan vanha laitos, runo 10, säkeet 217-220), mutta niiden tehtävistä kerrotaan pelkästään, että kipeät ja hädänalaiset anoivat niiltä apua ja tukea samalla tavoin kuin Maan emolta. Merkitsevämpää roolia runoissamme esittää niin kutsuttu Pellervoinen, pellon poika, myös Sampsaksi kutsuttu, sillä hänen avullaan Väinämöinen saa paljaan, aution maan kasvamaan puita ja kaikkia muita kasveja. Kalevalan vanhan laitoksen mukaan Pellervoinen suorittaa tämän tehtävän ensi kertaa ryöstettyään sammon Pohjolasta, mutta myöhemmän laitoksen mukaan Väinämöinen luottaa kyseisen jumaluuden tukeen kyseisissä toimissa pian maailman luomisen jälkeen. Väinämöinen tekee myös matkan Pellervoisen luokse tarvitessaan hyvää emäpuuta laivaansa (Kalevala, runo 16, säkeet 13-100). Tästä huomataan, että Pellervoinen ei ole pelkkä peltojen suojelusjumala, kuten hänen molemmat nimensäa ja epiteetti pellon poika antavat ymmärtää, vaan hän myös hallitsee puita ja kasveja ylipäätään. Pellervoinen on epäilyksettä sama jumaluus, jolla on Agricolalla, Gananderilla ym. nimenä Pellon Pekka tai Pekko ('pellon Petrus') ja jonka sanotaan huolehtineen paitsi viljankasvusta ja kevätkylvöstä yleensä, myös olleen mukana oluenpanossa, minkä johdosta ilmaisu maistaa (juoda) pellon pekkoa merkitsee Gananderin ${ }^{\mathrm{b}}$ mukaan 'juoda olutta tai sahtia.' ${ }^{43}$

Agricolan mukaan suomalaiset palvoivat ennen muinoin vielä muitakin maan ja eritoten peltojen hedelmällisyydestä määrääviä jumaluuksia. Hämäläisten heimon parissa tällainen oli Liekkiö, jolla uskottiin olevan valta ruohoon, juureksiin ja puihin. Karjalaisten parissa taas tällaisia olivat 1) Köndös (Kondus), joka huolehti kaski-

\footnotetext{
a Pellervoinen sanasta pelto; vrt. Kullervo ja Kullervoinen sanasta kulta, Kalervo sanasta kala, jne. Nimi Sampsa on väännös venäläisestä sankarinnimestä Samson kuten seuraavassa Pekka tai Pekko nimestä Pehr.

b Ganander 1789, 68.
} 
pelloista, ${ }^{a}$ 2) Rongoteus, joka suosi ruissatoa, ${ }^{\text {b }} 3$ ) Egres, herneiden, papujen, nauriiden, kaalin, hampun ja pellavan suojelusjumala, ${ }^{c}$ ja 4) Kannas, kaurapeltojen suojelija. ${ }^{d}$ Nämä jumaluudet ovat suurelta osin jo vaipuneet unholaan, olettaen että ne ovat koskaan kuuluneetkaan suomalaiseen mytologiaan, mitä niiden epäsuomalaiset nimet houkuttelisivat epäilemään. Kalevalassa mainitaan heistä ainoastaan Wirokannas, joka epäilemättä vastaa Agricolan Kannasta. Kalevalassa hän ei esiinny kuitenkaan jumalolentona vaan eräässä tilanteessa kastaa Jeesus-lapsen papin ominaisuudessa (runo 50, säe 434-) ja eräässä toisessa yrittää teurastaa valtaisan kokoisen härän mihin ei kuitenkaan kykene (runo 20, säe 54-). Sanaa liekkiö tiedetään käytetyn suomen kielessä, mutta sitä ei tavata Agricolan esittämässä merkityksessä, vaan Renvallin ${ }^{\mathrm{e}}$ mukaan se merkitsee 1) pahaa henkeä, myös ilkeää, pahantahtoista ihmistä tai 2) murhattua ja ulosjätettyä lasta. Ganander kuvaa Liekkiön olleen "henki, joka huusi metsissä tapettujen lasten vuoksi ja pelotteli huudollaan matkustajia; sillä oli valta ruohoon, juuriin ja puihin."

Laulujen ja kertomusten antamat vajavaiset kuvaukset juuri käsitellyistä jumaluuksista ovat negatiivinen todiste siitä, että nämä olennot ovat saaneet osakseen vain vähäistä palvontaa. Tähän päätelmään päästään muiden seikkojen perusteella. Rikkaissa, loisteliaissa ja lauhkean luonnon suosimissa maissa on rakennettu temppeleitä ja uhrattu maan tuottaville, hedelmällisille jumalille; mutta kylmässä pohjolassa, missä maan tuottamisvoima on heikko, näillä jumaluuksilla on ollut vähäinen merkitys. Erityisesti näin on täytynyt olla suomalaisten kohdalla, jotka elämäntapansa vuoksi tarvitsivat sitäkin vähemmän maan hedelmällisyyttä. Kaiken todennäköisyyden mukaan he eivät pakana-aikaan harrastaneet niinkään maanviljelyä kuin metsästystä, kalastusta ja karjanhoitoa. Erityisesti metsästys oli heille rakasta toimintaa ja elinkeino, joka epäilyksettä kantoi runsaimmat hedelmät.

\footnotetext{
a "Kondus arat colles, atque ustis semina tesquis / Credere, Sarmatica callidus arte, docet." (Forsius 1778, 114.)

b "Rongoteus ruista annoi."

c "Egres pavut, hernet, naurit loi, Kaalit, liinat ja hamput antoi."

d "Wironkannas kauran kaitsi. "

e Renvall 1826: I, 276.
} 
Metsästäjän ominta aluetta on kuitenkin hämärä metsän siimes, ja tällä alueella tunsivat muinaissuomalaiset parhaiten olevansa kotonaan. Tämä käsitys vahvistuu jo heidän mytologiastaan, sillä arvostetuimpia ja palvotuimpia kaikista maan jumalvoimista olivat ne, jotka hallitsivat metsää.

Metsän lukuisten ja mahtavien jumalten joukon johdossa seisoo niin kutsuttu Tapio, joka kuvataan vanhaksi mieheksi, jolla on tummanruskea parta ( halli-parta) ja päässään korkea havuhattu ja yllään naavaturkki. Hänen nimityksensä Tapio vaihtuu toisinaan Kuippanaksi, joka varsinaisesti merkitsee 'pitkäkaulaista' ja varmaankin viittaa Tapio-jumalan pituuteen. Korkean lakkinsa vuoksi häntä kutsutaan myös nimityksellä Hippa. Hänen tavallisimpiin epiteetteihinsä kuuluu tarkka 'huolellinen, tarkkaavainen' - epiteetti, joka tavataan liittää koko Tapion joukkoon siitä syystä, että kanssakäynti Tapion hallitsemien villien eläinten kanssa edellyttää suurinta mahdollista huolellisuutta ja tarkkaavaisuutta. Häntä kunnioitetaan varsin usein myös epiteeteillä metsän ukko, Tapiolan ukko, kummun ukko ja hiili ukko. Toisinaan hänelle annetaan lisänimiä, kuten maan isäntä, Tapion talon isäntä, metsän kuningas, korven kuningas, salon herra, maan pitäjä, anto-luoja 'lahjojen jakaja', luja jumala, suuri luoja, villan antaja jne. Kaikki nämä epiteetit todistavat siitä tavattoman suuresta palvonnasta, jota metsän hallitsijalle osoitettiin. Kuten tavallista, hän jakoi tämän palvonnan puolisonsa kanssa, jota useimmiten kutsutaan nimellä Mielikki, mutta jolla tavataan myös nimet Mimerkki, Miiritär, Simanter, Hiilitär (Gananderin mukaan). Hänen tavallisimpia epiteettejään ovat metsän emäntä, Tapion talon emäntä, metsän armas anti-muori, metsän metinen muori, Metsolan tarkka vaimo 'Metsolan valpas emäntä, metsän ehtoisa emäntä 'metsän suopea emäntä, metsän miniä jne. Häneen ei tietääkseni koskaan liitetä $u k k o a$ vastaavaa lisänimeä $a k k a$, vaan sen sijaan häntä nimitetään muoriksi ja jonkin kerran myös eukoksi. Tähän on syynä käsitys, joka ihmisillä oli Mielikistä: hän oli upea, herraskainen nainen (puhas muori) ja että hänellä oli kaunis ulkonäkö (muoto kaunis) - ominaisuuksia, joita ei voitaisi liittää [sanaan] akka. Mielikkiin liitetyt yksittäiset epiteetit eivät ole pysyviä, kuten on laita useimpien muidenkin suomalaisten jumaluuksien kohdalla. Epiteetit vaihtelevat monipuolisesti, ja niiden käyttö riippuu siitä, millä tavoin kyseiset jumaluudet kulloinkin esiintyvät 
suhteessa ihmiseen. Mikäli metsästäjä onnistui pyynnissään, oli Mielikki hyvä, suopea, rakastava ja kaunis katsella. Hänen käsiään koristivat kultaiset renkaat, sormissa hänellä oli kultaiset sormukset, päässä kultainen seppele, hiuksissa kultaiset nauhat, korvissa kultarenkaat, kulmilla helmiä ja jaloissa siniset sukat ja punaiset kenkänauhat. Mikäli metsästys ei sujunut toivotusti, hänet esitettiin rumana ja inhottavana olentona, joka kullan sijaan käytti käsirenkaissa, sormuksissa, seppeleessä, kaulanauhassa ja muissa koristeissa riisiä ja joka käytti heinäkenkiä ja ryysyisiä vaatteita ym. Mikäli metsästäjä anoi Mielikiltä onnea jahtiin, hän tapasi pyytää tätä heittämään pois surkean, kehnon ja ruman arkiasunsa ja pukemaan pyhävaatteensa, joita nimitetään hänen lahja-paidoikseen (anti-paiat). Hieno kullankimalteinen pyhäasu, jonka Mielikin sanotaan omistavan, liitetään toisinaan myös Tapioon ja kaikkeen Tapion väkeen (Kalevala, runo 14, säe 121-). Itse metsä käsitettiin toisinaan huonosti puetuksi ja tässä tapauksessa vastahakoiseksi metsästäjää kohtaan, toisinaan taas juhlallisesti koristetuksi ja sitä myöten suopeaksi. Tapio määräsi näin ollen metsämaita, mistä runo lausuu:

Metsän ukko halliparta, Metsän kultanen kuningas!

Pane nyt metsät miekka vyölle,

Salot kalpio kätehen;

Salot pannos palttinahan,

Metsät verkahan vetäös,

Haavat kaikki haljakkoihin,

Kuuset kultihin rakenna,

Vanhat hongat vaskivyölle,

Petäjät hopiavyölle,

Koivut kultakalkkaroihin.

Paa kun panit muinoselta

Sinun antiaikoinasi,

Minun pyytöpäivinäni;

Mentyä minun metsälle,

Ja salolle saatuani,

Korvelle kohottuani,

Mäen päälle päästyäni,

Kuuna paisto kuusen oksat,

Hopiana hongan oksat, 
Päivänä petäjän latvat, Haavan latvat haljakkoina; - -

(Vanha Kalevala, runo 7, säkeet 375-396.)

Sama kaksoiskäsitys, joka näkyy tässä, pätee myös kuvauksissa metsänjumalan asunnosta, jota kutsutaan nimityksellä Tapiola (sanasta Tapio) tai Metsola (sanasta metsä), myös Honkela (sanasta honka), Havu-linna, Lumi-linna, Sarvi-linna tai Metsän linna. Tavallisesti tämä asunto, jonka toisinaan sanotaan muodostuvan yhdestä, toisinaan useista kartanoista tai linnoista (Tapion talo tai linna, ja Tapion talot tai linnat), kuvataan varsin loisteliaaksi, ihanaksi ja mukavaksi, mihin sen nimityskin mieluisa Metsola viittaa. Siinä tapauksessa, että metsästäjän yritykset eivät johda toivottuun tulokseen, hän saattaa kuitenkin nähdä lumoavan Metsolan myös jokseenkin kehnona asuntona. Lemminkäinen lausuu huomanneensa metsästysmatkallaan metsässä kolme linnaa, yhden puisen, yhden luisen ja kolmannen, joka oli kivinen. Kivilinna oli herraskainen ja kaunis, kuusi kultaista ikkunaa loisti sen joka seinällä, ja siellä majailivat metsän jumalat ja jumalattaret, kun he ovat ystävällisellä päällä ja takasivat metsästäjälle saalista; mutta toisinaan he majailivat kehnommissa linnoissaan. (Näin käsitän tarkoitettavan Kalevalan vanhan laitoksen runossa 7, säkeet 318-326, joskin se on epäselvä ja uudessa laitoksessa kaikin puolin päinvastaisella tavalla ilmaistu.) Kalevalasta (runo 14, säkeet 91-94) käy ilmi, että niin kutsuttu Tapiola eli Metsola ja sen tietyt kartanot tai linnat, otaksuttavasti yhtäpitävästi esi-isiemme käytännön kanssa, sijaitsevat eteläpuolella mäkeä, jota [tässä yhteydessä] kutsutaan nimityksillä Tapio-vaara, myös Tuomi-vaara, Linna-vaara, Lumi-mäki tai Kytö-mäki. Se tarjoaa suojaa kylmiltä pohjoistuulilta. Tapion asunnon etu- eli eteläpuolella on laajoja korpia, ja sen ympärillä kasvaa pikku metsä.

Tapiolassa on lukuisia aarteita; ne on piilotettu tilavaan aittaan ( $\mathrm{Ta}-$ pion avara aitta), ja sen kuten muidenkin rakennusten kulta-avaimista huolehtii metsän emäntä, joka kantaa niitä renkaassa kupeellaan. Hänen huostaansa uskottuihin asioihin kuuluu muun muassa hunaja, metsän olut, jota Tapiolassa on ylenpalttisesti. Juuri hunajan vartijan ominaisuudessa metsän emännällä oli myös nimi Simanter (sanasta sima 'hunaja'). Hänen sanotaan säilyttäneen tätä ihanaa juomaansa 
lukitussa arkussa, jota kutsutaan runoissa hunaja-arkuksi (metinen arkku) tai hunajalippaaksi (mesi-lipas). Metsästäjä anoi häntä toisinaan avaamaan tämän arkun, joka oli mättäällä kultaisen mäen päällä, ja tuomaan hunajaa juotavaksi.

Tapiolan pääasiallinen rikkaus käsittää lukuisat, ympäri metsiä ja maita kuljeskelevat eläimet. Niitä käsitellään runoissa Tapion kartanon kotieläiminä, ja niiden pääasiallinen vartioiminen kuuluu niin Tapiolle itselleen kuin erityisesti hänen huomaavaiselle puolisolleen. Ilman heidän antamaansa lupaa ei ollut mahdollista tai luvallista ottaa saalista näistä laumoista, ja siksi metsästäjä tapasi yrittää suostutella metsän jumaluuksia ajamaan toivottua saalista hänen tielleen vilpittömin rukouksin ja lupauksin suurista uhreista. Lemminkäinen rukoilee eräällä metsästysmatkalla mahtavaa Tapio-jumalaa ottamaan avarasta aitastaan kultaisen nuijan (kultainen kurikka), vaskivasaran (vaskinen vasara) ja läiskimään sillä metsässä, jotta saalis pakenisi hänen luokseen (Vanha Kalevala, runo 7, säe 399-). Hän rukoilee yhtä lailla metsän muitakin jumaluuksia olemaan häntä kohtaan avuliaita kukin omalla paikallaan ja ajamaan metsän eläimet hänen tielleen.

Metsänjumalten suojeluksessa eivät olleet pelkästään villieläimet, vaan myös kesyjen eläinten uskottiin nauttivan heidän suojeluaan. Agricolan mukaan suomalaiset palvoivat tiettyä jumaluutta nimeltään Kekri, Käkri tai Köyry, jonka uskottiin huolehtivan kesyjen eläinten kasvusta ("Käkri se liseis karjan kasvon"); tästä jumalolennosta runot eivät kuitenkaan tiedä kertoa mitään. Kekri-jumalan olemassaoloa ei voida silti miltään osin epäillä, sillä hänen nimensä elää yhä perinteissä, ja suomalaisten tiedetään jopa pitäneen hänen kunniakseen pyhäinmiestenpäivän aikaan juhlia, joita yhä tänä päivänä kutsutaan kekriksi. On joka tapauksessa epävarmaa, mikä tehtävä oli uskottu tälle jumalalle. Lencqvist esittää, että myös Kekrin uskottiin suojelevan maanviljelystä, sillä hänen juhlansa sattuu siihen aikaan kun sato korjataan ja kannetaan sisään. Kuinka tämän asian laita onkin, ainakin on varmaa, että myös Tapiolan jumalpiirin uskottiin antavan kotieläimille suojaa niin silloin, kun ne pysyttelivät katon alla, kuin eritoten kesällä, kun ne kuljeskelivat ympäri metsiä ja etsivät ravintoa Tapiolan mailla. Tästä todistaa muun muassa rukous, jonka Ilmarin emäntä osoittaa Tapiolle, kauniille jumalalle, vakaalle luojalle (kaunoinen jumala, vakainen luoja), ja metsän muille jumalvoimille päästäessään 
kotieläimensä irralleen. Tämä rukous tavataan Kalevalassa (runo 32, säe 49-), ja se sisältää muun muassa seuraavaa:

Katso kaunoinen jumala,

Varjele vakainen luoja,

Varjele vahingon tieltä,

Kaitse kaikista pahoista,

Ettei tuskihin tulisi,

Häpeihin hämmentyisi!

Kuin katsoit katollisessa,

Alla varjon vartioitsit,

Niin katso katottomassa,

Vaali vartiattomassa,

Jotta karja kaunistuisi,

Eistyisi emännän vilja

Hyvän-suovan mieltä myöten,

Pahan-suovan paitsi mieltä!

Se suuri joukko villejä ja kesyjä eläimiä, joka kuljeksi ympäriinsä metsissä, johti suomalaiset melko luonnollisesti siihen käsitykseen, että Tapio-jumala ja hänen puolisonsa eivät yksinään voineet pitää riittävän tarkasti silmällä niitä kaikkia. Jokaisen kunnon isännän ja emännän tavoin heidän oli huolehdittava omaisuudestaan poikiensa ja tyttäriensä sekä palvelijoiden ja palvelijattarien avulla. Koko tämä väki luettiin yhteisellä nimityksellä Tapion väeksi, mutta sen lisäksi mainitaan runoissa usein Tapion pojat, Tapion neiet tai piiat, metsän immet ja viljan eukot 'saaliin emännät, jumalattaret'. Naispuolinen osa metsän jumalan ja jumalattaren palvelusväestä kantaa myös nimeä luonnottaret, luonnon tyttäret, mikä käy ilmi Kalevalasta (runo 32, 76-82), missä Ilmarin emäntä lausuu Tapiolle ylläkin siteeratussa runossa:

\footnotetext{
Työnnä luonnon tyttäriä

Minun viljan viitsiäksi,

Katsojaksi karjan kaiken!

Paljo on piikoja sinulla,

Saoin käskyn kuulioita,

Eläjiä ilman alla,

Luonnottaria hyviä.
} 
Olen yllä huomauttanut, että ilman luonnottaret käsitettiin taivaallisen Ukon palvelushengiksi, ja sama käsitys pätee myös viittauksissa luonnon tyttäriin, joiden majapaikka oli metsässä. Ero on ainoastaan siinä, että kun ilmassa heitä on kolme, on metsässä luonnottaria lukematon määrä. Todisteen tästä tarjoaa, vasta käsiteltyjen runonsäkeiden lisäksi, seuraava Lemminkäisen lausahdus Tapiolan emännälle:

Et emäntä lienekänä,

Jos et piikoa pitäne,

Sata piikoa pitäne,

Tuhat käskyn kuuliata,

Karjan kaiken kaitsiata,

Viitsiätä viljan kaiken.

Tapiolan isännän ja emännän hallintaan taipuvista metsän olennoista useimmat ovat naispuolisia, minkä perusta on epäilyksettä siinä, että metsän jumaluudet haluttiin käsittää hyväsydämisiksi ja suopeiksi luonnoltaan. Monet näistä jumaluuksista on nimetty erikseen, mutta Tapiota lukuun ottamatta vain yhdellä on miehen nimi. Tämä on Tapion poika, Nyyrikki tai Pinneys nimeltään. Hänet kuvataan siistiksi, puhtaaksi ja koreaksi mieheksi (mies puhas), joka kulkee pukeutuneena siniseen viittaan (sini-viitta) ja pitää päässään Tapion tavoin korkeaa lakkia, joka on toisinaan sininen, toisinaan punainen väriltään. Häntä rukoillaan lyömään puihin merkkejä, jotta metsästäjä ei eksyisi jäljittäessään riistaa metsäisillä tai mäkisillä seuduilla. Vastaavasti häntä pyydetään tekemään kesälaitumella olevalle karjalle siltoja upottaviin, märkiin kohtiin.

Metsänjumalan naispuoliseen lähipiiriin kuuluu hänen vaimonsa lisäksi niin kutsuttu Tellervo, myös Hillervo, jota tavallisesti kutsutaan nimityksellä Tapion neiti eli 'metsän tytär' (tyttö), mutta jonkin kerran hänet sekoitetaan Mielikkiin, jolloin häntä kutsutaan Tapion vaimoksi (Kalevala, runo 46, säkeet 57 ja 58). Hänellä on täyteläiset ja pyöreät muodot, hänen hiuksensa ovat kullankeltaiset, ja hänen asunsa käsittää kevyen paidan jossa on hieno helma (utu-paita, hienohelma). Hänen varsinainen velvollisuutensa on vahtia Tapiolassa metsän emännän karjaa, mutta häntä rukoillaan myös huolehtimaan kesystä karjasta, joka päästetään kesälaitumelle. Muun muassa Ilmarin 
emäntä rukoilee, että Tellervo antaisi hänen elukoilleen rujojen kalojen ja kauhistuttavien olentojen ulkomuodon, jotta metsän villieläimet eivät uskaltaisi napata niitä ja myös, että hän auringon laskiessa ajaisi ne terveinä ja hyväkuntoisina kotiin.

Toinen metsän piioista on Tapion tytär, ihana Tuulikki. Myös hänellä on paimenen tehtävät hoidettavinaan, sillä hän hoitaa Tapion karjaa, ja häntä anottiin suomaan metsästäjälle riistaa. Lemminkäinen osoittaa hänelle seuraavan rukouksen:

Metsän tyttö, mieli neiti,

Tuulikki tytär Tapion!

Aja vilja vieremille,

Aukeimmille ahoille;

Kun lie jäykkä juoksullehen,

Eli laiska laukallehen,

Ota vitsa viiakosta,

Koivu korven notkelmosta,

Jolla kutkutat kuvetta,

Sekä kaivat kainaloita;

Anna juosta joutuisasti,

Vikevästi viiletellä

Miehen etsivän etehen,

Aina käyvän askelille!

Kuin vilja uralle saapi,

Tupita uroa myöten,

Pane kaksi kämmentäsi

Kahen puolen kaiteheksi,

Jott' ei vija vieprahtaisi,

Tie-puolehen poikeltaisi;

Josp' on vilja vieprahtavi,

Tie-puolehen poikeltavi,

Tielle korvista kohenna,

Saata sarvista uralle!

Hako on tiellä poikkipuolin,

Sepä syrjähän syseä,

Puita maalla matkallansa,

$\mathrm{Ne}$ on katkaise kaheksi!

Aita vastahan tulevi,

Kaa’a aita kallellehen,

Viieltä vitsas-väliltä

Seitsemältä seipähältä! 
Joki joutuvi etehen,

Puro tielle poikkipuolin,

Silkki sillaksi sivalla,

Puna-verka portahaksi,

Saata poikki salmistaki,

Vetele vesien poikki,

Poikki Pohjolan joesta,

Yli kosken kuohuloista!

(Kalevala, runo 14, säkeet 173-212.)

Tapion piikojen joukkoon kuuluu myös metsän piika, jolta puuttuu henkilökohtainen nimitys. Hänet kuvataan hyvin pieneksi kooltaan (pikkarainen) ja häneen liitetään usein nimitys sima-suu 'hunajasuu', sillä hänen uskottiin nauttivan hunajaa juomakseen metsän muiden jumaluuksien tavoin. Paimenen ominaisuudessa hänellä oli huilu, jota kutsutaan sima-pilliksi 'hunajapilli, hunajahuilu', ja tätä hänen uskottiin käyttävän vaelluksillaan metsässä. Runossa metsästäjä rukoilee häntä puhaltamaan tällä samalla pillillä metsänemännän korvaan, jotta tämä heräisi unestaan, kuulisi metsästäjän rukoukset ja lähettäisi saalista. Lisäksi hänen kuten useimpien muidenkin metsänjumaluuksien tehtäviin katsottiin kuuluvan seipäiden pystyttämistä ja puiden merkitsemistä metsästäjän opastukseksi.

Metsänjumalana Tapion uskottiin määräävän myös jumalolentoja, jotka huolehtivat hänen hallussaan olevista puista. Myös nämä ovat naisellisia luonnoltaan, ja heidän joukostaan mainitaan Kalevalassa Tuometar 'tuomipuun suojelusjumalatar' (sanasta tuomi), jota kutsutaan Tapion tyttäreksi, Hongatar 'männyn hallitsijatar' (sanasta hon$k a$ ), jota nimitetään hyväksi emännäksi tai erämaan emännäksi (salon emäntä), Katajatar, kaunis neiti, 'katajan suojelijatar' (sanasta kataja), Pihlajatar, pieni piika, 'pihlajan suojelijatar' (sanasta pihlaja). Kaikkia näitä jumaluuksia rukoillaan huolehtimaan laitumella olevista kotieläimistä ja tarjoamaan niille runsaasti lehtiä syötäväksi.

Käsiteltyjen lisäksi Agricola, Lencqvist ja Ganander luettelevat vielä joitakin muitakin metsänjumaluuksia, joista runot joko antavat hämäriä tietoja tai eivät anna tietoja lainkaan. Yhtä niistä kutsutaan nimityksellä Käitös, ja hänen sanotaan kaitsevan kesyjä kotieläimiä metsässä. Toisen nimi on Nyrkkes eli Nyrkes, ja hän majailee kuusikoissa ja häntä rukoillaan suomaan metsästäjälle oravia. Kolmannen 
nimi taas on Hittavanin eli Hittavainen, ja hän määrää jäniksistä ja ajaa niitä saaliiksi metsästäjälle. Neljännen [nimi on] Käreitär, kettujen emäntä ja lahjoittaja. Ganander nimeää myös "metsänjumalan" nimeltään Lemmes, leppien isä, ja jumalattaren nimeltään Kati, joka "kasvattaa puita metsässä" ja jolla on sen vuoksi epiteetti puiden emuu. Renvallin mukaan Kati (sukua sanalle kadet 'kateus') merkitsee pahaa kateudenhenkeä. ${ }^{44}$

Jätän tähän kysymyksen siitä, missä määrin kaikki nämä nimet ovat autenttisia, sillä suomalainen mytologia hukkuu jumalnimiin, joista jotkin ovat enemmän tai vähemmän merkityksettömiä. Pääasia on, että ymmärrämme oikein suomalaisen mytologian luonteen, ja sitä varten haluan vielä muistuttaa siitä, että jokaisella kohteella luonnossa katsottiin olevan suojelusjumala, haltia - olento, joka on sen luoja ja huolehtii sen olemassaolosta. Kuten olen jo useasti maininnut, nämä haltiat eivät kuitenkaan ole sidottuja yksittäiseen, rajalliseen kohteeseen, vaan ne ovat vapaita, persoonallisia olentoja, jotka liikkuvat itse ja joilla on muoto ja henki, sielu ja ruumis. Niiden olemassaolo ei myöskään riipu yksittäisistä kohteista, sillä kuten luonnossa ei ole mitään, millä ei ole suojelusjumalaa, ei myöskään haltian toiminta ole kiinnittynyt yhteen ainoaan yksilöön, vaan ulottui sen koko sukuun tai lajiin ${ }^{45}$. Jokaisella pihlajalla, kivellä ja talolla on tiettävästi oma haltiansa, mutta samat haltiat huolehtivat myös muista pihlajista, taloista ja kivistä. Tietty pihlaja, kivi tai talo voi lopulta kadota, mutta niiden haltiat pysyvät hengissä ikuisesti niiden suvussa. Tällainen oli siis suomalaisten yleinen käsitys jumalolennoista, jotka jakautuvat mahtavampiin ja vähemmän mahtaviin jumaluuksiin. Edelliset esitettiin tavallisesti kuninkaina, isäntinä ja emäntinä, hallitsijoina ym., jälkimmäiset taas heidän auliina palvelijoinaan ja palvelijattarinaan.

Olen maininnut, että tämä käsitys jumalista ei ole vanhin ja alkuperäinen suomalaisten mytologiassa vaan että he ovat varhaisempana aikakautena palvoneet luonnonkohteita aistittavissa olevassa hahmossaan. Tällaista palvontaa he ovat osoittaneet myös metsälle joko kokonaisuudessaan tai osille siitä, mutta aina persoonallisena hahmona. Tästä voidaan löytää monia todisteita runoista. Esimerkiksi Kalevalan vanhassa laitoksessa (runo 7, säkeet 242 ja 243) sanotaan: "Lepy lehto, kostu korpi, taivu ainoinen Tapio", ja myös säkeissä 246248: "Ota metsä mieheksesi, urohoksesi Tapio, korpi kolkki-pojaksesi". 
Ja pian seuraavaksi (säkeet 249-254) metsästäjä osoittaa metsälle seuraavan rukouksen:

Soita metsä kanteletta,

Kukuta salo käkeä!

Jotta kulta kuunteleisi,

Hopia tilin tekisi

Alla kuusen kultalatvan

Alla kaunihin katajan.

Germaanisten kansojen tavoin myös suomalaiset palvoivat muinoin tiettyjä pyhiä lehtoja ja puita, ja sukulaiskansojemme parissa metsän palvonta on tavallisinta juuri tässä muodossa. Samojedeilla, ostjakeilla ja monilla muilla Siperian paimentolaisilla on tuskin mitään käsitystä mistään persoonallisesta jumalolennosta, joka hallitsisi metsää, mutta missä hyvänsä he autioilla tundrillaan löytävätkin pienen lehdon, jossa on lehtikuusia, kuusia jne., he osoittavat sille palvontansa ja pystyttävät sinne jumalkuvansa. Tämäntyyppiset pyhät paikat ovat vastaavasti hyvin tavallisia tšeremissien, tšuvassien ja mordvalaisten keskuudessa, ja he kutsuvat niitä nimityksellä keremet. Votjakit palvovat niitä nimityksellä $l u d .{ }^{\text {a }}$ Tulemme myöhemmin osoittamaan tälle aiheelle erityistä huomiota, mutta nyt riittää todeta yleisesti, että kulttuurin kehitystiellä vähemmän edenneiden sukulaiskansojemme parissa vallitsee pääasiassa aistittavan luonnon palvonta. On kuitenkin myös monia sellaisia kansoja, jotka liittävät metsään persoonallisen jumalolennon. Tällainen olento on tunguuseilla Mo eli Ogon Molgoro, ${ }^{\mathrm{b}}$ tšeremisseillä Wadaš, ${ }^{c}$ votjakeilla Palas murt tai Alida ${ }^{\mathrm{d}}$ ja ostjakeilla Meang (Ermanin mukaan Meik) jne. Itse asiassa olen kuullut lähes kaikkien suomalaisten ja heidän sukulaisheimoistaan ainakin niiden, joiden luona olen vieraillut, puhuvan jostakusta mahtavasta metsänjumalasta, joka kuvataan kuitenkin vedenhengen tapaan pahaksi ja kauhistuttavaksi olennoksi. Muun muassa samojedit ovat

\footnotetext{
Georgi 1776-1780, 58.

Georgi 1775, 276.

Georgi 1776-1780, 34.

Georgi 1776-1780, 59.
} 
antaneet tällaisen kuvauksen Parnesta ${ }^{46}$, jonka he yhdistävät venäläisten Lesovoihin [Лесовой]. He sanovat:

Parne on ilkeä olento, joka elää syvällä metsässä ja seuraa ihmisiä. Hänellä on pelkästään kolme sormea käsissään, mutta sormissa on terävät kynnet, joilla hän raatelee hengiltä jokaisen, joka joutuu hänen valtaansa. Hän syö kaikki uhrinsa. Hänellä ei ole telttaa, poroja eikä vaatteita. Hän kulkee aina jalan ja hän on vahva juoksija. Hänellä ei ole vaimoa vaan uskottu toveri, joka seuraa häntä minne hän meneekin.

Tätä hirveää metsänhenkeä vastaa lähinnä suomalaisen mytologian Hiisi. ${ }^{47}$ On oletettu, että Hiisi ja hiidet ovat olleet historiallinen kansa, ${ }^{48}$ joka on kenties muodostanut Suomen aborigines [lat. 'alkuperäisasukkaat'] - tähän oletukseen on tosiasiassa joitakin perusteitakin, mutta sitä ei miltään osin voi pitää todistettuna. Runoissa Hiisi merkitsee säännöllisesti pahaa, pahantahtoista, kauhistuttavaa jumaluutta. Häntä kutsutaan nimityksellä mies häiy ('häijy mies'), ja hänen sanotaan yhdessä Syöjättären kanssa synnyttäneen käärmeet. Hänellä uskotaan olevan kätensä kaikessa pahassa, jota maailmassa ilmenee. Kun Pohjolan tyttö kehottaa Väinämöistä veistämään hänelle veneen, on Hiisi heti käsillä, kajoaa kirveeseen ja aiheuttaa haavan Väinämöisen polveen. Hiiden katsottiin lähettävän ihmisille vaikeimmat vitsaukseet ja sairaudet, ja jokaista sellaista tämän vihatun jumalan lahjaa nimitettiin Hiiden heitoksi. Kaiken pahan persoonallistumana Hiisi esiintyy runoissa usein kuvaannollisessa merkityksessä merkiten 'pahaa olentoa ylipäätään'. Ollessaan vangittuna vanhan Vipusen vatsaan Väinämöinen lausuu huolissaan: "Jo taisi tuhoni tulla, hätä-päivä hämmenteä, tämän Hiien hinkalossa, tämän Kalman karsinassa." ${ }^{49}$ Vipunen puolestaan antaa vatsaansa pistelevälle Väinämöiselle nimityksen Hiisi. Käsitys Hiiden pahasta luonteesta näkyy myös siinä, että sanaa hiisi käytetään suomen kielessä usein kirosanana, esim. Oi Hiisi 'voi pahus', mene Hiiteen 'painu tiehesi', jne. Modernimmassa käsityksessä yhdistyy Hiisi usein kristittyjen helvettiin, ja tämän pohjalta muun muassa runot puhuvat Hiiden hiilistä (Hiien hiilet), Hiiden hehkusta (Hiien hiilos), Hiiden hiili-seipäistä ja hiili-kangasmaista (Hiien hiili-seiväs, hiili-kankaat), Hiiden padasta (Hiien pata) jne.

Pahoine ja kauhistuttavine luonteineen Hiittä pidettiin ominaisuuksiltaan ylivoimaisen vahvana, mahtavana ja kauhistuttavana 
olentona, ja nämä samat ominaisuudet liitetään runoissa kaikelle, mikä on Hiiden hallinnassa. Kun Lemminkäinen haluaa ylistää hyvää, terävää miekkaansa, hän sanoo sen olevan teroitettu Hiiden luona. Kun Joukahainen haluaa saada haltuunsa hyvän jousenjänteen ampuakseen Väinämöisen, hän käyttää siihen Hiiden hirven jänteitä. Tämän hirven pyydystäminen kuuluu vaikeimpiin tehtäviin, joita Pohjolan emäntä pystyy asettamaan Lemminkäisen tehtäväksi edellytyksenä tyttärensä käden saamiseksi. Väinämöinen valmistaa kielet harppuunsa Hiiden villin hevosen vahvoista harjaksista. Sanotaan, että tämän hevosen suusta ja sieraimista lentää kipunoita ja että sen kaviot ovat terästä. ${ }^{a}$ Hiiden koirat ja kissat ovat villejä luonnoltaan tai kuten Ganander ${ }^{\mathrm{b}}$ asian ilmaisee: "vihaista sukua ja samankaltaisia kuin isäntänsä.”

Pahana, mahtavana ja kauhistuttavana jumaluutena Hiittä kutsutaan runoissa usein nimityksellä Paha tai Paholainen, Juutas, Piru tai Pirulainen, Lempo, jotka ovat pahoja ja samanmerkityksisiä jumaluuksia. Näistä tosin Paha eli Paholainen sekä Juutas (Juudas) ovat kristinuskosta otettuja käsitteitä ja Piru samaten kuin Perkele on lainattu indogermaanisten kansojen mytologiasta, samaten kuin slaavilainen Perun (Piorun, Peraun), liettualainen Perkunas, lättiläinen Pehrkhors jne. Lempo sitä vastoin on suomalaisessa mytologiassa kotoperäinen sana, joka merkitsee ainakin Kalevalan runojen ja perinteen todistuksen perusteella 'pahuuden edustajaa' yleisemmässä merkityksessä. Hiidellä ei ole ollut tätä merkitystä alkuperäisenä käsitteenä, vaan sillä ymmärretään, kuten olen aiemmin maininnut, varsinaisesti 'pahaa metsänjumalaa'. Jo Agricola esitti, että Hiiden käsitettiin majailevan metsässä, joskin hän erehtyy Hiiden olennosta liittäessään tähän saaliin suomisen, joka on Tapiolle kuuluva tehtävä. Agricolan runon kääntäjä on korjannut tämän virheen kirjoittaessaan Agricolan Hiisi metselest soi voiton (varsinaisesti: 'Hiisi antoi voiton metsistä) tällä tavoin: Hisis presequitur tristeis ursosque luposque. ${ }^{50}$ Todisteena näkemykselleni Hiiden majapaikasta metsässä on myös se seikka, että Kalevalassa (runo 14, säkeet 241-242) Tapion vaara ja Hiien linna

a Toisessa runossa kerrotaan, että Väinämöinen olisi tehnyt kielet harppuunsa Hiisi-neidon palmikoista.

b Ganander 1789, 13. 
käsitetään synonyymisinä ilmauksina. Lisäksi Hiiden asuntoa, vastamainittua Hiien linnaa tai Hiitolaa, jota kutsutaan myös nimityksellä Vuori tai Tanikan linna, kuvataan syvien erämaiden, korkeiden vuorten ja hämyisten tunturien ympäröimäksi. Runoissa puhutaan myös Hiien pelloista, Hiien nurmista, Hiien hevosesta, Hiien härästä ym. jotka eivät sovi kovin hyvin metsämiehen elämään. Useammin onkin kyse Hiiden erä- tai hirsimetsästä (Hiien korpi, Hiien hirsikangas) jne. Hiiden ajateltiin erityisesti viihtyvän hämyisillä vuoriseuduilla, minkä vuoksi häntä kutsuttiin nimityksellä Vuoren ukko, ja Suomessa kutsutaan monia vuoria hänen mukaansa nimityksellä Hiiden vuori. Vastamainittu käsitys Hiiden mieltymyksestä vuorisiin metsäseutuihin selittää myös epämääräisiä puheita Hiien-linnoista. Näihin kohteisiin liittyvä traditio on osaltaan johtanut hypoteesiin, jonka mukaan Hiiden väki on todella olemassaollut kansa. Omasta puolestani pidän toistaiseksi näitä Hiiden linnoja luonnollisina maanmuodostumina, ${ }^{\mathrm{a}}$ ja Hiiden väellä on minulle sama myyttinen merkitys kuin Tapion väellä, veen väellä jne.

En jätä mainitsematta, että runot erottelevat tiettyjä Hiiden tyyppejä, kuten Vesi-Hiisi, Vuori-Hiisi ja Metsän Hiisi. ' Tämä erottelu vahvistaa aiemmin esittämääni kantaa, että Hiidellä on suomalaisessa mytologiassa merkitys 'pahana olentona ylipäätään'. Koska tämä sana merkitsee kuitenkin myös pahaa metsänjumalaa, ei ole epäilystä siitä, että jälkimmäinen merkitys on konkreettisempana alkuperäinen. Käsitteet Metsän Hiisi, Vesi-Hiisi jne. ovat luonnollisesti kehittyneet sen jälkeen, kun Hiiteen on liitetty yleinen, abstrakti merkitys.

Hiisi-sanaan liitetyistä tarkoitteista haluan sanoa, että tätä sanaa käytetään sanan Hiitola tavoin usein merkitsemään Hiisi-jumalan kotia tai asuntoa, mikä näkyy yllä käsitellystä ilmaisusta mene Hiiteen. Hiiden deminutiivimuotoja ovat Hiito, Hiitto ja Hitto. Renvallc ei tunne näille muuta merkitystä kuin 'Hiiden koti', mutta myös tässä muodossa Hiidellä on persoonamerkitys, kuten Topeliuksen teoksessa Wanhoja Runoja ([Topelius 1822-1831, V]: 33): Eipä Hiitto,

a Suomalainen perinne kertoo myös Hiiden kiukaista ja Hiiden pesistä, mutta ne ovat ainakin suurelta osin lappalaisten muinaisjäänteitä.

b Ganander 1789, 14.

c Renvall 1826: I, 73. 
tiennytkähän. Lappalaisten mytologiassa tavataan Hiisi muodossa Hita, mutta sitä käytetään Lindahlin ja Öhrlingin ${ }^{a}$ mukaan pelkästään kirosanana.

Hiittä käytetään henkilömerkityksessä usein monikossa muodossa Hiidet tai Hiiet viittaamaan Hiiden koko sukuun, jota kutsutaan myös nimityksellä Hiiden tai Vuoren väki. Tähän sukuun kuuluviksi mainitaan Hiiden itsensä lisäksi hänen pieni poikansa (Hiien poika pikkarainen) ja hänen tyttönsä (Hiien impi). Koska kaikki nämä olennot ovat pahoja, kauhistuttavia ja ihmisten vihaamia, muinaissuomalaiset rukoilivat niitä äärimmäisen harvoin. Kun näin joskus kuitenkin tapahtui, on tarkoitus suurelta osin ollut heidän avullaan rankaista rikollisia, erityisesti varkaita, tai aiheuttaa viholliselle onnettomuus, tehdä hänestä "kuuro, sokea, vapiseva ja monien sairauksien vaivaama". Toisinaan näyttää Hiiteen vedotun, kun on ollut kyse vaivojen, vammojen tai sairauksien karkottamisesta. Tällöin šamaani pyytää joko hänen kattilaansa, jolla keittäisi ja pysäyttäisi haavasta vuotavan veren, tai hänen nopeaa hevostaan ja keveitä suksiaan tehdäkseen näillä välineillä nopean matkan pahojen vaivanhenkien ${ }^{51}$ luokse.

Hiiden yhteydessä tuon esiin myös toisen pahan ja kauhistuttavan olennon, jonka ajateltiin majailevan metsien siimeksessä. Häntä kutsuttiin nimityksellä Ajatar. Kuten sanan pääte paljastaa, tämä oli naispuolinen jumaluus. Hänen ominaisuuksiinsa kuului johtaa metsästäjät ja metsämiehet eksyksiin, minkä vuoksi häntä kutsutaan Ajattareksi - sana merkitsee etymologiansa perusteella 'ajajatarta' (sanasta ajaa). Runoissa häntä ei tietääkseni mainita koskaan. Sitä vastoin runot käsittelevät muutaman kerran pahaa olentoa nimeltään Horna tai Worna, ${ }^{c}$ joka näyttää kuuluneen myös metsään. Tämän lähemmin häntä ei kuitenkaan opi tuntemaan runojemme pohjalta. Ainoa kuvaus, joka tähän suuntaan viittaa, on maininta siitä, että Joukahainen tunsi puut Pisa-mäellä ja hongat Hornan kalliolla. Sitä vastoin Hornaa käytetään nykyisessäkin kansankielessä kirosanana monissa muodoissa, mikä näyttäisi osoittavan, että Horna oli ainakin paha olento.

a Lindahl \& Öhrling 1780, 70.

b Ganander 1789, 14.

c Helsingfors Morgonbladissa 1845, nrot 12-14, kerrotaan hävytön tarina Wornasta, jossa hänet kuvataan naistenryöstäjänä. 
Olen lyhyesti yrittänyt selvittää maahan liittyviä jumaluuksia, joiden tehtävät muinaissuomalaisten käsitysten mukaan koskivat orgaanisen luonnon kahta suurta sfääriä: eläin- ja kasvikuntaa. Epäorgaanisessa luonnossa emme tapaa yhtään merkittävämpää jumaluutta, eikä tätä voi odottaakaan, sillä mikäpä siellä voisi vetää puoleensa luonnonihmisen aistien valppautta? Korkeat vuoret, suuret kalliot, oudot kivet voivat tietenkin herättää hänessä hämmästystä, ja tiedetään, että suomalaiset ennen muinoin osoittivat niille palvontaa, kuten monien sukukansojen kohdalla on laita yhä tänä päivänä. Koska niillä on kuitenkin vain epämääräinen vaikutus ihmisen onneen tai onnettomuuteen ja koska ne tuovat hänelle harvoin menestystä tai vahinkoa, niiden palvonta on ollut merkitykseltään vähäistä. Ainakaan suomalainen mytologia ei tunne yhtään mahtavampaa jumalaa, jolle olisi uskottu epäorgaanisen luonnon kohteiden hallitseminen. Ganander ${ }^{a}$ on esittänyt, että Kimmo tai Kammo olisi hallinnut kiviä, ja myös Kalevalassa (runo 40, säe 48) anotaan Kimmoa, jota tässä kutsutaan Kammon pojaksi, murskaamaan kivi vedessä; mutta käytettävissä oleva materiaali ei pysty kertomaan hänestä mitään luotettavaa. Tämän jumaluuden on joka tapauksessa täytynyt olla vähämerkityksinen, koska Agricola ja Lencqvist eivät tunne hänen nimeään ensinkään. Sama koskee vielä suuremmassa määrin niin kutsuttua Karilaista, joka Gananderin ${ }^{\mathrm{b}}$ mukaan olisi ollut karikoiden hallitsija.

Siirrymme nyt ulkoisesta maailmasta ihmiseen itseensä ja käymme jäljittämään niitä harvoja ja merkityksettömiä jumalolentoja, joiden katsottiin suuntaavan tahtonsa ja aikomuksensa ihmisiin. Kaikilla jumaluuksilla on tietenkin suurempi tai vähäisempi vaikutus ihmisten oloihin, mutta niiden joukossa on joitakin, joiden kaikki tehtävät on sidottu ihmiselämään. Näillä jumalilla ei ole silti mitään tekemistä ihmisen ylemmän, henkisen tai yliaistillisen luonnon kanssa, vaan ne vaikuttavat ihmiseen pelkästään luontokappaleena. Viisaus tai laulu, hyve tai oikeus eivät ole saaneet suomalaisessa mytologiassa suojelijaa jumalten joukosta; jumalat huolehtivat ainoastaan ihmisen maallisista ja ajallisista tarpeista.

\footnotetext{
a Ganander 1789, 39.

b Ganander 1789, 39.
} 
Kyseisellä [ihmisten] alueella ovat ylimpinä jumaluudet, jotka valvovat ihmisen luonnollisia viettejä. Tällainen on niin kutsuttu Sukkamieli, naispuolinen olento, jota Lencqvistin ${ }^{a}$ mukaan rakastavaiset rukoilivat sytyttämään rakkauden liekin rakkautensa kohteen sydämeen, mutta Gananderin ${ }^{\mathrm{b}}$ mukaan hänen uskottiin "istuttavan eripuran rehdin kansan keskuuteen”. Nähtävästi Ganander perustaa väitteensä käytössä olevaan ilmaisuun kävellä mustin sukin, so. 'olla mustasukkainen'; todellisuudessa on kuitenkin vaikea sanoa, mikä yhteys Sukkamielellä on tähän ilmaisuun. Sanana sukkamieli merkitsee kirjaimellisesti 'henkilöä, joka rakastaa sukkia'. Sukka on sileä ja pehmeä asia, ja rakkaudenjumalatar nimettiin Sukkamieleksi, koska hän huolehti hauraimmista ja herkimmistä sydämen tunteista. Sukkamielen olemus rakkaudenjumalattarena tulee selvimmin näkyviin sekä Lencqvistin että Gananderin siteeraamasta runosta, jossa sanotaan:

Sukkamieli mielen käändäjä,

Mesilläs tuon mieli haudo,

Haudo mieli mielettömän,

Armahani armottoman.

Myöhempinä aikoina kerätyissä runokokoelmissa Sukkamieltä ei, huomattavaa kyllä, mainita koskaan, ja myös perinteessä hän on lähes tyystin tuntematon. Tämän perusteella näyttäisi siltä, etteivät muinaissuomalaiset yleisesti tunteneet tai palvoneet tätä jumaluutta vaan että hän on saattanut saada paikan suomalaisessa mytologiassa vasta myöhemmällä ajalla. Tämä olettamus saa tukea siitä seikasta, että sukka ei ole kotoperäinen suomen kielen sana vaan lainattu indogermaanisista kielistä. Ehkäpä tätä jumaluutta merkittiin alun perin sanalla lempi, joka nykyaikaisessa kielessä merkitsee rakkautta, mutta jolla on toisinaan runokielessäc persoonallisen jumaluuden merkitys. Toisaalta sanan lempi deminutiivimuoto on lempo, jonka esitin yllä viittaavan tavallisesti pahaan, Hiiden ja Pirun kanssa identtiseen

\footnotetext{
Lencqvist 1782, 47.

Ganander 1789, 87.

c Lönnrot 1829-1831: I, 31-33.
} 
jumalvoimaan. Sanan tämä merkitys ei luultavasti ole kuitenkaan alkuperäinen, vaan sanan etymologian perusteella on oletettava, että Lempo on ennen muinoin viitannut rakkaudenjumalaan. Rakkaus kuvataan runoissamme toisinaan villiksi, vihaan liittyväksi, jonkin pahan noidan ihmisessä herättämäksi intohimoksi, ja siksi on helppo nähdä, kuinka Lempo on suomalaisessa mytologiassa saanut nykyisen merkityksensä pahana jumalolentona. Ihmisten muiden luonnollisten viettien joukosta personifioidaan toisinaan myös uni (demin. unonen), joka esiintyy ystävällisenä ja suopeana jumaluutena. Tästä saatetaan erottaa Untamo (sanasta uni), jota toisinaan rukoillaan selittämään unia (Kalevala, runo 5, säe 17-). Nimeä Untamo kantaa lisäksi Kalevalassa yksi Kalervon pojista, ja toisinaan sillä merkitään myös Pohjolaa nimityksellä Untamola. Untamon vaihteleva käyttö johtuu siitä, että sanan alkuperäinen merkitys on joutunut ajan kuluessa unohduksiin. Tämä huomio koskee myös monia muita nimiä muinaisissa runoissamme.

Muinaissuomalaiset palvoivat myös erityisiä jumaluuksia, joiden uskottiin vaikuttavan ihmisten terveydentilaan. Ganander ${ }^{a}$ nimeää heidän joukostaan Munnun, jonka uskottiin antavan apua silmäsairauksiin, ja Lemmaksen, naispuolisen jumaluuden, joka paransi haavoja ja lievensi niiden korvennusta. Runot osaavat kertoa heistä vain vähän jos lainkaan, mutta noitalauluissa mainitaan melko usein naispuolinen jumaluus Suonetar (sanasta suoni), jonka uskottiin kehräävän jänteitä ja suonia. Mikäli ne olivat syystä tai toisesta vaurioituneet, käännyttiin Suonettaren puoleen ja rukoiltiin uusia, jotka hän pistäisi ihmisvartaloon turmeltuneiden tilalle. Hänen tukeaan anottiin seuraavin sanoin:

Sorea on suonten vaimo,

Suonetar sorea vaimo,

Soma suonten kehreäjä

Sorealla kehrinpuulla,

Vaskisella värttinällä,

Rautaisella rattahalla;

Tule tänne tarvittaissa,

Käy tänne kutsuttaessa,

a Ganander 1789, 48, 60. 
Suoni-sykkyrä sylissä,

Kalvo-kääri kainalossa,

Suonia sitelemähän,

Päitä suonten solmimahan

Haavoissa halennehissa,

Rei’issä revennehissä!

(Kalevala, runo 15, säkeet 315-328.)

Suonettarelle ja muille terveyden jumaluuksille vastaista roolia esittää suomalaisessa mytologiassa Kivutar, sairauksien, ja Vammatar, vammojen jumalatar, mutta heihin palaamme myöhemmin.

Myyttisissä runoissamme mainitaan lopulta jumaluuksia, joilta rukoiltiin tukea tietyissä tehtävissä. Tällaisia ovat niin kutsutut Sinettäret (yks. Sinetär, sanasta sini 'väri, varsinaisesti sininen') ja Kankahattaret (yks. Kankahatar, sanasta kangas). [He ovat] naispuolisia jumaluuksia, joista edellisten uskottiin auttavan värjäyksessä, jälkimmäisten kutomisessa. Matkan suojelijana rukoiltiin tien jumalaa (tie-jumala) nimeltä Matka-Teppo - nimitys, jossa on tunnistettu kristillinen Stephanus ${ }^{52}$. Näihin jumaluuksiin voidaan lukea myös Aarni eli Haarni, jonka turviin uskottiin piilotetut aarteet.

\section{Maanalaiset jumaluudet}

Suomalaisten ja heidän sukulaiskansojensa parissa useimmat uskovat, että kuolema - se hämärä ja käsittämätön tapahtuma, jota he tarkastelevat rajattomalla pelolla ja kauhulla - ei tyystin katkaise ja tuhoa yksittäisen elämän olemassaoloa, vaan että ihmisellä on elämä vielä haudan tuolla puolenkin. Tämä usko kukoistaa ainakin kansan viisaiden parissa, ja vaikka on myös yksilöitä ja jopa tiettyjä kansoja, jotka uskovat että ihmisten ja eläinten olemassaolo tulee päätökseensä kuolemassa, näissäkin tapauksissa suoritetaan edesmenneille henkilöille tiettyjä seremonioita. Nämä seremoniat osoittavat selvästi, että he enemmän tai vähemmän tietoisesti tunnustavat sittenkin uskovansa jonkinlaiseen kuolemattomuuteen. Eräässä tällaisessa seremoniassa hautaan ja sen päälle lasketaan ruokaa ja vaatteita, kirves, veitsi, tulukset, pata, kelkka, keihäs ja ylipäätään kaikki sellaiset esineet, joita edesmennyt on käyttänyt eläessään. Kesyttömät kansat myöntävät itsekin tämän tavan perustuvan käsitykseen, jonka mukaan vainajilla 
on samat tarpeet kuin elävillä ja näiden tarpeiden täyttämiseksi he metsästävät, kalastavat ja ylipäätään toimittavat samoja askareita kuin eläessään. Jotkin kansat suovat heille jopa materiaalisen olemassaolon ja uskovat, että kuoleman jälkeen he saavat uuden ruumiillisen kodin. ${ }^{\text {a }}$ Toiset taas näkevät vainajat henkiolentoina, jotka joko majailevat haudassaan tai kuolleiden valtakunnassa tai kuljeskelevat ympäriinsä maan päällä ja ovat eritoten liikkeellä yön pimeydessä, myrskyllä ja rajuilmalla. Vainajat ilmaisevat itsensä tuulen ujelluksessa, lehtien rahinassa, tulen kipinöinnissä ja tuhansissa muissa luonnonilmiöissä. Šamaaneilla uskotaan olevan kyky nähdä heidät ja selvittää heidän ajatuksensa, mutta he ovat näkymättömiä tavallisten ihmisten katseelle. Vainajat voivat kuitenkin näyttäytyä myös tavallisille ihmisille kiusaamalla ja häiritsemällä heidän huonoa omaatuntoaan, tulemalla heidän uniinsa, langettamalla heille sairauksia ja aiheuttamalla heille kaikenlaista vahinkoa. Tällaisista hengistä on yleisesti sellainen käsitys, että ne vierailevat elävien luona eritoten vahingoittaakseen heitä. Tämän johdosta niiden vierailuja pelätään tavattomasti ja niiden torjumiseksi turvaudutaan kaikenlaisiin keinoihin. Niinpä kerrotaan, että kuolevan lakatessa hengittämästä tšuvassit katkaisevat pään kanalta mahdollistaakseen sen, että [vainaja] (ilmeisesti kanan hahmossa) lentäisi tiehensä eikä palaisi. Niin pian kuin vainaja on kannettu huoneesta, heitetään kirstun perään tulikuuma kivi, jonka uskotaan katkaisevan häneltä paluutien. Lisäksi tšuvassit tapaavat sitoa kirstun päälle kaksi tankoa poikittain estääkseen edesmennyttä kohottamasta sen kantta. Itse hautajaisissa, kuten muissakin vainajien kunniaksi vietetyissä juhlissa, he jättävät monenlaisia ruoka-aineita haudalle, jottei vainajan tarvitsisi etsiä ruokaansa elävien parista. ${ }^{\mathrm{b}}$ Siinä tapauksessa että vainajia, joita he kutsuvat nimityksellä viljaški, ei muisteta uhrein ja juhlin, heidän uskotaan lähettävän ihmisille tiettyjä tauteja. ${ }^{c}$

a Jessen-Schardebøll $(1767, \S 28)$ ja Ganander $(1789,21)$ kertovat, että lappalaisten käsitysten mukaan kaikki kuolleet ovat maan alla yhtä mahtavia kuin olivat maan päällä ja että heillä on siellä "uusi vartalo sen tilalla, joka on mädännyt maan alla." Vastaava käsitys näyttää vallinneen myös suomalaisten keskuudessa (vrt. Lencqvist 1782, 55).

b Višnevski 1846, 21.

c Višnevski 1846, 8. 
Suunnilleen samoin kerrotaan tšeremisseistä, joilla on lisäksi tapana ympäröidä hautansa paaluilla, joiden yli kuolleiden ei uskota pystyvän kiipeämään. Samojedien, ostjakkien ja useiden muiden napaseutujen kansojen parissa šamaanit pyrkivät loitsuillaan saamaan vainajien henget pysymään rauhassa haudoissaan. Ennen kaikkea heitä pyritään kuitenkin lepyttämään uhreilla, joita annetaan yhtä lailla itse hautauksen yhteydessä kuin myös sen jälkeen vuosien ajan.

Aasiassa on ollut ikivanhoista ajoista asti tapana uhrata vainajille. Hiongnu-kansan sanotaan luovuttaneen sotavankeja uhreiksi menehtyneille tšenjuilleen [päälliköilleen], jotka šamaanien väittämän mukaan raivostuisivat, mikäli tämä jätettäisiin tekemättä. ${ }^{a}$ Tämä kansa

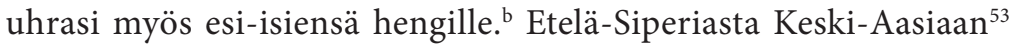
vaeltaneen topo-kansan sanotaan vielä pitkään muuttonsa jälkeen muistaneen esi-isiensä hautoja ja toimittaneen niille uhreja lähettien välityksellä. ${ }^{c}$ Myös Intiassa on osoitettu uhreja edesmenneille sukulaisille, ja Kiinassa heidän kunniakseen ei ole kannettu ainoastaan uhreja vaan myös pystytetty temppeleitä. Vainajan tällainen kunnioitus ei perustunut monien kansojen kohdalla pelkästään edellä mainittuun pelkoon hänen haitallisesta paluustaan vaan johtui osin uskosta hänen kuoleman kautta saavuttamaansa korkeampaan, jumalalliseen luontoon. Tätä uskoa on kutsuttu varsinaiseksi vainajakultiksi, joka hautamuistomerkkien loisteliaisuudesta päätellen näyttää vallinneen myös tataarikansojen parissa Keski-Aasiassa ja Etelä-Siperiassa. Myös pohjoisten kansojen eli suomalaisten ja samojedikansojen parissa on tunnistettavissa tiettyjä jälkiä tällaisesta korkeammasta ja jalommasta kultista. On tunnettua, että monet näistä kansoista eivät ole ainoastaan uhranneet ja järjestäneet juhlia vainajien kunniaksi vaan ovat myös rukoilleet näiltä apua ja tukea hädässä. Suomalaisten ja lappalaisten parissa kerrotaan, että heidän šamaaninsa kulkivat siinä tajuttomuuden tilassa, johon he toisinaan tapasivat vaipua, ympäriinsä myös maanalaisilla alueilla pyytämässä neuvoja ja apua vainajilta. Myös suomalaisessa Kalevala-eepoksessamme kerrotaan (runo 17),

a Deguignes 1768-1769: I, 185.

b Deguignes 1768-1769: I, 306.

c Deguignes 1768-1769: II, 5. 
että ollessaan vailla kolmea noitasanaa ${ }^{54}$ viisas Väinämöinen meni vanhan Vipusen haudalle saadakseen hänen huomastaan täydennystä viisauteensa. Ne jumaluudet, joita samojedien šamaanit pääasiallisesti rukoilevat kaikissa pyrinnöissään, ovat niin kutsuttuja tadebtsjoja ${ }^{55}$ eli näkymättömiä henkiolentoja, joiden uskottiin majailevan ilmassa, maassa, vedessä ja kaikkialla luonnossa. Olen kuullut monien samojedien kertovan, että tadebtsjot ovat pelkkiä edesmenneiden ihmisten henkiä, mutta toiset pitävät niitä omana, alempien jumalallisten olentojen lajinaan.

Kuinka suuri merkitys vainajakultille annetaankin, altailaisten kansojen parissa pelko on siihen aina tärkein vaikutin. Uhrit ja juhlat, joita järjestetään edesmenneiden kunniaksi, perustuvat pääasiassa tälle pelolle, kuten jo mainittiin. Tämän johdosta esim. tšuvassien parissa uhria toimittava henkilö tapaa puhutella vainajaa seuraavin sanoin: "Muistamme sinua juhlalla; katso, siellä sinulla on leipää ja tiettyjä keitoksia, kaikki sinulla on edessäsi, älä siis häiritse meitä, älä tule meidän luoksemme."a Nämä pojan sanat edesmenneelle isälleen osoittavat, ettei edes lähimmiltä kuoleman vuoksi joukosta poistuneilta odoteta mitään hyvää. Itse asiassa heille osoitetaan uhreja ja järjestetään juhlia juuri siksi, että vältyttäisiin heidän vihaltaan ja kotiinpaluultaan. Pelättäisiinkö siis yhtään vähemmän vieraiden henkiä, jotka eivät edes ole sukulaisia? Suurin on pelko, jota tunnetaan edesmenneitä šamaaneja kohtaan. Yhtä lailla kuin eläessään, he ovat myös kuolemansa jälkeen mahtavimpia, ja heidän uskotaan pystyvän aiheuttamaan eläville kaikenlaista mahdollista vahinkoa. Samojedit uskovat, että kuoleman jälkeen šamaaneista tulee tietyntyyppisiä, nimityksellä itarma ${ }^{56}$ kutsuttuja olentoja, joita he pitävät luonnon kaikkein vahingollisimpina henkinä. Myös ostjakeilla ja useilla muilla pohjoisaasialaisilla kansoilla on samanlaisia käsityksiä. Timowskyn mukaan [nämä käsitykset] vallitsevat myös mongolien parissa, jotka uskovat, että edesmennyt šamaani muuntautuu pahaksi hengeksi ja aiheuttaa heille kaikenlaista vahinkoa tarkoituksenaan pakottaa heidät osoittamaan hänelle uhreja.

Edellä on mainittu, että myös muinaissuomalaiset uskoivat kuolemanjälkeiseen olemassaoloon ja että he eivät ainoastaan kunnioit-

a Fuks 1840, 74. 
taneet vainajiaan uhrein ja juhlin vaan lisäksi myös anoivat heiltä apua ja tukea. Tiedetään myös, että vainajien uskottiin tekevän haitallisia vierailuja yhä elävien sukulaistensa luona, ja pääasiassa juuri näistä johtuen heitä muistettiin uhrein. Siitä ei ole kuitenkaan tietoa, millaisia arvoeroja ${ }^{57}$ esiintyi vainajien välillä suomalaisten tai heidän sukulaiskansojensa käsityksissä. Vainajien henkiä kutsuttiin suomen kielessä ilmeisesti useilla erityisillä nimityksillä, kuten manalaiset, männingäiset, keijuiset (myös keijut, keijukaiset), kööpelit ja peijot (myös peijaiset, peijakaiset), mutta en ala selvittää sitä, merkitsevätkö nämä nimitykset erityyppisiä edesmenneiden henkiä tai ovatko ne alun perin viitanneet lainkaan vainajiin. Etymologiat tarjoavat tavallisesti hyvää osviittaa, mutta kyseisten sanojen kohdalla ne eivät anna paljoakaan valaistusta. Suomen kielessä hyvin yleinen sana manalainen merkitsee varsinaisesti 'maanalaista olentoa ylipäätään', ja vaikka sillä tavallisesti viitataan vainajien henkiin, sitä käytetään yhtä lailla toisinaan myös kuolemanjumala Tuonen epiteettinä, eikä sitä näin ollen voi tulkita minkään tietyntyyppisten maan alla asuvien olentojen nimitykseksi. Sanat keiju, keijuinen ja keijukainen merkitsevät etymologiansa perusteella luultavasti 'liikkuvaisia, leijuvia olentoja', sillä ne on johdettava samaan kantaan kuin sana keijua tai keikkua 'keinua, keikkua'. Tästä johtuen ei ole yksinomaisen selvää, kuten olen kuullut vakuuteltavan, että keijuiset olisivat kuolleiden henkiä, eikä Gananderkaan anna yksiselitteisesti tätä merkitystä, vaikka hän vakuuttaa niiden epäilyksettä olevan "häiriintyneitä elämän-henkiä"58. Hän kutsuu niitä myös "pieniksi haltioiksi, lentäviksi hengiksi"59 ja sanoo niiden muistuttavan "tuiskuja, pieniä lastennukkeja, tulikiehkuroita" 60 ja olevan joko mustia tai valkoisia, pahoja tai hyviä. Lisäksi hän mainitsee, että ne näyttäytyvät tietyille, siihen taipuvaisille henkilöille ruumisseremonioiden yhteydessä kirkkomailla ja teillä, että ne ilmaantuvat sairaiden kuolinvuoteella ja ruumishuoneella ja että ne erittävät ruumiinhajua ( kalma). Niiden myötävaikutuksella voi myös aiheuttaa huonovointisuutta viholliselleen ja pelotella ja kiusata tätä kuljettamalla kirkkomaalta kuolleiden jäänteitä tai luita hänen makuuhuoneeseensa. ${ }^{a}$ Jossain määrin tästä poikkeava on Gananderin

a Ganander 1789, 36. 
kuvaus niin kutsutuista männingäisistä. Hän nimittää niitä "kirkkokummituksiksi"61 tai "haamuiksi"62 ja sanoo, että niillä on piilopaikkoja "haudoissa, vuorten rotkoissa ja erämaissa", mistä käsin ne aiheuttavat pelkoa ja kauhua ohikulkijoissa. ${ }^{a}$ Piispa Agricolan mukaan, sanoo Ganander, muinaissuomalaiset palvoivat männingäisiä jumaluuksina, jotka edesauttoivat aviollisia suhteita. Tämän merkityksen perusteella, mikäli se todella on oikeellinen, olisi mahdollista johtaa sana männingäiset, joka lausutaan myös menningäiset, germaanisesta sanasta menni ('muisti'), joka oli Grimmin' mukaan saksalaisten parissa yleinen korkeampien, yliluonnollisten naispuolisten olentojen nimitys. Minun käsitykseni mukaan sekä sanaa männingäiset että keijuiset, kuten myös sanaa maanalaiset, käytettiin synonyymisinä sanoina. Sitä vastoin sana kööpeli vaikuttaa eroavan näistä merkitykseltään myös nykykielessä. Renvall kääntää sen sanakirjassaan ${ }^{63}$ merkitykseen 'metsäkummitus' [skogsspöke; spectrum sylvestre], ja

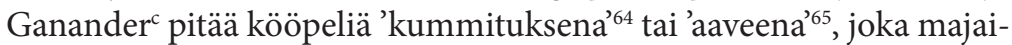
lee taloissa ja vanhoissa linnoissa, hirttomäillä ja hautausmailla ja joka näyttäytyy monenlaisissa hahmoissa ja antaa ihmisille tuhoisia isku$\mathrm{ja}^{66}$. Kuten Ganander huomauttaa, ${ }^{\mathrm{d}}$ männingäisten ja keijuisten tavoin myös kööpelit olivat vainajien henkiä, mutta hänen kuvauksensa perusteella vaikuttaa siltä kuin nimitys kööpelit olisi liitetty sellaisiin yksilöihin, jotka eläessään olivat tehneet vakavia rikoksia. Sana näyttää johtuneen germaanisesta sanasta Kobold (kreikan $\chi 0 \beta a \lambda$ o , latinan cobalus), joka alun perin lienee merkinnyt puusta veistettyä jumalkuvaa. ${ }^{e}$ Peiko (peikko, peijainen, peijakas) on Gananderin ${ }^{\mathrm{f}}$ mukaan synonyyminen sanojen piru, perkele, lempo, hiisi ym. kanssa. On varmaa, että sillä tarkoitetaan usein 'pahaa olentoa' ylipäätään, mutta lisäksi sanaa käytetään 'vainajien henkien' merkityksessä. Tämä merkitys on itse asiassa alkuperäinen, mikä näkyy siinä, että sanaa peijaiset käytetään monin paikoin myös hautajaisjuhlista. Etymologisesti sana

\footnotetext{
Ganander 1789, 56.

Grimm 1844, 404; vrt. 52-.

Ganander 1789, 42.

Ibid.

Grimm 1844, 469.

Ganander 1789, 68.
} 
tarkoittaa 'ilkeää, pahantahtoista olentoa', sillä se on varmasti sukua sanan peijata 'pettää kanssa.

Vaikka vainajat edellä antamani esittelyn mukaan majailivat usein maan päällä ja aiheuttivat ihmisille monenlaista pahaa, heidän varsinainen kotinsa oli kuitenkin maan alla, tai vielä oikeammin haudassa, joka säännönmukaisesti kaikkien altailaisten kansojen parissa sijaitsi maan huomassa. Mikäli kohtalo määräsi, ettei vainaja saanut lepopaikkaa maan sisältä vaan jäi sen päälle, jatkoi myös hänen henkensä vaeltelua maan päällä ja eritoten juuri siinä paikassa, missä hänen jäänteensä olivat. Niinpä samojedit ja kaikki muut pohjoiset kansat, jotka talvisaikaan hautaavat vainajansa kirstuissa maan päälle, uskovat, että myös henget oleilevat siellä. Samaten myös ne kansat, jotka ripustavat vainajansa ja eritoten menehtyneet lapsensa tiheälehvistöisiin puihin, uskovat heidän sielunsa majailevan puiden oksien lomassa ja kuuntelevan ilolla lintujen liverrystä ja tuulen suhinaa. Luulisin, että suomalaisten parissa kööpelit ovat sellaisten vainajien henkiä, joille kohtalo ei ole suonut hautapaikkaa ennen muuta siitä syystä, että he ovat olleet eläessään raakoja rikollisia ja pahantekijöitä. Koska tällaiset tapaukset olivat harvinaisia, suomalaiset käsittivät yleensä vainajien henget maanalaisiksi olennoiksi, mikä käy ilmi myös heidän yleisestä nimityksestään manalaiset. Suomalaisten muinaisissa lauluissa ja kertomuksissa ilmenee silti kaksi käsitystä henkien asuinpaikasta kuoleman jälkeen. Toisen mukaan ne jatkavat varjoelämäänsä haudassa, ${ }^{a}$ toisen mukaan ne kaikki kokoontuvat tiettyyn maanalaiseen paikkaan, jota nimitetään Tuonelaksi tai Manalaksi ja joka vastaa roomalaisten orcusta. Edellinen näkemys on epäilyksettä vanhempi, sillä se on myös kypsymättömämpi. Sitä tavataan myös kaikkien niiden suomensukuisten kansojen parissa, jotka yhä elävät alkukantaisessa kesyttömyydessään, kun taas jälkimmäistä tavataan tietääkseni ainoastaan suomalaisten, lappalaisten ja joidenkin Etelä-Siperian tataarikansojen parissa.

Käsitettiinpä kuolleiden henkien asuvan haudoissaan tai kuljeskelevan Tuonelassa, suomalaiset uskoivat niiden olevan riippuvaisia

a Ruotsin paasihaudoista [halfkorsgrafvarna] lausuu Nilsson (1838-1843: III, 13-) näkemyksen, että lappalaiset valmistivat ne asunnoiksi kuolleille. 
tietyistä enemmän tai vähemmän mahtavista jumalolennoista. Jumaluutta, joka pääasiallisesti hallitsi hautoja ja niiden asukkaita, nimitettiin Kalmaksi, kun taas Tuonelan hallitsija ilmenee sekä nimellä Tuoni että nimellä Mana. Kuten yllä jo mainittiin, merkitsee sana kalma 'ruumiinhajua, ja tätä merkitystä Renvall pitää sanakirjassaan alkuperäisenä. ${ }^{67}$ [Sana] kalma esiintyy Kalevalassa muutaman kerran 'hautausmaan' tai 'kalmiston' merkityksessä, kuten esim. runossa 33 (säkeet 259-260), missä sanotaan: "Sia on maassa maannehilla, kalmassa kaonnehilla", so. 'lepäävien paikka on maassa, kadonneiden Kalmassa. Tavallisesti runoissa kuitenkin viitataan sanalla kalma maanalaiseen jumaluuteen, jonka tehtäviin kuuluu valvoa niin kutsuttuja keijuisia, männingäisiä ym. Tässä ominaisuudessa hän toimii suunnilleen samassa roolissa kuin Tuoni ja myös sekoittuu runoissa jatkuvasti häneen. Joitakin kertoja hän sekoittuu myös Hiiteen, mikä osoittaa, että häntä pidetään pahana ja kauhistuttavana jumaluutena. Kalmalla sanotaan olevan tytär, Kalman impi nimeltään, ja myös tätä pidetään pahana olentona, sillä Kalevalassa kerrotaan (runo 26, säe 750), että käärme sai häneltä myrkylliset ikenensä. Suomalaiset runomme ovat hyvin säästeliäitä sekä Kalman itsensä että hänen perheensä käsittelemisessä. Sukulaiskansojemme parissa tätä jumaluutta ei tohdittu kutsua nimeltä lainkaan.

Paljon runsaampia ovat kuvaukset, jotka runot tarjoavat Tuonesta tai Manasta. Kuten juuri mainitsin, merkitsevät sanat Tuoni ja Mana varsinaisesti 'maanalaista hallitsijaa', mutta toisinaan niitä käytetään 'manalasta' ${ }^{68}$, johon silti tavallisesti viitataan nimityksillä Tuonela ja Manala. Käytetyistä sanoista on Tuoni (saamen Tuon, Tuona) epäi-

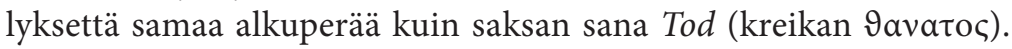
Sen voidaan katsoa olevan lainasana sitä suuremmalla syyllä, että se puuttuu useimmista sukulaiskielistämme. Sanaan Mana liittyy mitä omimmanlaisensa kehitysprosessi. Ensi näkemältä vaikuttaisi siltä, että se on kanta sanalle Manala ('Manan koti'), kuten Tuoni sanalle Tuonela, Tapio sanalle Tapiola jne., mutta tämä ei ole kuitenkaan asian laita. Suomen kielessä ilmaistaan manalaa sanaliitolla maan ala, josta yhdistymisen ja vokaalinlyhenemisen kautta kehittyi sana manala. Tämän muutoksen jälkeen sanan alkuperäinen merkitys jäi hiljalleen unohduksiin, ja kansa alkoi käyttää sitä kantana myöhemmällä ajalla tekeytyneeseen sanaan Mana. Koska Tuoni on lainasana ja Mana 
uudemman ajan muodostuma, käsitys vainajien majapaikasta Tuonelassa osoittautuu vähemmän alkuperäiseksi kuin se, jonka mukaan heidän henkensä uskottiin jatkavan elämäänsä haudassa. ${ }^{69}$

Runomme kuvaavat Tuonen eli Manan hallitseman paikan sijainneen maan alla. Kalevalassa (runo 20, säe 82) kerrotaan, että jättiläismäisen härän tappajaa etsittiin kaikkialta maapallolta ja myös maan alta Manalasta ("Manalasta maanki alta"). Tuonelan maanalaisesta sijainnista kertoo myös sen vaihtoehtoisen nimityksen Manala perusteella runoissa usein tavattavat ilmaukset kuten Manalan alusvesi 'Manalan alainen (maanalainen) vesi', Manalan alannet 'Manalan alanne' jne. Tuonelaan tullakseen tuli matkustaa yhdeksän ja puolen meren poikki; sitten tultiin virralle, ja sen takana näkyi Tuonela, jota joissakin paikoin (Kalevala, runo 16, säe 157) nimitetään Manalan saareksi - ilmaus, jota ei kuitenkaan tule tulkita kirjaimellisesti.

Finn Magnusen huomauttaa, että skandinaaviset kansat käsittivät manalansa (Helheim) olevan suunnilleen samoin koostunut kuin itse maa. ${ }^{a}$ Samaa voi sanoa suomalaisista, kenties jopa suuremmassa määrin. Tuonelassa paistaa aurinko kuten maan päällä ja sieltä ei puutu maata eikä vettä, metsää eikä aukeita, peltoja eikä niittyjä; siellä on karhuja, susia, käärmeitä, haukia jne. Mutta mitä Manala sitten piilotteleekin huomassaan, se on mitä suurimmassa määrin vahingollista, hämäräperäistä ja vastenmielistä laatua. Sen metsät ovat pimeitä ja täynnä villieläimiä, sen vesi on mustaa ja sen pellot kasvavat orasta, josta käärme eli niin kutsuttu Tuonen toukka on saanut hampaansa. Hyvin usein puhutaan runoissa aiemmin mainitusta Tuonelan joesta eli Tuonelan alusvedestä, jonka sanotaan olevan ylenpalttisen vuolas ja täynnä kuohuvia pyörteitä ja jossa sanotaan olevan kauhistuttava vesiputous, jota kutsutaan nimityksillä vihanen koski ja kova kynsi-koski. Luultavasti juuri kosken pelottavuuden vuoksi Tuonelan jokea usein nimitetään pyhäksi joeksi, pyhäksi virraksi. Sanotaan (Kalevala, runo 32, säe 381 [oik. 379-380]), että itse mahtava, jumalallinen karhu on vannonut tämän kosken äärellä, ettei koskaan ryhtyisi pahoihin tekoihin, ja tunnustanut siten olevansa alisteisessa suhteessa koskeen.

a Magnusen 1824-1826: IV, 220. 
Vielä kauhistuttavampia kuin ulkoiset luonnonkohteet olivat persoonalliset olennot, jotka asuttavat "Tuonelan tupia". Näistä erottuu eritoten isäntä, niin kutsuttu Tuoni, Mana, Manalainen tai Tuonen ukko, ylenpalttisen ankarana ja säälimättömänä voimana. Häneltä ei kannata odottaa lempeyttä, ja koska mitkään rukoukset eivät pääse hänen sydämeensä, häneen vedotaan runoissamme vain harvoin eli tuskin koskaan. Hänen ulkoinen hahmonsa vastaa täysin hänen sisäistä luontoaan, sillä hänet kuvataan kolmisormisena vanhana ukkona, jolla on hartioiden yli roikkuva hattu. Hänen varsinainen toimensa on vahtia jokaista, joka on joutunut hänen valtaansa. Jacob Grimm tekee saksalaisessa mytologiassaan ([1844,] 799) huomion, että muinaisaikojen kuolemanjumalaa ei yleensä pidetty kuolettavana olentona, vaan että sairaus, kirous ym. surmasi [ihmisiä], kun taas kuolemanjumala vain saattoi edesmenneet toiseen maailmaan. Suomalaisissa muinaislauluissammekaan ei esitetä, että Tuoni ottaisi ketään päiviltä, vaan Kalevalassa (runo 16, säe 183-) kerrotaan, että hän tapaa saattaa tai kuljettaa vainajat manalaan. Hänen toimensa eivät näytä siis olevan ehdottoman välttämättömiä kuoleman yhteydessä, vaan hänet esitetään tavallisesti vainajien vartijana ja hallitsijana. Tässä tehtävässä häntä tukee uskollisesti hänen vaimonsa Tuonen akka eli Tuonelan emäntä, jota toisinaan kutsutaan myös nimellä Tuonetar tai Manalatar, joskin tämä nimitys varsinaisesti kuuluu Tuonen tyttärelle. Hän on vanha nainen, jolla on käyristyneet sormet ja terävä leuka. Runot liittävät häneen ironisessa merkityksessä epiteetin hyvä emäntä, sillä hän tapaa kestitä vieraitaan käärmein ja sammakoin.

Tuonen poika on tämän "rakastettavan" jumalparin arvoinen jälkeläinen. Kuten äidillään, sanotaan hänellä olevan käyristyneet sormet, joiden päät ovat rautaa. Tällä tavoin kuvataan osuvasti hänen kovaa, armotonta, saaliinhimoista luontoaan, mistä hänen toimensa todistavat. Sopusoinnussa vanhempiensa kanssa hän valvoo tiukasti Manalan asukkaita ja murskaa heidät miekallaan. Ainakin hän yrittää kaikella mahdillaan pitää Väinämöisen Tuonelassa, ja kun hän näkee kostonhimoisen paimenen kuoliaaksi ampuman Lemminkäisen lipuvan alas Tuonelan jokea, hän lyö Lemminkäisen kappaleiksi miekallaan. Verenhimoisena häntä kutsutaan runoissa veriseksi, ja tästä johtuen häneen liitetään myös epiteetti punaposki. Kenties tästä syystä häneen vedotaan eräässä noitalaulussa verenseisautuksen yhteydessä, 
joskaan hänelle osoitettu pyyntö kehrätä lankaa suonten sitomiseen ei sovi kovin hyvin yhteen hänen muiden toimiensa kanssa.

Tuonelan iljettävään jumaljoukkoon kuuluu myös erityisiä kuolemanjumalan ja tämän puolison kasvattamia tyttäriä, joita kutsutaan yhteisesti nimityksillä Tuonen tyttäret, Manan neiet, Manuttaret, myös Kalman neiet. Useimmiten heistä nimetään [erikseen] Tuonetar eli Tuonen tytti, Manalan neiti eli Manalan impi, kuten häneen viitataan eri nimityksillä. Hänellä on, kuten Tuonelan muillakin jumaluuksilla, vihainen, pahantahtoinen ja riidanhaluinen luonteenlaatu, ja häntä kutsutaan runoissa usein nimityksellä ilkeä Manalan impi. Hänen kieroutunut luonteensa näkyy myös ulkoisesti, sillä hän on väriltään tumma (musta Tuonen tyttö) ja lyhytkasvuinen (lyhykäinen Tuonen tyttö, matala Manalan neiti). Huolimatta pahasta luonnostaan hän on kuitenkin koko Tuonen väestä ainoa, joka toisinaan antaa suopeamman tunteen saada vallan sydämestään. Tämä tunne näkyy siinä, kun hän (Kalevala, runo 16, säe 265-) neuvoo Tuonelan joen poikki sinnikkääsi haluavaa Väinämöistä palaamaan kotiinsa eikä altista häntä Tuoni-jumalan vääjäämättömälle vihalle. Hänen tehtävistään mainittakoon, että Väinämöisen juuri mainitun Tuonelanmatkan yhteydessä hän esittää Kharonin roolia kuljettamalla Väinämöisen virran poikki. Hän näyttää hoitavan tätä tehtävää kuitenkin vain tilapäisesti, koska hän seisoo rannalla ja pesee pyykkiä Väinämöisen saapuessa Tuonelan joelle.

Toinen Tuonen tytär kantaa nimeä Loviatar, ja tämän sanotaan Kalevalassa (runo 45, säkeet 25 ja 26), olevan "pahin Tuonen tyttäristä, ilkein manattarista”. Hänet esitetään rumana ja sokeana ikäneitona, tummana väriltään ja mustana mieleltään. Hänen pahimpana tekonaan pidetään sitä, että hän antaa tuulen saattaa itsensä raskaaksi ja synnyttää sitten maailmaan yhdeksän mitä kauhistuttavinta vaivanhenkeä. Tämä teko liitetään joissakin runoissa myös muihin hahmoihin, kuten Louheen, Pohjolan emäntään, mutta se sopii kaikin puolin parhaiten Tuonen sukulaiselle.

Tuonen kolmatta tytärtä kutsutaan nimityksellä Kiputyttö, tai tavallisemmin Kipu-tyttö Tuonen neiti. Hänellä ei ole tekemistä vainajien vaan pelkästään sairauksien kanssa, ja häntä pidetään niiden valtiattarena. Eräässä virrassa (luultavasti Tuonelan joessa) on lohkare tai vuori, joka kohoaa vedestä paikassa, missä kolme virtaa yhtyy. 
Tätä lohkaretta kutsutaan runoissa nimityksellä Kipukivi tai Kipuvuori, koska Kiputyttö pitää sairauksia suljettuna siihen. Itse hän tapaa istua lohkareen päällä ja pyörittää sitä ympäri, niin että sairauksien henget jauhautuvat kuin siemenet kahden myllynkiven välissä (Kalevala, runo 45, säkeet 270-274). Tarkoitus varmaankin on, että hän tällä tavoin hillitsisi ja vaientaisi niiden pahan luonnon. Kun nämä henget vapauttavat itsensä vankilastaan ja pääsevät kiusaamaan kuolevaisia, anotaan Kiputyttöä pyydystämään karanneet palvelushenkensä ja joko lukitsemaan ne sinisen kiven sisään tai upottamaan ne meren syvyyksiin (Kalevala, runo 45, säe 275-).

Kiputytöstä erotetaan Kalevalassa Kivutar (sanasta kipu 'sairaus') eli Vammatar (sanasta vamma 'vaiva'), jolla ei näytä olevan mitään yhteistä Tuonen tyttärien kanssa. Sitä vastoin hänet esitetään hyvää tekevänä olentona, jota myös kutsutaan nimityksillä hyvä emäntä ja valio vaimo. Häneen liitetään kuitenkin suunnilleen samat tehtävät kuin Kiputytölle. Niinpä häntä pyydetään (Kalevala, runo 45, säe 293-) karkottamaan vaivanhenget sairaasta, piilottamaan ne vaskiseen vakkaan ja kuljettamaan ne kipuvuoren huipulle, keittämään ne siellä pienessä kattilassa ja lopulta sysäämään ne vuoren sisään siinä olevan reiän läpi. Mikäli katsotaan, että nimet Kiputyttö ja Kivutar merkitsevät itse asiassa yhtä ja samaa, näyttää olevan todennäköistä, että nämä kaksi jumaluutta ovat alkujaan olleet yksi ja sama olento ja että ne on erotettu toisistaan pelkästään jonkin väärinkäsityksen kautta.

Tuonelan muihin asukkaisiin viitataan runoissa yleisellä nimityksellä Tuonelan väki eli Manalan tai Manan väki. Pidän selvänä, että tällä ilmaisulla on itse asiassa tarkoitettu vainajia, vaikkakaan tätä ei ole selvästi ilmaistu muinaisissa runoissamme. Niissä ei ole myöskään minkäänlaista kuvausta Tuonelan väen tai vainajien toimista ja muista oloista, mutta siitä, mitä aiemmin on kerrottu Tapiolan väestä, Vellamon väestä jne. voidaan varmuudella päätellä, että tämä väki toimi Tuoni-jumalan palvelijoina ja toimitti hänen antamiaan viestejä ja tehtäviä. Runossa kerrotaan, että Tuonen väki on melko lukuisa ja että siihen kuuluu niin vanhoja, nuoria kuin keski-ikäisiäkin henkilöitä, ja että vanhoilla on kepit, nuorilla miekat ja keski-ikäisillä keihäät. Valppaus ja hellittämätön ankaruus ovat myös heidän merkitseviä ominaisuuksiaan. Kun Lemminkäisen äiti (Kalevala, runo 15, säe 211-) tulee Tuonelan joelle nostaakseen sen aalloista kadonneen poikansa, hän 
ei uskalla ryhtyä toimeen ennen kuin on Auringon avulla nukuttanut koko "tylyn joukon" ${ }^{70}$ Tämän johdosta maanalaista kansaa kohtaan tunnettiin tavatonta pelkoa, mutta siitä huolimatta sanotaan elävien usein tekevän matkoja Tuonelaan.

Tällaisia matkoja tekevät tavallisesti Pohjolan tyttären kosijat tämän äidin vaatimuksesta, hän kun ei anna lastaan kehnommalle sankarille kuin sille, joka kykenee pyydystämään Tuonelan susia, karhuja ja haukia. Nämä matkat eivät ulotu kuitenkaan Tuonelan syvimpiin osiin, ja tavallisesti urheat seikkailijat eivät kohtaa lainkaan Tuonen väkeä. Sitä vastoin eräs Kalevalan laulu kertoo matkasta, jonka Väinämöinen tekee itse kuolemanjumalan asunnolle tavoitteenaan saada häneltä kolme aiemmin mainittua noitasanaa. On omintakeista, että Väinämöinen kääntyy itse Tuonen puoleen sellaisin tavoittein, sillä tavallisesti vainajien parista haettiin neuvoja ja viisautta joko heidän haudoiltaan tai tavallisemmin Tuonelasta. Ainoastaan mahtavat šamaanit pystyivät tekemään matkoja Tuonelaan (Tuonella käydä, Tuonelassa vaeltaa). Tämä ei koskenut ruumiillista muotoa, vaan šamaanit vaipuivat ensin uneen, minkä jälkeen sielu leijui alas edesmenneiden henkien maailmaan saadakseen sieltä kaivatun viisauden.

Kerrotaan, että Väinämöinen tekee matkan Tuonelaan maallisessa hahmossaan. Tämän matkan sanotaan myös epäonnistuvan, jolloin Väinämöinen menee vanhan Vipusen haudalle, mistä hän myös saa haltuunsa tavoittelemansa. Koska runo Väinämöisen Tuonelanmatkasta (Kalevala, runo 16, säe 151-) valaisee jonkin verran Manalan olosuhteita, haluan tässä lyhyesti käsitellä sen sisältöä. Väinämöisen taitettua kolme päivämatkaa hän saapuu Tuonelan joelle, joka katkaisee hänen tiensä Tuonen asunnolle. Ihmetellessään, kuinka pääsisi joen ylitse, hän näkee vastapäisellä rannalla Tuonen tyttären puuhailevan pyykkiensä parissa. Hän kääntyy tämän puoleen pyytäen, että tämä kuljettaisi hänet virran poikki. Tyttö lupaa täyttää hänen toiveensa, mutta sillä ehdolla, että Väinämöinen ensin paljastaa hänelle syyn Tuonelan-matkaansa. Väinämöinen yrittää aluksi johtaa hänet harhaan väärillä tiedoilla, mutta kun tämä ei onnistu, hän katsoo lopulta olevansa pakotettu kertomaan totuuden: veistäessään alusta noitaluvuin häneltä on jäänyt puuttumaan kolme sanaa, ja hän on nyt tullut Tuonelaan saadakseen ne. Tämän tiedon saatuaan Tuonen tytär alkaa moittia Väinämöistä tämän uskaliaasta yrityksestä ja neuvoo 
tätä olemaan jatkamatta matkaansa Tuonelaan vaan mieluummin kääntymään kotiinsa. Väinämöinen ei anna hänen sanomistensa pelotella itseään. Hän pysyy sinnikkäästi kyytivaatimuksessaan, ja hänen rukoustensa taivuttamana Tuonen tytär soutaa hänet lopulta virran poikki. Väinämöisen saavuttua Tuonen asunnolle emäntä tarjoaa hänelle olutta, mutta tuopissa ui sammakoita ja sen reunoilla ryömii käärmeitä. Väinämöinen kieltäytyy tästä ateriasta sillä verukkeella, ettei ole matkustanut Tuonelaan juhliakseen. Kun Väinämöiseltä kysytään, mikä on syy hänen saapumiseensa, hän paljastaa nyt epäröimättä asiansa Tuonelan emännälle. Väinämöinen saa tältä kuitenkin vastauksen: "Tuoni ei luovu sanoistaan, Mana ei jaa mahtiaan kenenkään kanssa”. ${ }^{71}$ Myöhemmin koittaa yö, ja emäntä osoittaa Väinämöiselle vuoteen, joka on nahoin pedattu. Vaaran aavistaen Väinämöinen teeskentelee nukkuvansa, mutta pitää tarkoin silmällä kaikkea, mitä Tuonelassa puuhataan. Hän näkee Tuonen eukon istuvan vedessä olevalla lohkareella ja kehräävän lankaa raudasta ja vaskesta. Samalla lohkareella istuu myös Tuonen poika kutomassa langasta hyvin suurta nuottaa. Kun nuotta on valmis, Tuonen poika heittää sen jokeen poikittain, pitkittäin ja vinottain. Tällä tavoin Väinämöisen ei pitäisi päästä palaamaan joen ylitse, mutta verrattomana tietäjänä tämä muuntautuu käärmeeksi ja kiemurtelee nuotan lävitse. Palattuaan Tuonen hämyisästä kodista hän antaa tuleville polville neuvon, ettei Tuonelaan tule pyrkiä vapaaehtoisesti, koska "moni on sinne mennyt, mutta harva palannut takaisin". ${ }^{72}$ Sen lisäksi hän varoittaa nuorisoa kohtelemasta huonosti ketään syytöntä, koska rikollisia rangaistaan Tuonelassa pahoista teoistaan ankarasti. Tämä varoitus ei juonnu kuitenkaan Väinämöisen ajoista ${ }^{73}$ vaan on kristillistä perua. Se tavataan Kalevalan runossa 16 (säkeet 401-412) ja kuuluu seuraavasti:

Elkätte imeisen lapset

Sinä ilmoisna ikänä

Tehkö syytä syyttömälle,

Vikoa viattomalle,

Pahion palkka maksetahan

Tuolla Tuonelan koissa:

Sia on siellä syyllisillä,

Vuotehet viallisilla,

Alus kuumista kivistä, 
Palavoista paateroista,

Peitto kyistä, käärmehistä,

Tuonen toukista kuottu!

Käsiteltyämme suomalaisten käsityksiä kuolleiden valtakunnasta käännymme nyt heimosukulaistemme lappalaisten puoleen, joiden mytologiassa mainitaan kuolemanjumala Tuona eli Tuon, joskin jälkipolville on jäänyt tästä muistiin tuskin muuta kuin hänen nimensä. Jessen-Schardebøll, joka on perusteellisimmin käsitellyt lappalaisten kansan mytologiaa, ei tunne tätä jumaluutta lainkaan nimeltä, vaan luettelee monia muita jumalolentoja, jotka jakavat manalan herruuden. Hänen teksteissään kuolleiden valtakunta ei ole myöskään nimeltään Tuonen aimo, kuten muut kirjoittajat ovat sitä toisinaan nimittäneet, vaan hän esittää lappalaisten muinoin uskoneen kahteen maanalaiseen valtakuntaan, joista toista he ovat kutsuneet nimityksellä Saivo-aimo, Jabme-aimo tai Sarakka-aimo, toista taas nimityksellä Rut-aimo, Mubben-aimo, Fudnos-aimo tai Zhjaeppes-aimo. Hän esittää myös, että käsitys Rut-aimosta, Mubben-aimosta ym. ei ole alun perin lappalainen vaan kristinuskosta lainattu ja että sanat rutu, mubben, fudno ym. merkitsevät 'paholaista' ja Rut-aimo, Mubbenaimo jne. 'kristittyjen helvettiä. ${ }^{a}$ Tämä väite paljastaa varsin vähäisen suomalaisten ja lappalaisten kielten tuntemuksen, sillä Rut-aimo merkitsee 'ruton kotia', Mubben-aimo (mubbe-aimo?) 'toista, tulevaa kotia', Fudnos-aimo 'huonoa kotia' ja Zhjaeppes (Zhjappes) -aimo 'mustaa kotia. Nimien merkityksestä päätellen voivat ne kaikki, Rut-aimo poikkeuksena, olla yhtä hyvin pakanallista kuin kristillistä alkuperää. Kummassakin tapauksessa ne täytyy kuitenkin käsittää pelkästään epiteetiksi kuolleiden valtakunnalle, jonka oma, varsinainen nimi on Jabme-aimo ('kuolleiden koti') tai Tuonen aimo ('Tuoni-jumalan koti', suom. Tuonela). Jälkimmäinen nimitys näyttää olleen erityisesti käytössä ruotsalaisessa Lappmarkissa, kun taas edellinen on tunnettu kaikkialla. Niin kutsutuksi Jabme-aimoksi Jessen-Schardebøll samastaa, kuten juuri mainittiin, sekä Saivo-aimon että Sarakka-aimon, mutta yritän seuraavaksi osoittaa, että tämä perustuu väärinkäsitykseen.

a Jessen-Schardebøll 1767, § 13. 
Lappalaisista kirjoittavien keskuudessa vallitsee sanan saivo merkityksestä paljon epäselvyyttä ja sekavuutta. Jessen-Schardebøll käsittää tämän sanan yhtäällä 'pyhän paikan' merkityksessä, toisaalla 'jumalallisen olennon' merkityksessä. Lindahlin ja Öhrlingin ${ }^{a}$ mukaan saivo, jonka he kirjoittavat saiva tai saiv, on itse asiassa nomen appellativum [yleisnimi], joka merkitsee 'pyhää, mutta he esittävät myös, että sanaa saiva-kedke ('saiva-kivi'), tai yksinkertaisesti saiv, käytetään myös lappalaisten kivi-idoleiden merkityksessä. Högströmilläb saivo merkitsee, sikäli kuin en ole käsittänyt hänen epäselvästi selittämäänsä merkitystä väärin, 'pyhää järveä. Sen selityksen mukaan, jonka olen Lapissa saanut, sana saivo on yleinen jumalepiteetti ja vastaa lähinnä suomalaista haltiaa, ts. 'suojelusjumalaa'. Sanan tämä [suojelusjumalan] merkitys on myös oikea, minkä katson itse asiassa olevan johdettavissa Jessen-Schardebøllin omasta saivo-kansan kuvauksesta. Hän esittää muun muassa, ${ }^{c}$ että lappalaisten parissa on vallinnut usko, että heidän nimityksillä saivo ja pusse-waarek kutsutuilla pyhillä vuorillaan ja tuntureillaan, kuten myös vainajien mailla maan alla (Jabmeaimo), majaili "samanlaisia henkilöitä kuin he itse (lappalaiset) ovat", jotka harjoittivat samoja elinkeinoja, joilla oli samanlaisia eläimiä, ja jotka sanalla sanoen elivät samalla tavoin kuin lappalaisten kansa. Saivon suku oli kuitenkin kaikessa saavuttanut korkeamman täydellisyyden kuin lappalaiset ja ylittänyt heidät vauraudessa, viisaudessa ja vallassakin, minkä johdosta heidän puoleensa tavattiin kääntyä, kun oltiin neuvojen ja avun tarpeessa. Tällaisissa tilanteissa saamelaiset lähtivät perinteen mukaan johonkin saivo-kotiin. Jokaisessa sellaisessa kodissa majaili aina ainakin yksi miespuolinen yksilö, joka eli naimattomana, mutta monilla näillä niin kutsutuilla saivoolmakeilla oli sekä vaimo että lapsia. Vierailijat otettiin aina hyvin vastaan saivo-kodeissa, ja usein he viettivät siellä jopa useita viikkoja, joiden aikana he saivat syödäkseen ja juodakseen ja laulaa ja tanssia saivojen kanssa. Ja vielä kaupan päälle he saivat saivoilta hyviä neuvoja ja oppeja varsinkin noitataidoissa. Mutta tässä ei ollut kaikki, vaan

a Lindahl \& Öhrling 1780, 390.

b Tornæus 1772, § 193.

c Jessen-Schardebøll 1767, § 10-. 
saivojen uskottiin myös tukevan lappalaisia koko näiden elämän ajan metsästysretkillä, kalassa ja kaikissa mahdollisissa yrityksissä. Sitä vastaan nämä puolestaan antoivat uhreja ja "palvelivat saivoa elämällään ja sielullaan". Jessen-Schardebøllin mukaan jokaisella lappalaisella tapasi miehen ikään tultuaan olla erinäisiä, usein 10, 12 tai jopa 14 saivokotia, joiden asukkaista tuli "hänen suojelusenkeleitään ja avunantajiaan noitataidoissa". Lisäksi saivo-kansalle kuuluvien eläinten katsottiin olevan auttavaisia lappalaisia kohtaan heidän tietyissä töissään ja toimissaan. Näiden eläinten joukosta mainitaan lintu (saivolodde), kala tai käärme (saivo-guelle tai guarms) ja poro (saivosarva). Nämä eläimet saattoivat olla erilaisia niin lajiltaan, väriltään kuin kooltaankin. Jessen-Schardebøll kertoo saivo-linnuista, että ne saattoivat olla [kooltaan kuin] ${ }^{74}$ varpusia, riekkoja, kotkia, joutsenia, metsoja tai haukkoja. Joillakin niistä uskottiin olevan musta selkä, valkoiset siivet ja harmaa rinta, toiset olivat väriltään vaaleanpunaisia, toiset edelleen harmaita, mustaharmaita tai valkoisia. Lintujen uskottiin tukevan kuolevaisia näyttämällä heille tien metsässä, kantamalla heidän metsästysvälineitään, auttamalla poronhoidossa, löytämällä kadonneita esineitä jne. Šamaanit kääntyivät niiden puoleen usein aiheuttaakseen vahinkoa vihamiehilleen, ja tässä tapauksessa sai saivolodde nimityksen wuornis-lodde. Saivo-loddesta uskottiin myös, että ne ottivat usein šamaanin selkäänsä ja kantoivat hänet sinne, minne hän halusi. Yleisesti ottaen näyttävät saivo-eläimet, kuten jo niiden nimitys noaaides vuoign ['noidan henki'] antaa ymmärtää, osoittaneen tukensa pääasiassa šamaaneille, sillä myös saivo-käärmeestä ja -kalasta kerrotaan, että lintujen lailla ne tapasivat kantaa šamaania selässään ja sen lisäksi auttaa häntä aiheuttamaan vihollisille vahinkoa. Saivo-porot käsitetään samalla tavoin šamaanien avustajaksi, ja nämä käyttivät niitä erityisesti siinä tilanteessa, kun kahden šamaanin välille sukeutui kaksintaistelu. Tällaisessa taistelussa šamaanit itse olivat täysin toimettomia, mutta he jakoivat kamppailevien porojen kohtalon, oli kyseessä sitten henki tai raaja. Jessen-Schardebøll huomauttaa, että jokaisella lappalaisella, jolla tavallisesti oli monta saivo-jumaluutta suojelijoinaan, oli myös suurempi tai pienempi määrä avuliaita saivoeläimiä, joita jumalten tavoin kunnioitettiin uhrein.

Jessen-Schardebøllin saivoa koskevan esityksen pääsisältö on lyhyesti kerrottuna siis tällainen. Tästä esityksestä havaitsee selvästi, 
että sana saivo on yleinen nimitys kaikille yksittäisille suojelusjumalille, ja että saivo-aimo merkitsee tällaisen suojelusjumalan kotia. Suomalaisessa mytologiassa ei ole yhtään saivo-aimoa täysin vastaavaa käsitettä, sillä vaikka käsitys jumalkodista on molemmille kansoille yhteinen, eivät suomalaiset näytä liittäneen sellaista kotia omiin yksittäisiin suojelusjumaliinsa haltioihin vaan ainoastaan joihinkin palvottuihin jumaluuksiinsa, kuten Ahtoon, Tapioon, Tuoneen ym. Lappalaisten parissa sitä vastoin yksittäisillä jumalilla käsitettiin yleensä olevan talo ja koti, kartano ja tavaraa, vaimo ja lapsia. Lappalaisista kirjoittavat [tutkijat] mainitsevat tietääkseni jumalten kodeista ylipäätään vain Sarakka-aimon ja Tuonen aimon eli Jabme-aimon jättäen mainitsematta Rut-aimon, joka kenties on synonyyminen Jabmeaimon kanssa, kuten suomalaisessa mytologiassakin vaivojen ja sairauksien kodin uskottiin olevan Tuonen asunnossa. Saivo-aimossa oli melko ahdasta, sillä Jessen-Schardebøllin yllä siteeratun väitteen mukaan uskottiin yhdellä ainoalla lappalaisella voivan olla alueellaan enemmän kuin kymmenen tällaista jumalkotia. Näiden saivokotien lukumäärä riippui epäilemättä siitä, kuinka monta jumalkuvaa eli seitaa kullakin lappalaisella oli; sillä missä vain seisoi pystytettynä seita, pidettiin paikkaa pyhänä ja sitä nimitettiin saivo-aimoksi. Itse asiassa tavalliset jumalkuvat tai seidat eivät ole minun mielestäni mitään muuta kuin saivo-jumalten näkyviä edustajia, minkä johdosta seidat esiintyvät Lindahlilla ja Öhringillä yllä esitellyllä nimellä saiva-kedke tai saiv. Jessen-Schardebøll huomauttaa, ${ }^{a}$ että todellisten, näkymättömien saivojen uskottiin majailevan "ylimmän maakerroksen" alapuolella, ja osittain tämän perusteella hän samastaa Saivoaimon Jabme-aimoon. Minusta on kuitenkin epätodennäköistä, että saivo-jumalat olisivat kuuluneet ainoastaan maan sisään, sillä olen kuullut lappalaisten vakuuttavan, että ne majailevat mielellään myös järvissä. Tästä puhuu myös Högström, vaikkakin hän erehtyy siinä, että hän uskoo saivon merkitsevän pyhänä pidettyä vettä. Esitän, että tunturilappalaiset palvoivat saivoina etupäässä maan (vuorten, tunturien) jumalallisia asukkaita, kun taas sitä vastoin kalastajalappalaiset sijoittivat ne veteen (järviin ja jokiin). Mikäli Jessen-Schardebøllin 
väite on täysin oikeellinen, ei se seikka, että saivo-olennot majailivat maan alla, ole osoitus saivo-aimon ja Jabme-aimon yhtäläisyydestä, sillä käsitteenä edellinen on yleinen ja viittaa jumalkotiin, jälkimmäinen sitä vastoin on erityinen ja ilmaisee vain sitä paikkaa, missä Tuona eli Jabme-akka hallitsi. Tärkeimmän tuen saivo-aimon ja Jabmeaimon yhtäläisyydelle on Jessen-Schardebøll epäilyksettä nähnyt siinä, että lappalaiset hänen väitteensä mukaan suuresti kaipasivat muuttoa kuolemansa jälkeen saivo-aimoon, "jonka asukkaita he pitivät lappalaisina, ja sellaisina, jotka eläessään olivat ahkerasti uhranneet, myret ja juoiget ${ }^{75}$ (laulaneet) Saivolle, ja siksi tulevassa elämässä nauttivat suurta onnea"a Tämä väite on itsessään melko tärkeä, koska siinä tapauksessa että [se] on ylipäätään luotettava, se osoittaa, että lappalaiset kunnioittivat merkittäviä henkilöitä heidän kuolemansa jälkeen suojelusjumalinaan. Mutta koska heidän kunnioituksensa voittaminen ja Saivo-aimoon pääsy edellytti sekä uhreja että rukouksia, on täytynyt olla myös jokin toinen paikka, jonne vainajat saattoivat joutua uhraamatta ja rukoilematta. Tällainen, jokaisen tavoitettavissa oleva paikka, oli niin kutsuttu Jabme-aimo.

Edellä tuli mainittua, että Jessen-Schardebøll pitää myös Sarakkaaimoa samana paikkana kuin Jabme-aimo, mutta tälle näkemykselle ei tietääkseni ole vähäisintäkään tukea. Sen mukaan, mitä Jessen-

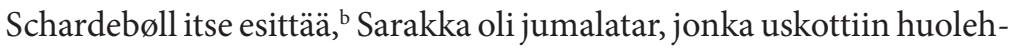
tivan elämän jatkumisesta saattamalla syntymättömiä sikiöitä maailmaan päinvastoin kuin että hän hallitsisi vainajia. Tämän toimen hänen sanotaan jakaneen useiden muiden jumaluuksien kanssa, joita olivat esimerkiksi Radien-kiedde, Mader-akka ja Uks- eli Juks-akka. Heistä Radien-kiedde loi hengen ja lähetti sen sen jälkeen Maderatjan luokse. Tämä antoi hengelle elämän ja toimitti sen Maderakan luokse, jonka tehtävä oli antaa sille ruumiillinen hahmo. Jos tästä olennosta piti tulla mies, Maderakka luovutti sen Uks- eli Juks-akalle, jota kutsuttiin myös nimellä Stauke-edne tai Stilko-edne; mutta jos sen tuli syntyä naispuoliseksi, sai Sarakka tehtäväkseen huolehtia sen muovaamisesta. Yhtä lailla Sarakan kuin Uks-akan tuli tavoitteen saavut- 
tamiseksi ensin ottaa sikiö omaan kohtuunsa ja tuoda se siinä naiselle, joka lopulta kantaisi sen ja synnyttäisi sen maailmaan. Tämä outo käsitys Sarakan ja muiden jumaluuksien osallisuudesta luomiseen on ehkä myöhemmän ajan keksintö, mutta minkä tehtävän lappalaiset ovat sitten alun perin liittäneetkin Sarakkaan, tätä ei voi millään tavoin liittää vainajien maailmaan. Jessen-Schardebøll yhdistää hänet Venukseen ja lausuu hänestä seuraavin sanoin:

Lappalaisilla oli tämä jumalatar aina huulilla ja sydämessä; hänelle osoitettiin heidän rukouksensa, häntä he palvoivat kaikilla teoillaan ja toimillaan, ja he pitivät hänestä kaiken hänen tarjoamansa lohdun ja turvan vuoksi. Lyhyesti sanottuna: Sarakka oli ensimmäinen ja viimeinen, rakkain ja luotettavin, ja se, johon he suurimmin luottivat kaikissa toimissaan. Häntä arvostettiin eniten kaikista ja palvottiin ylitse kaikkien muiden. Mitä sitten syötiin tai juotiinkin, häntä muistettiin aina, ja hänelle tehtiin sekä lupaukset että toimitettiin uhrit hakematta samalla neuvoja noitarummun avulla. Mutta hartaimmin häneen vetosivat hedelmälliset ja lapsenpäästössä autettavat naiset. Tällaisissa tilanteissa jotkut lappalaiset tapasivat pystyttää oman telttansa viereen toisen, joka oli määrätty Sarakan palvelemiseksi ja asunnoksi. ${ }^{\mathrm{a}}$

Myöskään tässä kuvauksessa ei ole mitään, mikä osoittaisi mitään yhteyttä Sarakan ja vainajien maailman välillä, vaan [Sarakka] esiintyy elämän parhaana varjelijana, ihmisten olemassaolosta ja hyvinvoinnista huolehtivana jumaluutena. Missä hänen kotinsa, nk. Sarakkaaimo onkin ollut, ainakin on selvää, että sitä ei tule etsiä Jabme-aimosta eli kuolleiden valtakunnasta.

Kyseisen Sarakan lisäksi Jessen-Schardebøll ei nimeä yhtään toista Jabme-aimoa hallitsevaa jumaluutta, mutta toiset kirjoittajat suovat sen hallitsemisen, kuten jo mainitsin, toisinaan Tuonalle, Tuonelle tai Tuonille, vielä useammin Jabmem- tai Jabmeki-akalle. Sana tuona käsitetään tavallisesti sen abstraktissa merkityksessä 'kuolema', mutta siihen liitettiin myös persoonallinen käsite, mikä näkyy tietyissä edelleen käytössä olevissa ilmauksissa, kuten Tuona tetab 'Tuona tietää,

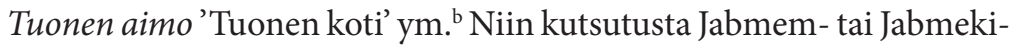

b

Jessen-Schardebøll 1767, 21, 22.

Lindahl \& Öhrling 1780, 506. 
akasta, joka vastaa suomalaisten Tuonen akkaa, antavat Lindahl ja Öhrling seuraavan kuvauksen:

Hän oli kuoleman (Tuonan) vaimo, kuolleiden isoäiti, yksi muinaisten lappalaisten keksimistä jumaluuksista, joka majaili maanalaisilla alueilla ja hallitsi kuolleita ja jota heidän elossa olevat jälkeläisensä palvoivat ja jolle he osoittivat uhreja ja jumalkultin sitä vastaan, että hän antaisi heille itselleen pidemmän elinajan. ${ }^{\mathrm{a}}$

Samojen kirjoittajien väittämän mukaan ${ }^{\mathrm{b}}$ lappalaiset ovat käsittäneet hänen valtakuntansa, aiemmin käsitellyn Jabmem- tai Jabmekiaimon, läpikulkupaikaksi (locus intermedius [lat.]), jossa vainajat oleilivat jonkin aikaa Jabmem-akan valvonnassa joko siirtyäkseen uudessa ruumiissa taivaallisen jumalan Radienin luokse tai kunnes heidät ajettiin syvyyksiin (Råtta-aimo), mikäli he olivat rikollisia. Tämä käsitys perustuu melko varmasti katolisiin oppeihin kiirastulesta. Tähän viittaa myös Jessen-Schardebøll mainitessaan, että šamaanien väitteet Radien-aimosta ja Rut-aimosta (Råtta-aimo [Lindahlilla ja Öhrlingillä]) ovat juuri tämän johdosta erittäin sekavia ja toisistaan poikkeavia. Hän esittää, että heillä oli paljon selkeämpi käsitys Jabme-aimosta, mutta kaikki, mitä hän tästä käsityksestä välittää, rajoittuu varsinaisesti matkoihin, joita šamaanien uskottiin tekevän tähän paikkaan.

Tällaiset matkat tehtiin yleensä kahdesta syystä: joko jotta šamaani saisi jabmekin, so. yhden kuolleista esi-isistä ja sukulaisista, vahtimaan poroja, tai sitten joku vanhemmista, joita ei haluttu menettää, oli kuolemansairas, ja hän [šamaani] yritti taivutella manalan asukkaat, kuolleiden henget, olemaan noutamatta sairasta alas Jabme-aimoon ja antamaan hänen elää vielä jonkin aikaa ihmisten parissa tälllä maan päällä. ${ }^{c}$

Ennen kuin tällainen matka tehtiin, šamaani tapasi rummuttaa ja loitsia, kunnes vaipui tajuttomuuteen ja jäi makaamaan kuin kuollut. Lappalaiset uskoivat, että tällä tavoin šamaanin sielu irtautui ruumiista

a Lindahl \& Öhrling 1780, 82.

b Lindahl \& Öhrling 1780, 8.

c Jessen-Schardebøll 1767, § 13. 
ja kulki aiemmin käsitellyn saivo-kalan tai -käärmeen mukana alas Jabme-aimoon. Täällä šamaani saattoi joutua suureen vaaraan, sillä oli mahdollista, että manalan asukkaat joko eivät halunneet antaa hänen viedä jotakin tovereistaan poropaimeneksi maan päälle tai vaativat, että sairaan oli välttämättä tultava alas Jabme-aimoon - vaatimus, jonka usein teki joku sairaan lähimmistä sukulaisista. Molemmissa tapauksissa maanalaiset olennot yrittivät aiheuttaa šamaanin kuoleman. Tällöin hänellä oli kuitenkin hyvä apu saivo-kalastaan tai -käärmeestään, joka taisteli vainajien kanssa, kunnes heidän oli pakko jättää šamaani rauhaan tai jopa taipua hänen vaatimuksiinsa. Tätä taipumista ei voinut saavuttaa vähemmällä kuin sillä, että šamaani rukouksissaan lupasi osoittaa uhreja niin tulevalle poropaimenelle kuin myös sukulaisten parista sille, joka vaati, että sairaan oli tultava alas Jabme-aimoon.

Tästä Jessen-Schardebøllin esityksestä käy selväksi, että olot Saivoaimossa ja Jabme-aimossa olivat melko erilaiset. Saivo-aimossa vierailijat otettiin aina hyvin vastaan, heitä kohdeltiin vieraanvaraisesti ja heille annettiin hyviä neuvoja ja opetuksia, kun taas sen, joka kulki Jabme-aimoon, täytyi valmistautua taistelemaan hengestään. Vanhemmat kirjoittajat antavat melko selviä kuvauksia siitä, että lappalaisilla oli sama pelko manalaa ja sen asukkaita kohtaan kuin suomalaisilla. Schefferus sanoo, ${ }^{\text {a }}$ että lappalaiset palvoivat vainajien henkiä omana jumalten lajinaan ja pelkäsivät niitä siitä syystä, että he uskoivat "sen, mikä kuolleista on jäljellä, olevan senlaatuista, että se voi vahingoittaa eläviä". Tämä väite on itse asiassa peräisin Samuel Rheeniltä, joka Schefferuksen mukaan ${ }^{\mathrm{b}}$ lausuu aiheesta tällä tavoin: "He (lappalaiset) uskovat, että jotakin on jäljellä kuoleman jälkeen, minkä vuoksi he myös välttelevät vainajia." ${ }^{\prime 6}$ Erityisesti lappalaiset olisivat pelänneet paljon edesmenneitä sukulaisiaan, ${ }^{c}$ sillä näiden uskottiin haluavan kovin saada vaimonsa, lapsensa ja muut maan päälle jääneet sukulaisensa lohdukseen ja ilokseen alas synkkään Jabme-

\footnotetext{
Schefferus 1673, 93.

Schefferus 1673, 93.

c "Pracipue terrentur et exagitantur a manibus cognatorum post mortem". Peucerus, de divinatione, Schefferuksen Lapponian [1673] mukaan, s. 93 ja 94.
} 
aimoon. Myös kuolleiden valtiatar Jabme-akka jakoi alamaistensa toiveet siltä osin kuin ne koskivat uusien asukkaiden hankkimista hänen asuntoonsa. Tästä johtuen lappalaiset tapasivat lepytellä yhtä lailla itse kuolemanjumalatarta kuin kuolleita sukulaisiaan muistamalla heitä uhrein. "He uhraavat kuolemalle tai edesmenneille vainajille", ${ }^{77}$ sanotaan lappalaisista yhdessä vanhemmassa Schefferuksen siteeraamassa ${ }^{a}$ käsikirjoituksessa, ja Ganander lausuu: " Jabmiakalle lappalaiset uhraavat, jotta ihmiset saavat elää; sillä Jabmiakka ja kuolleet itse haluavat saada elävistä alas luokseen ne, jotka ovat heille sukua, kuten lapset, lapsenlapset etc." Jälkimmäisenä mainittu kirjoittaja käsittelee paitsi Jabmiakkaa ja hänen alamaisiaan, niin kutsuttuja jabmekeja, myös toista Jabme-aimoon kuuluvaa olentojen luokkaa, jota hän kutsuu nimityksellä Jami-kiatser. Hän sanoo heidän olevan "maanalaisia henkiä’ ja esittää, että lappalaiset uhraisivat niille "luita ja muita pieniä osia, joita he ottavat eturaajoista uhrialttarilla ja joista he sanovat jumalten ja Jami-kiatser voivan tehdä uusia olentoja luomalla lihaa luiden päälle”.

Tämä käsittää lyhykäisesti kaiken tärkeimmän, mitä tähän päivään mennessä eri kirjoittajat ovat kertoneet koskien lappalaisten käsityksiä Jabme-aimon oloista. Kuvaukset tataarien käsityksistä kuolleiden valtakunnasta ovat vielä vajavaisempia. Omalta osaltani en tunne niitä yhtään sen laajemmin kuin mitä minulle on suullisesti kerrottu pakanallisten tataarikansojen parissa, jotka majailevat Sajanin aroilla Jenisein kuvernementin eteläosassa. Heidän mukaansa manalaa tai kuolleiden valtakuntaa hallitsee yhdeksän niin kutsuttua irle-khania ${ }^{78}$, joista yksi on ylimmäinen eli ataman. Näiden alamaisuudessa eivät ole pelkästään vainajat vaan myös lukuisa määrä niin näkyviä kuin näkymättömiä palvelushenkiä.

Näiden henkien joukosta puhutaan erityisesti eräästä yhdeksänpäisestä, jota kutsutaan nimellä Djilbegän ja jonka esitetään ratsastavan härällä, jolla on 40 sarvea. Eräässä muistiin kirjoittamassani tataarikertomuksessa kerrotaan tästä juuri nimetystä myös,

\footnotetext{
Schefferus 1673, 94.

Ganander 1789, 22.

c Ganander 1789, 22.
} 
että hän nousi kerran härällään manalasta ja katkaisi pään Komdeimirgän-nimiseltä sankarilta, joka oli katkaissut jalkansa pyytäessään erästä mustaa kettua. Tämän teon jälkeen Djilbegän palasi irlekhanien valtakuntaan sankarin pää mukanaan. Pian sen jälkeen kuolleen sankarin luokse tuli hänen siskonsa Kubaiko aikomuksenaan itkeä veljensä ruumiin äärellä. Kun hän löysi miehen päättömänä, hän päätti suomalaisten ja lappalaisten šamaanien tavoin matkata manalaan hakemaan päätä. Djilbegänin härän jäljet näyttivät hänelle tietä. Ne johtivat hänet maanalaiseen onkaloon, jonka lävitse hän astui alas irle-khanien valtakuntaan. Siellä hän kohtasi nyt monia ihmeellisiä asioita. Ensin hän huomasi tiellä seitsemän saviastiaa ja eukon, joka alituiseen kumosi maitoa ruukusta toiseen. Vähän pidemmällä hän näki hevosen seisovan sidottuna kolmen sylen pituiseen köyteen hiekkakentällä, jolla se ei saanut ruohoa eikä vettä, mutta tästä huolimatta hevonen oli ylenpalttisen lihava ja rehevä. Ei kovinkaan kaukana siitä seisoi toinen hevonen sidottuna pitkään köyteen viheriöivällä kentällä, jolla solisi vesi, mutta tämä hevonen oli hyvin laiha ja surkea. Eräässä paikassa hän näki puolikkaan ihmisruumiin patoavan joen, kun taas toisessa paikassa kokonainen ihmisruumis ei riittänyt hidastamaan toista samanlaista jokea.

Kubaiko ratsasti onnellisesti kaikkien näiden paikkojen ohitse ja kohtasi sitten toisen tytön, joka puhutteli häntä ja sanoi kuuluvansa valon maahan. Myös [tämä tyttö] oli lähtenyt manalaan pelastaakseen veljensä, mutta tultuaan irle-khanien asunnolle hän oli tuntenut vahvoja vasaraniskuja ja täynnä kauhua lähtenyt takaisin valon maahan. Tyttö antoi Kubaikolle silkkiliinan ja pyysi tätä antamaan sen veljelleen Kanmirgänille mikäli hän kohtaisi tämän, "jotta hän voisi pyyhkiä hikensä kun häntä paistetaan tulella". Tytöt erosivat ja Kubaiko jatkoi matkaansa yhä syvemmälle maan alle, missä sai nähdä yhä suurempia ihmeitä. Vasaraniskut alkoivat kuulua vahvemmin ja vahvemmin hänen korviinsa. Hän näki 40 miehen takovan vasaroita, toisten 40:n tekevän sahoja ja vielä 40:n valmistavan pihtejä. Seuraten Djilbegänin härän jälkiä hän ratsasti eteenpäin pelottomin mielin ja saapui lopulta korkean vuoren juurta seurailevan joen rantaan. Tällä joenrannalla kohosi irle-khanien asunto, 40-kulmainen kivitalo. Talon sisäänkäyntiä vastapäätä seisoi yhdeksän lehtikuusta, jotka kaikki kasvoivat yhdestä ainoasta juuresta. Tämän puun luona seisoivat 
irle-khanien hevoset sidottuina yksi kuhunkin kuuseen, ja myös Kubaiko sitoi hevosensa siihen. Silloin hän huomaa puussa kirjoituksen, joka kuuluu näin: "Kun Kudai loi taivaan ja maan, syntyi myös tämä puu, ja tähän päivään mennessä ei yksikään ihminen eikä yksikään eläin ole päässyt elävänä puun luokse.” Luettuaan kirjoituksen Kubaiko meni irle-khanien asuntoon ja sulki oven perässään.

Sisällä oli pimeää, ja Kubaiko eksyi pian huoneessa. Hän tunsi näkymättömien käsien koskettelevan itseään, hänen vaatteitaan revittiin, häntä puristeltiin ja kiusattiin; mutta kun hän ojensi kätensä ja yritti tarttua kiusanhenkiinsä, hänen oli mahdotonta ottaa niistä kiinni, sillä niillä ei ollut ruumiita. Pelästyksissään hän huusi; nyt avautui ovi, huone valaistui ja irle-khanien ataman astui sisään. Hän huomasi Kubaikon mutta kääntyi heti sanomatta sanaakaan. Kubaiko seurasi hänen jäljessään. Hän käveli ensin useiden huoneiden läpi, jotka olivat tyhiiä ja odottivat asukkaita, mutta sitten hänet vietiin toisten, ihmismäisten olentojen täyttämien asuntojen läpi. Yhdessä näistä hän näki vanhojen naisten istuvan ja kehräävän pellavaa kovalla vimmalla. Toisessa huoneessa istui myös vanhoja naisia, mutta he eivät tehneet kerrassaan mitään vaan näyttivät yrittävän niellä jotakin, jota eivät kuitenkaan saaneet kurkustaan alas. Kolmannessa huoneessa istui keski-ikäisiä naisia, joiden käsissä ja kaulassa roikkui suuria kiviä, joita he eivät kyenneet liikuttamaan. Neljäs huone oli täynnä miehiä, joilla oli köysi kaulassa, ja köysissä roikkui suuria tukkeja. Viidennessä huoneessa hän näki lävitseammuttuja miehiä, jotka olivat aseistautuneet kiväärein, juoksemassa ympäriinsä valittaen ja parkuen. Samaa juoksua, samaa parkua ja valitusta hän havaitsi myös kuudennessa huoneessa, jossa majoitettiin miehiä, joilla oli veitset, joilla he olivat haavoittaneet itseään. Tullessaan seitsemänteen huoneeseen hän näki hulluja koiria ja niiden puremia ihmisiä, jotka olivat myös hulluja raivosta. Näitä seurasi vielä yksi huone, kahdeksas järjestyksessä, missä mies ja vaimo makasivat kahdestaan peitteen alla. Vaikka tämä peite oli ommeltu yhteen yhdeksästä lampaannahasta, se peitti vain toisen makaavista, ja puolisot kamppailivat siksi peitteestä loputtomasti. Sitä vastoin yhdeksännessä huoneessa makasi mies ja vaimo yhdessä peitteen alla, joka oli tehty yhdestä ainoasta lampaannahasta mutta joka siitä huolimatta peitti molemmat puolisoista. 
Viimein hän astui sisään kymmenenteen huoneeseen, joka oli suuri kuin aro. Tässä huoneessa istui kahdeksan irle-khania, ja heidän pariinsa istuutui myös ataman, yhdeksäs. Kubaiko kumarsi irlekhaneille ja kysyi, miksi heidän palvelushenkensä Kjilbegän oli leikannut irti ja vienyt mennessään hänen veljensä pään. Irle-khanit vastaavat, että tämä tapahtui heidän käskystään mutta että he olivat valmiita palauttamaan pään, mikäli hän pystyisi nostamaan maasta seitsensarvisen pässin, joka oli kasvanut kiinni maahan niin syvälle, että vain sen sarvet olivat näkyvissä. Seikkailu oli myös vaarallinen, sillä irle-khanit ilmoittivat, että hän itse menettäisi päänsä, mikäli hänen yrityksensä epäonnistuisi. Kubaiko ei epäröinyt vähääkään ryhtyä yritykseen, jolloin irle-khanit nousivat ja lähtivät huoneesta ottaen tytön mukaansa. He johdattivat hänet jälleen yhdeksän huoneen läpi, kaikki täynnä ihmispäitä, joiden joukossa Kubaiko tunnisti myös veljensä. Tämän nähdessään hän pysähtyi ja purskahti itkuun, mutta irle-khanit ajoivat hänet kymmenenteen huoneeseen, missä pässi makasi maahan hautautuneena. Täällä he kehottivat Kubaikoa tarttumaan tehtävään, ja kolmella kiskaisulla hän kohottikin pässin hartioilleen. Nyt irle-khanit laskeutuivat Kubaikon jalkojen juureen ja kumarsivat hänelle, ja sitten he luovuttivat hänelle hänen veljensä pään ja saattoivat hänet takaisin asuntonsa lävitse. Matkalla he kysyivät häneltä, eikö hän niin mahtavana sankarittarena voisi neuvoa heille, kuinka he saisivat kärvennettyä Kanmirgän-sankarin, jota oli jo pitkän aikaa paistettu tulella, mutta jota ei saatu kärvennettyä. Kubaiko pyysi saada nähdä hänet, ja irle-khanit johdattivat hänet nyt vielä yhdeksän huoneen lävitse. Hän näki niissä seppiä takomassa. Kuljettuaan kaikkien näiden huoneiden läpi he tulivat kymmenennelle, missä Kanmirgäniä poltettiin. Kubaiko käytti nyt tilaisuutensa ojentaakseen sankarille tämän siskon liinan ja neuvoi irle-khaneja vapauttamaan Kanmirgän, sillä tämä oli oikeamielinen mies ja syyttä piinattu. He jatkoivat eteenpäin, ja irle-khanit saattoivat Kubaikon asunnostaan lehtikuusen luokse. Siellä Kubaiko nousi hevosensa selkään, mutta hän ei antanut irle-khanien vielä palata vaan vaati heitä näyttämään hänelle paluutien manalasta.

Matkalla Kubaiko kysyi kaikista niistä ihmeistä, joita hän oli nähnyt heidän maanalaisessa valtakunnassaan. Irle-khanit antoivat kaikkeen selityksen ja lausuivat: "Vanha nainen, jonka näit kaatamassa 
maitoa ruukusta toiseen, on eläessään tarjonnut vierailleen vedellä jatkettua maitoa. Hänen rangaistuksensa on tämän teon vuoksi erotella vettä maidosta, ja tässä työssä hän saa kärsiä ikuisesti. Puolikas ruumis, jonka näit patoavan joen, ei kärsi mitään rangaistusta. Se kuului hyvin viisaalle miehelle, joka pystyi patoamaan jokia ja saavuttamaan kaiken mitä halusi. Nyt hänen puolikas ruumiinsa lojuu muistutuksena ohikulkijoille siitä, että viisaskin mies, jolta on otettu raajat ja nahka, saattaa saavuttaa mahtavia asioita, kun taas toisaalta kokonainen ruumis, jonka yli joki häiriintymättä virtaa, muistuttaa siitä, että ihminen ei saavuta mitään pelkällä voimalla. Tämä ruumis on aiemmin kuulunut luonnostaan vahvalle mutta ymmärtämättömälle miehelle. Kuten vesi nyt virtaa hänen ruumiinsa ylitse, ovat kaikki asiat menneet yli hänen ymmärryksensä ilman, että hän olisi kyennyt niitä käsittämään tai saavuttamaan älyllä mitään.” Irle-khanit jatkoivat: "Lihava hevonen kuivalla nurmella on todiste siitä, että ajattelevainen mies voi pitää hevostaan seisomassa myös huonolla ravinnolla, kun taas sitä vastoin laiha hevonen rehevällä kentällä osoittaa, että elikko ei menesty edes parhaalla laidunmaalla, mikäli siltä puuttuu tarpeellinen hoito ja valvonta." Tällöin Kubaiko kysyi: "Mitä ne olennot olivat, jotka ottivat minusta kiinni pimeässä huoneessa, repivät vaatteeni rikki ja piinasivat minua mutta joilla ei ollut ruumista?" Irle-khanit vastasivat: "Ne olivat näkymättömiä palvelushenkiä, jotka voivat vahingoittaa ja jopa tappaa pahat, mutta aina irrottavat otteensa jokaisesta hyvästä ihmisestä eivätkä pysty tekemään hänelle mitään pahaa.”

Kubaiko jatkoi tiedustelemalla niiden ihmisten rikoksista, jotka hän näki suljettuna irle-khanien asuntoon, ja nämä vastasivat: "Naiset, jotka istuivat ja kehräsivät ensimmäisessä huoneessa, ovat saaneet tämän työn rangaistukseksi siitä, että he ovat eläessään kehränneet auringonlaskun jälkeen, kun ei ole sallittua tehdä mitään työtä. $\mathrm{He}$ taas, jotka istuivat toisessa huoneessa, ovat maan päällä saaneet lankaa kerittäväksi, mutta he ovat jättäneet kerän sisälle tyhjää ja työntäneet langan poveensa. Kerät, jotka he myöhemmin ovat koonneet varastetusta langasta, heidät on nyt tuomittu nielemään, mutta he eivät pysty siihen, vaan kerät jäävät ikuisiksi ajoiksi kiinni heidän kurkkuunsa. Nuoret naiset, jotka näit kolmannessa huoneessa istumassa kiviä kaulassaan ja käsissään, ovat myyneet voita ja voihin piilottaneet kiviä lisätäkseen sen painoa. Sen vuoksi he saavat nyt kantaa painavia 
kiviä, ja sitä he saavat tehdä iäti. Miehillä neljännessä huoneessa on kaulassaan köysi, joka uhkaa jatkuvasti kuristaa heidät, koska he ovat hirttäytyneet väsyttyään elämään. Läpiammutut miehet viidennessä huoneessa, jotka tavattomasti valittavat ja parkuvat, ovat myös itsemurhaajia, jotka ovat ampuneet itsensä siitä syystä, että elivät epäsovussa vaimonsa kanssa. Haavoittuneet miehet kuudennessa huoneessa ovat myöskin itsensäpilaajia, ja he ovat juovuksissa silponeet itseään. Seitsemännen huoneen asukkaat kärsivät rangaistusta siksi, että eivät varoneet hulluja koiria vaan yllyttivät niitä ja tulivat siksi niiden puremaksi. Kahdeksannessa huoneessa ovat sellaiset puolisot, jotka eläessään olivat epäsovussa keskenään ja kumpikin ajoi vain omaa etuaan, tuomittuina ikuisesti riitelemään peitteestä, joka sovussa ja yhteisymmärryksessä riittäisi paremmin kuin hyvin heille molemmille. Sitä vastoin ne puolisot, jotka yhdeksännessä huoneessa makaavat yhden ja saman peitteen alla, ovat esimerkkinä siitä, että myös vähäinen omaisuus voi riittää perheessä, jos vain puolisoiden kesken on yhteisymmärrystä. He eivät kärsi mitään rangaistusta, vaan ovat täällä ainoastaan siksi, että pahat heidät nähdessään tuntisivat rangaistuksensa vieläkin kovemmaksi."

Kun Kubaiko oli saanut kaikki nämä selitykset, hän erosi irlekhaneista ja palasi veljensä pään kera aurinkomaahan. Hän etsi veljensä ruumiin ja istuutui taas itkemään sen vierelle surullisena siitä, ettei kyennyt palauttamaan tätä henkiin. Mutta kudait säälivät tytön kyyneliä ja lähettivät hänelle elämänvettä, jotta hän virvottaisi vainajan sillä. Ja kun Kubaiko oli pirskottanut kolmesti elämänvettä edesmenneen veljensä jäänteille, tuli Komdei-mirgänistä jälleen elävä ja hän sai aiemmat voimansa. Silloin hän lähti erään toisen sankarin kanssa sisarensa ohjeiden mukaan alas manalaan vapauttaakseen Kanmirgänin - seikkailu, joka myös päättyi toivotusti.

Tämä lajissaan erittäin omaperäinen kertomus, josta yllä on vain ote, kuvaa myös paljon muita manalan olosuhteita. Siinä kerrotaan muun muassa, että kahden maakerroksen syvyydessä irle-khanien valtakunnan alla oli suuri meri, missä asui hallitsija nimeltään Talaikhan ('meren herra'), joka oli kauhistuttava ihmissyöjä ja jonka sanotaan myös nielleen aiemmin mainitun Djilbegän-hirviön, kun se yritti hakea turvaa hänen luotaan Komdei-mirgänin raivoisan koston pelossa. Tämä hallitsija ei esiinny jumalallisena olentona, ja kerrotaan 
myös, että Komdei-mirgän lopulta surmasi hänet. Irle-khanien sitä vastoin sanotaan olleen kuolemattomia, sillä kun Komdei-mirgän jännitti jousensa ja valmistautui ampumaan nuolen irle-khanien atamaniin, tämä lausui: "Ole ampumatta minua, Komdei-mirgän! Olen herra maan alla, ja minulla on täällä sama mahti kuin Kudailla maan päällä. Minua ei ole mahdollista eikä luvallista surmata.” Syvällä irlekhanien asunnon alla hallitsi Talai-khanin lisäksi myös toinen hänen kaltaisensa hallitsija nimeltään Ytzyt-khan. ${ }^{a}$ Satu kertoo, että hänellä oli tytär, Yljyn Aarakh, joka tapasi vaeltaa maan päällä mustan ketun hahmossa ja aiheuttaa ihmisille kaikkea pahaa. Juuri tämä pahantahtoinen tyttö houkutteli ketun hahmossa Komdei-mirgänin jahtaamaan itseään ja myöhemmin juonitteli väijytyksen tätä vastaan silläseurauksella, ettähän katkaisijalkansa eikävoinut estää Djilbegänia leikkaamasta päätään irti. Rangaistuksena tästä ja muista vastaavista rikoksista Komdei-mirgän ja hänen kumppaninsa lopulta surmasivat Yljyn Aarakhin.

Kuten tataareilla, myös samojedeilla on lukuisia kertomuksia monenlaisista sekä hyvistä että pahoista olennoista, joiden uskotaan majailevan maan huomassa. Tämän kansan keskuudessa ei kuitenkaan vallitse ainakaan yleisesti käsitystä maanalaisesta kuolleiden henkien kokoontumispaikasta. Olen silti kuullut yksittäisten jurakkiheimojen kertovan, että maan alla olisi jumaluus nimeltään $\mathrm{A}^{\prime}\left(\mathrm{Nga}^{\prime}\right)^{79}$, joka asuu läpipääsemättömässä pimeydessä, joka aiheuttaa kuolemaa ja sairauksia sekä ihmisille että poroille ja joka hallitsee lukemattomia henkiolentoja, aiemmin mainittuja tadebtsjoja, joiden jotkut olettavat olevan juuri vainajien henkiä. Muille kansoille nämä näkemykset ovat kuitenkin tyystin vieraita. Olen aiemmin maininnut, että samojedit palvovat tadebtsjoja tavallisesti omana jumalolentojen luokkanaan edesmenneinä ihmisinä. Mitä taas tulee edellä mainittuun jumalaan A', itä- eli tavgisamojedit pitävät häntä taivaanjumalana, jolla on näin ollen aivan sama merkitys kuin Numilla muiden samojedikansojen parissa. A. Fuks ${ }^{b}$ kertoo, että tšuvassit palvovat kuolemanjumalaa

a On sojot-heimoja, joilla ei ole mitään tietoa irle-khaneista, mutta jotka palvovat nimellä Yzyt manalan jumalaa, jonka sanotaan lähettävän sairauksia ja kuolemaa inmisille.

b Fuks 1840, 92. 
nimellä Esrel ja uskovat, että hän ottaa mukaansa edesmenneiden henget. Muut kirjoittajat esittävät kuitenkin perustellummin, että tämä nimi merkitsee jumaluutta, joka aiheuttaa ihmisille halvauksia. Minulle on epäselvää, kuinka laajalti ostjakkien, vogulien, votjakkien, tšeremissien ja muiden suomensukuisten kansojen parissa on vallalla käsitys kuolemanjumalasta ja hänen hallitsemastaan valtakunnasta.

\section{Erityisiä henkiolentojen lajeja}

Pohdittaessa suomalaisten ja heidän sukulaiskansojensa jumaloppia on osoittautunut, että he hakevat jumalallista myös ja eritoten luonnosta, taivaan ukkosista, meren aalloista, metsien syvyyksistä, manalan kätköistä - kaikesta siitä, mikä ulkoisessa luonnossa näyttäytyy suurena, mahtavana ja epätavallisena. Olemme myös vakuuttuneet siitä, että on ero tavassa, jolla paitsi eri kansat, myös yksi ja sama kansa eri kehitysvaiheissaan on käsittänyt jumalallisen. Alun perin on palvottu ulkoisia luonnonkohteita ja erityisesti eri elementtejä jumalten ominaisuudessa. Myöhemmin on tullut yleisimmin vallalle käsitys, että jumalallinen varsinaisesti on luonnossa mutta että se piiloutuu kohteiden taakse ja vaikuttaa niihin havaitsemattomin tavoin. Kummassakin tapauksessa jumalat käsitetään eläviksi, persoonallisiksi olennoiksi. Ne kansat, jotka palvovat luonnonkohteita niiden ulkoisessa manifestaatiossa, eivät kuitenkaan tunne toista elämää tai toista eksistenssiä ylipäätään, vaan tuntevat pelkästään aistittavan ja materiaalisen. Kuten olemme nähneet edellä käsitellyssä, esim. monet samojedikansat pitävät taivasta, Aurinkoa, maata ja vettä jumalina ja pitävät niitä elävinä olentoina ulkoisessa hahmossaan. Myös samojedeilla, puhumattakaan muista, sivistyneemmistä ${ }^{80}$ heimoista, on kuitenkin aavistus siitä, että kaikkialla luonnossa on piilotettuja voimia, jotka näkymättömässä muodossa vaikuttavat näkyvään maailmaan. Myös nämä luonnonvoimat käsitetään silloin eläviksi, persoonallisiksi olennoiksi, ja on luultavaa, että suomalaiset, useimpien sukulaiskansojensa tavoin, muodostivat juuri niistä jumalansa. He ovat niin sanoakseni erottaneet piilotetut voimat materiasta, johon ne varsinaisesti kuuluvat, ja antaneet niille objektiivisen olemassaolon omana itsenään suomalla niille elämän ja sielun, lihan ja veren, ruumiin 
ja hahmon. Koska jumalat tällä tavoin irtosivat siteestään luontoon ja saivat osakseen itsenäisen persoonallisuuden, niillä on nyt ulkoiseen luontoon suunnilleen samanlainen valta kuin isännällä omaisuuteensa. Tällainen isännänvalta on kuitenkin pelkästään mahtavimmilla: niillä, jotka hallitsevat ilmaa, vettä, maata, metsää jne.

Näiden lisäksi suomalainen mytologia tuntee lukemattoman määrän muita jumaluuksia, jotka näyttävät myös olevan personifioituja luonnonvoimia. Ne eivät eroa luonnoltaan muista elementtijumalista, mutta niiden mahti on vähäisempi. Ne hallitsevat pelkästään rajoitettuja kohteiden lajeja, ja ne käsitetään siksi tavallisesti suomalaisten runoissa palveleviksi jumaliksi. Tapio-jumala hallitsee koko metsää, mutta on myös paljon muita jumaluuksia, kuten Tuometar, Katajatar, Pihlajatar ym., joista yksi määrää tuomista, toinen katajista, kolmas pihlajista. Tuometar, Katajatar ja Pihlajatar ovat samanlaisia ruumiilla ja sielulla siunattuja persoonallisuuksia kuin itse Tapio, mutta koska heidän mahtinsa on rajoitetumpaa ja koska heidän hallitsemansa luonnonkohteet kuuluvat Tapio-jumalan alueeseen, heitä pidetään ainoastaan hänen palvelijoinaan. Kaikki jumaluudet eivät esiinny tällä tavoin henkilöityneinä suomalaisten parissa, ja vielä vähemmän heidän sukulaiskansojensa parissa. Kaikilla näillä [kansoilla] on käsitys, että koko luonto on täynnä henkiolentoja ja että jokaista kohdetta suurimmasta pienimpään hallitsee yksi tai useampi siinä asuva näkymätön henki. Nämä ulkoiseen kohteeseen kuuluvat henkiolennot eivät ole suurimmaksi osaksi muuta kuin luonnon piilotettuja voimia. Kypsymätön ihminen ei kuitenkaan kykene käsittämään ulkoisessa luonnossa vaikuttavia voimia muulla tavoin tai toisessa muodossa kuin siinä, joka ilmenee ja on sen omassa materiassa. Hän ei pysty käsittämään niitä muutoin kuin henkinä.

Kaikki ne altailaiset kansat, joiden uskonnollisiin käsityksiin olen tutustunut lähemmin, erottavat toisistaan jumalat ja henget ja tapaavat myös nimityksissä erottaa nämä toisistaan. On silti melko vaikea määrittää, missä niiden välinen ero varsinaisesti on. Ukert ${ }^{a}$ huomauttaa, että kreikkalaisten parissa sanoilla $\theta \varepsilon o \varsigma$ ja $\delta \alpha i \mu \omega v$ on ennen muinoin ollut usein sama ['jumalan'] merkitys, mutta että sanaa $\theta \varepsilon o \varsigma$

Ukert 1850, 140. 
pääasiallisesti käytettiin, kun tarkoitettiin jonkin jumalan fyysisiä, inhimillisiä ominaisuuksia, mitä vastoin $\delta \alpha i \mu \omega v$ merkitsi tämän henkistä olemusta. Myöhemmin kreikkalaiset viittasivat "demoneilla" $[\delta \alpha i \mu \omega v]$ olentojen luokkaan, jonka uskottiin olevan välimuoto jumalten ja ihmisten välillä. Altailaisten kansojen käsitykset jumalistaan ja demoneistaan ovat lähes yhtäpitäviä näiden kanssa. Niinpä suomalaisten parissa sana jumala merkitsee, kun sitä käytetään epiteettinä, aina henkilöitynyttä olentoa, kun taas haltiat, maahiset ym. käsitetään tavallisesti henkimäisemmiksi ${ }^{81}$ olennoiksi. Kuten olen osoittanut, samojedien parissa sana num merkitsee samaan aikaan 'jumalaa' ja 'materiaalista taivasta', kun taas sanalla tadebtsjo viitataan 'tiettyihin, ainakin tavallisen ihmisen katseelle näkymättömiin henkiolentoihin', joiden uskotaan olevan eräänlaisia välittäviä voimia jumalten ja ihmisten välillä kreikkalaisten demonien tavoin. Vastaavia käsityksiä tavataan, kuten seuraavassa tulemme näkemään, myös useimpien muiden sukulaiskansojemme parissa, mutta niiden kaikkien parissa paljastuu silti pyrkimys henkien personifioimiseen tavalla tai toisella.

Materian abstrahointi on luonnonihmiselle suoraan sanottuna mahdottomuus. Kaikki hänen ajatuksensa pyörivät aistittavien ilmiöiden maailmassa, ja hän pystyy vain vaivoin kuvittelemaan 'hengen' sanan varsinaisessa merkityksessä. Siksi hän tapaa alati suoda hengille jonkinlaisen materiaalisen olemuksen. Niissä tapauksissa, kun niiden ajatellaan kuuluvan johonkin luonnonkohteeseen, voi sama koskea niiden ruumiillista hahmoa. Monesti tapahtuu kuitenkin niin, että henget irtaantuvat siteistään näihin kohteisiin, jolloin ne puetaan jonkilaiseen ulkoiseen hahmoon, oli se sitten ihmisen tai eläimen, "kipunoita, tuiskua" jne. Olemme nähneet, että kun lappalaisen šamaanin henki on jättänyt ruumiillisen asuntonsa ja matkustanut vainajien valtakuntaan, sen käsitetään ottavan toisen ruumiin, joka kamppailee rivakasti vainajien kanssa. Vastaavasti lappalaiset uskoivat Gananderin ${ }^{\mathrm{a}}$ mukaan, että edesmenneet saavat manalassa uuden materiaalisen ulkoasun. Suunnilleen sama käsitys on myös altailaisilla kansoilla sellaisista henkiolennoista, jotka tilapäisesti vapautuvat luonnonkohteen materiaalisesta siteestä. Haluan tässä tuoda esiin esimerkkinä ainoastaan, 
että virolaisten muinaisten käsitysten mukaan veden hengen uskottiin toisinaan nousevan Võhandu-purosta ja siinä yhteydessä ottavan sinikeltasukkaisen miehen hahmon. ${ }^{a}$ Sittenkin henkien yleisiin ominaisuuksiin kuuluu, että ne mieluiten piiloutuvat siihen materiaaliseen kohteeseen, johon kuuluvat, ja pysyvät siinä sillä samalla käsittämättömällä tavalla kuin ihmissielu pysyy ruumiissa.

Mitä olen yllä sanonut hengistä koskee varsinaisesti pelkästään niiden yhtä lajia, siis sellaisia, jotka todelliselta luonnoltaan ovat vain luonnonvoimia ja kuuluvat tiettyihin luonnonkohteisiin, kuten Aurinkoon, maahan, mereen, puihin, vuoriin jne. Tämänluontoisten olentojen lisäksi olemme jo tutustuneet toiseen henkien luokkaan, jonka muodostavat kuolleiden henget. Eri kansoilla on monia erilaisia käsityksiä näiden luonnosta, kuten aiemmin olen osoittanut, mutta kaikki ovat yksimielisiä siitä, että myöskään nämä eivät ole tyystin immateriaalisia vaan että niillä on aina jonkinlainen ulkoinen, joskin tavalliselle ihmissilmälle näkymätön eksistenssi, ja että ne tarvitsevat ravintoa. Monet altailaiset kansat uskovat, että henget vaikuttavat eläviin ihmisiin ja varsinkin šamaaneihin, joissa ne herättävät suuremmat voimat, joille ne luovuttavat kaikenlaista tietoa sekä paljastavat piilotetun ja joiden sisäisen katseen ne antavat nähdä sellaisen läpi, mikä on ulkoisesti läpipääsemätöntä. Nämä henget eivät ole varsinaiselta luonnoltaan mitään muuta kuin ihmisen oman älyllisyyden syvyyksissä vallitsevia voimia. Ne ovat kuitenkin usein piilossa eikä ole helppoa saada niitä eloon ja toimintaan, ja siksi kypsymätön luonnonihminen ajautuu helposti ajatukseen, että ne eivät varsinaisesti kuulu häneen itseensä vaan ovat korkeampia olentoja, jotka ilmaantuvat hänelle ja antavat hänelle korkeampia kykyjä. Aasian šamaaneilla on tapana manata näitä henkiä esiin rummun kuminalla. Kun tarkkaillaan sitä tavatonta haltioitumista ja niitä uskomattomia voimia, jotka he tämän musiikin avulla pystyvät saamaan, ei voi mitenkään ihmetellä sitä, etteivät he koe tämän tilansa johtuvan omasta sisäisestä luonnostaan vaan toisten mahtavampien olentojen vaikutuksesta. He kuvittelevat lisäksi tunnistavansa näitä hahmossa tai toisessa, vaikka ne ovatkin kaikille muille näkymättömiä.

a Grimm 1844, 565. 
Yllä käsitellyt henkien lajit voidaan asiaankuuluvasti nimetä seuraavasti: 1) luonnon henget, 2) vainajien henget ja 3) elävien ihmisten henget, ja näihin voidaan lisätä vielä 4) sairaudenhenget. En tiedä, onko altailaisilla kansoilla näiden lisäksi muunlaisia henkiolentoja, enkä pysty edes varmuudella sanomaan, missä määrin kaikki altailaiset kansat tuntevat kyseiset kolme [neljä] henkien lajia. Käsitykset henkien eri lajeista ovat, kuten jo mainitsin, eri kansoilla hyvin erilaisia, ja koen sen vuoksi tarpeelliseksi kiinnittää erityistä huomiota jokaisen yksittäisen kansan demonologiaan siinä määrin, kuin se käsillä olevan aineiston puitteissa on mahdollista.

Lähtökohdaksi tarkastelulleni valitsen tavan mukaisesti suomalaisen kansan myytit ja traditiot, joskin ne tässä tapauksessa ovat vähemmän tyydyttäviä. Muinaislauluissamme on tuskin lainkaan nimettyjä demoneja, ja kuvaukset, joita niistä saadaan muita reittejä, ovat varsin vajavaisia. Paras lähde tähän, kuten moniin muihinkin tulkintoihin, on usein siteeraamani Lencqvistin tutkielma. Hän on esittänyt, että suomalaiset palvoivat jumaltensa lisäksi "eräitä henkiä tai suojelushenkiä ${ }^{82}$ ja demoneja, joiden he uskoivat kykenevän aiheuttamaan ihmisille sekä hyvää että pahaa”. Näitä olisi Lencqvistina mukaan ollut kuutta eri lajia, joiden nimitykset ovat: 1) haldia (haltia), 2) tontu (tonttu), 3) maahiset, 4) capeet (kapeet), 5) menningäiset (männingäiset), 6) paara (para).

Esitettyjen nimitysten joukosta tonttu ja para, kuten myös Lencqvist huomauttaa, on lainattu skandinaavisesta mytologiasta. Ruotsissa käytetään sanoja tomtgubbe, tomtkarl, tomtrå kuin latinan sanaa lar viittaamassa henkeen, joka huolehtii ihmisten kodeista. Lencqvist kertoo, että suomalaisten tontulta odotettiin vastaavasti apua ja tukea taloon liittyvissä asioissa. Ganander ${ }^{\mathrm{b}}$ erottaa toisistaan erityisiä tonttujen lajeja ja nimeää niitä: jyvä-tonttu, jonka uskottiin huolehtivan siementen kasvusta, raha-tonttu, joka hankki rahaa taloon, jne. Toisissa taloissa uskottiin olevan miespuolinen, toisissa naispuolinen tonttu, mutta kaikki olivat yksisilmäisiä. Tätä talonhenkeä pidettiin suuressa arvossa, ja hänen kestitsemisekseen jätettiin joka aamu ulos 
monta annosta puuroa. Jotta saisi tontun taloonsa, täytyi Gananderin mukaan "pääsiäisyönä ottaa tamman länget kaulaansa ja kulkea kirkon ympäri yhdeksän kertaa", jolloin tonttu omaehtoisesti näyttäytyi ja ryhtyi talon suojelijaksi. Näiden melko myöhäistä alkuperää olevien käsitysten joukosta ei yksikään vaikuta olevan kotoperäinen. Itse sana tonttu ei voi olla suomen kielessä kovin vanha, sillä se on tunnistettavasti muotoutunut ruotsin kielen sanasta tomt ('tyhjä pihakenttä), joka myös on myöhäistä alkuperää ja vanhemmassa kielessä oli muodossa toft. Lencqvist arvelee, että muinoin käytettiin samaan tarkoitteeseen viittaamaan sanaa huoneen haltia, ja mielestäni tämä arvelu on varsin perusteltu. Ainakin tänä päivänä elää yhä traditio, jonka mukaan suomalaiset muinoin liittivät jokaiseen taloon oman haltiansa.

Suomalaisten para eli paara on samantyyppinen kuin ruotsalainen bjäran eli bare - tietyllä tavalla tehty noitakalu, jonka uskottiin saavan elämän ja liikkumiskyvyn siten, että sen omistaja leikkasi itseään vasemman käden pikkusormeen ja tiputti kolme veripisaraa sen päälle lausuen samalla:

Maan päällä sinä saat minun puolestani juosta, Sinivuorella minä saan sinun puolestasi palaa. ${ }^{83}$

Tai:

Voita ja juustoa sinä saat minulle tuoda, Ja siksi (minä saan) helvetissä palaa. ${ }^{84}$

Nimityksillä björan ja bare uskotaan olevan perusta siinä, että kyseisen olennon uskottiin kantavan [ruots. bära] taloon maitoa, voita ja muita elintarvikkeita. Oli tämä johdos oikeellinen tai ei, epäilykselle sanan skandinaavisesta alkuperästä ei ole sijaa, sillä suomalaiset liittävät siihen täysin saman tarkoitteen kuin ruotsalaiset naapurimme. Sana para merkitsee suomen kielessä Lencqvistin mukaan "kyhättyä demonia, jonka noitanaisten uskotaan itse tekevän ja pakottavan hankkimaan maitoa ja juustoa". Paran tekemisen tavasta antaa sama kirjoittaja seuraavan kuvauksen: 
Pää tehdään lapsenmyssystä, joka täytetään värikkäillä tilkuilla, myssyyn piilotetaan myös öylätti, jonka joku vanha nainen on ottanut suuhunsa pyhällä ehtoollisella, ja se antaa olennolle elämän. Vatsa tehdään naisten pellavaisesta päähineestä, joka täytetään kankaalla. Tähän kiinnitetään lisäksi kolme keppiä, minkä jälkeen tämä kaunis tekele viedään kirkonportaille varhain jonkin pyhäpäivän aamuna. Ja kun se on saanut olla siinä hetken aikaa, sitä kuljetetaan yhdeksän kertaa kirkon ympäri jatkuvasti mutisten: "Synny para!" Ennen pitkää se saa elämän ja alkaa hypellä kolmella jalallaan. Paraa puhutellaan nyt seuraavin sanoin:

Kanna voita, kanna maito,

Tuo voita vuoren eucko,

Piimää pirun emändä!

Päästä piimen pindehestä,

Maito happaman hallusta.

Tämän olennon omistajalla uskotaan sittemmin olevan ylitsepursuavasti maitoa ja juustoa. ${ }^{a}$

Ganander huomauttaa, että para lypsää maitoa vieraista lehmistä ja kantaa sen emäntänsä voikirnuun. Hänen kuvauksensa ${ }^{\mathrm{b}}$ mukaan para on ulkomuodoltaan "karvainen, valko- ja mustapilkullinen, pikemmin pyöreä kuin pitkulainen, jalat kapeat kuin kurjella ja kolme lukumäärältään, muistuttavat paljon vanhan ajan sauvaa”. Mikäli para jäi oven väliin maitohuoneessa, uskottiin myös sen emännän menehtyvän pian sen jälkeen. Näihin kuvauksiin Ganander liittää vielä seuraavan:

Paran-voita, joka itse asiassa on eräänlainen sieni (mucor unctuosus flavus, Linn. Fl. Svec. 1282), he tapaavat taikauskoisina polttaa tervassa, suolassa ja soodassa ja piestä sitä ketjulla, sillä sen omistajattaren, noitanaisen, uskotaan silloin ilmaisevan sääliään ja paljastuvan vedotessaan palvelushenkensä puolesta.

Näistä melko laajalle levinneistä kuvauksista voidaan päätellä, että para oli varsinaisesti sellainen talon suojelushenki, joka tuki emäntää

a Lencqvist 1782, 53.

b Ganander 1789, 66, 67. 
hänen talonpidollisissa puuhissaan ja eritoten toi tälle runsain mitoin maitoa ja voita. Tästä hengestä tehtiin aina kuva, ja vaikka kuvaukset siitä ovat epämääräisiä, näyttää sillä silti olleen eläimen ulkomuoto, ja Ganander vertaa sitä nimenomaisesti kissaan. Tavassa, jolla tämä kuva muovattiin, näkyy sekä suomalaisessa että skandinaavisessa mytologiassa selvästi katolinen vaikutus.

Sana kave (mon. kapeet), dim. kapo, kaponen, on epäilyksettä alkuperältään suomea, mutta ei ole täysin selvää, mitä sillä varsinaisesti pitäisi ymmärtää. Renvallin väite, ${ }^{\text {a }}$ että kave merkitsee 'hienohiuksista', ei vaikuta luotettavalta, ja yhtä vähän pystyn yhtymään Lencqvistin käsitykseen, että se on sukua sanalle kapea. Totuudenmukaisempi on usean kirjoittajan ${ }^{85}$ ilmaisema näkemys, että sanalla kapeet viitataan mahtaviin, erityisesti hyväätekeviin henkiin eli suojelushenkiin. Tšeremissin vastaava sana kaba, kuten tšuvassien sana ke’be (Georgin ${ }^{\mathrm{b}}$ mukaan kabe), merkitsee hyviä henkiä, jotka varjelevat ihmisiä kaikelta pahalta ja jotka ovat verrattavissa kristittyjen enkeleihin. Sanaa kave ei kuitenkaan käytetä aina samassa merkityksessä kuin missä sitä käytetään vanhoissa runoissamme. Näissä se tavataan yhtä lailla jumaliin kuin huomattaviin sankareihin ja šamaaneihin ja myös tiettyihin eläimiin liitettynä epiteettinä. Jumaluus, jota ennen muita kunnioitetaan tällä epiteetillä, on Ilman tytär. Kalevalan vanhemmassa laitoksessa (runo 7, säe 613) kutsuu Lemminkäinen äitiään nimityksellä kave, ja myös Väinämöistä kutsutaan samalla tavoin joitakin kertoja. Kiro-kave, kiro-kapo ('kiroava kave') tavataan eräissä kohdissa epiteettinä šamaanille, ja eläinten joukosta ilvestä kutsutaan nimityksillä kave ja metsän kave. Tämän perusteella näyttää siltä, kuin sana kave voisi palvella runoissamme yleisenä nimityksenä kaikenlaisille eläville olennoille ${ }^{86}$ niin kauan kuin niissä on jokin tavallisuudesta poikkeava, hyvä tai huono ominaisuus. On silti mahdollista, että sanalla on alun perin ollut yllä esitetty merkitys 'henki'.

Olen juuri ilmaissut käsityksenäni, että menningäinen eli männingäinen ei ole kotoperäinen sana, vaan johtuu germaanisesta sanasta menni. Vastaavasti olen huomauttanut, että sanan männingäinen merkitys suomen kielessä ei ole aivan täsmällinen, vaan että sitä tavallisesti 
käytetään viittaamaan vainajien henkiin, joita tavataan kutsua myös nimityksillä keijuiset, manalaiset jne.

Sana maahinen, joka kuuluu myös muodoissa maahi ja maahiainen, johtuu epäilyksettä sanasta maa ja viittaa kaikkien kirjoittajien yksimielisen todistuksen mukaan omaan luonnonhenkien luokkaansa, jonka uskottiin majailevan maan, puiden, kivien ja kynnysten alla. Vaikka ne ovatkin ihmissilmälle näkymättömiä, niillä uskotaan olevan hahmo, joka on ihmisenkaltainen. Niiden ulottuvuuksia pidetään kuitenkin äärettömän pieninä, ja siksi niitä voidaan perustellusti verrata germaanisten kansojen olentoihin, joita kutsutaan nimityksillä dvergar ja Erdmännchen. Ne kuvataan äreäksi suvuksi, ja niiden sanotaan rankaisseen ihmisiä loukkauksista ihottumalla, kynsisienellä ja muilla ihosairauksilla. Niiden suosion saavuttamiseksi niitä on muistettava uhreilla. Mikäli pantiin olutta tai leivottiin leipää, piti ensiannos aina uhrata niille. Tarjoiluissa ja vieraanvaraisuudessakaan niitä ei saanut unohtaa. Emännän, joka oli tarkka navetastaan, tuli kestitä niitä maidolla. Kun muutettiin uuteen taloon, oli tarpeellista ensi käynnillä kumartaa talon kaikkia nurkkia kohden ja tervehtiä paikan maanalaisia asukkeja samaten kuin hyvitellä niitä "suolalla, mallaksella ja leivällä, taikka messingillä, jota oli raaputettu maitoon”." Mikäli niiden asumus jollain tavalla saastutettiin, tällaisesta rikkomuksesta rangaistiin sairaudella tai jollakin muulla onnettomuudella. ${ }^{b}$

Sana haltia merkitsee suomen kielessä 'ihmisten ja luonnonkohteiden suojelushenkeä ylipäätään'. Uskottiin, että luonnonympäristössä jokaista kohdetta hallitsi ylempi jumalvoima mutta että niillä oli myös niin kutsuttu haltia suojelijana. Näin ollen Ahti-jumalalla oli yleinen valta veteen, mutta sen lisäksi oli jokaisella järvellä, joella, lähteellä ja kaivolla oma veden haltiansa. Vastaavasti metsän haltia ei viittaa metsänjumala Tapioon, vaan jonkin pienemmän metsikön suojelushenkeen. Ihmiset käsitetään suomalaisessa mytologiassa, kuten aiemmin on jo mainittu, riippuvaisiksi kaikista jumaluuksista, mutta tämän lisäksi jokaisella yksilöllä on oma erityinen haltiansa, jonka "innostus ja myötävaikutus", kuten Lencqvist asian ilmaisee, johtaa ihmisen 
pyrintöjen menestykseen. Šamaanien uskottiin loitsiessaan olevan haltioiden vaikutuksen alaisina. Sitä ekstaasin tilaa, jossa he tällöin aina ovat, ja jossa he näyttävät kehittävän tavattomat voimat, kutsutaan suomen kielessä nimityksellä olla haltioissa, so. 'olla henkien luona. ${ }^{87}$ Tämä ilmaisu todistaa lisäksi, että yhdellä ainoalla henkilöllä saattoi olla useita haltioita, ja tämä uskomus vallitsee myös lappalaisten ja samojedien parissa. On merkillistä, että sana haltia tavataan vain harvoin vanhoissa runoissamme. On mahdollista, että tämä sana ei olekaan kuulunut alun perin suomen kieleen; mutta useampikin kohta runoissa todistaa, että itse käsitys on kotoperäinen. Esim. Lemminkäinen lausuu Kalevalassa (runo 12, säkeet 255-267):
Ylös maasta miekka-miehet,
Mannun aikaiset urohot,
Kaivoloista kalpamiehet,
Jokiloista jousi-miehet!
Nouse metsä miehinesi,
Korpi kaikki kansoinesi,
Vuoren ukko voiminesi,
Vesihiisi hirmuinesi,
Väkinesi veen emäntä,
Veen vanhin valtoinesi,
Neitoset joka norosta,
Hienohelmat hettehistä,
Miehen ainoan avuksi [...] !

Olennoiksi, joihin tässä kohdassa vedotaan, on epäilemättä käsitettävä niin kutsutut haltiat. Samaten on niiden suhteen, joita Vipunen kutsuu Kalevalassa (runo 17, säkeet 261-265) lausumalla:
Nostan maasta mannun eukot,
Pellosta peri-isännät,
Kaikki maasta miekkamiehet,
Hiekasta hevos-urohot,
Väekseni, voimakseni [...]

Luonnonkohteiden ja ihmisten olemuksen mukaisesti myös niiden haltioilla uskottiin olevan enemmän tai vähemmän hyviä ja ystävällisiä ominaisuuksia. Luonnollisestikin nämä henget olivat aina suosiollisia 
sitä kohtaan mitä hallitsivat, mutta suhteissaan toisiin olentoihin niiden uskottiin muistuttavan jumalia ja aiheuttavan niille sekä hyvää että pahaa. Veden haltialla oli muinaissuomalaisten käsitysten mukaan usein "surkeat tarjoomukset" kalastajille, jotka sen vuoksi aina pyrkivät lepyttämään häntä uhrein. ${ }^{\mathrm{a}}$ Lencqvist huomauttaa, ${ }^{\mathrm{b}}$ että he yrittivät välttää tällaiset tarjoomukset myös heittämällä veteen hylkeenihraa, joka olisi ollut veden haltialle vastenmielinen ruokalaji, ja sillä tavoin pakottaa hänet lähtemään tiehensä. Luultavasti veteen heitetyn hylkeenihran tarkoituksena ei alun perin ollut suinkaan karkottaa vedenhenkeä vaan päinvastoin osoittaa hänelle uhri. Myös ne haltiat, jotka pitivät huolta ihmisistä, nauttivat suojattiensa palvontaa eräänlaisina jumalina: heihin vedottiin ainakin rukouksin, ja heitä kunnioitettiin ehkä myös uhrein. Lencqvistin mukaan joka ikinen, joka lähti metsälle tai aikoi ryhtyä johonkin tärkeämpään puuhaan, tapasi vedota haltiaansa seuraavin sanoin:

Nouse luondoni lovesta,

Kiven alda kiilu silmä,

Paaden alda paicka poski,

Honga alda Haldiani!

Pue päälles palava paita $[\ldots]$

Tämä lyhyt runofragmentti osoittaa muun muassa sen, että muinaissuomalaiset uskoivat ihmisen suojelushengen majailevan hänen ulkopuolellaan kallioissa, kivien, paasien ja mäntyjen alla, vaikka sen sanottiinkin olevan osa hänen omaa luontoaan. Voimallisten ominaisuuksiensa vuoksi haltialla on tässä epiteetti kiilusilmä, joka muutoin tavataan liittää karhuun. Suojelushengen loimuava paita viittaa epäilyksettä sen raivoisaan, tuliseen luontoon, mutta sitä, kuinka paikkaposki pitäisi ymmärtää, en pysty varmuudella selittämään.

Näiden Lencqvistin luettelemien demonilajien [ks. s. 194] lisäksi suomalaiset laskivat myös monet sairaudet eläviksi hengiksi, jotka olivat pahoja luonnoltaan. Joillakin niistä uskottiin olevan eläimen muoto, ja näihin kuuluivat koi, hammasmato, läävä-mato, navetta-toukka

\footnotetext{
Ganander 1789, 9.

Lencqvist 1782, 50, 51.
} 
ym. Toiset taas käsitettiin ihmisenkaltaisiksi olennoiksi. Tämä koskee erityisesti yhdeksää Loviattaren kaitsemaa lasta, joita hän (Kalevala, runo 45, säkeet 163-170) kutsuu nimityksillä pistos, luuvalo, ähky, riisi, paiset, rupi, syöjä jne. Useimmille ei esitetty mitään tiettyä hahmoa, mutta niillä on toki jonkinlainen materiaalinen olemus ja ne ovat niin vähäisiä kooltaan, että monta saattaa keittää kerralla sormustimen kokoisessa kattilassa rangaistukseksi pahanteosta. Kuten huomautin jo aiemmin, kaikenlaisia vaivoja ja sairauksia (kivut, vammat) pidettiin Tuonen tyttären, Kivuttaren eli Vammattaren, alamaisina, mutta sen lisäksi ajateltiin myös koko luonnon olevan täynnä pahoja olentoja, jotka sairauksien muodossa piinaavat ihmisiä. Tästä todisteena palvelee Kalevalan runo 17 (säkeet 189-238), jonka sanat kuuluvat näin:

Tuolta ennen pulmat puuttui,

Tuolta taikeat tapahtui,

Tietomiesten tienohilta,

Laulumiesten laitumilta,

Konnien koti-sioilta,

Taikurien tanterilta,

Tuolta Kalman kankahilta,

Maasta manteren sisästä,

Miehen kuollehen koista,

Kaonnehen kartanosta,

Mullista muhajavista,

Maista liikuteltavista,

Somerilta pyöriviltä,

Hiekoilta heliseviltä,

Notkoilta noroperiltä,

Soilta sammalettomilta,

Hereistä hettehistä,

Läikkyvistä lähtehistä,

Metsän Hiien hinkalosta,

Viien vuoren vinkalosta,

Vaaran vaskisen laelta,

Kuparisen kukkulalta,

Kuusista kuhisevista,

Hongista hohisevista,

Latvasta lahon petäjän,

Mätäpäistä mäntylöistä,

Revon rääyntä-sioilta, 
Hirven hiihto-kankahilta,

Kontion kivi-kolosta,

Karhun louhi-kammiosta,

Pohjan pitkästä perästä,

Lapin maasta laukeasta,

Ahoilta vesattomilta,

Mailta kyntämättömiltä,

Suurilta sota-keoilta,

Miehen tappo-tanterilta,

Ruohoista rohisevista,

Hurmehista huuruvista,

Suurilta meren seliltä,

Ulapoilta aukeilta,

Meren mustista muista,

Tuhannen sylen syvästä,

Virroista vihisevistä,

Palavoista pyörtehistä,

Rutjan koskesta kovasta,

Ve’en vankan vääntehestä,

Takaisesta taivahasta,

Poutapilvien periltä,

Ahavan ajelo-teiltä,

Tuulen tuutima-sioilta.

Virolaisten käsitykset erillisistä demonien lajeista näyttävät olevan enimmäkseen yhdenmukaisia suomalaisten kanssa, mutta niitä on selvitetty vasta vähän. Virolaisessa mytologiassa tavataan käsitykset, että luonto on täynnä hyviä ja pahoja olentoja, että edesmenneiden ihmisten henget elävät kuoleman jälkeen ja että myös elävillä on suojelushenkensä. Siinä tavataan myös nimitys tont, jonka alkuperäinen merkitys lienee sama kuin suomen kielessä. ”Tont oli myös virolaisilla", sanoo Peterson, ${ }^{\text {a }}$ "henki, joka toi aarteita taloon. Häntä kutsuttiin sen vuoksi myös nimityksellä veddaja. Nyt nimitys tont tuo mieleen pelätyn kummituksen." Virolaisen mytologian maallused vastaavat suomalaisten maahisia. Peterson ${ }^{\mathrm{b}}$ mainitsee, että nämä "majailevat maan alla ja näyttäytyvät uudenvuodenyönä kääpiön 
hahmossa". Suomalaisten maahisten tapaan ne vaivaavat ihmisiä ihosairauksin, joita kutsutaan nimityksellä mahingaminne ('maan hengitys') tai ma-vihha ('maan viha'). Virolaisten käsitysten mukaan tällaisen saa ainoastaan siinä tapauksessa, että sattuu asettumaan sellaiseen paikkaan, jonka alla tämä maanalainen henki majailee.

Lappalaisten mytologiassa olemme jo tutustuneet kahdenlaisiin henkiolentoihin, joista toiset ovat vainajien henkiä, toiset niin kutsuttuja saivoja. Olemme havainneet edellisiä koskevien käsitysten olleen suunnilleen samanlaisia lappalaisten ja suomalaisten parissa, ja olemme verranneet saivoja suomalaisten haltioihin, vaikka niiden välillä on toki suuri ero. Saivot ovat kylläkin haltioiden tavoin sekä luontoa että ihmisiä suojelevia voimia, mutta siinä missä suomalaisten haltiat esiintyvät lähes tyystin hahmottomina, immateriaalisina, eivät lappalaiset suo saivoilleen, kuten jo yllä olemme nähneet, ainoastaan ruumista ja henkeä, vaan he antavat näiden jopa elää talossa, vaimon ja lasten kanssa, kodissaan kotitarpeineen. Samojedien siirtje on nähtävästi saivojen läheinen vastine. Lencqvist ${ }^{\mathrm{a}}$ mainitsee, että lappalaiset ovat palvoneet myös suomalaisten maahisia vastaavia henkiä ja uskoneet niiden majailevan teltan tulisijan tai kynnyksen alla, mutta ei mainitse nimitystä, jolla ne lappalaisten parissa olisi tavattu. Sitä vastoin Jessen-Schardebøllb ilmoittaa, että aiemmin käsitellyistä jumaluuksista Uks-akasta eli Juks-akasta ja Sarakasta edellisen uskottiin majailevan teltan sisäänkäynnin ( $u k s)$ luona, jälkimmäisen taas tulisijan luona. Tätä on vaikea käsittää muutoin kuin että lappalaisilla oli kuvat ${ }^{88}$ näistä jumaluuksista ja että näistä kuvista toinen oli asetettu oven suuhun, toinen tulisijan ääreen. Voi olla, että Lencqvist on sekoittanut kyseiset kuvat maahisiin, vai saattoivatko Uks-akka ja Sarakka mahdollisesti edustaa samaa talon suojelushenkien lajia kuin suomalaisten maahiset?

Tiedetään, että votjakit, tšuvassit, tšeremissit ja muut Itä-Venäjällä asuvat suomalaiset kansat ovat myös palvoneet ja osin yhä palvovat jumaltensa lisäksi sekä vainajien henkiä että muita alempia henkiolentoja, joista tiedetään toistaiseksi tuskin muuta kuin joitakin mainintoja. Näistä olen jo aiemmin käsitellyt tšuvassien sanaa kaba ja

b Jessen-Schardebøll 1767, § 9 . 
tšeremissien kebe, joiden käsitetään merkitsevän hyviä henkiä. Tiettyjä kuviin ikuistettuja henkiolentoja tšuvassit kutsuvat nimityksellä

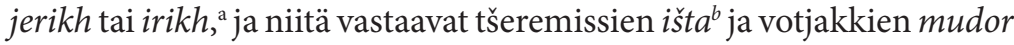
(modor). ${ }^{c}$ Myös niitä pidetään hyvinä, ihmisiä suojelevina olentoina, mutta mikäli joku kohtelee niitä kaltoin, ne eivät jätä sitä rankaisematta. Tšuvasseilla on uskomus, että heidän irikhinsä, samalla tavoin kuin suomalaisten maahiset ja virolaisten ma-allused, langettavat ihmisille paiseita ja kaikenlaisia ihosairauksia. ${ }^{\mathrm{d}}$ Myös ostjakit ja muut siperialaiset kansat palvovat suunnilleen samanlaatuisia kuvia, mutta näihin palataan myöhemmin.

Näiden kansojen uskonnosta välittää Georgi ${ }^{\mathrm{e}}$ joukon väitteitä, joita myöhemmin monet vanhemmat ja nuoremmat kirjoittajat ovat toistaneet hyvässä uskossa, vaikka useimmat niistä tuskin ovat luotettavia. Hän esittää muun muassa, että kyseiset kansat kaikki "uskoisivat yhteiseen jumalaan", joka on "kaikkeuden luoja", joka "rakastaa luomaansa ja tietää ja aiheuttaa kaiken, mutta ei välitä ihmisen yksittäisistä toimista”. Hän [jumala] ei välittäisi myöskään maailman ohjaamisesta, vaan hänen uskottaisiin luovuttaneen töidensä johtamisen tietyille alempiarvoisille jumaluuksille. Nämä väitteet jättävät melko vääristyneen kuvan niin "yhteisestä jumalasta" kuin hänelle alisteisista hengistäkin. On epäilemättä totta, että useimmat heimot uskovat pelkästään yhteen ainoaan jumalaan, jonka katsotaan majailevan taivaassa ja joka toisinaan samastetaan siihen, mutta siitä, että hän olisi maailman luoja, eivät kesyttömämmät kansat tiedä yhtään mitään, vaan tämä käsitys näyttää olevan lainattu muista, kehittyneemmistä uskontojärjestelmistä kuten kristinuskosta, muhamettilaisuudesta jne. Täysin luotettava ei ole myöskään väite, että taivaan jumala ei piittaisi maailman ohjaamisesta eikä osoittaisi lainkaan huomiota ihmisten puuhille. Päinvastoin olen usein kuullut kerrottavan, että hän seuraa tarkkaavaisella katseella kaikkea, mikä maailmassa häntä kiehtoo, ja että voimakkaalla kädellään hän ohjaa sen kulkua.

\footnotetext{
Georgi 1776-1780, 43.

Fuks 1840, 295.

Georgi 1776-1780, 60.

d Višnevski 1846, 8.

e Georgi 1776-1780, 378-.
} 
Georgi sanoo nimenomaisesti, että ihminen ei näytä pystyvän "uhmaamaan jumalaa eikä myöskään palvelemaan häntä" ja että jumala "ei palkitse eikä rankaise eikä häntä tarvitse pelätä taikka rakastaa". Täysin näiden väitteiden vastaisesti olen kuullut kerrottavan, että taivaallinen jumala suorittaa kostotoimet jo tässä elämässä ja että hän suo hyville terveyttä, vaurautta ja pitkän elämän kun taas lähettää pahoille sairautta, köyhyyttä ja ennenaikaisen kuoleman. Uskon hyvinkin, että nämä käsitykset eivät ole tyystin alkuperäisiä, enkä siksi ole myöskään käsitellyt niitä taivaanjumalan yhteydessä, mutta ne eivät kuitenkaan ole missään tapauksessa myöhempää alkuperää kuin käsitys jumalasta maailman luojana.

Harhaanjohtava on myös Georgin väite, että korkein olento olisi jakanut huolen maailman ohjaamisesta ja ihmisten kohtaloista monille alempiarvoisille jumaluuksille. Käsitys tällaisesta työnjaosta ei ole ainakaan koskaan yltänyt minun korviini, vaan sen sijaan olen kuullut usein puhuttavan, että taivaallisen jumalan lisäksi on alempia jumaluuksia, jotka tavallisesti käsitetään hengiksi, immateriaalisiksi olennoiksi. Ne ovat, kuten jo yllä huomautin, varsinaiselta perustaltaan niin ulkoisessa luonnossa kuin ihmisessä vaikuttavia voimia. Toisia niistä pidetään enemmän, toisia vähemmän voimakkaina sen kohteen laadun ja luonteen mukaisesti, mihin nämä henget tai voimat kuuluvat, mutta kaikki ne ovat mahdissa alisteisia taivaalliselle jumalalle, joka hallitsee ukkosta ja salamoita, myrskyä, sadetta ja kaikkia taivaallisia ilmiöitä. Pohjimmiltaan tämä jumala on samanlainen olento kuin kaikki muutkin luonnossa vallitsevat voimat, mutta koska hänen mahtinsa on niihin verrattuna paljon suurempi, häntä on - luultavasti myöhemmällä ajalla - alettu pitää niistä tyystin erillisenä, luontojaan korkeammilla ominaisuuksilla varustettuna persoonallisuutena. Pääasiassa juuri hän käy jumalasta, joka ohjaa ja hallitsee ei ainoastaan taivasta vaan myös maata ja sanalla sanoen koko luomakuntaa. Olemme aiemmin kuulleet tataarien maanalaisen hallitsijan Irle-khanin lausuvan, että hänen mahtinsa maan alla on yhtä suuri kuin Kudain maanpäällisillä alueilla, mutta käsitys tällaisista taivaallista jumalaa vastaavista olennoista on nykyään vähemmän tavallinen altailaisten kansojen parissa. Koska taivaallinen jumala hallitsee koko maailmaa, hänen mahtinsa katsotaan yltävän myös henkiin. Hän ei ole nimittänyt niitä sijaisikseen, vaan ne ovat hänelle alisteisia olentoja, jotka ihmisten 
tavoin usein anovat häneltä apua ja pelkäävät ryhtyä mihinkään, mikä olisi vastoin hänen tahtoaan.

Kun nyt käännän katseeni tiettyjen Aasiassa asuvien altailaisten kansojen käsityksiin henkimaailmasta, en voi olla ottamatta esiin seuraavaa I. J. Schmidtin ${ }^{a}$ antamaa kiinnostavaa kuvausta aiheesta:

Keskiaasialaisten kansojen uskomusten mukaan maa ja sen sisäosat, kuten myös sen ilmakehä, ovat täynnä henkihahmoisia olentoja, jotka vaikuttavat osin hyväntahtoisesti, osin vihamielisesti koko orgaaniseen ja epäorgaaniseen luontoon. Jokaisessa maassa, jokaisessa vuoressa, jokaisessa kalliossa, jokaisessa joessa, mäessä, lähteessä, puussa tai missä hyvänsä on henki asukkaana. Eivät pelkästään voimakkaat ja kauhistuttavat luonnonilmiöt johdu tällaisten henkien vihasta, vaan myös kato, epidemiat ja muut vaivat, kuten äkkinäiset sairaskohtaukset, epilepsia, raivohulluus ja muut sellaiset viat ihmisyksilöissä luetaan niiden vaikutukseksi. Ne [henget] jaetaan useisiin luokkiin, ja niiden toimialat, kuin myös niiden mahti, ovat hyvin vaihtelevia. Pääasiassa autioita, asumattomia ja hämyisiä alueita tai sellaisia, joissa luonto näyttää aikaansaannoksiaan giganttisissa massoissa ja kaikenlaisissa kauhistuksissa, pidetään tuhoisten henkien päämajoina tai kokoontumispaikkoina, mistä ne siirtyvät toisille alueille saavuttaakseen kaameita tavoitteitaan. Siksi Turanin autiomaat ja erityisesti suuri hiekka-autiomaa Gobi olivat jo hämärässä muinaisuudessa pahamaineisia pahojen henkien asuinpaikkoja.

Keskiaasialaisten kansojen parista eritoten mongoleilla on hyvin kehittynyt demonologia, mutta se on nykyisessä muodossaan paljolti sekoittunut vieraisiin, buddhalaisesta uskontojärjestelmästä lainattuihin käsityksiin. He kutsuvat demoneita nimityksellä tengri (tengeri), tegri, joka, kuten olen aiemmin maininnut, on alun perin merkinnyt 'taivasta' ja 'taivaan jumalaa' vastaavasti kuin samojedien num. Tämä sana on saanut luultavasti jo ennen buddhismin vaikutusta kaikenlaisten hyvien ja pahojen henkiolentojen merkityksen. Nykyisin sanaa tengri käytetään merkitsemään niin näkyvää taivasta kuin kaikenlaisia alempia henkiä. Taivaallista jumalaa en ole kuitenkaan koskaan kuullut nimitettävän näin, vaan häntä kutsutaan tavallisesti nimityksellä Burkhan ('Buddha, [jumala]'), myös Tengri- tai Oktorgoi-Burkhan

Schmidt 1829, 352. 
('taivaan Buddha, [taivaan jumala]'), ja šamanismille omistautuneet heimot palvovat häntä maailman luojana ja kaiken hyvän lähteenä. Hänelle vastakkainen olento on Ukudel (Okodil), jota tietyt heimot kutsuvat nimityksellä Šytkyr tai Tšytxyr ja jota pidetään pahojen päällikkönä. Hänellä ajatellaan kuitenkin olevan vähemmän valtaa kuin Burkhanilla, ja sen ajatellaan olevan riippuvainen hänestä. Kaikki nykyisin vallitsevat käsitykset niin Burkhanista kuin Ukudelista eli Šytkyristäkin ovat myöhäissyntyisiä.

Tämä koskee myös tiettyjä muita jumaluuksia, joita muun muassa šamanismille omistautuneet heimot tuntevat. Mainitsen niistä nimeltä ainoastaan niin kutsutun Khormusdan (Churmustu), maan mahtavan suojelusjumalan, jonka I. J. Schmidt ${ }^{\mathrm{a}}$ varsin hyvin perustein näkee olevan ei kukaan muu kuin persialaisten Ormusd tai Hormusd. Tiedetään varmuudella, että mongolien muinaiset jumaluudet ovat olleet elementtivoimia ${ }^{89}$ samaten kuin että erityisesti Aurinko, tuli, vesi ja maa ovat olleet palvonnan kohteina. Ei kuitenkaan tiedetä lähes lainkaan, millaisia käsityksiä niistä on ollut. Samassa tietämättömyydessä joudutaan painiskelemaan määritettäessä tarkoitetta, johon kyseiset kansat alun perin ovat liittäneet niin kutsutun tengrin. Mikäli tässä luotetaan mongolien kirjallisuuteen hyvin perehtyneen Schmidtin ${ }^{\mathrm{b}}$ auktoriteettiin, liittivät myös mongolit jokaiseen kohteeseen luonnossa oman erityisen suojelushenkensä eli tengrin. Tähän näkemykseen yhtyy myös Pallas, ${ }^{c}$ kun hän lausuu, että mongolien mukaan jokaisella maailmanjärjestyksen osalla, jokaisella valtakunnalla ja kansalla, jopa jokaisella ihmisellä on näkymätön enkelinsä eli suojelijansa. Näitä suojelushenkiä hän kutsuu nimityksellä esän, mutta Kovalevski liittää tähän tarkoitteeseen sanan orgon. Jälkimmäisen kirjoittajan mukaan näillä olennoilla ei olisi rajoittamatonta valtaa liikkua kaikkialla maailmassa, vaan ne olisivat jollakin tavoin kiinnittyneet niille määrättyihin asuinpaikkoihin. On olemassa, kuten sekä Pallas että Schmidt esittävät, sekä hyviä että pahoja demoneja, joista jälkimmäisten uskottiin pääasiassa majailevan metsissä ja hämyisillä, luoksepääsemättö-

a Schmidt 1824, 148.

b Schmidt 1824, 181-.

c Pallas 1801, 45-. 
millä alueilla. Pahoihin demoneihin luettiin erityisesti mahtavat luonnonhenget, jotka aiheuttavat pyörremyrskyjä, tulvia, maanjäristyksiä, vulkaanisia purkauksia ja muita pelottavia luonnonilmiöitä. Lisäksi on olemassa, kuten mainittua, myös pahoja henkiä, jotka tuovat ihmisiin ja heidän asuntoihinsa kulkutauteja ja kaikenlaisia sairauksia. Myös edesmenneet šamaanit saattavat ottaa pahan, kostonhaluisen, verenhimoisen henkiolennon hahmon. Jo näissä lyhyissä vihjeissä näkyy, että mongolien alkuperäiset käsitykset demoneista tarjoavat lähimmän yleisen vastineen niille, joiden olemme nähneet vallinneen suomalaisen heimon parissa.

Yhtä lailla kuin mongolien nykyiset näkemykset demoneista on suurimmaksi osaksi lainattu buddhismista, tunguusikansat ovat lainanneet paljon Kungfutsen opeista. Näin näyttää olevan myös niiden tunguusien suhteen, jotka tällä hetkellä asuvat Kiinan alueen ulkopuolella Siperian itäosissa. Omalta osaltani en löydä Georgin ${ }^{a}$ kuvauksesta siperialaisten tunguusien uskonnollisista käsityksistä mitään, mikä poikkeaisi erityisemmin heidän sukukansojensa parissa vallitsevista käsityksistä. Näiden tavoin myös tunguusit osoittavat palvontansa pääasiassa taivaanjumalalle nimeltään $\mathrm{Boa}(\mathrm{Buga})$, mutta he pitävät myös Aurinkoa, Kuuta, tähtiä, tulta, maata, vettä, metsää, vuoria ja muita elementtivoimia Boan alaisina jumaluuksina. Heillä on myös jumaluuksia, jotka tuovat onnea metsästyksessä ja matkoilla, suojelevat poroja, tuovat terveyttä, turvaavat naisia ja lapsia - kaikki jumalolentoja, jotka suurimmaksi osaksi tavataan myös suomalaisten ja lappalaisten keskuudessa. He palvovat myös demoneja, joita kutsutaan yhteisellä nimityksellä buni. Siperian pohjoisissa osissa olen kuullut niitä kutsuttavan nimityksellä agei. Niiden lukumäärä on mahdottoman suuri, ja Georgin mukaan ne majailisivat maassa ja vedessä (eikö siis kaikkialla luonnossa?). Samojedien ja muiden pohjoissiperialaisten kansojen tavoin myös tunguusit uskovat, että šamaanit "elävät suuressa luottamuksessa" bunien kanssa, että jokaisella šamaanilla on joitakin sellaisia ystävinään ja että hänen [šamaanin] "on usein kärsittävä niiden vuoksi" mutta että niiden myötävaikutuksella myös "voi kokea paljon, välttyä paljolta pahalta ja saada aikaan paljon hyvää". 
Sen jälkeen kun kristinusko alkoi tunkeutua tunguusien pariin, he ovat alkaneet pitää buneja pahoina olentoina, vaikka alun perin ne eivät olleet mitään muita kuin ihmisten ja luonnon suojelushenkiä. Jotkut niistä tunnetaan erityisillä nimillä. Georgi kertoo, että ylimmäinen veden buni on nimeltään Garan, ja sen uskotaan saavan vedet tyrskyämään, kumoavan (stoßen [saks.]) veneitä ja ajavan kaloja sekä rannoille että pois niiltä. Maan mahtavin buni on Dorokdi eli Kongdarokdi, jonka uskotaan tietävän kaiken, mitä sille tulee tapahtumaan. Šuro on nimeltään buni, joka paljastaa varkaita. Atšintitei on sen bunin nimi, jonka uskotaan hallitsevan hyttysiä. Vaikka jotkin näistä ja muista Georgin välittämistä tiedoista ovat mielestäni epäluotettavia, on vaivatta nähtävissä suuri yhteneväisyys, joka vallitsee tunguusien ja heidän sukulaiskansojensa demonikäsityksissä.

Turkkilaisten kansojen parissa on muhamettilaisuus ja osittain myös kristinusko peittänyt lähes kaikki jäljet heidän demoniopistaan ja pakanallisista uskonnoista ylipäätään. Niiden traditioiden vuoksi, jotka elävät yhä edelleen koibaaleiden ja eräiden muiden pakanallisten tataarikansojen parissa eteläisessä Siperiassa, olen kuitenkin vakuuttunut siitä, että myös he ovat palvoneet demoneita. He kertovat yleisesti, että luonnossa on loputon määrä henkiolentoja, joita eräät heimot kutsuvat nimityksellä aina, toiset $a s a$, ja jotkut taas nimityksellä $y z y t .{ }^{90}$ Näiden sanotaan majailevan enimmäkseen maassa, mutta niiden uskotaan pystyvän myös vaeltelemaan ympäriinsä kaikkialla luonnossa. Šamaanien uskotaan kykenevän kutsumaan niitä luokseen loitsujensa ja rumpunsa avulla. Tunguusien tavoin myös tataarit uskovat, että tällä tavoin hankitut henget suojelevat jokaista šamaania ja täyttävät kaikki hänen käskynsä uskollisesti ja halulla. Niihin liitetään sekä pahoja että hyviä ominaisuuksia, mutta nykyään ne käsitetään kuitenkin tavallisesti pahoiksi olennoiksi, jotka ovat irle-khanien tottelevaisia alamaisia ja tuovat ihmisille sairauksia, ja niiden uskotaan pystyvän aiheuttamaan jopa kuoleman. Niillä uskotaan olevan kyky ottaa mikä hyvänsä haluamansa hahmo, mutta erityisen mielellään ne ottavat maan päällä oleillessaan linnun, käärmeen, ketun, koiran tai jonkin muun eläimen hahmon. Tataarien kertomuksissa ne esiintyvät myös ihmishahmossa, mutta yleisesti sanotaan, että tässä hahmossa 
ne eivät nouse kokonaan näkyviin vaan pelkästään vyötäröään myöten maan yläpuolelle. ${ }^{a}$

Eräässä kertomuksessa puhutaankin ainasta nimeltään Ai-kyn ('aurinko ja kuu'), joka kohoaa kokonaan maasta käydäkseen sankareita, päälliköitä ja jumalia vastaan. Yksikään näistä ei uskalla antautua taisteluun pelottavan ainan kanssa, mutta seitsemän kudaita tietävät, että maan päällä on kolmivuotias poikanen, joka kykenisi peittoamaan Ai-kynin. Seitsemän kudaita sekä seitsemänkymmentä päällikköä ja sankaria lähettävät nyt tälle viestin, jossa on pyyntö, että hän kävisi matkaan ja taistelisi ainaa vastaan. Poika valmistautuu pikimmiten taisteluun, ja hänen onnistuu todellakin pitkän taistelun päätteeksi sitoa Ai-kyn käsistä ja jaloista. Kuinka kovia iskuja hän miekallaan tälle antaakin, hänen ei kuitenkaan onnistu saada ainaa hengiltä. Syy tähän on, että Ai-kynillä ei ole sieluaan ruumiissaan, vaan hän on kätkenyt sen 12-päiseen käärmeeseen, joka on hänen mukanaan säkissä hevosensa selässä. Kun poika on pakottanut Ai-kyniltä tämän tiedon, hän tappaa käärmeen, ja nyt saa myös Ai-kyn surmansa. Tässä kertomuksessa on tunnistettavasti ilmaistu eettinen ajatus, jonka mukaan viattomuus on voimakkain ase taistelussa pahoja vastaan, mutta minusta näyttää siltä, kuin siinä olisi myös fyysinen elementti mukana. Ei voi olla sattumaa, että pelottavalla ainalla, joka kohoaa ylös maasta, on nimenä 'aurinko ja kuu'. Joku paino on annettava myös sille seikalle, että kertomus antaa pojan kohdata Ai-kyn erään vuoren huipulla. Merkitykselliseltä vaikuttaa minusta erityisesti kuvaus ainan leimuavasta katseesta. "Kun hän katsoo ylös taivaaseen", kerrotaan, "pilvet palavat, ja kun hän katsoo alas maahan, palaa ruoho", ja kun hän tappelee pojan kanssa, "maa vavahtelee ja meri tulvii, ja arot peittyvät veteen, ja ihmiset ja eläimet pakenevat vuorille". Eikö tämä kaikki viittaakin vulkaaniseen purkaukseen? Tämä oletus vaikuttaa minusta sitäkin todennäköisemmältä, kun myös muut [tataarien] sukulaiskansat uskovat kaikenlaisten pelottavien luonnonilmiöiden johtuvan pahojen henkien vaikutuksesta. Nykyiset tataarit

a Tämä käsitys on epäilyksettä myöhäsyntyinen ja näyttää perustuvan siihen, että vanhat jumalkuvat, joita siellä täällä tapaa aroilla, ovat maan pinnalla vain vyötäröstään ylöspäin. 
eivät kuitenkaan liitä ainoihin tällaista toimintaa, vaan nämä toimivat enimmäkseen pelkästään šamaanien palvelushenkinä.

Kaikista altailaisista kansoista samojedit ovat nykyisin innokkaimpia demonien palvonnan harjoittajia, mutta heidän käsityksensä demoneista eivät ole kuitenkaan yhtenäisiä, kuten mikään, mikä liikkuu heidän mielessään. He tuntevat pääasiassa pelkästään kahta lajia henkiolentoja, joista toista yksittäiset heimot kutsuvat nimityksellä tadebtsjo, loh eli los, koika jne., toista taas nimityksellä itarma. Olen jo maininnut aiemmin, että jälkimmäiset ovat edesmenneiden šamaanien henkiä, joiden uskotaan kykenevän aiheuttamaan ihmisille kaikenlaisia sairauksia ja onnettomuuksia ja jopa aiheuttamaan kuolemaa. Mitä taas tulee tadebtsjoihin, jo sanan etymologia (tadebtsjo sanasta tadibea 'šamaani') osoittaa, että ne, kuten bunit eli ageit tunguusien parissa ja ainat tataarien parissa, ovat šamaanien avuliaita palvelushenkiä. Samojedit eivät käsitä niitä kiinnittyneiksi mihinkään kohteeseen, vaan uskovat, että ne kuljeskelevat vapaasti ympäriinsä kaikkialla luonnossa, niin maan päällä kuin ilmassa ja erityisesti maan alla. Missä ne ovatkin, kykenee šamaani kutsumaan niitä luokseen. Tätä hän ei jätäkään koskaan tekemättä, mikäli on kyse jonkin maagisen toimen suorittamisesta, sillä ainoastaan niiden avulla hän pystyy parantamaan sairauksia, löytämään kadotettuja esineitä, ennustamaan tulevia asioita jne. Tadebtsjoja pidetään immateriaalisina olentoina, joita ihmissilmä ei kykene näkemään, mutta šamaanit eivät ainoastaan kykene näkemään niitä sisäisellä katseellaan vaan jopa kykenevät keskustelemaan niiden kanssa ja saamaan niiltä neuvoja ja selvityksiä loitsuillaan.

Useimmat kirjoittajat kuvaavat tadebtsjoja pahoiksi, taivaallista jumalaa Numia kohtaan vihamielisiksi olennoiksi, mutta tämä ei kuitenkaan ole asian laita. Altailaisten kansojen parissa ei hyviä ja pahoja ylipäätään käsitetä absoluuttisina vastakohtina, vaan yhdellä ja samalla olennolla ajatellaan tavallisesti olevan sekä hyviä että pahoja ominaisuuksia. Näiden kansojen uskomusjärjestelmässä ${ }^{91}$ on nimittäin myös henkiä, joihin liitetään osin pahoja ominaisuuksia mutta jotka eivät ole koskaan itsenäisiä, vaan niitä pidetään aina riippuvaisina toisista, mahtavammista jumaluuksista. Mitä tulee tadebtsjoihin, niitä pitävät pahoina henkinä ainoastaan sellaiset yksilöt, joilla on tuntemusta kristinuskosta. Šamaanien parista ei kukaan myöntäisi 
harjoittavansa pyhää tehtäväänsä pahojen henkien myötävaikutuksella. Tekeytyäkseen tärkeiksi he tapaavat nimittäin liittää tadebtsjoihinsa kovan ja riippumattoman luonteenlaadun, sillä mitä suurempia vastuksia nämä henget pystyvät asettamaan šamaanin tielle, sitä suuremman arvon tämä voi saavuttaa ulkopuolisten silmissä. Mikäli tadebtsjot eivät olisi kovaluontoisia, kuinka šamaani pystyisi perustelemaan pyyntönsä tuoda niille uhreja joista šamaani itse aina pitää osuutensa? On siis hänen omissa intresseissään esittää tadebtsjot vastahakoisina ja kovaluonteisina olentoina. Leppymättömiä ne eivät silti ole, vaan šamaanit kykenevät taivuttamaan ne kaikenlaisiin sekä hyviin että pahoihin tekoihin. Samojedien jumalopissa ei ole varsinaisille eli näkymättömille tadebtsjoille mitään muuta määritelmää kuin `šamaanin palvelushenki. Šamaaneilla, kuten tulemme näkemään, on niin ikään kyky antaa niille jonkinlainen ulkoinen hahmo, kun taas tavalliset ihmiset kunnioittavat niitä suojelusjumalina.

Samojedit eivät puhu mihinkään tiettyyn kohteeseen kiinnittyneistä hengistä, vaan osoittavat palvontansa kohteille itselleen, toisin sanoen he eivät erottele henkeä materiasta, vaan palvovat kohdetta kokonaisuudessaan jumalallisena olentona. Jurakkisamojedien parissa olen kuullut lukuisia traditioita eräästä maan huomassa asuvasta suvusta, jota kutsutaan nimityksellä siirtje ${ }^{92}$. Nämä siirtjet muistuttavat niin ulkonäöltään, tavoiltaan kuin elämäntavaltaan ihmisiä, eritoten samojedeja, mutta heidän olonsa ovat paljon onnekkaammat. He asuvat mitä suurimmassa vauraudessa ja yltäkylläisyydessä, heiltä ei puutu kultaa eikä aarteita, heillä on kettuja, soopeleita ja majavia suuret määrät; porojen tilalla heillä on laumoittain mammutteja jne. Siitä johtuen, että venäläisillä on samanlaisia kertomuksia vanhoista tšuudeista, on oletettava, että myös samojedien traditiot siirtjestä lepäävät historiallisella pohjalla ja viittaavat tundran vanhempiin asukkaisiin suomalaisiin. ${ }^{93}$ Itse nimitys siirtje muistuttaa toisaalta hämmästyttävästi syrjääni-nimitystä, sillä lopputavut ${ }^{94}$ ovat venäjänkielisessä nimityksessä syrjan sekä samojedinimityksessä siirtje keskenään analogisia johdinaineksia ${ }^{95}$. 


\section{Jumalkuvat ja pyhät luonnonkohteet}

Sanalla "jumalkuva"96 on kielessämme varsinaisesti eri merkitys kuin mitä tulen seuraavassa siitä käyttämään. Tavallisesti sanalla ymmärretään pelkästään ulkoista kuvaa, symbolia jumaluudelle, joka taas käsitetään kuvasta erilliseksi, itsessään olemassa olevaksi olennoksi. Altailaisten kansojen parissa jumalkuvilla ei ole tätä muodollista merkitystä, vaan useimpien parissa asia käsitetään niin, että jumaluus asuu kuvassa tai on niin sanotusti inkarnoitunut siinä. ${ }^{97}$ Jumalkuvat ovat näin ollen heidän näkemyksensä mukaan todellisia jumalia, ${ }^{98}$ ja he uskovat vakaasti, että ne kykenevät suomaan ihmiselle terveyttä, hyvinvointia ja muita elämän etuisuuksia.

Jumalallisten olentojen ominaisuudessa palvotaan myös tiettyjä luonnonkohteita, kuten puita, kiviä ym. Tämänluonteisia kohteita ovat lyhyesti sanottuna vain ne, joita alempi, noituuden salaisuuksiin vihkiytymätön kansa palvoo jollakin ulkoisella kultilla. Viisailla tai šamaaneilla sitä vastoin, kuten mainittua, on se etusija muihin ihmislapsiin nähden, että he kykenevät ottamaan yhteyden henkiin ja pystyvät näkemään ne, keskustelemaan niiden kanssa, pyytämään niiltä neuvoa ja apua ja myös pakottamaan ne taipumaan tahtoonsa. Tavalliselta ihmiseltä taas henkien maailma on tyystin suljettu: hän ei pysty šamaanin tavoin loitsimaan niitä esille yöstään ja manaamaan niitä luokseen. Näissä oloissa ihminen ei voi myöskään laskea niiden apua ja tukea varmaksi, sillä useimmat kesyttömät kansat pitävät mahdottomana ajatusta, että henget piittaisivat ihmisen rukouksista, mikäli tämä ei ole niiden kanssa kasvokkain. Juuri tästä syystä myös samojedit ja muut altailaiset kansat pitävät hedelmättömänä rukousten suuntaamista niin taivaalliselle kuin muillekin mahtaville jumalille. Nämä jumalathan majailevat kaukana kuolevaisista, joten kuinka olisi mahdollista, että ne kuulisivat onnettoman ihmisen heikon kutsun? Pohjoisen Siperian villit puhuvat näin alati. Heillä ei ole mitään käsitystä henkisestä yhteydestä jumalten ja ihmisten välillä, ja vaikka siellä täällä kuulee kerrottavan, että taivaan mahtava jumala suuntaa huomionsa kuolevaisten toimiin, että hän palkitsee heitä hyvistä ja rankaisee pahoista teoista ym., he eivät pidä heikolle ihmiselle mahdollisena päästä henkiseen yhteyteen hänen kanssaan. Muinaisten suomalaisten uskonnolliset käsitykset ovat tässä kuten monissa muissakin 
näkemyksissä paljon korkeampia, sillä he eivät pidä hölmönä ja turhana lähestyä rukouksin jumalia, vaikka nämä olisivatkin pilvien yläpuolella, meren syvyyksissä tai maan huomassa. Heillä on iloinen luottamus siihen, että heidän sanansa löytävät aina tien katseelta kätkettyjen jumalten luokse ja että näiden parissa on suopeita, ihmisystävällisiä olentoja, jotka ottavat osaa kuolevaisten suruihin ja kiiruhtavat auliisti täyttämään heidän toiveitaan. ${ }^{99}$

Myös ostjakkien, samojedien ja muiden kesyttömämpien kansojen parissa tapahtuu sitä, että vedotaan jopa kaikkein mahtavimpaan, taivaalliseen jumalaan, mikäli šamaani ei saa palvelushengiltään tarvittavaa tukea, mutta silloinkin on aina henkien asia hankkia vetoomuksillaan toivottu apu taivaalliselta jumalalta. Eräässä muistiinpanemassani samojedilaulussa loitsitaan henkeä eli tadebtsjoa nousemaan korkeuksiin hankkimaan Numilta apua ja pelastusta sairaalle. Pelätessään Numin vihaa tadebtsjo yrittää kaikin keinoin välttyä tältä tehtävältä ja antaa šamaanille neuvon kääntyä itse omassa persoonassaan suoraan Numin puoleen. Tähän šamaani vastaa: "En minä saavuta Numia, hän on kaukana poissa. Mikäli pääsisin hänen luokseen, en pyytäisi sinua lähtemään; itse lähtisin silloin hänen luokseen. Mutta en saavuta häntä, joten mene sinä.” Jumalten ja ihmisten välinen suhde käsitetään yleisesti samanlaiseksi kuin se on ihmisten välillä. Siperialaisten villien käsityksissä on yhtä järjetöntä kääntyä rukouksin suoraan kätkettyjen, syrjässä majailevien jumalvoimien puoleen kuin on älytöntä pyytää apua ja tukea kaukana olevalta kanssaihmiseltä. Molemmissa tapauksissa on anojan, tai ainakin vetoomuksen välittäjän, ja anomisen kohteen henkilökohtainen läsnäolo välttämätöntä asian toimittamiseksi. Samojedeilla ja heidän sukulaiskansoillaan on jossain määrin käytössä nykyisin laajalle levinnyt tapa, jonka mukaan šamaani lähettää yhden apuhengistään jumalten luokse, ja mikäli en erehdy pahasti, tämä johtuu kokonaan kreikankristillisestä ${ }^{100}$ käsityksestä, jonka mukaan pyhimykset ovat jumalan ja ihmisen kesken välittäviä olentoja. Varsinaisesti siperialainen šamaani hakee tukea ainoastaan hengiltään, joiden kanssa hän on sisäisessä yhteydessä ollessaan ekstaattisessa tilassa. Nämäkin ovat, kuten juuri mainittiin, kuitenkin tavalliselle ihmiselle tavoittamattomia; ne eivät näyttäydy koskaan hänen katseelleen ja näin ollen hänen on tyystin mahdotonta kääntyä suoraan niiden puoleen. 
Tästä huolimatta ihminen ei ole koskaan niin köyhä ja surkea, niin korkeampien voimien hylkäämä101, ettei hän millään tavoin voisi saavuttaa niitä ja saada niitä ottamaan osaa hänen suruihinsa ja murheisiinsa. Niin lohduton oppi ei voisi saada sijaa villin sielussa, joka järjen suhteen köyhänä on sitäkin rikkaampi mielikuvituksessa ja kaikkein vähiten tuntee neuvottomuutta yliluonnollisia olentoja luodessaan. Olemme jo aiemmin nähneet, kuinka altailaiset kansat pitävätluonnonvoimia sellaisinaan yliluonnollisina, elämällä ja sielulla siunattuina olentoina. On myös mainittu, että sanalla sanoen jokaista kohdetta luonnossa hallitsee tällainen olento. Mikäpä olisi siis luonnollisempaa kuin että villi kääntyy rukouksineen juuri näiden kohteiden puoleen, jotka ovat niin lähellä häntä? Kyllä puiden, kivien, tyynten lampien ja hiljaisten vuorten henget kuulevat hänen vilpittömät rukouksensa ja hyväksyvät hänen uhrinsa. Mikäli hän onnistuu myös lepyttämään käärmeen, karhun, suden, joutsenen tai muita ilman lintuja ja maan eläimiä, on hänellä niissä hyviä suojelijoita, sillä niissä elää piilossa mahtavia henkiä. Tavallinen ihminen ei kuitenkaan kykene villieläinten kanssa muuhun kuin vihamieliseen suhteeseen; ainoastaan šamaanille on varattu kyky saada ne kuulemaan hänen rukouksensa. Kaikki muut kääntyvät rukouksineen luonnon vähemmän liikkuvaisten kohteiden puoleen, erityisesti kivien, joilla vakaan, vähemmän liikkuvaisen luontonsa vuoksi on jumalallisempi olemus kuin puilla ja muilla kasvikunnan kappaleilla. Kaikki kivet, puut, eläimet tai ylipäätään luonnonkohteet eivät kuitenkaan ole villin mielestä hänen palvontansa arvoisia, vaan kohteen on osoitettava tietyin ulkoisin, šamaanien tarkasti tuntemin ominaisuuksin, että väkevä henki on asettunut siihen.

Pohjois-Siperiassa useimmat eivät tiedä mitään hengistä, vaan palvovat luonnonkohteita niiden materiaalisessa muodossa tai täysin samalla tavoin kuin palvovat taivasta, Aurinkoa, tulta, vettä ja muita elementtivoimia. Tällainen palvonta on kenties myös alkuperäistä, mutta tässä kohtaa on muistutettava mieliin, että palvottuja luonnonkohteita, olivatpa ne vaikka puita ja kiviä, pidetään aina elävinä ja persoonallisina olentoina. Aivan sama on tilanne kyseisten kansojen jumalkuvien suhteen. Myös niillä ajatellaan olevan elämä ja persoona. Mikäli villiltä kysytään, kuinka kiven tai puun palanen taikka oravan- tai kärpännahasta tehty nukke on saanut tämän ominaisuuden, 
saadaan useimmiten tyytyä tähän vastaukseen: "Me emme tiedä sitä, mutta palvomme samanlaisia jumalia kuin joita isämme palvoivat ennen meitä ja joiden suojeluksessa he elivät onnellisen elämän." Pidemmälle ei ulotu tavallisesti šamaaninkaan tietämys, mutta olen silti heidän joukostaan tavannut viisaita miehiä, jotka ovat antaneet minulle paremman selityksen asiaan. He tukeutuvat jo aiemmin käsiteltyyn oppiin, jonka mukaan koko luonto on täynnä henkiolentoja, jotka pystyvät vaikuttamaan kaikkiin ihmisten yrityksiin joko suotuisasti tai vahingollisesti.

Kuten mainittua, šamaani pystyy kutsumaan näitä henkiä koska vain tuekseen, mutta vihkiytymätöntä ne tuskin auttavat. Tällä voi toisinaan olla tilaisuus saada šamaanin kautta rukouksensa välitettyä hengille, mutta usein tapahtuu niin, ettei šamaania ole käsillä silloin kun hän eniten tarvitsisi sellaisen apua. Tässä tilanteessa hänellä on vielä mahdollisuus mennä pyhien puiden ja kivien luokse, mutta paimentolaiskansoille eivät sellaisetkaan kohteet ole aina lähettyvillä. ${ }^{a}$ Jotta surkea ihminen ei tällöinkään jäisi aivan osattomaksi ja jumalten hylkäämäksi, säälivät henget häntä ja myöntyvät siihen, että šamaani kiinnittää ${ }^{102}$ ne jonkinlaiseen kuvaan. Itse asiassa niillekin on etua tästä vankeudesta, sillä niiden palvojat muistavat niitä luonnollisesti runsain uhrein. Ajatellaan, että mikäli niille ei anneta uhria, ne eivät kauaa pysy vapaaehtoisessa vankeudessaan. En uskalla esittää väitteitä siitä, kuinka laajalti tällaiset käsitykset jumalkuvien luonnosta ovat vallinneet altailaisten kansojen keskuudessa, mutta niitä tapaa yhä tänä päivänä yksittäisten kansojen parissa. Kaikkein selvimmin olen kuullut puhuttavan niistä Jenisein ostjakkien parissa, mistä kerron lähemmin tuonnempana.

Skandinaavisissa saagoissa kerrotaan, että vanhat bjarmit olivat Vienajoen rannoilla pystyttäneet kuvan jumalalleen, joka oli nimeltään Jumala. Kuvaa säilytettiin korkeassa aitauksessa, jonka sisällä oli myös uhrikumpu, missä oli sekaisin kultaa, hopeaa ja multaa. Aitaus oli varustettu lukitulla portilla, ja sitä vartioi joka yö kaksi miestä,

a Joillakin heimoilla on tapana raahata mukanaan pienempiä kiviä, joita palvovat jumalinaan, kun taas toiset liittävät tällaisiin jumaluuksiin vain vähäisen voiman niiden pienen koon vuoksi. 
jotka vaihdettiin kolmesti yössä. Tällä Jumala-kuvalla oli istuvan ihmisen muoto. Sen polvilla oli hopeamalja, joka oli täytetty uhratuilla hopearahoilla. Kaulassa riippui suuri kultakoru. Tällä tavoin Snorri Sturluson kuvaa Jumala-kuvaa Pyhän Olavin saagassa. ${ }^{103}$ Myöhemmissä saagakertomuksissa kuvaukset sekä kuvasta että pyhästä paikasta, jossa sitä säilytettiin, on koristeltu mitä loisteliaimmin värein. Bósin ja Herrauðrin saagan ${ }^{104}$ mukaan tätä kuvaa säilytettiin tilavassa temppelissä, ja sen yhteydessä oli alttari. Kuva oli pystytetty alttarille istuvaan asentoon, ja sillä oli päässään kruunu, jossa oli kaksitoista jalokiveä. Tässäkin saagassa puhutaan kaulakorusta ja uhrimaljasta, mutta kaulakoru oli helminauha, jonka arvo kohosi 300 markkaan kultaa, ja uhrimalja Jumalan polvilla oli kultaa kuten myös uhratut rahat. Maljan kerrotaan olleen niin suuri, että neljä miestä kykeni vain vaivoin tyhjentämään sen pohjiaan myöten kun se oli täytetty viinillä. Jumala-temppelissä oli myös noitataitoinen nainen, Kolfrosta, jota suojeli orja, härkä ja korppikotka, joista kaksi jälkimmäistä olivat noiduttuja. Temppelin yhteydessä oli rautaovella suljettu huone, jossa pidettiin vangittuna kaunista Hleiðria, jonka Kolfrosta oli määrännyt seuraajakseen.

Vaikkakin paljon näissä ja muissa vastaavissa saagakertomuksissa on laskettava runoiluksi, ei tietoa jumalkuvan olemassaolosta suomalaisten asuttamassa Bjarmiassa voi asettaa epäilyksenalaiseksi. Sen totuudenmukaisuudesta on riittävä vakuus siinä, että jumalkuvan kerrotaan tosiaankin esittäneen yhtä suomalaisten palvomaa jumaluutta. Tätä kuvaa palvoivat epäilemättä yhteisesti useat yksilöt, kenties jopa kokonaiset heimot ja kansat, sillä on tuskin uskottavaa, että yksi ainoa henkilö olisi kyennyt koristelemaan yksittäisen suojelusjumalansa niinkin kalliisti. ${ }^{105}$ Mutta oliko suomalaisilla suojelusjumalia, joita palvoi ainoastaan yksi yksilö tai perhe? Tähän kysymykseen muinaistutkimus ei vielä pysty antamaan tyhjentävää vastausta. Varmuudella voidaan kuitenkin päätellä, että suomalaisten keskuudessa oli sellaisia käytössä, sillä kaikilla suomalaisten sukulaiskansoilla oli yksityisiä suojelija- ja kotijumalia. Tämä oletus on sitäkin vahvemmalla pohjalla, kun tietyt luonnonkohteet, joita sukulaiskansamme palvovat suojelusjumalten ominaisuudessa, ovat olleet myös suomalaisten pyhinä pitämiä. Paavi Gregorius IX:n bullassa sanotaan, että hämäläiset tapasivat jahdata kristinuskoon langenneita veljiään 
pyhien puidensa ympäri kunnes he heittivät henkensä. ${ }^{106}$ Tämä johtui luonnollisesti siitä, että puiden uskottiin olevan jumalallisia olentoja, joita luopiot raivostuttivat ja jotka vaativat näiden hengen hyvitykseksi. Kalevalassa (runo 2, säe 50) on tammeen liitetty nimitys puu jumalan, mutta kyseisessä kohdassa voi tällaisella epiteetillä olla pelkästään allegorinenkin merkitys, ja se saattoi myös koskea ainoastaan tätä kyseistä tammea, joka olikin todellinen ihmepuu. Joissakin osissa maata osoitetaan pihlajalle vielä tänä päivänä tiettyä pyhää kunnioitusta, ja maalaiset istuttavat sen mielellään talonsa viereen. Kalevalassa (runo 46, säe 587-) sanotaan Väinämöisen ripustaneen karhun tai oikeammin karhunpään mäntyyn eräällä korkealla harjulla. Vastaava käytäntö tavataan myös sukulaiskansojemme keskuudessa. Kyseisen kunnian saavaa puuta pidetään aina pyhänä, ja se on palvonnan kohde. En jätä tässä mainitsematta, että piispa Agricola lukee Karjalan jumalten joukkoon myös niin kutsutun Wiron akan, mutta Tornæuksen $^{a}$ mukaan tämä nimitys merkitsee kuvaa, jota palvottiin Tornion Lapissa. Tämä oli mahdollisesti käytäntönä sekä suomalaisten että lappalaisten parissa. Saan myös seuraavassa tilaisuuden puhua Suomen pohjoisissa osissa tavattavista eräänlaisista puukuvista, joita siellä kutsutaan nimityksellä hurikkaiset ja jotka näyttävät olleen yhteisiä molemmille kansoille.

Kuten mainittua, korkeiden mäkien ja kallioiden kuten myös jokien, järvien ja lähteiden palvonta on ollut yhtä yleistä suomalaisten kuin heidän sukulaiskansojensakin parissa, joskaan he [suomalaiset] eivät palvoneet niitä yksittäisten suojelusjumalten ominaisuudessa. Altailaiset kansat ovat antaneet tämän arvon jopa pienemmille kiville, mutta ei ole varmoja todisteita, että myös suomalaiset olisivat uskoneet näiden kohteiden suojelevaan ominaisuuteen. Myöhemmin tulen sentään osoittamaan, että suomalaisilla on ollut suuri luottamus tiettyihin kiviin ja että he ovat pitäneet niitä jumalten ja demonien asuinpaikkoina. Itse meren jumaluudellahan on istuimensa kirjavassa kivessä meren pohjassa. Luultavasti myös Kimmo majailee kivessä puhumattakaan vaivanhengistä, jotka majailevat kivessä Kipumäellä, kuten aiemmin olen maininnut. Mielestäni on annettava erityinen

a Tornæus 1772, 15-16. 
paino sille seikalle, että sanalla sanoen jokaisesta harvinaisesta kivestä on ihmeellisiä kertomuksia. Tavallisesti niissä esiintyy paha henki tai jätti ${ }^{107}$, mutta on mahdollista, että suomalaisten muinaiset suojelusjumalat muuttuivat kristinuskon tulon myötä näiksi jäteiksi ja paholaisiksi.

Eläimistä muinaissuomalaiset pitivät karhun lisäksi tiettyjä lintuja eräänlaisina jumaluuksina. Kalevalan runot suovat kotkalle (vanha laitos, runo 1, säe 270-) ja sotkalle (uusi laitos, runo 1, säe 177-) osallisuuden luomistapahtumaan, ja käen sanotaan kukunnallaan tehneen maan hedelmälliseksi. Kuikkakin kävi pyhästä linnusta, koska se ennustaa tulevaa sadesäätä ja laulullaan ilmoittaa siitä. Myös mehiläistä pidettiin korkeassa arvossa, ja šamaanit anoivat sitä usein (esim. Kalevala, runo 15, säkeet 393-534) hankkimaan hyviä lääkeaineita. Ylitse kaikkien muiden eläinten palvottiin kuitenkin karhua, metsän omenaa, kaunista hunajatassua, erämaan ylpeyttä, monin tavoin ylistettyä "vanhaa miestä", jolla suomalaisten käsityksen mukaan (Kalevala, runo 46, säkeet 355-458) on alkuperä Auringon, Kuun ja Otavan asunnoilla. ${ }^{108}$ Yksi ilman tyttäristä vaeltaa taivaan rajoilla pilvien yläpuolella sinisissä sukissa ja kirjavissa kengissä kantaen kädessään villakoria. Hän antaa villaa pudota veden pinnalle, ja tuuli kuljettaa sen hunajaiselle metsärannalle. Mielikki, metsän emäntä, nostaa hienon villan vedestä, tekee siitä nauhan, sitoo sen kauniiseen vaahterakehtoon ja kiinnittää kehdon kultaketjulla kukkivan kuusen tuuheaan oksaan. Siinä hän nyt tuudittaa lempilastaan, josta kasvattaa kauniin Ohton. Mielikki on epävarma, uskaltaisiko hän antaa lapselle hampaat, mutta Ohto vannoo pyhän valan, ettei koskaan tekisi pahaa tekoa. Silloin Mielikki antaa hänelle myös hampaat, jotka repii hongan kultaisista oksista. Ohto ei ole kuitenkaan pitänyt valaansa, ja luultavasti tästä syystä muinaissuomalaiset pitivät tämän mahtavan olennon surmaamista luvallisena. Tästä huolimatta pidettiin velvollisuutena kunnioittaa jokaista kaadettua karhua juhlalla ja siten pyrkiä suojautumaan sen hengeltä ${ }^{109}$. Monien muiden sukukansojemme parissa pidetään yhä tänä päivänä tämän eläimen pyydystämistä jumalattomana, ja ne, jotka ryhtyvät moiseen tekoon, tekevät suomalaisten tapaan kaikkensa sovitellakseen sen hengen kanssa. Olen maininnut, että šamaanin uskotaan varsinaisesti kykenevän luottamaan niin karhun kuin muidenkin eläinten apuun ja suojelukseen. Ei voida 
varmuudella selvittää, onko tämä käsitys ulottunut myös suomalaisiin, mutta kaikki viitteet ohjaisivat tähän olettamukseen.

Lappalaisista jumalkuviin ja pyhiin luonnonkohteisiin liittyvistä traditioista on runsaammin kuvauksia kuin suomalaisista; mutta ne kaikki eivät ole täysin luotettavia. Schefferus ${ }^{a}$ uskoo tietävänsä, että lappalaisilla on ollut kuva Tiermeksestä tai jopa niin kutsutusta Aijesta, Aijekesta eli Thorista, ja kertoo, että tämä [kuva] on aina muovattu puusta ja että sillä on vasara kädessään ja päässään "rautanaula tai piikki ja pala piikiveä, jolla Thor iskee tulta”. Mikäli nämä väitteet ovat perusteltuja, lappalaisten Tiermes-kuva olisi rinnastettavissa suomalaisten Jumala-kuvaan, sillä aiemmin esittämäni käsitykseni mukaan Tiermes ja Jumala ovat yksi ja sama jumaluus. Varsin kyseenalainen on sitä vastoin Schefferuksen, Tornæuksen ja muiden kirjoittajien esittelemä kuva, jonka pitäisi esittää niin kutsuttua Wiron akkaa, ja jota Tornæuksen ${ }^{\mathrm{b}}$ mukaan palvottiin Tornion Lapissa mutta Högströmin ${ }^{c}$ mukaan Kemin Lapissa ja Turjanniemellä ${ }^{110}$. Tämä kuva oli muovattu puusta ja sillä oli ilmeisesti jonkinlainen ihmismäinen muoto kuten lappalaisten muillakin puukuvilla. Joissakin Lapin osissa tavataan myös kuvia, joita kutsutaan nimityksellä storjunkare ${ }^{\mathrm{d}}$ ja joiden Schefferus olettaa esittäneen Tiermestä eli Thoria. Toiset kirjoittajat taas ovat siinä minustakin paljon uskottavammassa käsityksessä, että storjunkaret esittivät ainoastaan jonkinlaisia suojelusjumalia, sillä sekä lappalaiset että heidän sukulaiskansansa esittivät juuri niitä mieluimmin kuvissa. Tällaisia kuvia tunnetaan kaikkialta koko Lapinmaasta yhä tänä päivänä, mutta niiden varsinainen nimitys ei ole storjunkare vaan sejda eli seita. Tätä sanaa ei tavata suomen kielessä tai muissa [saamelaiskielten] sukulaiskielissä, mutta se tavataan sitä vastoin muinaisnorjassa ja germaanisissa kielissä hiukan poikkeavassa

\footnotetext{
Schefferus 1673, 104-105.

Tornæus 1772, 15.

Högström 1747, 182.

d Sanan storjunkare merkityksestä kirjoittaa Samuel Rheen: "Tämä sana Storjunkare on omaksuttu norjalaisten kielestä, sillä he kutsuvat maaherraa nimityksellä junkare. [...] lappalaiset kutsuvat jumalankuviaan nimityksellä Storjunkare, nämä kun ovat ylempiä kuin muut maaherrat." (sit. Schefferus 1673, 96-97.)
} 
muodossa seidh tai seidhr, ${ }^{\text {a }}$ mikä merkitsee tietynlaista noituutta. Mikäli lappalaisten [sana] seida, kuten vaikuttaa luultavalta, on lainattu muinaisnorjasta, se merkitsee itse asiassa jumalkuvaa, jota lappalaiset tarvitsivat noituutensa harjoittamiseen. Jumalkuvilla on yhä juuri tämä merkitys useiden heidän sukulaiskansojensa parissa.

Useiden kirjoittajien yhdenpitävien todistusten mukaan lappalaisilla oli useita yksittäisiä seitojen lajeja, mutta tavallisesti ne on jaoteltu valmistusmateriaalin mukaisesti puuseitoihin ja kiviseitoihin. Puuseidat valmistettiin useimmiten juurineen ylösalaisin käännetystä puupöllistä. Juuret oli hakattu ja muotoiltu niin, että ne muistuttivat ihmispäätä, kun taas runko, joka esitti muuta vartaloa, jätettiin luonnonmukaiseen kuntoonsa. Tornæus ${ }^{b}$ kertoo, että jotkut puuseidat käsittivät yksinkertaisesti pylvään tai tolpan, joka oli kiilattu maahan. Oletan kuitenkin, etteivät ne olleet mitä hyvänsä pylväitä, vaan että niillä oli jonkinlainen ihmismäinen muoto. Tämän päättelen siitä seikasta, että Suomen pohjoisista osista on vastikään löydetty vanhoja puita, joiden pintaan on kuvattu ihmishahmoja. Sodankylän seurakunnassa, jonka jäsenet ovat suurimmaksi osaksi lappalaisia, on olemassa käytäntö, jonka mukaan jossakin paikassa ensimmäistä kertaa käyvä henkilö muovailee kuvan, jota kutsutaan suomenkielisellä sanalla hurikkainen. Luultavasti nämä hurikkaiset ovat samaa laatua kuin lappalaisten muinaiset puuseidat. Itse asiassa myös Tornæus kertoo, että eräältä saarelta, joka on keskellä erästä Tornionjoen kiivasta koskea, on löydetty selviä puuseitoja, ${ }^{c}$ joilla on ihmishahmo. "Ensimmäisenä rivissä seisoo suuri Mies ${ }^{111}$, hänen takanaan neljä kappaletta muita kansanasussa ja hattu päässä.” Niureniuksen mukaan lappalaisilla on ollut sekä kivi- että puuseitoja, joilla on lintuhahmo, ja S. Rheen kertoo, että seidoilla "on joko ihmisen taikka jonkin muun olennon ulkonäkö”d

a Grimm 1844, 988.

b Tornæus 1772, 15.

c Hän ei sano selvästi, että seidat olisivat olleet puuta, mutta tämä näyttää seuraavan asiayhteydestä.

d Schefferus 1673, 106. 
Tornæus $^{\mathrm{a}}$ antaa kiviseitojen ulkonäöstä kuvauksen, jonka mukaan niillä "ei ole mitään hahmoa tai muotoa, ei luonnon eikä käden antamaa", vaan ne ovat tavallisia, toisinaan jopa "rumia, rosoisia ja reikäisiä" harmaakiviä, joita lappalaiset "ovat nostaneet vedestä ja koskista". Myös Högström sanoo, ettei näillä seidoilla ole minkäänlaista ihmisen tai eläimen muotoa, "mutta silti niillä on", hän lisää, "useimmiten epätavallinen muoto kuin fossiileilla, aaltoileva ja rouhea". $\mathrm{On}$ luultavaa, että asia on pääasiassa ollut kuten Högström ja Tornæus sen kuvaavat, sillä kuinka lappalaiset olisivat voineet muovata jumalkuviaan kivestä kun heillä oli hädin tuskin kykyä muovata niitä puusta? Minulla on lisäksi itselläni ollut mahdollisuus nähdä monta lappalaisten muinaista kiviseitaa, ja olen tosiaan havainnut niiden olevan luonnonkiviä, joiden muodossa on kuitenkin aina jotakin silmiinpistävää. Kiviseitoja on muovattu poikkeuksellisesti ihmiskäsinkin. Olen nähnyt ainakin yhden sellaisen eräässä saaressa Inarinjärvessä. Se oli osittain koottu erillisistä kivistä, jotka ilmeisesti kuvasivat tiettyjä ihmisruumiin osia, ja ylimpänä seidassa oli suurempi kivi, joka esitti päätä. Niureniuksen ${ }^{c}$ mukaan useimmat lappalaisten kiviseidoista oli muovattu lintuhahmoisiksi, mutta tähän väitteeseen en voi luottaa. Yleensä kiviseitoja pidetään suuremmassa arvossa kuin puisia, ja ne on tavallisesti varustettu aitauksella.

Lähes kaikki kirjoittajat ovat yksimielisiä siitä, että joitakin seitoja palvoivat kokonaiset kylät, toisia taas yksittäiset yksilöt. Tornæus ${ }^{\mathrm{d}}$ kertoo, että koko kylän yhteiset seidat oli pystytetty "korkealle, majesteetilliselle paikalle", yksittäisten [kyläläisten] seidat sitä vastoin "kauniille ruohikolle" järven rannalle, missä lappalaiset harjoittivat kalastusta; toisten tiedonantojen mukaan tunturilappalaiset olisivat pystyttäneet seitansa korkeille tuntureille kun taas kalastajat järvien, koskien, saarten ja niemien tuntumaan ja ylipäätään jonnekin veden läheisyyteen. Luultavasti lappalaiset palvoivat mieluiten samoja, jo isiensä pystyttämiä seitoja, mutta jatkuvasti vaeltavalle tunturilappalaiselle tämä ei käynyt päinsä, sillä hän ei voinut pystyttää seitaa jokaiselle paikalle,

\footnotetext{
Tornæus 1772, 15.

Högström 1747, 182.

Schefferus 1673, 106.

d Tornæus 1772, 14.
} 
minne olosuhteet pakottivat hänet asettumaan. Tämän johdosta [tunturilappalaisten] oli joka vuosi pystytettävä uusia seitoja, mitä sanotaan tapahtuneen eritoten syysaikaan, kun he teurastivat porojaan ja heillä oli paras tilaisuus uhraamiseen.

Lappalaisilla ei ole ollut temppeleitä tai minkäänlaisia säilytystiloja jumalkuvilleen, vaan nämä ovat tavallisesti seisseet paljaan taivaan alla, toisinaan myös kallionkoloissa. Koska näiltä kuvilta odotettiin onnea kaikkiin yrityksiin, ne pystytettiin luonnollisesti mieluiten asunnon lähelle ja sellaisiin paikkoihin, missä tavattiin kalastaa ja metsästää. Mutta kuten keskiaasialaisten kansojen parissa, myös lappalaisten keskuudessa näyttää vallinneen usko siihen, että mahtavat jumalolennot tapasivat majailla siellä, missä luonto oli loisteliaimmillaan. Tällaisillekin paikoille tavattiin pystyttää kuvia ja lepytellä niitä uhrein. Erityisen mielellään niitä pystytettiin korkeille mäille ja kiivaiden koskien äärelle. Mihin hyvänsä tällainen kuva olikin pystytetty, pidettiin aluetta sen ympärillä pyhänä ja sitä kutsuttiin nimityksellä passe. Tämän johdosta tavataan yhä tänä päivänä lukuisia paikkoja, joilla on nimi passe waare ('pyhä vaara'), passe jaure ('pyhä järvi'), passe johka ('pyhä joki') jne. a Usein tavataan useita seitoja pystytettynä yhdelle ja samalle paikalle, toiset suurempia, toiset pienempiä. Ne esittävät yhdessä jumalperhettä, ja suurin niistä on itse isäntä eli sama, jota Rheenin mukaan eräät lappalaiset kutsuivat nimityksellä storjunkare. Sama kirjoittaja kertoo myös, että yhtä pienemmistä seidoista kutsuttiin storjunkaren vaimoksi ja muita hänen pojikseen ja tyttärikseen,

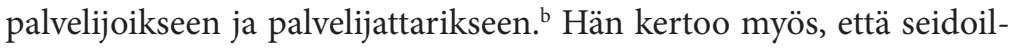
la oli omat määrätyt rajamerkkinsä ja ettei naimaikäisten naisten ollut sallittua lähestyä tätä aluetta "mikäli he halusivat välttää kuoleman tai muun onnettomuuden". ' Myöskään miespuolisille yksilöille ei ollut sallittua tulla liian lähelle näitä kuvia, mikäli he eivät tuoneet niille uhria ja suorittaneet monenlaisia seremonioita. Seidat nauttivat yleisesti palvelijoidensa ja suojattiensa rajatonta arvostusta ja nöyryyttä. Se,

a Myös monissa paikoissa Suomessa tavataan nimityksiä kuten Pyhäjoki, Pyhäkoski, Pyhävaara ym., eikä ole mahdotonta, että maan asuttajilla olisi ollut tällä tavoin nimetyille paikoille pystytettynä jumalkuvia.

b Schefferus 1673, 107.

c Schefferus 1673, 103. 
joka palvoi niitä tunteen palolla ja uskollisuudella sai odottaa osakseen suuria palkintoja, kuten vaurautta, menestystä kaikissa yrityksissä, terveyttä, pitkää ikää, suurta perhettä ja muita ajallisia etuja. Lappalaisten seitoihinsa liittämästä suuresta mahdista Högströma kertoo todisteeksi, että eräs lappalainen oli uhrannut metson pään, jalat ja siivet seidalle siinä tarkoituksessa, että tämä jumala kasvattaisi näistä jäämistä uusia lintuja joita hän saisi ampua.

On silmiinpistävää, että lappalaisten käsitykset seidasta ja saivosta ovat monin tavoin yhtenevät. Molemmat ovat suurimmaksi osaksi yksittäisten yksilöiden suojelusjumalia; molemmilla käsitetään olevan tietyt rajat, joiden sisällä niillä on valtaa, ja kuten monilla saivoilla uskotaan olevan perhe, liitetään myös seitoihin vaimo, lapsia ja palvelusväkeä. Saivoilla on asunto, ja myöskään ne eläinkuvat, joita lappalaiset muinoin ovat muovanneet ja joille he ovat osoittaneet palvontaa jumalina, eivät esitä mitään muuta kuin seita-isännän elikoita. Seitojen ja saivojen voimat ja tehtävät ovat myös täysin samanlaisia. Kaikki, mitä on kerrottu šamaanien suuresta luottamuksesta saivoa kohtaan koskee myös heidän suhdettaan seitoihin, sillä oli šamaanien asia tiedustella seitojen tahtoa, ja niitä tuskin uskallettiin lähestyä uhrein ilman, että šamaani oli paikalla. Kaikki nämä yhtäläisyydet osoittavat selvästi, että ainakaan tavalliset seidat eivät pohjimmiltaan ole muuta kuin saivojen kuvia. Tämä käy ilmi myös siitä, että niillä on joissakin paikoin nimenä saivo, saive tai saiv. Lindahl ja Öhrling ${ }^{\mathrm{b}}$ kertovat, että saiva-kedke ('saivo-kivi') on "pyhä kivi tai kivinen epäjumala", ts. 'kiviseita' ja saiva-muora ('saivo-puu') "pyhä puu; puu, jota palvottiin", so. 'puuseita' jne.

Seitoja ei kuitenkaan pidetty pelkkinä kuvina, vaikka ne esittivätkin saivoja, vaan korkeamman jumalallisen hengen uskottiin asuvan niissä. Seitojen luona rukoiltiin, niille tuotiin uhreja, niitä pyrittiin kaikin tavoin miellyttämään ja hyvittelemään - kaikki siinä käsityksessä, että niissä todella on hengellä ja elämällä siunattuja jumalallisia olentoja. Högström ${ }^{c}$ kertoo, että jotkut lappalaiset uskovat niillä

\footnotetext{
Högström 1747, 183.

b Lindahl \& Öhrling 1780, 390.

c Högström 1747, 183-184.
} 
olevan kyky liikkua vapaasti, mutta lisää myös, että seidat menettävät jumalallisen luonteensa heti kun niille lakataan uhraamasta ja että tämän jälkeen ne eivät pysty tekemään kellekään "hyvää taikka pahaa". Tämä huomautus sisältää ajatuksen, ettei materiaalinen kivi suinkaan ollut lappalaisten palvonnan ja kunnioituksen kohde, sillä mikäli jumalan olento olisi ollut itse materiassa, kiveä olisi pitänyt palvoa niin pitkään kuin se jatkoi olemassaoloaan. Mutta kun tämä ei siis ollut asian laita, ei voida ajatella kuin että kivien uskottiin olevan asuntoja jumalallisille olennoille, joiden oletettavasti uskottiin siirtyneen niihin šamaanien toimesta ja joiden uskottiin pitävän niissä asumista kannattavana, sillä ne saivat sillä tavoin osakseen runsaita uhreja. Uskon sitäkin vakaammin tämän käsityksen jumalkuvien luonteesta vallinneen lappalaisten keskuudessa, kun vastaavia käsityksiä tavataan myös toisten altailaisten kansojen parissa. Kuten seuraavassa tullaan paljastamaan, ovat monet niistä siinä uskossa, että luonnossa ympäriinsä liikkuvat henget ottavat tavallisesti omasta halustaan asunnon niissä kuvissa, joita šamaanit valmistavat niille. Tämä käsitystapa on siinä määrin selvästi poikkeava lappalaisten uskonnollisesta näkökannasta, että ainakaan joidenkin kirjoittajien mielestä nämä [lappalaiset] eivät palvo saivoissa, joiden kuvia seidat yleisesti ottaen ovat, näkymättömiä henkiä vaan ruumiillisia olentoja. On silti kaikki perusteet olettaa, että saivoilla ei alun perin ajateltu olevan ulkoista hahmoa vaan ajateltiin, että ne olivat näkymättömiä henkiolentoja kuten suomalaisten haltiat, samojedien tadebtsjot, tunguusien bunit, mongolien tengrit, jne.

Niiden kuvien lisäksi, joita pystytettiin Tiermeksen ja saivojen kunniaksi, mainitsee Högström, ${ }^{a}$ että lappalaiset tekevät toisinaan "jumalkuvia, jotka he heti tai uhraamisen jälkeen hautaavat maahan uhrin tavoin". Hän sanoo itse löytäneensä "kaikenlaisia kuvatuksia ${ }^{112}$ ja kuvia (jopa poron hahmoisia) kaivettuna maahan erilaisten uhrien kanssa ja kumpu päälle kasattuna”. Koska maata ei aina voitu jään ja lumen vuoksi kaivaa, on kyseisiä kuvia tavattu myös piilotettuna lumeen ja myös puulla ja risuilla peitettynä. Epäilyksettä nämä kuvat esittävät tiettyjä maanalaisia jumaluuksia, ja niitä näyttää valmistetun

a Högström 1747, 196. 
aina kun näille jumaluuksille on osoitettu uhri. Högströmin kertomasta päätellen on taivaallisille voimille uhrattaessa ollut tapana tehdä niistä kuvia, jotka on ripustettu uhrien kanssa läheisiin puihin.

Mainitsin aiemmin, että lappalaisilla oli kuvia myös tietyistä eläimistä. Mikäli väitteeni seitojen ja saivojen yhtäläisyydestä on oikeellinen, on myös luultavaa, että nämä eläintenkuvat esittävät saivo-kaloja tai -käärmeitä, saivo-lintuja ja -poroja. Siitä, millaisten kalojen ja lintujen lappalaiset uskoivat olevan saivo-eläimiä, so. jumalallisia luonnoltaan, ei ole lainkaan vanhempia tiedonantoja. Niiden kuvausten perusteella, joita olen aiheesta nähnyt, kuuluu tämä kunnia kuitenkin ennen muuta kotkalle lintujen joukosta ja hauelle kalojen joukosta. Näiden lisäksi nautti karhu myös lappalaisten keskuudessa arvoa jumalana, ja sen hautausta tavattiin sen vuoksi juhlistaa monin seremonioin.

Henrik Lättiläinen kertoo selvästi, että myös virolaisilla on ollut jumalkuvia, joskin näiden kuvien luonteesta on vain vähän ja vajavaisia kuvauksia. Henrik Lättiläisen kertoman mukaan ${ }^{a}$ virolaiset palvoivat suurta ja mahtavaa jumalaa nimeltään Tharapilla. Tämä jumaluus oli ikuistettu jonkinlaiseen kuvaan, mikä käy ilmi Henrikin sanoista, joiden mukaan Tharapilla heitettiin ulos eräästä linnasta, kun kristinusko tuotiin Saarenmaalle. ${ }^{\mathrm{b}}$ Myöhempien aikojen kirjoittajat ovat nähneet paljon vaivaa selvittääkseen sanan Tharapilla alkuperän ja merkityksen, mutta heidän tutkimuksensa eivät ole antaneet muuta tulosta kuin että Thara tai Tara on muinaisten virolaisten korkein jumala, ukkosenjumala. Sanan pilla merkityksenä viron kielessä pidetään 'narri', 'vähä-älyinen olento', mutta koska tällä merkityksellä ei voi tässä olla mitään käyttöä, on tavallisesti ajateltu Henrikin käsittäneen kyseisen nimen väärin. Pidän tätä ajatusta kuitenkin hätiköitynä niin kauan kuin ei ole otettu kunnolla selvää sanan pilla alkuperästä ja merkityksestä. En ole tavannut tätä sanaa missään muodossa [viron] sukukielissä, ja mikäli se, kuten Hupel $^{c}$ esittää, todella on viron kielen sana, sen on oltava tuhansien muiden sanojen tavoin lainaa

\footnotetext{
a Gruber 1740, 149.

b Gruber 1740, 182.

c Hupel 1818, 242.
} 
germaanisista kielistä. Kenties sen alkuperä palautuu saksalaisten sanaan Bild ['kuva']. Etymologiselta kannalta tämä ajatus ei kohtaa merkittäviä vaikeuksia, ja myös Hupelin antama merkitys sanalle pilla on helposti johdettavissa germaanisesta sanasta, sillä kypsymättömän ihmisen käsityksissä kuva on pelkkä vähä-älyinen, naurettava asia, ja tämä näkemys tapaa päteä eritoten jumalkuvien kohdalla - oletettavasti myös niiden, joita virolaisilla oli - sen jälkeen, kun on menetetty usko niissä asuviin jumalvoimiin. Haluamatta rakentaa mitään tämän hypoteesin varaan sanan Tarapilla [edellä Tharapilla] merkityksestä yhdyn täysin niiden näkemykseen, jotka esittävät, että virolainen jumala, josta Henrik puhuu, ei ollut nimeltään Tarapilla vaan Tara, ja oletan että hänen kuvansa oli sama kuin Jumala-kuva suomalaisten ja Torin eli Tiermesin kuva lappalaisten parissa.

Tämän lisäksi virolaisilla oli, kuten Henrik monin paikoin kertoo, myös muita jumalkuvia, joiden hän sanoo olleen imagines et similitudines deorum [lat. 'jumalten kuvia ja vastaavia'], ja joiden hän sanoo olleen tehty (factas) ihmiskäsin. Hänen kertomastaan voi päätellä myös, että ne oli muovattu puusta, sillä hän sanoo, että pappi Dietrich hakkasi maahan tällaisia kuvia, jolloin virolaiset hämmästyivät kovasti sitä, etteivät ne vuotaneet lainkaan verta. ${ }^{a}$ Näiden kuvien ulkonäöstä ei ole mainittu mitään, mutta luultavasti niillä oli ihmismäinen hahmo. Tämän voi päätellä siitä seikasta, että Henrik kertoo virolaisten lähimpien sukulaisten liiviläisten palvoneen jumalkuvaa, joka oli veistetty puuhun rinnasta päähän asti (imago excrescens ex arbore a pectore ad sursum usque [lat.]). Tämän kuvan sanotaan olleen piilossa eräässä metsässä, ja pidetäänkin varmana, että myös virolaiset ovat pitäneet jumalkuviaan metsissä ja kauniissa lehdoissa. Olen aiemmin maininnut, että lappalaisten ja oletettavasti myös suomalaisten jumalkuvat oli pystytetty mäille sekä jokien ja järvien äärelle, ja että näitä paikkoja pidettiin sen vuoksi pyhinä ja ne saivat nimekseen passe tai pyhä. Myös Virossa tavataan vastaavasti muodostuneita nimityksiä, kuten pühha järve ('pyhä järvi'), pühha jõe, pühha jõggi ('pyhä joki') ja pühha mäggi ('pyhä vuori', 'hautausmaa'), ja on melko luultavaa, että syy tähän on sama, sillä todennäköisesti myös virolaiset pystyttivät

a Gruber 1740, 149. 
jumalkuvansa sellaisiin lehtoihin, jotka olivat mäillä tai jokien ja järvien äärellä.

Georgi mainitsee, että tšeremissit eivät tee suurta numeroa jumalkuvistaan, mutta "koska he pelkäävät kovin ukkosenjumalaa (Kudortša) ja yhdistävät häneen maan hedelmällisyyden", heillä on tapana muovata kuva tästä jumaluudesta samalla tapaa kuin olen kertonut aiemmin suomalaisista, lappalaisista ja virolaisista. Tämä kuva on ihmisen tavoin puettu nukke, jota säilytetään huoneen nurkkaan sijoitetussa tuohirasiassa. Se ei saa osakseen kuitenkaan mitään erityistä palvontaa: "Toisinaan", sanoo Georgi, "tavataan vain valmistaa sille kakku". Kirjoittaja kertoo samassa yhteydessä, että tšeremissit tapaavat ripustaa tiettyihin kunnioitettuihin puihin vaaksan levyisiä ja neliön muotoisia tuohilevyjä. Niitä kutsutaan nimityksellä kuda wadaš. Niissä ei ole kuvia tai mitään merkityksellisiä merkkejä, ja jotkut pitävät niitä jumalallisina olentoina, toiset taas uhreina jumalille. Tšeremissit osoittavat palvontansa tietyille pyhille puille, jotka ovat heidän uhrilehdoissaan, mutta niihin ei ole veistetty mitään kuvia toisin kuin on

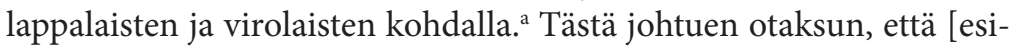
neet], joita Georgi kutsuu nimityksellä kuda wadaš, ovat pohjimmiltaan jumalkuvia.

Toisaalta on huomionarvoista, etteivät toiset kirjoittajat tunne kuda wadašia vaan puhuvat sen sijaan niin kutsutuista ištoista [išta] ja bulnista [bulna]. Aleksandra Fuks ${ }^{\mathrm{b}}$ kertoo, että eräällä matkallaan tšeremissien parissa hän vieraili yhdessä heidän uhrilehdoistaan ja huomasi siellä kolmessa puussa asetelman, joka oli koottu mansikanvarsista sekä kuusen, lehmuksen, mustaviinimarjapensaan ja koiranheiden oksista. Tämä asetelma oli pystytetty puolentoista sylen korkeuteen maanpinnasta, ja sitä kutsuttiin nimityksellä išta. Sen keskelle oli kiinnitetty tinalevy, joka muistutti vanhaa hopearuplaa, ja se kantoi nimeä bulna. Itse pyhää puuta, jossa nämä esineet riippuivat, kutsuttiin nimityksellä anapa. Kirjoittajatar mainitsee, että tämä bulna oli valettu ja että valumuotista oli havaittavissa, millainen figuuri tinasta oli tehty. Sille haluttiin ehdottomasti pää ja valua jatkettiin, kunnes

b Fuks 1840, 294-296. 
haluttu ruumiinosa oli muotoutunut. Tästä voidaan päätellä selvästi, että bulna esittää jumalkuvaa ja että sillä on sama merkitys kuin lappalaisten puuseitojen kaiverretulla hahmolla. Kirjoittajatar sanoo saaneensa saattajaltaan selityksen, että išta ainoastaan osoittaa eteläisen ilmansuunnan, minne tšeremissin katseen tulisi olla suunnattuna kun hän lähettää rukouksen jumalilleen, mutta luultavasti opas halusi tällä kuten monella muullakin selityksellään johtaa matkustavaisen harhaan. Kirjoittajatar kertoo, että itse lehto, jossa kyseisiä kuvia pidettiin, muodosti kehän ja että se käsitti vanhoja, hyvin korkeita ja kauniita lehmuksia ja tammia. Hän kutsuu sitä nimityksellä tšedra jumnota ('Jumalle pyhitetty metsä'), mutta Georgi ei tunne tätä nimeä, vaan puhuu sen sijaan ajoittain keremeteistä. Hän esittää muun muassa, ettei tšeremisseillä ole temppeleitä vaan että he palvovat jumaliaan aukeilla, pyhillä paikoilla, joita he kutsuvat nimityksellä keremet. Nämä jakautuvat yleisiin, koko kansalle yhteisiin (koga keremet) ja yksityisiin (ške keremet), jotka puolestaan kuuluvat pelkästään muutamalle harvalle perheelle. Kummankinlaiset keremetit ovat tavallisesti metsässä tai lehdossa, mutta mikäli tällaisia ei ole, pidetään huoli että niiden lähellä on edes joitakin puita, mieluiten tammia, joista on aina yksi pyhitetty Jumalle ja jäljelle jääneet tšeremissien muille jumalille. Avoin alue, jota Georgi kutsuu nimityksellä keremet, on suunnilleen 10-20 syltä halkaisijaltaan, ja mikäli sen ympärillä ei ole runsaammin puita, se ympäröidään aitauksella. Keremetissä on kolme sisäänkäyntiä: yksi länsipuolella sisään- ja uloskäyntinä, toinen idässä uhrieläimille ja kolmas etelässä vedenkantoa varten. Komeimman puun alla on alttarin ominaisuudessa pöytä ja keremetin sisäpuolella on myös katos (Schoppen [saks.]), jossa uhriliha kypsennetään. Yksikään nainen ei saa lähestyä keremetiä, ja myös mieshenkilöiden täytyy sitä ennen peseytyä ja pukeutua puhtaisiin vaatteisiin, eivätkä he saa tulla tyhjin käsin.

Tämä keremetin kuvaus on yhdenmukainen monin osin niiden tiedonantojen kanssa, joita olen aiemmin käsitellyt lappalaisten seidoille pyhittämien paikkojen yhteydessä. Kaikki, mitä tässä sanotaan aitauksista ja uhrialttarista, yhteisistä ja yksityisistä keremeteistä, tällaisten paikkojen tavattomasta kunnioittamisesta ym. sopii kirjaimellisesti myös lappalaisiin. Ja mikäli pyhät puut bulnoineen vastaavat lappalaisten seitoja, kuten olen yllä otaksunut, on näiden kansojen 
jumalkuvilla melko läheinen keskinäinen vastaavuus. Erittäin huomionarvoista tšeremissien suhteen on, että he merkitsevät sanalla keremet myös mahtavaa jumaluutta, joka pystyy aiheuttamaan ihmisille sekä pahaa että hyvää ja jota sen vuoksi on yritettävä lepytellä uhrein. Otaksuttavasti tämä jumaluus ei ole tämän kansan alkuperäisissä käsityksissä mitään muuta kuin pyhän paikan suojelushenki.

Myös tšuvassit ja mordvalaiset tuntevat sanan keremet, mutta edellisten sanotaan käyttävän sanaa irsan merkitsemään itse uhripaikkaa, kun taas keremet viittaa sekä uhripaikkaan että sen henkeen. Olen nähnyt mordvalaisten käyttävän sanaa keremet ainoastaan merkitsemään uhripaikkaa, joskin on luultavaa, että myös tähän sanaan on liitetty kaksoismerkitys. Georgin maininnan perusteella a tšuvassien ja mordvalaisten keremet ei eroa uhripaikan merkityksessä vähimmässäkään määrin tšeremissien vastaavasta. Mordvalaisilla ei ole jumalkuvia käytössä, vaan heidän sanotaan tuovan uhrinsa

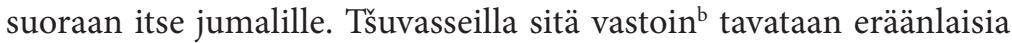
jumalkuvia, joita he kutsuvat nimityksellä irich tai jirich, mutta en tiedä, onko niitä sijoitettu pyhiin puihin. Ulkonäöltään niillä on paljon yhteistä tšeremissien ištojen ja bulnien kanssa. Šamaanit valmistavat ne sulasta tinasta, joka valetaan muottiin, mistä ne saavat ihmisen ulkomuodon käsineen, jalkoineen, päineen ja silmineen. Niiden koko tuskin ylittää peukalonmittaa. Tämä kuva sijoitetaan vajan nurkkaan ja aidataan viinimarjapensaan oksista tai ruusunvarsista tehdyllä punoksella, joka uusitaan joka syksy, jolloin vanha heitetään aina jokeen. Irichiin vedotaan silmäsairauksissa, hammassäryssä, korvasäryssä ym., jolloin hänelle osoitetaan uhriksi tavallisesti eräänlaista puuroa ja leipomuksia sekä kymmenen vuoden välein lammas.

Myös votjakeilla on Georgin ${ }^{c}$ mukaan keremetiä vastaavia uhripaikkoja eli pyhiä lehtoja, nimitykseltään $l u d$, jotka aina sijaitsevat mäillä ja muodostuvat männiköistä. Jokainen niistä on omistettu suojelusjumalalle, jota kutsutaan nimityksellä saltan djes ('saltanjumala'), mutta Georgi ei kerro, onko tämän kansan pyhissä lehdoissa

\footnotetext{
a Georgi 1776-1780, 42, 50, 51.

b Fuks 1840, 96-97.

c Georgi 1776-1780, 58.
} 
jumalkuvia. Toiset kirjoittajat kylläkin vahvistavat, että sellaisia on ylipäätään käytössä. Rytschkow kutsuu näitä kuvia nimityksellä modor ja sanoo niiden olevan pöytäkuusen ${ }^{113}$ (männyn) oksia, joihin on kiinnitetty lauta, joka oletettavasti on varsinainen jumalkuva. Matkustavainen [Rytschkow] oli huomannut tällaisen kuvan eräässä vajassa, ja hänelle oli kerrottu, että se oli talon suojelusjumala, että sille tavattiin uhrata nuori vasikka joka vuosi, jne.

Ugrilaisten ostjakkien jumalkuvista ja pyhistä paikoista on runsaammin tietoja, mutta ne näyttävät kerätyn eri seuduilla ja niissä on siksi monia eroavaisuuksia, jopa selviä ristiriitoja. Yksityiskohtaisimmin tätä aihetta käsittelee Erman; ${ }^{a}$ mutta vaikka hänen materiaalinsa on samoilta seuduilta kuin missä minäkin olen matkustanut, ovat havaintomme monilta osin toisistaan poikkeavia. Ermanin tiedon mukaan ostjakit palvovat yksittäisiä jumalolentoja kuten Toruim (Tuurum), Örtik, Jelan, Long, Meik ym. joista kaikista Tuurumia lukuun ottamatta tavataan tehdä kuvia. Näistä jumaluuksista Örtik kuvataan "hyvää tekeväksi olennoksi [sekä] Tuurumin suosikiksi ja kaikissa asioissa mahtavaksi edustajaksi". Hänen kuvansa on lappalaisten seitojen tapaan jalaton patsas. Kasvot tavataan valmistaa rautapellistä, joka naulataan puuhun, ja vartalo tehdään kaikenlaisilla turkiksilla täytetystä säkistä, johon ommellaan hihat käsivarsien sijaan. Koko kuva peitetään kankaisella päällystakilla ja pystytetään pöydälle, jolle lasketaan myös keihäitä ja miekkoja. Ermanin mielestä nimi Örtik vastaa varsin hyvin unkarilaisten ördög-sanaa, vaikka tällä unkarilaisella sanalla, varmaankin kristinuskon vaikutuksesta, on ollut päinvastainen merkitys 'paholainen'. Hän ei sano Jelanin jumalallisista ominaisuuksista mitään, mutta tämä on kuvattu suunnilleen samalla tavoin kuin Örtik. Pää on kuitenkin enimmäkseen suippo muodoltaan ja peitetty mustalla koirannahkalakilla. Vartalo on muovattu puusta, joka on osin peitetty vaatteella, osin paljas. Erman kertoo, että Longia palvotaan kaikkien arvostettujen ja harvinaisempien taitojen suojelijana, ja erityisesti Longin uskotaan vaalivan lääkärintaitoja. Myös tämä jumaluus on kuvattu suunnilleen samalla tavoin kuin Örtik, ja Erman mainitsee erikseen, että pääosa myös Longin vartalosta

a Erman 1833-1848: I, 677-680. 
muodostuu säkistä, joka on vyötäröltä sidottu huolella koristellulla vyöllä. ${ }^{a}$ Erman kertoo niin kutsutun Meikin olevan paha, harhaanjohtava metsänjumala, jota palvotaan puupölkystä tehdyn kuvan ääressä, jolla on yllään tavallinen majavannahkainen ostjakkianorakki.

Suomatta itselleni perusteellisempaa kritiikkiä näitä tietoja kohtaan haluan tässä ainoastaan välittää ostjakkien minulle antamien jumalkuviaan koskevien kuvausten pääsisällön. Siitä ei ole epäilystäkään, että Tuurumia eli taivaallista jumalaa ei esitetä minkäänlaisissa kuvissa, sillä tämä on yhdenmukaista kaikkien ostjakkien keskuudessa ja tässä kohdin vastaa samojedien, tunguusien ja monien muiden siperialaisten kansojen käytänteitä. Minulla ei ole ollut mahdollisuutta saada mitään tietoa kuvista, joita olisi tehty kauhistuttavalle ja harhaanjohtavalle Meikille eli Meangille, vaan päinvastoin minulle on kerrottu, että tätä jumaluutta ei kuvata eikä siihen vedota uhrein tai rukouksin. Nimi Örtik ei ole myöskään saavuttanut korviani. Vaikka minulla ei ole epäilystä siitä, etteikö tätä tai jotakin muuta samankuuloista nimeä voisi tavata heimon tai toisen parissa, otaksun, että sillä tuskin ymmärretään mitään yksittäistä jumalvoimaa, vaan että örtik merkitsee tiettyä suojelusjumalten lajia. Sitä paitsi tietyt ostjakkiyksilöt ovat vakuuttaneet minulle, etteivät he tunne Meangin ja Kuljin, jotka eivät ole minkäänlaisen palvonnan kohteita, lisäksi mitään muuta yksilöllistä jumaluutta kuin Tuurumin.

Päätellen asiain laidasta toisten siperialaisten kansojen parissa ostjakkien jumalkuvat ovat alun perin esittäneet näkymättömiä henkiolentoja. Heillä ei ole tästä selvää käsitystä, vaan he palvovat itse kuvia suojelusjumalinaan ja uskovat lappalaisten ja muiden sukulaisheimojensa tavoin vakaasti, että näkyvässä kuvassa piilee jumala. Sen mukaan kuin olen kyennyt heidän kertomuksistaan päättelemään, jotkut näistä suojelusjumalista ovat yhteisiä kokonaiselle suvulle tai heimolle, toiset taas kuuluvat pelkästään yksittäisille perheille tai yksilöille. Suvun jumalkuvat ovat yleensä perintöä menneiltä ajoilta, ja niiden voiman uskotaan olevan sitä suurempi, mitä vanhempia ne ovat. Tavallisesti jokaisella suvulla on useampi kuin yksi ja usein kokonainen

a Säkki esittää itse asiassa vatsaa ja on sillä tavoin tehty, että ostjakit pystyivät laskemaan sinne uhrilahjansa. 
varasto tällä tavoin saatuja kuvia. Jotkut niistä esittävät miespuolisia, toiset taas naispuolisia yksilöitä. Kaikki kuvat, jotka minulla on ollut mahdollisuus nähdä, on muovattu puusta ihmismäisiksi hahmoiksi, joskin niillä on suippo pää ja niiltä puuttuvat käsivarret ja jalat. Kooltaan ne ovat varsin vaihtelevia. Omalta osaltani en ole nähnyt yhtäkään, jonka mitta olisi ylittänyt puoltatoista kyynärää, ja useimmat ovat olleet paljon tätäkin pienempiä. Kertoman mukaan monet kyseisistä kuvista on aikojen kuluessa koristeltu punaisin vaattein, kaulaketjuin, rautapeltisin kasvoin jne. Tietyt miespuoliset jumalkuvat on lisäksi puettu panssaripaitoihin ja ne kantavat miekkaa sivullaan. Pallas ${ }^{\mathrm{a}}$ kertoo, että hänen aikanaan Voksarin ${ }^{114}$ jurtissa oli kaksi jumalkuvaa, toinen puettu miehen ja toinen naisen asuun. Miespuolista kuvaa palvoivat pelkästään miespuoliset henkilöt kun taas naispuolisen ääreen kokoontuivat ainoastaan naiset tuodakseen uhreja ja lahjoja. Samaan tapaan kuin ostjakkien parissa, molemmat kuvat oli puettu parhaimpiinsa, ja niillä oli kangasasut ja hienot turkikset. Vaatteisiin oli kiinnitetty kaikenlaisten eläinten kuvia, jotka oli tehty messingistä ja rautapellistä; päässä niillä oli hopeaseppelet. Kuvat olivat seisseet valikoitujen puiden ääressä, erityisessä majassaan. Puut oli puettu rungoltaan vaatteisiin ja muihin kankaisiin (Zeuge [saks.]), ja niiden latvaan oli kiinnitetty valkoista peltiä sekä pieni riippuva kello, joka soi tuulen liikuttaessa sitä. Puu, jonka äärelle miespuolinen jumalkuva oli pystytetty, oli koristeltu jousin ja nuolin ja kaikkiin ympäröiviin puihin oli ripustettu lukemattomia uhrattujen porojen taljoja sekä monenlaisia turkiksia. Jumalkuvien ympärillä oli kaikenlaisia ostjakkien taloustavaroita kuten kattiloita, kauhoja, kulhoja, nuuskapiippuja jne. joita oli tavallisesti tuotu jumalille uhreiksi.

Tämä kuvaus Voksarin kuvista vastaa pääosin varsin läheisesti tietoja, joita minulla on koskien ostjakkien jumalkuvia, mutta se sopii pelkästään rikkaimpiin sukuihin. Köyhempien jumalkuvia ei ole millään tavoin koristeltu, vaan ne seisovat kuin alastomat rakastavaiset paljaan taivaan alla, kasvavan puun äärellä. Varmaa on ainakin, että matkoillani jouduin kerran täysin arvaamatta ostjakkijumalten seuraan kun törmäsin niihin eräässä lehtikuusimetsikössä. Laskin siellä

a Pallas 1776-1778: III, 60-. 
niinkin monta kuin seitsemän yksittäistä kuvaa, kaikki erikokoisia ja pystytetty eri runkojen viereen. Läheisten puiden latvoissa huomasin uhrattuja porontaljoja ja sarvia, jotka oli ripustettu jumalten silmien eteen. Syrjäänioppaani vakuutti minulle, että nämä kuvat olivat suvun yhteistä omaisuutta.

Ostjakit pitävät jumaliaan paljaan taivaan alla, mutta he valitsevat aina lehdon niiden majapaikaksi, erityisesti sellaisesta paikasta, minne ne voidaan piilottaa ohikulkevien venäläisten ja syrjäänien katseilta. Mieluiten jumalkuvia säilytetään nykyään niille pyhitetyssä jurtassa, joka on rakennettu niin ikään koskemattomaan, syrjäiseen paikkaan. Ostjakkien yritykset kaikin keinoin kätkeä kirkkonsa ja pyhät paikkansa johtuvat siitä, että niissä on enemmän ja vähemmän arvokkaita uhreja, toisinaan jopa hopeaa ja kultaa, soopeleita ja sinikettuja, joiden anastamista venäläiset ja syrjäänit tuskin pitäisivät pyhäinhäväistyksenä omasta uskonnollisesta näkökulmastaan. Vielä suuremmaksi varmuudeksi monet näistä pyhätöistä ovat šamaanien valvonnassa.

Kuten Pallas ${ }^{a}$ huomauttaa, ostjakit pitävät lappalaisten tavoin varsin suurta aluetta jumalkuvien säilytyspaikan ympärillä niin pyhänä, etteivät he uskalla sen sisäpuolella katkoa puita tai ruohoa, eivät kalastaa tai metsästää eivätkä edes ottaa vettä juodakseen. Mikäli he kulkevat tällaisten alueiden läpi, he eivät uskalla kulkea veneineen lähellä rantaa tai edes koskea melalla maata, ja mikäli reitti pyhän alueen läpi on pitkä, he tapaavat varata ennalta mukaansa vettä ja kärsivät mieluummin janoa kuin uskaltautuvat juomaan jumalille pyhitettyä vettä.

Yksittäisten henkilöiden suojelusjumalat ovat suurelta osin samanlaisia kuin suvun suojelusjumalat. Ne muovataan tavallisesti puusta ja niillä on ihmiskasvot, mutta ne ovat melko vähäisiä kooltaan ja muistuttavat paljolti lasten nukkeja. Ne koristellaan mielellään parhaimmalla tavoin punaisin nauhoin, kangaskaistalein jne. Tällä tavoin varustettuina niitä säilytetään jurtassa tai teltassa, missä ne pystytetään nurkkaan, eivätkä ne saa ainoastaan kaikenlaisia eineitä vaan lisäksi niitä kunnioitetaan lahjoin, jotka Pallaksen ${ }^{\mathrm{b}}$ mukaan asetetaan jumalkuvan edessä olevaan rasiaan. 
Viimeksi mainittu kirjoittaja kertoo lisäksi, että ostjakit osoittavat palvontansa kaikenlaisille puupalasille, kiilan muotoon veistetyille pienemmille kalikoille ja jopa koristeellisille rasioille ja muille pikkuesineille, joita he hankkivat venäläisiltä. Olen lisäksi kuullut kerrottavan, että ostjakeilla on kaikenlaisia pikkukiviä, joita he palvovat suojelusjumaltensa ominaisuudessa. Kaikkien esineiden, jotka voivat olla palvonnan kohteita luonnollisessa hahmossaan, on kuitenkin oltava joko muodoltaan tai materiaalinsa laadulta harvinaisia ja omintakeisia. Sitä paitsi asiaan kuuluu, että ne koristetaan jollakin loisteliaalla asulla. Yleisesti ottaen ostjakit varustavat mielellään suojelusjumalansa parhaalla mahdollisella tavalla huolimatta siitä, kuuluvatko ne koko suvulle vai yksittäisille perheille tai yksilöille. Ainoastaan ne jumalat, jotka seisovat paljaan taivaan alla, jätetään yleensä alastomiksi, sillä hienoja vaatteita ei haluta jättää säiden armoille.

Kaikkia kyseisiä suojelusjumalten lajeja olen kuullut ostjakkien kutsuvan joko nimityksellä lonch tai tonch (varsinaisesti tlonch) tai nimityksellä jiljan (Ermanin jelan). Georgi ${ }^{\mathrm{a}}$ tuntee sanan lonch muodossa lus, ja hän esittää, toisin kuin Erman, että se on yleinen nimitys kaikenlaisille suojelusjumalille (Götze [saks.]). Tämä väite on yhdenmukainen myös minun havaintojeni kanssa, sillä aina kun olen kuullut ostjakkien puhuvan suojelusjumalistaan yleisesti, he ovat aina käyttäneet sanaa lonch. Kyseisellä sanalla on ostjakissa niin laaja merkitys, että se käsittää myös myyttisen tšuudi-kansan, joka tradition mukaan alun perin asutti niin ostjakkien maita kuin koko muutakin Siperiaa. Tomskin samojedien ${ }^{115}$ parissa tavataan sama sana muodossa $l o ̄ s$ tai $l o h$, ja sillä on suojelusjumalan yleinen merkitys, mikä vahvistaa Georgin ja minun käsityksen oikeellisuuden sanan merkityksestä. Ostjakit ovat kertoneet minulle, että sanalla jiljan merkitään ainoastaan yhdenlaisia suojelusjumalia, siis sellaisia, joilla on ihmismäinen hahmo. Mieleeni on tullut epäillä tätä tietoa sitäkin vähemmän kun vastaava erottelu tavataan myös samojedien keskuudessa. Juuri siksi, että esitetty merkitys on ollut minusta niin luotettava, olen jättänyt tekemättä aiheesta tarkkoja tutkimuksia.

a Georgi 1776-1780, 81. 
Tavallisten suojelusjumaltensa lisäksi ostjakit tapaavat kuvata myös edesmenneitä sukulaisiaan ja osoittaa heille samankaltaisia palvontamenoja ${ }^{116}$ kuin samojedit tavallisesti tekevät, kuten alla tullaan osoittamaan. Lisäksi heidän parissaan tavataan karhun kuvia. En kuitenkaan tiedä, kuuluvatko nämäkin kuvat yllä käsiteltyjen nimitysten piiriin vai onko niillä jokin erityinen nimitys. Ostjakit osoittavat palvontansa myös korkeille mäille ja kallioille, eritoten mikäli ne ovat muodoltaan terävähuippuisia samaan tapaan kuin jumalkuvien päät. Lisäksi pyhinä pidetään tiettyjä puita, ja niihin Pallas ${ }^{a}$ lukee kaikki sellaiset, joihin kotka on rakentanut pesänsä monena vuonna peräkkäin. Olen kuullut myös väitettävän, että missä seitsemän lehtikuusta seisoo yhdessä, pidetään sekä paikkaa että puita pyhinä. ${ }^{117}$ Käytäntönä olisi, että ohikulkeva ampuu aina yhden nuolen tällaiseen puuhun. Pallas esittää lisäksi, että kyseisiin puihin olisi tavattu ripustaa porontaljoja ja muiden eläinten nahkoja, mutta koska muukalaiset varastivat usein pyhät uhrit, alettiin puista hakata suuria paloja ja kuljettaa niitä turvallisempiin paikkoihin, missä niitä tavalliseen tapaan koristeltiin ja kunnioitettiin uhrein.

Mitä tässä on sanottu ostjakeista, pitää tietyin poikkeuksin ja muunnelmin paikkansa myös samojedien ja erityisesti läntisen eli jurakkisamojedihaaran suhteen. Heillä ei ole kuvia Numista eli taivaallisesta jumalasta, vaan heidän jumalkuvansa esittävät suojelusjumalia, jotka osin kuuluvat yhdelle ainoalle perheelle tai yksilölle mutta joita osin palvoo useampi perhe tai yksilö. En ole kuullut koskaan mainittavan tämän kansan parissa sellaisista suojelusjumalista, joita palvoisi vain yksi ainoa suku, mutta [olen kuullut] paljonkin sellaisista, joille jokainen samojedi, kuuluipa hän mihin sukuun hyvänsä, osoittaa lahjansa. Tällä tavoin kunnioitettuja suojelusjumalia on eritoten Vaigatš-saarella ${ }^{118}$, jota samojedit tämän vuoksi kutsuvat myös nimityksellä 'Jumalten maa' tai 'Jumalten saari' (Hahe-ja tai Hahe-o). Puhutaan etupäässä kolmesta jumalkuvasta, joita siellä palvotaan tai ainakin palvottiin ennen kuin lähetyssaarnaajat tekivät paikalle vierailun vuonna 1827. Yksi niistä oli sijoitettu saaren lounaiseen niemeen, jota samojedit

a Pallas 1776-1778, 61. 
kutsuvat nimityksellä Hahe-salje ('jumal-niemi'). Islavinin ${ }^{a}$ mukaan tällä kuvalla on ollut nimi Wesako ('ukko, naitu mies'), ja se on muovattu puusta ja varustettu kolmilla kasvoilla. Lähetyssaarnaajat kuitenkin polttivat sen yhdessä 420 muun samalla paikalla tavatun jumalkuvan ja suuren uhrimäärän kanssa.

Eräs toinen suojelusjumala nimeltään Ja jieru Hahe ('maan herra Hahe’) on yhä tänä päivänä keskellä saarta. Se käsittää kiven, joka on asetettu maassa olevan luolan viereen. Tarinan mukaan tämä kivi ei muinoin olisi ollut täällä vaan ilmaantui selittämättömän ihmeen kautta. Muodoltaan se muistuttaa paljon ihmistä, mutta sen pään sanotaan olevan suippokärkinen. Tätä kiveä alettiin myöhemmin palvoa jumalan ominaisuudessa, ja sekä samojedit että ostjakit tekevät nykyisin jumalkuvansa puusta mainitun mallin mukaan ja antavat niiden päälle suipon muodon. Näin tarina on minulle kerrottu, mutta Islavinin mukaan se ei olisikaan ollut tämä kivi vaan jokin muu rannalla oleva kallio, joka ilmestyi kerrotulla tavoin ja jota palvotaan jumalana. Hän kertoo myös keskellä saarta olevasta kivestä, joka nauttii arvostusta jumalana, joskin hän käyttää siitä nimitystä Njebe-hahe ('äiti-Hahe') ja sanoo sen olevan Wesako-hahen vaimo. Islavin esittää syyksi tähän nimitykseen, että Njebe-hahe säilyttää äidin tavoin kaikki uhrit ja lahjat sylissään. Otaksun kuitenkin, että täksi syliksi on ymmärrettävissä vain kiven vieressä oleva luola, josta on juuri ollut puhe, ja tämä on luultavasti sama luola, joka johti ostjakit liittämään joihinkin jumalkuvistaan säkistä tehdyn vatsan, johon uhrit lasketaan.

Kolmas Vaigatš-saarella tavattavista suojelusjumalista on niemellä saaren luoteispuolella, ja se käsittää kallion. Olen kuullut sitä kutsuttavan nimityksellä Ja maal Hahe ('maanäären Hahe'), mutta Islavin käyttää siitä nimitystä Nju-hahe ('poika-Hahe'). Viimeksi mainittu kirjoittaja esittää, että tämän hahen uskotaan olevan Wesakohahen ja Njebe-hahen holhokki. Näillä olisi sitä paitsi kolme muutakin lasta, nimittäin: 1) Minisei ${ }^{119}$, vuori Uralilla, 2) Jalmal ${ }^{120}$, niemimaa Obinlahden länsipuolella sekä 3) kivi, joka sijaitsee 20 virstaa Mesenistä ja jonka ympärillä oli aiemmin suuri määrä puukuvia, ${ }^{121}$

a Islavin 1847, 116-117. 
jotka lähetyssaarnaajat polttivat. ${ }^{a}$ En ole kokenut mitään, mikä viittaisi tällaisiin sukulaisuussuhteisiin yksittäisten jumalkuvien välillä. Sitä vastoin minulle on kerrottu, että samojedit osoittavat palvontansa oudon muotoisille kallioille ja kiville missä niitä tapaavatkin, ja koska niitä ei suuren kokonsa vuoksi voi ottaa kenenkään yksittäisen [ihmisen] omaisuudeksi, niistä tulee kansan yhteisiä suojelusjumalia, jotka vaativat uhreja kaikilta, jotka tulevat niiden läheisyyteen. Myös kauniita lehtoja, joihin he toisinaan törmäävät, pidetään pyhinä, ja niitä palvoo koko kansa. En ole löytänyt luotettavia tietoja siitä, osoittavatko samojedit niille jonkinlaista palvontaa. Minusta näyttää kuitenkin siltä kuin samojedit eivät palvoisi lehdoissaan yksittäisiä puita vaan että lehtoa pidetään pyhänä, koska sitä pidetään parhaana paikkana jumalten asunnoksi. Siksi he pystyttävät sinne kuvansa ja huolehtivat lehdoista temppeleinään. Tämän huomion uskon pitävän pitkälti paikkansa kaikkien altailaisten kansojen suhteen.

Vaikka yhteiset suojelusjumalat eivät ole tyystin tavattomia samojedien keskuudessa, he palvovat pääasiassa omia yksityisiä kuviaan. Kuten ostjakeilla, ne ovat joko yksittäisiä luonnonkohteita tai toisinaan ihmiskäsin muovattuja. Luonnonkohteista palvotaan eritoten erikoisia kiviä ja etupäässä sellaisia, joissa tunnistetaan jossain määrin ihmispäätä muistuttava osa. Jotkut niistä esittävät miespuolisia, toiset naispuolisia yksilöitä. Kaikkia luonnollisia jumalkuvia, olivat ne sitten yksityisiä tai yhteisiä, miespuolisia tai naispuolisia tai mistä hyvänsä materiaalista, jurakkisamojedit kutsuvat yhteisellä nimityksellä hahe, joka vastaa ostjakkien nimitystä lonch. Käsintehdyt kuvat, joita ostjakit kutsuvat nimityksellä jiljan, ovat eri samojedikansoilla jossain määrin erilaisia. Jurakkisamojedit muovaavat ne ostjakkien tavoin puusta, suippoine päineen ja kaiverrettuine ihmiskasvoineen. Tällaisia kuvia kutsutaan nimityksellä sjadaei, so. 'kasvoilla siunattu' (sanasta sja 'kasvot'). Niitä pystytetään tavallisesti paljaan taivaan alle tundrille ja metsiin samojedien kalastus- ja metsästysmaiden äärelle. Samojedit uskovat, että nämä kuvat antavat runsaan saaliin niin kauan kuin niitä muistetaan asiaankuuluvin uhrein. Tällä tavoin pystytetyt sjadaeit ovat tavallisesti alasti. Niitä käytetään kuitenkin myös 
talonjumalina, ja tällaisessa tapauksessa niillä on yllään siistejä vöitä, kirjavia nauhoja ja muita huolella valmistettuja samojedivaatteita. Yleisimmin haheja palvotaan kodinjumalten ominaisuudessa, ja erityisesti ne puetaan mielellään kirjaviin nukenvaatteisiin, jotka ovat miespuolisilla ja naispuolisilla haheilla erilaiset. Hahelta anotaan terveyttä, rikkautta, neuvoa, apua ja onnea kaikenlaisiin yrityksiin, ja joka kerta kun näin tehdään, niitä muistetaan uhrein. Tällaisissa tilanteissa hahe on asetettu teltan osaan, jonka nimi on sinikui ['posio']. Muutoin niitä säilytetään erityisessä reessä nimeltään hahem gan, jonka samojedi ottaa mukaansa mihin matkustaakin. Tällaista rekeä, joka on samojedien temppeli, kuvailee Islavin ${ }^{a}$ seuraavin sanoin:

Se oli seitsemän siteen varassa ja jalaksissa oli seitsemän uraa. Se oli peitetty porontaljalla, jossa oli kiinni pää, jalat ja kaviot, joita muutoin ei jätetty nahkoihin. Tämän alle oli levitetty täkki, joka peitti kahta jumalkuvaa, joista toisella oli verellä voideltu kivipää ja joka oli puettu harmaakankaiseen maalitsaan ${ }^{122}$ jossa oli punaiset päärmeet ja nauhat; toinen taas oli tavallinen musta kivi, jossa oli päätä muistuttava kärki ja joka myös oli voideltu verellä ja puettu vihreään maalitsaan, jossa oli punaisia ja keltaisia koristeita.

Minun ei ole onnistunut tutkia tällaista rekeä, mutta sen mukaan mitä olen kuullut samojedien kertovan, niissä säilytetään usein suurta määrää sekä mies- että naispuolisia jumalkuvia.

Itäisten eli tavgisamojedien parissa ovat samanlaiset jumalkuvat käytössä kuin jurakkisamojedien parissa, mutta tietääkseni niillä ei ole ensiksimainittujen parissa erillisiä nimiä, vaan niitä merkitään yhteisellä sanalla koika, jonka sitä paitsi sanotaan käsittävän myös näkymättömät henget eli jurakkisamojedien tadebtsjot. Yhtä kattava merkitys on ostjakkisamojedien sanalla loh eli $l o ̄ s$, koska sillä ei käsitetä ainoastaan näkymättömiä henkiolentoja vaan myös kaikkia kuvaan ikuistettuja suojelusjumalia. Jälkimmäiset ovat tai ovat ainakin aiemmin olleet ostjakkisamojedien keskuudessa, kuten myös ugrilaisen ostjakkien kansan keskuudessa, joko yhteisiä kokonaiselle suvulle tai yksittäisten perheiden tai yksilöiden omaisuutta. Ensiksi mainitun

a Islavin 1847, 115-116. 
tyyppinen suojelusjumala oli vielä muutama vuosi sitten Karbinon samojedikylässä Ket-joen varrella. Sen sanotaan olleen messinkinen ja muodoltaan ja kooltaan vastanneen ihmistä istuvassa asennossa. Kuvaa arvostettiin aiemmin suuresti niin tavattoman kauneutensa kuin ikänsäkin vuoksi. Traditio kertoo, että se oli ollut taiteessa harjaantuneiden tšuudien työtä, mutta oletettavasti se on kuitenkin peräisin mongoleilta, jotka palvovat samankaltaisia kuvia nimeltään burkhan. Tätä pyhää kuvaa oli säilytetty huolellisesti sitä varten rakennetussa vajassa, joka oli täynnä arvokkaita uhreja, kuten soopeleita, kettuja jne. Kostaakseen jonkun kärsimänsä vääryyden eräät kuljeskelevat tunguusit polttivat jonkin aikaa sitten talon kaikkine aarteineen, jolloin jumalkuva kärsi niin pahasti, että sen ei katsota enää ansaitsevan palvontaa.

Yhteisten suojelusjumalten palvonnan sanotaan kristinuskon vaikutuksesta jo kadonneen ostjakkisamojedien parissa, mutta sitä vastoin yksityiset kuvat ovat heidän parissaan hyvin tavallisia. Nämä eivät tietääkseni ole koskaan kiviä tai muita luonnonkohteita, vaan ne ovat aina šamaanin tekemiä. Mikäli joku tarvitsee tällaisen kuvan, hän antaa šamaanille oravan-, kärpän- tai jonkin muun eläimen nahan, jonka tämä muokkaa niin, että se muistuttaa jossain määrin ihmistä. Jotta hahmo olisi helpommin tunnistettavissa ihmismäiseksi, šamaani pukee jumalkuvan tavallisiin samojedivaatteisiin. Tätä asua hän ei saa valmistaa itse, vaan turmeltumattoman neidon tulee ommella se. Kuvalla on paikka korissa, jonka tulee myös olla viattoman neidon punoma. Kori ja siinä oleva jumalkuva ja sille osoitetut uhrit säilytetään vajassa, jossa ei saa säilyttää mitään muuta. Tätä säilytystilaa pidetään niin pyhänä, että naitu nainen ei saa astua sen kynnyksen yli eikä nainut henkilö ylipäätään saa edes kiertää sen ympäri. Suuremmat vapaudet, jotka ostjakit myöntävät naimattomille henkilöille ja erityisesti tahrattomille neidoille, johtuvat epäilyksettä kreikkalaisen kirkon korkeista käsityksistä munkkien ja nunnien puhtaudesta ja pyhyydestä. ${ }^{123}$

Varsin kuvaavaa tässä yhteydessä on myös se, mitä Jenisein-ostjakit kertovat jumalkuvistaan. Olen aiemmin kiinnittänyt vain vähän huomiota tähän kansaan, sillä kieli erottaa sen tyystin muista altailaisista kansoista, mutta etnografisesta näkökulmasta yhdenmukaisuuksia on niin paljon, etten katso olevan kyseenalaista ottaa Jenisein-ostjakkeja 
mukaan tähän keskusteluun. Tämä voi tuoda valoa muihin aihepiiriini kuuluviin kansoihin liittyviin kysymyksiin. Jo aiemmin on mainittu, että kaikkien altailaisten kansojen tapaan myös Jenisein-ostjakit palvovat eniten taivaallista jumalaa, joka on heillä nimeltään Ees. Sana merkitsee myös näkyvää taivasta. Hänen lisäkseen he uskovat kahteen muuhun melko voimakkaaseen jumaluuteen: toinen on Koi eli 'karhu', toinen Imlja eli Banguus, maanalainen jumaluus, jolla epäilemättä tarkoitetaan mammuttia. Koita pidetään miespuolisena, Imljaa naispuolisena jumaluutena, ja he muodostavat jumalparin. $\mathrm{He}$ ovat keskenään luoneet maan huomassa loputtoman määrän henkiolentoja, jotka ovat osin miespuolisia, osin naispuolisia. Joissakin paikoin edellisiä kutsutaan nimityksellä kinsj (kuus) ja jälkimmäisiä nimityksellä alol, kun taas toisissa paikoin nämä nimitykset ovat täysin samanmerkityksiset. Jenisein-ostjakit kertovat, että nämä henget voivat ottaa käärmeen, joutsenen, sorsan, hanhen ym. hahmon. He eivät palvo karhua ja mammuttia pelkkinä eläiminä, vaan elävät siinä käsityksessä, että niissä majailee mahtavia henkiä, jotka pystyvät myös jättämään eläinhahmonsa ja jotka tapaavat usein näyttäytyä šamaanille henkihahmossa ${ }^{124}$.

En tiedä, pystyvätkö henget Jenisein-ostjakkien käsitysten mukaan asettumaan kiviin ja puihin, mutta niiden sanotaan majailevan samojedien hahea, sjadaeita, loh'ia jne. vastaavissa kuvissa, jotka ovat varsin tavallisia myös kyseisen kansan parissa. Kuten muiden kansojen parissa, myös Jenisein-ostjakkien keskuudessa šamaanit valmistavat nämä kuvat. Ostjakkien käsityksen mukaan tämä ei voi kuitenkaan tapahtua ilman, että henget ovat pyytäneet šamaania tehtävään. Mikäli jollekulle on suotu šamaanin luonto, mutta häntä ei ole vielä vihitty šamanismin saloihin, henget ilmestyvät hänelle ja pyytävät häntä muovaamaan jumalkuvan. Ne päättävät, tuleeko kuva tehdä puusta, kuparista vai raudasta ja millainen muoto sillä tulee olla. Tavallisesti se tulee valmistaa raudasta ja varustaa käsin, jaloin, kahdella päällä sekä rautasauvalla, joka asetetaan sen käteen. Sen lisäksi kuva puetaan ostjakkiasuun, joka on ommeltu jonkin eläimen nahasta ja koristeltu kaikenlaisilla lasihelmistä ym. tehdyillä koristeilla. Henget päättävät myös, millaisesta nahasta vaatteiden tulee olla, ja ne kertovat šamaanille, missä ja koska hänen tulee pyydystää tarvittava saalis. Kuvan koko on täysin merkityksetön, kuten samojedeilla, ja sen ulkonäkö 
on kuin nukella. Nykyisin šamaanit valmistavat kinsjejä ainoastaan omaan laskuunsa, sillä Jenisein-ostjakkien parissa muilla ei ole suojelusjumalia, mikä otaksuttavasti on seurausta kristinuskon vaikutuksesta. Šamaanillakaan ei ole koskaan enempää kuin yksi kuva, jota hän ei saa vaihtaa koko elinaikanaan. Tähän kuvaan saattaa kuitenkin mahtua $200-300^{125}$ henkeä. Kuvaa säilytetään tätä tarkoitusta varten tehdyssä rautakelkassa, mutta šamaanin kuoleman jälkeen siinä olleiden henkien sanotaan lentävän tiehensä. Kaksi vuotta tämän jälkeen samat henget ilmestyvät šamaanitarjokkaalle, joka kuuluu edesmenneen sukuun, ja antavat hänen sulkea ne uuteen kuvaan. Itse asiassa juuri näistä kuvaan suljetuista hengistä tulee myöhemmin šamaanin avustajia ja neuvonantajia tämän maagisissa toimissa. Hänellä ei luonnollisestikaan ole vaikutusvaltaa muiden šamaanien henkiin, mutta Koi ja Imlja voivat antaa hänelle tukensa.

Turkkilaisten kansojen jumalkuvista minulla ei ole muita tietoja kuin ne, jotka pakanalliset tataarikansat ovat suullisesti välittäneet minulle eteläisessä Siperiassa. Heitä koskien olen jo aiemmin maininnut, että he palvovat tiettyjä maan huomassa piileskeleviä aina-nimisiä henkiolentoja, joihin šamaanit vetoavat ahkerasti ja jotka vastaavat jurakkisamojedien tadebtsjoja. Olen myös maininnut, että nämä henkiolennot voivat verhoutua paitsi ihmisten, myös karhujen, käärmeiden, kettujen, joutsenien ym. hahmoon. Tällaiset eläimet nauttivat tataarien keskuudessa suurempaa arvonantoa kuin muut. Tataarit pitävät erityisesti joutsenta suuressa arvossa, minkä seuraavassa esiteltävä, yhä tänä päivänä käytössä oleva tapa osoittaa. Mikäli tataari onnistuu pyydystämään joutsenen, hän lahjoittaa sen naapurilleen ja saa vastalahjaksi tämän parhaan hevosen. Joutsenen uusi omistaja antaa sen edelleen jollekin naapurilleen ja tekee yhtä hyvän vaihtokaupan. Tätä kauppaa jatketaan edelleen kunnes joutsen ehtii pilaantua, jolloin viimeisen omistajan pitää heittää se pois, eikä hän valitettavasti saa korvausta hevosestaan.

Myös tataarit tapaavat tehdä kuvia eläimistä, joiden hahmoon ainat mielellään verhoutuvat, ja [kuvat] koristavat yleensä šamaanien noitaasua. Kaikissa tällaisissa vaatteissa havaitsee ainakin pari kankaasta valmistettua ja tavallisesti jouhilla täytettyä käärmettä, jotka riippuvat selkäpuolella ulottuen niskasta aina kantapäihin asti. Eläinkuvien lisäksi asussa on lukematon määrä pieniä kangaslappuja, yksi jos 
toinenkin kello, metallilevyjä ja rautapaloja ym. Kaikkia näitä esineitä kutsutaan nimityksellä aina, ja niissä uskotaan olevan henkiä, jotka auttavat šamaania tämän kutsuessa niitä. ${ }^{\mathrm{a}}$

Olen joitakin kertoja kuullut nimitystä aina käytettävän myös kivipatsaista, joita tavataan Sajanin aroilla. Nämä patsaat on varustettu ihmispäällä, -kasvoilla ja -korvilla. Joillakin näkee lisäksi kuvattuna letit ja naisen rinnat. Tataarien kertomuksissa nämä patsaat ovat muinaisia sankareita ja sankarittaria, joille Kudai on alun perin antanut kuolemattoman luonnon ja jotka hän on asettanut hallitsijoikseen maan päälle mutta myöhemmin raivoissaan muuttanut kiviksi, koska he voimiensa tunnossa ovat alkaneet vastustaa hänen tahtoaan. Tässä käsityksessä voi mahdollisesti olla todenmukaista, että mainitut patsaat esittävät muinaisuuden kuuluisia sankareita ja sankarittaria. Tämän näkemyksen puolesta puhuu sekin seikka, että näkymättömien henkien sanotaan olevan Irle-khanin eli kuolemanjumalan alamaisia, ja se saa lisävahvistusta siitä, että useimmat näistä kuvista tavataan muinaisten hautojen yhteydessä. Tavalliset hautakivet ovat todellakin toisenlaisia, niissä ei ole ihmishahmoja, vaan ne ovat tunnistettavissa useimmin suipon, samojedien jumalkuvia muistuttavan lakensa perusteella. Haudoilla on kuitenkin myös varsinaisia patsaita, ja olen kuullut tataarien kertovan, että he ovat siirtäneet jotkut nykyään avoimella kentällä sijaitsevista patsaista nykyisille sijoilleen sen jälkeen, kun venäläiset talonpojat ja oppineet matkustavaiset ovat ryöstäneet haudat. Mikä kyseisten patsaiden alkuperäinen merkitys onkin ollut, ainakin on varmaa, että tataarit ovat kunnioittaneet ja osittain yhä palvovat niitä jumalina. Tämän voi päätellä niiden kasvojen tummemmasta väristä, jonka ne ovat luultavasti saaneet siten, että kun kuville on tuotu uhreja, niiden huulet on voideltu altailaisten kansojen parissa vallitsevan tavan mukaisesti rasvalla tai verellä. Tämä tapa ei ole unohtunut tataarien parissa, sillä vieraillessani erään tällaisen jumaluuden luona huomasin sen huulilla jotakin vastalaitettua, minkä tataarioppaani tunnisti olevan kermaa. Kuinka tataarit eivät palvoisikaan näitä epätavallisen hyvin muovattuja kuvia, kun he osoittavat

a En pysty varmuudella sanomaan, onko muilla kuin šamaaneilla tällaisia aina-kuvia, mutta on varmaa, että ainakaan tataarit itse eivät myönnä sitä. 
palvontansa myös muodottomille kallioille? On omintakeista, että kallioissa ja kivissä, joita Minusinskin tataarit palvovat luonnollisessa olemuksessaan, ei ole ainuttakaan kaiverrusta tai edes raaputettuja tai maalattuja kuvioita. Puista eritoten lehtikuusta pidetään jumalallisen pyhänä, ja sen latvaan tapaavat tietyt heimot otaksuttavasti tämän johdosta ripustaa menehtyneet lapsensa.

Liikkuvat mongolit kertoivat keskiaikaisille lähetyssaarnaajille, ettei heillä ole tapana osoittaa uhrejaan ja rukouksiaan korkeimmalle jumalalle Natagaille vaan "yksittäisille kuvilleen", joita pidetään tavattomassa arvossa. Tällaisen kuvan viemistä pidettiin rikkomuksena, josta uskottiin rangaistavan hengenmenetyksellä. Kuvat oli tapana pystyttää telttaan, toisinaan myös huolellisesti koristeltuihin kärryihin, ja ne peitettiin huovalla tai silkkikankaalla. Sadan ja tuhannen miehen päälliköillä oli aina tällainen kuva keskellä telttaansa, ja he tapasivat uhrata sille ensiosan hevosenmaidosta ja muista elintarvikkeista. Kun jokin eläin teurastettiin, sen sydän asetettiin jumalkuvan eteen, missä se sai olla seuraavaan päivään asti. Myös suurkaanin teltan edessä seisoi jatkuvasti hyvin arvokas jumalkuva, jota kunnioitettiin runsain lahjoin, eritoten hevosin, joita sen jälkeen pidettiin pyhinä eikä enää koskaan käytetty. ${ }^{a}$

Nykyään pakanallinen uskonnollinen kultti on suurimmaksi osaksi vaihtunut buddhismin puhtaampiin oppeihin mongolien parissa, ja tilanne on sama heidän sukulaiskansojensa burjaattien ja kalmukkien kohdalla, joista osa on lisäksi omaksunut kristinuskon. Siitä huolimatta matkustavaiset ovat vielä melko hiljattain antaneet lukuisia kuvauksia niin burjaattien kuin kalmukkienkin jumalkuvista. Näitä kuvia kutsutaan yhteisellä nimityksellä ongon, jolle Kowalevski antaa merkitykset 'näkymättömät suojelushenget' ja 'kuolleiden henget' sekä lisäksi myös 'hautakivi' ja 'uhri, joka annetaan kuolleiden kunniaksi'. Ne ovat aina šamaanien valmistamia, ja ne voivat olla puuta, huopaa, peltiä, lampaannahkaa, usein myös figuureja, jotka buddhalaisten burkhanien tavoin on maalattu kankaalle. Yleisimpiä ovat Georgin $^{\mathrm{b}}$ mukaan koivulaudasta tehdyt kuvat, jotka ovat vaaksan 
pituisia ja jopa kolmen tuuman levyisiä ja joiden ylempi osa muistuttaa jossain määrin ihmispäätä pyöreän muotonsa ja lyijy- tai korallisilmien sekä tiettyjen lautaan kaiverrettujen kasvonosien vuoksi. Käsivarsia esittää pari oksaa, ja jalat on kuvattu samalla tavoin. Kuva on toisinaan puettu täydelliseen burjaattiasuun, toisinaan pelkästään kasvot on koristeltu, toisinaan taas se on aivan paljas. Se seisoo tavallisesti munanmuotoisen, leveydeltään kolmen sormenleveyden kokoisen koivuisen vanteen sisällä, joka esittää noitarummun vannetta, joskus se on ainoastaan rasiassa. Huopa- eli wojlok-kuvat ovat samaa kokoa kuin yllä mainitut. Muodoltaan jotkut niistä ovat litteitä ja ihmishahmoisiksi leikattuja, toiset taas täytettyjä, jolloin ne muistuttavat nukkeja. Sekä edellisillä että jälkimmäisillä on lyijy- tai lasisilmät. Maalatut kuvat, joita kutsutaan nimityksellä nogit, esittävät ihmishahmoja, jotka šamaani piirtää punaisella liidulla vaaksan levyiselle neliskanttiselle kankaanpalalle. Jokaisella tällaisella palasella on vähintään yksi mutta yleensä kolme erillistä hahmoa. Näiden hahmojen silmät muodostuvat kahdesta koralli- tai rautarakeesta ${ }^{126}$. Usein figuurin päähän kiinnitetään pieni kimppu kotkansulkia. Lampaannahkakuvat, imegiltšin, on valmistettu mustan lampaan taljasta, jossa yhä riippuvat jalat. Lampaan pään tilalle on kiinnitetty paljas tai kankaalla peitetty lauta, joka esittää ihmispäätä ja on varustettu korallisilmin. Toisinaan talja on täytetty ja ommeltu kiinni vatsapuolelta, mutta toisinaan siinä ei ole lainkaan täytettä. ${ }^{a}$ Georgi mainitsee vielä pellistä muovatut figuurit, jotka ovat ihmishahmoisia ja sormen pituisia ja joita tavataan ripustaa imegiltšiniin.

a Pallaksen (1801, 347) mukaan imegiltšin eli Immegildschin, kuten hän sen kirjoittaa, käsittää kaksi toisissaan riippuvaa figuuria, joista toinen esittää jumalan puolisoa. Näiden kuvien kerrotaan olevan kaksi litteää, pitkää, yläosastaan kahteen pyöreään levyyn kaiverrettua tyynyä (Polster), joihin on laitettu silmät, nenä, rinnat, nisät ja napa kiinniommelluista nahkanapeista. Vartalon ympärillä niillä on pitkäkarvainen lampaannahkaturkki. Miespuolisella figuurilla on tavallisesti vyöllä remmi, jolla sidotaan laiduntavien hevosten toinen taka- ja molemmat etujalat yhteen, naispuolisiin taas on ripustettu kaikenlaisia pieniä koruja ja yöpymistarpeita, ja niitä seuraa tavallisesti samanlaisia, heidän lapsiaan esittäviä pikkufiguureja. Pallaksen mukaan imegildschiniä palvotaan lampaiden ja muun karjan suojelusjumalana. 
Kaikki jumalkuvat roikkuvat nipussa teltan länsisivulla eli sisäänkäynnin vasemmalla puolella. Huopa- tai lampaannahkakuvilla on usein nuora kaulassa tai nuora on pistetty niiden pään läpi. Maalattuja kuvia säilytetään pienissä neliskanttisissa huopakukkaroissa, joiden sisällä ne riippuvat. Joitakin näistä kuvista kunnioitetaan, kuten tavallista, uhrein ja rukouksin. Naispuoliset henkilöt eivät saa lähestyä niitä eivätkä koskaan lähteä teltasta sitä sivua pitkin, millä jumalkuvia säilytetään. ${ }^{\mathrm{a}}$

Nämä tiedot koskevat varsinaisesti burjaatteja, mutta ne näyttävät soveltuvan myös kalmukkeihin ja kenties joiltakin osin myös mongoleihin. Ainakin Pallas ${ }^{\mathrm{b}}$ kertoo, että kalmukkien keskuudessa tavataan suojelusjumalia, joita kutsutaan nimityksellä onggoi ja jotka huolehtivat talon onnesta. Ne valmistetaan neljästä punaisesta puuvillatilkusta, joista alin on pisin ja muut lyhenevät asteittain. Kokonaisuuden pitäisi esittää pukeutuneen ihmishahmon varjokuvaa. Näiden ja muiden niitä muistuttavien jumalkuvien lisäksi jotkin mongolikansat ovat tradition mukaan palvoneet samanlaisia kivipatsaita kuin tataarit. Palvonnan kohteiksi uskotaan korkeita kallioita ja mäkiä sekä korkeita puita ja eläimistä karhua, käärmettä jne. Yleisesti voidaan sanoa, että mongoli- ja turkkilaisheimojen uskonnolliset käsitykset pakana-aikaan ovat olleet varsin pitkälti keskenään yhdenmukaisia.

Tämä huomio soveltuu myös tunguuseihin, joskin nykyisenä aikana he eroavat uskonnollisilta näkemyksiltään merkittävästi mongoleista ja kalmukeista kuten myös kaikista muista altailaisista kansoista. Yksi näistä eroista on, että heillä ei ole kuvia pelkästään suojelusjumalistaan vaan suoraan sanoen joka ikisestä jumaluudestaan, ja näiden kuvien joukossa on myös sellaisia, jotka alun perin näyttävät olleen pelkkiä jumalten symboleja. Tunguusit eivät kuitenkaan tapaa kuvata taivaallista jumalaansa nimeltä Boa, sillä tämä on perustelujen mukaan näkymätön olento, jonka hahmosta ja ulkonäöstä ei voi olla käsitystä. Muista jumaluuksista Aurinko kuvataan pitkänomaisin ihmiskasvoin, jotka muovataan joko puusta tai pellistä. Kuu esitetään puoliympyränä, tähdet täplinä, maa pienenä neliskanttisena

b Pallas 1801, 346. 
peltiritilänä ${ }^{127}$, Dianda eli vedenjumala esitetään veneenä, jne. ${ }^{a}$ Kuten olen jo aiemmin maininnut, tunguusit palvovat kohteita enimmäkseen niiden ulkoisessa hahmossa, ja ne täytyy luonnollisesti myös kuvata samalla tavoin. Mutta sellaisia jumalallisina olentoina pidettyjä kohteita, joilla on vähemmän materiaalinen olemus, kuten tuli, pilvi, tuuli jne., ei ikuisteta minkäänlaisiin kuviin. Vedenjumala kuvataan veneen muodossa, koska hänen tukeaan pyydetään erityisesti venematkoilla. Erästä toista jumaluutta, jota Georgi kutsuu nimityksellä Sokjovo, esitetään kuvissa porolla, sillä sen tehtävänä katsotaan olevan poroista huolehtiminen.

Tunguusit kutsuvat Georgin mukaan suojelus- ja kotijumaliaan nimityksellä šovokoi, mutta Jenisein varrella olen kuullut niitä kutsuttavan nimityksellä hargi. Ne ovat aina šamaanien valmistamia, ja ne ovat puuta, rautaa ja kuparia, toisinaan myös kiveä ja tinaa. Ulkonäöltään ne muistuttavat ihmisiä tai ihmiskasvoja, lintuja, kaloja tai muita eläimiä. Puukuvilla on aina ihmismäiset kasvot, jotka toisinaan ovat kuparipellistä, ja niissä on silmät koralleista tai lyijystä. Niillä ei ole käsivarsia, ja jalat ovat vähäiset. Jotkin niistä ovat alasti, toiset puettu šamaaniasuun. Ne voivat olla pituudeltaan $1 \frac{1}{2}$ jalkaa. Peltikuvilla on erityinen nimitys han, ja ne esittävät ihmisiä, leijonia, karhuja, erityisiä kaloja, joutsenia, sorsia ja hanhia, jne. Ihmismäiset figuurit ovat pelkästään kahdeksan sormenleveyden mittaisia ja varustettu käsin ja jaloin, silmät ja suu on kuvattu pistein. Eläin-hanit ovat tavallisesti pelkästään sormenmittaisia ja enemmän tai vähemmän helposti tunnistettavia. Useimpia peltikuvia eli haneja pidetään ainoastaan šamaaniasussa ja valmistetaan yksinomaan tätä tarkoitusta varten. Hevos- eli arotunguusit ripustavat muut jumalkuvat jurttaan vasemmalle puolelle sisäänkäyntiä, joskin metsätunguusit asettavat ne paljaan taivaan alle ja kiinnittävät ne puusauvoista yhteenkoottuun telineeseen, jonka päälle yleensä levitetään nahkapeite. Tämä teline on nimeltään šonan, ja se seisoo yleensä jurtan takana muutaman askeleen päässä siitä. Tunguusit palvovat useimpien muiden altailaisten kansojen tavoin kaikenlaisia epätavallisesti muodostuneita kiviä,

a Georgi 1775, 275-276. 
joissa šamaanin mielikuvituksen voima voi tunnistaa ihmiskasvoja muistuttavan osan. Joitakin mäkiäkin pidetään pyhinä, ja puiden joukossa ovat koivu ja paju korkeassa arvossa, minkä vuoksi myös noitarumpu valmistetaan näistä puulajeista. ${ }^{a}$

\section{Sankarit}

Kehittyneen ihmisen näkökulmasta villin elämä tarjoaa monin tavoin yhtäläisyyksiä lapsen elämään, ja siksi kansojen kesytöntä, luonnonmukaista tilaa tavataan nimittää niiden lapsuudeksi. Mutta mikäli tarkastelemme asiaa villien kansojen omasta näkökulmasta, niistä on vaikeaa löytää ainoatakaan, joka ei pitäisi lapsuus- ja nuoruusaikaansa jo kadonneena. Samoin kuin kypsä ja kokenut ihminen ${ }^{128}$ monesti katsoo haikeana taaksepäin menneisiin päiviin, kun sydämessä asui pelkkä ilo ja riemu ja kun elämä oli niin helppoa ja suloista, kuulee myös villeimpien samojedikansojen puhuvan kadonneesta kulta-ajasta, jota he kuvaavat mielellään kauneimmin värein. He arvostavat tätä aikaa eritoten sen jumalanpelon ja tapojen puhtauden vuoksi, joka silloin vallitsi ja jolla esi-isät ansaitsivat mahtavien jumalten suosion ja suojeluksen. Tänä aikana kansan parissa vallitsi yleinen vauraus ja hyvinvointi, ${ }^{129}$ sairauksia ei tunnettu, ja ihmiset olivat suuria ja tavattoman vahvoja ja korkealla viisaudella siunattuja.

Tänä ylistettynä aikana elivät myös suuret sankarit, jotka nykyään ovat tyystin kadonneet maan päältä. Kaikkien altailaisten kansojen parissa näiden sankareiden suorittamat teot muodostavat kaikkein rakkaimman kertomusten ja laulujen aiheen. Siperian autiot arot, metsät ja tundrat kaikuvat yhä tänä päivänä lauluista, jotka viritetään jalojen miesten kunniaksi. He eivät ansainneet mainettaan kuitenkaan pelkästään sotaisin teoin, vaan sankareilla oli runsaasti kaikkia ihmiselle arvon antavia ominaisuuksia. He olivat ylenpalttisen viisaita, huomattavan taitavia laulajia, päteviä seppinä ja myös muissa töissä. He olivat myös paljon paremmin vihittyjä noituuden saloihin kuin nykyajan šamaanit. Heissä yhdistyivät kaikki mahdolliset avut, mutta 
lauluissa tavataan lisäksi suoda heille kullekin jokin tietty erottava ominaisuus. Yhdellä on loistavan laulajan lahja, toinen erottuu viisautensa ja älynsä puolesta, kolmannella on kyky ottaa karhun, käärmeen, linnun jne. ulkomuoto. Yhteistä kaikille ovat sankarinvoimat, rohkeus ja urheus, ja myös sankarisukuun kuuluvilla naisilla on näitä ominaisuuksia. Asian luonteeseen kuuluu, että tällaisilta kuvauksilta ei voi välttyä, mikäli sankarit ovat muutoin nimityksensä veroisia ja mikäli laulu tosiaan lepää historiallisella pohjalla. ${ }^{130}$ Tätä ei ole mielestäni mahdollista epäillä, sillä suomalaisia lukuun ottamatta kaikkien muiden kansojen ${ }^{131}$ eeppiset laulut ja kertomukset viittaavat melko säännönmukaisesti sotaisiin tekoihin. Ja mitä tulee suomalaisiin lauluihin, on niidenkin taustalla usein toinen toistaan arvostetumpien ominaisuuksien kyllästämiä sankaritekoja, ja joka tapauksessa sota on aiheena myös useimmissa meidän esi-isiemme eeppisissä runoissa. $\mathrm{Ne}$ sodat, joita kuvataan niin suomalaisten kuin sukukansojemme lauluissa, eivät ole kuitenkaan syttyneet yleisemmästä, kansallisesta intressistä, vaan voimakkaat sankarit lähtevät taisteluun ja sotaan pelkästään oman itsensä tai korkeintaan sukunsa ja lähimpiensä puolesta. Useimmissa tapauksissa [sankarin] pyrinnöt päättyvät niin, että hän voittaa käsivarsiensa voimalla kauniin neidon käden. Tämä tapa vallitsee yhä tänä päivänä monien siperialaisten kansojen parissa, joten on helppo nähdä, että sankarilauluilla on historiallinen pohja. Suuret saavutukset, jotka laulut liittävät muinaisuuden sankareihin, ovat itse asiassa samanlaisia seikkailuja kuin joihin voimakkaat ja rohkeat yksilöt joutuvat yhä vieläkin toisinaan kesyttömämpien kansojen keskuudessa. Kertomukset ovat korostaneet taitavien sankareiden tekojen loistokkuutta tavanomaiseen tapaansa, ja samaan tapaan ne toimivat tulevaisuudessa niiden seikkailujen suhteen joihin tänä päivänä joudutaan, edellyttäen, että kertomuksilla on näiden kansojen parissa tulevaisuutta.

Kertomukset ovat luonnolleen uskollisesti luoneet itsessään yksinkertaisesta ja merkityksettömästä jotakin suurta ja loistavaa ja siten muuttaneet taitavat sankarit omaksi olentojen lajikseen. [Sankareilla] on paljon yhteistä ihmisten kanssa, mutta he eivät kuitenkaan varsinaisesti kuulu ihmissukuun vaan muodostavat välimuodon jumalten ja ihmisten välillä. Korostaakseen sankarien loistokkuutta ja mainetta 
tapaavatkin jotkut kansat johtaa heidän juurensa jumaliin. Niinpä tataarit uskovat, kuten olen jo aiemmin maininnut, sankareidensa olevan taivaanjumalan jälkeläisiä, jotka tämä alun perin määräsi hallitsijoikseen maan päälle ja joille tämä antoi kuolemattoman luonnon, minkä he myöhemmin kuitenkin menettivät. Virolaiset pitävät taivaanjumalaa, Vanna issaa eli Taraa sankareiden isänä ja antavat hänen luoda heidät jo ennen maailman luomista. Virolaiset sijoittavat myös sankareidensa alkuperäisen asuinpaikan tämän "vanhan isän" taivaalliseen lehtoon. Suomalaisten parissa tavataan traditio, jonka mukaan taivaallinen neito nimeltään Ilmatar synnytti Väinämöisen ja Ilmarisen laskeuduttuaan korkeasta asunnostaan veteen, missä tuuli saattoi hänet raskaaksi. Myös heidät luodaan siis ennen maailman luomista, ja he osallistuvat myöhemmin luomistyön viimeistelyyn virolaisten sankareiden tapaan. On myös olemassa traditio, jonka mukaan Väinämöinen synnytti maailman, ja toinen esittää, että Ilmarinen takoi taivaankannen. Nämä ja monet muut epätavalliset tehtävät, jotka suomalaiset runot liittävät sankareihinsa, ovat johtaneet siihen oppineiden keskuudessa hyvin yleiseen näkemykseen, että suomalaiset olisivat alun perin palvoneet niin Väinämöistä ja Ilmarista kuin myös Lemminkäistä jumalina. ${ }^{132}$ Tämä näkemys ansaitseekin huolellisen tarkastelun, ${ }^{133}$ mutta sen suorittamiseksi ja ylipäätään todenmukaisen käsityksen saamiseksi suomalaisista heeroksista on tarpeen selvittää lyhyesti vanhojen sankarilaulujen sisältöä. Niitä on eritoten Kalevalaeepoksessamme. Ennen kuin ryhdymme tähän, meidän on tutustuttava muutamaan runoissa usein tavattavaan paikkaan: Kalevalaan ja Pohjolaan.

Sana Kalevala viittaa varsinaisesti paikkaan, kuten sen pääte paljastaa, ja sen voidaan tulkita tarkoittavan 'Kalevan-kotia'. Mutta tästä herää kysymys: Mitä merkitsee sana kaleva? Ganander ja monet muut kirjoittajat sekä ennen häntä että hänen jälkeensä pitävät Kalevaa henkilönnimenä ja esittävät, että tämä henkilö on ollut mahtava jättiläinen, jolla on ollut lukuisa määrä poikia (Kalevan pojat), joiden joukkoon luetaan myös Väinämöinen, Ilmarinen ja Lemminkäinen. ${ }^{134}$ Minusta näyttäisi kuitenkin siltä, että kaleva ei koskaan esiinny muinaisissa runoissamme henkilön nimityksenä vaan että sitä käytetään aina voimakkaan sankarin epiteettinä. Runot puhuvat vanhasta edes- 
menneestä miehestä, jota nimitetään Kalevaksi ja vanhaksi Kalevaksi, mutta häntä kutsutaan vielä useammin nimellä Vipunen, joka epäilyksettä onkin henkilön varsinainen nimi. Sitä vastoin kaleva näyttää liitetyn häneen epiteetin ominaisuudessa. Näkemykseni sanan kaleva henkilömerkityksestä nojaa pääasiassa siihen, että Vipusen lisäksi myös viisasta Väinämöistä nimitetään toistuvasti runoissamme Kalevaksi, vaikka Vipunen ja Väinämöinen selvästi ovat kaksi eri henkilöä. Tähän liittyy myös se seikka, että Väinämöistä kutsutaan melko usein Kalevan pojaksi, mikä on vielä uusi ristiriita, mikäli kaleva käsitetään henkilönnimeksi. Lopuksi ansaitsee mainittavan, että tätä nimitystä ei suoda pelkästään Väinämöiselle vaan myös Lemminkäiselle, vaikka nämä henkilöt eivät missään nimessä ole saman isän poikia. Näiden ilmiselvien ristiriitojen johdosta, joihin törmätään, mikäli kaleva pyritään käsittämään henkilönnimenä, en voi muuta kuin pitää sitä epiteettinä. Uskon siihen olevan sitäkin enemmän syytä, kun turkin kielessä on samansukuinen sana aalep, joka merkitsee sankaria ja ainakin tataarikertomuksissa toimii aina epiteettinä vastaaville yksilöille kuin millaisia Väinämöinen, Lemminkäinen ja Kullervo ovat suomalaisissa. Tämän olettamuksen myötä katoavat myös aiemmin käsitellyt ristiriidat, sillä sekä Vipusta että Väinämöistä voi molempia hyvällä syyllä kutsua sankareiksi, eikä siihenkään ole vastaansanomista, että niin Väinämöistä kuin Lemminkäistä ja Kullervoakin olisi kunnioitettu epiteetillä 'sankarinpojat'. Mikäli sana kaleva tulkitaan näin, kalevala merkitsisi itse asiassa 'sankarien kotia ylipäätään', mutta sen merkitys ei kuitenkaan ole runoissa näin lavea. Nämä [runot] tunnustavat Väinämöisen (Kalevala, runo 6, säe 234) Kalevalan parhaaksi mieheksi (Kalevalan kaunihin), ja eritoten hänen kotiaan nimitetään niissä Kalevalaksi, joskin sen nimi on toisinaan myös Suvantola tai Osmola, sanasta osmo joka on yksi Väinämöisen epiteeteistä, ja yleisimmin sillä on nimenä eritoten Väinölä, kannasta Väinö, joksi Väinämöistä myös usein tavataan kutsua.

Väinämöiselle on annettu Kalevalassa asuvana henkilönä eräissä runojen kohdissa lisänimi kalevalainen, so. 'Kalevalan asukas', ja tämä epiteetti on liitetty myös Lemminkäiseen ja Ilmariseen. Näin ollen Kalevala on myös heidän kotinsa, mutta tätä [kotia] ei voida etsiä Väinölästä, sillä laulu sanoo selvästi, että joka ikisellä nimetyistä 
sankareista on oma erityinen kartanonsa. ${ }^{a}$ Mikäli näillä kolmella Kalevalan sankarilla on kullakin tietty kartanonsa ja kaikki ovat myös Kalevalan asukkaita (kalevalaiset), täytyy nimen Kalevala [tarkoitteen] käsittää vähintäänkin kylän rajat. Tämä käsitys ei olekaan itse asiassa vieras runoillemme, mikä näkyy melko selvästi siinä, että joidenkin Kalevalan asukkaiden sanotaan kuuluvan samaan sukuun (Kalevan suku), eikä voida saattaa epäilyksen alaiseksi, että suomalaiset suvut elivät muinoin yhdessä kukin omassa kylässään.

Joissakin kohdin runoissa puhutaan myös Kalevan kansasta eli Kalevan väestä, ja nämä nimitykset viittaavat siihen, että Kalevala käsitti kokonaisen maan. En pidä lopulta epäuskottavana Agricolan ja monien muiden kirjoittajien esittämää väitettä, että ainakin jotkut heimot olisivat joskus palvoneet kyseisiä kolmea Kalevalan sankaria jumalina, ja tässä tapauksessa Kalevalalla olisi skandinaavisen mytologian Asgårdia ${ }^{135}$ vastaavan 'jumalkodin' merkitys.

Kalevalan rinnalla puhutaan vanhemmissa runoissamme myös kuuluisasta, sitä kohtaan vihamielisestä paikasta, jota kutsutaan nimityksellä Pohjola tai Pohja. Nämä nimitykset ovat yleisessä käytössä suomalaisten parissa yhä tänä päivänä, ja ne viittaavat koko pohjoiseen Suomeen, erityisesti Pohjanmaan pohjoisiin osiin. Sama merkitys tavataan jo runoissa; nykyisen kielenkäytön tavoin myös niissä Pohjola eli Pohja tapaa kuitenkin saada nimityksekseen Pohjan-maa (ks. Kalevala, runo 1, säe 20; runo 10, säe 87; ym.). Silloin kun tämä ymmärretään kokonaisen maan merkityksessä vastaavasti kuin nimityksessä Lapinmaa, käytetään usein myös muotoa Pohjola tai Pohja. Niinpä Lemminkäinen lausuu Kalevalassa (runo 12, säkeet 35-36)

a Kalevalassa (runo 10, säe 61-) kerrotaan tosiaankin, että ensimmäisen matkansa jälkeen Pohjolaan Väinämöinen palasi kotiinsa, missä hän tapasi Ilmarisen, mikä näyttää johtavan siihen olettamukseen, että nämä sankariveljekset asuivat samassa paikassa. Runossa 18 (säe 101-) lausutaan sitä vastoin, että Väinämöinen toisella Pohjolan-matkallaan rantautui Ilmarisen kartanolle ohi kulkiessaan. Sitä paitsi myös monet muut runonkohdat liittävät Ilmarisen omaan erilliseen kartanoonsa, kuten Kalevalassa (runo 24, säe 524; runo 34, säe 12; ym.). Vastaavasti myös Lemminkäisellä eli niin kutsutulla Ahdilla eli Kaukomielellä oli kotinsa, jossa hän asui yhdessä iäkkään äitinsä kanssa, ja runo 39 (säe 390) väittää, että hänen asuinpaikkansa oli kylä. 
aikovansa lähteä Pohjan poikien tulille, Lapin lasten tanterille, mihin voi verrata runoa 13, säkeitä 129-130. Säkeissä 169-170 viimeksi mainitussa runossa tavataan myös sanat Pohjan pitkästä perästä, Lapin lasten tanterilta, ja runossa 17, säkeet 219-220 (vrt. runo 32, säkeet 465-466) sanotaan: Pohjan pitkästä perästä, Lapin maasta laukeasta. Pohjolaa pidetään Lapin synonyyminä kylmyyden kotina, ja sen johdosta Ilmarinen anoo eräässä noitalaulussa (Kalevala, runo 48, säkeet 324-346) Pohjan poikaa hakemaan jäätä Pohjolasta lääkkeeksi palovammoihin. Todisteeksi siitä, että nimitys Pohjola viittaa Lappiin, käy myös se seikka, että siellä vallitsi kylmyyden lisäksi myös suuri pimeys, ja että siellä oli poroja, kivisiä tuntureita (kivi-kummut) ja muita Lapin luontoon kuuluvia asioita. Kielikään ei ollut Pohjolassa sama kuin Kalevalassa, vaan siellä puhuttiin lapin kieltä, kuten Kalevalan runossa 12 (säkeet 198-200) selvästi sanotaan. Pohjolaakin tavataan toisinaan Lapin tavoin nimittää Turjaksi ja Pohjolan asukkaita turjalaisiksi (ks. Kalevala, runo 26, säe 291-; vrt. runo 48, säkeet 313-314), mutta varsinaisesti Turja merkitsi Norjaa, sillä tämä sana on epäilyksettä sama kuin Rutja, jota suomalaisten parissa käytetään yhä tänä päivänä Norjan nimityksenä.

Vaikka käsitellyn perusteella on käynyt selväksi, että Pohjola ja Pohja samastetaan usein runoissamme Lappiin, on runoissa monia kohtia, jotka sijoittavat sen kauas pohjoiseen mutta siitä huolimatta suomalaisten asuttaman alueen sisäpuolelle. Siellä viljeltiin peltoja, kansa asui taloissa ja tavat olivat suunnilleen samat kuin Kalevalassa. Ennen kuin sampo ryöstettiin Pohjolasta, siellä vallitsi uskomaton vauraus. Mikään tästä ei sovi Lappiin. Mutta Pohjola on aina merkinnyt Lappia, minkä osoittaa erityisesti se, että Väinämöisen äiti kehottaa [Väinämöistä] hankkimaan itselleen morsiamen Pohjasta, koska hänen mukaansa (Kalevala, runo 5, säkeet 230-233) siellä tytöt eivät ole Lapin lapsilönttäreitä vaan näitä kaksi kertaa somempia ja kauniimpia.

Pohjola ymmärretään usein Kalevalan tavoin kylän merkityksessä, ja sitä tavataan kutsua myös kylmäksi kyläksi; monta kertaa runoissa puhutaan useasta Pohjan kartanosta, joiden kuvataan olevan lähellä toisiaan, ja kun hätä on suuri, antoi kuuluisa emäntä kiireesti kutsua Pohjan väen kokoon (Kalevala, runo 42, säe 61-). Pohjan kansan 
ajateltiin olevan keskenään sukulaisuussuhteissa, ja sen vuoksi sitä nimitetään toisinaan Pohjan suvuksi tai Pohjan suureksi suvuksi.

Pohjola tavataan myös kartanon merkityksessä, ja tämä merkitys onkin itse asiassa tavallisin. Kalevalassa lausutaan (runo 42, säkeet 93-94), että kerran Väinämöinen nukuttaa niin Pohjolan kotiväen kuin kylän muunkin väen (kaiken Pohjolan perehen, ja kaiken kyläisen kansan). Runossa 28 (säkeet 5-6) sanotaan Lemminkäisen pakenevan pimeästä Pohjolasta, hämyisestä Saran kartanosta (pimeästä Pohjolasta, sangasta Saran talosta). Saran talo on tässä sama kuin Sariola. Tämä nimi vaihtelee runoissa usein Pohjolan kanssa, ja etymologiansa mukaan (sariola sanasta sara, 'saraheinä) todennäköisesti merkitsee 'saraheinää kasvavaa paikkaa'. Toinen Pohjolan nimitys on Pimentola, 'pimeä paikka'.

Kalevalan vastakohtana Pohjola merkitsee pahinta mahdollista paikkaa inhottaville noidille ja pahoille olennoille. Pohjolaa käytetään tässä merkityksessä, kun Pohjan poikaa pyydetään tulen sanoissa parantamaan palovammoja, kuten aiemmin mainittiin. Tähän viittaavat myös nimitykset Lemmon kansa, joka liitetään Pohjan kansaan Kalevalan runossa 29 (säe 566), ja paha-valta, kuten sitä kutsutaan runossa 42 (säe 308). Tässä merkityksessä Pohjola on yhdenmukainen muinaispohjoismaisen mytologian Jotunheimin ${ }^{136}$ kanssa.

Näiden paikallisuuksien lisäksi mainitaan eräässä Kalevalan episodissa Joukola eli Luotola, joka oli nuoren Joukahaisen koti ja joka uudessa laitoksessa on selvästi sijoitettu Lappiin. Eräässä toisessa episodissa kerrotaan lisäksi paikasta, jolla on nimi Untamola, mutta sen sijaintia ei täsmennetä lähemmin. Näihin ja muihin vähäisempiin paikallisuuksiin palaamme seuraavassa, ja nyt ryhdymme tutkimaan Pohjolan ja Kalevalan välisiä suhteita, sillä niiden ympärillä Kalevalan runot etupäässä liikkuvat.

Runo kertoo, että pimeässä Pohjolassa on kirkkaana valopilkkuna eräs kaunis neito, joka on laajalti kuulu maalla ja merellä. Kalevalan miesten mieli on kiinnittynyt tähän neitoon, eivätkä he jätä kokeilematta yhtäkään keinoa voittaa hänen rakkautensa ja kiintymyksensä. Vanha Väinämöinen on aiemmin suunnannut ajatuksensa nuoren Joukahaisen sisareen, mutta tämä ei taivu vanhuksen puolisoksi huolimatta äitinsä rukouksista vaan vaipuu mieluummin meren syvyyksiin elääkseen veden kalojen sisarena. Väinämöinen yrittää 
pyydystää hänet sieltäkin, mutta kun tämä ei onnistu, hän päättää haudasta puhuvan äitinsä neuvosta lähteä miehiä tuhoavaan Pohjolaan kosiakseen Pohjan neitoa. Nuori Joukahainen saa tietää tästä ja päättää käydä väijymään vanhusta, joka kevyellä oriillaan ratsastaa pitkin meren aavaa ulappaa. Joukahaisen tavoite on ampua Väinämöinen, mutta nuoli osuu hevoseen, jonka selästä Väinämöinen putoaa pää edellä mereen. Nousee hurja myrsky, joka ajaa Väinämöisen autiolle ulapalle. Joukahainen iloitsee jo Väinämöisen tuhosta, mutta se ei ole vielä koittanut. Eräs kotka, joka on kiitollinen Väinämöiselle tämän jätettyä puun lepopaikaksi siivekkäille raivatessaan kerran metsää, auttaa nyt vanhusta kantamalla hänet siivillään Pohjolaan. Perillä Väinämöinen kaipaa takaisin kotiinsa, mutta Louhi, Pohjolan emäntä, vaatii että hän takoisi sampo-nimisen laitteen vastineeksi vapaudestaan, ja lupaa, että siinä tapauksessa Väinämöinen saa myös hänen kauniin tyttärensä puolisokseen. Väinämöinen kertoo, ettei osaa takoa, mutta lupaa kotiin palattuaan lähettää Pohjolaan seppä Ilmarisen, joka on mestari takomisen taidossa. Tämän lupauksen ansiosta Väinämöinen vapautetaan vankeudestaan, ja Louhi lähettää hänet kotiinsa.

Matkalla [Väinämöinen] näkee Pohjan neidon "istuvan ilman kaarella kutomassa hopeaa ja kultaa". ${ }^{137}$ Väinämöinen tekee hänelle heti ehdotuksen ja taivuttelee neitoa astumaan rekeen kanssaan, mutta tämä asettaakin hänelle tehtäviä eikä lupaudu hänen puolisokseen, ellei hän kykene halkaisemaan jouhta terättömällä veitsellä, vetämään munaa solmuun niin ettei solmua havaitse, repimään tuohta kivestä, lohkomaan aidanseipäitä jäästä murusenkaan irtoamatta ja lopuksi vielä veistämään venettä värttinän osista ja laskemaan sitä aalloille koskematta siihen käsin tai jaloin. Väinämöinen ryhtyy urheasti suorittamaan tehtäviä, ja hänen onnistuukin saada kolme ${ }^{138}$ ensimmäistä onnellisesti suoritettua, mutta venettä veistäessään hän iskee itseään kirveellä jalkaan. Näin toivo neidon käden saamisesta on menetetty, ja hän saa huolekseen saada parannettua haavansa, josta veri valuu vuolaina virtoina. Erään vanhan noidan avulla Väinämöinen saa veren pysäytettyä ja haavan sidottua. Hän jatkaa sitten matkaansa ja saapuu enemmittä seikkailuitta Väinölän lehtoihin ja Kalevalan kankaille. Matkalla niiden läpi hän laulaa kukkivalatvaisen kuusen, joka ulottuu jopa pilvien yläpuolelle ja jossa on kultaiset, laajalle avaruuteen 
levittäytyvät oksat. Kuusen latvaan hän laulaa sitten Kuun ja Otavan sen oksille. Kotiin tultuaan hän on huolissaan Pohjolan emännälle henkeään vastaan antamastaan lupauksesta lähettää seppä Ilmarinen tämän luokse. Lupaus täytyy pitää, ja Väinämöinen lähtee Ilmarisen pajalle toivoen, että kuuluisan neidon suloisuuden lumoama seppä lähtisi vapaaehtoisesti Pohjolaan. Kun tämä toive ei toteudu, Väinämöinen alkaa puhua ihmeellisestä kuusesta ja esittää asiansa niin, ettei Ilmarinen ainoastaan halua nähdä kuusta vaan Väinämöisen kehotuksesta myös kiipeää puuhun hakeakseen Kuun ja Otavan alas. Mutta tuskin seppä on päässyt ylös, kun Väinämöinen laulaa myrskytuulen, joka lennättää tämän ilmojen halki Pohjolaan. Siellä Pohjolan emäntä pyytää heti häntä takomaan sammon, joka tulee valmistaa joutsenen sulasta, ohranjyvästä ja kesäuuhen hienosta villasta, joihin Kalevalan uusi laitos lisää mahon lehmän maidon. Ilmarinen ei epäröi ryhtyä tehtävään eikä lopeta ennen kuin onnistuu suorittamaan sen. Tytön sydäntä hän ei kuitenkaan onnistu tällä kertaa voittamaan, vaan joutuu petetyin toivein palaamaan kotiin, minne alkaa kaivata.

Sitten laulu rientää kertomaan kolmannesta sankarista, joka on nimeltään Ahti eli Lemminkäinen, myös Kaukomieli. Laulussa kerrotaan, että hän on ottanut oman käden oikeudella kauniin Kyllikin omakseen ja päässyt tämän kanssa molemminpuolisin valoin vahvistettuun sopimukseen, ettei itse lähtisi enää koskaan sotiin ja ettei tämä juoksentelisi pitkin kyliä etsimässä iloista seuraa. Kyllikki ei kuitenkaan pysty pitämään valaansa, vaan lähtee kerran tyydyttämään tanssihaluaan Lemminkäisen ollessa muualla. Kun Lemminkäinen kuulee tästä sisareltaan Ainikilta, hirmuinen raivo saa hänet valtaansa ja hän päättää lähteä Pohjolaan hakeakseen kauniin Pohjan neidon toiseksi vaimokseen. Hänen sopuisan äitinsä rukoukset ja varoitukset eivät voi estää häntä toteuttamasta rohkeaa päätöstään. Kun äiti esittelee hänelle lukuisat vaarat, joita hän tulisi kohtaamaan niin matkalla kuin Pohjolassa, ja ennustaa hänelle väistämätöntä tuhoa, hän vain paiskaa seinälle harjan, jolla jatkuvasti kampaa kutrejaan, ja lausuu päättäväisesti:

Silloin on hukka Lemminkäistä,

tuho poikoa pätöistä,

kun suka verin valuvi,

harja hurmehin loruvi. ${ }^{139}$ 
Lemminkäinen lähtee matkaan sotaisissa varusteissa ja saapuu onnellisesti Pohjolaan. Siellä hän aiheuttaa loitsuillaan tuhoa kaikille, sekä vanhoille että nuorille. Hän ei katso kuitenkaan erään vanhan, sokean paimenen olevan raivonsa arvoinen kohde ja jättää tämän sen vuoksi vahingoittumattomaksi. Tämä häväistys suututtaa paimenen niin, että hän kiiruhtaa Tuonelan joelle ja asettuu väijymään ylimielistä Lemmen-poikaa, joka palaisi tätä kautta kotiinsa. Lemminkäinen painostaa nyt kiertelemättä Pohjolan emäntää vaatien tämän tytärtä vaimokseen. Emäntä asettaa hänen toiveensa täyttymisen ensimmäiseksi ehdoksi, että hän pyydystäisi Hiiden nopean hirven. Monien vaikeuksien päätteeksi Lemminkäinen onnistuu suoriutumaan tehtävästä, mutta kun hän palaa hirvineen Pohjolaan, hän saa tehtäväkseen suitsia Hiiden tulisen hevosen. Kun tämäkin tehtävä on onnellisesti suoritettu, on Lemminkäisen heittäydyttävä vielä kolmanteen seikkailuun, ampumaan Tuonelan joelta joutsenta. Kun Lemminkäinen saapuu joelle, sokea paimen ampuu hänet väijyksistä "umpinaisella putkella" hengiltä ja heittää hänet Tuonelan virtaan. Tuonen poika tulee ja hakkaa hänet miekallaan kappaleiksi.

Myöhemmin Lemminkäisen kotona häntä odotetaan huolestuneena palaavaksi, ja eräänä päivänä Kyllikki huomaa, että Lemminkäisen harjasta vuotaa verta. Tästä arvataan, että Lemminkäinen on saanut surmansa, ja äiti lähtee Pohjolaan saadakseen tarkemman tiedon hänen kohtalostaan. Louhi ei halua aluksi paljastaa totuutta; hän tunnustaa, millaisia tehtäviä on Lemminkäiselle antanut suoritettavaksi, mutta sanoo, ettei tunne hänen lopullista kohtaloaan. Lemminkäisen äiti kääntyy nyt tiedusteluineen puiden, tien, Kuun ja lopulta Auringon puoleen, joka kertookin hänelle hänen poikansa tuhosta. Silloin Lemminkäisen äiti taotuttaa Ilmarisella rautaharavan, kiiruhtaa sen kanssa Tuonelan joelle, nostaa sen pohjasta jokaisen kappaleiksihakatun poikansa jäsenen, liittää irralliset osat yhteen ja valaa rakkaaseensa uuden elämän, minkä jälkeen he lähtevät yhdessä kotiinsa.

Laulu palaa Väinämöiseen ja antaa hänen veistää itselleen venettä aiotulle Pohjolan-matkalle. Häneltä puuttuu kuitenkin kolme sanaa, ja hän lähtee Tuonelaan hankkiakseen ne, mutta palaa sieltä suorittamatta tehtävää, koska joutuu mitä suurimpiin hengenvaaroihin. Sitten hän saa eräältä paimenelta neuvon lähteä vanhan Vipusen, jonka huomassa on tallessa tuhansittain sanoja ja lauluja, haudalle. 
Väinämöinen noudattaa paimenen ohjetta ja löytää moninaisten vaarojen kautta tien edesmenneen Vipusen luokse. Väinämöinen tulee tämän nielaisemaksi mutta saavuttaa siitä huolimatta matkansa tavoitteen, palaa kotiinsa ja viimeistelee veneensä. Sillä hän sitten lähtee Pohjolaan mutta pysähtyy matkalla Ilmarisen rannassa. Sepän sisar Annikki seisoo rannalla ja huuhtelee pyykkiään. Hän antautuu keskusteluun Väinämöisen kanssa ja saa siten selville, että [Väinämöinen] valmistautuu kosiomatkalle Pohjolaan. Silloin Annikki kiiruhtaa heti veljensä luokse ja kertoo hänelle Väinämöisen aikeista, ja silloin myös Ilmarinen lähtee maitse kohti Pohjolaa. Molemmat sankarit saapuvat nyt samanaikaisesti kyseiseen paikkaan; heidän aikeensa tunnetaan, ja Pohjolan emäntä neuvoo tytärtään antamaan kätensä Väinämöiselle, mutta tyttö ottaakin seppä Ilmarisen. Ilmarinen saa sitten äidiltä tehtäväkseen kyntää käärmeitä täynnä olevan pellon, suitsia Tuonen karhun ja Manalan suden sekä pyydystää hauen Tuonelan joesta. Suoriuduttuaan onnellisesti kaikista näistä seikkailuista Ilmarinen saa myös äidin hyväksynnän avioliitolle.

Nyt valmistellaan suuret häät. Vieraita kutsutaan niin Pohjolasta kuin Kalevalastakin: köyhät ja rikkaat, jopa vaivaiset, rammat ja sokeat kutsutaan häihin, mutta Lemminkäinen yksin jätetään kutsumatta. Kiukustuneena rohkea "Lemmen-poika" päättää lähteä kutsumatta Pohjolaan vastoin äitinsä varoituksia. Kun hän saapuu sinne, ovat häät jo päättyneet, ja kutsumaton vieras otetaan pilkalla vastaan. Lemminkäinen ei kuitenkaan ole mies, joka sietää loukkauksia. Hän haastaa Pohjolan isännän kaksintaisteluun, lyö häneltä pään irti ja asettaa sen aidanseipääseen. Sitten hänen on paettava, sillä Pohjolan emäntä on kutsunut kaiken kansansa kokoon kostaakseen miehensä murhan. Lemminkäinen saapuu kiireessä kotiinsa, mutta koska hän ei ole siellä turvassa vihollistensa takaa-ajolta, hän lähtee äitinsä kehotuksesta eräälle syrjäiselle saarelle, mistä myös hänen isänsä on aiemmin sotaisina aikoina löytänyt turvallisen pakopaikan. Saareen saavuttuaan pakoileva Lemminkäinen alkaa olla ylenpalttisen hyvissä väleissä sekä saaren neitojen että naineiden naisten kanssa, mikä suututtaa miehiä niin, että he päättävät tuhota hänet. Lemminkäinen saa tämän kuitenkin ajoissa selville, ja hänen on taas paettava, jolloin hän ottaa kurssin kotiin. Matkalla nousee hirmuinen myrsky, joka rikkoo hänen aluksensa. Hän pääsee silti uimalla rantaan, saa uuden veneen 
ja pääsee sillä onnellisesti kotiinsa. Vaan siellä on Lemminkäistä takaa ajanut Pohjolan joukkio polttanut tuvan tuhkaksi. Myös äiti on kadonnut, mutta hänet Lemminkäinen sentään löytää elossa syvältä erämaasta, missä hän asuu pienessä vaahteratuvassa. Lemmikäinen lupaa rakentaa hänelle parempia tupia ja hakea kostoa Pohjolan väeltä. Jälkimmäistä varten hän liittyy yhteen vanhan aseveljensä Tieran eli Kuuran kanssa, ja nämä sankarit lähtevät nyt Pohjolaan. Heidän ollessaan matkalla Pohjolan emäntä lähettää heitä vastaan kireän pakkasen, jolloin heidän aluksensa jäätyy kiinni mereen, ja vain vaivoin he selviävät rantaan. He harhailevat sitten pitkään erämaassa, kunnes saapuvat lopulta kotiinsa toimittamatta tehtäväänsä.

Nyt seuraa pitkä episodi, jolla ei ole mitään muuta yhteyttä muihin Kalevalan lauluihin kuin että [sen mukaan] rohkea Kullervo tuhoaa Ilmarisen emännän. Vaimonsa kuoleman murtama Ilmarinen ottaa tehtäväkseen takoa uuden kullasta ja hopeasta. Hän onnistuu antamaan kultaiselle kuvalle jopa kauniin ulkomuodon, mutta levätessään yöllä sen vierellä hän tuntee jäätävän kylmyyden hohkavan elottomasta morsiamestaan. Tyytymättömänä työnsä jälkeen hän tekee uuden matkan Pohjolaan tarkoituksenaan kosia toista sen tyttäristä. Pohjolan emäntä ottaa hänet vastaan tiukoin sanoin ja kieltäytyy päättäväisesti antamasta hänelle toista tytärtään. Ilmarinen turvautuu nyt oman käden oikeuteen, paiskaa tytön rekeensä ja kiiruhtaa hänen kanssaan kotiaan kohti. Matkalla hän huomaa, että ryöstetty morsian on ollut hänelle uskoton, jolloin hän noituu tämän lokiksi meren luodoille kirkumaan.

Kotimatkalla Ilmarinen tapaa vanhan Väinämöisen, joka kertoo matkastaan ja kysyy, kuinka Pohjolassa eletään. Ilmarinen lausuu vastaukseksi:

\footnotetext{
Mi on Pohjolan eleä!

Siell' on sampo jauhamassa,

Kirjokansi kallumassa:

Päivän jauhoi syötäviä,

Päivän toisen myötäviä,

Kolmannen kotipitoja.

Jotta sanon kuin sanonki,

Vielä kerran kertaelen:

Mi on Pohjolan eleä,
} 
Kun on sampo Pohjolassa!

Siin’ on kyntö, siinä kylvö,

Siinä kasvo kaikenlainen,

Siinäpä ikuinen onni. ${ }^{140}$

Silloin Väinämöinen ehdottaa, että Ilmarinen liittyisi hänen seuraansa matkalle Pohjolaan ryöstämään sampoa. Tähän Ilmarinen vastaa:

Ei ole sampo saatavana, kirjokansi tuotavana

Pimeästä Pohjolasta,

Summasta Sariolasta!

Siell' on sampo saatettuna,

Kirjokansi kannettuna

Pohjolan kivimäkehen,

Vaaran vaskisen sisähän

Yheksän lukon ta’aksi;

Siihen juuret juurruteltu

Yheksän sylen syvähän,

Yksi juuri maaemähän,

Toinen vesiviertehesen,

Kolmas on kotimäkehen. ${ }^{141}$

Väinämöinen ei anna tämän estää itseään, vaan seisoo lujana päätöksensä takana. Päätetään, että sankarit tekisivät matkan meritse, vaikkakin Ilmarinen omalta osaltaan on maitse tehtävän matkan kannalla. Aalloilla purjehtiessaan he huomaavat Lemminkäisen, joka tarjoutuu heille aseveljeksi ja sellaiseksi pääseekin. Nämä kolme sankaria saapuvat erääseen koskeen, missä vene juuttuu suuren hauen selkään. Kala tapetaan, ja Väinämöinen tekee sen leukaluusta kanteleen. Sitten matka jatkuu, ja sankarit saapuvat onnellisesti Pohjolaan. Väinämöinen ehdottaa Pohjolan emännälle sammon jakamista, mutta kun tämä ei suostu ehdotukseen, Väinämöinen uhkaa häntä sen menettämisellä tyystin. Emäntä kutsuu silloin kokoon kaikki Pohjan miehet, jotka ilmaantuvatkin täydessä taisteluvarustuksessa. Kanteleensa sävelin Väinämöinen nukuttaa koko Pohjan väen, ja sillä välin kun se on vaipuneena syvään uneen, Kalevalan sankarit ryöstävät sammon. Kolmantena päivänä Pohjolan emäntä herää unestaan. Silloin hän 
näkee, että sampo on ryöstetty häneltä, ja lähettää sumua, myrskyä ym. hidastaakseen Kalevalan sankareiden matkaa ja saavuttaakseen heidät mahdollisesti matkalla. Nousseessa rajuilmassa Väinämöinen menettää hauenluukanteleensa, jonka myrsky paiskaa mereen Ahdin, aaltojen kuninkaan saaliiksi. Sitten Pohjola varustaa sotalaivan, jolla [Pohjolan emäntä] lähtee väkensä johdossa seuraamaan Kalevalan sankareita. Hän saavuttaakin heidät, ja nousee kiivas taistelu, jonka Kalevalan sankarit voittavat. Pohjolan emännän onnistuu kuitenkin suistaa heidän veneestään sampo, joka siinä yhteydessä rikkoutuu kappaleiksi. Suurimmat kappaleet uppoavat merenpohjaan, mutta jotkut kelluvat vedessä ja ajautuvat aaltojen mukana rantaan. Väinämöinen ennustaa, että nämä kappaleet toisivat hyvinvointia Suomeen. Pohjolan emäntä uhkaa pilata kasvun, sadon ja karjan kylmyydellä ja pakkasella, villieläimillä jne. Väinämöinen pitää pintansa, ja Pohjolan emännän on myönnettävä valtansa kutistuneen siksi, että hän on menettänyt sammon. Murheellisena hän palaa kotiinsa saamatta sammosta muuta kuin pelkän kannen: "Siit' on polo Pohjolassa, elo leivätöin Lapissa." ${ }^{142}$ Väinämöinen kerää rantaan ajautuneet muruset ja vie ne kotiinsa kantamaan runsaasti hedelmää ja tuomaan sekä olutta että leipää.

Onnellisesti päättyneen Pohjolan-matkansa jälkeen Väinämöinen tuntee tarvetta ilmaista iloaan sävelin, mutta hänen kanteleensa on kadonnut meren syvyyksiin. Hän yrittää nostaa sen, mutta kun kaikki hänen yrityksensä jäävät hedelmättömiksi, hän keksii ratkaisuksi tehdä koivupuusta uuden kanteleen. Hän lumoaakin kaikki olennot sen sävelin. Pohjolan emäntä toteuttaa sittemmin uhkauksensa. Ensin hän täyttää Kalevalan ennenkuulumattomin sairauksin, ja kun Väinämöinen karkottaa ne runoillaan ja lääkkeillään, hän lähettää karhun tuhoamaan karjaa. Väinämöinen kaataa karhun, minkä jälkeen järjestetään suuret pidot lepyttämään edesmenneen [karhun] henkeä. Silloin Väinämöinen näppäilee kanteleensa kielistä niin suloisia säveliä, että itse Aurinko ja Kuu laskeutuvat paikoiltaan nauttiakseen niiden kauneudesta. Pohjolan emäntä kiiruhtaa heti kaappaamaan nämä taivaankappaleet ja piilottaa ne kallion sisään. Samalla hän varastaa myös tulen Kalevalasta. Silloin taivaanjumala Ukko päättää luoda uuden auringon ja kuun: hän sytyttää tulen, piilottaa kipinän kultaiseen 
kukkaroon hopeakehässä ${ }^{143}$ ja jättää sen Ilman tyttärelle, jotta tämä tuudittaisi sen liekeiksi, jotka voisivat palvella uusina taivaankappaleina. Neito käsittelee kipinää kuitenkin niin huolimattomasti, että se putoaa maan päälle. Väinämöinen huomaa kipinän putoamisen ja lähtee Ilmarisen kanssa etsimään sitä. He onnistuvat löytämään sen erään hauen kuvusta, mutta kun Ilmarinen aikoo ottaa tulikipunan kiinni, se polttaa hänen käsiään ja kasvojaan ja katoaa sitten metsään aiheuttaen siellä suurta tuhoa.

Vähittäin Väinämöinen saa kipinän hallintaansa ja Kalevala saa taas tulen haltuunsa, mutta Aurinko ja Kuu ovat yhä poissa. Toivuttuaan vammastaan Ilmarinen yrittää takoa kullasta ja hopeasta uuden auringon ja kuun, mutta näistä ei ollut tarkoitukseen. Noitataitojensa avulla Väinämöinen saa silloin selville, että todelliset Aurinko ja Kuu ovat kätkettyinä Pohjolan kivimäkeen. Aikeenaan vapauttaa ne vankeudestaan hän lähtee taas Pohjolaan ja käy sen miesten kanssa hurjan taistelun. Väinämöinen voittaa heidät, mutta hänellä ei ole työkaluja joiden avulla tunkeutua kallioon, jossa Aurinkoa ja Kuuta säilytetään. Saadakseen ne haltuunsa hän lähtee taas Kalevalaan. Pohjolan emäntä on sillä välin kuitenkin kauhistunut niin, että näkee parhaaksi päästää Aurinko ja Kuu vankilastaan. Tämän jälkeen hän jättää Kalevalan rauhaan, eikä runo osaa kertoa hänestä sen enempää. Mutta Väinämöisestä on vielä yksi runo, joka kuvaa hänen lopullista kohtaloaan. Kristuslapsi on syntynyt maailmaan, ja eräs ukko on kutsuttu kastamaan hänet. Koska lapsi on isätön, kastetta ei voida antaa ilman että tuomitaan, saako lapsi pitää henkensä. Tuomio annetaan viisaalle Väinämöiselle, joka tekee päätöksen, että lapsi pitää surmata. Silloin poika korottaa äänensä ja syyttää Väinämöistä väärästä tuomiosta, ja ukko kastaa poikalapsen Karjalan kuninkaaksi. Väinämöinen suuttuu tästä ja purjehtii vaskiveneellä tiehensä paikkaan, joka sijaitsee maan ja taivaan välissä. Hän jättää kanteleensa ikuiseksi iloksi Suomen kansalle.

Kun tarkastelee ennakkoluulottomasti näiden laulujen olemusta, joiden sisällön yritimme lyhyesti esitellä, jokainen epäilyksettä vakuuttuu siitä, että ne lepäävät ainakin suurelta osin historiallisella pohjalla. Näin on todistettavasti laita kaikkien niiden laulujen kohdalla, jotka kuvaavat kolmen sankarin - Väinämöisen, Ilmarisen ja Lemminkäisen - kosiomatkoja, ja niiden joukkoon kuuluvatkin useimmat Kalevalassa tavattavista runoista. Sisältö on samankaltainen myös 
selkeästi suurimmassa osassa sankarilauluista, jotka elävät lähempien ja etäisempien sukukansojemme parissa: ostjakkien, samojedien, tataarien jne. Näillä on yhä tänä päivänä tiettyjä tapoja ja instituutioita, jotka selkeästi selittävät kaikkien tämäntyyppisten runojen synnyn ja historiallisen merkityksen. Yksi näistä instituutioista on jokaisen kansan jakautuminen suurempaan tai pienempään määrään sukuja, jotka aina pysyttelevät lähekkäin yhdessä mutta elävät tiukasti erillään toisista, itseensä kuulumattomista suvuista. Eri sukujen keskinäiset välit olivat muinoin erittäin vihamieliset, ja suvut organisoivat usein ryöstöretkiä toistensa luokse. Vielä myöhempinäkin aikoina venäläiselle virkavallalle on aiheutunut paljon vaivaa kesyttömien kansojen pitämisestä lieassa ja niiden keskinäisten vihamielisyyksien hillitsemisestä. Nykyään ne eivät kuulemma enää harjoita raaempaa väkivaltaa, mutta vanha viha ei ole tyystin kadonnut vaan leimahtelee tavalla tai toisella ja estää erillisiä sukuja harjoittamasta lähempää kanssakäymistä toistensa kanssa.

Ainoastaan aviollisia suhteita solmittaessa sukujen on nykyään pakko ojentaa toisilleen sovinnon käsi joko mielensä mukaan tai vastentahtoisesti, sillä vanhastaan on vallalla laki, jonka mukaan avioliittoa ei saa solmia saman suvun sisällä. On yleinen sääntö, tietyin poikkeuksin, että jokaisen nuoren miehen on hankittava itselleen morsian jostakin vieraasta suvusta. Tyttöä ei vielä tänä päivänäkään voi saada ilman varsin merkittävää morsiuslahjaa, jonka sulhanen luovuttaa tytön vanhemmille tai holhoojille. Muinaisina aikoina tämä lahja oli luultavasti paljon suurempi sukujen välillä tuolloin vallinneiden voimakkaampien vihamielisyyksien vuoksi. Näyttää myös siltä, että näiden vihamielisyyksien vuoksi neidon kättä ei monesti voinut saada millään hinnalla. Suuret vaikeudet, jotka näin ollen olivat aviollisten pyrkimysten tiellä, pakottivat rohkean miehen usein taistelemaan nuorikon kädestä oman käden oikeudella - tapa, joka ei ole kokonaan poistunut käytöstä Siperian villien ja puolivillien kansojen keskuudessa. Kuten olen jo maininnut ja kuten tulen lähemmin tarkastelemaan, juuri tätä aihetta käsitellään useimmissa mainittujen kansojen sankarilauluissa, ja samansisältöisiä ovat myös enimmät Kalevalan lauluista. Yhdessä näistä runoissa kerrotaan, että rohkea Lemminkäinen hankkii kauniin Saaren neidon Kyllikin väkivalloin. Toisessa taas Ilmarinen ryöstää Pohjolan nuoremman tyttären. Runoissa, jotka 
kuvaavat Väinämöisen, Ilmarisen ja Lemminkäisen yrityksiä kosia vanhempaa, kauneudestaan laajalti kuulua Pohjan neitoa, eivät tällaiset väkivaltaisuudet tule kysymykseen, vaan niin äidin kuin itse tytönkin kanssa yritetään neuvotella sovussa. Jälkimmäisen silmissä ei ratkaise mikään muu ominaisuus kuin kauneus, ja sen vuoksi hän valitsee Ilmarisen pikemmin kuin vanhan, viisaan Väinämöisen. Äiti antaisi omasta puolestaan tyttärensä mieluiten ikuiselle laulajalle, mutta tytön mieltymyksen lisäksi Väinämöistä vastaan on se, että hän ei kykene tuomaan emännän vaatimaa morsiuslahjaa. Lahja on itse asiassa sampo, jonka Ilmarinen valmistaa, kuten yllä näimme. Tämän jälkeen Ilmarinen kosii neitoa vielä monta vuotta ja vierailuillaan tuo runsaita lahjoja Pohjolaan. Hän onnistuu jopa suorittamaan menestyksekkäästi kaikki vaikeat sankarin kokeet, jotka äiti hänelle asettaa, minkä ansiosta hän lopulta kaikkien uhrausten päätteeksi saa kauniin Pohjolan neidon vaivoin puolisokseen.

Kalevalassa on paljon muitakin todisteita, jotka tässä kuitenkin ohitamme, sen näkemyksen puolesta, että myös muinaissuomalaisten keskuudessa kosintayrityksiin on liittynyt sekä suuria kuluja että vaikeita seikkailuja. Syy tähän ei voi olla mikään muu kuin että myös esi-isiemme keskuudessa on vallinnut yllämainittu tapa hankkia vaimo ei omasta vaan vieraasta suvusta, jonka kanssa tavallisesti oltiin vihamielisissä suhteissa. Mikäli tällaista sääntöä ei olisi ollut, olisi vaikea löytää tyydyttävä syy siihen, että niin Väinämöinen kuin Ilmarinen ja myös Lemminkäinen esitetään hankkimassa vaimoa pimeästä, miehiä tuhoavasta Pohjolasta, jota he pelkäävät ja inhoavat. On helppo ajatella, että Pohjan tytön vertaansa vailla oleva kauneus vetää sankareita puoleensa, mutta senkin jälkeen kun hänen kauneutensa valo lakkaa loistamasta, näemme Ilmarisen valmiina kosiomatkalle Pohjolaan. Menetettyään toivonsa onnistumisen suhteen [Ilmarinen] ryhtyy kerran kehnoon yritykseen takoa itselleen vaimo hopeasta ja kullasta. Mutta miksei hän koskaan kosi Kalevalan tyttäriä? Runoissa kerrotaan, että sekä Lemminkäisellä että Ilmarisella on molemmilla sisar. Mikseivät Kalevalan sankarit koskaan käänny heidän puoleensa ehdotuksineen? Syy tähän ei voi olla mikään muu kuin se, että avioliitto saman suvun sisällä ei ole sallittu. ${ }^{14}$ Tässä säännössä on eittämättä historiallinen pohja kaikille runoille, jotka kuvaavat Väinämöisen, Ilmarisen ja Lemminkäisen seikkailurikkaita kosiomatkoja. Mikäli 
mainituilla runoilla on tällainen pohja, on selvää, että Pohjolan ja Kalevalan väki edustavat alun perin kahta erillistä sukua. Voi olla yhdentekevää, ovatko nämä suvut joskus olleet sen nimisiä kuin nykyään runoissa; nimi tai toinen niillä on kuitenkin täytynyt olla jo ennen suomalaisten vaellusta Aasiasta. Se sama yhteinen pohja, johon suomalaisten ja heidän Aasiassa majailevien heimosukulaistensa kosintarunot nojaavat, puhumattakaan monista muista yhteneväisyyksistä, paljastavat aivan selvästi, että näiden runojen on täytynyt syntyä siihen aikaan, kun [suomalaiset] vielä elivät läheisessä kanssakäymisessä aasialaisten sukukansojensa kanssa ja kun heillä oli vielä yhteisiä instituutioita. ${ }^{145}$ Näin ollen minun on mainittava, että runoissamme ei missään selkeästi esitetä Kalevalan ja Pohjolan asukkaita kahtena eri sukuna, vaan että se on luultavasti jälkeenpäin joutunut unohduksiin. Yksin ja ainoastaan vertailun kautta sukukansojen sankarirunoihin tästä voi saada selkeämmän käsityksen.

Laulut sammosta näyttävät sitä vastoin kuuluvan myöhempään aikaan, jolloin suomalaiset olivat jo eronneet muista sukulaiskansoistaan. Tähän olen päätynyt eritoten sen seikan perusteella, että tähän merkittävään esineeseen liittyviä traditioita ei tavata ainoankaan sukukansamme keskuudessa. Olen eräässä yhteydessä kiinnittänyt huomiota siihen, että mongolit ovat antaneet vanhimmalle buddhalaiskirkolleen nimeksi Sampo. Vaikka on todellakin luultavaa, että suomalaiset ovat jättäneet asuinsijansa Aasiassa jo paljon ennen tämän perustamista, olisi silti ajateltavissa, että he ovat saaneet jälkeenpäin pitkän kansainvaellusajan kuluessa jotakin tietoa tästä temppelistä, joka oli kuuluisa kautta koko Aasian. Olen tullut entistäkin vakuuttuneemmaksi tästä näkemyksestä johtuen Lönnrotin tutkimuksista, jotka johtivat hänet siihen tulokseen, että Pohjola on vanha bjarmikaupunki Holmogor ja sampo bjarmien kuuluisa Jumala-kuva. Minusta nimittäin sammon kuvaus sopii aivan yhtä hyvin ellei jopa paremmin itse temppeliin kuin jumalkuvaan. Sen kuvaus on kuitenkin niin fantastinen, ettei se viittaa kirjaimellisesti yhteenkään kohteeseen tässä maailmassa, ja uskonkin, että sampo-kertomus, mikäli sillä on alun perin ollutkaan historiallista tarkoitetta, on paljolti ymmärrettävä allegorisessa merkityksessä. Sampo taotaan, kuten aiemmin näimme, joutsenensulasta, ohranjyvästä, kesäuuhen hienosta villasta (yhdestä karvasta) ja mahon lehmän maidosta. Nämä aines- 
osat liitetään sammossa yhteen sillä perusteella, että juuri tällaisia asioita - jyviä, karjaa, maitoa, lintuja ja villieläimiä - Pohjolan emäntä toivoo saavansa. ${ }^{146}$ Kun sampo on taottu valmiiksi, se jauhaa yhtenä iltapuhteena kolme laaria täyteen jauhoja. Jauhamista ei pidä tässä ottaa kirjaimellisesti, vaan sen merkitykseksi on tulkittavissa, että sampo hankkii Pohjolan emännälle elintarpeita ylenpalttisesti. Erittäin tyytyväisenä siihen, kuinka väline vaikuttaa hänen ja hänen väkensä hyvinvointiin, [Pohjolan emäntä] piilottaa sammon Pohjolan kivikallioon yhdeksän lukon taakse ja kiinnittää sen juuret yhdeksän sylen syvyyteen, yhden juuren maahan, toisen veden reunaan, kolmannen kotimäkeen. Otaksun, että myös nämä juuret tulee ymmärtää allegorisessa merkityksessä. Kasvin juurten tehtävä on imeä kosteutta maasta ja hankkia ravinteita kasville. Vastaavasti myös sammon juuret toisivat maasta ja vedestä ravinteita Pohjolaan. Kun Kalevalan sankarit ovat ryöstäneet sammon ja kun Väinämöinen on koonnut sen levinneet kappaleet merenrannalta, hän kuljettaa ne Kalevalaan kasvamaan ja kypsymään olueksi ja leiväksi, so. tuottamaan vaurautta ja hyvinvointia. Tästä näyttää voitavan päätellä, että sampo käsitettiin jonkinlaiseksi välineeksi, jolla uskottiin saatavan hallintaan kaikkia sellaisia asioita, jotka tyydyttävät ihmisen materiaalisia tarpeita.

Aiemmissa tutkimuksissani olen verrannut sampoa talismaaneihin, joita on siellä täällä käytössä myös suomalaisten parissa heidän šamaaniensa valmistamina. ${ }^{147}$ Pidän tätä näkemystä edelleen uskottavimpana, mutta se ei poissulje sitä, että käsitykset sammosta olisi lainattu jostakin todellisuudessa olemassa olleesta kohteesta, eikä sitä, että tämä kohde olisi voinut vallan mainiosti olla temppeli. Jumalilta anottiin apua ja suojelusta eritoten pyhäkön holvin alla ${ }^{148}$, joten kaiken hyvän, mitä heiltä rukouksin saatiin, saattoi näin ollen tietyllä tavoin sanoa olevan peräisin temppelistä. Itse asiassa myös kyseinen sana sampo, jonka alkuperä juontuu Tiibetistä missä se kuuluu muodossa sangfu, merkitsee tämän maan kielessä kirjaimellisesti 'hyvän lähde', ja tämä merkitys sopii täydellisesti myös suomalaisten sampoon. Suomalaisissa runoissamme usein tavattava tieto, että sammossa on kirjava kansi, saattaa soveltua temppelin kattoon. Tätä hypoteesia vastaan puhuvat sitä vastoin runojen lukuisat todistukset siitä, että sampo suljetaan vaskivuoreen, että se kuljetetaan Pohjolasta Kalevalaan 
veneellä ja että kaiken lisäksi vain kolme miestä tarvitaan kantamaan se veneeseen. Siksi etsimme vielä jotakin muuta, mikä vastaisi sammon luonnetta paremmin.

Monet ovat toistaneet olettamusta, että sampo olisi mylly. Tämän näkemyksen tueksi on esitetty ensinnäkin äänteellinen vastaavuus sanan sampo ja ruotsin kielen sanan stamp ('käsimylly') välillä, ${ }^{149}$ toisekseen runojen todistus, että sampo jauhoi viljaa, ja lopulta Kalevalan uudessa laitoksessa (runo 10, säkeet 414-416) tavattava tieto, että Ilmarinen takoi sammon yhdelle sivulle jauhomyllyn, toiselle suolamyllyn ja kolmannelle rahamyllyn. Minun mielestäni sammon myllyominaisuuden puolesta puhuu kaikkein parhaiten se seikka, että myös monilla muilla kansoilla on traditioita samanlaisista ihmemyllyistä.

Niinpä muinaispohjoismaisessa mytologiassa puhutaan käsimyllystä, Grotti ${ }^{150}$ nimeltään, jonka Tanskan kuningas Frodi Fridleifsson $^{151}$ on saanut mieheltä nimeltään Hengikjöpt ${ }^{152}$. Grotti kykenee tuottamaan kaikkea, mitä jauhaja toivoo, ja kuningas Frodi pistää sen jauhamaan kultaa, onnea ja rauhaa. Se ei kuitenkaan jauha itsekseen, kuten asia näyttää olevan sammon kohdalla, vaan Frodi ostaa Ruotsista kaksi suurta ja vahvaa jättinaista, Fenjan ja Menjan, joille uskotaan raskaiden myllynkivien pyörittäminen. Yksikään mies Tanskassa ei saa niitä liikkeelle. Kuningas Frodi pitää kaksi jättinaista, jotka ovat sisaruksia, niin tiukasti töissä, etteivät he saa pitää sen pidempää taukoa työssään kuin mitä käki kukkuu tai he itse tarvitsevat esittääkseen laulun. Yhden tällaisen välitauon aikana he laulavat kauniin Grottilaulun ${ }^{153}$, joka on kirjattu Snorrin Eddaan. ${ }^{154}$ Tässä laulussa he toivovat, että Frodi tapettaisiin, ja tämä toive toteutuukin. Vielä samana yönä tulee merikuningas Mysing ${ }^{155}$, joka peittoaa ja tappaa Frodin, mutta myllyn ja kaksi orjatarta hän ottaa mukaansa. Mysing määrää jättinaiset jauhamaan suolaa, ja he jatkavat tätä työtä kunnes Mysingin laivat on lastattu niin täyteen, että ne uppoavat Petlanninlahteen ${ }^{156}$. Paikalle syntyy kurimus, joka aiheutuu veden syöksymisestä ulos ja sisään myllynkiven silmästä.

On pakko myöntää, että tämä kertomus tarjoaa useita yhtymäkohtia suomalaisten sampo-runoon. Sekä sammolla että Grottilla on kyky jauhaa kaikkea, mitä niiltä halutaan. Grottin jauhamista asioista mainitaan erikseen kulta ja suola. Samoja tuotti myös sampo, sillä kuten olen jo maininnut, Ilmarinen takoi sen laitoihin suola- ja rahamyllyt. 
Edda kertoo, että Mysing peittoaa Frodin ja ryöstää Grottin, ja vastaaavasti kerrotaan myös Kalevalassa, että Väinämöinen taistelutovereineen vie sammon väkisin Pohjolan kivimäestä. Molemmat kertomukset ovat yhteneväisiä lisäksi myös siinä, että yhtä lailla niin skandinaaviset kuin suomalaiset sankarit suorittavat toimensa yön pimeydessä. Grottin tavoin myös ryöstetyn sammon sanotaan uponneen merenpohjaan. Mikäli kertomukset Grottista ja sammosta todella käsittelevät yhtä ja samaa aihetta, on hyvät perusteet otaksua, että suomalaiset ovat lainanneet [sampo-kertomuksen] perusrakenteen skandinaavisilta naapureiltaan. ${ }^{157}$ Perustan tämän näkemyksen siihen jo käsiteltyyn seikkaan, että sampo-kertomusta ei tavata minkään muun suomensukuisen kansan parissa, kun taas Grotti-kertomus on ollut laajalti tunnettu Ruotsissa, Norjassa, Tanskassa ja Saksassa. ${ }^{158}$

Joka tapauksessa, esikuvansa Grottin tapaan, sampo ei niinkään viittaa mihinkään varsinaisesti olemassa olleeseen kohteeseen kuin edustaa kaikenlaista ajallista onnea tuottavaa talismaania. ${ }^{159}$ Talismaanin käsittäminen myllyksi johtuu osittain siitä, että myllyn tuottamaa jauhoa pidettiin ihmisen elossapysymisen suhteen parhaana ja tärkeimpänä aineena. Osittain se voi johtua myös siitä, että herkeämättömällä jauhamisellaan mylly antaa ihmisille runsain mitoin sitä, mitä se luontonsa mukaisesti pystyy tuottamaan. ${ }^{160}$ Minun on lisättävä, että käsitys sammosta talismaanina vastaa läheisesti suomalaisten yleistä käsitystapaa, sillä kaikissa vanhemmissa runoissamme käsitellään maagisia, ihmeellisiä ja käsittämättömiä asioita erityisellä lämmöllä. Mutta mikäli sampoa pidetään tällaisena, sillä ei ole sanan varsinaisessa merkityksessä historiallista tarkoitetta. Mielestäni sampo-myytin synnyn perusta onkin suunnilleen seuraava: Pohjolan asukkaat olivat kuuluisia tavattomista kyvyistään noitataidoissa, ja koska šamaaneilla on välttämättä oltava tietyt noitavälineet, kuten amuletteja, talismaaneja jne., uskottiin luonnollisesti, että nämä olivat tehokkaampia Pohjolassa kuin muissa maissa. Kun siellä huhun mukaan vallitsi vauraus ja hyvinvointi, oli luonnollista, että tämä hyvinvointi yhdistettiin asukkaiden noituuteen. Kanssakäynnissään skandinaavisten kansojen kanssa olivat suomalaiset saaneet tietoa ihmemylly Grottista. Se siirrettiin Pohjolaan, ja tämän paikan poikkeuksellinen hyvinvointi selitettiin kyseisen merkittävän talismaanin ansioksi. ${ }^{161}$ Olen [kuitenkin] varma siitä, että tämä selitys ei tyydytä kaikkia ja että sammolle 
pyritään edelleen osoittamaan historiallinen merkitys. Onnistuisipa tämä pyrkimys jatkossa paremmin kuin tähän asti!

Vaikka meidän olisi näin ollen luovuttava toivosta löytää oikeasti jokin sampoa täydellisesti vastaava kohde, sampo-kertomuksella on siinä määrin historiallinen pohja että se viittaa varsin selvin sanoin Pohjolan ja Kalevalan välillä käytyihin kiivaisiin taisteluihin. Niin kauan kuin kolme Kalevalan sankaria yrittää voittaa kauniin Pohjan neidon kiintymystä, he eivät voi ryhtyä mihinkään vihollisuuksiin Pohjolaa vastaan, vaan heidän täytyy yrittää elää ainakin päällisin puolin hyvässä yhteisymmärryksessä tämän naapurinsa kanssa. Myöhemmin myös kosintarunoissa nousee esiin syvältä kumpuava viha, [joka vallitsee] näiden kahden paikan välillä, ja Lemminkäinen antaa tämän vihan päästä valloilleen omalla kosintaretkellään, kun hän noitalaulullaan tuhoaa suuren osan Pohjan kartanon asukkaista. Pohjolan ja Kalevalan väliset vihamieliset suhteet kuvataan täsmällisesti ja korostetusti sampo-runoissa. Vihamielisyydet puhkeavat, kun yksi Pohjolan tytär on tapettu ja toisen Ilmarinen on loitsinut kalalokiksi. Tyttäriensä myötä Pohjolan emäntä menettää parhaan suojansa Kalevalan sankareita vastaan. Pohjolan ja Kalevalan välillä ei ole muita yhdyssiteitä, joten ainoa side niiden väliltä on katkennut, ja taistelu leimahtaa täyteen liekkiin. Väinämöinen, Ilmarinen ja Lemminkäinen päättävät tehdä yhteistyötä, ja yhdistetyin voimin he murskaavat Pohjolan mahdin, joka perustuu ihmeelliseen noitamyllyyn. Heidän myös onnistuu saattaa Pohjola tuhon partaalle sammon ryöstöllä. Mutta Louhi, Pohjolan mahtava emäntä, käyttää puolestaan kaikkia mahdollisia keinoja kostaakseen ja tuhotakseen Kalevalan sarastavan hyvinvoinnin. Viisaalta Väinämöiseltä vaatii paljon vaivaa torjua hänen pahantahtoiset toimensa; lopulta Väinämöinen kuitenkin saa voiton ja Kalevalan mahti vakiintuu.

On esitetty, että eritoten sampo-runoissa kuvatulla Pohjolan ja Kalevalan välisellä taistelulla olisi eettinen merkitys samaten kuin että hyvä ja paha esiintyisivät Väinämöisen ja Louhen muodossa ja että ne näin ruumiillistuneina kamppailisivat keskenään maailman valtiudesta. ${ }^{162}$ Omalta osaltani en pysty yhtymään tähän näkemykseen. Kaikki viittaa siihen, että muinaissuomalaisten Kalevala-aikaiset ${ }^{163}$ moraaliset käsitykset eivät olleet saavuttaneet sitä kehitystasoa ja selkeyttä, että olisi ymmärretty hyvä ja paha keskenään vastakkaisina, yhteensopi- 
mattomina prinsiippeinä, vaan ne esiintyivät pelkästään relatiivisina käsitteinä. Olen osoittanut jumaloppeja esitellessäni, kuinka yhtä ja samaa jumaluutta yhtäällä pidetään hyvänä, toisaalla pahana voimana. Sama seikka pitää paikkansa myös sankareiden kohdalla. Väinämöinen on suomalaisen laulunjumalattaren etummainen suosikki, ja sen vuoksi häneen liitetään osin hyviä ominaisuuksia. Siitä huolimatta hän saa lastikseen sen moraaliltaan alhaisen teon, että säästääkseen oman henkensä antaa veljensä Ilmarisen maksuksi siitä Pohjolan emännälle. Väinämöisen ylimpänä vihollisena ja vastustajana on Louhen luonnollisesti esiinnyttyvä synkimmässä valossa ${ }^{164}$, mutta toisaalta hän on paras, armeliain ja rakastettavin äiti, jonka sanalla sanoen koko suomalainen kansanrunous pystyy tuomaan esiin. Mitä puuttuu niiden sanojen äärettömästä ihanuudesta, jotka hän osoittaa tyttärelleen hyvästiksi? Kalevalan vanhemmassa laitoksessa (runo 15, säkeet 200-221) hän lausuu esim.

Vielä neuon neitoani,

Orpolastani opetan:

Morsian, sisarueni,

Kapulehti, laklueni!

Kuulestamma kun sanelen,

Vaimo vanha lausuelen.

Tulet toisehen talohon,

Toisehen emän alahan,

Parehesen vierahasen;

Toisin toisessa talossa,

Toisessa emän alassa,

Perehessä vierahassa,

Ei niinkun emon koissa,

Oman vanhemman varassa.

[...]

Ellös sie sinä ikänä,

Kuuna kullan valkiana,

Tavaton talohon mennö,

Miehueton mieholahan.

Talo tapoja kysyvi,

Tapoja talo pahaki;

Mies on mieltä koittelevi,

Mies mieltä epäpätöki. 
Kuinka tällaisten sanojen puhujaa voitaisiinkaan pitää pahuuden edustajana?

Lukuun ottamatta Väinämöisen ja Louhi-naisen persoonallisuuksia runoissa ei ole kuitenkaan mitään, mikä antaisi syytä siihen otaksumaan, että taistelua Kalevalan ja Pohjolan välillä käytäisiin eettisin perustein. Tämän taistelun luonne on niin yksinkertainen, selvä ja luonnollinen, että on vaikea ymmärtää, kuinka sen ylipäätään voi käsittää väärin. Pohjolan asukkaat ovat saavuttaneet suuren hyvinvoinnin omistamalla sammon, sillä tämän ihmeellisen välineen avulla heillä on tavaraa, kultaa ja muita elämän ulkoisia välttämättömyyksiä ilman mitään ponnisteluita. Tämän tavattoman menestyksen täytyy luonnollisesti tuntua sitä vaille jäävistä Kalevalan miehistä katkeralta, etenkin kun Pohjola on saanut onnea tuovan esineen juuri heiltä. Väinämöinen huolehtii alati omiensa hyvinvoinnista, ja siinä toivossa, että toisi hyvinvoinnin Kalevalaan ja murskaisi vihollisensa mahdin, hän keksii rohkean suunnitelman, jonka avulla sampo voitaisiin ryöstää. Monien taisteluiden ja vaikeuksien päätteeksi hän myös toteuttaa suunnitelman. Tätä syvempää merkitystä ei taistelulle sammosta voi antaa vääristelemättä tarkoitushakuisesti laulun selviä sanoja.

Tällä tavoin ymmärrettynä Väinämöisen aikaansaama taistelu ei ole täysin oikeutettu, vaan sillä on ryöstöretken, ahneuden ja voitonhimon aiheuttaman teon piirteet. Tässä yhteydessä on tuotava silti esiin se lieventävä seikka, että Väinämöinen, joka ei ryhdy taisteluun omin päin vaan Ilmarisen ja Lemminkäisen seurassa, ei myöskään aja sammon ryöstöllä omaa etuaan, vaan haluaa tehdä väkensä onnelliseksi. Tämä on lausuttu varsin selvin sanoin Kalevalassa; sillä kun Väinämöinen näkee rikkimenneen sammon hajalleen joutuneiden kappaleiden ajelehtivan kohti rantaa, hän lausuu profeetallisesti:

Tuost' on siemen sikiö,

Alku onnen ainiaisen,

Tuosta kyntö, tuosta kylvö,

Tuosta kasvu kaikenlainen,

Tuosta kuu kumottamahan,

Onnen päivä paistamahan

Suomen suurille tiloille,

Suomen maille mairehille.

(Kalevala, runo 43, säkeet 297-304.) 
Ja koottuaan merenrannalla joitakin niistä ja vietyään ne rauhallisen saaren niemeen hän lausuu runossa 43, säkeet 401-406:
Anna luoja, suo jumala,
Anna onni ollaksemme,
Hyvin ain' eleäksemme,
Kunnialla kuollaksemme
Suloisessa Suomen maassa,
Kaunihissa Karjalassa.

Sammon on siis tarkoitus tuoda onni ja pelastus koko suloiseen Suomeen, ja toisaalta sen puuttumisen on tarkoitus tuoda puutetta ja leivätöntä eloa Lappiin. On erittäin omintakeista ja huomionarvoista, että Pohjolan ja Kalevalan asukkaat eivät enää ole vastakkain kahden vihamielisen suvun ominaisuudessa vaan toimivat ainoastaan erillisinä kansoina. Kyseisissä lauluissa sanotaan lopulta varsin selvästi, että kansa, jonka kärjessä Väinämöinen on, on suomalainen, kun taas Louhen edustama on lappalainen. Minusta se on varsin uskottavaa, vaikkakaan kaikki eivät sitä hyväksy.

Pääasiassa sen suuren vaurauden perusteella, joka runojen todistuksen mukaan vallitsee Pohjolassa ennen kuin se menettää sammon, on otaksuttu, ettei nimitys ole voinut viitata köyhään Lappiin, vaan että sen on täytynyt viitata muinoin niin rikkaaseen ja kukoistavaan Bjarmiaan. ${ }^{165}$ Lönnrot on esittänyt näkemykselle Mehiläisessä $1839^{166}$ moninaisia muitakin perusteita, joilla on kuitenkin vain vähän painoarvoa ja joita kritiikin on sitä paitsi vaikea hyväksyä. Kyseinen hypoteesi Bjarmian samastamisesta Pohjolaan näyttää minusta yleensä ottaenkin hätiköidyltä. Se asettaa bjarmit eli pohjolaiset ja karjalaiset eli kalevalaiset vihamielisiin suhteisiin siitä huolimatta, että on tunnettu ja selvitetty fakta, että myös bjarmit, vaikka asuivatkin Vienanjoen varrella Holmogorin alueella, olivat karjalaista alkuperää. Tämän vastalauseen kumoamiseksi voisi tietysti väittää, että karjalaiset olivat muinoin jakautuneet eri haaroihin; mutta runot eivät tue tällaista hypoteesia. Pohjola ja Kalevala esiintyvät niissä päinvastoin oloiltaan toisilleen niin vieraina, että jopa kielen sanotaan olleen näissä paikoissa erilaista ja että Pohjolassa puheenparsi olisi ollut lappalainen. $\mathrm{Ka}$ levalassa (runo 3, säe 168) sanotaan, että Pohjolassa oli poroja. ${ }^{167}$ Tätä vastoin on tosin monia tietoja, joiden mukaan tavat ja elintavat olivat 
Pohjolassa tyystin samat kuin Suomessa. Tämä näennäinen vastalause on kuitenkin helposti kumottu, kun otetaan huomioon suomalaisten Pohjolaan eli Pohjaan liittämän tarkoitteen epämääräisyys. EteläSuomessa kuulee jo tiettyjä Hämeen osia kutsuttavan tällä nimityksellä, ja hämäläiset käyttävät sitä kaikista omiaan pohjoisempana sijaitsevista alueista ja erityisesti koko Pohjanmaasta. Vaasalaiset sitä vastoin käsittävät sanan Pohjois-Pohjanmaana, jonka asukkaat taas siirtävät nimityksen tarkoitteen Lappiin. Tätä sanaa ei käytetä missään oman paikan nimityksenä, koska Pohja on pahamaineinen siellä harjoitetun noituuden ja taikauskon vuoksi. Kun sanalla Pohjola on yhä tänä päivänä niin epätäsmällinen merkitys, että sillä ei viitata ainoastaan lappalaisiin vaan myös maan pohjoisosissa asuviin suomalaisiin, eikö tämä ole vähintäänkin vastannut tilannetta myös muinaisina aikoina, kun lappalaiset ja suomalaiset luultavasti asuttivat yhdessä suurta osaa maata? Etelämmässä asuneet heimot olisivat kutsuneet kaikkia pohjoisempia nimityksellä pohjalaiset ja tarkoittaneet tällä nimityksellä pikemminkin heidän pohjoisia asuinpaikkojaan kuin eri kansallisuutta ${ }^{168}$. Mutta yhtä usein kuin kansallisuudesta tulee runoissa selkeästi puhe, esitetään Pohjola lappalaisten kotina ja Kalevala samastetaan Suomeen.

Minun ei tarvinne muistuttaa siitä, että Pohjolalla ja Kalevalalla on tämä merkitys varsinaisesti vain sampo-runossa, sillä kosintarunoissa pidetään Pohjolan ja Kalevalan asukkaita, kuten mainittua, kahtena vihamielisenä sukuna. Näiden nimitysten yleisempi merkitys sampo-runoissa todistaa kehittyneemmästä yhteiskuntajärjestyksestä, joka on johtanut sukujen ymmärtämiseen kansakunniksi ja joka liittyy lisäksi siihen, mitä olen jo puhunut näiden runojen myöhäisestä alkuperästä. ${ }^{169}$

Kyseisten sanojen laajemman merkityksen piirissä myös [runojen] kolmella sankarilla, Väinämöisellä, Ilmarisella ja Lemminkäisellä, on ollut suurempi merkitys. Kosintarunoissa he toimivat vain omaksi edukseen, sillä kukin heistä kamppailee ainoastaan hankkiakseen itselleen puolison; sampo-runoissa he sen sijaan taistelevat koko Suomen kansan tulevaisuuden puolesta. Sampoa ryöstäessään Väinämöinen esiintyy Suomen hyväntekijänä, joskin hän tietyllä tapaa jakaa kunnian Ilmarisen ja Lemminkäisen kanssa. Väinämöinen ei kuitenkaan ansaitse jälkimaailman kiitollisuutta pelkästään sammon ryöstöllä. 
Hän hedelmöittää maan, keksii harpun ja runouden, hankkii Auringon ja Kuun takaisin paikoilleen, palauttaa tulen Kalevalaan ja lopulta jättää perinnöksi syvällisiä runoja, monia hyviä neuvoja sekä opetuksia. Siksi hän lausuu Suomesta lähtiessään kiukkuisena:
Annapas ajan kulua,
Päivän mennä, toisen tulla,
Taas minua tarvitahan,
Katsotahan, kaivatahan,
Uuen Sammon saattajaksi,
Uuden soiton suorijaksi,
Uuen kuun kulettajaksi,
Uuden päivän päästäjäksi,
Kun ei kuuta, aurinkoa,
Eikä ilmaista iloa.

Mutta palataksemme taisteluun sammosta, jonka kuvaus kattaa suuren osan Kalevalasta, on varsin huomionarvoinen seikka, että [Kalevalan kertomuksissa] asioita ajetaan miekkaan turvautuen erittäin harvoin ja pelkästään poikkeustilanteessa. ${ }^{170}$ Sana on miekka, jolla suomalainen sankari mieluiten saavuttaa voittonsa. Muinaissuomalaisten käsityksen mukaan sanassa oli ihmeellinen, kaiken voittava voima. Sana merkitsee runoissa sekä 'laulua' että 'viisautta', mutta eritoten korkeampaa tai maagista laulua ja viisautta. ${ }^{a}$ Tätä viisautta ei ollut kuitenkaan helppo saavuttaa: se oli isien perintöä, eikä itse Väinämöinenkään kykene luomaan kolmea noitasanaa, vaan joutuu etsimään niitä maan alta kuolleiden valtakunnasta sekä vanhan Vipusen haudasta. Mutta sillä, joka oli sanassa vahva, joka oli hankkinut tarvittavan viisauden, oli paljon terävämpi ase kuin teroitettu rauta. Sanoissa ja viisaudessa vahva on erityisesti vanha Väinämöinen, jota kunnioitetaan runoissa epiteetillä viisas ja joka kuvataan vanhaksi mieheksi siitä syystä, että viisautta pidettiin ominaisuutena, joka

a Yleisesti muinaissuomalaiset uskoivat vähintään joka toisella olevan noitavoimia, ja siksi on luonnollista, että heidän sankareillaankin piti olla tämä voima. Mutta kuten [sankarit] ylittivät tavalliset ihmiset kaikissa suhteissa, myös heidän kykynsä noituudessa olivat paljon suuremmat kuin tavallisten šamaanien. 
saavutettiin iän ja kokemuksen myötä. ${ }^{a}$ Vaikuttaa lisäksi siltä, ettei Väinämöinen katso miekkaan tarttumisen olevan arvonsa mukaista. Kun nuori, ylimielinen Joukahainen kokee kunniansa loukatuksi Väinämöisen ylivertaisten tietojen vuoksi ja haastaa tämän kaksintaisteluun miekoin, Väinämöinen kieltäytyy tiukasti haasteesta mutta peittoaa itsetietoisen nuorukaisen sinkoamalla tätä kohti runoja, joilla on mahti saada meri kuohumaan, maa järisemään, kuparivuori vapisemaan, kiinteät kivipaadet vyörymään ja kalliot halkeamaan. Nuori Joukahainen uppoaa maahan, mistä Väinämöinen, liikuttuneena hänen rukouksistaan ja lupauksistaan, nostaa hänet pyhien sanojensa avulla. Tätä samaa sanan mahtia Väinämöinen käyttää aseena myös Pohjolan emäntää vastaan taistelussa sammosta, minkä yhteydessä hän erityisesti käyttää noitataitojaan. Vain tällä tavoin hän pystyy selviämään kamppailusta tätä äkäistä naista vastaan, joka yrittää kaataa kukoistavan Kalevalan kaikilla pahan noituuden ${ }^{171}$ katalilla keinoilla. Yhdessä ainoassa tilanteessa (Kalevala, runo 49, säe 210-) [Väinämöinen] on pakotettu tarttumaan miekkaan, ja silloin hän leikkeleekin Pohjolan poikien päitä kuin nauriin naatteja.

Ilmarinen osallistuu taisteluun sammosta varsin passiivisesti. Hänen mielensä on ylipäätään vain vähän suuntautunut taisteluiden kumuun; hän elää mielellään rauhassa maailman kanssa ja on kotonaan nokisessa pajassaan. Väinämöinen arvostaa häntä suuresti hänen terävän älynsä vuoksi ja turvautuu usein hänen taitoihinsa. Vaikkei [Ilmarinen] olekaan siunattu syvemmällä viisaudella Väinämöisen tapaan, hänellä ei ole vertaista, kun on kyse epätavallisten asioiden

a Väinämöisen, "iänikuisen tietäjän" noitataidoista on runoissa mitä erikoisimpia todisteita. Hän ei ainoastaan ennusta tulevia tapahtumia, paranna sairauksia, karkota peikkoja ja pahoja henkiä, kesytä villieläimiä, estä onnettomuuksia jne., vaan hänellä on myös kyky muuttaa itsensä eläimeksi, kiveksi ja sanalla sanoen muuntautua mihin ulkomuotoon haluaa. Hänen yli-inhimillisen noitataitonsa piirissä on myös kyky luoda luontoon uusia asioita. Jo aiemmin olen maininnut, että hän rakensi laulun voimalla veneen, mutta että häneltä puuttui kolme sanaa, jotka hän lopulta monien seikkailujen päätteeksi hankki Vipusen haudasta. Kuuluisassa taistelussa sammosta hän yritti kaikin voimin paeta Pohjolan emäntää, joka seurasi häntä vahvasti miehitetyllä sotalaivalla; mutta kun tämä ei onnistunut, hän heitti pelkästään kivenpalan ja taulan vasemman olkansa yli mereen, ja heti tähän paikkaan kohosi karikko, johon Pohjan laiva murskautui. 
tuottamisesta käsityötaitojen turvin. Runot antavat hänelle epiteetin seppä eli seppo, mikä ei merkitse yksinomaan 'seppää' vaan myös 'mestaria ylipäätään' Ilmarinen suorittaakin suurimmat tekonsa vasaralla: hän valmistaa taivaankannen ja sammon, muovaa neidon hopeasta ja kullasta ym. Aivan kuten hän tekee vakavaa työtä, hän on myös luonteeltaan vakava, perusteellinen, läpeensä kunniallinen mies, mutta juuri siksi hyväuskoinen ja helppo ylipuhua. Tekee lähes huvittavan vaikutelman nähdä vakava seppä, taipuneena Väinämöisen juonikkaaseen maanitteluun, kiipeämässä puuhun kurottaakseen sen oksilta Auringon, Kuun ja Otavan. Laulunjumalattaren tarkoitus ei ole tehdä hänestä pilkan kohdetta vaan päinvastoin suosia häntä tietyissä suhteissa myös vanhan, viisaan Väinämöisen kustannuksella. [Väinämöinen] joutuu vanhoilla päivillään halun valtaan hankkia nuori, kaunis puoliso, ja tämä heikkous paitsi aiheuttaa hänelle monia nöyryytyksiä, myös johtaa hänet suuriin vaaroihin, vaikeuksiin ja hankaluuksiin, joista hän selviää vain vaivoin. Sitä vastoin Ilmarinen on mies, joka saa nuorikkojen luottamuksen, sillä hänellä ei ole vanhuuden puutteita eikä nuoruuden kevytmielistä, epäluotettavaa luonnetta, vaan hän esiintyy miehekkäänä ja vakaana hahmona, jonka huomaan heikko nainen uskaltaa luottavaisesti uskoa tulevan kohtalonsa. Olemme nähneet, että monien seikkailujen päätteeksi juuri Ilmarinen myös saa Pohjolan kauniin ruusun. Taisteluihin hän ei näytä olevan kovin tottunut. Seikkailut, joihin Pohjolan emäntä hänet saattaa, jotta hän saisi tytön käden, hän selvittää menestyksellisesti, mutta Kalevalan uuden laitoksen mukaan hänen valittu morsiamensa opastaa hänelle etukäteen välineet, joilla hän selvittäisi kaikki vastaan tulevat vaikeudet. Menetettyään ensimmäisen vaimonsa [Ilmarinen] lähtee Pohjolaan sankarimielellä ja ryöstää toisen Pohjolan tyttären kun ei saa häntä hyvällä. Taistelussa sammosta emme näe häntä, kuten jo mainittiin, suorittamassa tekoja, jotka todistaisivat suuresta urheudesta, vaan hän esiintyy siinä päinvastoin varsin arkana.

Sekä Väinämöistä että Ilmarista sotaisampi luonne on kolmannella Kalevalan sankarilla, Lemminkäisellä. Siinä kun edelliset heittäytyvät vaaroihin ja seikkailuihin pelkästään päästäkseen suuriin tavoitteisiin, Lemminkäinen etsii taistelua sen itsensä vuoksi. Hänestä puuttuu tyystin se syvällinen, luja vakavuus, joka määrittää hänen molempia tovereitaan, ja hän heittäytyy kevytmielisesti jokaiseen seikkailuun, 
joka hänelle tarjoutuu. [Lemminkäisen] vilkkaan luonteen vuoksi näyttää laulu antaneen hänelle lempeän, huomaavaisen ja syvällisillä näkemyksillä siunatun äidin, joka kaitsee häntä kaikella rakkaudellaan ja yrittää kaikin tavoin käännyttää hänet uskaliaista, hengenvaarallisista yrityksistä. Lemminkäinen puolestaan on rajattoman kiintynyt äidilliseen ystäväänsä, mutta huolimatta kaikista tämän lämpimistä rukouksista ja kyynelistä poika ei pysty tukahduttamaan taipumatonta luonnettaan, joka ajaa häntä levottomasti "vaarojen teille"172. Hänet kuvataan tavallisesti kauniiksi mieheksi, joka on ryhdikäs ja siisti - ominaisuuksia, joiden ansiosta hän sulkeutuu helposti naisten suosioon. Tätä kiintymystä hän käyttää usein tavalla, joka tuskin on hänelle kunniaksi, ja sitä paitsi useammin kuin kerran se uhkaa johtaa hänet tuhoon.

On merkillepantavaa, ettei tämä vilkas veikko koskaan lähde kotoaan ilman, että temmellys ja sota seuraisi hänen jäljessään. Ensimmäisellä matkallaan hän ryöstää Saaren kauniin neidon Kyllikin, kun ei saa tämän kättä hyvällä. Toisen matkansa hän suuntaa Pohjolaan ja tuhoaa suuren osan sen asukkaista, mutta tulee lopulta itse "sokean paimenen" hengiltä ampumaksi. Henkiin palautettuna hän lähtee uudelleen Pohjolaan kostaakseen häpeän, joka hänelle on koitunut, kun häntä ei ole kutsuttu Ilmarisen häihin. Hän tappaa Pohjolan isännän, mutta joutuu Pohjan väen takaa-ajamana pakenemaan ja piiloutumaan syrjäiseen saareen, missä voittaa kaikkien naisten kiintymyksen. Tämä kuitenkin herättää miesten vihan, ja hänen on lähdettävä takaisin kotiin pelastaakseen henkensä. Hän löytää kartanonsa Pohjan kansan polttamana, ja kostonhalu leimahtaa hänessä uudelleen. Hän päättää ryhtyä jälleen Pohjolan-matkaan, joka ei kuitenkaan suju toivotusti. Lopulta hän ottaa osaa Ilmarisen ja Väinämöisen kuuluisaan taisteluun sammosta ja on itse asiassa se, joka tyypillistä ajattelemattomuuttaan estää taistelua päättymästä siten kuin mihin Väinämöinen on järkevällä varovaisuudella pyrkinyt, kun on noitataidoillaan vaivuttanut Pohjan kansan syvään uneen. On jo kaikki toivo saada sampo vietyä Kalevalaan ennen kuin vihollinen heräisi unestaan, mutta kotimatkalla Lemminkäisen valtaa vastustamaton tarve rikkoa matkan yksitoikkoisuus laululla. Kun ei saa Väinämöistä taivutettua laulamaan, hän korottaa oman epämusikaalisen äänensä ja karjuu niin vaikuttavasti, että se kuuluu Pohjolassa asti herättäen 
loitsitun kansan. Kun Pohjolan emäntä sen jälkeen tulee lentäen kotkan hahmossa ja yrittää ryöstää sammon Väinämöisen veneestä, Lemminkäinen on heti valmis tarttumaan miekkaan. Hän ei kuitenkaan kykene aiheuttamaan minkäänlaista vahinkoa vihamieliselle naiselle, kun taas Väinämöinen kurittaa tätä ja tämän kaikkia miehiä pelkällä melalla. Vaikkakin Lemminkäinen tällä tavoin kuvataan miekkamieheksi kiireestä kantapäähän, suomalainen laulunjumalatar antaa hänen kamppailla myös noitalauluin. Hän on kuulu myös siitä, että on vihitty noituuden salaisuuksiin varhaisesta lapsuudestaan asti, ja ensimmäisellä Pohjolan-matkallaan hän tuokin tuhon sen asukkaille juuri noitalauluillaan.

Yllä antamani esittelyn perusteella Kalevalan sisällöstä pitäisi olla täydellisen selvää, että Väinämöisellä, Ilmarisella ja Lemminkäisellä ei ole jumalallisten olentojen roolia, kuten usein on annettu ymmärtää, vaan että he esiintyvät ainoastaan lahjakkaampina ihmisinä eli sankareina. ${ }^{173}$ Heidän pääasialliset toimensa liittyvät ensiksikin siihen, että he naimapuuhissaan huolehtivat yksityisestä onnestaan perheessä, toisekseen siihen, että he tekevät itsensä ja kansansa tyytyväiseksi ryöstämällä sammon, joka edistää maaperän hedelmällisyyttä ja tuottaa kaikenlaisia ajallisia hyödykkeitä. Nämä teot eivät ole todellisuudessa niin merkittäviä, että niiden yhteydessä voitaisiin puhua jumalallisista voimista. Laulut osoittavat kyseisille henkilöille ja erityisesti Väinämöiselle tiettyjä ominaisuuksia, jotka meidän näkemyksemme mukaan ovat yliluonnollisia, mutta kuten olen jo aiemmin yrittänyt selittää, nämä perustuvat muinaissuomalaisten käsityksiin magian ihmeellisestä voimasta ja vaikutuksesta. Yhtä kaikki, siinä kun laulu ylistää Väinämöistä, Ilmarista ja Lemminkäistä, huomioi se myös tavallisia ihmisiä, joskaan ei samassa muodoin. Suomalaiset heerokset erottuvat tavallisista ihmisistä vain voimiensa, viisautensa, sankarillisuutensa jne. määrässä. Heillä on samat tarpeet, samat pelot ja surut, samat sairaudet, vaivat ja kivut, sanalla sanoen samat tunteet ja kärsimykset kuin muillakin kuolevaisilla. Tämä koskee tietyssä määrin myös jumalia, mutta [jumalia] luonnehtii se, että jokaisella niistä on absoluuttinen valta omalla alueellaan. Näin ei ole heerosten kohdalla, jotka kompastuvat lähes joka askeleella esteisiin ja vaikeuksiin, joiden voittaminen vaatii heidän kaikki sankarivoimansa. Monesti he ovat nääntyä ponnisteluissaan, heidän kuullaan itkevän ja valittavan 
hädissään, he hakevat tukea muilta kuolevaisilta ja he valittavat vähäisiä voimiaan ja muita puutteita, jotka kuuluvat heidän heikkoon luontoonsa. Usein he turvautuvat jumalten armoon vetoamalla heihin rukouksin ja antamalla uhreja heidän kunniakseen. On sanalla sanoen päivänselvää, että vaikka Väinämöinen, Ilmarinen ja Lemminkäinen kohoavat korkealle tavallisen ihmisen yläpuolelle, heillä ei ole niitä ominaisuuksia, jotka muinaissuomalaiset liittivät jumaliinsa.

Sama huomio koskee myös mahtavaa Pohjolan emäntää Louhea. Hän on noitataitojensa vuoksi lähes Väinämöisen vertainen, ja tässä onkin hänen koko mahtinsa. Tämä mahti on kuitenkin paljon kauhistuttavampi, sillä päinvastoin kuin Väinämöinen hän käyttää sitä ainoastaan vahingollisiin ja pilaaviin tarkoituksiin. Hän on noita sanan pahimmassa merkityksessä, ja hänet kuvataan siksi vanhaksi, harvahampaiseksi, iljettäväksi naiseksi. On luonteenomaista, että suomalainen laulunjumalatar on asettanut Pohjolan asukkaiden kärkeen tällaisen henkilön. [Pohjolan kansaa] on kautta aikojen pidetty noitataitoisena sukuna, ja se on hankkinut maineen, että kykenee aiheuttamaan viholliselleen kaikkea mahdollista vahinkoa noituuden avulla. Tämän lisäksi [Pohjolan väkeä], tai pikemminkin lappalaisia, jotka minun mielestäni ovat runoissa esiintyvän Pohjolan varsinaisia asukkaita, on syytetty pelkurimaisesta ja epämiehekkäästä luonteesta. Heillä ei näytä olevan rohkeutta taistella vihollisensa kanssa kasvokkain, vaan he pyrkivät vahingoittamaan häntä salassa oveluudella ja kaikenlaisilla pirullisilla kieroiluilla. Koska tällaiset aseet ovat miehen arvolle sopimattomia, on muinaislauluissamme varsin osuvasti valittu ilkeä noita edustamaan koko sukua. Siellä täällä mainitaan tietysti myös Pohjolan isäntä, mutta hän esiintyy aina vähäisenä hahmona. Myös sampo-taistelussa juuri Louhi seisoo Pohjan väen kärjessä; hän kutsuu sen taisteluun, varustaa suuren aluksen, jota myös johtaa, ja lopulta hän käy kotkan hahmossa Väinämöisen veneen kimppuun viedäkseen sammon. Tämä tilanne on ainoa, jossa Louhi ryhtyy avoimeen taisteluun. Hänhän on menettää omansa ja väkensä onnen ja hyvinvoinnin varmistavan esineen. Muutoin hän taistelee aina salassa, ja hänen toimiinsa kuuluvat vihollisten vahingoittaminen sairauksin, karhun lähettäminen tuhoamaan näiden karjaa, Auringon ja Kuun ryöstäminen, tulen varastaminen näiden paimenilta jne. Väinämöisen on kamppailtava tällaista vihollista vastaan, mikä selittää joltain 
osin, miksi sekä hän että hänen taistelutoverinsa tavallisesti turvautuvat noitakeinoihin taistelussa Pohjolaa vastaan sen sijaan, että kävisivät taistoon miekka kädessään.

Tällä Louhen kuvauksella haluan mahdolliset väärinkäsitykset estääkseni muistuttaa siitä jo aiemmin esiintuodusta seikasta, että samporunossa [Louhi] omaksuu hahmon, joka eroaa suuresti siitä, joka hänellä on kosintarunoissa. Ei riitä, että jälkimmäisissä hän näyttäytyy lempeänä, hyvänä ja huolehtivana äitinä, vaan hän ottaa myös vastaan Kalevalan sankareita, erityisesti Väinämöisen ja Ilmarisen, kaikella hyvyydellä ja vieraanvaraisuudella, mikä sopii erinomaiselle emännälle. Toisinaan hänen paha, lappalainen luonteensa käy kuitenkin ilmi myös näissä runoissa ja näyttäytyy erityisesti siinä, kuinka hän kohtelee Lemminkäistä. Kun katse kiinnitetään pelkästään kosintarunoihin, [Louhea] on yleisesti ottaen pidettävä pikemmin hyväluonteisena suomalaisena emäntänä kuin pahantahtoisena lappalaisena noitana. Tämä kaksinaisuus hänen hahmossaan on selitettävissä ainoastaan niillä kahdella erilaisella suhteella, jotka hänellä on Kalevalan sankareihin sampo-runossa ja kosintarunoissa. Toinen syy tähän saattaa olla siinä, että kyseiset kaksi runosykliä melko varmasti ovat peräisin eri ajoilta ja kaiken todennäköisyyden mukaan ovat peräisin eri paikoista ja eri heimojen parista. Kosintarunoissa on tavallisesti kyse ainoastaan kahdesta suvusta, jotka näyttävät molemmat olevan suomalaista alkuperää, kun taas sampo-laulut viittaavat kahteen eri kansaan. Kenties tämän vuoksi Louhi esiintyy Kalevalan runoissa alati inhimillisenä olentona ja eritoten sampo-runoissa mahtavana, kaikkien šamaanien yläpuolelle kohoavana noitana.

Kalevalan sankareiden Väinämöisen, Ilmarisen ja Lemminkäisen tavoin myös Louhea, heidän vannoutunutta vihollistaan, ovat aiemmat mytologiantutkijat pitäneet yhtenä muinaissuomalaisten pakanallisista jumaluuksista. Useimmat myöhempien aikojen tutkijoista ovat hylänneet tämän näkemyksen, koska se ei heidän mielestään ole kestänyt kritiikkiä. Ne harvat, jotka ovat sen hyväksyneet, eivät ole kuitenkaan onnistuneet esittämään perusteita sen tueksi. Näin ollen näyttää olevan painavat syyt siihen, että omistamme tälle kysymykselle huolellisen tutkimuksen ja yritämme päästä kiistan kohteena olevassa asiassa tulokseen. Omistamme joka ikiselle kyseisistä 
henkilöhahmoista oman pohdintansa ja aloitamme vanhasta, viisaasta Väinämöisestä. ${ }^{174}$

Olen maininnut jo aiemmin, että Väinämöinen ilmaantuu alkuperänsä vuoksi tavallisia ihmisiä aiemmin. Runo kertoo tästä seuraavalla tavoin: Aikojen alussa ei ole maata eikä Aurinkoa, Kuuta eikä tähtiä, vaan ainoastaan ilmaa ja vettä. "Ilman pitkillä pihoilla" on neito, yksi luonnon kauniista tyttäristä nimeltään Ilmatar, joka on koko ikänsä elänyt siveänä, neitseellisenä, pyhänä. Vähitellen hän kuitenkin väsyy yksinäiseen elämäänsä "avarilla autioilla" ja laskeutuu meren selälle. Idästä nousee voimakas tuuli, meri kuohuu ja aallot ajavat Ilmatar-neitoa ympäri laajaa ulappaa. Hän tulee raskaaksi tuulesta ja jatkaa ajelehtimistaan tässä tilassa "vuotta 700, yhdeksän uroon ikää" pystymättä saattamaan maailmaan sikiötä, jota kantaa kohdussaan. Lopulta aika käy hänelle pitkäksi myös merellä, hän tuntee itsensä sikiönsä kiusaamaksi, vilu kalvaa hänen niveliään ja hän valittaa katkerasti ymmärtämättömyyttään kun ei jäänyt ilmaan neitsyenä vaan ryhtyi ajelehtimaan ympäri merta "veden emona". Murheissaan hän vetoaa Ukkoon, taivaanjumalaan, että tämä tulisi ja vapauttaisi hänet sietämättömästä sikiöstä. Päästön hetki ei ole vielä kuitenkaan tullut, ja edelleen hän ajelehtii ympäri aaltoja, ja uudessa Kalevalan laitoksessa kerrotaan, että sinä aikana hän luo maailman. Myöhemmin hänen syntymätön sikiönsä Väinämöinen alkaa tuntea olonsa tukalaksi pimeässä asunnossaan ja kaivata päivänvaloon. Hän kääntyy Auringon, Kuun ja Otavan puoleen rukoillen apua vapautumiseensa, mutta kun tämä ei johda mihinkään, hän raivaa itse tien valoon. Väinämöinen syntyy merellä, ajelehtii sitten ympäriinsä ulapoilla monta vuotta ja rantautuu lopulta eräälle niemelle.

Sama synty liitetään myös Ilmariseen, sillä Kalevalan vanhassa editiossa (runo 14, säe 267-) hän muistuttaa Väinämöistä siitä, että he ovat:

[...] yhen emosen lapset, Yhen kantamat kaposen, Yhen peipposen pesemät, Yhen sotkan suorittamat.

ja lisää vielä: 
Sinä synnyit yötä ennen,

Minä päiveä jälestä.

Myös Väinämöinen nimittää Ilmarista usein veljekseen, kuten vanhan laitoksen runossa 20 (säkeet 206-207), missä hän lausuu:

Weli seppo Ilmarinen,

Lankoni emoni lapsi.

Se, mitä Kalevalan uudessa editiossa (runo 9, säkeet 107-112) kerrotaan Ilmarisen syntymästä, on sitä vastoin epäilyksettä myöhempien aikojen tuotantoa.

Mikäli nyt käsiteltyjä traditioita Väinämöisen ja Ilmarisen synnystä voitaisiin pitää täysin luotettavina, olisi niissä melko painava todiste näiden sankareiden jumalallisuudesta. Onhan selvää, että muinaissuomalaiset palvoivat niin Ilmatarta kuin säätä jumalallisina olentoina, ja suomalaisessa mytologiassa jumalten lapset esiintyvät säännöllisesti jumalina. Joihinkin heistä vedotaan runoissa jopa useammin kuin heidän vanhempiinsa, jotka mielellään elelevät rauhassa ja uskovat useimmat tehtävät lastensa käsiin. On tuskin luultavaa, että Väinämöinen ja Ilmarinen tekisivät poikkeuksen tästä yleisestä säännöstä. Voidaan kuitenkin kysyä, uskottiinko näiden henkilöiden todella olevan Ilmattaren ja tuulen tekemiä. Kalevalan vanhemmassa laitoksessa ei mainita sanallakaan heidän jumalallisesta synnystään, ja niiden runonlaulajien parissa, joilta minulla on ollut mahdollisuus kysyä neuvoa, ei yksikään ole johtanut heidän alkuperäänsä Ilmattareen. Lisäksi Kalevalan uudesta laitoksesta (runo 5, säe 220) $)^{175}$ löytyy tieto, että Väinämöisen äiti oli kuollut ja haudattu - tieto, jota ei voi soveltaa jumalalliseen Ilmattareen vaan inhimilliseen äitiin. Runo, joka kertoo Väinämöisen syntyneen tuulesta ja ilman tyttärestä on lisäksi ristiriidassa jo käsitellyn tradition kanssa, jonka mukaan hänen isänsä oli sankari, Kaleva, eikä siis tuuli. Kalevalan uuteen laitokseen otetun Väinämöisen syntymästä kertovan laulun oikeellisuus näyttää minusta myös sen perusteella epäilyttävältä, että kyseisestä laulusta on olemassa variantti, joka on yhtenäisempi ja vaikuttaa senkin vuoksi luonteeltaan vanhemmalta, alkuperäiseltä, että se on levinnyt kaikkialle maahan. ${ }^{176}$ Tämän variantin mukaan tuuli oli yhdessä Loviattaren, kuoleman tyttären, kanssa siittänyt kauhistutta- 
vimmat vaivanhenget, joita maailmasta löytyy. Tätä liittoa pidetään runoissa sopimattomana ${ }^{177}$, mutta se sopii hyvin sekä iljettävälle kuoleman tyttärelle että kevytmieliselle tuulelle. On myös varsin luonnollista, että pahojen henkien alkuperä on säässä, joka aiheuttaa ihmiselle niin paljon vahinkoa ja onnettomuuksia. Tämä sopii niin heikosti yhteen Väinämöisen totisen, vakaan, rehdin, syvämielisen olemuksen ja luonteen kanssa, että hänen alkuperänsä tuskin juontuu niin oikukkaasta isästä kuin sää. Tämä vaikuttaisi sopivan niin huonosti siihen syvään kunnioitukseen, jota laulu alati osoittaa Väinämöiselle, että häneen on kyllä liitetty väärä alkuperä. Kaikesta tästä näyttäisi olevan selvästi johdettavissa, että laulu Väinämöisen synnystä sellaisena kuin se tavataan Kalevalan uudessa laitoksessa ei ole alkuperäinen vaan myöhempinä aikoina kehitetty [runosta, joka kertoo] vaivanhenkien synnystä. Varmaa on, että tämän tiedon varaan - ainoan, joka osoittaa Väinämöisen jumalallisen synnyn - ei voi perustaa lopullista tuomiota koskien hänen ja hänen veljensä Ilmarisen jumalallista luontoa.

Selvemmin Väinämöisen jumalallisuus on ilmaistu runossa, joka kertoo maailman luomisesta, eritoten muodossa, jossa se tavataan Kalevalan vanhassa laitoksessa. Tässä runossa kerrotaan, että Väinämöinen, jota tässä kutsutaan nimityksellä Kawe Ukko Pohjan her$\mathrm{ra}^{178}$, makaa 30 kesää ja 30 talvea äitinsä kohdussa mutta sen jälkeen alkaa pitkästyä kohtaloonsa joutua olemaan koskaan näkemättä päivänvaloa. Hän vetoaa Aurinkoon, Kuuhun ja Otavaan, jotta nämä vapauttaisivat hänet vankilastaan, mutta kun rukouksilla ei ole vaikutusta, hän hankkiutuu omin voimin ulos maailmaan. Sen jälkeen tämä kolmekymmenvuotias lapsi menee pajaan ja takoo kevyen, "herneenvartisen oriin"179, jolla lähtisi Pohjolaan. Hän kulkee ensin Väinölän lehtoja ja Kalevalan soita, lähtee sen jälkeen merelle ja ratsastaa sen aukeita ulapoita myöten. Runo kertoo, että kierosilmäinen lappalainen (Joukahainen) vihaa vanhastaan Väinämöistä ja väijyy hänen tuloaan "korwalla tulisen kosken, pyhän virran pyörtehessä". ${ }^{180}$ Kun hän näkee Väinämöisen ratsastavan kohti, hän ampuu tätä jousellaan. Ensimmäinen nuoli nousee aivan liian korkealle ja osuu taivaankanteen, toinen menee Väinämöisen alitse "alasehen maa-emähän", ${ }^{181}$ mutta kolmannella lappalainen ampuu hevosen vanhuksen alta. [Väinämöinen] joutuu aaltojen saaliiksi, ja kuten Ilmatar Kalevalan uudessa editiossa, hän ajelehtii suojattomana ympäri meren aavoja 
ulapoita. Tässä olotilassa Väinämöinen ryhtyy luomistyöhön eli kuten runo kertoo:

Siinä mies meret lukevi, Uros aallot arvelevi;

Kussa päätänsä kohotti, Sihen saaria saneli;

Kussa kättä käännähytti, Sihen nientä siivoeli; Kussa jalka pohjautu, Kalahauat kaivaeli; Kussa maat on maata vasten, Sihen siunasi apajat; Kuhun seisottu selällä, Sihen luopi luotoloita, Karipäitä kasvatteli, Joihin laivat lasketahan, Päät menevi kauppamiesten.

(Vanha Kalevala, runo 1, säkeet 255-269.)

Turjanmaasta tulee kotka, joka kaartelee ilmassa etsien paikkaa pesälleen. Väinämöinen kohottaa polvensa merestä "heinäseksi mättähäksi”, 182 jolle kotka rakentaa pesänsä ja laskee siihen seitsemän munaa. Kotkan hautoessa munia Väinämöinen tuntee polvensa lämpenevän: hän liikauttaa niveliään, [jolloin] munat putoavat merenpohjaan ja murskautuvat. Niiden palasista Väinämöinen luo taivaan ja maan, Auringon, Kuun ja tähdet, ja lausuu:

Munasen alanen puoli

Alaseksi maaemäksi!

Munasen ylänen puoli

Yläseksi taivoseksi!

Mi munassa valkiata,

Se päiväksi paistamahan!

Munasen muruja muita

Ne tähiksi taivahalle!

(Vanha Kalevala, runo 1, säkeet 306-315.)

Samalla tavoin kuvataan maailman luominen myös uudessa editiossa, joskin sillä erotuksella, että Väinämöisen sijaan Ilmatar-neito tekee 
luomistyön ja synnyttää niin maailman kuin Väinämöisenkin. Runosta on olemassa myös kolmas variantti, jossa kerrotaan että kotka, palatessaan matkoiltaan pesälleen ja löytäessään munansa murskautuneina, päättää luoda munien palasista maailman, koska ei kykene kasvattamaan poikasia.

Todellisuudessa on varsin odottamatonta, että Suomen kansan myyteissä tavataan maailmanmunamyytti, jonka tuntevat vain intialaiset, kiinalaiset, persialaiset, foinikialaiset ja kreikkalaiset - sanalla sanoen jotkut maailman vanhimmista ja Suomesta kaukaisimmista kansoista. ${ }^{183}$ Indogermaanisen kantaheimon nuorempien jälkeläisten keskuudesta se on kadonnut kauan sitten mikäli on koskaan siellä ollutkaan. Esimerkiksi pohjoismaisessa edda-opissa se on tunnistettavissa rappeutuneena, mikäli ei halua Petersenin ${ }^{a}$ ym. mukaisesti ajatella, että kertomus maailman muovanneesta jätti Ymiristä on kehittynyt maailmanmunamyytistä. Suomalaisten sukulaiskansojen parista ei tietääkseni yhdelläkään, lukuun ottamatta virolaisia, ole tätä myyttiä. Kuten olen jo yllä esittänyt, [näiden kansojen] käsitykset maailman luomisesta ovat yleisesti ottaen varsin myöhäistä alkuperää ja suurimmaksi osaksi kristinuskosta lainattuja. Sitäkin hämmästyttävämpää on tavata tämä myytti suomalaisten keskuudessa, ja voidaan esittää melkoisella varmuudella, että he toivat sen Aasiasta, sillä Euroopassa he eivät tiettävästi koskaan ole eläneet tiiviissä yhteyksissä sellaiseen kansaan, joka olisi tuntenut kyseisen myytin. Olisi siis väitettävissä, että myytti maailmanmunasta on kehittynyt suomalaisten parissa kotoperäiseltä pohjalta ilman ulkoista vaikutusta, mutta näin tyystin eristettyjä myyttejä ei tavata koskaan. Mitä tulee eritoten maailmanmunaan, on mielestäni varsin todennäköistä, ettei se laajalle eteläiseen ja läntiseen Aasiaan levinneenä ole voinut olla tuntematon niille keskiaasialaisille kansoille, joiden kanssa suomalaisten on entisaikoina ollut oltava läheisissä tekemisissä.

Mistä tämä myytti onkin peräisin, se on kehittynyt suomalaisessa mytologiassamme tyystin omintakeisesti. Sen alkuperäisen merkityksen on täytynyt olla se, että muna on kehittynyt maailmaksi oman sisäisen voimansa vaikutuksesta. Taivaankannen kaareva ulkomuoto

a Petersen 1849, 63. 
on ehkä ruokkinut tätä ajatusta jossain määrin, mutta eritoten se on saanut tukea suomalaisten ja monien muiden kansojen parissa tavattavasta käsityksestä, jonka mukaan maailma on elävä olento, mistä johtuen sen on ollut synnyttävä munasta muiden samantyyppisten olentojen tavoin. Tämä ajatus on ilmaistu selvimmin intialaisessa brahmalaisuudessa, jonka mukaan muna kehittyi omasta sisäisestä voimastaan ja kehittyi maailmaksi. Suomalaisten keskuudessa sitä vastoin maailmanmunan alkuperäinen merkitys on kadonnut ja toinen, syvällisempi idea on tullut sen tilalle. Suomalainen laulu antaa munan, tai oikeammin seitsemän munan, mennä rikki, mutta tässä yhteydessä niiden kehityskyky loppuu, eivätkä ne pysty luomaan itsestään mitään, ja kotkaäiti ilmaisee sen vuoksi syvää surua niiden särkymisen vuoksi. On kuitenkin voima, jonka kautta niinkin vähäisen asian kuin muutaman munansirun saattaa saada kehittymään, ja tämä voima on hengen, sanan voima. Tarvitaan vain muutama voimaisa sana, ja murskautuneet munat muuttuvat kokonaiseksi maailmaksi.

Olen maininnut aiemmin useaan otteeseen, että sanan mahdin kunnioitus on ominaista suomalaisille, ja siksi ei voi hyväksyä, että heidän käsityksensä maailman luomisesta sanan avulla perustuisi mahdolliseen raamatullisten oppien tuntemukseen. Se näyttää olevan alkujaankin kasvanut yhdessä kansan yleisen maailmankatsomuksen kanssa. Kaikki suuri ja epätavallinen, mitä ei voi aiheuttaa tavallisella fyysisellä voimalla, tehdään suomalaisessa laulussa tavallisesti kaikenvoittavan sanan avulla; kuinkapa siis maailma - ihmeiden ihme - voitaisiin synnyttää vähäisemmin voimin? Juuri sana saa suomalaisessa luomismyytissä aikaan kaiken oleellisen, ja maailmanmuna on siinä saanut alisteisen merkityksen, mikä koskee myös kotkaa.

[Kotka] ei varsinaisesti kuulu koko myyttiin, johon ei ainakaan toisten kansojen parissa kuulu mitään muuta maailman luomista edeltävää materiaa kuin muna, mutta suomalaisten kaiken alkuperää alati pohdiskelevassa mielessä oli mahdotonta välttyä vaaralliselta kysymykseltä: mistä muna oli saanut alkunsa? Tähän maalaisjärki vastasi: kaikkein mahtavimmasta linnusta, kotkasta. Siten aito myytti maailmanmunasta meni pilalle, sillä sen mukaan munan pitäisi olla alkio, jossa on koko universumi ja jossa sillä on ensimmäinen olomuoto; mutta nyt kävi tarpeelliseksi hyväksyä maailman luomista edeltäväksi myös ensiksikin ilma, missä kotka liiteli, ja toisekseen paikka, johon 
kotka saattoi laskea munansa. Tällaisen paikan löytymiseksi oletettiin myös vesi valmiiksi jo ennen luomistapahtumaa. Märkään veteen ei kotka voinut kuitenkaan rakentaa pesäänsä laskeakseen siihen munansa. Oli tarpeen, että meren pinnalla oli kiinteä kohta, ja Väinämöisen tai Ilmatar-neidon polvi siis palveli sellaisena.

Tutkiskeleva mieli ei kuitenkaan voinut pysähtyä vielä tähänkään, vaan heräsi kysymys, mistä Ilmatar, mistä Väinämöinen oli peräisin. Ilmattaren synnystä runo kertoo, että hän oli aiemmin majaillut pitkään taivaankannella, joka näin ollen oli siis myös ollut valmis jo ennen luomistapahtumaa. Eräässä variantissa Väinämöisen synnystä ei puhuta ainoastaan taivaankannesta, Auringosta, Kuusta tai Otavasta, vaan myös Väinölän kunnaista ja jopa tietyistä henkilöistä, kuten Väinämöisen äidistä, kierosilmäisestä lappalaisesta, tämän äidistä ym., jotka kaikki olivat siis olemassa jo ennen luomistapahtumaa. Suomalainen myytti maailman luomisesta sotkeutui tällaisiin ristiriitoihin, koska ei tyytynyt munaan maailman alkusiemenenä. Monilla näistä ristiriidoista voi olla perusta eri runofragmenttien väärässä yhdistelyssä. Tässä ristiriitojen verkostossa ansassa olevista heijastumista on nähtävissä selvästi ja kirkkaasti se pääpiirteittäinen kehitysprosessi, jonka myytti maailmanmunasta on suomalaisessa mytologiassa käynyt läpi. Suomalaiset ovat kohonneet materiaalisesta käsityksestä, jonka mukaan universumi oli alun perin muna josta kaikki kehittyi, siihen korkeampaan ymmärrykseen maailman synnystä, että se on hengen työtä ja syntynyt sanan kautta.

Mutta kuka lausui ne mahtavat sanat, jotka antoivat maailmalle alun? On helppo nähdä, ettei kotka brutaalin syntyperänsä vuoksi tosiaan kyennyt tähän tehtävään, vaikka muinaissuomalaiset kunnioittivatkin sitä jumalallisena olentona. Lönnrotin näkemyksen mukaan Ilmatar näyttäisi olevan tähän sopivin henkilö, sillä muutoin hän ei olisi varmasti valinnut tätä varianttia Kalevalan uuteen editioon. [Varianttia] tavataan kuitenkin varsin harvoin. Vaikka sillä onkin etuna, että siitä puuttuu lukuisa määrä ristiriitaisuuksia, joita ensimmäisen edition luomismyytti on täynnään, minun on silti pakko suosia jälkimmäistä varianttia muun muassa sen suuremman poeettisen arvon vuoksi sekä siksi, että Väinämöinen esitetään myös muissa kohdissa maailman luojana. Hän lausahtaakin Joukahaisen kanssa käymänsä taistelun tiimellyksessä: 
Omat on meret kyntämäni,

Meren kolkot kuokkimani,

Kalahauat kaivamani,

Siveret syventämäni,

Sarkajaot sanomani,

Mäet mullermoittamani,

Kivet luomani kokohon;

Olin ma miessä kolmantena

Ilman pieltä pistämässä,

Toivon kaarta kantamassa,

Taivoa tähyttämässä.

(Vanha Kalevala, runo 30, säkeet 84-94.)

Vanhemmassa Kalevalassa (runo 21, säe 291) Väinämöistä nimitetään lisäksi luojaksi. Tällä sanalla ei kuitenkaan ole täysin yksiselitteistä merkitystä. Myöskään Kalevalan uudessa editiossa Väinämöisen osallisuutta luomistyössä ei ole pystytty täysin hävittämään, vaan hän ilmaantuu eräissä runoissa hahmona, joka tuo maan päälle kasvit ja puut ja sanalla sanoen täydentää luomistyön. Tässä voi mainita, että virolaisessa myytissä niin Väinämöisellä kuin muillakin Kalevalan pojilla on tämä tehtävä, siis täydentää ja kaunistaa kaoottinen maailma, jonka Ukko on luonut. Tästä kerrotaan seuraavin sanoin: ${ }^{a}$

Vanna issa asui korkeassa taivaassaan, [jossa] hänen saliaan valaisi majesteettinen Aurinko. Hän oli luonut sankarit hyötyäkseen heidän neuvoistaan, taidoistaan ja voimistaan. Vanhin heistä oli Wannemuine. Vanna issa oli muovannut hänet vanhaksi, harmaahiuksiseksi ja -partaiseksi, ja antanut hänelle viisauden iän mukana; mutta hänen sydämensä oli nuori, ja hänellä oli runon ja laulun lahja. Vanna issa hyötyi hänen viisaista neuvoistaan, ja mikäli suru varjosti hänen otsaansa, Wannemuine soitti hänelle ihmeellistä harppuaan ja lauloi ihastuttavia laulujaan. Toinen oli Ilmarine, parhaassa miehen iässä ja miehisissä voimissa, viisaus otsallaan ja ajattelevaisuus katseessaan. Hänelle oli annettu taiteilijankyvyt. Kolmas oli Lämmeküne, iloluonteinen nuorukainen, hullunkurinen, aina iloinen, taipuvainen kaikkeen ylenpalttiseen. Toiset, kuten Wibboane - suuri jousiampuja - olivat vähempimerkityksisiä. Kaikki pitivät toisiaan veljinä, ja Vanna issa kutsui heitä lapsikseen. Heidän asuinpaikkansa oli Kalleve eli Kaljove eli Kaljovald ('kalliovalta').

Faehlmann 1847. 
Vanhus asteli sankareiden luokse ja sanoi: "Olen viisaudessani päättänyt luoda maailman." Hämmästyneet sankarit katsoivat häntä ja vastasivat: "Mitä viisaudessasi päätätkin, se ei voi olla pahaa." Hän loikin maailman heidän nukkuessaan, ja kun he heräsivät, he hieroivat silmiään ja katselivat työtä häkeltyneinä. Vanhus oli väsynyt maailmanluomistyöstä ja kävi lepäämään. Silloin Ilmarine otti kappaleen parasta terästään ja takoi sen holviksi, nosti sen teltaksi maan yläpuolelle ja kiinnitti siihen hopeiset tähdet ja kuun; hän otti Vanna issan eteisestä lyhdyn ja kiinnitti sen ihmeellisellä mekanismilla telttaan niin, että se nousi ja laski itsekseen. Täynnä iloa Wannemuine otti harppunsa, kohotti ylistyslaulun ja juoksi alas maan pällle, missä laululinnut seurasivat häntä, ja missä hänen tanssivat jalkansa koskivat maahan, siihen puhkesi kukkia, ja missä hän lauloi kivellä istuen, siihen kasvoi puita. Laululinnut istuivat puihin ja yhtyivät hänen lauluunsa. Lämmeküne kulki juhlien ympäri metsiä ja mäkiä ja Wibboane kokeili joustaan. Vanhus heräsi meteliin ja ihmetteli, kuinka erilainen maailmasta oli tullut kuin millaiseksi hän oli sen luonut. Hän sanoi sankareille: "Juuri näin, lapseni! Olen luonut maailman kuolleeksi kappaleeksi, on teidän tehtävänne kaunistaa se. Kansoitan maailman kaikenlaisin eläimin, ja sitten luon ihmiset hallitsemaan maailmaa. Haluan kuitenkin tehdä ihmisestä heikon, jotta hän ei voisi ylpeillä voimillaan. Teen teistä ihmisten sukulaisia yhdyttämällä teidät heihin, ja siitä syntyy suku, joka ei helpolla taivu pahuuteen. Pahuutta en voi enkä aio estää, sillä se on hyvien koetinkivi ja kiihoke."

On helppoa nähdä, ettei Vanna issa ole kukaan muu kuin Jehova ja että maailman todelliset luojat olivat epäilyksettä alun perin Kalevalan poikia. Näin on ainakin suomalaisessa myytissä. Väinämöisen lisäksi sanotaan myös Ilmarisen varmasti osallistuneen maailman muovaamiseen. Kolmas mies, jolla oli kätensä luomistyössä, ei voi luonnollisestikaan olla kukaan muu kuin Lemminkäinen, vaikkei runoista löydykään siitä täsmällistä kuvausta.

Olen eräässä aiemmassa yhteydessä kiinnittänyt huomiota siihen, että luomisvoima ei suomalaisessa mytologiassa välttämättä merkitse jumalallista ominaisuutta, ja olen esittänyt tästä todisteena, että myös sellaiset hahmot, jotka eivät voineet kuulua jumalten luokkaan, saattoivat luoda yksittäisiä kohteita luontoon maagisin keinoin. Olen myös sanonut, että Väinämöisenkin uskottiin luoneen maailmankaikkeuden kenties juuri maagisin toimin, ja olen esittänyt tälle tueksi, että luomistyössään hän käyttää lukuja eli loitsuja (lukea) sekä taikasanoja (sanella). Mitä tulee Ilmarisen osallisuuteen luomistapahtumassa, 
runon sanat, joiden mukaan Ilmarinen "[...] on taivoa takonut, ilman kantta kalkutellut: ei tunnu vasaran jälki eikä pihtien pitämät" (Uusi Kalevala, runo 7, säkeet 335-338), on yleisesti tulkittu allegoriseksi puheeksi, jolla on haluttu korostaa hänen epätavallisia kykyjään. Minun on nykyisin pakko hylätä tämä näkemys. Se on välttämätöntä hylätä selvimmin siksi, että Ilmarisen sanotaan muovanneen taivaan "ilman alkusen alutta, riporihman tehtyisettä" (Uusi Kalevala, runo 10, säkeet 279-280). Hän suoritti siis osuutensa luomistyöstä taitojensa avulla, vasarallaan, kun taas Väinämöinen käyttää pääasiassa sanan mahtia.

Aiemman tarkasteluni mukaisesti sana ei ole tässä ainoa toimiva väline kuten sairauksien parantamisessa, yksittäisten kohteiden luomisessa ja muissa vähempimerkityksisissä toimissa. Tällaisissa vähäisemmissä tapauksissa sillä on tuskin merkitystä, kuka sanan lausuu, sillä sanan oma eikä niinkään lausujan voima aiheuttaa tavoitellun vaikutuksen. Väinämöisen henkilökohtainen läsnäolo ei ole kuitenkaan merkityksetöntä luomismyytin kokonaisuudelle sellaisena kuin se näyttäytyy katseellemme, vaan Kalevalan ensimmäinen runo näyttää lähtevän juuri hänen valmistelemisestaan maailman ylimmäiseksi tekijäksi ja luojaksi. Tämä runo ei anna hänelle pelkästään erinomaista äitiä nimeltään Kave, vaan antaa hänen olla tämän kohdussa kokonaiset 30 vuotta, jotta hän kehittyisi täydelleen. Väinämöisestä tulee niin voimakas, että kun Aurinko, Kuu ja Otava eivät anna hänelle tukeaan, hän päästää itsensä omin voimin ulos maailmaan. Hän ryhtyy suurtekoihin heti synnyttyään, takoo itselleen hevosen ja ratsastaa sillä avomerellä. Kierosilmäisen lappalaisen nuoli ei pysty porautumaan häneen, vaan ainoastaan hänen hevosensa kaatuu siihen. Kun Väinämöinen sitten ajelehtii suojattomana ympäriinsä, hän kehittää itselleen tavattoman luomisvoiman tai, kuten laulussa sanotaan: "Siinä mies meret lukewi, uros aallot [...]". (Vanha Kalevala, runo 1, säkeet 255-269). Kun tätä kohtaa tarkastelee kokonaisuutena, on myönnettävä, että kyse on jostakin aivan muusta kuin tavallisesta magiasta. Väinämöinen käyttää myös lukuja ja loitsuja, mutta pääasiassa hänen oma voimansa saa kaiken aikaan. Seuraavaksi hän luo jopa taivaan, maan ja koko maailmankaikkeuden. Tämä tapahtuu kyllä pelkästään sanan mahdilla, mutta sanojen, joita hän tässä käyttää, sanotaan olleen hänen omiaan eikä mitään tavallisia, isiltä perittyjä noitasanoja. Näin 
ollen Väinämöinen ei luonut maailmaa suuret taidot perineenä šamaanina, vaan kyvyt olivat hänellä myötäsyntyisesti. Näyttääkin siltä kuin joku isistämme olisi antanut hänelle oikeutetusti jumalallisen olemuksen, myös siinä tapauksessa, että hän ja hänen toverinsa Ilmarinen ja Lemminkäinen olisivat ainoastaan täydentäneet luomistyötä. ${ }^{184}$

Ellen erehdy, myös skandinaavisen mytologian Odinin ${ }^{185}$ jumalallisista ominaisuuksista yksi oli se, että hän toi järjestyksen ja elämän kaoottiseen luomistyöhön liitossa muiden aasojen kanssa. Hän ei kuitenkaan ollut varsinainen toimija, vaikka häntä kutsuttiinkin nimityksillä gautr ja mjötuðr ('luoja'). ${ }^{186}$

En ole esittänyt skandinaavisen Odinin nimeä suomalaisen Väinämöisen rinnalla ilman tarkoitusta. En uskaltaisi tosissani uskoa rohkeaan olettamukseen, että näillä kahdella hahmolla olisi pohjimmiltaan yhteinen alkuperä, mutta toisaalta en pysty tukahduttamaan näkemystäni, sillä heitä käsittelevissä Eddojen ja Kalevalan runoissa on hämmästyttäviä yhtäläisyyksiä. Ei ole kenties suomalaiskansallisuuden intresseissä, että tämä ajatus tulee lausutuksi, mutta tiede edellyttää, että asia tuodaan keskusteluun. Mikään ei tule ilahduttamaan minua enempää kuin nähdä seuraavassa esittämieni näkemysten tulevan oikeellisen kritiikin kumoamiksi. ${ }^{187}$

En kiinnitä sen enempää huomiota epäselvään myyttiin maailman luomisesta, ja jätän päättämättömäksi, missä määrin Odinin ja Väinämöisen osallisuudella luomistyöhön on sisällöllisiä yhteyksiä. Molemmille [hahmoille] yhteinen piirre on kuitenkin viisaus koko siinä merkityksessä, joka sanalla suomalaisessa runossa on. Väinämöinen on "vanha", kokenut, monissa kohtaloissa koeteltu mies, ja Vafpruðnismál antaa Odinin sanoa itsestään: "Minä matkasin paljon, kokeilin paljon, sain mahtitietoa monta."188 Yksi Väinämöisen pysyvistä epiteeteistä on tietäjä iänikuinen ('ikivanha tietäjä'), ja Odinista sanotaan, että hän on "kaikista viisain aina". ${ }^{189}$ Kuten olen jo edellä maininnut, Väinämöistä on arvostettu eritoten syvien näkemystensä vuoksi šamaanien salaisissa tiedoissa, ja sama ominaisuus liitetään myös Odiniin. ${ }^{190}$ Tämä kertoo Hávamálissa, ${ }^{191}$ kuinka roikkui kokonaiset yhdeksän yötä tuulenpieksämässä puussa, keihään haavoittamana ja itsensä itselleen uhraamanaan, ilman ruokaa ja sarvellistakaan juomaa, jotta saisi riimut syvyyksistä, kuinka hän sitten oppi yhdeksän 
muinaista laulua Bölthornin ${ }^{192}$ viisaalta pojalta, Bestlan isältä, ja kuinka hän sen jälkeen alkoi viisastua ja saada viisautensa vuoksi arvostusta. Hän sanoo tuntevansa monia lauluja, joita ei tunne kuninkaan puoliso eikä myöskään yksikään ihmislapsi. Näillä lauluilla hän saa avun kaikkiin tilanteisiin ja suruihin, sairaudet paranemaan, vihollisen miekat tylsistymään ja huomion herpaantumaan, kahleet ja siteet käsistä ja jaloista särkymään, vihollisen ampuman nuolen pysähtymään kesken parhaan vauhdin jne. Mikäli joku vahingoittaa häntä villin puun juurella, hän pystyy laulunsa voimalla kääntämään pahan vastustajaansa kohti. Mikäli talo syttyy palamaan, hän tuntee laulun, jonka avulla tuli sammuu heti. Yhtä nopeasti hän pystyy tukahduttamaan vihan, joka leiskuu Hildingin poikien [siis sotureiden] ${ }^{193}$ välillä. On niin ikään hänen vallassaan nostaa myrsky tai tyynnyttää meri sekä kurittaa peikkoja niin, että ne erkanevat ruumiistaan ja mielestään. Kilven alla laulamalla hän pystyy suojelemaan ystäviään niin, että he palaavat taistelusta ja mistä hyvänsä vaarasta vahingoittumattomina. Hän sanoo osaavansa myös herättää henkiin hirteen ripustetun miehen niin, että tämä tulee puhumaan hänelle. Mikäli hän kaataa vettä nuoren miehen päälle, tämä ei kaadu miekasta osallistuessaan taisteluun. Mikäli hän haluaa nauttia valkeakätisen neidon suosiosta, hän kääntyy tämän ajatusten puoleen ja muuttaa tämän mielen. Hän pystyy luettelemaan kaikki aasat ja haltiat, pystyy laulamaan aasoille voimia, haltioille menestystä ja Hroptatýrille ${ }^{194}$ viisautta jne.

Yllä esitetty ei osoita mitään muuta kuin että Odin oli Väinämöisen tavoin vihitty moniin salaisiin, erityisesti magian piiriin kuuluviin taitoihin. Useimmat niistä taidoista, jotka Odinilla tässä sanotaan olevan, liitetään myös paitsi Väinämöiseen, myös tuntemattomampiin šamaaneihin. Odinin sanotaan ilmaisseen itseään riimuin, mutta mitä nämä riimut merkitsevät? Tähän kysymykseen vastaa eräs tanskalainen mytologia seuraavin sanoin:

Odinin riimuissa on se voima ja viisaus, jolla hän hallitsee kaikkea luontoa, myös sen piilotetuimpia ilmiöitä ja jopa sitä, mikä antaa suurimman vastuksen ja mikä näyttää olevan vaikeimmin alistettavissa. ${ }^{195}$ 
Suomalaiset eivät tiettävästi tunteneet riimukirjoituksen taitoa, mutta Väinämöinen saavuttaa lauluillaan saman kuin mitä Odin Petersenin mukaan tekee riimuillaan. "Hänen noitavoimansa", lausuu eräs suomalainen kirjoittaja, " "on rajaton, ja laulunsa ja kanteleensa avulla hän hallitsee sekä kuollutta että elävää luontoa.” Kaikessa viisaudessaan ja näkijänkyvyssäänkin Väinämöinen joutuu muutaman kerran turvautumaan hankalissa tilanteissa yhteen jos toiseenkin kykyyn, kuten olemme aiemmassa nähneet. Samoin on laita Odinin kohdalla. Runossa nimeltä Vegtamskviða ${ }^{196}$ kerrotaan, kuinka Odin ratsastaa Sleipnir-hevosellaan Niflheliin ${ }^{197}$ kysyäkseen neuvoa eräältä ennustajattarelta ${ }^{198}$. Tällä matkalla hän tulee ensin Helin asunnolle, mistä hän ratsastaa ennustajattaren hautakummulle. Siellä hän laulaa kuolleiden loitsua, kunnes ennustajatar nousee ja alkaa laulaa. Tämä tuo tahtomattakin mieleen Väinämöisen matkan Tuonen asunnolle ja Vipusen haudalle, vaikka lauluilla ei näytä olevan mitään yhteistä sisältönsä puolesta. Perustavanlaatuisempi on yhdenmukaisuus [Runo-]Eddan Vafpruðnismálin ja sen Kalevalan runon välillä, joka kertoo Joukahaisen ja Väinämöisen välisestä taistelusta. Toisessa paljastuu Odinin, toisessa Väinämöisen viisaus. Samalla tavoin kuin Joukahainen yllyttää Väinämöisen mittaamaan viisaammutta kanssaan suomalaisessa laulussa, muinaispohjoismaisessa runossa jätti Vafthrudnir ${ }^{199}$ haastaa Odinin koettamaan kummalla heistä on enemmän tietoa. Runot päättyvät siihen, että Odin ja Väinämöinen lähtevät voittajina kamppailuistaan.

Odinin ja Väinämöisen välinen merkittävä yhdenmukaisuus näkyy myös siinä, että molemmat esitetään runouden keksijöinä, vaikkakin he ovat sitä oleellisesti eri merkityksissä. Siinä kun Odin tuo jättien eli huurretursaiden ${ }^{200}$ luota maan päälle juoman, jonka nauttiminen antaa inspiraation ja runoilun lahjan, muovaa Väinämöinen kanteleen ja tuottaa oman henkensä syvyyksistä lauluja, joita jumalat, ihmiset ja eläimet kuuntelevat ihmetellen ja antaumuksella. Yksinomaan tämän ominaisuuden liittää Agricola runossaan Väinämöiseen, jota hän kutsuu nimityksellä Äinemöinen ja jonka hän lukee hämäläisten jumaluuksiin. Tässä runossa ei mainita lainkaan kannelta, vaan Väinämöinen

a Tengström 1845, 174. 
esitetään ainoastaan laulujen keksijäksi ja sivuutetaan näillä kolmella sanalla: "Äinemöinen virdhet tacoi", so. 'Äinemöinen takoi laulut'. Pidetäänpä viisautta näin ollen yleisenä kyvykkyytenä ja kokeneisuutena tai noitataitona taikka runoutena, on todettava, että Odinin ja Väinämöisen ominaisuudet ovat varsin yhdenmukaisia keskenään. ${ }^{201}$

Mikäli joku ei näissäkään ominaisuuksissa näe perustetta oletukselle suomalaisten ja skandinaavisten myyttien välisestä yhteydestä, hän voi palauttaa mieleensä ne merkittävät yhtäläisyydet, joita on niiden laulujen välillä, [jotka kertovat] Joukahaisesta ja Vafthrudnirista ja [jotka kertovat] Odinin ratsastusmatkasta Heliin ja ennustajattaren luokse sekä Väinämöisen matkasta Tuonelaan ja Vipuseen, puhumattakaan aiemmin esiin nostetuista yhtäläisyyksistä sammosta ja Grottista kertovien laulujen välillä.

Tekemäämme Odinin ja Väinämöisen rinnastamista vastaan voi väittää, että viisaus muodostaa lyhyesti sanottuna Väinämöisen ainoan merkitsevän piirteen, kun taas Odinilla on monta muutakin ominaisuutta ja häntä palvotaan pääasiassa voiman jumalana, taisteluiden suojelijana ja voiton suojana. Tämä huomio on täysin oikea, eikä tarkoitukseni ole millään muotoa samastaa näitä hahmoja kaikilta osin. Minun on vain ollut mahdotonta sivuuttaa näin monta heidän kuvauksissaan silmiin osuvaa samankaltaisuutta. Myöskään juuri mainittu soturivoima, joka liitetään Odiniin, ei ollut varmasti vieras Väinämöisen yhteydessä, vaikkakaan hän ei turvautunut siihen kovin usein vaan käytti sen sijaan viisauden jalompaa voimaa. Kalevalassa on useampi kuin yksi todiste siitä, että tarvittaessa hän käsitteli miekkaansa tehokkaammin kuin Lemminkäinen tai Ilmarinen.

Sodanjumalana Odiniin on liitetty kaapu (hekla [isl.]), jonka hän lainaa sankareille suojaksi taistelussa. On erittäin huomionarvoista, että myös Väinämöisellä uskottiin olevan tällainen viitta. Kalevalassa ei kerrota siitä mitään, mutta tällaisen käsityksen on pakko olla ollut tunnettu suomalaisten keskuudessa, kuten Ganander päättäväisesti esittää. Hän lausuu tästä suomalaisessa mytologiassaan ([1789], 101) seuraavasti:

Väinämöisen viitta, takki ja (tai?) huopa oli niin suojeleva, että sitä pyydettiin panssariksi kiivaimmissa taisteluissa, jolloin sanottiin:

Waippa vanhan Wäinämöisen, 
Kaapu kauka Lappalaisen,

Sepä tänne tuotavohon

Suurillen sotikeoillen.

Odinille ja Väinämöiselle ovat yhteistä suojaavan viitan lisäksi myös laiva sekä nopea ja säyseä hevonen, jota $E d d a s s a^{202}$ kutsutaan nimityksellä Sleipnir. Vyötä, vakauden ja voiman symbolia, jonka suomalainen laulu liittää Väinämöiseen, ei ole liitetty Eddassa Odiniin vaan Thoriin. ${ }^{203}$

Perustuvatpa esitetyt yhtäläisyydet Odinin ja Väinämöisen välillä sitten niin sanottuun alkusukulaisuuteen ${ }^{204}$ suomalaisten ja indogermaanisten kansojen välillä tai johtuvatpa ne keskinäisestä vuorovaikutuksesta skandinaavisten ja suomalaisten kansojen välillä myöhempinä aikoina, mikä vaikuttaakin minusta todennäköisemmältä, on joka tapauksessa erittäin huomionarvoinen tosiasia, että nämä kaksi henkilöhahmoa ovat sekoittuneet keskenään. Tästä näyttää voitavan vetää johtopäätös, että koska Odinia kiistatta palvottiin jumalana, sama arvo on täytynyt myöntää myös Väinämöiselle. Kalevalan runot eivät tue tätä näkemystä poikkeuksitta, vaikka toki yksi jos toinenkin niistä vaikuttaa vahvistavan sitä. Sitä vastoin Ganander ja Lencqvist siteeraavat tiettyjä runokohtia, jotka selvästi osoittavat, että [Väinämöistä] on palvottu jumalana kaukaisemmassa menneisyydessä. Vastikään esitin joitakin säkeitä, joissa rukoillaan Väinämöiseltä tämän viittaa suojaksi taistelussa. Gananderilla on myös toinen fragmentti, jossa pyhää neitsyttä pyydetään hakemaan Väinämöisen sulallisesta vyöstä simainen sulka kipeän kohdan parantamiseksi. ${ }^{205}$ Sekä Lencqvist että Ganander ${ }^{a}$ esittävät sen lisäksi ilmanjumalalle, Väinämöiselle, Ilmariselle ja neitsyt Marialle osoitetun rukouksen, joka kuuluu seuraavasti:

Itse ilmoinen Jumala,

Itse vanha Wäinämöinen,

Itse seppä Ilmarinen,

Neity Maria emonen

Täsä myös tarvitahan,

Tämä jakso jaksamahan,

Tämä päästö päästämähän $[\ldots]$ 
Nämä kirjoittajat esittävät todisteeksi Väinämöisen jumalallisesta olemuksesta lisäksi sen, kuinka eräs kuuluisa karjalainen noita vastasi kysymykseen siitä, ketä pakanalliset suomalaiset pitivät ylimmäisenä jumalvoimana, seuraavalla tavalla: "Itse vanha Väinämöinen ja neitsyt Maria emonen.” Lisäksi Porthan ja muut esittävät myös näkemyksen, jonka mukaan Väinämöinen oli sama henkilö kuin Ukko, ilmanjumala, mistä on esitetty todisteeksi, että Väinämöistä kutsutaan toisinaan nimityksellä Ukko vanha Väinämöinen, ja että salaman, jota yleensä pidetään Ukon aikaansaamana, toisinaan sanotaan olevan myös Väinämöisen ja Ilmarisenkin aiheuttama. Minusta vaikuttaa todennäköisemmältä, että Ukko ja Väinämöinen on toisinaan sekoitettu keskenään, mutta tällaisen sekaantumisen mahdollisuus edellyttää, että Väinämöistä on Ukon tavoin palvottu jumalana. Minusta hänen palvontaansa jumalana ei itse asiassa näytä voitavan epäillä; kysymys on pikemmin siitä, onko tämä palvonta alkuperäistä vai periytyykö se mahdollisesti myöhemmiltä ajoilta. Ennen kuin edes yritän vastata tähän kysymykseen, haluan vielä lausua muutaman sanan Kalevalan muista päähenkilöistä.

Olen jo aiemmin maininnut, että Ilmarinen syntyi Väinämöisen tavoin ilmanjumalattaresta ja osallistui maailman luomiseen, ja että häntä anottiin ilmanjumalan ja Väinämöisen ohella osoittamaan tukensa sairaalle - näiden ominaisuuksien uskotaan todistavan hänen jumalallisesta luonnostaan. Sama koskee hänen nimeään, sillä Ilmarinen on deminutiivi nimestä Ilmari, joksi häntä myös toisinaan kutsutaan, ja sen kantasana taas on ilma. Tämän johdoksen oikeellisuuden tunnistaa esimerkiksi Kalevalasta, sillä runossa 24 (säe 524) hänen sanotaan saapuvan Pohjolan matkansa jälkeen "ilman tuville". Tämän perusteella olisi houkuttelevaa ajatella, että Ilmarista olisi palvottu ilmanjumalana. Agricolakin ilmoittaa, että Ilmariselta rukoiltiin matkoille hyvää ja suotuisaa ilmaa, sillä vain tämä merkitys tulee antaa Agricolan sanoille "Ilmarinen rauhan ja ilman tei, Ja matkamiehet edhesvei". Lähes kaikki vanhemmat mytologit ovat antaneet niille merkitykseksi, että Ilmarinen hallitsi Väinämöisen tavoin salamoita, mutta tämä voidaan kyseenalaistaa. Mikäli Ilmarisella olisi kuitenkin ollut jotakin tekemistä taivaallisen tulen kanssa, tästä voisi löytää selityksen siihen, että hän joutui maan päälle tultuaan tekemisiin maallisen tulen kanssa kun hänelle uskottiin sepän tehtävät. Näkemys 
Ilmarisesta ilmanjumalana saa lisäksi vahvistusta siitä, että votjakit kutsuvat kristillistä jumalaa yhä tänä päivänä nimityksellä Ilmar (Inmar). Sana merkitsee pakanallisten votjakkien keskuudessa taivaan ja ilman jumalaa. ${ }^{206}$ Lappalaisessa mytologiassa nimi tavataan muodossa Ilmaris. Se viittaa jumaluuteen, jonka uskottiin aiheuttavan myrskyn ja kehnon ilman. ${ }^{a}$ Näin ollen hänkin oli ilmanjumala. Minusta näyttää todennäköiseltä, että näin on myös Ilmarisen laita, sillä luomisruno ilmoittaa selvästi, että hän takoi ilman kannen, taivaankaaren. Seppänä hänellä oli luonnollisesti vasara. Edda-opin mukaan Thor, joka määräsi ukonilmaa, oli myös ilmanjumala, ja hänellä oli Ilmarisen tapaan vasara. [Thor] ei käytä sitä niinkään käsityökaluna kuin aseena, jolla hän murskaa jättien päitä.

Lemminkäisellä on, kuten olen jo aiemmin maininnut, runoissamme monia eri nimityksiä, joiden joukossa on myös Ahti, deminutiivi Ahto. Ahdilla eli Ahdolla on, kuten olen jo aiemmin esittänyt, myös merenjumalan merkitys. Sanan etymologia näyttää viittaavan siihen, että tämä merkitys on itse asiassa alkuperäinen. Mikäli näin ollen kysytään, kuinka merenjumalan nimitys on voinut liittyä Lemminkäiseen, en pysty vastaamaan tyydyttävästi muutoin kuin että merenjumala Ahti ja sankari Lemminkäinen ovat alun perin olleet sama henkilö. Tämä näkemys saattaa vaikuttaa uskaliaalta, mutta jo esitetyn lisäksi sen tueksi on yhtä ja toista. Kalevalan runossa 5 (säe 25-) kerrotaan, että merenjumalan asunto sijaitsi "nenässä utuisen niemen, päässä saaren terhenisen", ja samassa paikassa sanotaan myös Lemminkäisen (Vanha Kalevala, runo 11, säkeet 9-10) asuneen. Merenjumalan omaisuus käsittää pääasiassa kalaa, ja vastaavasti kertoo laulu Lemminkäisestä, että kalat muodostavat hänen pääasiallisen ravintonsa. Kalevalassa sanotaan (runo 11, säkeet 9-10): "kaloin siinä Kauko kasvoi, Ahti ahvenin yleni." Meri on rauhaton, epävakaa, epäluotettava, ja samoin on laita Lemminkäisen luonteen kanssa. On varsin kuvaavaa, että yhtä lailla mereen kuin Lemminkäiseen liitetään epiteetti lieto 'märkä, hyllyvä, epävakaa' juuri molempien epävakaan luonnon vuoksi. Myös siitä löytyy mahdollisesti syvempi merkitys, että Lemminkäinen ajelehtii laajalti ympäri vesiä ja päätyy lopulta yhdeksän ja 
puolen meren taakse, kärsii haaksirikon, on jäätyä kiinni, jne. Hyvä kuulo, jonka runot (Kalevala, runo 26, säkeet 5-6) liittävät häneen, voi saada selityksen siitä, että veden asukkaat, kalat, erottavat helposti vähäisimmänkin äänen.

Tässä esitetyn perusteella näyttää siltä, että Ilmarista ja Lemminkäistä olisi alun perin palvottu elementtivoimina eli ilman ja veden jumalina. Mikään ei ole tavallisempaa pakanallisissa uskonnon muodoissa kuin että jumalat tällä tavoin syntyvät uudelleen ihmisinä. Eritoten polyteismin luonteeseen kuuluu antaa jumalten hiljalleen ottaa ihmismäinen muoto. Mikäli uskonto tunnustaa useita jumalia, on kunkin jumalan tehtäviä luonnollisesti rajattava ja rajoitettava suhteessa muihin, ja jokainen yksittäinen jumala näyttäytyy näin ollen rajallisena olentona. Tämän mukaisesti lausuu myös eräs tunnettu kirjoittaja: "Mitä suurempi ero (eri jumalten välillä) ilmenee, sitä rajallisempia ja rajoittuneempia ne ovat, sitä selvemmin ihmismäisemmiksi ne tulevat, kunnes ne ovat tyystin jumalallisuuden ulkopuolella pelkkinä ihmisinä eivätkä siis enää uskon kohteina vaan historiallisina henkilöinä."

Tämä prosessi oli suomalaisessa mytologiassa luonnollinen, sillä jumaliin liitettiin osittain inhimillisiä attribuutteja ja ihmisten kanssa yhdenmukaisia tehtäviä, kuten olen aiemmin pyrkinyt tuomaan esiin. Sekin seikka on huomionarvoinen, että monet Kalevalassa jumaluuksina esiintyvistä henkilöhahmoista ovat saaneet myöhemmissä kansankertomuksissa lähes inhimillisen hahmon. Tämä ei koske ainoastaan Tapiota, Syöjätärtä, Wornaa ja muita vaan lisäksi, ellen erehdy, myös itse taivaallista Ukkoa, joka vaeltelee toisinaan maan päällä ja suorittaa mahtavia tekoja. Näin ollen on aivan mahdollista, että Väinämöinen, Ilmarinen ja Lemminkäinen, jotka Kalevalassa esiintyvät mahtavina sankareina, olisivat jonakin aiempana aikakautena esiintyneet jumalina. Olen aiemmassa verrannut Väinämöistä Odiniin, ja on tunnettua, että jälkimmäinen jumaluus on saanut myöhempinä aikoina yhä inhimillisempiä ominaisuuksia ja että häntä on pidetty noitataitoisena kuninkaana. Vastaava kohtalo koitui myös muille aasoille. Kreikkalaisten Zeus, roomalaisten Janus jne. muuttuivat myös aikojen kuluessa historiallisiksi henkilöiksi. Vielä enemmän todisteita jumalten inhimillistymisestä löytyy Orientista. Toisaalta erityisesti länsimaista löytyy lukuisia todisteita myös siitä, että kuuluisia 
sankareita on kuolemansa jälkeen alettu kunnioittaa jumalkultilla, minkä vuoksi monet kenties haluavat uskoa, että sen sijaan, että Kalevalan kolme sankaria olisi alennettu jumalista ihmisiksi, [heidät] olisikin päinvastoin korotettu jumaliksi sen jälkeen kun [he] ovat ensin olleet ihmisiä. Voisi myös heittää oletuksen, että Väinämöisen jumalalliset ominaisuudet olisi lainattu edda-opista. Tämä heitto havaitaan kuitenkin lähemmin tarkasteltuna täysin pitämättömäksi. On helppo ymmärtää, että ihmistynyt merenjumala esiintyy sellaisena kevytmielisenä, seikkailuihin valmiina viikinkinä kuin Lemminkäinen. Sitä vastoin ei ole mahdollista käsittää, kuinka Lemminkäinen olisi voinut muuttua merenjumalaksi. Vastaavasti siinäkään ei ole mitään luonnotonta, että Ilmarinen, hallittuaan jumalana tuulia ja salamoita, käsittelee inhimillisessä hahmossaan palkeita ja ahjon hehkua, mutta vastakkaisen väittäminen johtaa lievästi sanottuna naurettavuuksiin.

Mikäli Ilmarinen ja Lemminkäinen ovat ihmishahmoisia jumalia, tämän on luonnollisesti koskettava vielä suuremmassa määrin Väinämöistä, koska hän ylittää nämä ystävänsä ja luotetut kumppaninsa kaikissa suhteissa. Elementti, johon hän jumalana näyttää pääasiallisesti vaikuttaneen, on epäilyksettä maa. Jo luomistapahtumassa hän huolehtii eniten siitä, ja myöhemmin hän kylvää siihen kaikenlaisia kasveja ja puita, valmistaa niittyjä, tekee pelloista hedelmällisiä jne. Hänen jatkuva yrityksensä tehdä ihmisistä onnellisia näyttää myös merkitsevän sitä, että häntä palvottiin maanjumalana. Lencqvistina mukaan jotkut kirjoittajat ovat pitäneet Väinämöistä veden jumaluutena ja perustelleet näkemyksensä nimellä, joka heidän ortografiansa mukaan kuuluu Weinemoinen ja joka merkitsisi 'veden emoa' (wein eli ween emoinen), ${ }^{207}$ mutta tätä näkemystä vastaan Lencqvist huomauttaa perustellusti, että Väinämöinen kuvataan runoissa aina mieheksi. Todennäköinen kantasana Väinämöiselle on Väinä, joka tavataan Topeliuksella (Wanhoja Runoja, 5. vihko, s. 1) ja jonka deminutiivimuoto Väinö on käytetympi. Väinämöisen sijaan Agricola kirjoittaa Äinemöinen, ja tämän kirjoitustavan puolesta puhuu se seikka, että suomen kielessä lisätään $v$ sanan alkuäänteessä usein aspiraatioksi vokaalin eteen, kun taas altailaisissa kielissä se ei yleensä sovi tähän 
paikkaan. Olisin taipuvainen yhdistämään kyseisen kannan sanaan aina, jolla tataarit pääasiassa kutsuvat maan henkiä, ja tällä tavoin Väinämöisen olemus maan jumaluutena saisi lisävahvistuksen.

Olen jo aiemmassa maininnut sen omintakeisen seikan, että suomalaisessa mytologiassa on jumaluuksia kaikille mahdollisille elementeille ja että yksin maaperältä puuttuu minkäänlainen kattava jumaluus. Syy tähän saattaa olla juuri siinä, että maaperälta ryövättiin jumalallinen hallitsijansa Väinämöisen inhimillistymisen myötä. Toisin on meren ja ilman suhteen. Merenjumala Ahti esiintyy tiettävästi ihmishahmossa maan päällä, mutta siitä huolimatta hän jatkaa majailuaan tyystin eri hahmona vedessä, missä hallitsee aaltoja. Mitä tulee Ilmariseen, on Ukko eli ukkosenjumala saanut osakseen ilman hallitsemisen, mikä alun perin näyttää kuuluneen edellä mainitulle.

Mikäli äskeisen esitykseni mukaisesti Väinämöinen, Ilmarinen ja Lemminkäinen muodostavat jumalkolmikon, on myös Louhelle, Louhittarelle eli Loviattarelle myönnettävä paikka Suomen kansan jumaluuksien joukossa, sillä hänen mahtinsa on varsin lähellä heidän mahtiaan. Itse asiassa Lencqvist ${ }^{\mathrm{a}}$ on jo kauan sitten ilmaissut tämän näkemyksen ja esittänyt todisteena, että Louhi käsitetään kylmyyden ja pahimpien sairauksien äidiksi ja että hänen uskotaan synnyttäneen maailmaan koiran ja suden. Lisäksi hänen uskotaan pystyneen sekä aiheuttamaan että estämään kaikkia mahdollisia onnettomuuksia. Useimmat näistä ominaisuuksista liitetään häneen myös Kalevalassa, ja monet niistä ovat sen luonteisia, että muinaissuomalaisten uskonnon näkökulmasta niistä voidaan puhua jumalallisina kykyinä. Hänen jumalallista luontoaan kuvaa myös se seikka, että Ilmarinen vetoaa tulenloitsimislaulussaan Pohjolan poikaan, jota on pidettävä joko Louhen miehenä tai poikana, rinnan Panun ja Ukon kanssa. Tämä rukous kuuluu seuraavasti:

Tule poika Pohjolasta, Lapsi täyestä Lapista, Mies pitkä Pimentolasta, Korpikuusien kokoinen, Suopetäjän suuruhinen, 
Hyiset kintahat käessä, Hyiset saappahat jalassa, Hyinen lakki päälaella, Hyinen vyöhyt vyölle vyötty!

Tuoos hyytä Pohjolasta, Jäätä kylmästä kylästä! Paljo on hyytä Pohjolassa, Jäätä kylmässä kylässä, Hyyss' on virrat, jäässä järvet, Ilmat kaikki iljenessä; Hyiset hyppivät jänikset, Jäiset karhut karkelevat, Keskellä lumi-mäkeä, Lumi-vaaran liepehellä; Hyiset joutsenet joluvat, Jäiset sorsat soutelevat Keskellä lumi-jokea, Jäisen kosken korvaksella. Hyytä kelkalla vetäös, Jäätä reellä reutoellos, Tuiman tunturin laelta, Vaaran vankan liepeheltä! Sillä hyyllä hyy'yttele, Jää-vilulla jäähyttele Tulen viemiä vikoja, Panun tuiki paahtamia!

(Kalevala, runo 48, säkeet 324-354.)

Edeltävissä säkeissä vedotaan myös Turjan tyttäreen, jolla tarkoitettaneen varsinaisesti Pohjolan tytärtä. Hänestä kerrotaan lisäksi Kalevalassa (runo 8, säkeet 28-30), että hän istui ilman kaarella ja kutoi kultaista kangasta, mikä paljastaa mitä selvimmin hänen jumalallisen olemuksensa.

Mikäli nyt esitetyt näkemykset ovat oikeellisia, on helppoa nähdä, että suomalaisilla jumaltaruilla ${ }^{208}$ on tiettyjä kosketuskohtia muinaisskandinaavisten ja germaanisten kanssa yleensäkin. Meillä on tässä merkittävä jumalkolmikko, joka käsittää Väinämöisen, joka vastaa Odinia, Ilmarisen, jolla on yhtäläisyyksiä Thorin kanssa, sekä Lemminkäisen, jota voi rohkean ja sotaisan luonteensa vuoksi verrata Tyriin ${ }^{209}$. Lemminkäinen muistuttaa lisäksi kuolintapansa vuoksi 
myös Baldia ${ }^{210}$, sillä kuten tämä kuolee sokean Hödin ${ }^{211}$ ampumasta mistelinoksasta, myös Lemmen-pojan tappoi Pohjolan sokea paimen näennäisen harmittomalla aseella - "umpinaisella putkella". ${ }^{212}$ Kaikkia näitä kolmea jumalaa voi yleisesti verrata aasoihin, kun taas toisaalta Pohjolan asukkailla on paljon yhtäläisyyksiä jättien kanssa. Lisäksi Louhi, Pohjolan emäntä, muistuttaa sekä nimensä että toisia jumalia kohtaan osoittamansa vihamielisyyden puolesta Lokia. Mutta emme halua täydentää tämän pidemmälle näitä vertailuja, sillä tämä tie on liukas ja johtaa helposti eksyksiin. Sitä paitsi muinaispohjoismaista mytologiaa on selvitetty vasta heikosti, ja suomalaisen suhteen ei ole edes materiaaleja saatu kokonaan talteen. ${ }^{213}$

\section{Castrénin mytologialuentojen lähteet}

Deguignes, Joseph 1768-1769: Allgemeine Geschichte der Sunnen und Turken, der Mogols und anderer occidentalischen Tartarn, vor und nach Christi Geburt bis auf jedige Zeiten I-III. Hreisswald.

Diefenbach, Lorenz 1831: Vergleichendes Wörterbuch der germanischen Sprachen und ihrer sämtlichen Stammverwandten I-II. Joseph Baer, Frankfurt am Main.

Erman, Adolph 1833-1848: Reise um die Erde durch Nord-Asien und die beiden Oceane in den Jahren 1828, 1829 und 1830 I-V. G. Reimer, Berlin. Faehlmann, Friedrich Robert 1847: Wie war der heidnische Glaube der alten Esten beschaffen? - Verhandlingen der gelebrten Estnischen Gesellschaft zu Dorpat II (2), 63-69.

Forsius, Sigfried Aaron 1778: Finlands fordne Afgudar. - Tidning Utgifne af et Sällskap i Åbo 15 / 1778, 113-114.

Fuks 1840: Фукс, Александра 1840: Записки Александры Фукс о чувашах и черемисах Казанской губернии. Казань.

Ganander, Christfrid 1789: Mythologia Fennica, eller förklaring öfver de nomina propria deastrorum, idolorum, locorum, virorum \&c. eller Afgudar och Afgudinnor, Forntidens Märkelige Personer, Offer och Offer-Ställen, Gamla Sedvänjor, Jättar, Troll, Skogs- Sjö- och Bergs-Rån m.m. som Förekmma i de äldre Finska Troll-Runor, Synnyt, Sanat, Sadut, Arwotuxet \&c. samt än brukas och nämnas i dagligt tal. Åbo.

Ganander, Christfrid Thomasson 1821: Finnische Mythologie. Carl Dullo, Reval. [Saksantanut Christian Jaak Peterson.]

Georgi, Johann Gottlieb 1775: Bemerkungen einer Reise im Russischen Reich im Jahre 1772. Erster Band. Kayserl. Academie der Wissenschaften, St. Petersburg.

Georgi, Johann Gottlieb 1776-1780: Beschreibung aller Nationen des russischen Reichs: Ihrer Lebensart, Religion, Gebräuche, Wohnungen, 
Kleidungen und übrigen Merkwürdigkeiten. Erste Ausgabe, Nationen vom Finnischen Stamm. Kupfer zur Beschreibung aller Nationen des Russischen Reichs. C.W. Müller, St. Petersburg.

Grimm, Jacob 1844: Deutsche Mythologie. Göttingen. [1835.]

Grimm, Jacob 1845: Om det Finska Epos. Teoksessa Fosterländskt album II. Toimittaneet Herman Kellgren, Robert Tengström \& Karl Tigerstedt. Helsingfors.

Gruber, Johann Daniel (toim.) 1740: Origines Livoniae sacrae et civilis, seu Chronicon livonicum vetus. Frankfurt \& Leipzig.

Högström, Pehr 1747: Beskrifning öfver de til Sveriges krona lydande Lapmarker, innehollande kort underrättelse så väl om landets belägenhet och beskaffenhet i gemen, som des invånares tilstånd och husholdning, deras seder, maner och lefnadsart, samt laster: och vidskepelser. m.m.

Hupel, August Wilhelm 1818: Ehstnische Sprachlehre für die beuden Hauptdialekte, den revalschen und dörptzchen, nebst einem vollständigen ehstnischen Wörterbuche. J. J. Steffenhagen und Sohn, Witau.

Islavin 1847: Иславин, Владимір 1847: Самогды въ домашнемъ и общественномъ быту (Самоеды в домашнем и общественном быту). Санкт-Петербург.

Jessen-Schardebøll, Erik Johan 1767: Afhandlungen om de Norske Finners og Lappers hedenske Religion. Kjøbenhavn.

Kalevala. Ks. Lönnrot 1835 (Vanha Kalevala), 1849 (Uusi Kalevala). Castrénin tekstissä "Kalevala" ilman painoksen täsmennystä viittaa Uuteen Kalevalaan.

Kellgren, Herman 1849: Om den heliga bäcken Wöhhanda i Liefland. - Suomi: Tidskrift i fosterländska ämnen 1849, 79-92.

Kellgren, Herman, Robert Tengström \& Karl Tigerstedt 1847: Fosterländskt album III. A. C. Öhmans förlag, Helsingfors.

Klemm, Gustav 1843-1852: Allgemeine Cultur-Geschichte der Menschheit $I-X$. Leipzig.

Kowalewski, Joseph Étienne 1844-1849: Dictionnaire mongol-russe-français I-III. Imprimerie de l'université, Kasan.

Kreutzwald, Friedrich Reinhold 1850: Ueber den Charakter der Estnischen Mythologie. - Verhandlungen der gelehrten Estnischen Gesellschaft zu Dorpat 2(3).

Leem, Knud 1767: Beskrivelse over Finmarkens Lapper, deres Tungemaal, Levemaade og forrege Afgudsdyrkelse. Kjøbenhavn.

Lencqvist, Christian 1782: De superstitione veterum Fennorum theorethica et practica I-II. Aboae.

Lindahl, Erik \& Öhrling, Johann 1780: Lexicon Lapponicum, cum interpretatione vocabulorum Sveco-Latina et indice Svecano Lapponico. Holmiæ.

Lönnrot, Elias 1829-1831: Kantele, taikka Suomen kansan, sekä wanhoja että nykysempiä runoja ja lauluja I-IV. Helsinki.

Lönnrot, Elias 1835: Kalewala taikka Wanhoja Karjalan Runoja Suomen Kansan muinoisista ajoista. Suomalaisen Kirjallisuuden Seura, Helsinki.

Lönnrot, Elias 1836: Muinelmia. Teoksessa Elias Lönnrot - Valitut teokset 2: Mehiläinen. Toimittanut Raija Majamaa. Helsinki: Suomalaisen Kirjallisuuden Seura. 
Lönnrot, Elias 1840-1841: Kanteletar taikka Suomen Kansan Wanhoja LauIuja ja Wirsiä I-III. Suomalaisen Kirjallisuuden Seura, Helsinki.

Lönnrot, Elias 1849: Kalevala. Suomalaisen Kirjallisuuden Seura, Helsinki.

Magnusen, Finn 1824-1826: Eddalæren og dens Oprindelse, eller Nöjagtig Fremstilling af de gamle Nordboers Digtninger og Meninger om Verdens, Gudernes, Aandernes og Menneskenes Tilblivelse, Natur og Skjæbne I-IV. Gyldendalske Boghandling, Kjøbenhavn.

Nilsson, Sven 1838-1843: Skandinaviska Nordens ur-invånare: Ett försök i komparativa ethnografien och ett bidrag till menniskoslägtets utvecklings-historia I-IV. Berlingska boktryckeriet, Lund.

Nordisk familjebok: Konversationslexikon och realencyklopedi. Sextonde bandet. Teniers-Üxkull. Stockholm 1892.

Pallas, Peter Simon 1776-1778: Reise durch verschiedene Provinzen des Russischen Reichs in einem ausführlichen Auszuge I-III. Johann Georg Fleischer, Frankfurt und Leipzig.

Pallas, Peter Simon 1801: Sammlungen historischer Nachrichten über die Mongolischen Völkerschaften: Zweiter Teil. Der Kajserl. Akademie der Wissenschaften, St. Petersburg.

Petersen, Niels Matthias 1849: Nordisk mythologi: Forelæsninger. Kjøbenhavn. Renvall, Gustav 1826: Suomalainen Sana-Kirja: Lexicon linguæ Finnica cum interpretatione duplici, copiosiore Latina, breviore Germanica. Aboae.

Schefferus, Johannes 1673: Lapponia, id est Regionis Lapponum et Gentis Nova et Verissima Descriptio. Francofurti.

Schmidt, Isaac Jacob 1824: Forschungen im Gebiete der älteren religiösen, politischen und literärischen Bildungsgeschichte der Völker Mittel-Asiens, vorzüglich der Mongolen und Tibeter. Karl Kray, St. Petersburg; Carl Cnobloch, Leipzig.

Schmidt, Isaac Jacob 1829: Geschichte der Ost-Mongolen und ihres Fürstenhauses, verfasst von Ssanang Ssetsen Chungtaidschi der Ordus. N. Gretsch, St. Petersburg.

Schott, Wilhelm 1849: Über das Altai'sche oder Finnish-Tatarische Sprachengeschlecht. G. Reimer, Berlin.

Tengström, Johan Robert 1845: Teckningar från den fosterländska vitterhetens område I: Kalewala. Teoksessa Fosterländskt album I. Toimittaneet Herman Kellgren, Robert Tengström \& Karl Tigerstedt. A.C. Öhmans förlag, Helsingfors.

Topelius, Zachris 1822-1831: Suomen Kansan Vanhoja Runoja, ynnä myös Nykyisempiä Lauluja I-V. Turku.

Tornæus, Johannes Jonæ 1772 [1672]: Beskrifning öfver Torneå och Kemi Lappmarker. Stockholm.

Ukert, Friedrich August 1850: Über Dämonen, Heroen und Genien. Leipzig: Weidmann.

Uusi Kalevala: ks. Lönnrot 1849.

Vanha Kalevala: ks. Lönnrot 1835.

Višnevski 1846: Вишневский, Виктор Петрович 1846: О религиозных повериях чуваш. 


\section{Toimitukselliset huomautukset eli loppuviitteet}

1 [stam] Termi voi viitata tekstissä heimoon, kantaheimoon tai kansaan. Castrén ei käytä termiä täysin johdonmukaisesti missään näistä merkityksistä, ja käännöksessä se on tulkittu tilanteesta riippuen jollakin näistä tavoista.

2 [elementar-gudar] Termi viittaa lähinnä peruselementtien jumaluuksiin. Näitä olivat Castrénin mukaan ilma, vesi ja maa sekä tulkinnasta riippuen myös esim. metsä ja tuli. Castrén viittaa elementtijumaluuksilla myös luonnonvoimiin (esim. ukonilma), joita palvottiin itsenään erotuksena erikseen personifioidusta jumaluudesta luonnonvoiman takana.

3 [bragt]

4 Tässä Castrén viittaa kulttuurien kehittymiseen ja tämän kehityksen eri tasoihin, ei yksittäisen ihmisen kehitykseen.

5 [så vida den erkänner den subjektiva viljans beroende af en objektiv] Castrén tarkoittanee tällä melko vaikeasti avautuvalla, tiiviisti ilmaistulla ajatuksella muutosta, joka tapahtui, kun käsitys ihmisen (šamaanin) kyvystä vaikuttaa suoraan luontoon vaihtui käsitykseen, jonka mukaan vaikutus tapahtui välittäjien (henkien tai jumalten) kautta.

6 [moment] 'pykälä'.

7 Nämä esimerkit ovat Gananderilta (1789), sv. Jumala.

8 Jorma Koivulehto $(1999,228)$ esittää sanan jumala kannan *juma johtuvan indoarjalaisesta jumaluusnimityksestä (*juma- < arjal. *dyumān-). Janne Saarikivi (2014, 207 alaviite 11) esittää vedoten suomalais-ugrilaisten kansojen tapaan viitata ylimpään jumalaansa "ylhäällä olevana" jumaluutena, että sanan jumala pääte -la edustaa varhempaa muotoa ylä. Siinä missä sana *juma on viitannut 'jumalaan ylipäätään', sana jumala viittaisi siis 'ylimpään jumalaan, ylijumalaan'.

9 Sana kudai viittaa tässä yhteydessä tataarien ylijumalan seitsemään poikaan, mutta erisnimenä (Kudai) se viittaa itse ylijumalaan.

10 Tundranenetsin sanalla num on kolme perusmerkitystä. Se tarkoittaa taivasta, säätä ja nenetsien taivaanjumalaa, Jiljebja' pærtja, 'elämäntekijä', on historiallisissa lähteissä toisinaan numin kanssa synonyyminen, toisinaan tästä erillinen hahmo. Molempien asuinpaikkana pidetään taivasta eikä niistä kumpaakaan pidä lähestyä ilman šamaanin apua.

11 Kamassin kieli on kuollut. Sen viimeinen puhuja Klavdija Plotnikova kuoli vuonna 1989.

12 Tässä Castrén viittaa sanaan jumala.

13 Pyhän Olavin saagan (Óláfs saga Helga) teksti kuuluu alkukielellä [...] en í garðinum stendr goð Bjarma er heitir Jómáli (Jónsson 1911, 313) ja Bósin ja Herrauðrin saagan (Bósa saga ok Herrauðs) teksti kuuluu Par er göfgat goð pat, er Jómali heitir (Jónsson \& Vilhjálmsson 1944, 478). Perusmuodossa nimitys on siis käsikirjoituksissa Jómáli tai Jómali, joka taipuu muinaisislannissa genetiivissä, akkusatiivissa ja datiivissa muotoon Jómála tai Jómala.

14 [edda-läran] 'skandinaavinen mytologia'. Skandinaavien mytologiaa on tulkittu etupäässä keskiajalla ylös kirjoitetun myyttisen runouden, niin 
kutsutun edda-runouden perusteella. Tätä runoutta on säilynyt lähinnä vain yhdessä, Islannissa 1200-luvun jälkipuolella kootussa käsikirjoituksessa (GKS 2365 4to), jota kutsutaan nimellä Codex Regius. Runokokoelmaa kutsutaan myös Runo-Eddaksi. Keskiajalta on myös peräisin niin kutsuttu Proosa-Edda tai Snorrin Edda, sen oletetun kirjoittajan, 1200luvun ensimmäisellä puoliskolla eläneen islantilaisen Snorri Sturlusonin mukaan. Proosa-Edda on proosamuotoinen perinteenmukaisen islantilaisen runouden sepittämisen opas. Runoudessa ovat keskeisessä roolissa erilaiset viittaukset mytologiaan, joten oppaassa on esitetty jumalten, jättien ja erilaisten myyttisten olentojen nimitysten ja kuvausten lisäksi myös myyttisiä kertomuksia, joiden on tarkoitus selventää mytologiaa lukijalle. Vaikka tekstit on kirjoitettu Islannin oltua kristitty jo vuosisatojen ajan, niitä pidetään monin osin avaimina esikristilliseen skandinaaviseen uskomusmaailmaan.

15 [In der gesammten Lehre von den Aimos möchte ich eine Nachbildung der germanischen Edda-Lehre und ihrer verschiedenen Heime (Muspelheim, Fiflheim, Jotunheim) wiederkennen, zumal da die Zauberer wenig Uebereinstimmung in ihren Lehren beobachten und ihre armselige Umgebung mit fremden Erzeugnissen ausschmücken.]

16 Lönnrot 1836.

17 Vrt. Lönnrot 1836, missä Lönnrot esittää, että jumala merkitsi alkujaan 'taivaan tuojaa eli luojaa', sittemmin 'kaiken luojaa', ja että vasta myöhemmin ajateltiin olevan muitakin jumalia. Tällöin pääjumalaa, taivaallista jumalaa, olisi alettu kutsua Ukoksi.

18 Tässä kohden näkyy erityisen selvästi Castrénin ajattelu uskonnon kehittymisestä, joka vastaa Hegelin ajatuksia uskonnon kehittymisestä polyteismistä monoteismiin. Vrt. Hodgson 1988, 268-270.

19 [C'est une expression respecteuse, comme en françois monsieur]

20 Lencqvist 2011, 9-10.

21 Renvall 1826, 10, 40.

22 Aluksi jumala oli siis Castrénin mukaan merkitykseltään 'taivaanjumala', jonka epiteettinä saattoi olla ukko; sittemmin ukko tuli merkitsemään 'taivaanjumalaa', jolloin taas jumala saattoi toimia sen epiteettinä.

23 Ukkosenjumala Thor (isl. Pórr) suojeli aasoja, skandinaavien jumalia, kaaosvoimia edustavilta jäteiltä (jǫtnar), ja tässä tehtävässä Mjǫ/lnirniminen vasara oli hänelle välttämätön apu.

24 [saga] 'kertomus, taru, satu, saaga' Castrén käyttää termejä saga ja sagoberättelse laveasti kansankertomuksista eikä ainoastaan yhdestä kansankertomusten lajista, saduista, tai islantilaisesta saagakirjallisuudesta. Suomennoksessa on jouduttu tulkitsemaan merkitys tilannekohtaisesti.

25 Grimm 1845, 90.

26 Vrt. Lönnrot 1836.

27 Vrt. Grimm 1844, 160.

28 Ks. Uusi Kalevala, runo 36, säkeet 235-250.

29 Akka- ja ämmä-johdannaisista paikannimistä ks. Kaija Mallat (2007).

30 Ukkoa koskevaa keskustelua on käyty Castrénin jälkeenkin paljon. Ks. esim. Harva 1948, 74-151; Haavio 1959, 79-102; 1961; Salo 2012 I, 472-477. 


\section{1 [spåtrummor]}

32 Lönnrot 1840-1841.

33 Lönnrot 1849, runo 11, säkeet 39-42.

34 Ks. Lönnrot 1849, runo 48, säkeet 151-178.

35 Vrt. SKVR VII 3 loitsut: 711; I: 292; 294; 319 (Castrénin taltioima). Castrén tunsi siis vaihtoehtoisiakin tulensyntymyyttejä, mutta hänen voi olettaa kyseenalaistaneen näiden arvon mytologian lähteinä esimerkiksi ristiriitaisuuden vuoksi suhteessa omaan mytologianäkemykseensä (Vrt. SKVR $\mathrm{I}_{4}: 250$ ja tämän teoksen s. 296-297) tai kristillisen vaikutuksen turmelemina (SKVR I: 240).

36 Tapa on edelleen käytössä. Savulla pyhitetään ja puhdistetaan ihmiset tai ympäristö ennen rituaaleja. (Golovnev 1995; Ljarskaja 2015.)

37 Sittemmin Uno Harva (1948, 164-169) on käsitellyt aihetta myöhäisten perinnetallenteiden pohjalta.

38 [personliga ändelsen], varsinaisesti feminiinijohdin.

39 Nimi tulkitaan taivutusmuotonsa (Ahti : Ahdin (ei *Ahden)) vuoksi nykyään melko nuoreksi, ja siksi sen katsotaan olevan lainattu. Nimen etymologiaa on käsitellyt hiljattain Mikko Heikkilä (2013), joka esittää nimelle kolme rinnakkaista, eritaustaista etymologiaa. Kaksi näistä palautuisi muinaispohjoismaisiin kieliyhteyksiin vaurauteen liittyvin merkityksin.

40 [... überhaupt scheinen Wassergeister gern Seelen festzuhalten.]

41 Tursaan merkityksen myöhemmistä tulkinnoista ks. Harva 1933; Haavio 1967, 102-124; Salo 2012 I, 48-53.

42 Isl. purs; Castrén oli yksi ensimmäisiä, joka esitti tämän yhteyden (Siikala 2012 , 223). Aiemmin yhteyden oli tuonut esiin Jacob Grimm $(1845,67)$.

43 Alkuperäistekstissä muodossa [dricka vört, eller buska, färskt gäsit dricka.]

44 Renvall 1826, 146.

45 [slägtet eller slaget]

46 Parne on nenetsien aliseen maailmaan sijoittama, pahantahtoinen henki, joka saa toisinaan epiteetin sjesawei 'pihkainen' (Lehtisalo 1924, 40-42).

47 Nykykäsityksen mukaan sana hiisi on alkujaan merkinnyt kulttipaikkaa tai kalmistoa ja sellaisena siis yhteisölle hyvin keskeistä maastonkohtaa. Sana olisi saanut yliluonnollisen olennon merkityksen vasta kristinuskon vaikutuksesta. (Ks. Koski 1967, 214-220; Anttonen 1996, 116-118.)

48 Ks. Rühs 1827, 171-174.

49 Kalevala, runo 17, säkeet 115-118.

50 Tämä on Sigfrid Aaron Forsiuksen latinannos (Forsius 1778, 114), suomennettuna 'Hisis jahtaa vihaisia karhuja ja susia.' Forsiuksesta ks. Harva 1948, 24.

51 [plågo-andar]

52 Pyhä Stephanus, suomalaisittain Tapani ja karjalaisittain Tahvana, liitettiin Pohjoismaissa sydäntalven hevosjuhliin, mistä todennäköisenä muistumana Suomessakin käytiin pitkään tapaninpäivän hevosajeluilla. Vienan Karjalassa Tahvana esiintyi myös Matka-Teppona, jota rukoiltiin matkoilla neuvomaan kulkijalle tietä.

53 [Högasien] eli Keski-Aasia määritellään teoksessa Nordisk familjebok (1892, 964) seuraavasti: Sedan namnen Buchariet, Turan och Tatariet kommit ur bruk och Hög-Asien nyttjas blott som rent geologisk term, 
qvarstå $i$ det allmänna språkbruket Central-Asien såsom betecknande ett område, hvilket utan närmare bestämda gränser ligger mellan Vest-Sibirien i n., Kaspiska hafvet $i$ v., Persien, Afganistan och Tibet i s. och Mongoliet $i$ ö. (dock ofta med den utsträckning, att det äfven omfattar hela Gobiöcknen i ö. och Tibet $i$ s.), samt Turkestan, än såsom synonymt med CentralAsien (utom Tibet och Gobi), än åter och oftare såsom betecknande vestra och största delen deraf. De flesta nyare geografer hafva emellertid enat sig om en noggrannare bestämning på det sätt att Central-Asien omfattar de fyra orografiskt strängt skilda områdena: Turkestan, deladt i Vest-Turkestan och Öst-Turkestan, Dsungariet och det egentliga Gobi (ö. om Tarimbäckenet), hvilket sistnämnda dock af några geografer icke inbegripes i Central-Asien.

54 [trollord]

55 Sana tadebtsjo merkitsee šamaanin apuhenkeä, jota tämä kutsuu rituaalissa avukseen. Sana on peräisin tundranenetsin sanasta tadebja, joka merkitsee šamaania.

56 Sana ngitarma, tundranenetsin länsimurteilla itarma, on ihmisen kuoltua hänen kuvakseen tehty nukke, jota säilytetään vainajan perheen kodassa. Se on myös vainajista käytetty nimitys. Läntisten nenetsien parissa ngitarma-nukke on ilmeisesti tehty ainoastaan šamaanin kuoltua.

57 [rangskilnad]

58 [förstörda lifs-andar] (Ganander 1789, 36.)

59 [små elfvar, flygande genier] (Ganander 1789, 36.)

60 [snöfjun, små barn-dockor, eldstrimmor] (Ganander 1789, 36.)

61 [kyrkspöken]

62 [vålnad]

63 Renvall 1826, 247.

64 [gast]

65 [spöke]

66 [stämplar emot menniskorna förderfliga anslag]

67 Renvall 1826, 155.

68 [underjorden]

69 Tästä esimerkistä näkee erityisen hyvin, kuinka Castrén käyttää käsitysten ikäämisen välineenä analogiaa sanan ja sen tarkoitteen välillä mukaan lukien tarkoitteeseen liittyneet käsitykset. Sanan ikä antaisi siis analogian mukaan viitteita myös siihen liittyvien käsitysten iästä. Hän jättää vähemmälle huomiolle ongelmat, jotka liittyvät sanojen merkitysten tai sanoihin vielä löyhemmin liittyneiden käsitysten muuntumiseen aikojen saatossa.

70 Kalevala: "nukutteli nuivan joukon." Runo 15, säe 230.

71 Kalevala: "Ei Tuoni sanoja anna, Mana mahtia jakele!" Runo 16, säkeet 323-324.

72 Kalevala: "Äijä on sinne saanehia, vähä tuolta tullehia" Runo 16, säkeet 393-394.

73 "Väinämöisen ajat" viittaavat aikaan, jolloin kalevalamittaiset runot (joissa Väinämöinen esiintyy) sepitettiin eikä niinkään ota ainakaan tässä yhteydessä kantaa Väinämöisen historiallisuuteen henkilöhahmona.

74 Jessen-Schardebøllin teksti kulkee rinnan tanskan- ja latinankielisenä. Alkuteksti viittaisi molemmilla kielillä lintujen vaihtelevaan kokoon 
pikemmin kuin erilajisuuteen. [Fuglene vare af forskiellig Størrelse: nogle somSvaler; noglesom Spurrer; andresom Ryper, Ørne, Svaner, Teddere, Heirer, Uhrhaner, og Høge] - [Aves non unius magnitudinis erant, aliis hirundines, passeres aliis, nonnullis lagopodes, aqvilas, cygnos, gallos sylvestres, accipitres, \& colymbos, mole corporis æqvantibus.] (Jessen-Schardebøll $1767,25$.$) Castrén vaikuttaa viittaavan saivolintujen moninaisiin lajeihin,$ mutta tässä käännöksessä muotoilu on saatettu vastaamaan JessenSchardebøllin alkuperäistä tarkoitusta.

75 Jessen-Schardebøllin latinankielisessä tekstissä tämä on ilmaistu muodossa [... jugi artis magicæ, per Juoigen \& Myran, exercitio] (JessenSchardebøll 1767, 28-29).

76 [Att nogot ær quar effter doeden, troo thee, hvvarfoere the och sky myket foer the doeda.]

77 [The offra doeden eller the framledne doede]

78 Termi irle-khan viittaa yleisnimenä manalanjumaluuksien joukon jäseneen, erisnimenä (Irle-khan) se voi viitata myös manalan ainoaan jumaluuteen.

79 Nga, tundranenetsin länsimurteilla $A$, on Numin vastapuoli, alisen maan jumala. Termillä voidaan viitata myös yleisemmin pahoihin henkiin.

80 [mera hyfsade]

81 [af en mera andlig natur]

82 [genier]

83 [På jorden skall tu för mig springa, I Blåkulla skall jag för thig brinna]

84 [Smör och ost skall du mig bringa, Och derför (skall jag) i helvetet brinna.]

85 Ennen muuta Ganander 1789, 34-36.

86 Vrt. Ganander 1789, 35-36.

87 Toisin sanoen haltioissaan. Moni Castrénia edeltäväkin kirjoittaja oli liittänyt haltia-sanaan haltioitumisen tilan, joskaan ei näin konkreettisesti. Esim. Ganander $(1789,9)$ mainitsee sanan viittaavan myös 'ihmisen luonteeseen ja luontoon'; Renvall $(1826,50)$ selittää haltioissa olemisen 'haltioitumisen tilaksi, status ecstaseos'.

88 [bilder]: jonkinlaiset jumalkuvat, patsaat tai talismaanit. Sana kuva (bild) viittaa tässä teoksessa tämäntyyppisiin esineisiin pikemmin kuin esim. piirroksiin tai maalauksiin.

89 [elementära makter]

90 Henkityyppi nimitykseltään aina merkitään vastedes kursiivilla, jottei se sekoittuisi suomen kielen adverbiin aina.

91 [religions-lära]

92 Sihirtja-, tundranenetsin länsimurteilla sirtja-perinnettä on tulkittu niin myyttisenä kuin historiallisenakin perinteenä. Nenetsit liittävät jotkut kertomukset maasta löytyviin mammutinluihin, joiden he uskovat liittyvän ennen heitä maassa eläneisiin ihmisiin. Nenetsejä ennen Jäämeren rannoilla on elänyt lukuisia, nykyään paleoeuraasialaisiksi kutsuttuja metsästäjä-keräilijäyhteisöjä, joista tiedetään hyvin vähän. (Ks. Lukin 2011.)

93 Tšuudi-nimitys viittaa yhteen tai useampaan Luoteis-Venäjällä asuneeseen suomalais-ugrilaiseen väestöryhmään, joita ei ole pystytty tarkemmin identifioimaan (ks. Saarikivi 2006, 11, 14). Castrénin maininta suomalaisista 
tundran vanhempina asukkaina liittynee tuohon aikaan vallinneeseen vaellusteoriaan, jonka mukaan suomalaiset olisivat siirtyneet kansana idästä ja kaakosta nykyisille asuinsijoilleen. Se liittynee myös suoraan Castrénin nk. uralilais-altailaiseen hypoteesiin, joka esittää itäiset ja kaakkoiset kontaktit keskeisiksi suomalaisten kielellisen - ja myös olemuksellisen - alkuperän suhteen. (Vrt. s. 265.)

94 [slutstafvelsen]

95 [härlednings-ändelse]

96 [gudabild]

97 Castrénin määritelmä tässä vastaa fetisismin määritelmiä hänen aikanaan ja häntä ennen, vrt. s. 51-52.

98 Tästä kohtaa Castrén on yliviivannut alkuperäisessä käsikirjoituksessa seuraavan tekstiosion:

[...] mutta on ennenkuulumattoman teennäistä väittää kristillisen fanatismin ja myös yleisen, mukaan lukien monien oppineiden tiedemiesten, käsityksen mukaisesti, että jumaluuksilla ei olisi niiden esiintymisten perusteella muuta itsenäisyyttä kuin se joka ilmenee kuvassa. On nimittäin yksilöitä, mahdollisesti jopa kokonaisia heimoja ja mahdollisesti jopa tiettyjä kansoja, jotka tuskin osaavat sanoa jumalkuvistaan enempää kuin että nämä kuvat, kun niihin vedotaan rukouksin ja uhrein, suovat ihmiselle sekä terveyttä että hyvinvointia ja kaikkia muita elämän mukavuuksia. Mikäli heiltä kysytään, miltä hengiltä kivenkappale tai nahka on saanut niin tavattoman voiman, saadaan useimmissa tapauksissa tyytyä tähän vastaukseen: "Emme tiedä, mutta palvomme samanlaisia jumalia kuin isämme palvoivat ennen meitä ja joiden turvissa he elivät onnellisen elämän." Sen pidemmälle ei yleensä ulotu šamaanienkaan tietämys, mutta heidän keskuudessaan on kuitenkin myös viisaita miehiä, jotka ovat antaneet minulle paremman selityksen jumalkuvien merkityksestä. He tukeutuvat siihen jo aiemmin käsittelemääni dogmaan, että koko luonto on täynnä henkiolentoja, joilla on kyky vaikuttaa ihmisiin sekä hyväätekevällä että vahingoittavalla tavalla. Asiasisältö tulee esiin muualla tekstissä, mutta viittaus "kristilliseen fanatismiin" on ainutkertainen.

99 Castrén käyttää tulkintaansa lähinnä 1700- ja 1800-luvuilla koottuja aineistoja, joista tapaa haltia- ja sielu-uskon merkkien lisäksi rukouksia ja vetoomuksia, jotka on osoitettu suoraan jumalillekin. Aineiston myöhäisyydestä huolimatta hän liittää rukoukset uskonnonhistorian varhaiseen vaiheeseen ja pyrkii näin osoittamaan suomalaisten uskonnolisen ajattelun ja sitä myötä kulttuurin kehittyneisyyden jo tuolloin. Arvio liittynee ainakin osin ajan suomalaisuuskeskusteluihin.

100 so. kreikkalaiskatolinen eli nykytermein ortodoksinen.

101 [förskjuten]

102 [innefatta]

103 Óláfs saga helga, luku 133 (Jónsson 1911, 313).

104 Bósa saga ok Herrauðs, luku 8 (Jónsson \& Vilhjálmsson 1944, 478-482).

105 Vrt. Lönnrot 1836.

106 Tässä viitataan paavi Gregorius IX:n Uppsalan arkkipiispalle joulukuussa 1237 osoittamaan bullaan, jossa hän kehottaa Ruotsin kuningaskuntaa 
ryhtymään taisteluun pakanallisiin käytänteisiin palanneita ja kapinoivia hämäläisiä vastaan. Pontimeksi bullassa kuvataan raakuuksia, joita hämäläisten väitetään tehneen kristittyjä kohtaan, kuten sikiöiden repimistä raskaana olevien naisten kohduista, raajojen irtileikkaamista, kuoliaaksi polttamista ja tässä esitettyä puun ympäri hengiltä juoksuttamista (vsque ad amissionem spiritus arbores circuire compellunt). (Finsk Sv. Dipl. I n:o 298. Sv. Trakt. I n:o 86. Hausen 1910, 29-30.)

107 [jätte]: 'jätti, peikko'

108 Karhun roolia suomalaisessa muinaisuskonnossa on hiljattain käsitelty esimerkiksi uskontoarkeologian keinoin teoksessa Karhun kannoilla (Tolley 2006).

109 [maner (mon.)] Sana viittaa erityisesti kuolemassa ruumiista irtaantuviin henkiin, alkup. latinan manes.

110 [Trinnäs]: Kuolan niemimaa.

111 [Karl]

112 [beläten]

113 Lat. Picea abies $f$. tabulaeformis.

114 Paikka sijaitsee Obin varrella lähellä sen suuta, 18 kilometriä Aksarkasta alavirtaan. Pallas kirjoittaa: "Gegenmärtig ist der von allen Obischen Ostjaken und auch von benachtbarten Samojeden vorzuglich verehrte Götze in der gegend der Woksarstischen Jurten, siebenzig Werste unterhalb Obdorsk befindlich." Gerhard Millerin muistiinpanoissa kuvataan näin: "Ворвашские юрты, по-остяцки Wor-wasch, по-самоедски Netschi-garden, на правом берегу, в 17 верстах от Воксарского городка. Как показывают остяцкое и самоедское названия, здесь также раньше была крепость. Сейчас здесь имеется лишь одна остяцкая хижина."

115 Castrén viittaa tässä Länsi-Siperian selkuppeihin.

116 [samma slags kult]

117 Alkuperäisessä käsikirjoituksessa (MAC Varia III: 467) tekstiosio "ja niihin Pallas lukee kaikki sellaiset, joihin kotka on rakentanut pesänsä monena vuonna peräkkäin. Olen kuullut myös väitettävän, että missä seitsemän lehtikuusta seisoo yhdessä, pidetään sekä paikkaa että puita pyhinä" on marginaalissa.

118 Ven. Baŭzáy. Saari Novaja Zemljan kaakkoispuolella. Vaigatšin saarta on pidetty kaikkien nenetsien yhteisenä pyhänä paikkana tai kaikkein pyhimpänä paikkana. Tarkemmin myös Veniamin 1855, 122-125; Žitkov 1913.

119 Minisei tunnetaan myös nimellä $P e^{\prime}$ mal' hada, sananmukaisesti 'Kivenlopun isoäiti', jossa kivi viittaa Uralin vuoristoon. Se on pyhä paikka Uralin vuoriston pohjoisessa päässä vuorella, joka tunnetaan nimellä Hada' pe 'Isoäidin vuori' Ks. Vallikivi 2011, viite 10.

120 Jawmal, sananmukaisesti 'merenpää', jossa "meri" viittaa Ob-jokeen: kohta, jossa Obin sivujoki Irtyš laskee Obiin. Lehtisalon mukaan niin nenetsit kuin hantitkin ovat uhranneet paikalla.

121 Tässä Castrén viitannee paikkaan, joka tunnetaan nenetsiksi nimellä Harv pod 'Lehtikuusitie' ja venäjäksi Kozmin perelesok 'Kozminin metsikkö'.

122 Maalitsa on pään yli vedettävä, pitkä ja hupullinen, poronnahkainen vaate, johon on usein ommeltu hihoihin rukkaset. 
123 Tästä kohtaa Castrén on yliviivannut käsitirjoituksesta seuraavan tekstiosion:

Samojedien keskuudessa on käsitys, että kaikki heidän jumalkuvansa, vastaavasti kuin lappalaisten seidat, ovat eläviä olentoja, jotka eivät ainoastaan esitä vaan jopa ovat todellisia, eläviä jumaluuksia. Niillä katsotaan olevan jumalallinen luonto sillä tavoin, että henget ottavat kuvat asunnoikseen. Šamaanin ominaisuuksiin kuuluu, kuten olen jo maininnut, että hän kykenee ottamaan yhteyden henkiin, kykenee näkemään ne, keskustelemaan niiden kanssa, pyytää niiden neuvoa ja apua, ja lisäksi pakottamaan ne taipumaan hänen tahtoonsa. Tavalliselle ihmiselle henget ovat sitä vastoin saavuttamattomissa, hän ei šamaanin tavoin kykene kutsumaan niitä lähelleen, ja hänelle on mahdoton ajatus että henget taipuisivat hänen rukouksiinsa, mikäli hän ei seiso vastapäätä niitä. Juuri tästä syystä samojedit pitävät hedelmättömänä osoittaa rukouksiaan Numille ja osoittaa tälle uhreja. Hänhän majailee aivan liian kaukana kuolevaisista, joten kuinka olisikaan mahdollista, että hän pystyisi kuulemaan heikot huudot? Samanlaisia henkiolentoja kuin mihin he itse vetoavat.

Kivet, puut ja erityiset kuvat, joita he palvovat suojelusjumaltensa ominaisuudessa, joihin he vetoavat rukouksin ja kunnioittavat uhrein, eivät ole muita kuin henkiä, joista näillä kansoilla ei ole täydellistä tietoisuutta, mutta näin olen silti kuullut heidän viisaiden miestensä selittävän. Tämä ja heidän viittauksensa osoittavat selvästi, että monet [yllä] käsitellyistä kansoista nimittävät samoin sanoin sekä henkiään että suojelusjumaliaan.

Osion sisältö toistuu käytännöllisesti katsoen kokonaan toisaalla.

124 [i andelig måtto]

125 Käsikirjoituksessa muodossa [2-300].

126 [hage/]: raudan pelkistysprosessissa syntyviä metallirakeita.

127 [bleck-halster]

128 [man]

129 Käsikirjoituksen marginaalissa on Castrénin lisäys: "metsät ja niityt olivat täynnään poroja ja soopeleita ja muuta riistaa, joet ja järvet [...] sairaudet olivat silloin lähes tuntemattomia."

130 [Det ligger också $i$ sakens natur, att sådana företräden ej kunna umbäras, om annars hjeltarna göra skäl för namnet, samt om sången verkligen hvilar på en historisk grund.] Historiallisuudella Castrén viittaa keskusteluun siitä, olisiko eeppistä sankariperinnettä tulkittava myyttisinä ja tällöin jollakin tapaa allegorisina tai vertauskuvallisina teksteinä vai historiallisina eli inhimillisiä, mahdollisesti historiallisia tapahtumia kuvaavina teksteinä. Castrén taipui jälkimmäiseen tulkintaan, joskin epäili, ettei suullinen sankariperinne kyennyt taltioimaan muistoa yksittäisistä tapahtumista tai henkilöistä kovin pitkäksi aikaa vaan että se heijasteli pikemmin yleisempiä menneisyyden oloja.

131 Castrén puhuu myöhemmin nimenomaisesti suomalaisten sukulaiskansoista tällaisessa yhteydessä.

132 Näkemyksen ovat esittäneet esim. Lönnrot 1836; anonyymi 1836; Collan 1838. 
133 Käsikirjoituksesta on ylivedetty tästä kohtaa seuraava tekstiosio: "mutta ennen kuin voimme jatkaa siihen, on tarpeen, että luomme yleiskatsauksen suomalaisiin sankarikertomuksiin, jotta saamme vakaan tuen Kalevalan tutkimuksille ja itse asiassa käsitellä kaikkia tapahtumia, jotka viittaavat esikristilliseen aikaan. Oikeastaan on selvyydeksi, jos jaamme Kalevalan runot erillisiksi sykleiksi, mutta tällaisen tutkimuksen suorittamiseksi on tarpeen, että tutustumme niihin muinaislauluihin, joista Kalevalaeepoksemme koostuu."

134 Esim. Cajanus 1777; myös Lencqvist 1782; Lönnrot 1835, 12-18; Lönnrot $(1836,69)$ esittää, että Kaleva oli yksi päälliköistä, jotka johtivat suomalaisia maahan muuttaneita ryhmiä.

135 Isl. Ásgarðr'aasojen kotipaikka'. Aasat (isl. æsir, sing. áss) ovat skandinaavisessa mytologiassa toinen kahdesta jumalluokasta, joista toinen on vaanit (isl. vanir, sing. vanr). Myös vaanit asuvat mytologisten tekstien mukaan Ásgarðrissa.

136 Isl. Jǫtunheimr 'jättien koti'.

137 Kalevala, runo 8, säkeet 3-8.

138 Itse asiassa neljä.

139 Kalevala, runo 12, säkeet 209-212.

140 Kalevala, runo 38, säkeet 301-314.

141 Kalevala, runo 39, säkeet 9-22.

142 Kalevala, runo 43, säkeet 383-384.

143 Kalevala, runo 47, säe 78: "hope'isehen kehä'än".

144 Vrt. Becker 1820c.

145 Castrénille, kuten saksalaiselle vertailevalle mytologiantutkimukselle, mytologia ja kieli olivat kiinteässä liitoksessa keskenään. Castrén näki siis kieliä koskevan uralilais-altailaisen hypoteesinsa soveltuvan myös mytologioiden ja perinteiden historialliseen tutkimukseen, ellei teoria jopa kehkeytynyt alkujaankin kielen ja mytologian käsittävänä kokonaisuutena. Uralilais-altailaisesta hypoteesista tarkemmin ks. s. 41-42.

146 Vrt Grimm 1845, 75.

147 Castrén 1837; Grimm 1845.

148 [under helgedomens hvalf]

149 Schiefner 1851.

150 [Grotte], alkukielellä isl. Grótti.

151 [Frode eller Fredfrode], alkukielellä isl. Fróði Friðleifsson.

152 [Hängekjäst], alkukielellä isl. Hengikjöptr 'riippuleuka'. Nimi on yksi Odinin monista nimistä, ja myös kerronnallisten stereotypioiden perusteella voi olettaa, että hahmolla on viitattu Odiniin.

153 Alkukielellä isl. Gróttasöngr.

154 Snorrin Eddassa eli Proosa-Eddassa Skáldskaparmál 8. Tämä on keskeinen lähde Grotti-laulun ymmärtämiseksi, sillä se antaa runolle kehyskertomuksen. Itse runoa tavataan erikseen myös muissa käsikirjoituksissa.

155 Alkukielellä isl. Mýsingr.

156 [Petlandsfjorden]: voimakkaista vuorovesivirtauksista ja niiden aiheuttamista pyörteistä tunnettu salmi Skotlannin ja Orkneyn välissä.

157 Myös myöhemmät tutkijat ovat kiinnittäneet huomiota skandinaavisten Grottiin liittyvien käsitysten ja kertomusten ja kalevalamittaisen sampo- 
runoston välisiin yhteyksiin; ks. esim. Kuusi 1963, 223-229; Haavio 1967, 189; Siikala 2012, 189-190.

158 Vrt. Grimm 1844, xxxix.

159 Vrt. Grimm 1845, 76.

160 Lauseen merkitys on hiukan epäselvä: [...dels äfven måhända af den omständighet, att qvarnen genom sitt rastlösa malande $i$ ymnigt mått förlänar menniskan hvad den i följe af sin natur kan tillvägabringa.]

161 Castrén viittaa (joskaan ei suoraan) luonnonmyytillisiin tutkimuksiin, mutta käyttää niistä vain metodista osaa pitäytyen itse historiallisessa tulkinnassa. Hän oli siis erittäin tietoinen luonnonmyytillisistä tulkinnoista (vrt. viitteet yllä) mutta ei halunnut opettaa niitä luennoillaan. Luonnonmytologisilla tulkinnoilla oli kuitenkin eurooppalaisessa mytologiantutkimuksessa vahva asema, mikä vaikutti myös näkemyksiin suomalaisesta mytologiasta. Esim. Wilhelm Mannhardt viittasi Grimmiin ja Schiefneriin tulkitessaan sammon 'huhmareksi' > 'pilveksi' teoksensa Germanische Mythen (1858) alaviitteessä (s. 399-400). Suomalaistutkijoista mm. Otto Donner (esim. 1863) jatkoi suomensukuisten myyttien luonnonmytologista tulkintalinjaa.

162 Castrén viittaa Collaniin (1838; 1839).

163 [under Kalevala-åldern] Castrén viittaa ilmauksella aikaan, jolloin kalevalamittainen epiikka hänen käsityksissään sepitettiin, ei kansalliseepos Kalevalaan.

164 [mörkaste dager]

165 Castrén viittaa Collanin artikkeliin "Om Bjarmaland och Pohjola" (1839).

166 Lönnrot 1839.

167 "Pohjola porolla kynti"

168 [nationalitet]; nykyisin puhuttaisiin todennäköisesti etnoksista, mutta kuten alla käy ilmi, Castrén käyttää sanaa kansallisuus myös muinaissuomalaisten käsitysten yhteydessä juuri jonkinlaisen laajemman yhteisöllisen identifioitumisen merkityksessä kontrastina pienemmille yhteisöille, joista puhuu varhaisimmaksi tulkitsemansa runouden yhteydessä.

169 Kalevalan ja Pohjolan käsittäminen kansakunniksi todistaa Castrénin mukaan siis, että runot on sepitetty kehittyneen yhteiskuntajärjestyksen piirissä, missä kansakunnat ovat merkityksellisiä viitekehyksiä.

170 Tätä Castrén käsitteli jo artikkelissaan "Om Finnarnes trollkonst" (1837).

171 [svartkonsten]

172 ["på farans bröllop"]

173 Castrén oli esittänyt perusteita sen puolesta, että Väinämöinen, Ilmarinen ja Lemminkäinen olisivat sankareita eivätkä jumalia, jo artikkelissaan "Om finnarnes trollkonst" (1837).

174 Katso myös Castrénin esipuhe Kalevalan ruotsinnokseensa (1841, viii-x), missä hän pohtii näitä kysymyksiä paljolti samassa hengessä.

175 "Emo hauvasta havasi"

176 Tässä argumentaatiossa Castrén itse asiassa tulee tuoneeksi esiin hänen jälkeensä (ja hänen työnsä kritiikistä osittain nousevan) kansanperinteentutkimuksen varsinaiseksi metodiksi kohoavan nk. maantieteellis-historiallisen menetelmän avainasiat. Metodilla pyrittiin tavoittamaan kalevalamittaisten runojen alkumuotoja filologisin keinoin analysoimalla 
runojen tekstirakenteen variointia ja eri variaatioiden maantieteellistä levinneisyyttä sekä tekemällä näiden pohjalta arvioita runojen kehitys- ja leviämishistoriasta. Tarkemmin menetelmästä ks. Krohn 1926.

177 [olaglig]

178 Runo 4, säe 79. Vrt. Ganander (1789, 34), joka esittää saman säkeen yhteydessä, jossa Kawe on Väinämöisen isä; ks. myös Becker 1820b ja Niemi 1922.

179 [Ärtskaftslig hingst]

180 Vanha Kalevala, runo 1, säkeet 177-178.

181 Vanha Kalevala, runo 1, säe 224.

182 Vanha Kalevala, runo 1, säe 280.

183 Vrt. Lönnrot 1839; Grimm 1845; Kellgren 1849. Sittemmin maailmanmunamyytin levinneisyyttä on esitellyt esim. Haavio 1950.

184 Virke on vaikeaselkoinen: [...och synes, om något, hafva bordt berättiga honom till ett gudomligt anseende hos våra fäder, liksom samma ära äfven i det fall, att han och hans kamrater Ilmarinen och Lemminkäinen endast skulle hafva fulländat skapelse-verket, icke heller hade bordt kunna dem bestridas.]

185 Isl. Óðinn, sodan ja runouden jumala, joka esitetään monissa myyteissä jumalista vanhimpana ja ylijumalana. Joidenkin myyttien mukaan hän oli mukana myös luomistapahtumissa. (Ks. esim. Voluspá 17-18; Gylfaginning 3, 6-9.)

186 Tämä, kuten suurin osa muistakin Castrénin esittelemistä ajatuksista skandinaavisen mytologian suhteen, on Peterseniltä, joka kirjoittaa: "[Odin] skaber ikke tingenes begyndelse, men ordner og opholder alt; livet udgår fra ham, og for såvidt kaldes han skaber (gautr, mjotudr)". Petersen 1849, 153.

187 Tässä kappaleessa erottuvat erityisen selvästi paineet, joita Castrén koki suomalaisuusliikkeen suunnasta työtään kohtaan.

188 Vafpruðnismál 48: 1-3 [Fjöld eg för, fjöld eg freistaðag, fjöld eg reynda regin] (Sigurðsson 1998, 71). Tässä on lainattu Aale Tynnin kaunista suomennosta (1982).

189 Vafpruðnismál 56: 3 [pú ert æ vísastur vera] (Sigurðsson 1998, 73). Suom. Aale Tynni 1982.

190 Vrt. Strinnholm 1834, 198-200, missä Odinin viisaudesta puhutaan samassa sävyssä kuin Castrénin tekstissä ja jopa samaan runoon viitaten.

191 Hávamál 138-161.

192 Isl. Bolporn.

193 Isl. Hildings sonar. Kyseessä on kiertoilmaisu, kenning. Nimi Hilding voisi viitata tanskalaiseen merovingiaikaiseen päällikködynastiaan, mutta edda-runoudessa se merkitsee 'sotapäällikköä'. Ilmaisu Hildingin pojat merkitsee siis 'sotapäällikön poikia' eli 'sotureita ylipäätään'.

194 [Kropatýr] Tässä Castrén on tulkinnut väärin. Kropatýr (isl. Hroptatýr) on yksi Odinin nimistä, ei hänestä erillään oleva hahmo. Ks. Schiefner 1853, 330. Hroptatýr Odinin nimenä: ks. Proosa-Eddan Gylfaginning 12. Ks. myös Grimm 1844, 178.

195 [Odins runer er den magt og den visdom, hvormed han behersker hele naturen, endog dens mest skjulte fenomener, ondog det, der gör mest modstand og synes sværest at betvinge.] 
196 Sama kuin edda-runo Baldrs draumar.

197 Niflhel ('pimeä, utuinen Hel') on skandinaavisessa mytologiassa alin manala. Proosa-Eddan Gylfaginningissä (3) kerrotaan, että pahat ihmiset joutuvat kuolemanvaltakunta Heliin ja sieltä edelleen Niflheliin.

198 [Walan] Castrén esittää nimityksen ikään kuin erisnimenä, "Ennustajatar". Muinaisislannin 'ennustajatarta' merkitsevä sana vǫlva käännettiin 1800-luvulla skandinaavisille kielille ja saksaksi usein muodossa vala, wala tai (die) Wala (ks. Grimm 1844, 87; Petersen 1849, 57 viite 1, 142), ja tässä käännöksessä pitäydytään yleisnimimerkityksessä alkutekstien hengessä.

199 Isl. Vafpruðnir.

200 [hrimturserna]; isl. hrímpurs, 'maailman alkuaikojen jätti'. Itse asiassa Suttungr, jonka hallusta Odin nouti siman, ei ollut huurretursas vaan aasojen naapureina asuvia jättejä (jotnar).

201 Viimeaikaisista tutkijoista näitä vastaavuuksia on nostanut esiin ennen muuta Anna-Leena Siikala (2012, esim. 240-247).

202 Odinin kahdeksanjalkaista, myyttistä alkuperää olevaa hevosta Sleipniriä kuvaillaan Proosa-Eddassa: Gylfaginning 15, 41, 42, 49; Skáldskaparmál 3.

203 Thorin (isl. Pórr) vyötä kutsutaan nimityksellä Megingjǫrð 'voimavyö'. Ks. Gylfaginning 21.

204 [urförvandtskap]; vrt. seuraavana vuonna julkaistu D. E. D. Europaeuksen kielitieteellinen tutkimus indoeurooppalaisten ja suomalais-unkarilaisten kansojen yhteisistä juurista (1853), johon maininta ilmeisesti tekee viittauksen.

205 "Siwalla simanen siipi / Wyöltä Wanhan Wäinämöisen / Wyöltä ainosen kapeen." (Ganander 1789, 101.) Ganander vertaa samassa yhteydessä Väinämöistä ulkoasunsa puolesta pohjoisamerikkalaiseen intiaaniin.

206 Janne Saarikiven (2015) mukaan udmurtin inmar on itse asiassa lainaa itämerensuomalaisista kielistä.

207 Vrt. Lönnrot 1839.

208 [gudasagan]

209 Tyr (isl. Týr) kuvataan Proosa-Eddassa (Gylfaginning 25) rohkeaksi ja sotaisaksi jumalaksi, johon rohkeutta tarvitsevien soturien kannatti vedota.

210 Isl. Baldr, skandinaavien kauneimpana ja puhtaimpana pitämä aasa, ylijumala Odinin poika.

211 Isl. Hǫðr, Baldin sokea veli ja siis yksi aasoista.

212 Castrénin esiinnostama ajatus Lemminkäisen ja Baldin hahmojen välisestä yhteydestä on noussut sittemmin monien tutkijoiden käsittelyn kohteeksi. Esimerkiksi Julius (1889) ja Kaarle Krohn (1903) samastivat Baldin ja Lemminkäisen Kristukseen. Kemppinen (1960) ja Haavio (1967) liittivät molemmat egyptiläiseen Osiris-tarustoon. Anna-Leena Siikala (1994), John Lindow (1997) ja Frog (2010) ovat käsitelleet aihetta viime vuosina ja osoittaneet yhteydet Lemminkäiseen ja Baldiin liittyvien kertomusten välillä varsin monitulkintaisiksi.

213 [inbergadt]: 'saatettu suojaan'. Castrénin terveys ei enää kestänyt käsitellä suomalaisen ja skandinaavisen mytologian välisiä yhtäläisyyksiä ja yhteyksiä pidemmälle, mutta vertailukohtia on sittemmin pohtinut useakin tutkija. Ne ovat keskeisessä roolissa esimerkiksi Matti Kuusen hahmottamassa kalevalamittaisen runouden periodisaatiossa (Kuusi 1963, 24-27; $1977,49)$ ja Anna-Leena Siikalan tulkinnoissa kalevalamittaisen runouden sisältämien mielikuvien kerrostuneisuudesta (erit. 1994). 


\section{Toimituksellisten huomautusten lähteet}

[Anonyymi] 1836: Några ord om Kalevala. - Helsingfors Morgonblad 95-96. Anttonen, Veikko 1996: Ihmisen ja maan rajat: 'Pyhä' kulttuurisena kategoriana. Suomalaisen Kirjallisuuden Seura, Helsinki.

Becker, Reinhold von 1820: Muutamia lyhykäisiä tietoja Suomalaisten Esiwanhemmista ja heiän entisistä asunto-paikoistansa. - Turun WiikkoSanomat 26 / 1820.

Cajanus, Johannes 1777: Om Paldamo. - Tidning utgiven af ett Sällskap i Åbo 16-18 / 1777.

Castrén, Matthias Alexander (käänt.) 1841: Kalevala. J. Simelii, Helsingfors.

Castrén, Matthias Alexander 1837: Om finnarnes trollkonst. - Helsingfors Morgonblad 27-28 / 1837.

Collan, Fabian 1838: Wäinämöinen och Ilmarinen. - Helsingfors Morgonblad 56, 57, 59, 61, 62 / 1838.

Collan, Fabian 1839: Om Bjarmaland och Pohjola. - Helsingfors Morgonblad 53-54 / 1839.

Donner, Otto 1863: Indernas föreställningar om verldsskapelsen femförda med Finnarnes. J. C. Frenckell \& Son, Helsingfors.

Europaeus, David Emanuel Daniel 1853: Komparativ framställning af de finskungerska språkens räkneord: Till bevis för ungarnes stamförvandtskap med finnarne, och den indogermaniska folkstammens urförvandtskap med den finsk-ungerska. J. C. Frenckell \& Son, Helsingfors.

Frog 2010: Baldr and Lemminkäinen: Approaching the evolution of mythological narrative through the activating power of expression.

A case study in Germanic and Finno-Karelian cultural contact and exchange. University College London, London.

Golovnev 1995: Головнев, А. В. 1995: Говорящие культуры. УрО РАН, Екатеринбург.

Grimm, Jacob 1844: Deutsche Mythologie. Göttingen. [1835.]

Grimm, Jacob 1845: Om det Finska Epos. Teoksessa Fosterländskt album II. Toimittaneet Herman Kellgren, Robert Tengström \& Karl Tigerstedt.

Haavio, Martti 1950: Väinämöinen: Suomalaisten runojen keskushahmo. WSOY, Porvoo \& Helsinki.

Haavio, Martti 1959: Karjalan jumalat. WSOY, Porvoo \& Helsinki.

Haavio, Martti 1961: Ukko ylijumala. Teoksessa Kalevalaseuran vuosikirja 41. WSOY, Porvoo \& Helsinki.

Haavio, Martti 1967: Suomalainen mytologia. WSOY, Helsinki.

Harva, Uno 1933: Turisas. Teoksessa Suomi: Kirjoituksia isänmaallisista aiheista nro. 16 / jakso 5. Suomalaisen Kirjallisuuden Seura, Helsinki.

Harva, Uno 1948: Suomalaisten muinaisusko. WSOY, Porvoo \& Helsinki.

Hausen, Reinhold (toim.) 1910: Finlands medeltidsurkunder 1150-1530. Finlands statsarkiv, Helsingfors.

Heikkilä, Mikko 2013: From Surging Waves to the Spirit of Waves: On the Germanic and Sami Origin of the Proper Names Ahti and Vellamo in Finnic Mythology. - SKY Journal of Linguistics 26, 71-86. 
Hodgson, Peter C. (toim.) 1988: Georg Wilhelm Friedrich Hegel: Lectures on the Philosophy of Religion. The Lectures of 1827. University of California Press, Berkeley, Los Angeles \& London.

Jónsson Finnur 1911 (toim.): Heimskringla: Nóregs konunga sögur. G. E. C. Gads forlag, København.

Jónsson, Guðni \& Bjarni Vilhjálmsson (toim.) 1944: Fornaldarsögur norðurlanda II. Bókaútgáfan forni, Reykjavík.

Kellgren, Herman 1849: Mythus de Ovo Mundano, indorumque de eodem notio. Frenckell, Helsingfors.

Kemppinen, livar 1960: Suomalainen mytologia. Kirja-Mono, Helsinki.

Koivulehto, Jorma 1999: Varhaiset indoeurooppalaiskontaktit: Aika ja paikka lainasanojen valossa. Teoksessa Pohjan poluilla: Suomalaisten juuret nykytutkimuksen mukaan. Toimittanut Paul Fogelberg. Societas scientiarum Fennica, Helsinki.

Koski, Mauno 1967: Itämerensuomalaisten kielten hiisi-sanue: Semanttinen tutkimus 1. Väitöskirja. Turun yliopisto, Turku.

Krohn, Julius 1885: Suomalaisen kirjallisuuden historia I: Kalevala. Helsinki.

Krohn, Kaarle 1926: Die folkloristische Arbeitsmethode. H. Aschehoug \& co, Oslo.

Krohn, Kaarle 1903-1910: Kalevalan runojen historia. Suomalaisen Kirjallisuuden Seura, Helsinki.

Kuusi, Matti (toim.) 1963: Suomen kirjallisuus I: Kirjoittamaton kirjallisuus. Suomalaisen Kirjallisuuden Seura, Helsinki.

Kuusi, Matti 1977: Introduction. Teoksessa Finnish Folk Poetry: Epic. Toimittaneet Matti Kuusi, Keith Bosley \& Michael Branch. Finnish Literature Society, Helsinki.

Lehtisalo, T. 1924:Entwurf einer Juraksamojedischen Mythologie. Suomalais-Ugrilainen Seura, Helsinki.

Lencqvist, Christian 2011: Vanhojen suomalaisten tietoperäisestä ja käytännöllisestä taikauskosta. Salakirjat, Helsinki. (Alkuteos: Rein, Edvard (suom.) 1904: Henrik Gabriel Porthanin tutkimuksia. Suomalaisen Kirjallisuuden Seura, Helsinki.)

Lindow, John 1997: Murder and Vengenance among the Gods: Baldr in Scandinavian Mythology. Suomalainen tiedeakatemia, Helsinki.

Ljarskaja 2015: Лярская, Е. Т. 2015: Женские запреты и комплекс представлении о нечистоте у ненцев. - Антропологический форум 2, 317-326.

Lukin, Karina 2011: Elämän ja entisyyden maisemat. Suomalaisen Kirjallisuuden Seura, Helsinki.

Lönnrot, Elias 1835: Kalewala taikka Wanhoja Karjalan Runoja Suomen kansan muinoisista ajoista. J. C. Frenckell \& son, Helsinki.

Lönnrot, Elias 1836b: Muinelmia: Lieto Lemminkäinen. Mehiläinen toukokuu 1836. Teoksessa Majamaa 1990: 69-76.

Lönnrot, Elias 1839: Alkuluomisesta. Mehiläinen joulukuu 1839. Teoksessa Majamaa 1990: 557-560.

Majamaa, Raija (toim.) 1990: Elias Lönnrot: Valitut teokset 2: Mehiläinen. Suomalaisen Kirjallisuuden Seura, Helsinki.

Mallat, Kaija 2007: Naiset rajalla. Kyöpeli, Nainen, Naara(s), Neitsyt, Morsian, 
Akka ja Ämmä Suomen paikannimissä. Suomalaisen Kirjallisuuden Seura, Helsinki.

Mannhardt, Wilhelm 1858: Germanische Mythen: Forschungen. Ferdinand Schneider, Berlin.

Niemi, Aukusti Robert 1922: Reinhold von Becker Kalevalan kokoonpanijan edelläkävijänä. Kalevalaseuran vuosikirja 2, 24-51.

Renvall, Gustav 1826: Suomalainen Sana-Kirja: Lexicon linguæ Finnica cum interpretatione duplici, copiosiore Latina, breviore Germanica. Aboae.

Rühs, Friedrich 1827: Finland och dess invånare. Stockholm.

Saarikivi, Janne 2006: Substrata Uralica: Studies on Finno-Ugrian Substrate in Northern Russian Dialects. Väitöskirja. Tartu University Press, Tartu.

Saarikivi, Janne 2014: Reconstruction of culture and ethnicity. Teoksessa New focus on retrospective methods: Resuming methodological discussions: Case studies from Northern Europe. Toimittaneet Eldar Heide \& Karen Bek-Pedersen. Suomalainen tiedeakatemia, Helsinki.

Saarikivi, Janne 2015: Finnic Borrowings in Permian. Teoksessa Peri orthoteton ton etymon. Uusiutuva uralilainen etymologia. Toimittaneet Sampsa Holopainen \& Janne Saarikivi. Suomalais-Ugrilainen Seura, Helsinki.

Salo, Unto 1997: Ukko ukkosen jumala: Muinaissuomalaisten ukkosenjumala ja hänen indoeurooppalainen sukunsa. Teoksessa Itämerensuomi: Eurooppalainen maa. Toimittanut Kyösti Julku. Atena, Jyväskylä.

Schiefner, Anton 1851: Zur Sampo-Mythe in Finnischen Epos. - Bulletin de la classe des sciences historiques, philologiques et politiques de L'académie Impériale des Sciences de Saint-Pétersbourg 173, 71-77.

Schiefner, Anton 1853: M. Alexander Castrén's Vorlesungen über die finnische Mythologie. Kaiserlichen Akademie der Wissenschaften, St. Petersburg.

Sigurðsson, Gísli 1999: Eddukvæði. Mál og menning, Reykjavík.

Siikala, Anna-Leena 1994: Suomalainen šamanismi: Mielikuvien historiaa. Suomalaisen Kirjallisuuden Seura, Helsinki.

Siikala, Anna-Leena 2012: Itämerensuomalaisten mytologia. Suomalaisen Kirjallisuuden Seura, Helsinki.

[SKVR]: ks. Suomen Kansan Vanhat Runot.

Strinnholm, Anders Magnus 1834: Svenska folkets historia från äldsta till närwarande tider I: Skandinavien under hedna-åldern. Johan Hörberg, Stockholm.

Suomen Kansan Vanhat Runot I-XIV. Helsinki: Suomalaisen Kirjallisuuden Seura, 1908-1948.

Tolley, Clive (toim.) 2006: Karhun kannoilla: In the Footsteps of the Bear. Turun yliopisto ja Satakunnan museo, Turku.

Tynni, Aale (suom.) 1982: Eddan jumalrunot. WSOY, Helsinki.

Vallikivi, Laur 2011: What does matter? Idols and Icons in the Nenets Tundra - Journal of Ethnology and Folkloristics 5(1), 75-95.

Veniamin 1855: Вениамин 1855: Самоеды мезенские. - Вестник Императорскаго Русскаго географическаго общества XIV (II), 77-136.

Žitkov 1913: Житков, Борис 1913: Полуостров Ямал. Типография М. М. Стасюлевича, С.-Петербург. 


\section{Asiasanahakemisto}

A' 189

Aallotar 135

Aarni 161

Ahti (jumaluus) 101, 131-137, 198;

(sankari) ks. Lemminkäinen;

(jumala ja sankari) 297-300

Ahto ks. Ahti

Ahtola 95, 132-134

Ai-kyn 210

Aija 113-115, 220; ks. myös Tiermes

Aijeke ks. Aija

Aijeke vuetšera 114

aina 209, 242-243, 300

Ainikki 256

Ajatar 157

Akka 101, 104, 111

Alida ks. Palas Murt

Annikki 258

Aracho 125

asa ks. aina

Atšintitei 209

Aurinko 25, 82, 85, 91, 98, 103, 106, 115-127, 131, 173, 190, 193, 207209, 215, 219, 246, 261-262, 274, $276,279,281,283-284,287-290$

Bald 302

Banguus ks. Imlja

bjarmit 92-93, 216-217, 265, 272

Boa ks. Buga

Bósin ja Herrauðrin saaga 92-93, 217; loppuviite 13

buddhalaisuus 116, 206-208, 244, 265

Buga 82, 89, 116, 208, 246

buni 208-211, 225

burjaatit 244-246

Burkhan 206-207

burkhan 240, 244

demonit 192-212, 218

Dianda 247

Diermes ks. Tiermes

Djilbegän 183-185, 188-189

\section{Dorokdi 209}

Edda ks. Proosa-Edda ja Runo-Edda edda-oppi ks. skandinaavinen mytologia

Ees 241

eettinen myytinselitys 22-23, 210, 269-271

Egres 104, 143

eläinuhrit 112, 117, 129-130, 222224, 229, 233-236, 240, 244;

ks. myös uhraaminen

enetsit ks. samojedit

Esrel 189-190

esän 207-208

Etelätär 128

euhemeristinen myytinselitys 20 , 298-299

evenkit ks. tunguusit

Fenja ja Menja 267

fetissi ks. jumalkuva

Frodi Fridleifsson 267-268

Fudnos-aimo ks. Rut-aimo

Garan 209

Grotti 267-269; loppuviite 157;

G.-laulu 267, 294; loppuviite 154

Gylfaginning ks. Proosa-Edda

haltia $16,28,31,152,176,192$, 194-195, 198-200, 203, 225, 292; loppuviitteet 87, 99; ks. myös suojelusjumala

hantit ks. ostjakit

hauki 119, 132, 139, 173, 226, 258, 260-262

Hávamál 291

Hengikjöpt 267, loppuviite 152

hevonen 106, 118, 155-157, 184-

$187,210,242,244-245,255,257$, 283, 290, 293, 295; loppuviitteet 52,202

Hiilitär ks. Mielikki 
Hiisi 154-157, 166; loppuviite 47

Hillervo ks. Tellervo

hiongnu-kansa 81-82, 89, 105, 108, 117,163

Hippa ks. Tapio

historiallinen myytinselitys 21-22, 25-26, 30, 154, 212, 249-250, 262-265

Hittavainen ks. Hittavanin

Hittavanin 151-152

Hongatar 151

Horna 157

hurikkainen 218, 221; ks. myös seita hämäläiset 27, 125, 142, 217-218, 273, 293; loppuviite 106

Iku-Turso ks. Tursas

Ilma ks. Ilmatar

IImarinen 22-24, 28, 30-31, 106, 109-111, 138-139, 250-253, 255-264, 267, 269-283, 288-291, 294-301

Ilmatar 85, 105, 111-112, 127, 250, 281-285, 287

Imlja 241-242

irikh ks. jerikh

irle-khan 183-189, 209-210; loppuviite 78

Irle-khan 205-206, 243

islamilaisuus 204, 209

išta 228-229

itarma 164, 211; loppuviite 56

Itoga 82, 244

Ja jieru Hahe 237

Jabme-aimo 95-96, 175-182

Jabme-akka 179, 183

jakuutit 99-100

Jehova 67, 289

Jelan 231

jelan 235

Jenisein-ostjakit 69, 70, 96-97, 216217, 240-242

jerikh 204

Jilibeambaertje 90-91

Jo 139

Jotunheim 96, 254; loppuviite 136
Joukola 254

joutsen 130, 177, 215, 241, 242, 247, 265, 301; tuonelan j. 256-257

Juks-akka ks. Uks-akka Jumala (jumaluus) 84-98, 107, 115, 216-217, 220, 295, loppuviite 8 jumala (käsite) 16-17, 24, 28-29, 31, 51-54, 82-87, 91-92, 97-98, 115-116, 128-129, 190-193, 213-215

jumalkuva 17-18, 82, 92-93, 153, 166-167, 213-218, 220-229, 231248, 265; loppuviite 88

Jupiter 84, 88, 100, 113

jurakkisamojedit $69,89,212,236-$ 239, 242; ks. myös samojedit

Kaleva 250-252

Kalevala (myyttinen paikallisuus) 250-255, 264-277

Kalevala 13, 32; Castrén ja $K .8-9$, $13,15,30,32-35,62,115-116$, 134-135, 282-283; $K: n$ historiallisuus 18, 20-27, 248-250, 262265, 268-269

Kalma 154, 168, 171, 201

kalmukit 244, 246

kamassit 69, 90-91; loppuviite 11

Kammo ks. Kimmo

Kankahatar 161

Kanmirgän 184, 186, 188

Kannas 143

Kanteletar 118, 121

kapeet ks. kave

karagassit 70, 117

karhu 24, 99-100, 111, 117, 169, 173, 200, 202, 218-219, 226, 236, 241, 261, 279, 301; loppuviitteet 50, 108

Karilainen 158

karjalaiset 25, 27, 45, 61, 103, 142143, 272, 296; loppuviite 52

Katajatar 151, 191

Kati 152

kave 28, 125-126, 194, 197

keiju 165-168, 198

Kekri 28, 147-148 
keremet 153, 229-230; ks. myös palvontapaikat

ketit ks. jenisein-ostjakit

Khormusda 207

kiinalaiset 81-82, 89, 96, 105, 117, 163,285

Kimmo 158, 218-219

Kipu-tyttö 171

kivien palvonta 28, 200, 213-219, 221-222, 224-225, 235, 237-238, 243-248

Kivutar 161, 172, 201

Koi (karhujumala) 241-242; ks. myös karhu

Koi 126

Komdei-mirgän 188-189

komit ks. syrjäänit

Kongdarokdi ks. Dorokdi

Kosken neiti 135, 137

Kratti 104

kristinusko 22, 24, 25, 26, 40, 47, 50; johdantoluvun loppuviite 11; k:n vaikutus kotoperäiseen mytologiaan 89-90, 100, 155, 175, 204, 209, 211, 217-218, $219,226,231,240,242,244$, 285; loppuviite 47

Kristus 88, 90, 123, 262; loppuviite 212

Kubaiko 184-188

Kudai (ylijumala) 185, 189, 205, 243

kudai (yleisnimi jumaluudelle) 89, 188, 210; loppuviite 9

Kudortša Juma 110, 228

Kuippana ks. Tapio

Kulj 139

Kullervo 109, 142, 251, 259

Kuu 85, 115-119, 123-126, 210, 246247, 261-262, 290

Kuumet 124

Kuura ks. Tiera

Kuutar 121, 124, 128

Kuutola 121

Kyllikki 118-119, 256-257, 263, 277

Käitös 151

Käreitär 152 käärme 132, 139, 154, 168, 169, 170, 174-175, 177, 182, 209, 210, 241, $242,246,258$

Köndös 142-143

kööpeli 165-167

lappalaiset 22, 25, 29, 87-88, 92, 95$96,113-117,141,162-163,175-$ 184, 203-204, 220-229, 272-273, 279-280, 297

Lemmes 152

Lemminkäinen 85, 106, 108, 111, $123,131,134,137-138,154-155$, $170,172-173,197,250-254,256-$ 260, 262-264, 269, 273, 276-280, 289, 291, 297-302

Lempo 28, 104, 155, 159-160, 166, 254

Lesovoi [Лесовой] 154

Liekkiö 28, 142-143

lintu 177, 209, 215, 219, 221, 222, $224,226,266,286-287$

Long 231-232

Louhi 23, 28, 93, 106, 109, 110, 125 , $127,132,138-139,171,255-262$, 266, 269-271, 275-276, 278-280, 300, 302; ks. myös Loviatar

Loviatar 171, 201, 282-283, 300; ks. myös Louhi

lud 153, 230

luojajumala 21, 26, 82, 85, 88-89, $113,152,185,204-205,206-207$, 287-291; loppuviite 17; ks. myös maailmansyntymyytti

luonnonmytologinen myytinselitys $15,16-17,24,28,43,49,51-52$, 53-54, 63, 82-83, 89-90, 95-99, $116,128-129,140,153,158$, 190-191, 193, 207-208, 215-216; loppuviitteet 2, 161

luonnonvoimien palvonta 16-17, 24, 28, 82-98, 129-132, 190-191, 215-216, 298-301; ks. myös luonnonmytologinen myytinselitys luonnotar 105, 126-127, 148-149 Luotola 254 
Maa-emma 140; ks. myös Maan emo maahiset 16, 28, 192, 194, 198, 202204

maailmansyntymyytti $21,31,85,113$, 204, 286-290; ks. myös luojajumala

Maan emo 101, 139-142, 283

Madderakka 141, 179

Madderattje 141, 179

mammutti 212, 241; loppuviite 92

Mana ks. Tuoni

Mánagarmr 126

Manala 68, 95, 167-173, 258

Manala ks. Tuonela

manismi 54-55, 64, 161-168, 173, 181-183, 189, 192-194, 202-203,

208, 211, 236; ks. myös vainajat mansit ks. vogulit

mantšut 99-100

marit ks. tšeremissit

Matka-Teppo 161, loppuviite 52

Meang 153, 231, 232

Meik ks. Meang

Melatar 135, 137

menninkäinen 28, 165-168, 194, 197-198

Meri-Tursas ks. Tursas

Metsola ks. Tapiola

metsänjumala 16, 53, 85, 97-98, 111 , 143-144, 147, 151-158, 208, 232; loppuviite 2

Mielikki 144-145, 149, 219

Miiritär ks. Mielikki

Mimerikki ks. Mielikki

Mo 153

mokša 69, 96; ks. myös mordvalaiset mongolit 41, 61, 82, 89-90, 96, 98, $99,100,116-117,120,125,139$, 164, 206-208, 240, 244, 246, 265

mordvalaiset 153, 230

Mubben-aimo ks. Rut-aimo mudor 204

Mysing 267-268

männinkäinen ks. menninkäinen

Natagaj 82, 244

Natagaj ks. Itoga

nenetsit ks. jurakkisamojedit
Nga' ks. $A^{\prime}$

nganasanit ks. tavgisamojedit

Njebe-hahe 237

Nju-hahe 237

Num 82, 88-92, 96, 100, 115, 189, $206,211,214,236$

Nyrkkes 151

Nyyrikki 149

Odin 23-24, 84, 291-295, 298, 301; loppuviitteet 152, 185, 186

Ogon Molgoro ks. Mo

Ohto ks. karhu

orgon ks. esän

Ormusd ks. Khormusda

osmanit 99

Osmola 251

ostjakit 21, 69, 96, 99-100, 115, 117, 129, 139, 153, 163-164, 190, 204, 214, 231-238, 262-263

ostjakkisamojedit 69, 100, 239-240

Otava 118, 121, 122, 219, 256, 276, 281, 283, 287

Otavatar 121, 124

Paha 85, 155

painaja 28

Palas Murt 153

palvontapaikat 216-217, 223, 229230, 233-234, 236-239, 244, 246

Panu 119-120, 300-301

para 28, 194-196

Parne 153-154; loppuviite 46

Pehrkhors 155

peijo 165

Pellervoinen 140, 142

Pellon Pekka ks. Pellervoinen

Perkele 84, 166; ks. myös Perkunas

Perkunas 155

permit 69, 139

persialaiset 89, 207, 285

Perun 155

Pietarin akatemia 13, 36, 37

Pihlajatar 151, 191

Pikku mies 119, 135, 137

Pimentola ks. Pohjola

Pinneys ks. Nyyrikki

Pitkäinen 107, 112; ks. Ukko 
Pohjan neito 255-256, 264, 269

Pohjantähti 118, 121

Pohjola 18, 30, 106, 122, 138, 142, 160, 250, 252-273, 276-280, 300-302

Pohjolan emäntä ks. Louhi

poro $69,120,129,177,181-182,189$, 208, 212, 223, 225, 233-234, 236, 239, 247, 253, 272

Proosa-Edda 267-268, 291, 295; loppuviite 14

puiden palvonta 17, 153, 213-216, $218,221,229,233,236,246,248$ pyhä (sana) 32, 85, 113, 129, 223, 227

Pyhä Tapani 161; loppuviite 52

Pyhän Olavin saaga 92-93, 217; loppuviite 13

Päivälä 121, 122

Päivän poika 85, 118-119, 122

Päivätär 121, 124, 128

Raamattu 31, 50

Radien-attje ks. Radien-kiedde

Radien-kiedde 113, 179, 181

Rauni 28, 103-104

Rongoteus 104, 143

Runo-Edda 291, 293, 295; loppuviite 14

ruotsalaiset 100, 194-195, 268

Rut-aimo 175, 178, 181

saamelaiset ks. lappalaiset

saivo 176-179, 182, 203, 224-226;

s.-aimo 95, 175, 178-179, 182;

s.-eläin 177, 182, 226

salama $90,103,107-110,112,115$, 120, 205, 296, 299; ks. myös ukkonen

Salme 118

šamaani 16, 32, 81-83, 90, 105, 116, 157, 162-164, 173, 177-178, 181-182, 193, 197, 199, 208212, 213-216, 224-225, 234, 240-245, 247-248, 268, 280, 291-292; loppuviitteet 5, 10, 55,56 šamanismi $12,40,52,62,64,65-66$, 81-83, 206-207, 241; ks. myös šamaani

samojedit 38-39, 41, 69, 82, 86, 88$92,94-98,117,120,127,129$, 153-154, 163-164, 167, 189-190, 192, 199, 203, 208, 211-214, 232, 235-242, 248, 262-263

sampo $23,24,45,53,63,68,132$, 138, 142, 253-255, 259-261, 264-273, 275-279, 294; loppuviite 161

Sampsa ks. Pellervoinen

Sarakka 95, 179-180, 203; S.-aimo $95,175,178-179,180$

Sariola 254, 260

seita 178, 220-223, 224-225, 226, 229, 231; loppuviite 123

selkupit ks. ostjakkisamojedit

Seulaset 118

siirtje 203, 212

Simanter ks. Mielikki

Sinetär 161

skandinaavinen mytologia 95, 104, 285, 297, 299; loppuviite 14

Sleipnir 293, 295; loppuviite 202

Snorrin Edda ks. Proosa-Edda

Sokjovo 247

Sotkotar 135

Stephan (Stepanus) ks. Pyhä Tapani storjunkare 220, 223

Sukkamieli 28, 159

suojelushenki ks. suojelusjumala suojelusjumala $16,82,90,111-112$, $124,128,141-143,147,151-152$, 158, 159-161, 176-179, 194-204, 207-212, 215-224, 229-248, 294; ks. myös haltia

Suomalaisen Kirjallisuuden Seura 13, 26, 33, 66

suomalaisuusliike 12-13, 19-20, 25, 58-59

Suometar 118, 121, 124

Suonetar 160-161

Šuro 209; ks. myös buni

Suvantola 251

Suvetar ks. Etelätär 
syrjäänit $69,86-87,88,89,96,139$, $212,233-234$

Šytkyr ks. Ukudel

Syöjätär 28, 139, 154, 298

tadebtsjo 164, 189-190, 192, $211-$ 214, 225, 239, 242; loppuviite 55 taivaanjumala 16, 30-31, 82, 87, 89-96, 97-98, 100-102, 105, 107, 110, 112-115, 117, 140, 181, 189, 204-207, 208, 213-214, 232, 236, 241, 246, 250, 288-289, 296-297; loppuviitteet 10, 17, 22

Tapio 28, 62, 100-102, 144-145, 147$152,155-156,168,178,191-192$. 198,298

Tapiola 95, 146-147, 168, 172; ks. myös Tapio

Tara 112, 115, 226-227, 250

tataarit 70, 97, 117, 129, 163, 167, 183-189, 205, 209-211, 242-244, 246, 250-251, 262-263, 300; loppuviite 9

tavgisamojedit 69, 189, 239-240

Tellervo 101, 149-150

tengri 89, 96-98, 206-208, 225

Terhenetär ks. Udutar

Thor (saam.) 114, 220; ks. Aija, Tiermes

Thor (skand.) 84, 103, 295, 297, 301; loppuviite 23, 203

Thordon ks. Thor (saam.)

Tiera 259

Tiermes 113-115, 220, 225-226, 227

tonttu 28, 194-195, 202

topo-kansa 163

Tora 115

Tōrom 115

Toruim ks. Tuurum

tšeremissit 69, 86-89, 92, 110, 139, 153, 162-163, 190, 197, 203-204, 228-230

tšuudit 212, 235, 240; loppuviite 93 tšuvassit 70, 115, 153, 162, 164, 189 $190,197,203-204,230$

tuli 103, 108-111, 119-121, 165, 200, 203, 207, 247, 257, 262, 283, 292 tunguusit $63,70,82,89-90,116-117$, 120, 129, 139, 153, 208-209, 211, $225,240,246-248$

Tuometar 151, 191

Tuonela 31-32, 68, 95, 123, 167-175, 257-258, 294; T:n joki 169, 170, 171, 172, 173, 257, 258

Tuoni 101, 168-175; T:n aimo 175, 178, 180; T:n akka 101, 170-171, 181; T:n poika 170, 174, 257; T:n tytär (Tuonetar) 170, 171-174, 201

Turisas 28

turkkilaiset kansat $63,82,89,96,99$, 120, 129, 139, 209, 242, 246

Tursas 105, 138-139

Turso ks. Tursas

Tuurum 231-232

Tyr 301, loppuviite 209

Tähetär 121

Tähtelä 121

udmurtit ks. votjakit

Udutar 127

uhraaminen $82,89,109,112,116$ $117,120,129-131,143,147,154$, 162-165, 177, 179-183, 198, 200, 212, 215-217, 223-246, 279

Ukko 16, 21, 23, 25, 28, 30-31, 68, 85, 93-94, 98-115, 127, 131, 261, 281, 288, 296, 298, 300; loppuviite 30

ukkonen 30, 53, 62-63, 90-92, 9495, 107-115, 190, 205

ukkosenjumala $30,87,100,102$, 107-110, 114-115, 140-141, 226, 228,300 ; ks. myös taivaanjumala Uks-akka 179-180, 203

Ukudel 207

Untamo 109, 160

Untamola 160, 254

uralilais-altailainen hypoteesi 41-42; loppuviitteet 93, 145

Uros ks. Pikku mies

Vafpruðnismál 291, 293

vainajainpalvonta ks. manismi

vainajat 120, 161-164, 167, 170, 179, 
181, 183, 189-190; loppuviite 56;

ks. myös manismi

Vammatar 161, 172, 201

Vanna issa 102, 107, 112-113, 126, 250, 288-289

Vanna taat ks. Vanna issa

vedenhenki 138-139, 193, 198, 200,

209; ks. myös vedenjumala

vedenjumala $16,24,28,83,101$, 128-139, 153, 193, 200, 207, 247, 281, 297-298, 299-300

Vegtamskviða 293

Vellamo 101, 128, 134-136, 137, 139, 172

Vesi (jumaluus) 131

vesi $16,111,129-132,134,135,136$, $169,184,187,207,222,229$, 254-255, 266, 267, 281, 286-287, 297-298; loppuviite 2

Vesi-Hiisi 138-139, 156, 199

Vetehinen 139

Vipunen 105, 154, 164, 173, 199, 251, 257-258, 274-275, 293, 294 virolaiset $45,86,88-89,107,110$,

$112-113,115,117-118,126,129$ 131, 141, 192-193, 202-203, 204, 226-228, 250, 285, 288-289

Vironkannas ks. Kannas vodennoj (водяной) 139 vogulit $69,117,122,190$

votjakit 69, 129, 139, 153, 190, 203, 204, 230-231, 296-297

Vuolainen 28

Vuolatar 28

Väinämöinen 18, 21-24, 28, 30-31, $34,85,93,105,109,110,111$, $119,122,127,128,132,137$, $138,142,154-155,164,170,171$, 173-174, 197, 218, 250-284, 287296, 298-302; loppuviitteet 73, $173,178,205$

Väinölä 95, 251-252, 255, 283, 287

Wadaš 153

Wesako 237

Wu-murt 139

Yljyn Aarakh 189

Ytzyt-khan 189

yzyt ks. aina

Zhjaeppes-aimo ks. Rut-aimo

Äijä ks. Äiö

Äiö 104, 111; ks. myös Ukko

Ämarik 126

Örtik 231-232 


\section{Henkilöhakemisto}

Agricola, Mikael 9, 27, 28, 29, 103$104,110,125-126,142-143,147$, $151,155,158,166,218,252$, 293-294, 296, 299

Alindje 82

Arwidsson, A. I. 21

Baer, K. M. 59

Bahadur Abulghasi 82

Becker, Reinhold von 21; loppuviitteet 144, 178

Bopp, Franz 43, 44-45

Borg, Carl G. 11, 14, 66

Brosses, Charles de 51

Buslajev, Fjodor I. 47-49

Cajan, Johan F. 31-32; johdantoluvun loppuviite 7

Castrén, Kristian 12

Castrén, Robert 26

Collan, Fabian 22-23; loppuviitteet $132,314,165$

Comte, Auguste 51-52

Creutzer, Georg 42, 46

Dietrich 227

Dupuis, Charles 51

Erman, Adolph 153, 231-232, 235

Europaeus, D. E. D. 33

Fuks, Aleksandra 164, 189, 204, 228-230

Ganander, Christfrid 8, 20, 29, 33; johdantoluvun loppuviite $5 ; 84$, 104, 111-112, 113-114, 121, 124, $125-126,128,138,140,142,143$, 144, 151-152, 155, 158-159, 160, 165-167, 183, 192, 194-197, 200, 202, 250, 294-296; loppuviitteet 7, 85, 86, 87, 178, 205

Georgi, Gottlieb 37, 58, 116-117, 120, 129, 152-153, 197, 204-205,
208-209, 228, 229, 230-231, 235, 244-248

Gottlund, Carl A. 20-21

Grimm, Jacob 7, 23-24, 29, 42, 4344, 45-46, 47, 49-50; johdantoluvun loppuviite $11 ; 100,104$, 122, 130, 133, 166, 170, 193, 221; loppuviitteet 25, 27, 42, 146, 158, 159, 161, 183, 194

Gutslaff, Johann 112-113, 130

Haavio, Martti 63, 64; loppuviitteet 30, 41, 157, 183, 212

Harva (Holmberg), Uno 63; loppuviitteet 30, 37, 41, 50

Hautala, Jouko 22

Hegel, Georg W. F. 24, 51-52, 53, 54; loppuviite 18

Henrik Lättiläinen 226-227

Herder, Johann G. von 42, 46, 55-56 Herodotos 89

Heyne, Christian G. 51

Holbach, Paul 51

Humboldt, Wilhelm von 43, 52, 55

Hume, David 51, 53; johdantoluvun loppuviite 12

Hupel, August W. 226-227

Högström, Pehr 88, 113, 114-115, $176,178,220,222,224-226$

Islavin, Vladimir 237-239

Jessen-Schardebøll, Erik J. 113, 117, 141, 162, 175-182, 203; loppuviitteet 74,75

Juslenius, Daniel 29

Justinus Zemarchus 120

Katariina I 36

Katariina II Suuri 37

Kemppinen, livar 63-64; loppuviite 212

Klemm, Gustav 95-96

Kowalewski, Joseph E. 96-97, 99 
Krohn, Julius 32, 34, 48, 61, 62; loppuviite 212

Krohn, Kaarle 34, 62-63; loppuviitteet 176,212

Leibniz, Gottfried W. von 56-57, 58

Lencqvist, Erik K. 27-29, 33, 50, 84$85,88,98,100,102,103-104$, 147, 151, 158, 159, 194-201, 203, 295-296, 299, 300

Lencqvist, Erik 28

Lindahl, Erik 114, 156-157, 176, 178180, 181, 224

Lönnrot, Elias 8, 9, 12, 13, 18, 22, 23, 26, 30-32, 33, 34-35, 61, 64; johdantoluvun loppuviitteet 6 , 7; 87, 95, 97, 131, 159, 265, 272, 287; loppuviitteet 17, 26, 105, 132, 134, 183, 207

\section{Marco Polo 82}

Messerschmidt, Daniel G. 36-37, 57

Müller, Gerhard F. 37, 57

Nervander, Johan 12

Niurenius, Olaus P. 221, 222

Pallas, Peter S. 37, 57, 58, 207-208, 233-236, 245-246; loppuviitteet 114,117

Pentikäinen, Juha 64

Petersen, Niels M. 285, 292-293; loppuviitteet 186, 198

Pietari Suuri 36, 37, 56

Plano Carpini 82, 120

Poppius, Abraham 21

Porthan, Henrik G. 27-28, 29, 38, 41, 49, 64, 100-101, 296

Rask, Rasmus 38, 44-45

Rein, Gabriel 26-27

Renvall, Gustav 29, 101, 143, 152, 156, 166, 168, 197; loppuviite 87
Rheen, Samuel 114, 182, 220, 221, 223

Runeberg, Johan L. 12

Rühs, Friedrich 20; loppuviite 48

Rytschkow, Nicolas 231

Salo, Unto 65; loppuviitteet 30, 41

Schefferus, Johannes 87, 113, 114$115,182-183,220-223$

Schiefner, Anton von 11, 22, 43; loppuviitteet 314, 194

Schlegel, Friedrich von 44

Schlözer, August L. von 57-58

Schmidt, Isaac J. 120, 206, 207-208

Schott, Willhelm 41, 95, 98-99

Schröter, Hans R. 20, 21

Setälä, Emil N. 22, 63

Siikala, Anna-Leena 65-66; loppuviitteet 42, 157, 201, 212, 213

Siikala, Jukka 55

Sjögren, Anders J. 14, 21, 37-39, 45, $55,56,58-59,63$

Snellman, Johan V. 19, 23, 24-25, 43, 58-59

Spencer, Herbert 54

Strabo 89

Tatištšev, Vasili N. 37, 56-57

Tengström, Johan J. 26

Tengström, Lovisa N. 26

Tengström, Robert 23, 24-26, 52, 293

Theophylactus Simocatta 82, 120

Topelius, Sakari nuorempi 12

Topelius, Sakari vanhempi 21-22, $26,33,85,119,122,156-157$, 299

Tornæus, Johannes J. 176, 220-223

Tylor, Edward B. 53-54; johdanto-

luvun loppuviite 14

Öhrling, Johann 114, 156-157, 176, 178-180, 181, 224 


\section{Paikannimihakemisto}

Aasia 11, 13, 36, 42, 89, 163, 193, 206, 265, 285; Keski-A. 35, 81, 163; loppuviite 53; Pohjois-A. 35 Akka 111

Akonjärvi, Akonkoski, Akonlahti 111

Argunsk 36

Arkangeli 30

Baikal-järvi 14, 36, 37

Berezov 13

Eim-järvi 130

Göttingen 57

Hahe-Salje 237

Halle 57

Holmogor 265, 272

Häme 273

Irkutsk 36

Jalmalin niemimaa 237

Jenisei-joki 36, 247

Jenisein kuvernementti 183

Jeniseisk 36

Kamtšatka 36, 37, 57

Karbino 240

Ket-joki 240

Kiina 36, 37, 163, 208

Krasnojarsk 36

Kuolan niemimaa 30, 220; loppuviite 110

Lappi 13, 30, 99, 104, 115, 176, 202, 220, 252-254, 261, 272-273, 300;

Tornion L. 218, 220; Kemin L. 220 Lappmark 175

Lena-joki 36

Mangazeja 36

Mesen 237
Minisei 237; loppuviite 119

Minusinski 244

Mongolia 36

Mädäjoki 129

Norja 113, 253, 268

Ob-joki 13, 129, 237; loppuviitteet 114,120

Obdorsk 13

Otepää 129

Oulu 12

Pietari 36, 38

Pohjanmaa 252, 273

Pohjoinen Jäämeri 36, 91; loppuviite 92

Pyhäjoki, Pyhäjärvi, Pyhävesi 129

Ruotsi 167, 267, 268; loppuviite 106

Saarenmaa 226

Sajan 14, 37, 41, 183, 243

Salehard ks. Obdorsk

Samarovsk 36

Siperia 35, 36, 38, 39, 56-58, 59, 81, 86, 153, 214, 235, 248, 263;

Etelä-S. 117, 129, 163, 167, 209, 242; Itä-S. 208; Länsi-S. 14, 37 , 39; Pohjois-S. 208, 213, 215

Sodankylä 221

Suomi 12, 13, 19, 23, 26, 30, 38, 45, $59,99,104,108,110,129,154$, $156,218,221,223,252,261$, 271-274

Taka-Baikalia 36

Tartto 129

Tervola 7, 12

Tiibet 266

Tjumen 13

Tobolsk 13 
Paikannimihakemisto

Tunguska-joki 36

Turjanniemi ks. Kuolan niemimaa

Ural 13, 37, 237; loppuviite 119

Vaigatš-saari 236-237; loppuviite 118

Vienan Karjala 7, 30
Vienanjoki 31, 216, 272

Vienanmeri 13

Viro 99, 227

Võhandu-joki 129, 193

Voksar 233

Äijänpaikka 111

Ämmänkoski, Ämmänlahti 111 


\section{TIETOLIPAS}

Tiivistä tietoa vuodesta 1945.

125 Pertti Virtaranta \& al. AMERIKANSUOMI

126 Jyri Vuorinen ESTETIIKAN KLASSIKOITA

127 Ulla Piela toim. AIKANAISIA

128 Olli Nuutinen HETKISEN PITUUS

129 Seppo Knuuttila TYHMÄN KANSAN TEORIA

130 Jari Kupiainen \& al. toim. KULTTUURINTUTKIMUS

131 Juha Pentikäinen \& al. JOHDATUS SAAMENTUTKIMUKSEEN

132 Katja Hyry toim. SAIRAUS JA IHMINEN

133 Kaisa Häkkinen KIELITIETEEN PERUSTEET

134 Arvi Hurskainen \& Ari Siiriäinen AFRIKAN KULTTUURIEN JUURET

135 Yrjö Sepänmaa TUHATJÄRVINEN

136 J.P. Roos \& al. toim. MIEHEN ELÄMÄÄ

137 Markku Ihonen \& Yrjö Varpio toim. HELMI SIMPUKKA JOKI

138 Jyri Vuorinen ESTEETTINEN TAIDEMÄÄRITELMÄ

139 Pirjo Lyytikäinen toim. SUBJEKTI. MINÄ. ITSE.

140 Kimmo Katajala toim. MANAAJISTA MAALAISAATELIIN

141 Anja Tuomisto \& Heli Uusikylä toim. KUVA, TEKSTI JA KULTTUURINEN NÄKEMINEN

142 Pam Morris FEMINISMI JA KIRJALLISUUS

143 Leena Suurpää \& al. toim. NÄIN NUORET

144 Yrjö Sepänmaa KUUKÄVELYLLÄ

145 Pirjo Lyytikäinen \& al. toim. KATSOMUKSEN IHANUUS

146 Eeva-Liisa Kinnunen \& al. toim. VITSISTÄ VIDEOON

147 Kaisa Häkkinen SUOMALAISTEN ESIHISTORIA KIELITIETEEN VALOSSA

148 Tero Norkola \& al. toim. SIVUPOLKUJA

149 Jyri Vuorinen TAIDETEOS MERKKINÄ

150 Lasse Koskela \& Lea Rojola LUKIJAN ABC-KIRJA

151 Pertti Karkama \& al. toim. ÄLYMYSTÖN JÄLJILLÄ

152 Katariina Eskola toim. ELÄMYSTEN JÄLJILLÄ

153 Pirjo Lyytikäinen toim. DEKADENSSI

154 Vesa Heikkinen \& al. toim. TUPPISUINEN MIES

155 Bo Lönnqvist \& al. toim. KULTTUURIN MUUTTUVAT KASVOT

156 Sari Näre toim. TUNTEIDEN SOSIOLOGIAA I

157 Sari Näre toim. TUNTEIDEN SOSIOLOGIAA II

158 Jyrki Pöysä \& Anna-Leena Siikala toim. AMOR, GENUS \& FAMILIA

159 Tuija Laine toim. VIERASKIELINEN KIRJALLISUUS SUOMESSA RUOTSIN VALLAN AIKANA

160 Lea Laitinen \& Lea Rojola toim. SANAN VOIMA

161 Pertti Karkama KULTTUURI JA DEMOKRATIA

162 Teppo Korhonen TEKNIIKKAA, TAIDETTA JA TAIKAUSKOA

163 Päivikki Suojanen USKONTOTIETEEN PORTAILLA

164 Irja Seurujärvi-Kari toim. BEAIVVI MÁNÁT

165 Matti Kamppinen AJAT MUUTTUVAT 
166 Pertti Lassila RUNOILIJA JA RUMPALI

167 Timo Joutsivuo \& al. toim. RENESSANSSIN TIEDE

168 Juhani Niemi KIRJALLINEN ELÄMÄ

169 liro Kajanto LATINA, KREIKKA JA KLASSINEN HUMANISMI SUOMESSA

170 Juha Pentikäinen toim. Lars Levi Laestadius LAPPALAISTEN MYTOLOGIAN KATKELMIA

171 Jyri Vuorinen AITOJA JA ALUEITA

172 Pekka Pesonen toim. VENÄLÄINEN FORMALISMI

173 Johanna Ruusuvuori, Markku Haakana \& Liisa Raevaara toim. INSTITUTIONAALINEN VUOROVAIKUTUS

174 Outi Alanko \& Tiina Käkelä-Pumala toim. KIRJALLISUUDENTUTKIMUKSEN PERUSKÄSITTEITÄ

175 Kari Immonen \& Maarit Leskelä-Kärki toim. KULTTUURIHISTORIA

176 Marjatta Rahikainen \& Tarja Räisänen toim. "TYÖLLÄ EI OO KUKKAAN RIKASTUNNA"

177 Jorma Kalela \& Ilari Lindroos toim. JOKAPÄIVÄINEN HISTORIA

178 Sulevi Riukulehti, Anssi Halmesvirta \& Kari Pöntinen POLITIIKKAA LASTENKIRJOISSA

179 Ilmari Vesterinen \& Bo Lönnqvist toim. PANDORAN LIPAS

180 Riho Grünthal toim. ENNEN MUINOIN

181 Erkki Pihkala SUOMI MAAILMANTALOUDESSA KESKIAJALTA EUSUOMEEN

182 Vesa Heikkinen toim. VIRKAPUKUINEN KIELI

183 Matti Kamppinen TULEVAT AJAT JA TEKNOLOGIA

184 Oiva Kuisma toim. SUOMALAINEN ESTETIIKKA 1900-LUVULLA

185 Tuomas Heikkilä \& Maiju Lehmijoki-Gardner KESKIAJAN KIRKKO

186 Helena Saarikoski toim. TANSSI TANSSI

187 Sanna Aaltonen \& Päivi Honkatukia TULKINTOJA TYTÖISTÄ

188 Jukka Sarjala MITEN TUTKIA MUSIIKIN HISTORIAA?

189 Marja-Liisa Honkasalo, Ilka Kangas \& Ullamaija Seppälä toim. SAIRAS, POTILAS, OMAINEN

190 Hannele Jönsson-Korhola, Anna-Riitta Lindgren MONENA SUOMI MAAILMALLA

191 Vesa Haapala toim. KUVIEN KEHÄSSÄ

192 Päivi Mehtonen POETRIA NOVA

193 Ilmari Vesterinen KELTAISENMEREN TAKANA

194 Kimmo Saaristo toim. HYVÄÄ PAHAA ROCK 'N' ROLL

195 Urpo Kovala \& Tuija Saresma toim. KULTTIKIRJA

196 Sanna Talja \& Sari Tuuva toim. TIETOTEKNIIKKASUHTEET

197 Lasse Koskela \& Pasi Lankinen OPAS KAUNOKIRJALLISUUDEN LUKEMISEEN

198 Marjo Mela \& Pirjo Mikkonen toim. SUOMI KAKKONEN

199 Taina Kaivola \& Hannele Rikkinen NUORET YMPÄRISTÖISSÄÄN

200 Tom Sjöblom DRUIDIT

201 Maija-Leena Hänninen \& Maijastina Kahlos toim. ROOMALAISTA ARKEA JA JUHLAA

202 Maarit Knuuttila \& Jyrki Pöysä \& Tuija Saarinen toim. SUULLA JA KIELELLÄ 
203 Sari Katajala-Peltomaa \& Raisa Maria Toivo PAHOLAINEN, NOITUUS JA MAGIA

204 Riku Hämäläinen toim. POHJOIS-AMERIKAN INTIAANIUSKONNOT

205 Outi Fingerroos toim. USKONNON PAIKKA

206 Markku Haakana\& Jyrki Kalliokoski toim. REFEROINTI JA MONIÄÄNISYYS

207 Pirjo Lyytikäinen \& al. toim. LAJIT YLI RAJOJEN

208 Helena Saarikoski LEIKKIKENTILTÄ

209 Eija Timonen PERINTEESTÄ MEDIAVIRTAAN

210 Marja-Leena Sorjonen \& Liisa Raevaara toim. ARJEN ASIOINTIA

211 Jaana Hallamaa \& al. toim. ETIIKKAA IHMISTIETEILLE

212 Tuomas Martikainen toim. YLIRAJAINEN KULTUURI

213 Anne Mäntynen \& al. toim. GENRE - TEKSTILAJI

214 Outi Fingerroos \& al. toim. MUISTITIETOTUTKIMUS

215 Tapani Lehtinen KIELEN VUOSITUHANNET

216 Marjo Mela \& Pirjo Mikkonen SUOMI KAKKONEN JA KIRJALLISUUDEN OPETUS

217 Satu Grünthal \& Elina Harjunen toim. NÄKÖALOJA ÄIDINKIELEEN JA KIRJALLISUUTEEN

218 Heikki Pihlajamäki, Virpi Mäkinen \& Jussi Varkemaa KESKIAJAN OIKEUSHISTORIA

219 Hanna Lappalainen ja Liisa Raevaara toim. KIELI KIOSKILLA

220 Sara Routarinne \& Tuula Uusi-Hallila NUORET KIELIKUVASSA

221 Terhi Ainiala, Minna Saarelma \& Paula Sjöblom NIMISTÖNTUTKIMUKSEN PERUSTEET

222 Toni Lahtinen \& Markku Lehtimäki toim. ÄÄNEKÄS KEVÄT

223 Tuomas Martikainen, Tuula Sakaranaho \& Marko Juntunen ISLAM SUOMESSA

224 Sirpa Leppänen, Tarja Nikula \& Leila Kääntä toim. KOLMAS KOTIMAINEN

225 Jari Niemelä TALONPOIKA TOIMESSAAN

226 Samuli Hägg, Markku Lehtimäki \& Liisa Steinby toim. NÄKÖKULMIA KERTOMUKSEN TUTKIMISEEN

227 Jyrki Kalliokoski ja Lari Kotilainen KIELET KOHTAAVAT

228 Anna Idström \& Sachico Sosa toim. KIELISSÄ KULTTUURIEN ÄÄNI

229 Vesa Heikkinen toim. KIELEN PIIRTEET JA TEKSTILAJIT

230 Maarit Grahn ja Maunu Häyrinen toim. KULTTUURITUOTANTO

231 Lars Levi Laestadius LAPPALAISTEN MYTOLOGIAN KATKELMIA

232 Veikko Anttonen USKONTOTIETEEN MAASTOT JA KARTAT

233 Tuomas Martikainen ja Lotta Haikkola toim. MAAHANMUUTTO JA SUKUPOLVET

234 Irja Seurujärvi-Kari, Risto Pulkkinen, Petri Halinen toim. SAAMENTUTKIMUS TÄNÄÄN

235 Maria Laakso, Toni Lahtinen \& Päivi Heikkilä-Halttunen toim. TAPION TARHOISTA TURKISTARHOILLE

236 Siru Kainulainen, Karoliina Lummaa \& Katja Seutu toim. TYÖMAANA RUNOUS

237 Antti Salminen, Jukka Mikkonen \& Joose Järvenkylä toim. KIRJALLISUUS JA FILOSOFIA 
238 Aino Mäkikalli \& Liisa Steinby JOHDATUS KIRJALLISUUSANALYYSIIN

239 Kaisa Ahvenjärvi \& Leena Kirstinä KIRJALLISUUDEN OPETUKSEN KÄSIKIRJA

240 Anna Rastas toim. KAIKILLE LAPSILLE. LASTENKIRJALLISUUS LIIKKUVASSA, MONIKULTTUURISESSA MAAILMASSA

241 Anneli Kauppinen toim. OPPIMISTILANTEITA JA VUOROVAIKUTUSTA

242 Aino Koivisto \& Elise Nykänen toim. DIALOGI KAUNOKIRJALLISUUDESSA

243 Outi Tuomi-Nikula, Riina Haanpää \& Aura Kivilaakso toim. MITÄ ON KULTTUURIPERINTÖ?

244 Pirjo Kristiina Virtanen, Lea Kantonen ja Irja Seurujärvi-Kari toim. ALKUPERÄISKANSAT TÄMÄN PÄIVÄN MAAILMASSA

245 Marleena Mustola toim. LASTENKIRJA. NYT

246 Johanna Isosävi ja Hanna Lappalainen toim. SAAKO SINUTELLA VAI TÄYTYYKÖ TEITITELLÄ? TUTKIMUKSIA EUROOPPALAISTEN KIELTEN PUHUTTELUKÄYTÄNNÖISTÄ

247 Johanna Ahonen \& Elina Vuola toim. USKONNON JA SUKUPUOLEN RISTEYKSIÄ

248 Simo Häyrynen KULTTUURIPOLITIIKAN LIIKKUVAT RAJAT. KULTTUURI SUOMALAISESSA YHTEISKUNTAPOLITIIKASSA

249 Elina Vuola toim. USKONTO JA KEHITYS. NÄKÖKULMIA SUOMALAISEEN KEHITYSYHTEISTYÖHÖN JA -TUTKIMUKSEEN

250 Jukka Kortti MEDIAHISTORIA. VIESTINNÄN MERKITYKSIÄ JA MUODONMUUTOKSIA PUHEESTA BITTEIHIN

251 Harri Kalha toim. KUMMAT KUVAT

252 M. A. Castrén, LUENTOJA SUOMALAISESTA MYTOLOGIASTA 